QE

- 150

5666
cRES SI

\title{
Atlas of Paleocene Planktonic Foraminifera
}




\title{
SERIES PUBLICATIONS OF THE SMITHSONIAN INSTITUTION
}

Emphasis upon publication as a means of "diffusing knowledge" was expressed by the first Secretary of the Smithsonian. In his formal plan for the institution, Joseph Henry outlined a program that included the following statement: "It is proposed to publish a series of reports, giving an account of the new discoveries in science, and of the changes made from year to year in all branches of knowledge." This theme of basic research has been adhered to through the years by thousands of titles issued in series publications under the Smithsonian imprint, commencing with Smithsonian Contributions to Knowledge in 1848 and continuing with the following active series:

\author{
Smithsonian Contributions to Anthropology \\ Smithsonian Contributions to Botany \\ Smithsonian Contributions to the Earth Sciences \\ Smithsonian Contributions to the Marine Sciences \\ Smithsonian Contributions to Paleobiology \\ Smithsonian Contributions to Zoology \\ Smithsonian Folklife Studies \\ Smithsonian Studies in Air and Space \\ Smithsonian Studies in History and Technology
}

In these series, the Institution publishes small papers and full-scale monographs that report the research and collections of its various museums and bureaux or of professional colleagues in the world of science and scholarship. The publications are distributed by mailing lists to libraries, universities, and simllar institutions throughout the world.

Papers or monographs submitted for series publication are received by the Smithsonian Institution Press, subject to its own review for format and style, only through departments of the various Smithsonian museums or bureaux, where the manuscripts are given substantive review. Press requirements for manuscript and art preparation are outlined on the inside back cover.

\author{
I. Michael Heyman \\ Secretary \\ Smithsonian Institution
}


SMITHSONIAN CONTRIBUTIONS TO PALEOBIOLOGY • NUMBER 85

\section{Atlas of Paleocene Planktonic Foraminifera}

Richard K. Olsson, Christoph Hemleben, William A. Berggren, and Brian T. Huber

EDITORS

\section{ISSUED}

MAR 31999

SMITHSONIAN INSTITUTION

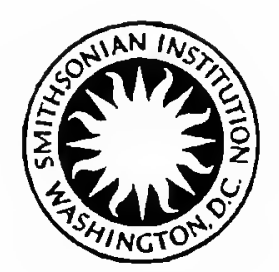

SMITHSONIAN INSTITUTION PRESS

Washington, D.C. 


\section{A B S T R A C T}

Olsson, Richard K., Christoph Hemleben, William A. Berggren, and Brian T. Huber, editors. Atlas of Paleocene Planktonic Foraminifera. Smithsonian Contributions to Paleobiology, number 85, 252 pages, 37 figures, 71 plates, 1999.- - Sixty-seven species of Paleocene planktonic foraminifera are described and illustrated, including three species of Eoglobigerina, four species of Parasubbotina, five species of Subbotina, two species of Hedbergella, 10 species of Globanomalina, six species of Acarinina, 12 species of Morozovella, three species of Igorina, four species of Praemurica, one species of Guembelitria, one species of Globoconusa, three species of Parvularugoglobigerina, two species of Woodringina, six species of Chiloguembelina, one species of Rectoguembelina, and four species of Zeauvigerina. Taxonomic classification of normal perforate taxa are organized according to wall texture. Spinose cancellate genera include Eoglobigerina, Parasubbotina, and Subbotina; cancellate nonspinose genera include Igorinina and Praemurica; smooth-walled genera include Hedbergella and Globanomalina; and muricate genera include Acarinina and Morozovella. Taxonomic classification of microperforate taxa (including Guembelitria, Globoconusa, Parvularugoglobigerina, Woodringina, Chiloguembelina, Rectoguembelina, and Zeauvigerina) are organized according to test morphology.

Scanning electron microscope (SEM) images of type species described by Morozova in the collections of the Geological Institute, Academy of Sciences (GAN), Moscow, and the type material described by Subbotina in the collections of the All Union Petroleum Scientific Research Geological Prospecting Institute (VNIGRI), St. Petersburg, are shown on Plates 8-12. Twelve species described by Morozova, nine species described by Subbotina, and one species described by Bykova are illustrated. In addition, SEM images of 28 holotypes and two paratypes from the Smithsonian Institution collections are shown on Plates 13-17, and the lectotype for Globigerina compressa Plummer, 1926, and the neotype for Globorotalia monmouthensis Olsson, 1961, are designated and illustrated with SEM images.

Paleobiogeographic maps showing the global distribution of 29 commonly occurring Paleocene taxa are included in the atlas, as well as figures showing the stratigraphic ranges of species by genus and stratigraphic first and last appearances. The biostratigraphic framework used in the atlas is the revised biostratigraphy given in Berggren et al., 1995, which is summarized in the atlas. Wall texture and morphological relationships between species and genera form the basis of phylogenetic interpretations. This is discussed in the section "Wall Texture, Classification, and Phylogeny" and is referenced to Plates 1-7.

OfFICIAL PUBLICATION DATE is handstamped in a limited number of initial copies and is recorded in the Institution's annual report, Annals of the Smithsonian Institution. SERIES COVER DESIGN: The trilobite Phacops rana Green.

Library of Congress Cataloging-in-Publication Data

Atlas of Paleocene planktonic foraminifera / Richard K. Olsson ... [et al.], editors.

p. cm. - (Smithsonian contributions to paleobiology ; no. 85)

Includes bibliographic references and index.

1. Foraminifera, Fossil. 2. Paleontology-Paleocene. I. Olsson, Richard K. II. Series.

QE701.S56 no.85 [QE772] $560 \mathrm{~s}-\mathrm{dc} 21 \quad$ [561'.994] 98-3474

(1) The paper used in this publication meets the minimum requirements of the American National Standard for Permanence of Paper for Printed Library Materials Z39.48-1984. 


\section{Contents}

Introduction (by R.K. Olsson, W. A. Bergaren, and Ch. Hemleben)

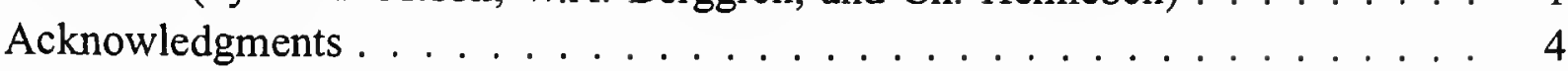

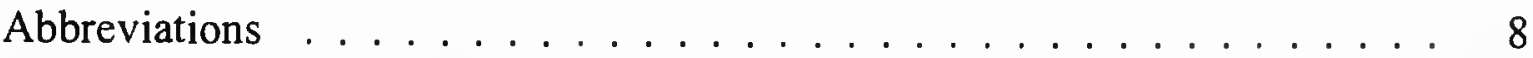

Biostratigraphy (by W.A. Berggren and R.D. Norris) . . . . . . . . . . 8

Wall Texture, Classification, and Phylogeny (by Ch. Hemleben, R.K. Olsson,

W.A. Berggren, and R.D. Norris) . . . . . . . . . . . . . . . . 10

Globorotaliid Wall Texture . . . . . . . . . . . . . . . . . . 11

Muricate Wall Textures . . . . . . . . . . . . . . . . . . . . 12

Neogloboquadrinid Wall Texture (Praemuricate) . . . . . . . . . . . . 12

Spinose Wall Texture . . . . . . . . . . . . . . . . . . . 12

Preservation and Diagenesis .................. 13

Phylogeny . . . . . . . . . . . . . . . . . . 13

Spinose Lineages . . . . . . . . . . . . . . . . . . . . . . . . 13

Cancellate Lineages . . . . . . . . . . . . . . . . . . . . . 13

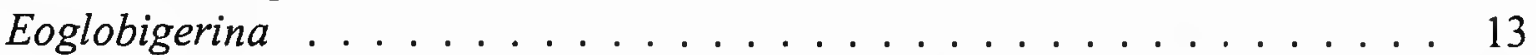

Parasubbotina ........................ . 17

Subbotina ......................... 17

Nonspinose Lineages . . . . . . . . . . . . . . . . . . . . . . . . 17

Praemuricate Lineages .................... . . 17

Praemurica ........................ 17

Igorina . . . . . . . . . . . . . . . . . . . . 17

Smooth-Walled Lineage . . . . . . . . . . . . . . . . . . . 17

Globanomalina . . . . . . . . . . . . . . . . . 17

Muricate Lineages . . . . . . . . . . . . . . . . . . . . 18

Acarinina . . . . . . . . . . . . . . . . . 18

Morozovella ....................... 18

Taxonomy . . . . . . . . . . . . . . . . . . . . . . 19

Family GlobigERINIDAE Carpenter, Parker, and Jones, 1862 (by R.K Olsson,

Ch. Hemleben, C. Liu, W.A. Berggren, and R.D. Norris) . . . . . . . . . . 19

Genus Eoglobigerina Morozova, $1959 \ldots \ldots \ldots$

Eoglobigerina edita (Subbotina, 1953) . . . . . . . . . . . . . 19

Eoglobigerina eobulloides (Morozova, 1959) . . . . . . . . . . 20

Eoglobigerina spiralis (Bolli, 1957) . . . . . . . . . . . . 22

Genus Parasubbotina Olsson, Hemleben, Berggren, and Liu, 1992 . . . . . . 24

Parasubbotina pseudobulloides (Plummer, 1926) . . . . . . . . . . 24

Parasubbotina aff. pseudobulloides (Plummer, 1926) . . . . . . . . 25

Parasubbotina varianta (Subbotina, 1953) . . . . . . . . . . 26

Parasubbotina variospira (Belford, 1984) . . . . . . . . . . . 28

Genus Subbotina Brotzen and Pożaryska, $1961 \ldots \ldots$. . . . . . . . . . 28

Subbotina cancellata Blow, $1979 \ldots \ldots \ldots$. . . . . . . . . 29

Subbotina triangularis (White, 1928) . . . . . . . . . . . 30

Subbotina triloculinoides (Plummer, 1926) . . . . . . . . . . 31

Subbotina trivialis (Subbotina, 1953) . . . . . . . . . . . . 32

Subbotina velascoensis (Cushman, 1925) . . . . . . . . . . . . 33

Family HEDBERGELLIDAE Loeblich and Tappan, 1961 (by R.K. Olsson,

Ch. Hemleben, and C. Liu) . . . . . . . . . . . . . . . . 34 
Genus Hedbergella Brönnimann and Brown, 1958 . . . . . . . . . . 34

Hedbergella holmdelensis Olsson, 1964 . . . . . . . . . . . . 35

Hedbergella monmouthensis (Olsson, 1960) . . . . . . . . . . . 35

Genus Globanomalina Haque, 1956, emended . . . . . . . . . . . . . . 37

Globanomalina archeocompressa (Blow, 1979) . . . . . . . . . . . 37

Globanomalina australiformis (Jenkins, 1965) . . . . . . . . . 38

Globanomalina chapmani (Parr, 1938) . . . . . . . . . . . . 39

Globanomalina compressa (Plummer, 1926) . . . . . . . . . . . . 40

Globanomalina ehrenbergi (Bolli, 1957) . . . . . . . . . . . . 42

Globanomalina imitata (Subbotina, 1953) . . . . . . . . . . . . . . 42

Globanomalina ovalis Haque, $1956 \ldots \ldots$. . . . . . . . . . . 43

Globanomalina planocompressa (Shutskaya, 1965) . . . . . . . . . . 44

Globanomalina planoconica (Subbotina, 1953) . . . . . . . . . . . 44

Globanomalina pseudomenardii (Bolli, 1957) . . . . . . . . . . . 45

Family TRUNCOROTALOIDIDAE Loeblich and Tappan, 1961 (by W.A. Berggren,

Ch. Hemleben, R.D. Norris, and R.K. Olsson) . . . . . . . . . . . . . . . 45

Genus Acarinina Subbotina, 1953 . . . . . . . . . . . . . . . . . 46

Acarinina coalingensis (Cushman and Hanna, 1927) . . . . . . . . 47

Acarinina mckannai (White, 1928) . . . . . . . . . . . . . . 48

Acarinina nitida (Martin, 1943) . . . . . . . . . . . . 48

Acarinina soldadoensis (Brönnimann, 1952) . . . . . . . . . 50

Acarinina strabocella (Loeblich and Tappan, 1957) . . . . . . . . . . . 50

Acarinina subsphaerica (Subbotina, 1947) . . . . . . . . . . 52

Genus Morozovella McGowran in Luterbacher, $1964 \ldots . . . . . . . .54$

Morozovella acuta (Toulmin, 1941) . . . . . . . . . . . 55

Morozovella acutispira (Bolli and Cita, 1960) . . . . . . . . . 56

Morozovella aequa (Cushman and Renz, 1942) . . . . . . . . . 57

Morozovella angulata (White, 1928) . . . . . . . . . . . 58

Morozovella apanthesma (Loeblich and Tappan, 1957) . . . . . . . . . 59

Morozovella conicotruncata (Subbotina, 1947) . . . . . . . . . 60

Morozovella gracilis (Bolli, 1957) . . . . . . . . . . . . . . 61

Morozovella occlusa (Loeblich and Tappan, 1957) . . . . . . . . 62

Morozovella pasionensis (Bermúdez, 1961) . . . . . . . . . . 63

Morozovella praeangulata (Blow, 1979) . . . . . . . . . . . . . 64

Morozovella subbotinae (Morozova, 1939) . . . . . . . . . . . 65

Morozovella velascoensis (Cushman, 1925) . . . . . . . . . . 66

Genus Igorina Davidzon, $1976 \ldots \ldots \ldots$. . . . . . . . . . 68

Igorina albeari (Cushman and Bermúdez, 1949) . . . . . . . . . . 69

Igorina pusilla (Bolli, 1957) . . . . . . . . . . . . . . . 70

Igorina tadjikistanensis (Bykova, 1953) . . . . . . . . . . . 71

Genus Praemurica Olsson, Hemleben, Berggren, and Liu, 1992 . . . . . . . 72

Praemurica inconstans (Subbotina, 1953) . . . . . . . . . . . . 73

Praemurica pseudoinconstans (Blow, 1979) . . . . . . . . . . . 74

Praemurica taurica (Morozova, 1961) . . . . . . . . . . . . . 75

Praemurica uncinata (Bolli, 1957) . . . . . . . . . . . . . . . 76

Family GuembelitriddaE Montanaro Gallitelli, 1957 (by S. D'Hondt, C. Liu,

and R.K. Olsson) . . . . . . . . . . . . . . . . . . . 77

Genus Guembelitria Cushman, $1933 \ldots \ldots$. . . . . . . . . . . . 79

Guembelitria cretacea Cushman, 1933 . . . . . . . . . . 79

Genus Globoconusa Khalilov, 1956 . . . . . . . . . . . . . . . . . 80

Globoconusa daubjergensis (Brönnimann, 1953) . . . . . . . . . 81

Genus Parvularugoglobigerina (Hofker, 1978), emended . . . . . . . . . 82

Parvularugoglobigerina alabamensis (Liu and Olsson, 1992) . . . . . . 83

Parvularugoglobigerina eugubina (Luterbacher and Premoli Silva, 1964) 
Parvularugoglobigerina extensa (Blow, 1979) . . . . . . . . . 85

Genus Woodringina Loeblich and Tappan, 1957 . . . . . . . . . . . 86

Woodringina claytonensis Loeblich and Tappan, 1957 . . . . . . . 86

Woodringina hornerstownensis Olsson, 1960 . . . . . . . . . . 87

Family CHILoguembelinidae Reiss, 1963 (by S. D'Hondt and B.T. Huber) . . . 88

Genus Chiloguembelina Loeblich and Tappan, 1956 . . . . . . . . . . . . . 89

Chiloguembelina crinita (Glaessner, 1937) . . . . . . . . . . . 90

Chiloguembelina midwayensis (Cushman, 1940) . . . . . . . . . . 990

Chiloguembelina morsei (Kline, 1943) . . . . . . . . . . . . . . . 91

Chiloguembelina subtriangularis Beckmann, 1957 . . . . . . . . . 92

Chiloguembelina trinitatensis (Cushman and Renz, 1942) . . . . . . . . 92

Chiloguembelina wilcoxensis (Cushman and Ponton, 1932) . . . . . . . 92

Family HeTEROHELICIDAE Cushman, 1927 (by B.T. Huber) . . . . . . . . . . . 93

Genus Rectoguembelina Cushman, 1932 . . . . . . . . . . . . . . 93

Rectoguembelina cretacea Cushman, 1932 . . . . . . . . . . . 94

Genus Zeauvigerina Finlay, 1939 . . . . . . . . . . . . . . . . 94

Zeauvigerina aegyptiaca Said and Kenawy, 1956 . . . . . . . . . 95

Zeauvigerina teuria Finlay, $1947 \ldots \ldots \ldots$. . . . . . . . 96

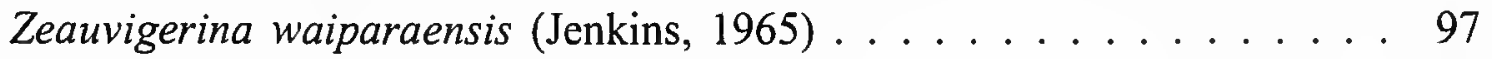

"Zeauvigerina" virgata (Khalilov, 1967) . . . . . . . . . . . . . 98

Literature Cited . . . . . . . . . . . . . . . . . . . . . 100

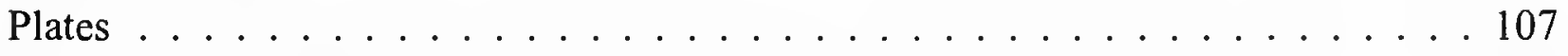

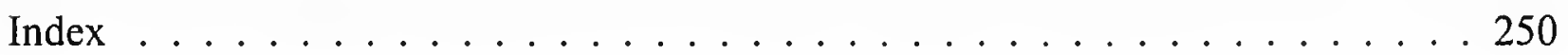




\section{Members of the Paleogene Planktonic Foraminifera Working Group}

William A. Berggren (Chairman), Department of Geology and Geophysics, Woods Hole Oceanographic Institute, Woods Hole, Massachusetts, 02543, United States.

Steven D'Hondt, Graduate School of Oceanography, University of Rhode Island, Kingston, Rhode Island, 02881, United States.

Christoph Hemleben, Institute und Museum für Geologie und Paläontologie, Universität Tübingen, D-72076 Tübingen, Germany.

Brian T. Huber, Department of Paleobiology, MRC NHB 121, National Museum of Natural History, Smithsonian Institution, Washington, D.C. 20560, United States.

D. Graham Jenkins (deceased), Department of Geology, National Museum of Wales, Cathays Park, Cardiff CF1 3NP, United Kingdom.

Chengjie Liu, Department of Geological Sciences, Rutgers University, New Brunswick, New Jersey 08903, United States.

Richard D. Norris, Woods Hole Oceanographic Institute, Woods Hole, Massachusetts 02543, United States.

Richard K. Olsson (Secretary), Department of Geological Sciences, Rutgers University, New Brunswick, New Jersey 08903, United States.

Paul N. Pearson, Department of Geology, University of Bristol, Queens Road, Bristol BS8 1RJ, United Kingdom.

Fred Rögl, Naturhistorisches Museum, Paleontologisches Abt., Burggring 7, A1014 Vienna, Austria. 


\title{
Atlas of Paleocene Planktonic Foraminifera
}

\author{
Richard K. Olsson, Christoph Hemleben, William A. Berggren, \\ and Brian T. Huber
}

Editors

\section{Introduction}

(by R.K. Olsson, W.A. Berggren, and Ch. Hemleben)

The Paleogene Planktonic Foraminifera Working Group of the International Subcommission on Paleogene Stratigraphy, International Union of Geological Sciences, was formed in 1987 following a meeting (organized by W.A. Berggren) at the British Petroleum Research Centre in Sunbury on Thames, U.K., of researchers interested in improving the understanding of Paleogene planktonic foraminiferal taxonomy and lineage phylogenies. The consensus of the meeting was that a concerted effort among workers was needed to unravel conflicting taxonomic usages of Paleogene taxa due to misunderstanding and lack of access to type collections, particularly in the former Soviet Union. The origins of many of the important biostratigraphic lineages was obscure so that the radiation of Paleogene planktonic foraminifera was poorly understood, and, in fact, some long-held concepts proved to be erroneous. Some of the important questions included the origin of the basal Cenozoic radiation, the taxa involved and how to distinguish them, the origin of the genus Acarinina, and the phylogeny of the morozovellids. In the following years, important breakthroughs in research led to the evolution of the working group's understanding of the taxonomy and phylogeny of Paleogene planktonic foraminifera.

Richard K. Olsson, Department of Geological Sciences, Rutgers University, New Brunswick, New Jersey 08903. Christoph Hemleben, Institute und Museum für Geologie und Paläontologie, Universität Tübingen, D-72076 Tübingen, Germany. William A. Berggren, Department of Geology and Geophysics, Woods Hole Oceanographic Institute, Woods Hole, Massachusetts 02543. Brian T. Huber, Department of Paleobiology, MRC NHB 121, National Museum of Natural History, Smithsonian Institution, Washington, D.C. 20560.

Reviewer: William V. Sliter (deceased), U.S. Geological Survey, Menlo Park, California.
The first official meeting of the Paleogene Planktonic Foraminifera Working Group was held at the Institute of Geology and Paleontology at the University of Tübingen, Tübingen, Germany. In order to achieve a meaningful reconstruction of the taxonomy and phylogeny of Paleogene planktonic foraminifera the working group decided to focus on unraveling the origins and evolution of the earliest Paleocene (Danian) taxa so as to identify lineages of species that could be traced into the later Paleocene and ultimately through the Paleogene.

An important step in the understanding of Danian taxonomy came about with the visit by W.A. Berggren and F. Rögl to study type collections of V.G. Morozova housed in Moscow and with the study of Russian species in the collections of W.A. Berggren and H.P. Luterbacher. The work of Ch. Hemleben provided a preliminary understanding of a classification of living species, which was based on whether or not spines were used in their biological behavior, a division that Parker (1962) clearly showed could be applied to living plankonic foraminifera based on the presence or absence of spines. His work focused on the identification in fossilized specimens of the spinose condition, because spines are used only when the individual is alive and are shed during gametogenesis. The presence of spine holes and spine bases in and on the chamber walls of fossil specimens indicated a spinose condition. The importance of wall structure was emphasized by Steineck and Fleisher (1978) in their seminal paper on a phylogenetically based classification of planktonic foraminifera. An important breakthrough in using wall texture and structure in the taxonomic classification of Paleocene planktonic foraminifera was announced at the 1989 meeting of the working group in Tübingen. This was the discovery by Ch. Hemleben and R.K. Olsson of spinose wall texture in specimens of Eoglobigerina eobulloides (Morozova) from Zone P $\alpha$ in the Danian section at 
Millers Ferry, Alabama. This discovery showed that the spinose condition had developed in planktonic foraminifera following the terminal Cretaceous mass extinction. It was an innovation not present in Cretaceous planktonic foraminifera, and it meant that a phylogenetic classification based on wall texture might be applied to Danian planktonic foraminifera. In addition to E. eubulloides, Parasubbotina pseudobulloides (Plummer) was subsequently shown to have a spinose wall texture. This discovery abruptly uprooted long-held notions about Paleocene planktonic foraminiferal phylogenies (Bolli, 1957a; Blow, 1979) in which P. pseudobulloides was considered the ancestor of the nonspinose post-Danian muricate morozovellid radiation. The study by F.T. Banner (1989) of the planktonic foraminiferal genus Globanomalina clarified the taxonomy of the smooth-walled group of Paleocene planktonic foraminifera and showed that wall texture was highly important in tracing phylogeny and in identifing lineages. His work identified the earliest Danian species, Globanomalina archeocompressa (Blow), as the first species of a smooth-walled nonspinose lineage. By the next meeting in 1990 in Tübingen the first Danian cancellate nonspinose species, Praemurica taurica (Morozova), was identified. It was now clear that Danian planktonic foraminifera consisted of four groups based on wall texture. These four groups had the same kind of wall texture as did the four groups of living planktonic foraminifera (Hemleben et al., 1991). The wall textures are microperforate, normal perforate smooth-walled nonspinose, normal perforate cancellate nonspinose, and normal perforate cancellate spinose. Using this classification (Olsson et al., 1992), the new genera Parasubbotina and Praemurica were erected to represent two distinct Danian lineages.

During the 1991 and 1992 meetings in Tübingen and the 1993 meeting of the working group at the Cushman Laboratory, National Museum of Natural History (NMNH), Smithsonian Institution, Washington, D.C., details of the Danian phylogeny had been worked out (Pearson, 1993), and the origin of the smooth-walled, cancellate nonspinose, and cancellate spinose groups from Hedbergella was demonstrated (Liu and Olsson, 1994); however, two opposing interpretations of the origin of the morozovellids remain unresolved as this atlas goes to press. At issue is the derivation of this group from either Praemurica, the traditional view, or from Globanomalina, which is a newly developed view. The traditional view, based on the original hypothesis of Bolli (1957a), is emphasized in the recent work of Norris (1996) and Kelly et al. (1996). The alternate view, which is based on the studies of Olsson and Hemleben (1996), emphasizes the development of the characteristic heavy pustulose wall texture of these groups from a smooth-walled Globanomalina ancestor. These views and their alternate phylogenetic interpretations are presented in "Wall Texture, Classification, and Phylogeny," below.

During the first meeting of the working group it was recognized that the microperforate wall texture separated a distinct group of planktonic foraminifera that dominate the lowest Danian assemblages. This group was viewed as opportunistic following the terminal Cretaceous mass extinction of planktonic foraminifera. It included Chiloguembelina, Globoconusa, Guembelitria, Parvularugoglobigerina, and Woodringina. Confusion over the difference between the normal perforate and microperforate species had led Brinkhuis and Zachariasse (1988) and Keller (1988) to erroneously identify microperforate specimens from the lower Danian at El Kef as normal perforate species (cancellate spinose and cancellate nonspinose). Thus, clarification and phylogeny of the microperforate group became an objective of our working group. By 1992 the phylogeny of the microperforates from the Cretaceous survivor species Guembelitria cretacea (Cushman) had been constructed (D’Hondt, 1991; Liu and Olsson, 1992). Confusion with regard to the possible Cretaceous origin of Chiloguembelina, however, prompted a careful morphologic comparison of Danian Chiloguembelina with the species Chiloguembelina waiparaenis Jenkins, which, although described from the Danian of New Zealand, occurs in the uppermost Cretaceous at Ocean Drilling Program (ODP) Site 758 in the Southern Ocean. At the 1993 meeting in Washington, D.C., it was shown that waiparaensis has a distinctive morphology separating it from Chiloguembelina and that it is properly placed in the genus Zeauvigerina, which has a Cretaceous to Paleocene range. Zeauvigerina, which is restricted to the southern latitudes, is tentatively placed in the Heterohelicidae as it does not have a phylogenetic relationship with the Guembelitriidae (Huber and Boersma, 1994).

Work on the origin and phylogeny of Acarinina by W.A. Berggren and R.D. Norris led to an important revision of Paleocene Zone P4. They showed that the consecutive appearances of $A$. subsphaerica Subbotina and $A$. soldadoensis (Brönnimann) allow Zone $\mathrm{P} 4$ to be divided into three subzones. This plus other refinements has resulted in an updated version of the Berggren and Miller (1988) zonation of the Paleocene (Berggren and Norris, 1993; Berggren et al., 1995), which is summarized in this volume (Figure 1).

An important development in the clarification of Russian species appears on Plates 8-12, where many holotypes are illustrated by SEM for the first time. F. Rögl was able to borrow the type material described by Morozova in the collections of the Geological Institute, Academy of Sciences (GAN) in Moscow and the type material described by Subbotina in the collections of VNIGRI in St. Petersburg and was able to obtain low KV SEM images of these species. One big surprise is that the widely used but poorly understood species, Globigerina fringa Subbotina, has a coarsely cancellate wall and thus is not closely related to any of the earliest Danian taxa. In fact, this species appears to be described from an upper Danian stratigraphic level and has affinities with Subbotina cancellata. This illustrates the pitfalls for workers who use poorly illustrated drawings of Russian species in identifying taxa for biostratigraphic studies. These SEM images of Russian types and the personal observations of Russian taxa by W.A. 


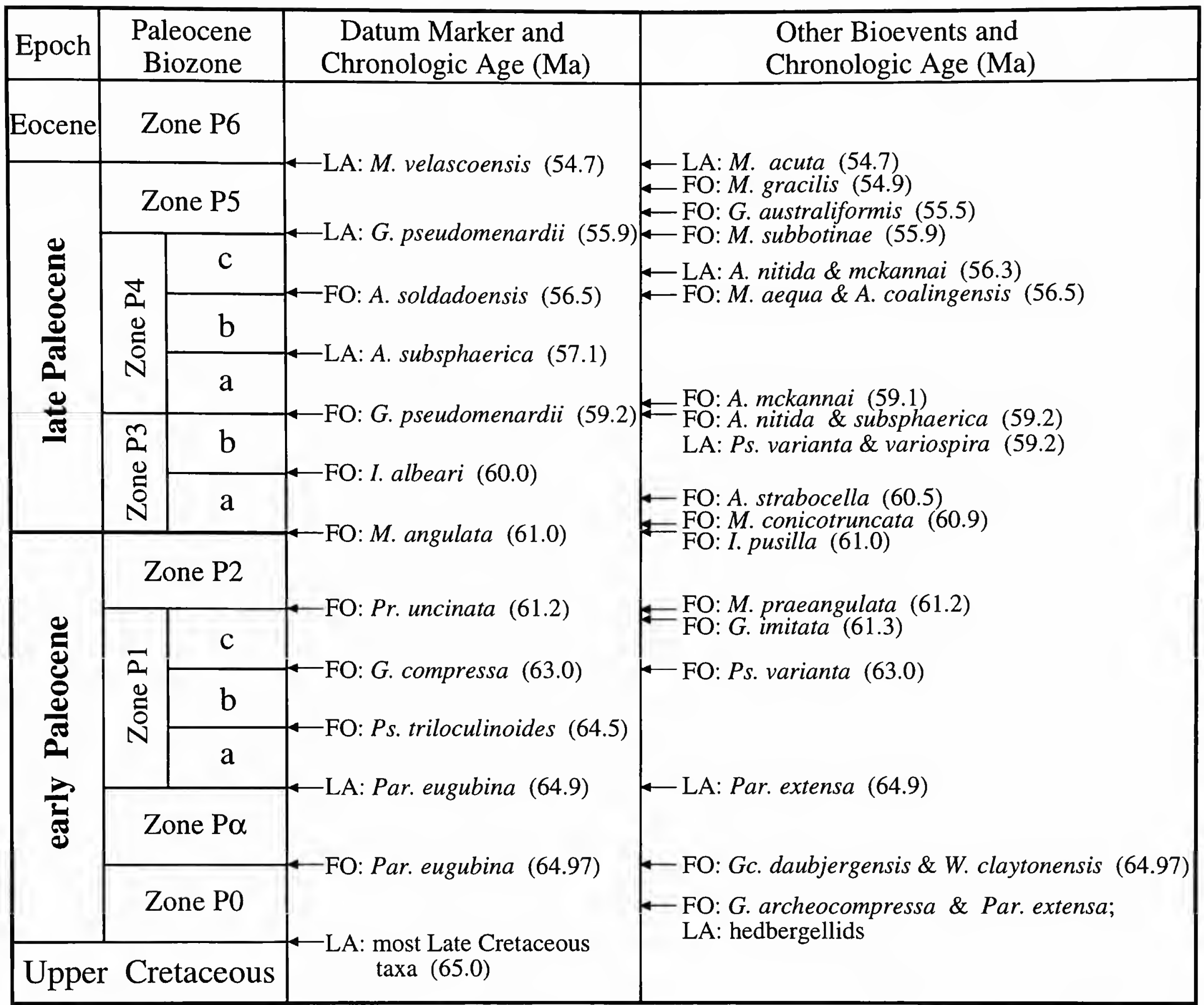

FIGURE 1.-Paleocene biostratigraphic zonation showing the first occurrence (FO) and last appearance (LA) of zonal species and other important bioevents.

Berggren and F. Rögl have greatly improved the understanding of these species, their taxonomy, and their synonymy. In addition to the SEM images of Russian types (Plates 8-12), low KV SEM images taken by B.T. Huber of types in the Cushman collections are also shown (Plates 13-17). The atlas also includes SEM images of topotypes of Globanomalina australiformis (Jenkins), Hedbergella holmdelensis Olsson, Hedbergella monmouthensis (Olsson), Morozovella acutispira (Bolli and Cita), Woodringina hornerstownensis Olsson, and specimens of Parvularugoglobigerina eugubina (Luterbacher and Premoli Silva) from the type level at Gubbio, Italy.

The atlas includes a section on the newly revised zonation for the Paleocene (Figure 1), with range charts showing the maximum known range of each species organized according to generic classification, which, in turn, is organized by walltexture groups (Figure 2). Other range charts show the order of the first appearances of taxa (Figure 3 ) and the last appearances of taxa (Figure 4). The section on wall texture and classification describes the basis for the classification used in this atlas and illustrates in Plates 1-6 the comparison of the types of wall texture in living species and Paleocene species of planktonic foraminifera. The section on taxonomy includes the species considered valid by the working group and includes a synonymy of species considered to be junior synonyms by personal observation of working group members. Most of the species are illustrated by a plate of figures in order to illustrate 
the range of morphologic variability of the species. Species that are obscure or are poorly known are not included because their validity is unproven. These species names are mentioned in the taxonomic discussion under the species considered to be the probable senior synonym. Paleobiogeographic maps showing the known distribution of nominate species representative of each genus is included under that species. Reconstruction of paleobiogeographic maps was generated using the PGIS/Mac ${ }^{\mathrm{TM}}$ software package. Land-sea distributions are modified from Barron (1987). Occurrences are plotted only for welldocumented identifications either by SEM showing unequivocal images, by unequivocal drawings, or by personal observation of a working group member. Lists of identified species without illustrations were not used. Interested workers can update these maps through their own research. A database for each figure on the plates is archived at the Cushman Laboratory, at Rutgers University, and at the University of Tübingen.

The working group was saddened by the sudden death of Graham Jenkins in August 1995. He played an active role at the meetings of the working group in his capacity as secretary of the International Subcommission on Paleogene Stratigraphy and was valued for his expert knowledge of Paleocene Southern Ocean planktonic foraminifera.

\section{ACKNOWLEDGMENTS}

The Paleogene Planktonic Foraminiferal Working Group (PPFWG) is indebted to Hans Bolli (Zurich), Walter Blow (deceased), and Nina Subbotina (deceased) whose pioneering contributions to the study of Paleogene planktonic foraminifera spanned nearly a half-century from the mid-1930s to the mid-1980s and laid the groundwork and provided the inspiration for the taxonomic revision presented in this Atlas. The Paleogene Planktonic Foraminifera Working Group was organized in 1987 at a meeting at the British Petroleum (BP) Research Centre in Sunbury on Thames, U.K. We thank J. Athersuch of BP for hosting this important first meeting. The next five meetings of the working group were held at the Institute und Museum für Geologie und Paläontologie, Universität Tübingen, Tübingen, Germany, where Ch. Hemleben graciously hosted those meetings. The invaluable logistical assistance of J. Breitinger and D. Mühlen at those meetings is deeply appreciated. We thank $H$. Hütteman for his assistance in examining specimens using a scanning electron microscope and H.P. Luterbacher, Universität Tübingen, for access to his collections of Russian species and samples from the type level of the "Globigerina" eugubina Zone. Brian T. Huber hosted the seventh meeting of the working group at the National Museum of Natural History, Smithsonian Institution, Washington, D.C., and R.K. Olsson hosted the final meeting at Rutgers University, Piscataway, New Jersey.

Discussions with Nina Subbotina (St. Petersburg, deceased), Valery Krasheninnikov (Moscow), and Khalil Alliyula (Baku, deceased) were helpful in elucidating problems of taxonomy among species housed in the collections of VNIGRI (St. Petersburg), AN (GI) (Moscow), and AN (GI) (Baku), respectively, during various visits $(1958-1988)$ by W.A. Berggren. We appreciate the assistance of S.P. Jakovleva, VNIGRI, St. Petersburg, and N. Muzylöv, Geological Institute, Russian Academy of Sciences, Moscow, to F. Rögl in obtaining a loan of Russian type material. These specimens are shown on Plates 8-12 of the atlas. Scanning electron micrographs (SEM) of primary types at the National Museum of Natural History (collections of the former United States National Museum (USNM)) shown on Plates 13-17 were taken and mounted by B.T. Huber. Scanning electron microscopy by S. D'Hondt at the University of Rhode Island was assisted by P. Johnson.

Material used in preparing scanning electron micrographs of Paleocene species were supplied by members of the working group. Specimens were selected from personal collections and from Deep Sea Drilling Project (DSDP) and ODP sites. These are illustrated on Plates 17-71. Micrographs for wall texture and preservation illustrated on Plates $1-7$ are from the collections of $\mathrm{Ch}$. Hemleben. We deeply appreciate the indefatigable work of $\mathrm{H}$. Hüttemann, Universität Tübingen, in taking of the thousands of micrographs needed for composing the plates for the atlas. These plates were prepared in the laboratory of Ch. Hemleben. We thank J. Breitinger, D. Mühlen, and B. Rödiger for their assistance. We acknowledge the opportunity to investigate specimens collected by $\mathrm{W}$. Weiss.

The following research support is acknowledged: W.A. Berggren (Marine Geology and Geophysics Branch, Ocean Sciences Division of NSF), Ch. Hemleben (Deutsche Forschungsgemeinschaft (DFG) He 697/15), S. D'Hondt (supported in part by the Earth Sciences Division of NSF), and R.D. Norris (Earth Sciences Division of NSF). We thank the Ocean Drilling Program for supplying samples used in this study.

A number of scientists with interest in Paleogene planktonic foraminifera attended some of the meetings and participated in the discussions of the working group. They include A.J. Arnold, Florida State University, Tallahassee, Florida, U.S.A.; F.T. Banner, University College of London, London, U.K.; C. Benjamini, Ben Gurion University of the Negev, Beer Sheva, Israel; A. Boersma, Microclimates Research Consultants, Stony Point, New York, U.S.A.; R. Corfield, University of Oxford, Oxford, U.K.; R.L. Fleisher, Chevron U.S.A. Inc., Houston, Texas, U.S.A.; S. Gaboarrdi, University of Milano, Milan, Italy; A. v. Hillebrandt, Technical University of Berlin, Berlin, Germany; C. Kelly, University of North Carolina, North Carolina, U.S.A.; E. Kitchell, University of Michigan, Michigan, U.S.A.; Q. Li, Imperial School of Science and Technology, London, U.K.; H. Luterbacher, Universität Tübingen, Tübingen, Germany; E. Molina Martinez, University of Zaragoza, Zaragoza, Spain; N. MacLeod, University of Michigan, Ann Arbor, Michigan, U.S.A.; I. Premoli Silva, University of Milano, Milan, Italy; S. Radford, Imperial School 


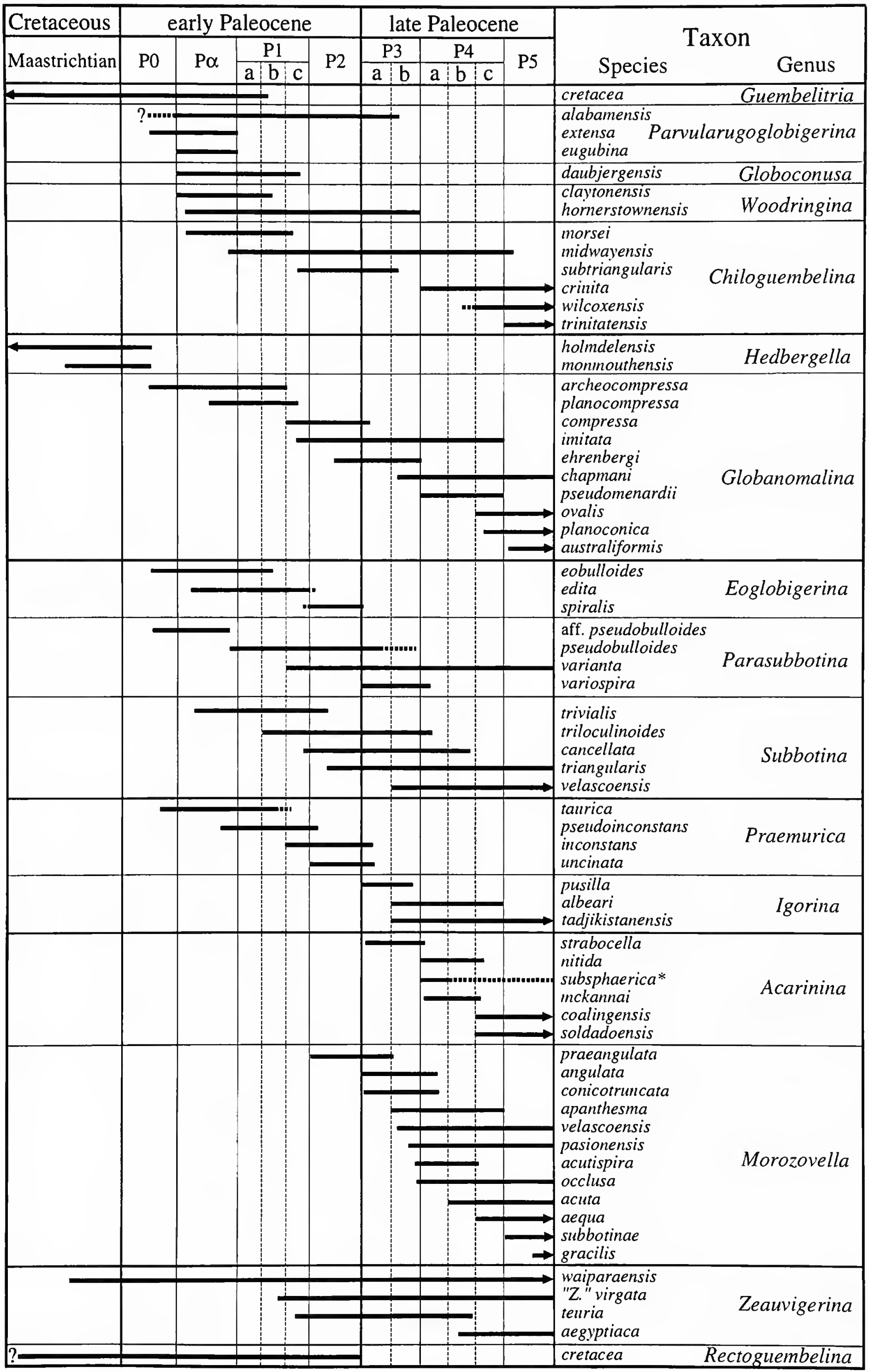

FIGURE 2.-Stratigraphic ranges of Paleocene planktonic foraminiferal species by genus. (* dashed line represents range extension at southern high latitude sites.) 


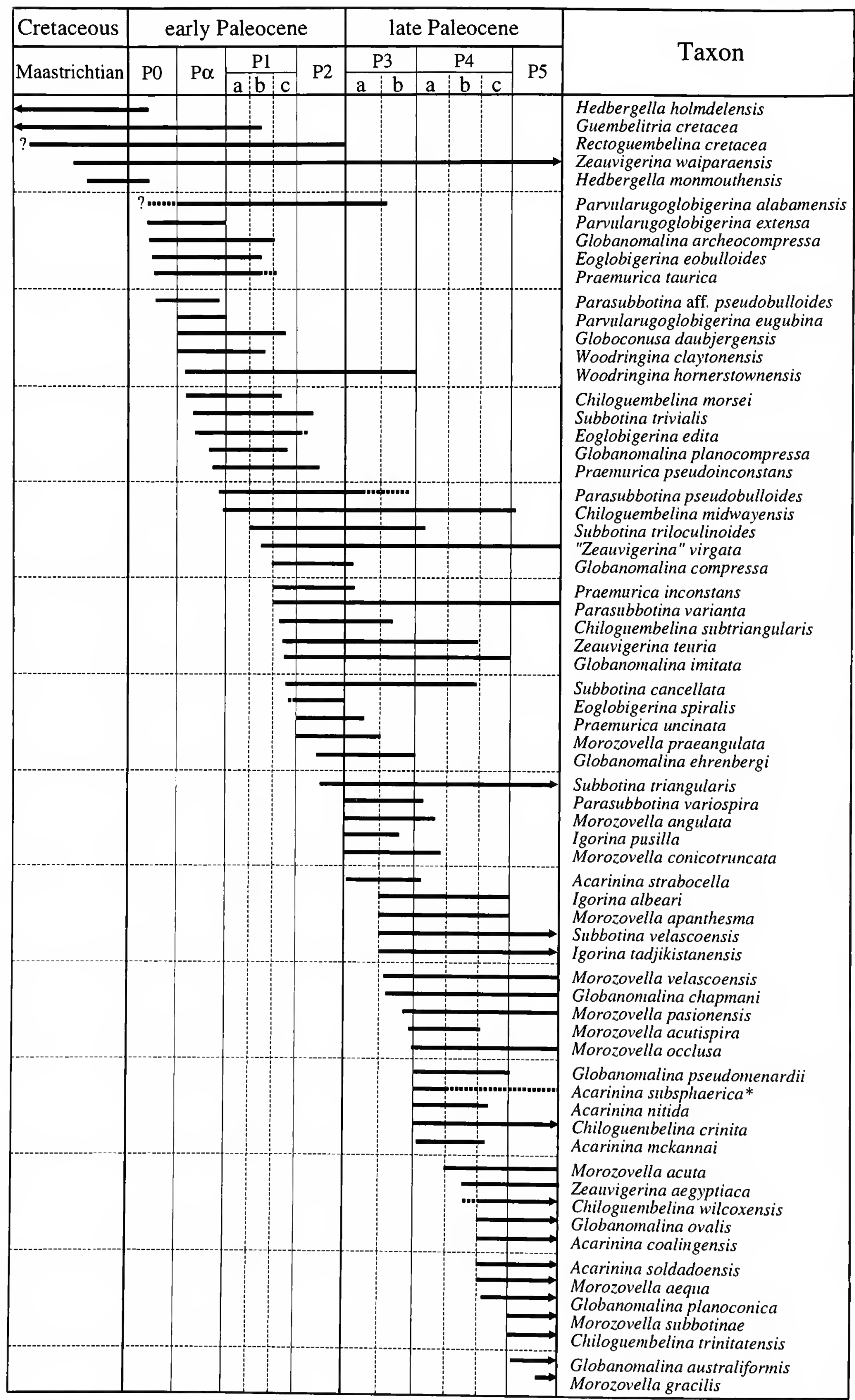

FIGURE 3.-Stratigraphic ranges of Paleocene planktonic foraminiferal species by first occurrence. $\left({ }^{*}\right.$ dashed line represents range extension at southern high latitude sites.) 


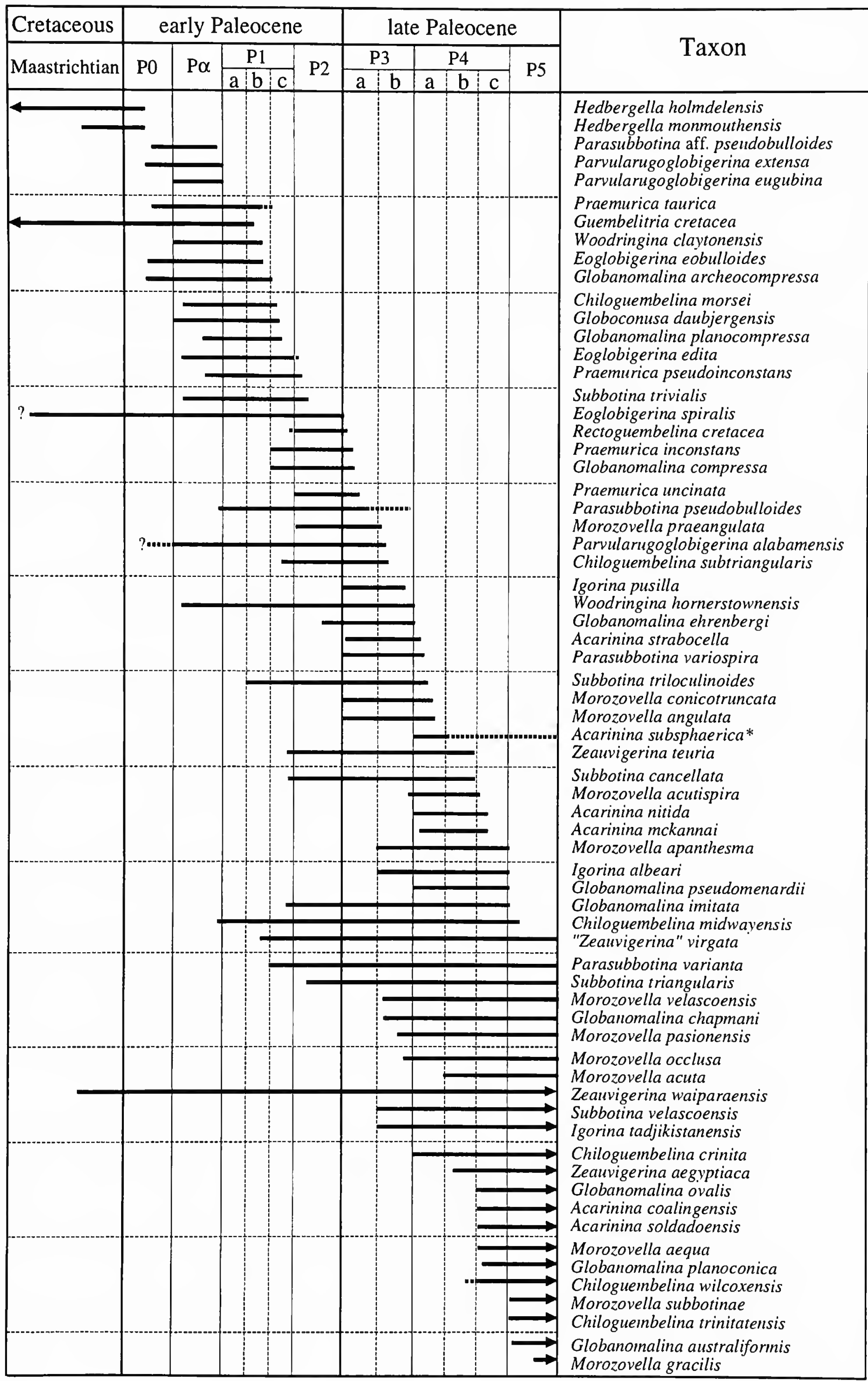

FIGURE 4.-Stratigraphic ranges of Paleocene planktonic foraminiferal species by last occurrence. $\left({ }^{*}\right.$ dashed line represents range extension at southern high latitude sites.) 
of Science and Technology, London, U.K.; S. Spezzaferri, University of Milano, Milan, Italy; and S. Sturrock, British Petroleum Ltd., Sunbury, U.K. We thank J.V. Browning, Rutgers University, for his assistance in the preparation of figures.

ABBREVIATIONS.-Index of abbreviations used in the atlas for foraminifer collections and collection examiners is as follows.

Foraminifer Collections:

$\begin{array}{ll}\text { BP } & \text { British Petroleum, London, England } \\ \text { CC } & \text { Cushman Collection Catalog (USNM) } \\ \text { CPC } & \text { Commonwealth Paleontological Collection, } \\ & \text { Canberra, Australia } \\ \text { GAN } & \text { Geological Institute, Academy of Sciences, } \\ & \text { Moscow, Russia } \\ \text { P } & \text { Protozoa Catalog (USNM) } \\ \text { UC } & \text { Collections of the University of Chicago } \\ & \text { Walker Museum in the Field Museum, } \\ & \text { Chicago, Illinois }\end{array}$

USNM Collections of the former United States National Museum now in the National Museum of Natural History, Smithsonian Institution, Washington, D.C.

UWA University of Western Australia, Perth, Australia

VNIGNI Vsesoyuznogo Neftyanogo NauchnoIssledovatel'skogo Geologo Instituta (All Union Petroleum Scientific Research Geological Institute), St. Petersburg, Russia

VNIGRI Vsesoyuznogo Neftyanogo NauchnoIssledovatel'skogo Geologo-Razvedochnogo Instituta (All Union Petroleum Scientific Research Geological Prospecting Institute), St. Petersburg, Russia

$\begin{array}{ll}\text { Examiners: } & \\ \text { BTH } & \text { Brian T. Huber } \\ \text { CL } & \text { Chengjie Liu } \\ \text { FR } & \text { Fred Rögl } \\ \text { GJ } & \text { Graham Jenkins } \\ \text { RDN } & \text { Richard D. Norris } \\ \text { RKO } & \text { Richard K. Olsson } \\ \text { SD } & \text { Steven D'Hondt } \\ \text { WAB } & \text { William A. Berggren }\end{array}$

\section{BIOSTRATIGRAPHY}

(by W.A. Berggren and R.D. Norris)

The use of planktonic foraminifera in biostratigraphy may be said to be an essentially post-World War II phenomenon (although there were several pre-war contributions of less than lasting value) that resulted from the recognition of their usefulness in local and regional biostratigraphic zonation and correlation. These studies were often, but not exclusively, connected with the exploration for petroleum, particularly in the North Caucasus, Crimea, Tadzhik Depression, and other southwestern portions of the former Soviet Union (Subbotina, 1947, 1953; Morozova, 1959, 1961; Leonov and Alimarina, 1960; Alimarina, 1962, 1963), in the Caribbean region (Brönnimann, 1952; Bolli, 1957a, 1957b), and in the Gulf of Mexico and Atlantic Coastal Plain regions (Loeblich and Tappan, 1957a). Various biostratigraphic zonal schemes were developed by the authors cited above and by others, and these have been rapidly ensconced in the classic biostratigraphic hagiography of the past half century. Since the advent of the DSDP (1968) and its successor program the ODP (1985present) the various zonal schemes have found widespread application in regional and global biostratigraphic studies. In the following section we present a brief review of the major Paleocene biostratigraphic zonal schemes developed over the past 50 years. It should be remembered that some of these schemes were developed as part of a larger zonal scheme-the Paleogene or the Cenozoic-so that reference to the larger framework is unavoidable in certain instances.

A detailed zonal biostratigraphy of the Danian and Montian stages (as recognized) in the Crimea, North Caucasus, and "Boreal" areas (Russian Platform and Precaspian Basin) was developed by Morozova $(1959,1960)$. In these and subsequent studies (Morozova, 1961), she recognized several taxa that have become important in lower Paleocene (lower Danian Stage) biostratigraphy, such as Eoglobigerina eobulloides and Globigerina taurica.

Coarsely muricate acarininids have figured prominently in middle to late Paleocene zonal biostratigraphies, particularly that of the "official" Paleogene zonation of the former Soviet Union (Permanent Interdepartmental Stratigraphic Commission for the Paleogene of the USSR, 1963). This is because of the general paucity of keeled morozovellids (M. acuta, $M$. velascoensis) and of globanomalinids (G. pseudomenardii) in the formation(s) above the strata bearing Morozovella angulata-M. conicotruncata in the northern foothills of the Caucasus Mountains (Subbotina, 1953; Alimarina, 1963) and in southwestern Crimea (Morozova, 1959, 1960). This latter scheme would appear to have drawn heavily upon the detailed studies by the authors cited above as well as those of Shutskaya (1956, Precaucasus; 1962, Crimea, Precaucasus, and Transcaspian Region; 1965, Turkmenistan). (The taxonomic treatment of taxa is not up-to-date, and the identification of some taxa shouldn't be attempted when preservation is so poor.) Shutskaya subsequently presented a detailed synthesis of her decade-long studies in the southwestern Soviet Union, including a detailed zonal scheme for the Paleocene to lower Eocene in her doctoral thesis (1965) and then concluded with an exhaustive historical overview of the Paleogene (bio)stratigraphic succession and zonal characteristics of the Crimea, northern Precaucasus, and western part of Central Asia (1970a). In the latter work she included 40 plates containing detailed illustrations of the faunal content (planktonic and 
benthic taxa) of each Paleocene and lower Eocene zone from each region, making it possible to better understand the basis for biostratigraphic subdivision of the Paleogene of the southwestern Soviet Union. It also allows for correlation of her zonal scheme with that subsequently proposed in the West over the past 35 years. Krasheninnikov $(1965,1969)$ also made significant contributions to Paleocene biostratigraphy of the southwestern area of the former Soviet Union as well as other (sub)tropical areas of the world.

Paleocene planktonic foraminiferal biostratigraphy in the West was essentially baptized in the form of a detailed zonation developed for the Paleocene and lower Eocene of Trinidad by Bolli (1957a; modified in 1966), which was followed soon after by a zonal scheme developed for (sub)tropical regions by Berggren (1969a, 1971a; modified and (re)defined by Berggren and Miller, 1988) and Blow (1979). Premoli Silva and Bolli (1973) made minor changes to the earlier zonation of Bolli (1957a) with the insertion of the Globorotalia edgari Zone between the Globorotalia velascoensis Zone (below) and the Globorotalia rex (= G. subbotinae) Zone (above; see Toumarkine and Luterbacher, 1985). Jenkins (1971) formulated a relatively broad zonal biostratigraphic scheme for the Paleocene (as part of a larger Cenozoic study) of New Zealand. With the recognition that Paleocene low latitude, (sub)tropical zonation(s) are not fully applicable at high latitudes, Stott and Kennett (1990) developed a zonal biostratigraphy for high (austral) latitudes of the Antarctic.

We have adopted the following seven-fold (sub)tropical biostratigraphic zonation of the Paleocene (Figure 1), which is based on the studies of Berggren and Norris (1993) who redefined the zonal boundary definitions of Zones $\mathrm{P} 3 \mathrm{a} / \mathrm{b}, \mathrm{P} 4 / 5$, and proposed a threefold subdivision of Zone P4. This zonal biostratigraphy has been more fully defined and elaborated upon in Berggren et al. (1995). The definition of the seven Paleocene zones (and their subdivisions), magnetochronologic calibration, and estimated age is presented below. Additional information on the characterization of these zones may be found in Berggren et al. (1995). Modifications to this scheme have been proposed by $\mathrm{Lu}$ and Keller (1995) based on their study of DSDP Site 577. Additional information on the history of Paleogene/Paleocene planktonic foraminiferal biostratigraphy may be found in Berggren and Miller (1988).

P0. Guembelitria cretacea Partial Range Zone (P0, Keller, 1988; emendation of Smit, 1982).

Definition: Biostratigraphic interval characterized by the partial range of the nominate taxon between the Last Appearance Datum (LAD) of Cretaceous taxa (Globotruncana, Rugoglobigerina, Globigerinelloides, among others) at the $\mathrm{K} / \mathrm{P}$ boundary as delineated by the essentially global iridium spike and the First Appearance Datum (FAD) of Parvularugoglobigerina eugubina.

Magnetochronologic calibration: Chron C29r (late).

Estimated age: 65.0-64.97 mya; earliest Paleocene (Danian).
P $\alpha$. Parvularugoglobigerina eugubina Total Range Zone (Liu, 1993; emendation of $\mathrm{P} \alpha$ of Blow, 1979; Luterbacher and Premoli Silva, 1964).

Definition: Biostratigraphic interval characterized by the total range of the nominate taxon, Parvularugoglobigerina eugubina.

Magnetochronologic calibration: Chron C29r (late).

Estimated age: 64.97-64.9 mya; earliest Paleocene (Danian).

P1. Parvularugoglobigerina eugubina-Praemurica uncinata Interval Zone (P1, defined in Berggren et al., 1995; emendation of Berggren and Miller, 1988).

Definition: Biostratigraphic interval between the LAD of Parvularugoglobigerina eugubina and the FAD of Praemurica uncinata.

Magnetochronologic calibration: Chron C29r (late)-Chron $\mathrm{C} 27 \mathrm{n}(0)$.

Estimated age: 64.9-61.2 mya; early Paleocene (Danian).

Pla. Parvularugoglobigerina eugubina-Subbotina triloculinoides Interval Subzone (Pla, defined in Berggren et al., 1995; emendation of Parasubbotina pseudobulloides Subzone (P1a) in Berggren and Miller, 1988).

Definition: Biostratigraphic interval between the LAD of Parvularugoglobigerina eugubina and the FAD of Subbotina triloculinoides.

Magnetochronologic calibration: Chron C29r (late)Chron C29n (middle).

Estimated age: 64.9-64.5 mya; early Paleocene (early Danian).

Plb. Subbotina triloculinoides-Globanomalina compressa/Praemurica inconstans Interval Subzone (Plb, defined in Berggren et al., 1995; emendation of, but equivalent to, Subzone Plb in Berggren and Miller, 1988).

Definition: Biostratigraphic interval between the FAD of Subbotina triloculinoides and the FADs of Globanomalina compressa and/or Praemurica inconstans.

Magnetochronologic calibration: Chron C29n (middle)Chron C28n (middle).

Estimated age: 64.5-63.0 mya; early Paleocene (Danian).

P1c. Globanomalina compressa/Praemurica inconstansPraemurica uncinata Interval Subzone (Plc, defined in Berggren et al., 1995; emendation of, but equivalent to, Subzone Plc in Berggren and Miller, 1988).

Definition: Biostratigraphic interval between the FAD of Globanomalina compressa and/or Praemurica inconstans and the FAD of Praemurica uncinata.

Magnetochronologic calibration: Chron C28n (middle)Chron C27n(o).

Estimated age: 63.0-61.2 mya; early Paleocene (Danian). 
P2. Praemurica uncinata-Morozovella angulata Interval Zone (P2, defined in Berggren et al., 1995; emendation of, but biostratigraphically equivalent to, Zone P2 in Berggren and Miller, 1988).

Definition: Biostratigraphic interval between the FAD of Praemurica uncinata and the FAD of Morozovella angulata.

Magnetochronologic calibration: Chron C27n(o)-Chron $\mathrm{C} 27 \mathrm{n}(\mathrm{y})$.

Estimated age: 61.2-61.0 mya; late early Paleocene (late Danian).

P3. Morozovella angulata-Globanomalina pseudomenardii Interval Zone (P3, defined in Berggren et al., 1995; emendation of Zone P3 in Berggren and Miller, 1988).

Definition: Biostratigraphic interval between the FAD of Praemurica angulata and the FAD of Globanomalina pseudomenardii.

Magnetochronologic calibration: Chron C27n(y)-Chron C26r (middle).

Estimated age: 61.0-59.2 mya; late Paleocene (Selandian).

P3a. Morozovella angulata-Igorina albeari Interval Subzone (P3a, defined in Berggren et al., 1995).

Definition: Biostratigraphic interval between FAD of Morozovella angulata and FAD of Igorina albeari.

Magnetochronologic calibration: Chron $\mathrm{C} 27 \mathrm{n}(\mathrm{y})-\mathrm{Chron}$ C26r (early).

Estimated age: 61.0-60.0 mya; early late Paleocene (Selandian).

P3b. Igorina albeari-Globanomalina pseudomenardii Interval Subzone (P3b, defined in Berggren et al., 1995).

Definition: Biostratigraphic interval between FAD of Igorina albeari and the FAD of Globanomalina pseudomenardii.

Magnetochronologic calibration: Chron C26r (early)Chron C26r (middle).

Estimated age: 60.0-59.2 mya; late Paleocene (Selandian).

P4. Globanomalina pseudomenardii Total Range Zone (P4, Bolli, 1957a).

Definition: Biostratigraphic interval characterized by the total range of the nominate taxon, Globanomalina pseudomenardii.

Magnetochronologic calibration: Chron C26r (middle)Chron C25n(y).

Estimated age: 59.2-55.9 mya; middle part of late Paleocene (late Selandian-Thanetian).

P4a. Globanomalina pseudomenardii/Acarinina subsphaerica Concurrent Range Subzone ( $\mathrm{P} 4 \mathrm{a}$, defined in Berggren et al., 1995).

Definition: Biostratigraphic interval characterized by the concurrent range of the nominate taxa between the FAD of Globanomalina pseudomenardii and the LAD of Acarinina subsphaerica.
Magnetochronologic calibration: Chron C26r (middle)Chron C25r (early).

Estimated age: 59.2-57.1 mya; late Paleocene (latest Selandian-early Thanetian).

P4b. Acarinina subsphaerica-Acarinina soldadoensis Interval Subzone (P4b, herein defined).

Definition: Biostratigraphic interval between the LAD of Acarinina subsphaerica and the FAD of Acarinina soldadoensis.

Magnetochronologic calibration: Chron C25r (early)Chron C25r (late).

Estimated age: 57.1-56.5 mya; late Paleocene (Thanetian).

P4c. Acarinina soldadoensis/Globanomalina pseudomenardii Concurrent Range Subzone (P4c, defined in Berggren et al., 1995).

Definition: Biostratigraphic interval characterized by the concurrent range of the nominate taxa between the FAD of Acarinina soldadoensis and the LAD of Globanomalina pseudomenardii.

Magnetochronologic calibration: Chron C25r (late)Chron C25n(y).

Estimated age: 56.5-55.9 mya; late Paleocene (late Thanetian).

P5. Morozovella velascoensis Interval Zone (P5, Bolli, 1957a; P5 and P6a of Berggren and Miller, 1988).

Definition: Biostratigraphic interval between the LAD of Globanomalina pseudomenardii and the LAD of Morozovella velascoensis.

Magnetochronologic calibration: Chron $\mathrm{C} 25 \mathrm{n}(\mathrm{y})-\mathrm{Chron}$ C24r (middle).

Estimated age: 55.9-54.7 mya; latest Paleocene-earliest Eocene (latest Thanetian-earliest Ypresian).

\section{Wall Texture, Classification, and Phylogeny}

(by Ch. Hemleben, R.K. Olsson, W.A. Berggren, and R.D. Norris)

The recovery of early Paleocene planktonic foraminifera following the end of the Cretaceous mass extinctions led to fundamental changes in the wall structure of the test, changes linked to the way in which the earliest Paleocene species adapted to the water-mass environment. These changes in wall structure, consequently, reflect biological activity. Five species are known to have survived into the Paleocene. We believe that the planktonic foraminiferal species that came to occupy the Paleocene oceans were derived from three survivors, which rapidly gave rise to distinct lineages. The structural differences in the test wall allow basic groups to be recognized. Two groups are separated by pore size, one being microperforate (pore diameter $<1 \mu \mathrm{m}$ ) and the other normal perforate (pore diameter 2-7 $\mu \mathrm{m}$ ). The microperforate species, which evolved from the survivor-species Guembelitria cretacea, have been 
dealt with in various studies (D'Hondt, 1991; Liu and Olsson, 1992). In the earliest Paleocene (Danian), trochospiral and biserial microperforate taxa evolved from a triserial taxon. Although there are fundamental changes that occurred in the shape of the test, the wall structural changes are moderate (a thin wall pierced by micropores, and pustule growth in rounded mounds or short, sharp protuberances).

Wall structure changes in normal perforate planktonic foraminifera were often quite dramatic. Most notable is the development of a cancellate wall that is a distinctive and diagnostic feature of the Cenozoic. This feature, which developed in two groups, one with spines and the other without spines, indicates that the biological activities of planktonic species that possessed this structure were significantly different from the biological activities in Cretaceous species where this structure is absent. Another dramatic wall structural change was the development of the "pseudospinose" (Benjamini and Reiss, 1979) or "muricate" wall (Blow, 1979), identified by a heavy pustulose growth. All the taxa in this group can be separated phylogenetically on the basis of their distinctive pustulose wall texture. Perhaps the most dramatic change in wall structure was the development of spines, which was accompanied by growth of a cancellate wall. Wall growth in species using spines is different from wall growth in nonspinose pustule bearing species. Pustules are layered structures, which form during ontogeny as part of the wall, in contrast to spines, which are elongated single crystals planted in the shell wall (Hemleben, 1969; Hemleben, et al., 1991). Pustulose growth is rare in spinose species. Due to the development of these distinctive wall structures Paleocene normal perforate planktonic foraminifera can be classified and organized in phylogenetic lineages.

A classification based on functional morphology is somewhat more complex than one based on simple test morphology as it presumes that one can correctly interpret the function of a structure in an extinct species. In the Paleocene this is made easier because direct comparison can be made to living planktonic species in which there is much data on the function of test morphology and biological activity (Hemleben et al., $1977,1985,1989,1991)$. The basic underlying bilamellar wall concept of Reiss (1957) can be applied to all known Paleocene planktonic foraminiferal species. The introduction of spines in the earliest Danian allowed planktonic foraminifera to develop a different habit of food gathering and to invade different habitats. It is possible that some species may have collected symbionts as is suggested by the carbon isotopic studies of D'Hondt and Zachos (1993) on Eoglobigerina eobulloides. Thus, photosymbiosis may have developed along with the evolution of some of the first spinose planktonic species of the Cenozoic. Species having symbionts would have been bound to the photic zone.

The nonspinose planktonic foraminifera are distinguished by two basic types of wall texture, smooth-walled and cancellatewalled. In the smooth-walled type, pustules may be absent, sparsely developed, or heavily developed as is observed in modern Globorotalia. Heavy pustule development in the Paleocene led to the "muricate structure," which characterizes the genera Acarinina and Morozovella. The cancellate texture develops by lateral growth of small pustules into smooth ridges upon which additional pustules may grow. This texture is observed in the modern Neogloboquadrina dutertrei.

It would appear, then, that some adaptations that evolved in Paleocene species of planktonic foraminifera are similar, if not identical in some cases, to the adaptations that are shown by living species of planktonic foraminifera. Because wall texture reflects the adaptive strategies exhibited in the biological activity of living species, it may be an important guide to phylogenetic study. We regard this relationship as a unifying concept in the classification and phylogenetic study of Cenozoic planktonic foraminifera. Although more work needs to be done on wall texture and morphologic change in the evolution of Paleogene planktonic species, it seems clear from the results of the Paleogene Planktonic Foraminifera Working Group that wall texture provides a guide to understanding the evolution and phylogeny of Paleocene planktonic foraminiferal species and for their classification (Plates 1-6).

\section{GLOBOROTALIID WALL TEXTURE}

The globorotaliid type, which includes the juvenile up to the neanic stage (Brummer et al., 1986), is characterized by a smooth nonspinose wall with more or less scattered pustules. Pustules increase in number during ontogeny, serving as anchor points for rhizopods (Plate 1: Figures 1, 2, 5, 6; Plate 3). During continued growth, more pustules form on the center of the spiral side, around the aperture, and, if a keel is present, on the keel. The last growth stage may be characterized by a coarse crystal growth or the pustules may coalesce to form a coarse crystalline outer layer (Plate 3: Figures 10, 11, 14). The abundance of pustules varies from species to species. The interpustule area is usually smooth with no or very low relief. Some typical living representatives of this type are Globorotalia hirsuta, G. menardii, G. truncatulinoides and others (Hemleben et al., 1977, 1985, 1991), and their ancestors. The Paleocene genus Globanomalina has this type of wall texture (Plate 4: Figures 4-13, 16). The smooth-walled genus Globanomalina was derived from the late Maastrichtian hedbergellid, Hedbergella holmdelensis, with the first species being G. archeocompressa (Plate 4: Figures 4, 5). In this transition, the morphologic characters of the descendant species (compressed test with an imperforate peripheral band and with an extraumbilical aperture bordered by a narrow lip) are derived from the ancestral species. The wall of $H$. holmdelensis is smooth with scattered small pustules on the chamber walls (Plate 4: Figures 1-3). In $G$. archeocompressa the pustules become confined to the umbilical area rather than being scattered over the entire test. A change to somewhat more angular-shaped chambers accompanies the transition. Although the change in overall morphology is small, the wall becomes 
distinctly smooth, a character that identifies species of Globanomalina and its possible descendant, Pseudohastigerina.

\section{Muricate Wall TeXtures}

In the Paleocene, a heavily pustulose wall texture occurs in the genera Acarinina and Morozovella (Plates 39-55). The test wall is characterized by large very coarse pustules that may cover the entire test, be concentrated on the umbilical shoulders, or be confined to the periphery of the test and forming a keel (Plate 4: Figures 14, 15; Plate 5: Figures 1-4). The pustules grow on a smooth globorotaliid surface. In the first species of Acarinina, A. strabocella, the early ontogenetic stage has a rather smooth wall resembling that of modern globorotaliid species, but later in ontogeny (or chamber calcification) the typical pustule pattern appears, which is similar to that in modern Globorotalia inflata (Plate 3: Figures $3,4,7)$. The pustules are spread over the entire test; however, they are arranged in lines leading towards the aperture and are especially large and thick in front of the aperture (see Plate 43: Figure 4). This development is a short step to the more typical heavily pustulose acarininids in which the pustules become broad and elongate (Plates 39-42, 44). The wall texture develops by the growth of conical to blade-like pustules at triple points between the pores. As these pustules grow larger they coalesce into larger structures, which give the muricate wall a somewhat cancellate appearance. Pustule enlargement is greatest around the umbilicus and often completely closes off the pores.

In the evolution of Morozovella two groups of species are separated by different types of muricate wall texture. The muricate wall texture in the Morozovella aequa line of species develops by growth of conical pustules of various sizes at triple points between pores on rather smooth chamber walls (Plates $47-49,54)$. Heavier pustule growth occurs on the umbilical shoulders of the chambers and along the test periphery forming an imperforate muricate keel in some species. In the Morozovella velascoensis line of species the surface of the chambers are smooth (Plates 45, 46, 50-52, 55). Very heavy conical pustule growth occurs on the umbilical shoulders of the chambers and along the axial periphery of the test forming a strong, imperforate muricate keel. Scattered small pustules also may occur on the chamber surfaces. Extensions of the muricate keel occur on the spiral side of the test along the chamber sutures and the spiral suture. The genus Morozovella is further characterized by the development of conical-shaped chambers.

\section{Neogloboquadrinid Wall TeXture (Praemuricate)}

This type of wall texture is seen in the living species Neogloboquadrina dutertrei (Plate 5: Figures 5-11). The growth pattern during ontogeny consists of the development of longer or shorter subparallel low ridges of plate-like crystals, often oriented towards the aperture (Plate 5: Figures 9, 10).
They become more and more prominent as short ridges connecting the subparallel ones start to grow and, eventually, form a honeycomb cancellate wall structure (Hemleben et al., 1991). The short ridges are less developed and may extend only part way from one elongate ridge to the other (Plate 5: Figures $9,10)$. It is a very common structure in Paleogene and Neogene planktonic foraminifera. This type of wall texture occurs in the Paleocene genera Igorina and Praemurica (Plates 56-62). A calcite crust (Plate 5: Figures 8,11), which is a normal feature in Neogloboquadrina, has not yet been observed in Paleocene species. This is probably due to the warmer Paleocene surface waters as this crust is a feature usually developed in the cold waters of the modern ocean. In the modern $N$. dutertrei, however, as pustule growth becomes more and more prominent the test wall becomes thicker and encrusted, a feature that also is observed in Igorina (Plates 56-58). In Zone P0 the transition from the ancestral Maastrichtian Hedbergella monmouthensis to Praemurica involves the buildup of subparallel pustulose ridges and short connective ridges, thus producing the cancellate texture (Plate 5: Figures 12, 18; Plate 6: Figures 1-4). In Praemurica taurica (Plate 61), the first Praemurica species, the test remains a very low trochospiral with an extraumbilical aperture, but selection is to a H. monmouthensis morphotype with a lower rate of chamber expansion in the ultimate whorl (six-chambered test). In order to avoid confusion with the term neogloboquadrinid we propose the use of praemuricate for Paleocene taxa with this wall texture.

\section{SPINOSE WALL TEXTURE}

The spinose habit indicates that a group of new planktonic foraminifera intruded into the carnivorous food niche. The food catching process is supported by long calcitic spines along which flows the rhizopodial cytoplasm. Actively swimming zooplankton are snared and held without losing control of a struggling zooplankton organism. The spines are separated from the wall and are planted like telephone poles (Plate 1: Figures 3, 4, 7-20). During the reproductive process (gametogenesis) the spines are dissolved, leaving a vacated spine hole as an indication of the spinose condition, and gametogenetic calcite is deposited along the interpore ridges (Plate 2: Figures 2-16). More fundamental changes in wall texture and test morphology took place in the transition from Hedbergella monmouthensis to the spinose genera Eoglobigerina and Parasubbotina (Plates 18-23). The fundamental morphologic characters (trochospiral test with an extraumbilical aperture bordered by a narrow lip) are maintained in the descendent species, but the evolution of wall texture involves the innovation of a cancellate spinose wall. In H. monmouthensis the wall is lightly pustulose throughout the test, and low depressions or primitive pore pits occur in the chamber walls especially surrounding the umbilicus (Plate 31 ). The test is a very low trochospiral with rapidly inflating chambers in the ultimate whorl, but as noted in Liu and Olsson (1994), there is a range of morphotypes that show (1) a reduced rate of 
chamber-size increase with generally six chambers in the ultimate whorl, and (2) a moderately elevated trochospiral test with five chambers in the ultimate whorl. In the transition to the first spinose species, Eoglobigerina eobulloides, the moderately elevated trochospiral test becomes weakly cancellate and spinose (Plate 19). The cancellate texture is enhanced by gametogenetic calcification. Due to the moderately elevated trochospiral test the aperture shifts to a more umbilical position and is only slightly extraumbilical. In the derivation of Parasubbotina (Plates 21, 22) the rate of chamber increase is much more rapid than in Eoglobigerina, which produces a very low trochospiral test with large globular chambers in the ultimate whorl. The wall becomes weakly cancellate and spinose. The aperture remains extraumbilical. Subbotina (Plate 2: Figures 3-6, 15, 16; Plates 24-29) evolves from Eoglobigerina by a reduction in the number of chambers in the final whorl, a shifting of the aperture towards an umbilical position, and the development of a stronger cancellate-wall texture.

\section{PRESERVATION AND DIAGENESIS}

Preservation of fossil planktonic foraminifera plays an important role in taxonomic and phylogenetic studies. The effect of the lysocline and the carbonate compensation depth controls the preservation or partial preservation of an assemblage of planktonic foraminifera. Absence of a species could be due to its greater susceptibility to dissolution than other species, thereby leading directly to loss of information. Preservation of planktonic foraminifera can be loosely measured by visual inspection under the light microscope and more recently by the SEM. It is especially important to assess the degree of preservation of foraminifera tests in isotopic analyses, but it is also important in various other studies utilizing planktonic foraminifera. For instance, in taxonomic and phylogenetic studies, the degree of preservation may appear to be excellent (pristine) preservation under the light microscope but may actually be rather poor when examined using the SEM under high magnification. In working out phylogenetic lineages it is important to be able to recognize the original wall texture in order to assess whether an ancestordescendant relationship exists. Preservation is an important factor in census work where many individuals of a species have to be accurately identified for the data to be meaningful. Census work should not be attempted where the tests of foraminifera are heavily recrystallized and overgrown, thus making identification very subjective due to similar morphology of different species. Plate 7 illustrates common types of diagenetic alteration of a planktonic foraminiferal test.

Recrystallization can vary from slight to heavy (Plate 7: Figures $1,2,5-8,10-15)$. If the degree of recrystallization is substantial, subhedral and euhedral calcite crystals form and obscure the original wall (Plate 7: Figure 12). Overgrowth of calcite (Plate 7: Figures 4, 8, 10) further obscures the original wall. Corrosion of a test removes the outer wall layers (Plate 7: Figures $3,5,6)$ thereby destroying the original wall texture.
Dissolution (Plate 7: Figures 3,9) may destroy parts of the test wall leaving holes or may strip away outer wall layers, altering the appearance of the specimen. Accurate identification is precluded under such circumstances. Plates 1-6 illustrate well-preserved original wall texture that can be used as a guide in assessing the effects of diagenesis on samples of fossil planktonic foraminifera.

\section{PhylogenY}

The phylogeny of the normal perforate Paleocene planktonic foraminifera is shown in Figure $5 a, b$ and that of the microperforate Paleocene planktonic foraminifera is shown in Figure 6. Comments on the phylogeny of the microperforates are given under each species in the Taxonomy section (also see D'Hondt, 1991; Liu and Olsson, 1992). The lineages of the normal perforates based on the study of wall texture is given below along with comments on the major morphologic changes that occurred in the evolution of the species in each lineage.

\section{Spinose Lineages}

CANCellate Lineages

Eoglobigerina

(Plates 18-20)

E. eobulloides-E. edita-E. spiralis lineage is characterized by

(1) a cancellate spinose test;

(2) development of a higher trochospiral test in E. edita and E. spiralis;

(3) a reduced rate of chamber expansion in E. edita compared to E. eobulloides;

(4) a more strongly developed cancellate wall that is enhanced by gametogenetic calcification in E. edita and E. spiralis.

E. eobulloides-Subbotina lineage is characterized in the transition to Subbotina by

(1) a more strongly developed spinose cancellate wall;

(2) a reduced number of chambers in the ultimate whorl;

(3) development of a tripartite test due to a more rapid rate of chamber-size increase;

(4) a more umbilically directed aperture in Subbotina.

NOTE.- In E. eobulloides the aperture has an umbilical to slightly extraumbilical position due to the moderately elevated trochospire. In Subbotina the increase in the rate of expansion of chambers causes the aperture to shift to a more umbilical position. This trend culminates in S. triloculinoides by producing a large ultimate chamber with an umbilically directed aperture. The lip maintains its position relative to the apertural opening. With a greater expansion rate of chambers, the initial moderately elevated coil is enveloped by the expanding chambers thus producing a test with an apparent low trochospire. 


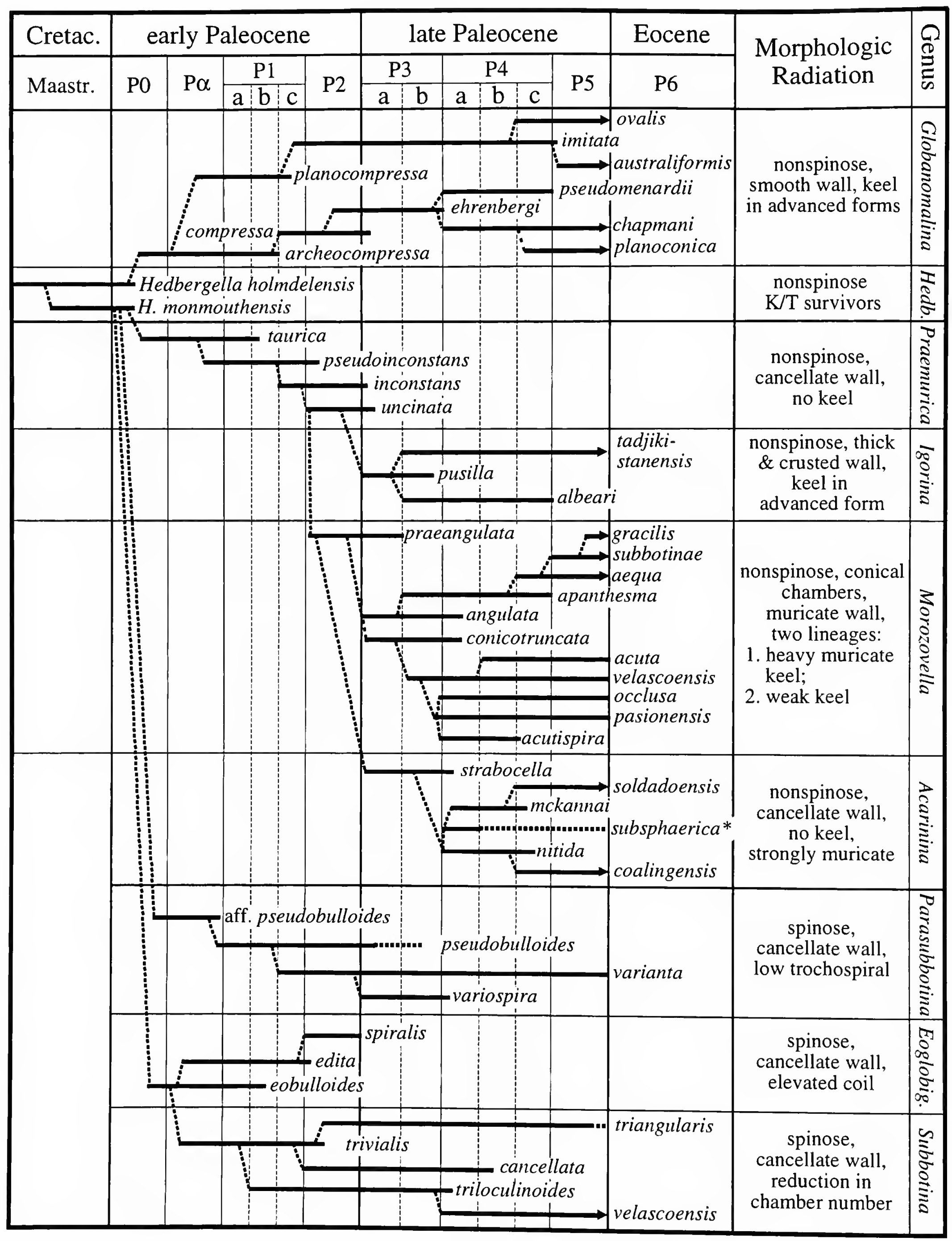

FIGURE 5a.-Phylogenetic reconstruction of normal perforate planktonic foraminifera showing the origin of Morozovella from Praemurica uncinata following the hypothesis of Bolli (1957a). See text for explanation. ( ${ }^{*}$ dashed line represents range extension at southern high latitude sites.) 


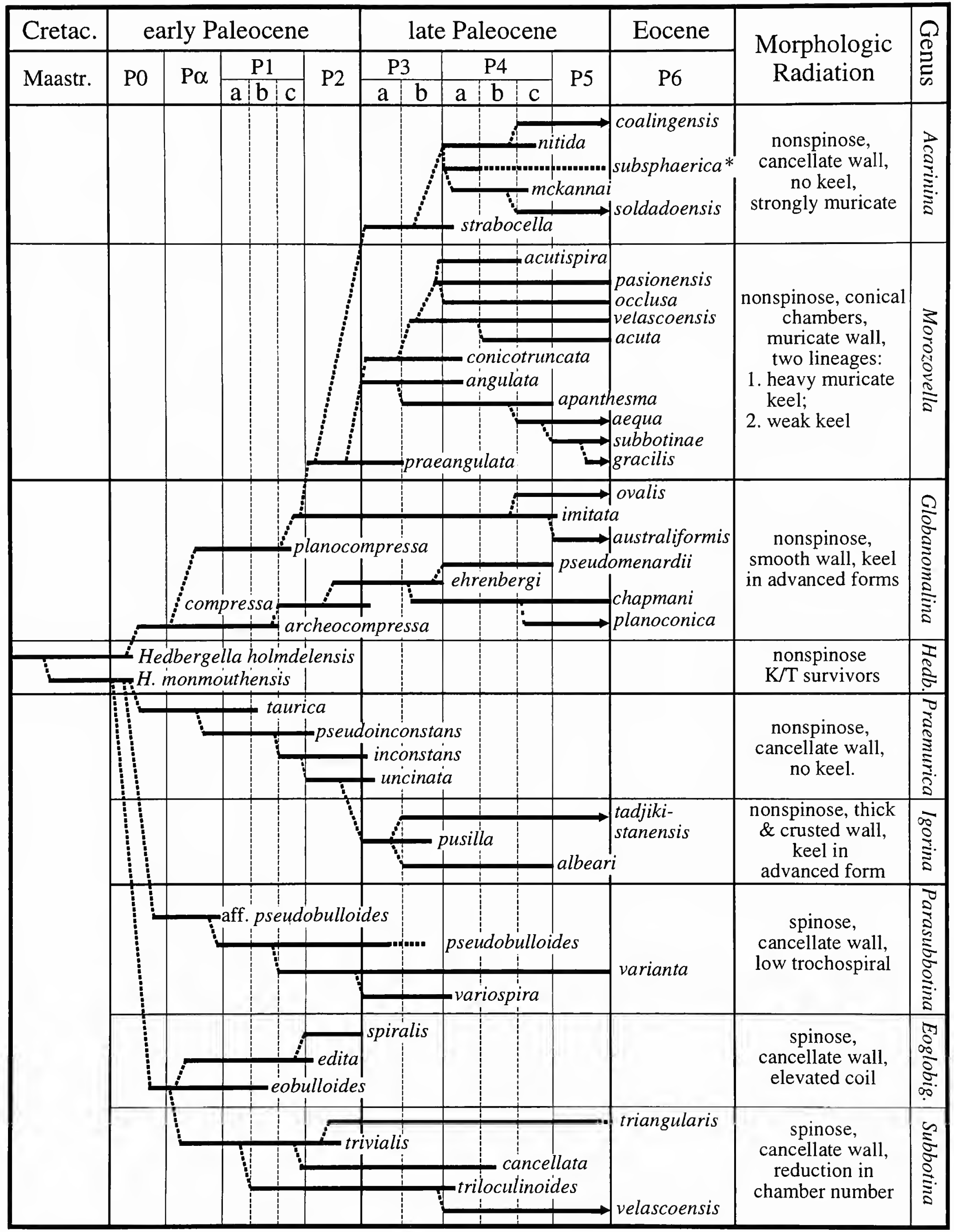

FIGURE 5b.-Phylogenetic reconstruction of normal perforate planktonic foraminifera showing the origin of Morozovella from Globanomalina imitata following the interpretation of Olsson and Hemleben (1996). See text for explanation. (* dashed line represents range extension at southern high latitude sites.) 


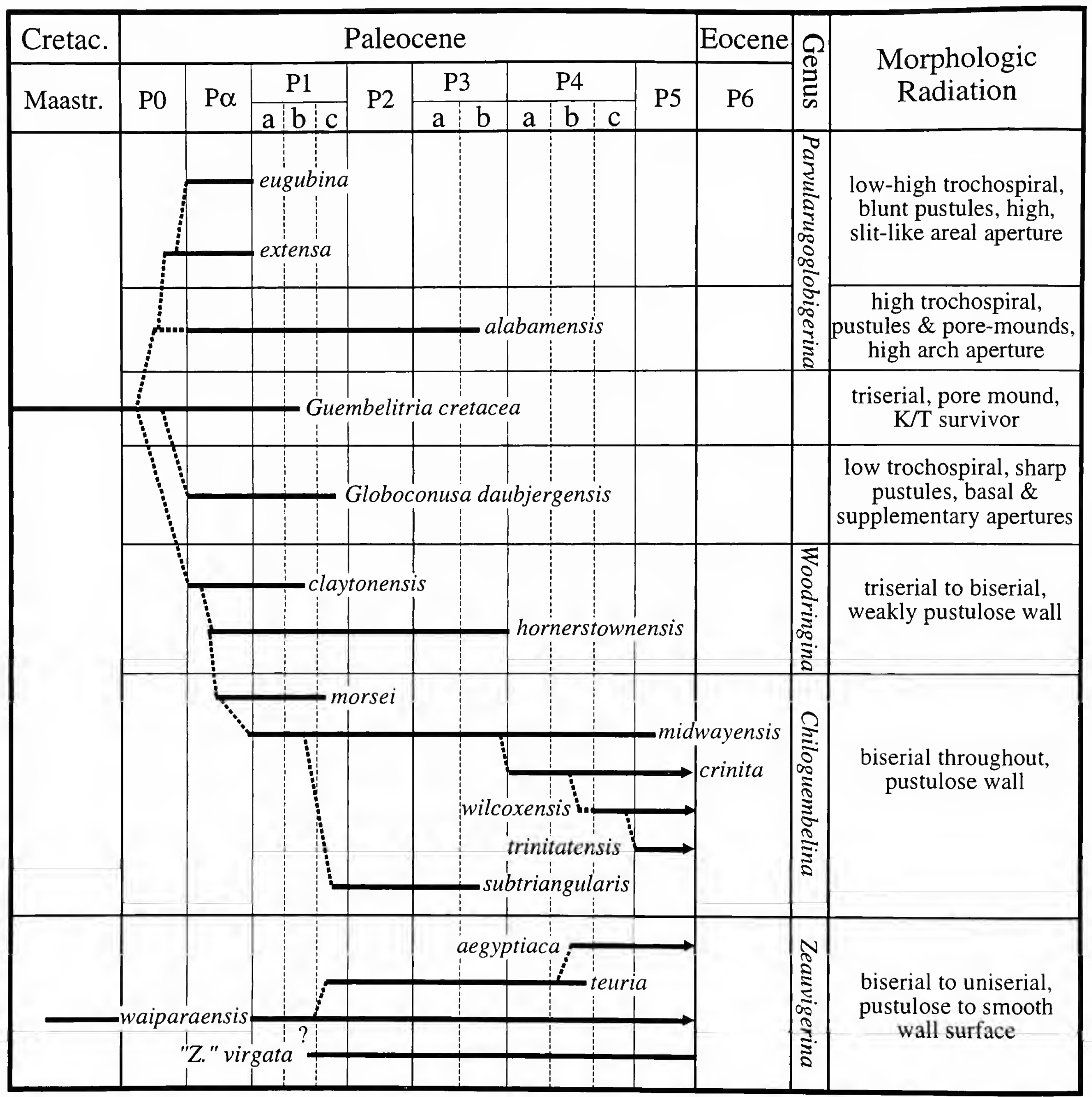

FIGURE 6.-Phylogenetic reconstruction of microperforate planktonic foraminifera and Zeauvigerina. 


\section{Parasubbotina}

(Plates 21-23)

$P$. aff. pseudobulloides- $P$. pseudobulloides $-P$. varianta lineage is characterized by

(1) a weakly developed cancellate spinose wall in $P$. aff. pseudobulloides;

(2) development of a pronounced cancellate spinose wall that is enhanced by gametogenetic calcification in $P$. pseudobulloides;

(3) an increase in test size in P. pseudobulloides;

(4) a decreased number of chambers in the ultimate whorl in $P$. varianta;

$P$. varianta- $P$. variospira lineage is characterized by

(1) an increased expansion of the chamber coil and a shift to a moderately elevated trochospire in $P$. variospira;

(2) a decreased rate of expansion of chambers in $P$. variospira;

(3) a test-size increase in $P$. variospira;

(4) development of tooth-like apertural lips in P. variospira.

NOTE.-Parasubbotina is distinguished from Subbotina by its very low trochospire, the greater number of chambers in the ultimate whorl, and high-arched umbilicalextraumbilical aperture.

\section{Subbotina}

(Plates 24-29)

$S$. trivialis-S. aff. cancellata-S. cancellata-S. velascoensis lineage is characterized by

(1) development of a coarsely cancellate spinose wall in $S$. cancellata;

(2) a more rapid rate of chamber-size increase that ultimately closes the umbilicus in $S$. velascoensis;

(3) a test-size increase in the lineage;

(4) development of flattened, oval-shaped chambers in $S$. velascoensis.

S. trivialis-S. triloculinoides lineage is characterized by

(1) a more strongly developed cancellate spinose wall in $S$. triloculinoides;

(2) a more rapid rate of chamber-size increase that ultimately closes the umbilicus in $S$. triloculinoides;

(3) a test-size increase in S. triloculinoides.

S. trivialis-S. triangularis lineage is characterized by

(1) development of an asymmetric cancellate spinose pore pattern with well-developed coalescing spine collars in $S$. triangularis;

(2) development of wider than high oval-shaped chambers in S. triangularis;

(3) increased test size in S. triangularis.

NOTE.-The widening of the chambers in $S$. triangularis causes the umbilicus to open more than in $S$. trivialis and also lengthens the lip so that it becomes long and narrow.

\section{Nonspinose Lineages}

PraEmuricate Lineages

Praemurica

(Plates 59-62)

$P$. taurica-P. pseudoinconstans $-P$. inconstans $-P$. uncinata lineage is characterized by

(1) development of a praemuricate cancellate nonspinose wall texture in $P$. taurica in the transition from Hedbergella monmouthensis;

(2) increased number of chambers in the final whorl in $P$. taurica;

(3) development of subconical-shaped chambers in the transition from $P$. inconstans to $P$. uncinata.

Igorina

(PlATES 56-58)

Praemurica uncinata-Igorina lineage is characterized by

(1) development of a thick, encrusted pustule layering over the praemuricate wall in the transition from Praemurica to Igorina;

(2) development of slightly conical to elongate oval-shaped chambers in Igorina;

(3) development of a somewhat elevated trochospire in Igorina.

I. pusilla-I. albeari lineage is characterized by

(1) low conical chambers in the lineage;

(2) development of a peripheral keel in I. albeari.

I. pusilla-l. tadjikistanensis lineage is characterized by

(1) development of inflated ovoid-conical chambers in $I$. tadjikistanensis.

\section{SMOOTH-WALLED LINEAGE}

\section{Globanomalina}

(Plates 32-38)

$G$. archeocompressa-G. compressa-G. ehrenbergi-G. pseudomenardii lineage is characterized by

(1) a compressed test with an imperforate peripheral margin that becomes keeled in G. pseudomenardii;

(2) increased size and rate of expansion of chambers in the lineage;

(3) a change in chamber shape from compressed ovoid in $G$. archeocompressa-G. ehrenbergi to low conical in $G$. pseudomenardii. 
G. compressa-G. chapmani-G. planoconica lineage is characterized by

(1) a compressed, nearly planispiral test with an imperforate peripheral margin that becomes thickened into a blunt keel in G. planoconica;

(2) increased size and rate of expansion of chambers in $G$. chapmani;

(3) decreased rate of expansion of chambers, increased number of chambers in the ultimate whorl, and reduced test size in $G$. planoconica.

$G$. archeocompressa-G. planocompressa-G. imitata-G. ovalis lineage is characterized by

(1) a low trochospiral, nearly planispiral test with rapidly inflating globular chambers in $G$. planocompressa- $G$. imitata;

(2) a largely perforate peripheral margin in the lineage;

(3) a large extraumbilical aperture that extends slightly onto the spiral side in $G$. ovalis.

G. imitata-G. australiformis lineage is characterized by

(1) development of low conical chambers in G. australiformis;

(2) development of fine pustules covering the test walls;

(3) increased test size in G. australiformis.

\section{MURICATE LINEAGES}

\section{Acarinina}

(Plates 39-44)

A subtle but significant coiling change, which is first observed in the ancestral species Acarinina strabocella, occurs in the development of Acarinina. In $A$. strabocella, the coil becomes slightly elevated, thereby shifting the aperture from an extraumbilical to a more umbilical position (Plate 43). This evolved character is maintained in all subsequent species of Acarinina.

Morozovella praeangulata-Acarinina strabocella lineage is characterized by

(1) development of a muricate wall texture in $M$. praeangulata;

(2) development of oval-elongate chambers in A. strabocella;

(3) development of a slightly elevated trochospire in $A$. strabocella;

(4) a more umbilically directed aperture in $A$. strabocella.

NOTE.-The muricate wall is developed by growth of pustules on a smooth surface at triple points between the pores; moderate to strong pustule growth occurs on the umbilical shoulders surrounding the aperture. The elevated trochospire in $A$. strabocella causes the aperture to take a more umbilical position and tends to close off the umbilicus.
A. strabocella-A. nitida lineage is characterized by

(1) development of muricate wall texture;

(2) development of a more elongate chamber shape than in A. strabocella.

A. nitida-A. subsphaerica lineage is characterized by

(1) development of a higher trochospire and a more tightly coiled test in $A$. subsphaerica.

A. subsphaerica-A. mckannai lineage is characterized by

(1) development of muricate wall texture;

(2) oval-elongate chambers that are derived from $A$. strabocella.

A. mckannai-A. soldadoensis lineage is characterized by

(1) a change in chamber shape to less elongate-oval in edge view in $A$. soldadoensis.

A. nitida- $A$. coalingensis lineage is characterized by

(1) a change to more elongate-oval chambers in spiral view and less elongate-oval chambers in edge view in $A$. coalingensis;

(2) increased rate of chamber-size leading to a more tightly coiled test in $A$. coalingensis.

\section{Morozovella}

(Plates 45-55)

As noted in the introduction, two opposing hypotheses of the phylogeny of the morozovellid lineage remain unresolved. The traditional view, based on the original hypothesis of Bolli (1957a), was adopted by Blow (1979), Toumarkine and Luterbacher (1985), and others. It derives Morozovella through the enhancement of the anguloconical chambers in the ultimate and penultimate whorls of Praemurica uncinata and further peripheral compression of the test, along with the development of a muricate test in Morozovella (see Plates 53 and 62). Other morphological features shared by the two genera relate to the interpretation of pore shape, development of muricae, umbilical morphology, and apertural morphology. In addition to these criteria, carbon and oxygen isotopic data are interpreted as supporting this phylogenetic hypothesis (Norris, 1996; Berggren and Norris, 1997). The alternate view (Olsson and Hemleben, 1996) emphasizes the development of the characteristic heavy pustulose wall texture of Morozovella from a smooth-walled Globanomalina ancestor, i.e., G. imitata. It is based on the observation that the wall texture of Morozovella develops through the growth of pustules on a smooth wall surface, thus linking this genus to Globanomalina. Anguloconical chambers and a lightly pustulose wall are observed in the inner whorl of G. imitata (see Plate 12: Figures 10-12; Plate 36). In contrast, the Praemurica wall texture develops as elongate subparallel ridges with short connective ridges, giving the wall a cancellate texture similar to the modern species 
Neogloboquadrina dutertrei. The two phylogenetic hypotheses are shown in Figure $5 a, b$.

\section{M. praeangulata is characterized by}

(1) development of a pustulose wall surface;

(2) development of conical chambers;

(3) maintenance of 5 chambers in ultimate whorl.

M. praeangulata-M. apanthesma-M. aequa-M. subbotinae lineage is characterized by

(1) development of high to moderately high conical chambers in the transition to Morozovella from Globanomalina;

(2) increased rate of chamber expansion in $M$. aequa and $M$. subbotinae.

M. apanthesma-M. gracilis lineage is characterized by

(1) development of moderately high conical chambers in $M$. gracilis;

(2) a change to a higher rate of expansion of chambers in $M$. gracilis.

$M$. praeangulata-M. angulata-M. conicotruncata-M. velascoensis-M. pasionensis lineage is characterized by

(1) development of high conical chambers in M. conicotruncata;

(2) development of a strong muricate keel in M. conicotruncata;

(3) development of strongly muricate umbilical shoulders in M. conicotruncata.

M. pasionensis-M. occlusa lineage is characterized by

(1) development of low conical chambers in M. occlusa;

(2) development of a more tightly coiled test that narrows the umbilicus in $M$. occlusa.

M. pasionensis-M. acutispira lineage is characterized by

(1) development of low conical chambers in M. acutispira;

(2) increased rate of chamber expansion in M. acutispira.

\section{Taxonomy}

\section{Family GlobigerinidaE Carpenter, Parker, and Jones, 1862}

(by R.K. Olsson, Ch. Hemleben, C. Liu, W.A. Berggren, and R.D. Norris)

ORIGINAL DESCRIPTION.- "Under the general designation Globigerinida we bring together, for the reasons already stated, all those hyaline or vitreous Foraminifera which have their shell-substance coarsely perforated for the exit of pseudopodia, so as to resemble that of Globigerina; a character by which they are differentiated from the Lagenida on the one hand, and from the Nummulinida on the other. They are further differentiated from the former of these families by the form and character of their aperture; for although there are instances in which the chambers communicate with each other, and the last chamber with the exterior, by circular pores, yet this is only in aberrant forms of the group; and the typical aperture is a crescent, which may either be contracted to a narrow fissure, or which may open-out so as to have the proportions of a gateway. There is not a like difference in the form of the aperture between Globigerinida and Nummulinida; but generally speaking, it is of much larger size, so as to permit a much freer communication between the segments of the body in the former group than in the latter." (Carpenter, Parker, and Jones, 1862:171.)

DiagnOSTIC CHARACTERS.-Test lobulate, trochospiral or planispiral, usually with $3 \frac{1}{1 / 2}-6$ globular chambers in final whorl; wall spinose, cancellate, or noncancellate; aperture interiomarginal, umbilical, a low to high arch, with or without a lip, may have supplementary apertures.

DISCUSSION.-A great variety of species and genera with diverse morphologies evolved from the simple trochospiral globigerine forms in the Paleocene. Only the genera Eoglobigerina, Parasubbotina, and Subbotina are represented in the Paleocene.

\section{Genus Eoglobigerina Morozova, 1959}

TYPE SPECIES.—Globigerina (Eoglobigerina) eobulloides Morozova, 1959, emended.

ORIGINAL DESCRIPTION.- “Test trochoid. Chambers subsphaerical. Wall thin, smooth. Aperture small, opening into the umbilicus or into the circumumbilical part of the marginal suture. From representatives of the subgenus Globigerina this one differs by its thin and smooth or not clearly microreticulate test wall and by the small size of the aperture. Family Globigerinidae. Senonian to Danian." (Morozova, 1959:1115; translated from Russian.)

DIAGNOSTIC CHARACTERS.-Low, trochospiral test with 10-16 chambers, $4-6^{1 / 2}$ globular chambers in ultimate whorl. Trochospire moderately to highly elevated; aperture interiomarginal, umbilical to slightly extraumbilical, a low, rounded arch bordered by a thin, narrow lip; umbilicus small and open to the apertures of surrounding chambers. Cancellate and spinose wall with spine holes situated along cancellate ridges.

Discussion.-Hemleben et al. (1991) demonstrated that Eoglobigerina had a spinose morphology, which separates it from other cancellate forms in the Danian that are nonspinose. The concept of Eoglobigerina followed herein is similar to that of previous workers except that it is emended to include the spinose character.

\section{Eoglobigerina edita (Subbotina, 1953)}

\section{Figure 7; Plate 8: figures 13-18; Plate 9: figures 1-6;} Plate 18: FIGURES 1-16

Globigerina edita Subbotina, 1953:62, pl. 2: fig. la-c [Zone of rotaliform Globorotalia (Danian Stage), Kuban River section, northern Caucasus].- 
Fox and Olsson, 1969:1398, pl. 168: figs. 1-4 [lower Paleocene, Cannonball Fm., North Dakota].-Shutskaya, 1970b, pl. 18: fig. 14a-c [middle subzone of Globigerina trivialis-Globoconusa conusa-Globorotalia compressa Zone, Malyi Balkhan Ridge, western Turkmenia] [in part, not pl. 18: fig. $12 a-c]$.

Globigerina edita Subbotina var. polycamera Khalilov, 1956:235, pl. 1: fig. la-c [Danian Stage, Akhchakuima, northeastern Azerbaizhan].-Shutskaya, 1970a:119, pl. 18: fig. 11a-c [middle subzone of Globogerina trivialisGloboconusa daubjergensis-Globorotalia compressa Zone, Khazin-Don River section, northern Caucasus].

Globigerina (Eoglobigerina) hemisphaerica Morozova, 1961:11, pl. 1: fig. 4 [Zone Dnl II, lower substage of Danian Stage, Tarkhankut Peninsula, Crimea].

Globigerina (Eoglobigerina) pentagona Morozova, 1961:13, pl. 1: fig. 3 [Zone Dn1 I, lower substage of Danian Stage, Tarkhankut Peninsula, Crimea].

Globigerina (Eoglobigerina) tetragona Morozova, 1961:13, pl. 1: fig. 2 [Zone Dn1 I, lower substage of Danian Stage, pre-Caspian Basin, Novouzensk].

Globigerina (Eoglobigerina) theodosica Morozova, 1961:11, pl. 1: fig. 6[Zone Dn1 I, lower substage of Danian Stage, Tarkhankut Peninsula, Crimea].

Globorotalia (Globorotalia) edita (Subbotina).-Hillebrandt, 1962:130, pl. 11: figs. 14, 15 [Zone A, lower Paleocene, Reichenhall-Salzburg Basin, Austro-German border].

Eoglobigerina edita edita (Subbotina).-Blow, 1979:1210, pl. 61: figs. 2, 3, pl. 66: fig. 1 [Zone P $\alpha$, DSDP Hole 47.2/11/3: 148-150 cm], pl. 69: fig. 6 [Zone P1, DSDP Hole 47.2/11/3: 0-5 cm], pl. 72: figs. 6, 8 [Zone P1, DSDP Hole 47.2/11/3: fig. 6, 148-150 cm; fig. 8, top section; Shatsky Rise, northwestern Pacific Ocean], pl. 79: fig. 3 [Zone P2, DSDP Hole 20C/6/4: 72-74 cm; Brazil Basin, South Atlantic Ocean].

Eoglobigerina edita (Subbotina).--Hemleben, Mühlen, Olsson, and Berggren, 1991:126, pl. 7: fig. 4-6 [Zone P $\alpha$, Clayton Basal Sands, Millers Ferry, Alabama].-Berggren, 1992:562, pl. 1: figs. 5, 6 [Zone Plb, ODP Hole $747 \mathrm{~A} / 19 \mathrm{H} / \mathrm{CC}$; Kerguelen Plateau, southern Indian Ocean].-Olsson, Hemleben, Berggren, and Liu, 1992:197, pl. 2: figs. 1-5, 7 [figs. 1-4, Zone $\mathrm{P} \alpha$, Clayton Basal Sands; figs. 5, 7, Zone Pla, Pine Barren Mbr., Clayton Fm., Alabama].

Eoglobigerina edita polycamera Khalilov.-Olsson, Hemleben, Berggren, and Liu, 1992:197, pl. 2: fig. 6 [Zone Pla, Pine Barren Mbr., Clayton Fm., Millers Ferry, Alabama].

ORIGINAL DESCRIPTION.- -"Shell small, rounded, with tall spiral consisting of $2 \frac{1 / 2}{2} 3$ whorls. The last whorl is made up of $4^{1 / 2-5}$ spherical chambers, usually of almost equal size. Peripheral margin rounded, scalloped. The most characteristic feature of this species is the turret-like dorsal surface which is associated with the large size of the chambers in the earlier whorls.

"The ventral side is feebly convex compared with the dorsal. The umbilicus is small and shallow but distinct. The chambers of the early whorls are compactly arranged and closely packed together, those of the last whorl are arranged much more freely giving a scalloped appearance to the peripheral margin. Sutures deep, slightly curved. The orifice has the form of a small slit which extends along the marginal suture. Walls smooth, with small pores. Mean dimensions: diameter $0.25 \mathrm{~mm}$, thickness $0.15 \mathrm{~mm}$." (Subbotina, 1953:62; translated from Russian.)

DIAGNOSTIC CHARACTERS. - Species characterized by moderately high trochospiral test with $4^{1 / 2-5}$ (occasionally up to 7) globular chambers increasing gradually in size in ultimate whorl, and a strongly lobulate peripheral margin. Rounded umbilical to slightly extraumbilical aperture bordered by narrow lip. Umbilicus small but open to previous chambers.
Cancellate wall weakly developed and spinose with numerous spine holes along cancellate ridges. Overall size of test generally $<250 \mu \mathrm{m}$.

DisCUSSION.-A considerable variation in the height of the initial coil and the position of the aperture from an umbilical toward an extraumbilical position occurs in this species. Blow (1979) discussed the high degree of variability among early eoglobigerinids and the apparent fact that few morphotypes exhibit a consistent expression of morphologic characters. Thus, he cautioned that strict morphologic limits cannot be as rigidly applied to early eoglobigerinids as to the later, more stable morphospecies of globigerinacean genera. Blow also distinguished as a subspecies of edita the morphospecies praeedita, which can be viewed as intermediate between eobulloides and edita. Eoglobigerina edita is an intermediate member of the eobulloides-edita-spiralis lineage, which terminated in Zone P2 (see also Pearson, 1993).

Examinations of the holotypes (Plate 8: Figures 13-18, Plate 9: Figures 1-6) of Eoglobigerina hemisphaerica Morozova, $E$. theodosica Morozova, E. tetragona Morozova, and E. pentagona Morozova suggest that these are junior synonyms of edita Subbotina. These Morozova species are all characterized by having a weakly cancellate test and an elevated initial whorl, which places them within the edita plexus. The difference between these morphotypes is the elevation of the spire (high in hemisphaerica and pentagona, lower in theodosica and tetragona) and the number of chambers in the ultimate whorl $\left(5^{1 / 2}\right.$ in hemisphaerica, 5 in theodosica, $4^{1 / 2}$ in pentagona, 4 in tetragona). The $5^{1 / 2}$-chambered, finely cancellate holotype of hemisphaerica has a distinctly elevated spiral side; Morozova (1961) drew attention to the "stepped nature" of the antepenultimate and penultimate whorls, which was said to serve to distinguish hemisphaerica from edita. We regard this as being within the range of variation of $E$. edita.

STABLE ISOTOPES.-No data.

STRATIGRA.PHIC RANGE.-Zone P $\alpha$ to Zone P1c; ? P2.

Global Distribution.-Worldwide in high and low latitudes (Figure 7).

ORIGIN OF SPECIES.-This species evolved from Eoglobigerina eobulloides near the base of Zone P $\alpha$ by an increase in the number of chambers in the last whorl and a slowing of the rate of growth of these chambers. In addition, there is a trend towards an elevated initial spire. An increase in the degree of spinosity is also evident in the evolution of $E$. edita.

REPOSITORY.-Holotype (No. 3975) deposited in the micropaleontological collections at VNIGRI, St. Petersburg, Russia. Examined by WAB.

\section{Eoglobigerina eobulloides (Morozova, 1959)}

Figure 8; Plate 8: figures 10-12; Plate 19: figures 1-15

Globigerina (Eoglobigerina) eobulloides Morozova, 1959:1115, text-fig. 1a-c [Zone I, zone of smooth-walled globigerinids (eoglobigerinids), lower Danian Stage (Uylinian Stage), Tarkhankut Peninsula, Crimea]. 


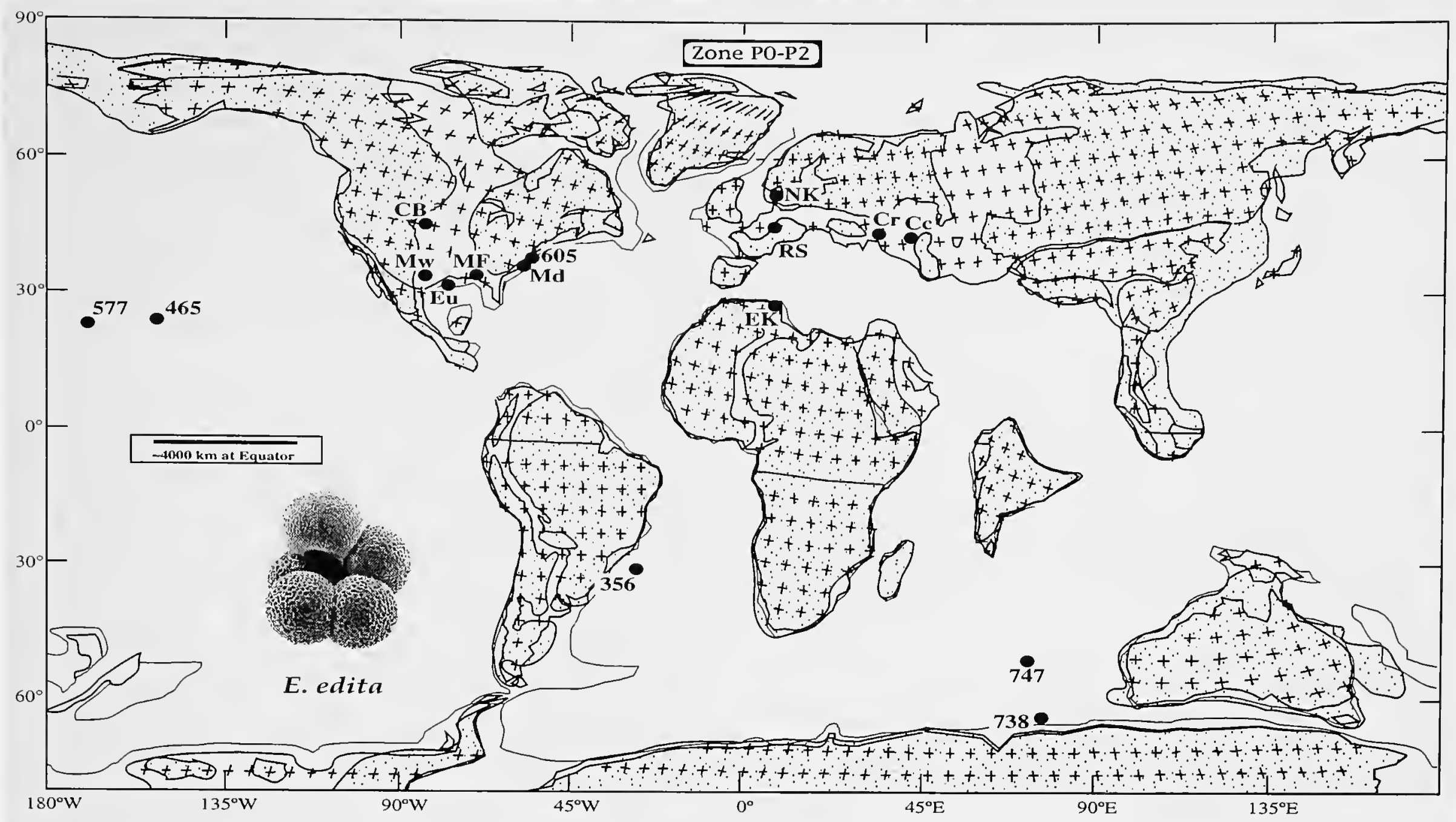

FIGURE 7.-Paleogeographic map showing distribution of Eoglobigerina edita (Subbotina) in Zone P1. Paleogeographic base map for this and following figures based on reconstruction by Barron (1987) for the Maastrichtian, with adjustments for the 60 mya continental distributions of Scotese and Denham (1988) and land-sea distributions in western Europe by Ziegler (1982). Abbreviations used in this and following figures given in Table 1.

Globigerina fringa Subbotina.-Premoli Silva and Bolli, 1973:541, pl. 7: figs. 6, 9 [Zone P $\alpha$, DSDP Site 152/10/1: 127-130 cm; eastern Caribbean Sea]. [Not Subbotina, 1953.]

Eoglobigerina eobulloides eobulloides (Morozova).-Blow, 1979:1214, pl. 60: fig. 9, pl. 61: fig. 1 [Zone P $\alpha$, DSDP Hole 47.2/11/4: 148-150 cm], pl. 65: figs. 8, 9, pl. 66: figs. 6, 9 [Zone P $\alpha$, DSDP Hole 47.2/11/3: 148-150 cm], pl. 70: figs. 3, 4 [Zone P1, DSDP Hole 47.2/11/3: 0-5 cm], pl. 73: fig. 6 [Zone P1, DSDP Hole 47.2/11/1: $148-150 \mathrm{~cm}$; Shatsky Rise, northwestern Pacific Ocean].

Eoglobigerina fringa (Subbotina).-Smit, 1982:329, pl. 2: fig. 11 a-c [base of Zone $\mathrm{Pa}$, Gredero section, southeastern Spain].-Stott and Kennett, 1990:559, pl. 1: figs. 5, 6 [Zone AP $\alpha$, ODP Hole 690C/15X/4: $28-30 \mathrm{~cm}$; Maud Rise, Weddell Sea, Southern Ocean]. [Not Subbotina, 1953.]

Eoglobigerina eobulloides (Morozova).-Huber, 1991c:461, pl. 2: figs. 9-11 [Zone AP1A, ODP Hole 738C/20R/5: 376.54 mbsf; Kerguelen Plateau, southern Indian Ocean].--Hemleben, Mühlen, Olsson, and Berggren, 1991:126, pl. 7: figs. 1-3 [Zone P $\alpha$, Clayton Basal Sands, Millers Ferry, Alabama].-Olsson, Hemleben, Berggren, and Liu, 1992:197, pl. 1: figs. 1-7 [Zone P $\alpha$, Clayton Basal Sands, Millers Ferry, Alabama].

ORIGINAL DESCRIPTION.—-"Test with a flattish spiral; 4-41/2 chambers per whorl. Diameter $0.225 \mathrm{~mm}$., height $0.13 \mathrm{~mm}$. Differentiated from $G$. (Globigerina) bulloides d'Orbigny and $G$. (G.) pseudobulloides Plummer by its small aperture and smooth or definitely micro-cellular test wall." (Morozova, 1959:1115; translated from Russian.)
DiAGNOSTIC CHARACTERS.- Spinose species with moderately elevated trochospire, globular chambers, an umbilical to slightly extraumbilical rounded aperture bordered by narrow, slightly flaring lip. Four to $4 \frac{1}{1} 2$ chambers in final whorl increase moderately in size. Umbilicus small but open to previous chambers. Cancellate wall texture very weakly developed and difficult to view with the light microscope, especially where wall preservation is poor. Pores average about $1 \mu \mathrm{m}$ in diameter at narrowest point and occur at base of shallow pit surrounded by cancellate ridges. Wall ranges from 4-7 $\mu \mathrm{m}$ in thickness; overall size of test generally $<250 \mu \mathrm{m}$.

DISCUSSION. - Considerable uncertainty and confusion surrounds the identification of this species and Globigerina fringa Subbotina, 1953, due to the very small size and generalized drawing of the holotype of $G$. fringa. Examination of the holotype (WAB and FR) under a light microscope shows it to be similar to E. eobulloides in general morphology and, thus, a possible senior synonynm. Scanning electron micrographs (SEM) taken by FR (Plate 8: Figures 10-12, Plate 9: Figures 7-9) of the two holotypes, however, show that they are distinctly different species. "Globigerina" fringa has a coarsely cancellate wall similar to that of Subbotina cancellata Blow, 1979 (Plate 24: Figures 1-14). This type of cancellate 
TABLE 1.-Abbreviations used in the paleobiogeographic maps.

\begin{tabular}{|c|c|}
\hline$A L$ & Alabama \\
\hline $\mathrm{Au}$ & Austria \\
\hline $\mathrm{Az}$ & Azerbaijan \\
\hline $\mathrm{BA}$ & Bikini Atoll \\
\hline $\mathrm{BB}$ & Bulgarian Black Sea \\
\hline BG & Bongerooda Greensand, Australia \\
\hline Bo & Bottacione, Italy \\
\hline $\mathrm{Br}$ & Braggs River, Alabama \\
\hline $\mathrm{BR}$ & Brazos River, Texas \\
\hline $\mathrm{CB}$ & Cannonball Fm. \\
\hline $\mathrm{Cc}$ & Northern Caucusus \\
\hline $\mathrm{Cr}$ & Crimea \\
\hline $\mathrm{Cu}$ & Cuba \\
\hline $\mathrm{Cv}$ & Caravaca, Spain \\
\hline Eg & Egypt \\
\hline EK & El Kef, Tunisia \\
\hline $\mathrm{Eu}$ & Eureka Core \\
\hline FR & Flaxburne River, New Zealand \\
\hline $\mathrm{Gb}$ & Gubbio, Italy \\
\hline $\mathrm{Gu}$ & Guatemala \\
\hline Ir & Iran \\
\hline $\mathrm{Ka}$ & Kamchatka \\
\hline $\mathrm{Li}$ & Lindi, Tanzania \\
\hline Lo & Lodo Fm. \\
\hline Md & Maryland \\
\hline MF & Millers Ferry, Alabama \\
\hline Mo & Morocco \\
\hline $\mathrm{Mw}$ & Midway Fm., Texas \\
\hline MW & Mid Waipara River, New Zealand \\
\hline NE & Northeast Atlantic Ocean \\
\hline $\mathrm{Nf}$ & Nanafalia Fm., Alabama \\
\hline $\mathrm{NF}$ & Northwest Florida \\
\hline $\mathrm{Ng}$ & Nûgssuaq, Greenland \\
\hline $\mathrm{Ni}$ & Nigeria \\
\hline $\mathrm{NJ}$ & New Jersey \\
\hline NK & Nye Klov, Denmark \\
\hline $\mathrm{Nv}$ & Navarro Fm., Texas \\
\hline $\mathrm{Pa}$ & Papua New Guinea \\
\hline PA & Paterno d'Adda, Italy \\
\hline Pd & Pondicherry, India \\
\hline $\mathrm{Pk}$ & Pakistan \\
\hline PP & Pebble Point, Australia \\
\hline RS & Reichehall-Salzburg \\
\hline SB & Salzburg Basin \\
\hline $\mathrm{Se}$ & Senegal \\
\hline SF & South France \\
\hline SI & Seymour Island, Antartica \\
\hline SM & Salt Mountain Fm., Alabama \\
\hline Tk & Turkey \\
\hline $\operatorname{Tr}$ & Trinidad \\
\hline Tu & Turkmenia \\
\hline TU & Te Uri Stream, New Zealand \\
\hline $\mathrm{Va}$ & Virginia \\
\hline$V_{c}$ & Veracruz, Mexico \\
\hline Vo & Velasco Fm., Mexico \\
\hline WC & Woodside Creek, New Zealand \\
\hline $\mathrm{Zu}$ & Zumaya, Spain \\
\hline
\end{tabular}

wall texture is more advanced than that seen in Zone $\mathrm{P} \alpha$ globigerinids, which suggests that fringa was described from a higher Danian stratigraphic level. See "Discussion" under Subbotina cancellata for additional data on this species.
Four-chambered forms of $E$. eobulloides were named by Blow (1979) as the subspecies E. eobulloides simplicissima. This form seems to be the same as Globigerina moskvini Shutskaya, 1953, a name that could be used for E. eobulloides except that some of the Shutskaya collections were destroyed during the 1960s, and, thus, the usage of this name is not advisable. Blow's (1979) illustrations of $E$. eobulloides agree well with the holotype (Plate 8: Figures 10-12). The small size of $E$. eobulloides and its very thin pore-filled walls make this species very susceptible to dissolution, which is common in lowermost Danian sections.

STABLE ISOTOPES.-Eoglobigerina eobulloides has a $\delta^{13} \mathrm{C}$ and $\delta^{18} \mathrm{O}$ signature similar to Parasubbotina and Globanomalina but typically with heavier $\delta^{18} \mathrm{O}$ and more negative $\delta^{13} \mathrm{C}$ than coexisting Praemurica and Woodringina (D'Hondt and Zachos, 1993; Berggren and Norris, 1997). The species shows little change in $\delta^{18} \mathrm{O}$ or $\delta^{13} \mathrm{C}$ over a large size range (Berggren and Norris, 1997), although a positive size $/ \delta^{13} \mathrm{C}$ relationship has been reported for the species at small shell sizes from the early Danian (D'Hondt and Zachos, 1993).

STRATIGRA PHIC RANGE.- Upper Zone P0 to Zone Plb.

Global Distribution.-Worldwide in high to low latitudes (Figure 8).

ORIGIN OF SPECIES.-Eoglobigerina eobulloides evolved from Hedbergella monmouthensis (Olsson) in late Biochron P0 by the development of a spinose cancellate wall texture (Liu and Olsson, 1994). It is the earliest spinose taxon of the Cenozoic, and, as such, it represents a completely new adaptive innovation (carnivory?) following the terminal Cretaceous event(s). Olsson et al. (1992) suggested that the spinose $E$. eobulloides lies at the base of an early Paleocene (Danian) radiation of normal perforate, cancellate spinose forms referable to Eoglobigerina and Subbotina (see also Pearson, 1993).

REPOSITORY.-Holotype No. 3508/1, Moscow, GAN. Examined by WAB and FR.

\section{Eoglobigerina spiralis (Bolli, 1957)}

Figure 9; Plate 16: figures 10-12; Plate 20: figures 1-11

Globigerina spiralis Bolli, 1957a:70, pl. 16: figs. 16-18 [Globorotalia uncinata Zone, lower Lizard Springs Fm., Trinidad].-Bolli and Cita, 1960:12, pl. 32: fig. 2a-c [Globorotalia trinidadensis-Globigerina daubjergensis Zone, Paderno d'Adda section, northern Italy].-Hillebrandt, 1962:130, pl. 11: figs. 14, 15 [Zone E, lower Paleocene, ReichenhallSalzburg Basin, Austro-German border].

Eoglobigerina spiralis (Bolli).-Blow, 1979:1222, pl. 79: figs. 5-9 [Zone P2, DSDP Hole 20C/6/4: 72-74 cm; Brazil Basin, South Atlantic Ocean].

Igorina spiralis (Bolli).-Huber, 1991c:461, pl. 3: figs. 13-15 [Zone AP2, ODP Hole 738C/16R: 338.50 mbsf; southern Kerguelen Plateau, southern Indian Ocean]

ORIGINAL DESCRIPTION.- - "Shape of test medium to high trochospiral, biconvex, spiral side distinctly convex, umbilical side less so; equatorial periphery lobate; axial periphery rounded. Wall calcareous, perforate, surface smooth. Chambers inflated, globular or slightly compressed laterally; about 15 , 


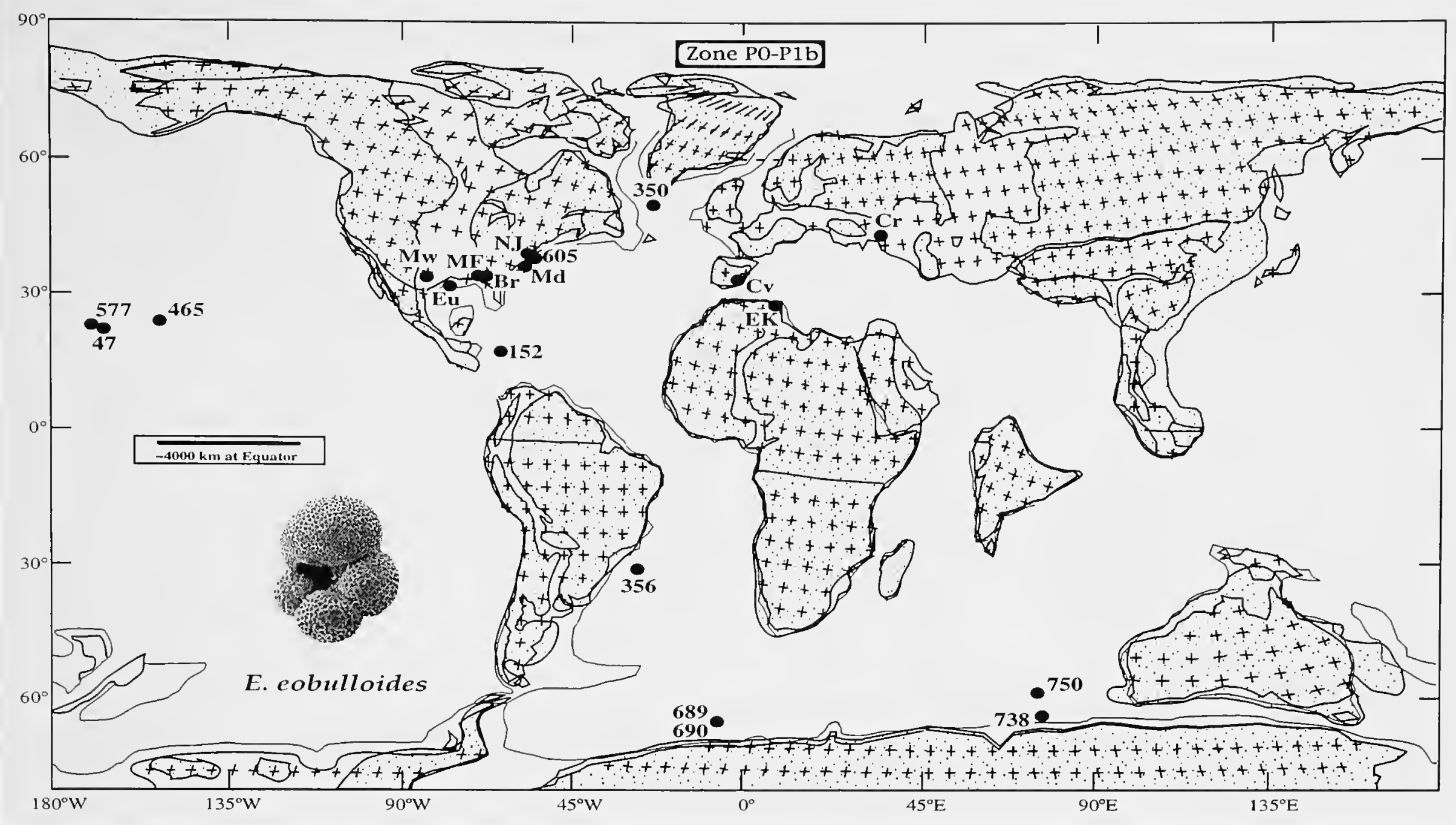

FIGURE 8.-Paleogeographic map showing distribution of Eoglobigerina eobulloides Morozova in Zone PI.

arranged in 3 whorls; the 5-6 chambers of the last whorl increase moderately in size. Sutures on spiral side radial or slightly curved, depressed; on umbilical side radial, depressed. Umbilicus narrow, open. Apertures distinct arches with faint lips, interiomarginal, umbilical; that of last chamber in some specimens tends to an extraumbilical-umbilical position. Coiling random. Largest diameter of holotype $0.28 \mathrm{~mm} . "$ (Bolli, 1957a:70.)

DIAGNOSTIC CHARACTERS.-Spinose species with distinct elevated spire and $4^{1 / 2}-5^{1 / 2}$ chambers in ultimate whorl. Chambers closely appressed with an umbilically directed aperture. Radially directed intercameral sutures on umbilical side appear as distinct valleys when surrounded by gametogenetic calcification. Aperture bordered by thin discontinuous lip. Wall texture more strongly developed than in ancestral species, E. edita. Umbilicus very small and often overlapped by ultimate chamber. Spine holes set along cancellate ridges appear not as numerous as in E. edita.

DISCUSSION.-Bolli (1957a) regarded E. spiralis as the immediate ancestor of Igorina pusilla (Bolli). Although Blow (1979) agreed with Bolli, he noted that the transition from spiralis to pusilla involved the loss of a porticus as well as the extraumbilical extension of the aperture. Blow placed great emphasis on the importance of the porticus as distinct from an apertural lip. The study of Olsson et al. (1992) on the wall texture of Danian globigerinids and globorotaliids, however, showed that the separation of these two kinds of apertural apparatuses is erroneous, as the apparent differences noted by Blow are due to ontogenetic and gametogenetic calcification. The fact that Blow (1979:1223) regarded the spiralis-pusillaalbeari lineage as "so remarkably taxonomically and stratigraphically isolated" indicates that he considered the morphological change involved in the origin of pusilla (i.e., Igorina) as quite distinct from the mainstream globigerinacean evolutionary history. His belief holds true to some degree in regards to the origin of the Igorina lineage (see "Discussion" under this genus). The ancestral relationship of spiralis to pusilla must be ruled out, however, because the former species has a spinose wall texture whereas the latter has a nonspinose, praemuricate wall texture. Eoglobigerina spiralis is the end member of the eobulloides-edita-spiralis lineage, which terminated in Zone P2 (see also Pearson, 1993).

Our work has revealed a spinose wall texture in E. spiralis and suggests that these spinose forms are unrelated to the nonspinose igorinids; however, we have recognized an apparently nonspinose wall texture in some specimens that we have initially attributed to $E$. spiralis. Indeed, the holotype of $E$. spiralis is too poorly preserved to verify the original presence or absence of spines. Consequentially, we are not completely sure of the generic designation of this species. Should the paratypes of $E$. spiralis prove to have a nonspinose wall texture, we would be forced to consider this taxon as a possible ancestor to 


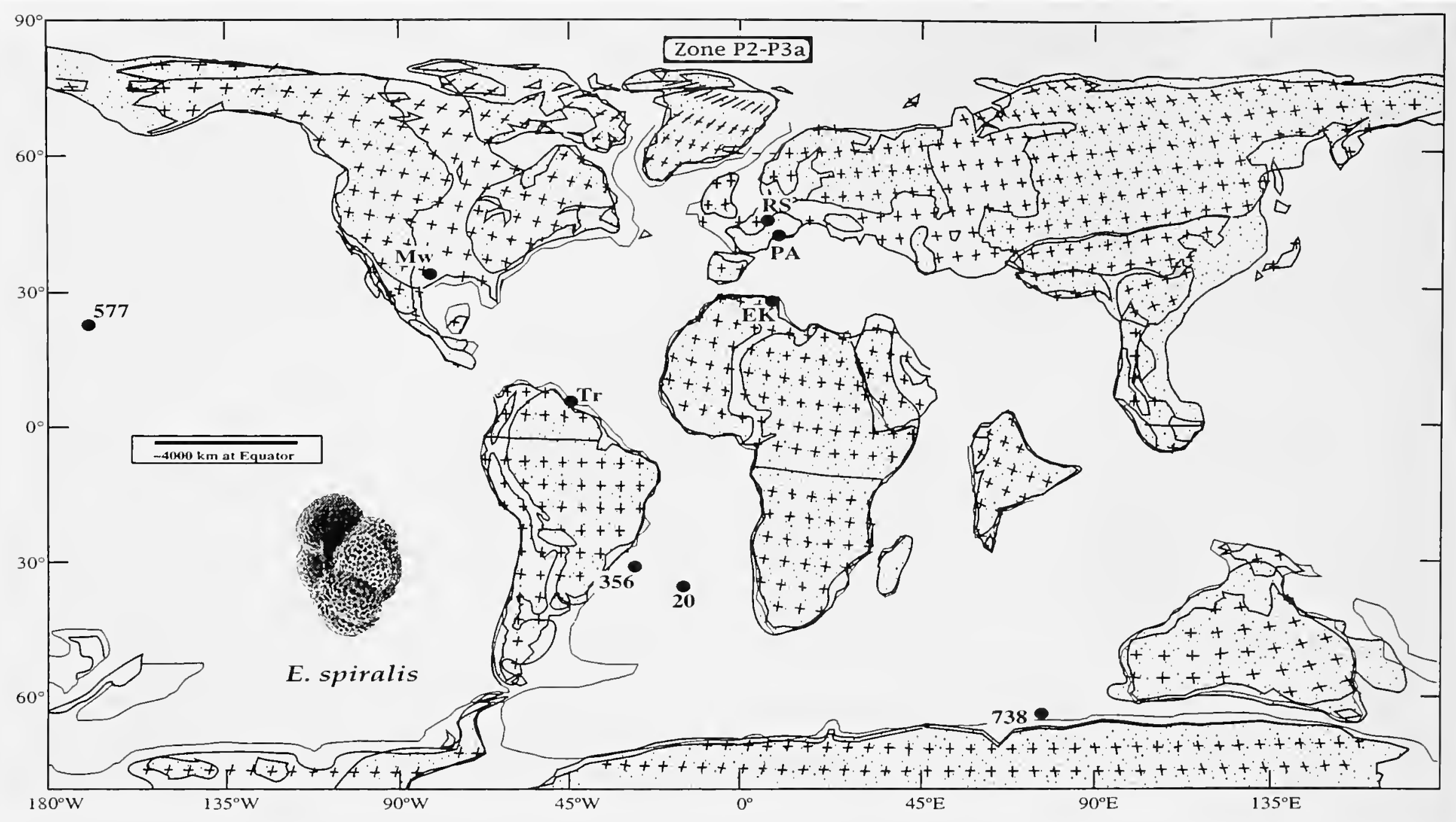

FIGURE 9.-Paleogeographic map showing distribution of Eoglobigerina spiralis (Bolli) in Zone P2

I. pusilla as originally suggested by Bolli (1957a) and to regard the spinose homeomorphs as derivatives of Eoglobigerina edita.

STABLE ISOTOPES.-No data available.

STRATIGRA PHIC RANGE.-Zone P2; ? uppermost Zone P1c. GLOBAL DISTRIBUTION.-Apparently worldwide in high to low latitudes (Figure 9).

ORIGIN OF SPECIES.-This species evolved from E. edita near the base of Zone P2 by the development of a tighter coil, a distinct elevated early coil of chambers, and a more strongly cancellate test wall.

REPOSITORY.-Holotype (USNM P5030) deposited in the Cushman Collection, National Museum of Natural History. Examined by WAB, BTH, and RKO.

\section{Genus Parasubbotina Olsson, Hemleben, Berggren, and Liu, 1992}

TYPE SPECIES.-Globigerina pseudobulloides Plummer, 1926.

ORIGINAL DESCRIPTION.- "Test very low trochospiral with 10-12 chambers, and with 4 to 5 chambers in the ultimate whorl. The chambers which are inflated globular and slightly ovoid in shape increase rapidly in size. The aperture is interiomarginal, umbilical to extraumbilical, a high rounded arch which is bordered by a narrow lip. The umbilicus is narrow, deep and open to the previous chambers. The wall is weakly to strongly cancellate and spinose. Spine holes are numerous and located at the juncture of and along the cancellate ridges. They may be obscured by gametogenetic and/or diagenetic calcification." (Olsson, Hemleben, Berggren, and Liu, 1992:197.)

DIAGNOSTIC CHARACTERS. - Genus distinguished by very low trochospiral test, chambers increasing rapidly in size in ultimate whorl, and high-arched umbilical-extraumbilical aperture. Number of chambers never exceeds 5 in ultimate whorl. Last two chambers may be offset toward umbilicus ( $P$. variospira) giving test the appearance of a higher spire.

DISCUSSION.- In the lower Danian, low trochospiral, cancellate-walled, planktonic foraminiferal species are common and were thought to be phylogenetically linked together. Olsson et al. (1992) showed that two groups can be separated on the basis of a spinose or a nonspinose test morphology. In the earliest Danian, Parasubbotina and Eoglobigerina represent the spinose group and Praemurica represents the nonspinose group.

\section{Parasubbotina pseudobulloides (Plummer, 1926)}

Figure 10; Plate 21: Figures 1-15

Globigerina pseudo-bulloides Plummer, 1926:133, pl. 8: fig. 9a-c [Zone P2, Wills Point Fm., Midway Group (upper Danian), Navarro Co., Texas]. 
Globigerina pseudobulloides Plummer-Subbotina, 1950:106, pl. 4: figs. 8-10 [Danian Stage, northern Caucasus].-Troelsen, 1957:128, pl. 30: fig. 6a-c [Tylocidaris oedumi Zone, Hojerup, Stevns Klint], fig. 7a-c [basal Danian, Bogelund], fig. 8a-c [? Tylocidaris oedumi Zone, Hjerm] [all Danian Stage, Denmark].-Bolli and Cita, 1960:385, pl. 33: fig. 4a-c [Globorotalia trinidadensis-Globorotalia pseudobulloides Zone, Paderno d'Adda section, northern Italy].—Gohrbandt, 1963:44, pl. 1: figs. 7-9 [lower Paleocene, north of Salzburg, Austria].

Globorotalia pseudobulloides (Plummer).-Bolli, 1957a:73, pl. 17: figs. 19-21 [Globorotalia pusilla pusilla Zone, lower Lizard Springs Fm., Trinidad].-Loeblich and Tappan, 1957a:192, pl. 40: fig. 3a-c [Tylocidaris oedumi Zone, Danskekalk Fm., Stevns Klint, Denmark, type Danian Stage], pl. 41: fig. 1a-c [Zone P1, McBryde Fm., Maryland], pl. 42: fig. 3a-c [Zone P1, Brightseat Fm., Maryland], pl. 43: fig. 3a-c [Zone P1, Kincaid Fm., Midway Group, northeastern Texas], pl. 44: fig. 6a-c [Wills Point Fm., Midway Group, northeastern Texas], pl. 45: figs. 1a-2c [Zone P3, Matthews Landing Marl Mbr., Porters Creek Clay, Wilcox Co., Alabama], pl. 46: fig. 6a-c [Coal Bluff Marl Mbr., Naheola Fm., Wilcox Co., Alabama] [in part, not pl. 40: fig. 9a-c (= Praemurica pseudoinconstans (Blow)), pl. 43: fig. 4a-c (= indeterminate abortive individual), pl. 44: figs. 4, 5 (= indeterminate abortive individuals)].-Olsson, 1960:46, pl. 9: figs. 19-21 [Zone P1, Hornerstown Fm., New Jersey].

Globorotalia (Globorotalia) pseudobulloides (Plummer).-Hillebrandt, 1962:124, pl. 12: fig. 2a-c [lower Paleocene, Reichenhall-Salzburg Basin, Austro-German border].

Globorotalia (Turborotalia) pseudobulloides (Plummer).-Blow, 1979:1096, pl. 69: figs. 2, 3 [Zone P1, DSDP Hole 47.2/11/3: 0-5 cm], pl. 71: figs. 4, 5 [Zone P1, DSDP Hole 47.2/11/1: top section; Shatsky Rise, northwestem Pacific Ocean], pl. 75: figs. 2, 3 [Zone P1, Lindi area, Tanzania], pl. 248: figs. 6-8 [Zone P2, topotypes from Plummer locality 23, Navarro Co., Texas], pl. 255: figs. 1-6 [Zone P1c?, Karlstrup, Denmark; upper Danian].

Subbotina pseudobulloides (Plummer).-Berggren, 1992:563, pl. 1: figs. 7, 8 [Zone P1b, ODP Hole 747A/19H/CC; Kerguelen Plateau, southem Indian Ocean].

Parasubbotina pseudobulloides (Plummer),-Olsson, Hemleben, Berggren, and Liu, 1992:197, pl. 3: figs. 1-7 [figs. 1-5: Zone Pla, Pine Barren Mbr., Clayton Fm., Alabama; figs. 6, 7: Zone P2, upper Midway Fm., Texas].

ORIGINAL DESCRIPTION.—“Test rotaliform, very obtusely trochoid to plane dorsally, composed of about two and one-half convolutions, of which the last consists most generally of 5 (rarely 6) highly ventricose chambers increasing rapidly in size; periphery broadly rounded and lobate; shell wall thin and distinctly punctate but finely reticulate; superior face bearing a spire of small chambers only very slightly elevated, if at all, above the circumambient chambers of the final whorl; inferior face less convex and with a very distinct, though not large, umbilical depression; aperture a single, moderately large, lunate opening on the last chamber extending from the margin to the umbilicus and edged with a narrow, delicate, flaring lip. Diameter up to $.4 \mathrm{~mm}$." (Plummer, 1926:133.)

DiAGNOSTIC CHARACTERS.- Test very low trochospiral with 10-12 chambers, and with 5 chambers in ultimate whorl. Inflated, globular chambers slightly ovoid in shape and increase rapidly in size. Aperture interiomarginal, umbilicalextraumbilical, with high rounded arch bordered by narrow lip. Umbilicus narrow, deep, and open to previous chambers. Cancellate spinose wall weakly developed in early forms of species but become stronger in later forms. Spine holes numerous, located at the juncture of and along cancellate ridges, possibly obscured by gametogenetic and/or diagenetic calcification. Overall test size generally $>250 \mu \mathrm{m}$.

DisCUSSION.-The demonstration that $P$. pseudobulloides has a cancellate, spinose wall texture (Olsson et al., 1992) and that it is a member of a relatively minor offshoot of the early eoglobigerinid radiation, has given pause to long-held notions about early Paleocene planktonic foraminiferal phylogenies (see also Pearson, 1993). This is because it has been commonly accepted for nearly 40 years that $P$. pseudobulloides was the ancestor of the post-Danian muricate morozovellid radiation (Bolli, 1957a; Blow, 1979). Parasubbotina pseudobulloides is a member of a lineage that includes $P$. varianta and apparently $P$. variospira.

The identification of $P$. pseudobulloides must be made with care because of the general, superficial similarity with Praemurica pseudoinconstans (see also Blow, 1979). The fundamental difference in wall texture between Parasubbotina and Praemurica may not be evident in poorly preserved specimens.

STABLE ISOTOPES.-Parasubbotina pseudobulloides has a positive $\delta^{18} \mathrm{O}$ and negative $\delta^{13} \mathrm{C}$ similar to Subbotina, Eoglobigerina, and Globanomalina. Both $\delta^{18} \mathrm{O}$ and $\delta^{13} \mathrm{C}$ display little size-related variability (D'Hondt and Zachos, 1993; Berggren and Norris, 1997).

STRATIGRA PHIC RANGE.- - Uppermost Zone P $\alpha$ to Zone P3a; ? P3b.

Global Distribution.-Worldwide in low to high latitudes (Figure 10).

ORIGIN OF SPECIES.-This species evolved from $4 \frac{1}{2} 2-5$ chambered, weakly cancellate, spinose morphotypes identified as Parasubbotina sp. aff. pseudobulloides (Olsson et al., 1992, pl. 4: figs. 1-4) that occur at the top of Zone P0 and in Zone P $\alpha$. They are not the same as the 5-6-chambered forms identified as $G$. (T.) aff. pseudobulloides by Blow (1979), which he regarded as having a phylogenetic relationship with pseudoinconstans.

REPOSITORY.-Cotypes: Walker Museum Collection 33076, Station 23. Examined by BTH and RKO.

\section{Parasubbotina aff. pseudobulloides (Plummer, 1926)}

\section{PLATE 22: FIGURES 1-5}

Parasubbotina aff. pseudobulloides (Plummer).-Olsson, Hemleben, Berggren, and Liu, 1992:197, pl. 4: figs. 1-4 [upper Zone P0 and Zone P $\alpha$, Millers Ferry, Alabama].

Diagnostic ChARACTERS.-Small, very low trochospiral test with $4^{1 / 2} 2-5$ chambers in ultimate whorl, globular chambers increase rapidly in size, high arched umbilical-extraumbilical aperture with a thin lip, weakly developed cancellate wall, spinose. Maximum diameter $<225 \mu \mathrm{m}$.

DISCUSSION.-This small morphotype apparently has often been identified as Globigerina fringa Subbotina, 1953. This species, however, has a coarsely cancellate wall and morphol- 


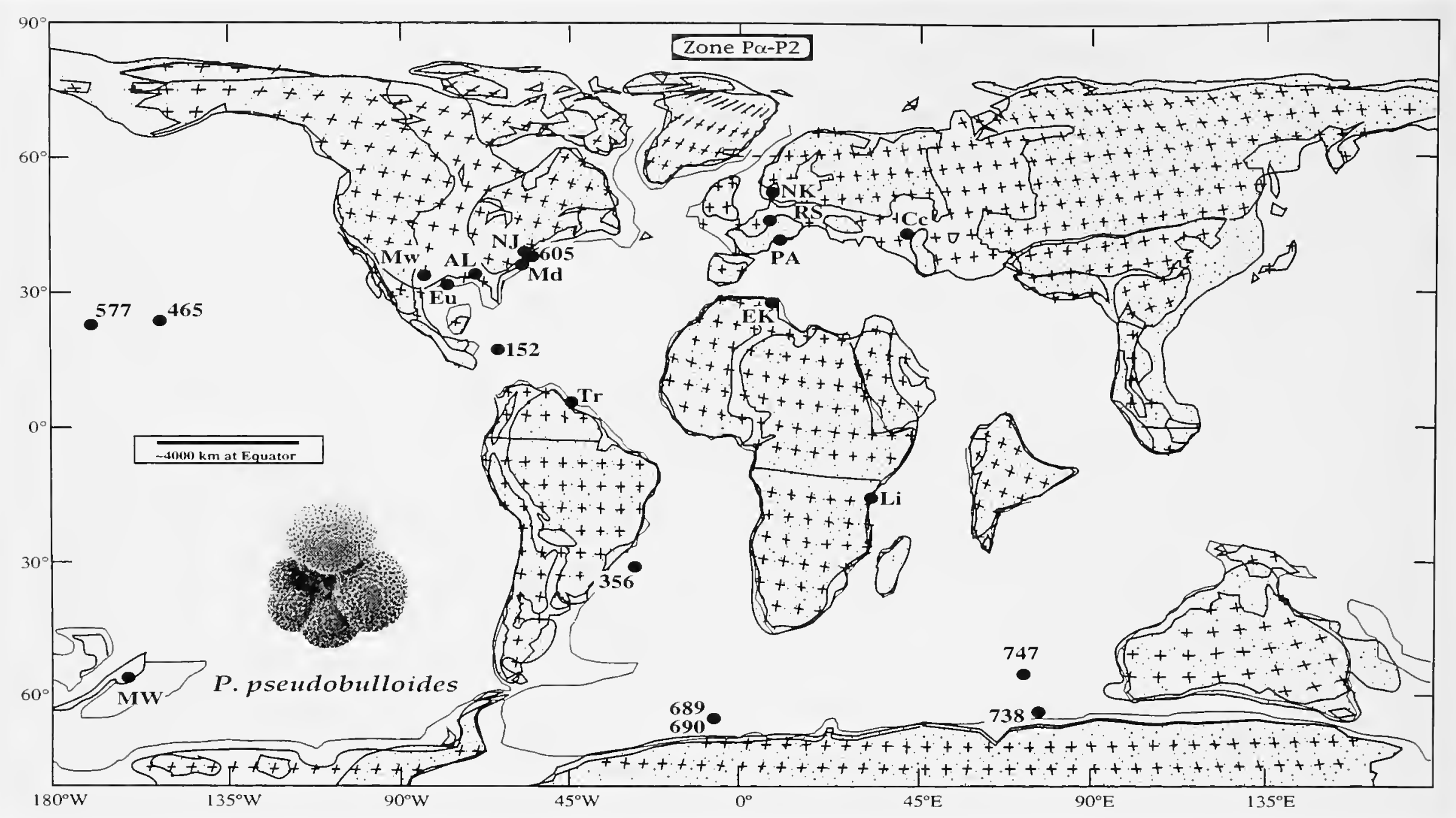

FIGURE 10.-Paleogeographic map showing distribution of Parasubbotina pseudobulloides (Plummer) in Zone P1.

ogic characters belonging to Subbotina. Parasubbotina aff. pseudobulloides is smaller than $P$ pseudobulloides, and it has a very weakly developed cancellate wall in contrast to the strongly developed cancellate wall of pseudobulloides. The spinose condition is already present. As the cancellate wall becomes more strongly developed, along with an increase in size, this morphotype grades into $P$. pseudobulloides. Because of this fact, it is often difficult to consistantly identify the first occurrence of $P$. pseudobulloides and hence the base of Zone P1a. A more useful criterion for the base of Zone P1a is the last occurrence of Parvularugoglobigerina eugubina (Luterbacher and Premoli Silva).

STABLE ISOTOPES.- There are no existing isotope data that are unambiguously attributed to this taxon. Data for $P$. pseudobulloides from the early Danian show that this taxon has $\delta^{18} \mathrm{O}$ and $\delta^{13} \mathrm{C}$ similar to Eoglobigerina and distinctly heavier $\delta^{18} \mathrm{O}$ than Woodringina (D'Hondt and Zachos, 1993).

STRATIGRAPHIC RANGE.- - Upper Zone P0 to Zone P $\alpha$.

GLOBAL DisTRIBUTION.-Probably widespread, but few reliable identifications have been made.

ORIGIN OF SPECIES.-Parasubbotina aff. pseudobulloides evolved from Hedbergella monmouthensis in Biochron $\mathrm{P} 0$ by achieving a more rapid increase in chamber size, by the development of a primitive cancellate wall texture, and by becoming spinose.
REPOSITORY.-Micropaleontology collections, University of Tübingen, träger 9120-27; 9121-10. Examined by $\mathrm{ChH}$ and RKO.

\section{Parasubbotina varianta (Subbotina, 1953)}

Figure 11; Plate 9: Figures 16-18; Plate 22: Figures 6-16

Globigerina varianta Subbotina, 1953:63, holotype: pl. 3: fig. 5a-c; paratypes: pl. 3: figs. 6a-7c, 10a-11c [zone of rotaliform Globorotalia, Elburgan Fm., Kuban River section, northern Caucasus], pl. 3: fig. 12a-c [zone of compressed Globorotalia, base of lower White Series, Murzai-Tai, Mangyshlak Peninsula, southwestern Russia], pl. 4: figs. 1a-3c [zone of rotaliform Globorotalia, base Foraminiferal Layer F1, Khieu River section, near Nal'chik, northern Caucasus] [in part, not pl. 3: figs. 7a-c, 8a-c, pl. 15: figs. 1a-c, 2a-c, 3a-c].

Globorotalia (Globorotalia) varianta (Subbotina).-Hillebrandt, 1962:125, pl. 12: figs. 10a-c, 11a,b [Zone D, Reichenhall-Salzburg Basin, AustroGerman border].

Globorotalia (Turborotalia) quadrilocula Blow, 1979:1109, holotype: pl. 87: fig. 7 [Zone P3, DSDP Hole 47.2/10/1: 72-74 cm], paratypes: pl. 75: fig. 8 [Zone P1, Lindi, Tanzania], pl. 78: figs. 2-4 [Zone P2, DSDP Hole 20C/6/4: 72-74 cm; Brazil Basin, South Atlantic Ocean], pl. 83: fig. 3 [Zone P2, DSDP Hole 47.2/10/3: $78-80 \mathrm{~cm}$; Shatsky Rise, northwestem Pacific Ocean], pl. 87: fig. 8 [Zone P1, Lindi, Tanzania].

Subbotina varianta (Subbotina).-Berggren, 1992:563, pl. 1: fig. 3 [ODP Hole 747A/19H/CC; southern Kerguelen Plateau, southern Indian Ocean].

ORIGINAL DESCRIPTION.- - "Shell globigerinelliform planoconvex, oval outline, consisting of 2 whorls with 4 chambers to 


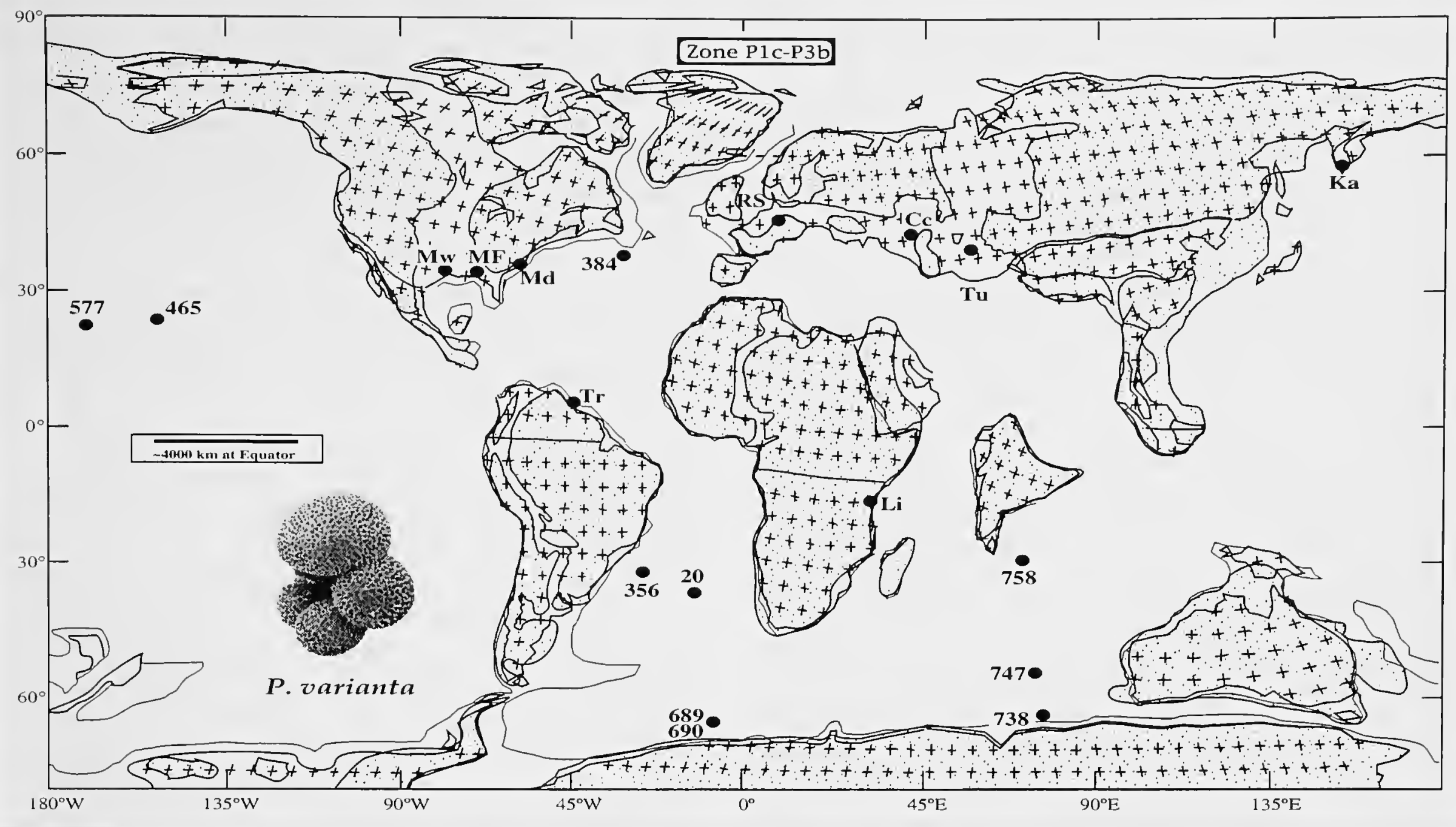

FIGURE 11.-Paleogeographic map showing distribution of Parasubbotina varianta (Subbotina) in Zones P1 and P2.

the last whorl, rapidly increasing in size and closely packed together. The chambers to the last whorl, as is usual in the genus, are strongly inflated.

"Dorsal side compressed, ventral convex. The chambers on the dorsal side are clearly defined and compressed whereas on the ventral side they are inflated and hemispherical. The last chamber is particularly large and is almost spherical. Sutures short, very slightly curved almost straight. On the dorsal side they are not deeply incised, on the central side they are strongly incised. Peripheral margin broadly rounded and coarsely scalloped. Umbilicus always distinct though small and having the form of a shallow depression in the middle of the ventral surface. Orifice slit-like, usually with small, indistinct lips forming a lamelliform border to the slit. Orifice along marginal suture. Dimensions: diameter $0.28-0.50 \mathrm{~mm}$, thickness $0.12-$ 0.24 mm." (Subbotina, 1953:63; translated from Russian.)

DIAGNOSTIC CHARACTERS.-Test a very low trochospiral, generally with four rapidly expanding chambers in ultimate whorl. Wall cancellate spinose with spine holes on interpore ridges. Umbilical-extraumbilical aperture a rounded high arch bordered by fairly broad continuous lip. Small, rounded umbilicus deep and open to surrounding chambers.

DISCUSSION.-The species is smaller and has fewer chambers in the ultimate whorl than does the closely related Parasubbotina pseudobulloides. Blow (1979) regarded $P$. varianta as an ecophenotypic variant of $P$. pseudobulloides comprising a rather specialized side branch of the pseudobulloides plexus. At the same time he erected the species Globorotalia (Turborotalia) quadrilocula, which he considered to have originated from a "four-chambered last-whorl variant" (Blow, 1979:1110) of pseudobulloides. The holotype of $P$. varianta (Plate 9: Figures 16-18) is a 4-chambered form with an ultimate chamber somewhat more inflated than Blow's concept of quadrilocula. We regard G. (T.) quadrilocula as falling within the morphologic range of variability of $P$. varianta.

STABLE ISOTOPES.-Parasubbotina varianta has a $\delta^{13} \mathrm{C}$ and $\delta^{18} \mathrm{O}$ signature similar to that of $P$. pseudobulloides, Subbotina triloculinoides, and Globanomalina compressa but typically with heavier $\delta^{18} \mathrm{O}$ and more negative $\delta^{13} \mathrm{C}$ than coexisting Praemurica and Morozovella. The species shows little change in $\delta^{18} \mathrm{O}$ or $\delta^{13} \mathrm{C}$ over a large size range.

STRATIGRAPHIC RANGE.-Zone Plc to Zone P5.

GLOBAL Distribution.-Worldwide in high and low latitudes (Figure 11).

ORIGIN OF SPECIES.-Blow's (1979) observations on the close relationship of this species with $P$. pseudobulloides is supported by our observations. The species evolved in Zone Plc from $P$. pseudobulloides by a reduction in the number of chambers in the ultimate whorl and a tightening of the whorl. 
REPOSITORY.-Holotype (No. 3994) and paratypes (Nos. 3995-4003, 4215), deposited in the micropaleontological collections, VNIGRI (378/20), St. Petersburg, Russia. Examined by FR.

\section{Parasubbotina variospira (Belford, 1984)}

PLATE 23: FIGURES 1-16

Globorotalia (Turborotalia) variospira Belford 1984:18, pl. 24: figs. 15-17, pl. 25: figs. 1-7 [WABAG Sheet area, Papua, New Guinea].

Morozovella variospira (Belford).—Van Eijden and Smit, 1992:113, text-fig. 26A-D, pl. 5: figs. 1-8 [Zone P3, ODP Hole 758A/30X/CC; eastern Indian Ocean].

ORIGINAL DESCRIPTION.- - "Test large, trochoid, consisting of about 12 chambers arranged in three whorls, usually 5 but sometimes 4 chambers visible from ventral side. Equatorial periphery lobate, axial periphery rounded. Chambers increasing only slowly in size, four chambers in penultimate whorl, coiling in most specimens then becoming looser and more open, generally with five chambers in final whorl, umbilicus wide, open, shallow. Occasional specimens with final chamber directed towards umbilicus, coiling also becoming tighter, $4-41 / 2$ chambers visible from ventral side. Sutures on both dorsal and ventral sides narrow, deeply depressed, radial. Test wall perforate, with small pustules at umbilical margin of early chambers of last whorl, otherwise finely pitted. Aperture interiomarginal, umbilical-extraumbilical, low elongate, not clearly observed." (Belford, 1984:18.)

Diagnostic CHARACTERS.-Large $(\sim 0.4$ to $>0.7 \mathrm{~mm}$ in diameter), low to (less frequent) moderately high, loosely coiled trochospiral test with strongly lobulate outline; any or all of last 3-4 chambers with inwardly projecting umbilical "teeth," aperture an interiomarginal, umbilical-extraumbilical arch; loose coiling between chambers in final whorl occasionally produce secondary spiral apertures with apertural lips, wall texture spinose and distinctly cancellate with large pore pits.

DISCUSSION.-Although described a decade ago, this species has been overlooked in studies of Paleocene planktonic foraminiferal faunas. This absence of attention is surprising because $P$. variospira is large and homeomorphic with the Neogene species Neogloboquardina dutertrei (d'Orbigny). Van Eijden and Smith (1992) drew attention to the distinct features of this large mid-Paleocene taxon and noted its globoquadrinid-like umbilical "teeth" that are unique among Paleocene species. Parasubbotina variospira overlaps for a short stratigraphic interval with Globanomalina pseudomenardii and early members of the acarininid radiation (nitida, mckannai, subsphaerica) within the lowermost part of Zone P4.

STABLE ISOTOPES.-Parasubbotina variospira has a $\delta^{13} \mathrm{C}$ and $\delta^{18} \mathrm{O}$ signature similar to $P$. pseudobulloides, $P$. varianta, Subbotina triloculinoides, and Globanomalina compressa, but it typically has a heavier $\delta^{18} \mathrm{O}$ and more negative $\delta^{13} \mathrm{C}$ than coexisting Morozovella.

STRATIGRA PHIC RANGE.-Zone P3a to Zone P4 (lower part).
GLobal Distribution.-This species has been observed at (sub)tropical sites in the Atlantic, Indian, and Pacific oceans.

ORIGIN OF SPECIES. - This species evolved from $P$. varianta by the development of a more loosely coiled test and inflated chambers. Both $P$. varianta and $P$. variospira share enlarged apertural flaps. These structures are restricted to the final chamber of $P$. varianta but are found on the last 3-4 chambers in the final whorl of $P$. variospira.

REPOSITORY.-Holotype (CPC 21919) and paratypes (CPC 21920-21922) deposited in Commonwealth Paleontological Collection, Bureau of Mineral Resources, Canberra, Australia.

\section{Genus Subbotina Brotzen and Pożaryska, 1961}

TYPE SPECIES.—Globigerina triloculinoides Plummer, 1926, emended.

ORIGINAL DESCRIPTION.- "Le génotype est la Globigerina triloculinoides Plummer. La figure 3[4] (1961, op. cit., pl. 4) montre aussi la surface de l'holotype. Le diamètre des pores est de 1 à 2 microns et ils débouchent à la surface dans un double entonnoir entouré d'une couronne de rayons. Le diamètre de l'entonnoir varie entre huit à douze microns. Entre les différents entonnoirs et leurs courrones radiales, la surface est divisée en petites papilles, prismes, qui ont pent-être porté de fines épines calcaires. La même construction de surface est représentée chez Brady (1884, Rept. Challenger Expedition, Zool., pt. 22, vol. 9, pl. 77, fig. 1). On y voit une Globigerina représentée comme Globigerina bulloides d'Orbigny, mais elle doit, selon toute certitude, représenter un tout autre type. Là aussi, le mince canal du pore débouche dans un grand entonnoir et d'après le dessin, la couronne radiale elle-même porte les longues et fines épines calcaire. Toute l'image montre une espèce typique de Globigerina à surfaces reticulée qui, à notre point de vue, s'oppose à la Globigerina s. str. et doir être traité comme une Subbotina. Si l'on prend de telles étrudes de détails comme point de départ, l'observation du diamètre des pores et de leur répartition devient sans valeur si elles ne tiennent pas compte des détails de structure." (Brotzen and Pożaryska, 1961:160.)

DiAGNOSTIC CHARACTERS.-Low trochospiral, tripartite test with 10-12 chambers, with 3-4 rapidly inflating, globular chambers in ultimate whorl. Aperture interiomarginal, umbilical to slightly extraumbilical in some species, a low arch. Apertural lip varies from narrow to fairly broad and distinct apparatus extending over umbilicus. Umbilicus small and nearly closed by tight coiling. Wall cancellate and spinose; spines set at juncture of the cancellate ridges with or without spine collars. Cancellate texture varies from weak to very strong and from moderate to very coarse or distinctly honeycombed.

DISCUSSION.-Olsson et al. (1992) showed that Subbotina was spinose. The concept of the genus followed herein is similar to that of previous workers except that it is emended to include the spinose character. 


\section{Subbotina cancellata Blow, 1979}

Plate 9: Figures 7-9; Plate 24: Figures 1-14; PLATE 25: FIGURES 1-15

?Globigerina fringa Subbotina, 1953:62, pl. 3: fig. 3 [Danian, Pecten horizon, Azov-Black Sea flysch, Anapa, Caucasus].

Subbotina triangularis cancellata Blow, 1979:1284, holotype: pl. 80: fig. 7 [Zone P2, DSDP Hole 20C/6/4: 72-74 cm], paratypes: pl. 80: figs. 2-6, 8 , 9 [Zone P2, DSDP Hole 20C/6/4: 72-74 cm; Brazil Basin, South Atlantic Ocean], pl. 238: fig. 6 [enlargement of pl. 80: fig. 4].

ORIGINAL DESCRIPTION.- - "The test is coiled in a low trochospire with about 10-12 chambers comprising the spire and with four chambers visible in the last convulution of the test. The chambers of the last whorl are inflated and subglobular but are moderately appressed and embracing. The dorsal intercameral sutures are depressed but not incised and are radially or subradially disposed. The ventral intercameral sutures are also depressed, slightly incised and are disposed. The equatorial profile is lobulate and oval in outline whilst the axial profile is smoothly rounded. The umbilicus is small, but open and deep, and the umbilical depression is fairly sharply delimited by the umbilical shoulders of the last whorl of chambers. The aperture is virtually limited in lateral extent to the limits of the umbilical depression although it extends a little further towards the anterior side of the last chamber than it does towards the posterior side of this chamber. Thus, the aperture is a low arched opening slightly asymmetrically placed with respect to the centre of the umbilicus. The aperture is bordered by a strongly developed porticus which can be seen clearly cutting across the surface structures of the primary wall of the last chamber; from this, the porticus can be seen to be a structure additional to the primary wall of the last chamber and is not a simple, direct, reflexed continuation of the chamber wall. The porticus is not significantly thickened. The primary walls of the test bear large mural-pores which open into very large, sharply defined pore-pits with massively developed inter-pore ridges. Maximum diameter of holotype $0.29 \mathrm{~mm}$." (Blow, 1979:1285.)

DIAGNOSTIC CHARACTERS.-Tightly coiled test with $3^{1 / 2-4}$ chambers in ultimate whorl; an umbilically directed aperture bordered by broad, somewhat irregular lip; and coarse cancellate wall on all chambers of the test. Test compact, rounded in outline, and slightly lobulate.

DisCUSSION.-Blow (1979) recognized the significance of the coarsely cancellate wall as a primary taxonomic character. The coarsely cancellate wall is a diagnostic feature of the cancellata-velascoensis lineage. Blow's figures only showed umbilical views of his new taxon. Spiral views (Plate 24) show a rounded, somewhat lobulate outline, with the ultimate chamber varying in size from slightly smaller to distinctly larger than the penultimate chamber, and the coarse cancellate wall of the earlier chambers. The axial periphery is broadly rounded.

In his discussion of this species, Blow (1979) emphasized the apertural lip, which he identified as a porticus. He believed that the porticus was a feature that was added as a later ontogenetic structure to the test. He based his belief on his study of the structure, which in a SEM (1979, pl. 238: fig. 6) he interpreted as an infilling of pore-pits. At that time little was known about the ontogeny and gametogenesis of planktonic foraminifera. It is quite clear now that the lip forms as an extension of the primary chamber wall and that the cancellate texture develops throughout ontogeny and is enhanced during gametogenesis. The cancellate texture does not develop on the apertural lip, which, apparently, led Blow to interpret it as a separate, late-stage structure.

Blow named cancellata as a subspecies of Subbotina triangularis (White); however, triangularis has a distinctly different wall texture (Plate 2: Figures 15, 16, Plate 26) than cancellata. The recognition of a coarsely cancellate Subbotina lineage separates cancellata from triangularis and elevates it to species level.

Considerable confusion exists on the correct identification of Globigerina fringa Subbotina, 1950. The species is mostly identified in the lower Danian in Cretaceous/Paleogene boundary sections and is regarded as one of the earliest Danian species. The small size of the original figures of the holotype and its morphologic similarity to Eoglobigerina eobulloides Morozova, 1959, suggested that these species are synonymous (see Toumarkine and Luterbacher, 1985). SEMs taken by FR of the holotypes of the two species, however, shows this not to be the case (Plate 8: Figures 10-12, Plate 9: Figures 7-9). The distinguishing characteristic of $G$. fringa is a coarsely cancellate wall texture, which is similar to that in Subbotina cancellata Blow (1979). Furthermore, the coarsely cancellate wall texture observed in $G$. fringa is an advanced development in the evolution of wall texture in the Danian and is not present in Zone $\mathrm{P} \alpha$ stratigraphic levels. In fact, $G$. fringa was described from the "Pecten Horizon," which is apparently an upper Danian horizon in the Elburgan Formation in the northwest Caucasus.

Coarsely cancellate Subbotina cancellata morphotypes (Plate 25: Figures 1-15) occur in Zone P1c at DSDP Site 356 in the Southern Atlantic Ocean. They appear to be quite similar to the SEM of the holotype of Globigerina fringa Subbotina, 1953, shown on Plate 9: Figures 7-9. These morphotypes are smaller than typical $S$. cancellata and have $4-4^{1 / 2}$ chambers in the ultimate whorl. Although Subbotina described this species as having 4 chambers in the ultimate whorl, she chose a $4^{1} / 2$-chambered specimen as the holotype. Most of the specimens in a suite of adults from DSDP Site 356 are 4-chambered (Plate 25). Small immature specimens often have $4^{1} / 2$ chambers in the ultimate whorl, and these specimens have an umbilical to a slightly extraumbilical aperture (Plate 25: Figures 4,10 ). In the adult specimens, the inner whorl is composed of $4 \frac{1}{2} 2$ chambers. This ontogenetic progression proceeds from an Eoglobigerina morphotype to a Subbotina morphotype and suggests that $S$. cancellata may have evolved from E. eobulloides; however, the strong cancellate wall texture is a distinctive characteristic of Subbotina. In general 
test morphology the cancellata morphotypes at DSDP Site 356 are similar to Subbotina trivialis Subbotina, 1953, suggesting that cancellata evolved from this species by enhancement of the cancellate wall.

The development of a coarsely cancellate wall begins a lineage that extends through $S$. cancellata to Subbotina velascoensis (Cushman, 1925). Although it is tempting to apply the name fringa to the DSDP Site 356 cancellata morphotypes, we recommend that this not be done pending further study on the morphologic characteristics of this taxon and on the stratigraphy and phylogeny of the coarsely cancellate Subbotinas in Zone P1.

Thus, it is clear that identification of fring $a$ and its taxonomy should be considered carefully when using literature data in interpretative studies. For example, Brinkhuis and Zachariasse (1988) included fringa (together with edita) in the monophyletic genus Parvularugoglobigerina Hofker, 1978, emended, which is characterized by having a microperforate, nonspinose wall texture. Similarly, specimens identified by Keller (1988) as fringa (and indeed, other forms as cf. edita, hemisphaerica, and taurica) from the basal Paleocene of El Kef (Tunisia) are microperforate, nonspinose forms referable to Parvularugoglobigerina.

STABLE ISOTOPES.--No data available.

STRATIGRAPHIC RANGE.-Zone Plc to Zone P4, currently known range.

GLOBAL DISTRIBUTION.-The full geographic extent of this species at this time is unknown. The species has been identified from North Atlantic (Site 549) and South Atlantic (Sites 20C, 356) DSDP drill sites.

ORIGIN OF SPECIES.-Subbotina cancellata is believed to have evolved from $S$. trivialis in the middle part of Zone P1, possible Plb. It is the first species of the coarsely cancellate Subbotina lineage. A reduction in the number of chambers in the ultimate whorl to $3^{1 / 2}$ and an increase in test size characterizes Zones $\mathrm{P} 2$ to $\mathrm{P} 4$ morphotypes.

REPOSITORY.- Holotype (BP Cat. No. 41/31) and paratypes (BP Cat. Nos. 41/9, 41/13-41/15, 41/18, 41/20, 41/22) deposited in The Natural History Museum, London.

\section{Subbotina triangularis (White, 1928)}

\section{PLATE 26: Figures $1-13$}

Globigerina triangularis White, 1928:195, pl. 28: fig. la-c [Paleocene, Velasco Fm., Mexico].-Bolli, 1957a:71, pl. 15: figs. 12-14 [Globorotalia pseudomenardii Zone, lower Lizard Springs Fm., Trinidad].-Shutskaya, 1970a:104, pl. 3: fig. 5a-c [lower part Acarinina tadjikistanensis djanensis Zone, Khieu River section, Nal'ckik, northern Caucasus]; 1970b:1 18, pl. 20: fig. 7a-c [Globorotalia angulata Zone, Chaaldzhin Group, Malyi Balkhan Ridge, western Turkmenia], p. 220, pl. 23: fig. la-c [lower part of Acarinina tadjikistanensis djanensis Zone, Khieu River section, Nal'ckik, northern Caucasus], p. 224, pl. 25: fig. la-c [upper part of Acarinina tadjikistanensis djanensis Zone, Khieu River section, Nal'chik, northern Caucasus] [in part, not pl. 17: fig. 14a-c (= Subbotina triloculinoides)].
Globigerina inaequispira Subbotina.-Loeblich and Tappan, 1957a:181, pl. 52: figs. 1a-2c [Zone P4, Vincentown Fm., New Jersey] [in part, not pl. 49: fig. 2a-c, pl. 56: fig. $7 \mathrm{a}-\mathrm{c}$, pl. 61 : fig. 3a-c (= Acarinina coalingensis), pl. 62: fig. 2a-c].

Globigerina triloculinoides Plummer.-Loeblich and Tappan, 1957a:183, pl. 62: fig. 3a-c [Zone P4, Velasco Fm., Mexico] [in part, not pl. 62: fig. 4a-c and other illustrations of Subbotina triloculinoides]. [Not Plummer, 1926.]

Globigerina gerpegensis Shutskaya, 1970a:104, pl. 3: fig. 3a-c [holotype; upper part of Acarinina tadjikistanensis djanensis Zone, Kachan Stage, lower Danatin Subgroup, Malyi Balkhan Ridge, western Turkmenia].

Globigerina pseudotriloba Shutskaya, 1970a:85, pl. 2: fig. 7a-c [Acarinina conicotruncana Zone, Urukh River section, N. Ossetiya, northern Caucasus]. [Not White, 1928.]

Globigerina uruchaensis Shutskaya, 1970a:87, pl. 2: fig. 6a-c [holotype; Acarinina conicotruncana Zone, Urukh River section, N. Ossetiya, northern Caucasus].

Subbotina patagonica/triangularis group Tjalsma, 1977:510, pl. 4: fig. 2 [Zone P5, DSDP Site 329/32/4: 67-68 cm], figs. 3-6 [Zone P6, DSDP Site 329/32/4: 139-141 cm; flank of Falkland Plateau, southwestern Atlantic Ocean].

Subbotina triangularis triangularis (White).-Blow, 1979:1281, pl. 91: figs. 7, 9 [Zone P4, DSDP Hole 21 A/3/6: 74-76 cm; South Atlantic Ocean], pl. 98: fig. 6 [Zone P4, given as P5, Lindi area, Tanzania], pl. 107: figs. 8, 9 [Zone P4, given as P6, DSDP Hole 20C/6/3: 76-78 cm; Brazil Basin, South Atlantic Ocean].

ORIGINAL DESCRIPTION.- -Test triangular, composed of about two coils arranged in a low trochoid spire; chambers inflated, somewhat appressed, three sub-equal chambers comprising the last whorl; sutures deep; aperture must be in the small umbilicus.

"Diameter of type specimen, $0.4 \mathrm{~mm}$; thickness, $0.2 \mathrm{~mm}$." (White, 1928:195.)

DiagnOSTIC CHARACTERS.- Test a somewhat loose coil of $3^{1 / 2}$ chambers in ultimate whorl, with narrow, deep umbilicus sometimes obscured by an overlapping ultimate chamber. Shape of test triangular in umbilical view, ultimate chamber often smaller than penultimate one, low oval in shape. Axial periphery broadly rounded. Aperture umbilical to slightly extraumbilical, bordered by thin, sometimes irregular lip. Wall cancellate, spinose with an asymmetrically developed pore pattern and well-developed coalescing spine collars.

Discussion.- Shutskaya's (1970a, 1970b) references to pseudotriloba, triangularis, uruchaensis, and gerpegensis are all considered synonymous with Subbotina triangularis. The criteria she provided to distinguish between these forms and her text-illustrations are insufficient for consistent discrimination. Moreover, she (1970a:104) included Bolli's illustration of $G$. triangularis (1957a, pl. 15: figs. 12-14) in the synonym of her new taxon, G. gerpegensis.

The distinctive spinose wall texture of Subbotina triangularis sets it apart from the trivialis-triloculinoides lineage and the cancellata-velascoensis lineage. Subbotina triangularis may be a stem form for a separate lineage that links. with Eocene species, but this possibility has not been investigated. It may be linked with Globigerina praebulloides, which has a similar wall texture (compare Plate 2: Figures 14-16). 
STABLE ISOTOPES. - Subbotina triangularis displays a more positive $\delta^{18} \mathrm{O}$ and more negative $\delta^{13} \mathrm{C}$ than coexisting Morozovella and Acarinina (D'Hondt et al., 1994). The species shows little change in $\delta^{18} \mathrm{O}$ or $\delta^{13} \mathrm{C}$ over a large size range (D'Hondt et al., 1994).

Stratigraphic RANGe.-Zone P2 to Zone P5, ? P6.

GLOBAL DisTRIBUTION.-Apparently this species has a global distribution in the low to middle latitudes.

ORIGIN OF SPECIES.-This species probably evolved from $S$. triloculinoides in Zone $\mathrm{P} 3$ by developing a more evolute coil, by increasing its test size, and by achieving a more asymmetical pore pattern with well-developed coalescing spine collars.

REPOSITORY.-Columbia University Paleontology Collection (No. 19881, locality No. 11); collection now at the American Museum of Natural History, New York.

\section{Subbotina triloculinoides (Plummer, 1926)}

Figure 12; Plate 9: Figures 13-15; Plate 14: Figures 15, 16; Plate 27: Figures 1-13

Globigerina triloculinoides Plummer, 1926:134, pl. 8: fig. 10a-b [Zone P2, Wills Point Fm., Midway Group, Navarro Co., Texas, Station 23].-Bolli, 1957a:70, pl. 15: figs. 18-20 [Globorotalia pusilla pusilla Zone, Lizard Springs Fm., Trinidad] [in part, not pl. 17: figs. 25, 26].- - Loeblich and Tappan, 1957a:183, pl. 40: fig. 4a-c [Tylocidaris oedumi Zone, Danian Stage, western Denmark], pl. 41: fig. 2a-c [Zone P1c, McBryde Limestone of Clayton Fm., Wilcox Co., Alabama], pl, 42: fig. 2a-c [Zone P1c, Brightseat Fm., Maryland], p1. 43: fig. 5a-c [Zone P1, Kincaid Fm., Travis Co., Texas], pl. 43: figs. 8a,b, 9a-c [Zone P2, Wills Point Fm., Midway Group, Navarro Co., Texas], pl. 45: fig. 3a-c [Zone P3, Matthews Landing Marl, Naheola Landing, Tombigbee River, Alabama] [in part, not pl. 46: fig. la-c, pl. 47: fig. 2a-c, pl. 52: figs. 3-7, pl. 56: fig. 8a-c, pl. 62: figs. 3, 4].-Bolli and Cita, 1960:13, pl. 31: fig. 1a-c [Globorotalia trinidadensisGlobigerina daubjergensis Zone, Paderno d'Adda section, northern Italy].Berggren, 1962:86, pl. 14: figs. la-2b [Zone P1b, type Danian, Stevns Klint, Denmark].-Hillebrandt, 1962:119, pl. 11: fig. la-c [Danian Stage, Richenhall-Salzburg Basin, Austro-German border].-Shutskaya, 1970b:118, pl. 18: fig. la-c [upper subzone of Globigerina trivialisGloboconusa daubjergensis-Globorotalia compressa Zone, Malyi Balkhan Ridge, western Turkmenia], pl. 19: fig. 3a-c [Acarinina inconstans Zone, Malyi Balkhan Ridge, western Turkmenia], pl. 21: fig. 5a-c [Acarinina praepentacamerata Zone, Urukh River section, northern Caucasus], pl. 23: fig. 12a-c [lower subzone of Acarinina tadjikistanensis djanensis Zone, Malyi Balkhan Ridge, western Turkmenia].

Globigerina pseudotriloba White, 1928:194, pl. 27: fig. 17a,b [Velasco Fm., Mexico].

Globigerina stainforthi Brönnimann, 1952:23, pl. 3: figs. 10-12 [Paleocene, Trinidad].

Globigerina (Globigerina) microcellulosa Morozova, 1961:14, pl. 1: fig. 11 [Danian, Tarkhankut, Crimea].

Subbotina triloculinoides (Plummer).-Brotzen and Pożaryska, 1961:160, text-fig. 2, pl. 4: fig. 4 [lower Paleocene, Midway Group, Texas].-Belford, 1967:7, pl. 1: figs. 1-5 [Paleocene, Australia].-Stott and Kennett, 1990:559, pl. 2: fig. 12 [Zone AP1a, ODP Hole $690 \mathrm{C} / 15 \mathrm{X} / 2: 46-50 \mathrm{~cm}$; Maud Rise, Weddell Sea, Southern Ocean].

Subbotina triloculinoides triloculinoides (Plummer).-Blow, 1979:1287, pl. 74: fig. 6 [Zone P1, DSDP Hole 47.2/11/1: 148-150 cm; Shatsky Rise, northwestern Pacific Ocean], pl. 80: fig. 1 [Zone P2, DSDP Hole 20C/6/4: 72-74 cm; Brazil Basin, South Atlantic Ocean], pl. 98: fig. 7 [Zone P4, given as P5, Lindi area, Tanzania], pl. 238: fig. 5 [same specimen as pl. 98: fig. 5], pl. 248: figs. 9, 10 [topotypes, Zone P2, Navarro Co., Texas], pl. 255: fig. 9 [Zone D2 of Bang, 1969, probably Zone P1c, Karlstrup, Denmark], pl. 257: fig. 9 [Zone Plc, upper Danian, Klagshamn, Sweden].

ORIGINAL DESCRIPTION.- "Test spiral, trochoid, composed of about 2 convolutions, the last of which is composed of $3^{1 / 2}$ very rapidly increasing and highly globose chambers; periphery very broadly rounded and distinctly lobate; shell surface strongly reticulate; superior face rounded with a very low spire of neatly coiled tiny chambers of the preceding whorl; inferior face rounded with a very shallow umbilical depression; aperture a small arched slit on the last chamber and edged with a more or less prominent, delicately notched flap that extends from a point near the periphery to the umbilical depression.

"Greatest diameter up to $.35 \mathrm{~mm}$.; usually less." (Plummer, 1926:134.)

Diagnostic CHARACTERS.-Medium sized, lobulate, trilobate test with $3-3^{1 / 2}$ chambers in ultimate whorl increasing moderately in size, ultimate chamber occupies up to $1 / 2$ of test size. Intercameral sutures depressed, straight to slightly curved on umbilical and spiral sides of test. Umbilicus narrow, deep, often covered by well-developed apertural lip. Aperture umbilical, slightly asymmetrical towards an extraumbilical direction. Test walls strongly cancellate, spinose, with spines occurring at the juncture of and along cancellate ridges.

Discussion.-Together with Parasubbotina pseudobulloides (Plummer), this taxon is probably one of the most cited, yet most frequently misidentified, taxa of the Paleocene. The detailed analysis of Blow (1979) may serve as a guide to a reasonably consistent delineation of the main characteristics of this species. Although $S$. triloculinoides has a strongly cancellate wall texture, its does not possess the symmetrical, coarsely cancellate wall of the cancellata-velascoensis lineage. The ancestral $S$. trivialis is more weakly cancellate, and $S$. triangularis has an asymmetrical cancellate surface with distinct spine collars. Unlike Blow (1979), we do not recognize the two subgroups (aside from $S$. triloculinoides sensu stricto) to which some sort of formal nomenclature may be applied: $S$. triloculinoides stainforthi Blow and $S$. triloculinoides nana Blow. The former is interpreted as a junior synonym of $S$. triloculinoides, as has been more or less suggested by Bolli (1957a), and the "taxon" nana Khalilov is a squat, subquadrate form with a linaperta-like aperture referable to $S$. velascoensis (Cushman) and not to $S$. triloculinoides (verified by examination of the holotype by WAB). Khalilov (1967) indicated that the range of nana is upper Paleocene to lower Eocene in the Malyi Caucasus (Azerbaizhan) and Malyi Balkhan (Turkmenia); the morphology of velascoensis (= nana), however, already appears in Zone P3. The SEMs of the holotype (Plate 9: Figures 13-15) of $S$. microcellulosa (Morozova) show this taxon to be a junior synonym of triloculinoides.

STABLE IsOTOPES. Subbotina triloculinoides has a $\delta^{13} \mathrm{C}$ and $\delta^{18} \mathrm{O}$ signature similar to $P$. pseudobulloides, $P$. varianta, $G$. compressa, and $G$. planocompressa, but it typically has a heavier $\delta^{18} \mathrm{O}$ and more negative $\delta^{13} \mathrm{C}$ than coexisting Praemu- 


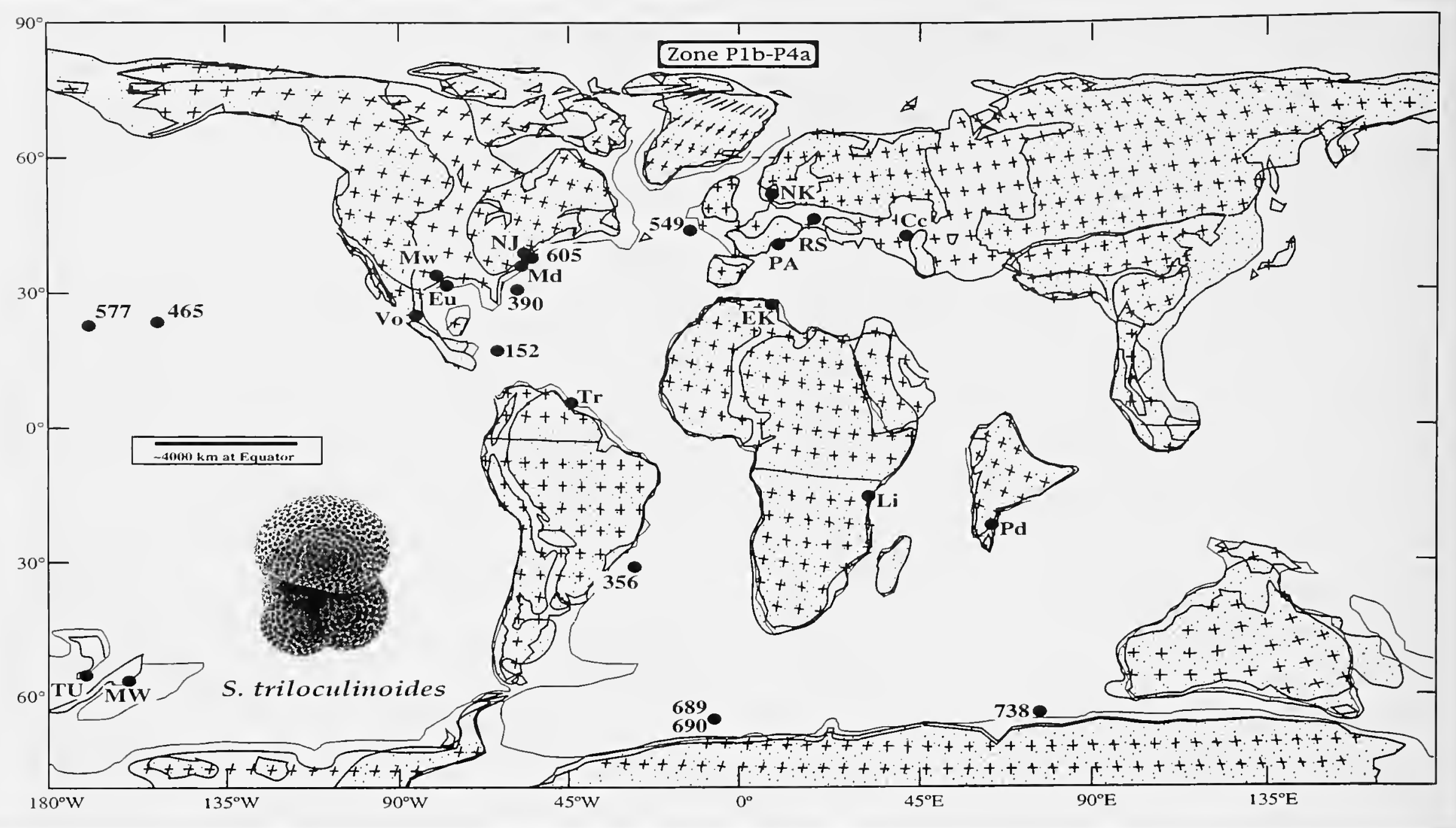

FIGURE 12.-Paleogeographic map showing distribution of Subbotina triloculinoides (Plummer) in Zones P1 to P3.

rica and Morozovella. The species shows little change in $\delta^{18} \mathrm{O}$ or $\delta^{13} \mathrm{C}$ over a large size range (Berggren and Norris, 1997).

StratigraPHIC RANGE.-Zones P1b to P4. Although its upper stratigraphic limit remains somewhat equivocal, we have not observed it above Zone $\mathrm{P} 4$ and believe it is restricted to the Paleocene.

GLOBAL Distribution.-Essentially a worldwide distribution in the low to high latitudes (Figure 12).

ORIGIN OF SPECIES.-Although Blow (1979) was of the opinion that the origin of $S$. triloculinoides lay in the plexus of forms that radiate from Eoglobigerina eobulloides sensu lato toward E. trivialis and $S$. triloculinoides, and, more specifically, with $F$ eohulloides simplicissima, we view its evolution from $S$. trivialis to be more likely (see also Olsson et al., 1992).

REPOSITORY.-Holotype: Walker Museum Collection 33076, Station 23, now in the Field Museum, Chicago. Paratype (USNM 370088) deposited in the Cushman Collection, National Museum of Natural History. Holotype examined by WAB; paratype examined by BTH.

\section{Subbotina trivialis (Subbotina, 1953)}

Plate 9: figures 10-12; Plate 28: figures 1-13

Globigerina trivialis Subbotina, 1953:64, holotype: pl. 4: fig. 4a-c; paratypes: pl. 4: figs. 5a-7c [zone of rotaliform Globorotalia (= Pl), basal Elburgan
Fm., Kuban River section, northern Caucasus] [in part, not pl. 4: fig. 8a-c (same horizon; = S. triloculinoides)].-Shutskaya, 1970b:118, pl. 18: fig. 2a-c [upper subzone of Globigerina trivialis-Globoconusa daubjergensisGloborotalia compressa Zone, Malyi Balkhan Ridge, western Turkmenia], pl. 18: fig. 16a-c [middle subzone of Globigerina trivialis-Globoconusa daubjergensis-Globorotalia compressa Zone, Malyi Balkhan Ridge, westem Turkmenia] [in part, not pl. 21: fig. 3a-c, pl. 23: fig. 6a-c].

Eoglobigerina trivialis (Subbotina).-Blow, 1979:1224, pl. 65: figs. 1-3, pl. 66: figs. 4, 7 [Zone P $\alpha$, DSDP Hole 47.2/11/3: 148-150 cm], pl. 69: fig. 9, pl. 70: fig. 8 [Zone P1, DSDP Hole 47.2/11/3: 0-5 cm; Shatsky Rise, northwestern Pacific Ocean], pl. 70: figs. 1, 2 [Zone P2, DSDP Hole 20C/6/4: 72-74 cm; Brazil Basin, South Atlantic Ocean].-Stott and Kennett, 1990:559, pl. 2: fig. 11 [Zone AP1, ODP Hole 690C/15X/2: 46-50 cm; Maud Rise, Weddell Sea, Southern Ocean].-Berggren, 1992:563, pl. 1: fig. 1 [ODP Hole 747C/19H/CC; Kerguelen Plateau, southem Indian Ocean]. Eoglobigerina aff. trivialis (Subbotina).-Blow, 1979:1228, pl. 61: fig. 8 [Zone Pa, DSDP Hole 47.2/11/4: 148-150 cm], pl. 69: fig. 8 [Zone Pl, DSDP Hole 47.2/11/3: 0-5 cm], pl. 74: figs. 7, 8 [Zone P1, DSDP Hole 47.2/11/1: 148-150 cm; Shatsky Rise, northwestern Pacific Ocean].

Eoglobigerina cf. trivialis (Subbotina).-Blow, 1979:1229, pl. 55: fig. 9 [Zone Pa, DSDP Hole 47.2/11/5: 148-150 cm; Shatsky Rise, northwestern Pacific Ocean].

Subbotina trivialis (Subbotina).--Huber, 1991c:461, pl. 3: figs. 16, 17 [Zone AP1, ODP Hole 738C/17R: 350.45 mbsf; Kerguelen Plateau, southern Indian Ocean].-Olsson, Hemleben, Berggren, and Liu, 1992:202, pl. 4: figs. 5-8 [Zone Pla, Pine Barren Mbr., Clayton Fm., Millers Ferry, Alabama].

ORIGINAL DESCRIPTION.- "Shell inflated with tall first whorls which are 2 in number and large in size. The last whorl consists of $4-4 \frac{1}{2}$ almost regular, spherical chambers which 
differ very slightly in size. The chambers are closely packed together and partially overlap each other. Because of this the shell is very compact. Peripheral margin broadly undulate; septal sutures curved, deeply incised as is characteristic of species with strongly inflated shells. Orifice small, and forming a slightly curved or straight slit which is situated along the marginal suture and near to, or more rarely above, the umbilicus. Walls with relatively large pores and a cellular pattern. Mean dimensions: diameter $0.40 \mathrm{~mm}$, thickness 0.23 mm." (Subbotina, 1953:64; translated from Russian.)

DIAGNOSTIC CHARACTERS. - Low trochospiral, tightly coiled test with $3^{1 / 2}$ chambers in ultimate whorl, umbilical aperture with thin lip. Ultimate chamber equal to, or slightly smaller than, penultimate one. Wall weakly cancellate and spinose. Spines set at junctures of cancellate ridges (Plate 28: Figures 12,13). Umbilicus small and nearly closed by tight coiling. Overall size of test generally $<250 \mu \mathrm{m}$.

DISCUSSION.-Although Subbotina's original description refers to $4-4^{1} / 2$ chambers in the final whorl, her illustrations of the holotype and paratypes show only $3^{1 / 2}$ chambers. Blow (1979) presented a thorough analysis of this morphospecies with which we in large part agree. Like Blow, we have not observed individuals as large as $0.4 \mathrm{~mm}$ in diameter as noted by Subbotina (1953) for her holotype from the northern Caucasus. In fact, remeasurement of her holotype (Plate 9: Figures 10-12) shows a diameter of $0.35 \mathrm{~mm}$. Blow (1979) also described forms with more closely appressed chambers and abortively developed final chambers (as Eoglobigerina cf. trivialis) and forms with a turreted, high-spired umbilical side (as Eoglobigerina aff. trivialis). We include these morphotypes here in the concept of trivialis, as they do not appear to have any significant numerical representation or stratigraphic continuity in occurrence.

STABLE ISOTOPES. - No data available.

STRATIGRAPHIC RANGE.-Zone P $\alpha$ to Zone P2.

GLOBAL DisTRIBUTION.-Essentially a worldwide distribution in the low to high latitudes.

ORIGIN OF SPECIES.-Although we agree with Blow (1979) that the distinction between the wall texture of eoglobigerinids and subbotinids is one of degree rather than kind, we view trivialis as the earliest representative of Subbotina (in contrast to Blow, 1979, who retained it in Eoglobigerina) and the main lineage that ultimately gave rise to the late Paleogene-Neogene spinose globigerinid radiation (see also Pearson, 1993; Liu and Olsson, 1994).

REPOSITORY.-Holotype (No. 4004) and paratypes (Nos. 4005-4007) deposited in the micropaleontological collections, VNIGRI, St. Petersburg, Russia. Examined by FR.

\section{Subbotina velascoensis (Cushman, 1925)}

Figure 13; Plate 29: figures 1-12

Globigerina velascoensis Cushman, 1925:19, pl. 3: fig. 6a-c [Paleocene, Velasco Fm., Tamalte Arroyo, Hacienda el Limon, San Luis Potosi,
Mexico].-White, 1928:196, pl. 28: fig. 2a,b [Paleocene, Velasco Shale, Tampico Embayment, eastern Mexico].-Bolli, 1957a:71, pl. 15: figs. 9-11 [Zone P4, Lizard Springs Fm., Trinidad].-Bolli and Cita, 1960:374, pl. 34: fig. 8a-c [Globorotali pseudomenardii Zone, Paderno d'Adda section, northern Italy].-Hillebrandt, 1962:120, pl. 11: fig. 4a,b [Paleocene, Reichenhall-Salzburg Basin, Austro-German border].-Gohrbandt, 1963:47, pl. 2: figs. 1-3 [upper Paleocene, north of Salzburg, Austria].Shutskaya, 1970a:94, pl. 4: figs. 3a-4c, 6a-c [figs. 3, 6: Acarinina subsphaerica Zone, Kambileevka River, Black Mountains, northern Caucasus; fig. 4: Acarinina subsphaerica Zone, Tarkhankut Peninsula, Crimea]. Globigerina velascoensis Cushman var. compressa White, 1928:196, pl. 28: fig. 3a,b [Velasco Fm., Tampico Embayment, eastern Mexico].

Globigerina quadritriloculinoides Khalilov, 1956:237, pl. 1: fig. 5a-c [holotype, upper Paleocene, Akhchakuima, NE foothills of Malyi Caucasus, Nakhichevan Autonomous Republic, Azerbaizhan].

Globigerina triloculinoides Plummer nana Khalilov, 1956:236, pl. 1: fig. 4a-c [holotype, upper Paleocene, from Akhchakuima, NE foothills of Malyi Caucasus, Nakhichevan Autonomous Republic, Azerbaizhan].

ORIGINAL DESCRIPTION.- "Test much compressed, the dorsal side with all the chambers visible, ventral side only those of the last-formed coil, sides nearly parallel, periphery broadly rounded; chambers distinct, three or four making up the last-formed coil, early chambers subglobular, later ones becoming more compressed, and the inner margin fairly straight; wall finely and evenly reticulate; aperture on the ventral side, elongate.

"Diameter $0.45 \mathrm{~mm}$. ; thickness $0.25 \mathrm{~mm} . "$ (Cushman, 1925:19.)

DiagnOSTIC CHARACTERS.-Tightly coiled test with compressed chambers and subquadrate test shape with umbilical aperture. Ultimate chamber much compressed, elongate ovalshaped, about one-half test size, and typically overhanging earlier chambers. Aperture bordered by thin elongate lip; lip extending less than full length of aperture and squared off at termination. Test wall coarsely and symmetrically cancellate, spinose.

DISCUSSION.-Although the holotype specimen is deformed, Bolli (1957a) defined the concept of this species, which is followed herein. The species was described from the Velasco Shale from which White (1928) illustrated better preserved specimens that he identified with Cushman's species. White's concept was followed by Bolli. White's figures, although drawings, illustrate a quadrate-shaped test with much compressed chambers. Furthermore, his drawings clearly indicate a symmetrical, coarsely cancellate test wall. Cushman (1925) in his description referred to an evenly reticulate wall, which suggests that he observed the wall texture that characterizes this species.

Bolli (1957a) and Blow (1979) considered that $S$. velascoensis evolved from $S$. triangularis at, or near, the Zone P3/P4 boundary and believed that $S$. velascoensis represented a dead-end lineage. Subbotina velascoensis has a much different wall texture than does $S$. triangularis. The latter species has a finer asymmetrical cancellate wall with coalescing spine collars, whereas $S$. velascoensis has a symmetrical, coarsely cancellate wall texture. In $S$. velascoensis, the spines are set at the intersection of the cancellate ridges and are not supported 


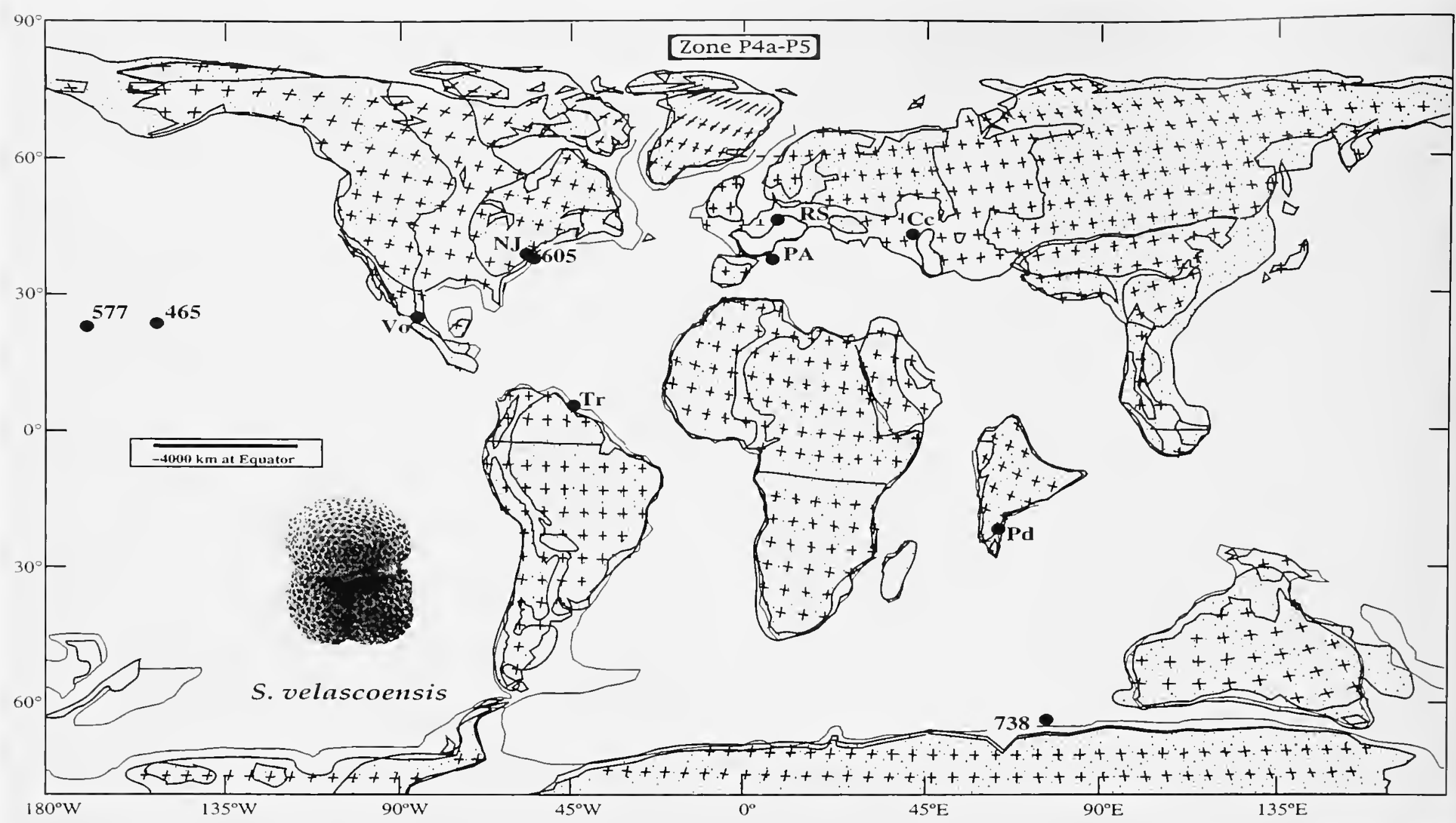

FIGURE 13.-Paleogeographic map showing distribution of Subbotina velascoensis (Cushman) in the upper Paleocene.

by spine collars (Plate 29: Figure 11) as in S. triangularis (Plate 26: Figures 12,13). We consider $S$. velascoensis as the end member of the symmetrical coarsely cancellate lineage that begins with $S$. cancellata. Subbotina cancellata, gives rise to $S$. velascoensis at, or near, the Zone P3/P4 boundary. We agree with Bolli and Blow that $S$. velascoensis represents a dead-end lineage. Globigerina quadritriloculinoides Khalilov (1956) from the upper Paleocene of Azerbaizhan exhibits the characteristic quadrate-shaped morphology of $S$. velascoensis. The holotype figures show a coarsely cancellate wall, also typical of $S$. velascoensis.

STABLE ISOTOPES.- Subbotina velascoensis has a $\delta^{13} \mathrm{C}$ and $\delta^{18} \mathrm{O}$ signature similar to $P$. varianta, $G$. compressa, and $G$. pseudomenardii, but it typically has a heavier $\delta^{18} \mathrm{O}$ and more negative $\delta^{13} \mathrm{C}$ than coexisting Acarinina and Morozovella (Berggren and Norris, 1997).

STRATIGRAPHIC RANGE.-Zone P3b to Zone P6a.

GLOBAL DISTRIBUTION.-Essentially a worldwide distribution in the low to middle latitudes, with preferential development in the middle to higher latitudes as is common with the subbotinids (Figure 13)

ORIGIN OF SPECIES.-This species evolved from $S$. cancellata by the development of a more tightly coiled, quadrate test and compressed chambers.

REPOSITORY.-Holotype (USNM CC4348) deposited in the
Cushman Collection, National Museum of Natural History. Examined by WAB and RKO.

\section{Family HedBergellidae Loeblich and Tappan, 1961}

(by R.K. Olsson, Ch. Hemleben, and C. Liu)

ORIGINAL DESCRIPTION.- - "Primary aperture only, commonly with prominent aperture lip, those of previous chambers remaining as projections into the umbilical region." (Loeblich and Tappan, 1961:309.)

DIAGNOSTIC CHARACTERS.-Test trochospiral with umbilical-extraumbilical aperture with a prominent lip. Apertures of earlier formed chambers remain visible around the umbilicus.

DISCUSSION.-The vast majority of hedbergellids are represented by Cretaceous genera. Only one genus, Hedbergella, a very common form throughout the Cretaceous, survived into the Cenozoic where it gave rise to Globanomalina in the early Danian.

\section{Genus Hedbergella Brönnimann and Brown, 1958}

TYPE SPECIES.-Anomalina lorneiana d'Orbigny var. trochoidea Gandolfi, 1942. 
ORIGINAL DESCRIPTION,- "The smooth- to rough-walled, calcareous hyaline test is trochospirally coiled. Its small early chambers are globular, inflated, and globigerine-like. The last few chambers are elongated and extend into a relatively small umbilicus. The aperture is rounded, interiomarginal, and opens into the umbilicus. Short apertural flaps extend into the umbilicus but do not form an umbilical cover-plate. Family Globotruncanidae." (Brönnimann and Brown, 1958:16.)

DiAGNOSTIC CHARACTERS.-Test low to very low trochospiral with 18 or more globular chambers. Number of chambers in ultimate whorl varing from 5 to 8 . Aperture interiomarginal, umbilical-extraumbilical, a low to high arch, bordered by a narrow lip. Umbilicus small, deep, and open to apertures of previous chambers. Normal perforate wall, smooth to heavily pustulose, nonspinose.

DisCUSSION.- - Late Cretaceous species of Hedbergella are generally typified by more numerous chambers in the ultimate whorl and by more pustulose chambers. The late Maastrichtian species Hedbergella holmdelensis and H. monmouthensis, however, show a reduced number of chambers in the ultimate whorl and less pustulose chambers.

\section{Hedbergella holmdelensis Olsson, 1964}

\section{Plate 30: Figures 1-17}

Hedbergella holmdelensis Olsson, 1964:160, holotype: pl. 1: fig. 2a-c; paratype: pl. 1: fig. 1a-c [upper Maastrichtian, Navesink Fm., New Jersey].-Huber, 1994:18, pl. 2: figs. 1-8 [upper Maastrichtian, Navesink Fm., New Jersey].

ORIGINAL DESCRIPTION.- "Test very low trochospiral, nearly planispiral in appearance, much compressed; equatorial periphery strongly lobate; axial periphery rounded. Wall finely perforate, delicately hispid. Chambers five, occasionally six, in final whorl, increasing rather rapidly in size, moderately inflated, ovate, elongate in direction of coiling compressed ovate in axial view. Sutures depressed and gently curved on spiral side, depressed and radial on umbilical side. Aperture a low arch, interiomarginal, umbilical-extraumbilical, bordered by a thin lip; apertures of previously formed chambers open into the umbilicus.

"Greatest diameter of holotype $0.20 \mathrm{~mm}$., greatest thickness $0.10 \mathrm{~mm}$. Unfigured paratypes range from 0.15 to $0.24 \mathrm{~mm}$. in maximum diameter, from 0.07 to $0.12 \mathrm{~mm}$. in maximum thickness. Greatest diameter of figured paratype $0.26 \mathrm{~mm}$., greatest thickness $0.10 \mathrm{~mm}$." (Olsson, 1964:160.)

DIAGNOSTIC CHARACTERS. - Characterized by small, nearly planispiral test with 5 , occasionally 6 chambers in ultimate whorl. Six to 7 chambers in penultimate whorl. Ovate, elongated, compressed chambers typify species. Axial periphery imperforate for most part, only sparsely penetrated by pores. Wall surface smooth but lightly covered by small pustules. Aperture, a high arch extending from umbilicus to axial periphery, bordered by a thin, narrow, uniformly wide lip.
DISCUSSION.-Hedbergella holmdelensis is the ancestral species of the genus Globanomalina that first appears in Zone P0 of the basal Danian. Morphologically, H. holmdelensis is very similar to the first species of Globanomalina, $G$. archeocompressa. The key morphologic characters that phylogenetically link the two species are the small, compressed, smooth-walled test, the imperforate axial periphery, and the umbilical-extraumbilical aperture with its narrow lip. Hedbergella holmdelensis retains two typical hedbergellid characters: the numerous, spherical-shaped chambers in the inner whorl, which is an adult character of the majority of hedbergellid species in the Cretaceous, and the pustulose surface of the test, which is distributed rather uniformly over the chambers, in contrast to the more restricted occurrence of pustules in Paleogene species of Globanomalina. Pustule growth, particularly in the umbilical area, is related to gametogenetic calcification in smooth-walled species in the Cenozoic. Pustule growth in Hedbergella is largely unexplored, and its relationship to gametogenesis is unknown. Nevertheless, the difference in its distribution on the test suggests a different biological function for this genus than for Globanomalina. Globanomalina, however, is placed in the Hedbergellidae to reflect its phylogenetic linkage with this important Cretaceous group of planktonic foraminifera.

STABLE ISOTOPES. - No data available

STRATIGRAPHIC RANGE.-Lower Maastrichtian to lower Zone P0.

GLOBAL DISTRIBUTION.-Apparently worldwide in the high to low latitudes.

ORIGIN OF SPECIES.-This species evolved in the Maastrichtian from a multichambered ancestor.

REPOSITORY.-Holotype (USNM 640917) and paratype (USNM 640919) deposited in the Cushman Collection, National Museum of Natural History. Examined by BTH and RKO.

\section{Hedbergella monmouthensis (Olsson, 1960)}

Figures 14, 15; Plate 31: figures 1-15

Globorotalia monmouthensis Olsson, 1960:47, pl. 9: figs. 22-24 [upper Maastrichtian, Redbank Fm., New Jersey].

Hedbergella monmouthensis (Olsson).-Olsson, 1964:160, pl. 1: fig. 3a-c [upper Maastrichtian, Redbank Fm., New Jersey].-Sliter, 1976:542, pl. 3: figs. 1-3 [Maastrichtian, DSDP Hole 327A/12/1: 69-72 cm; eastern Falkland Plateau, South Atlantic Ocean].-Huber, 1990:503, pl. 2: figs. 6-8, pl. 6: fig. 2 [Maastrichtian, ODP Hole $690 \mathrm{C} / 20 \mathrm{X} / 5$ : 108-110 cm; Maud Rise, Southern Ocean]; 1991a:292, pl. 1: figs. 2, 3 [Abathomphalus mayaroensis Zone, ODP Hole 698A/16R/2: $67-71 \mathrm{~cm}$; northeast Georgia Rise, South Atlantic Ocean]; 1994:22, pl. 2: figs. 9-16 [upper Maastrichtian, Redbank Fm., New Jersey].

ORIGINAL DESCRIPTION.- “Test.-very low trochospiral, nearly planispiral in appearance. Equatorial periphery strongly lobate. Axial periphery rounded. Wall.-calcareous, finely perforate, covered with short minute spines. Chambers.- 
inflated, globular; about 15 arranged in $2^{1 / 2}$ whorls. The 5 , occasionally 6 , chambers of the final whorl increase rather rapidly in size; the last two make up over $1 / 2$ of the test. Sutures.-spiral side: oblique in early stages to straight in adult stages, depressed, Umbilical side: radial, depressed. Umbilicus. - narrow, deep. Aperture.- - low arch with a distinct lip; interiomarginal, extraumbilical-umbilical. Coiling.-random. Diameter 0.20 to $0.25 \mathrm{~mm}$." (Olsson, 1960:47.)

DiagnostiC CHARACTERS.-Small species with 5-51/2 inflated chambers in ultimate whorl rapidly increasing in size. Penultimate whorl with 7 or more spherical chambers increasing slowly in size. Periphery distinctly lobulate; test surface relatively smooth and evenly covered with small pustules. Axial periphery imperforate but pierced by occasional pores. Aperture a high rounded umbilical-extraumbilical arch bordered by a thin, narrow lip.

DISCUSSION.- - Liu and Olsson (1994) showed that a variety of morphotypes existed within an assemblage of $H$. monmouthensis. This species is regarded as ancestral to the normal perforate cancellate species of the earliest Danian, which also have the general shape of these morphotypes. Thus, it is believed that these variations may have established trends that resulted in the separation of the Paleocene globigerinids and globorotaliids. Very primitive pore pits can be observed in the chamber walls of $H$. monmouthensis. In the earliest Danian this character was strongly developed, resulting in the cancellate wall texture that is the most important distinguishing feature of Cenozoic planktonic foraminifera. Two important cancellate groups of planktonic foraminifera are derived from $H$. monmouthensis, cancellate spinose and cancellate nonspinose. Eoglobigerina and Parasubbotina represent the first of the cancellate spinose genera, and Praemurica represents the first of the cancellate nonspinose genera. A discussion of these transitions is given in Liu and Olsson (1994).

STABLE ISOTOPES.-Hedbergella monmouthensis has among the most positive $\delta^{18} \mathrm{O}$ of any Cretaceous trochospiral planktic foraminifer (Boersma et al., 1979). The $\delta^{18} \mathrm{O}$ of $H$. monmouthensis is similar to Abathamphalus mayaroensis and is distinctly more positive than Rugoglobigerina rotundata, $R$. rugosa, Globotruncanella petaloidea, and Globotruncana arca (Berggren and Norris, 1997). The $\delta^{13} \mathrm{C}$ of $H$. monmouthensis is lighter than coexisitng Rugoglobigerina.

STRATIGRAPHIC RANGE.-- Upper Maastrichtian to lower Zone P0.

Global Distribution.-Worldwide in the high and lower latitudes (Figure 14).

ORIGIN OF SPECIES.-The species originates in the upper Maastrichtian from $H$. holmdelensis.

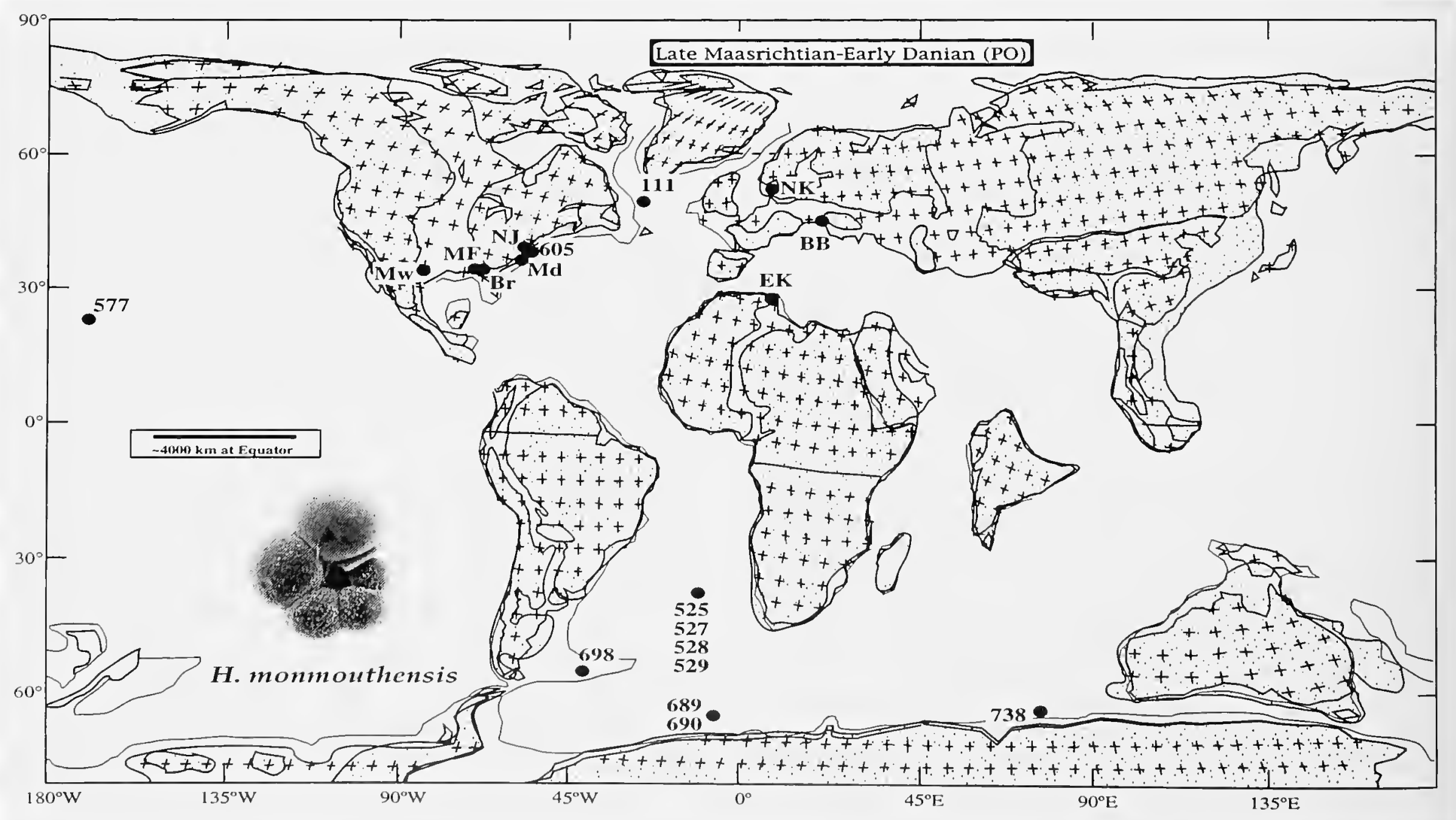

FIGURE 14.-Paleogeographic map showing distribution of Hedbergella monmouthensis (Olsson) in the upper Maastrichtian. 


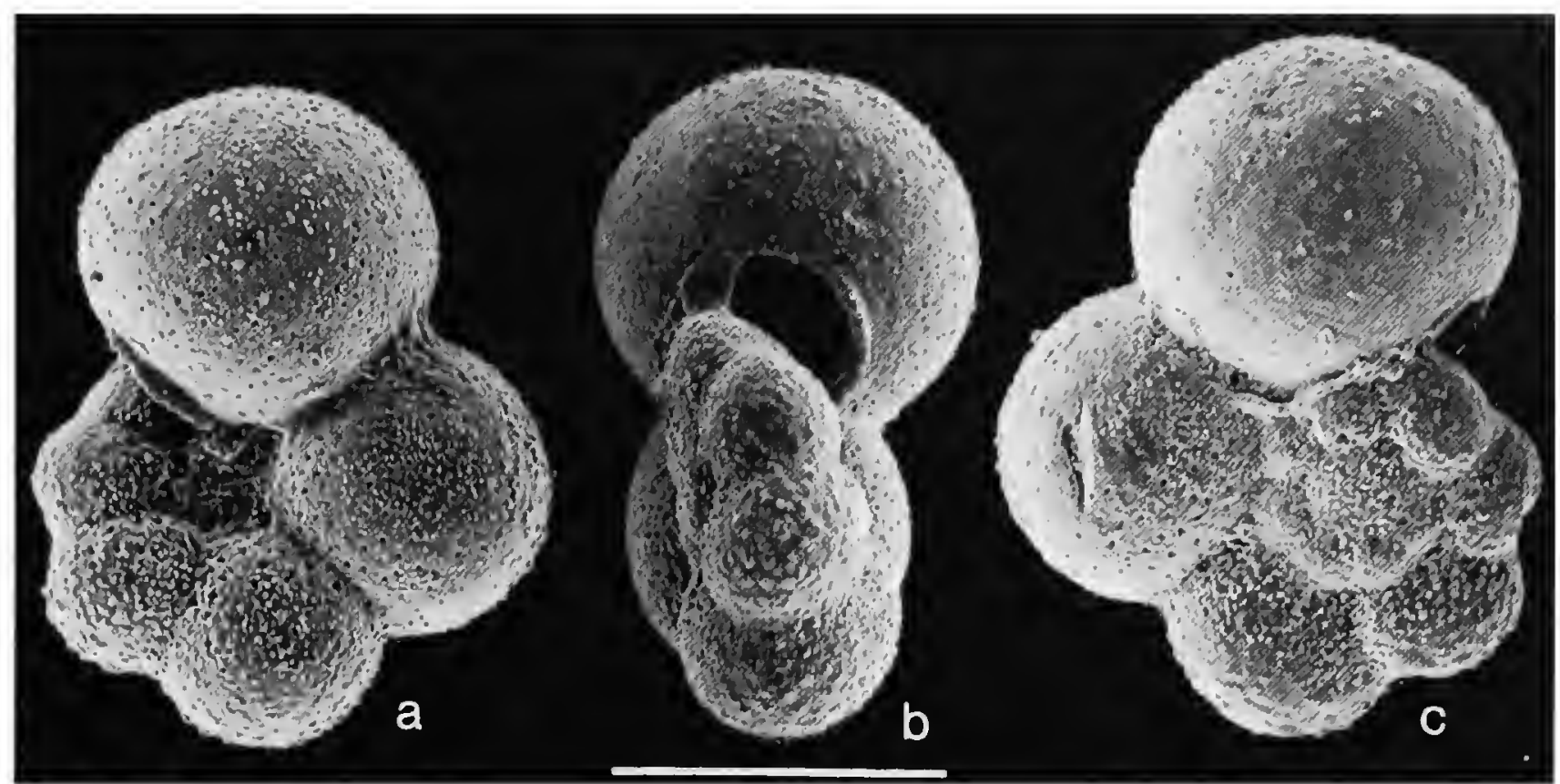

FIGURE 15.-Neotype of Hedbergella monmouthensis (Olsson), USNM 488562: $a$, umbilical view; $b$, edge view; $c$, spiral view. (Scale bar $=100 \mu \mathrm{m}$.)

REPOSITORY.-Holotype (USNM 626471, lost), topotype (USNM 640920), and neotype (USNM 488562, herein designated and illustrated in Figure 15) deposited in the Cushman Collection, National Museum of Natural History. Examined by BTH and RKO.

\section{Genus Globanomalina Haque, 1956, emended}

TYPE SPECIES. - Globanomalina ovalis Haque, 1956.

ORIGINAL DESCRIPTION.- - "Test oval to nearly circular in outline, periphery lobate, composed of somewhat globular chambers arranged in a trochoid spiral, usually very low. All chambers are visible from the dorsal side, which may be flattened or convex. Ventral side completely involute, umbilicate. Surface smooth, shiny. Wall calcareous, finely perforate, built of radially arranged crystals of calcite. Aperture peripheral, sometimes extending to the umbilicus on the ventral side, usually with a short lip. Lower Eocene." (Haque, 1956:147.)

DiAGNOSTIC CHARACTERS.-Test very low trochospiral with 12-15 chambers, with 5-6 chambers in ultimate whorl; chambers vary from globular to ovoid to low conical in shape. Aperture interiomarginal, umbilical-extraumbilical, a moderately high arch bordered by narrow lip that may broaden slightly towards umbilicus; aperture may extend slightly onto spiral side. Umbilicus small, generally deep. Wall normal perforate, smooth, but may be covered with pustule growth in some species, particularly in umbilical area. Peripheral margin either perforate, an imperforate band, or keeled.

DisCUSSION.-Banner's 1989 study of Globanomalina clarified its taxonomic status, clearly distinguishing the genus from the planispiral Pseudohastigerina, which Loeblich and Tappan (1988) regarded as a junior synonym of this genus. Banner emended the genus to clearly separate it from Pseudohastigerina and discussed its evolutionary relationship with this genus. He, however, regarded Globanomalina as having a microperforate wall with low, bluntly margined perforation pits. His observations appear to be based on poorly preserved specimens with corroded and recrystallized walls. All of the species of Globanomalina included in this atlas are normal perforate. Banner's observation of perforation pits is, however, correct, but as he pointed out, they are not to be confused with a cancellate wall. Globanomalina is herein emended to include the smooth-walled species of the Paleocene, which are members of two distinct lineages, one with an imperforate margin that leads to the carinate species $G$. pseudomenardii and one with a perforate margin that leads to the planispiral genus Pseudohastigerina.

\section{Globanomalina archeocompressa (Blow, 1979)}

Plate 32: Figures 1-10

Globorotalia (Turborotalia) archeocompressa Blow, 1979:1049, holotype: pl. 58: figs. 8, 9 [Zone P $\alpha$, DSDP Hole 47.2/11/5: 148-150 cm], paratypes: pl. 56: figs. 1, 2 [Zone P $\alpha$, DSDP Hole 47.2/1 1/6: 148-150 cm], pl. 58: figs. 2, 6, 7 [Zone P $\alpha$, DSDP Hole 47.2/1 1/5: 148-150 cm], pl. 64: figs. 5, 9 [Zone $\mathrm{P} \alpha$, DSDP Hole 47.2/11/3: 148-150 cm], pl. 68: figs. 5, 6 [Zone P1, DSDP Hole 47.2/11/3: 0-5 cm; Shatsky Rise, northwestern Pacific Ocean].

ORIGINAL DESCRIPTION.- “The very small test consists of about 11-12 chambers coiled in a low, lax trochospire with $5^{1 / 2}$ chambers visible in the final convolution of the test. In dorsal aspect, the chambers are almost hemispherical with inflated dorsal surfaces and depressed, sensibly radially disposed, intercameral sutures; the chambers are almost equidimensional with the tangential length only very slightly greater than the radial breadth. The inflation of the dorsal surfaces of the last convolution of chambers is such that the initial spire of chambers is depressed below the level of the later chamber 
surfaces. In equatorial profile, the test is moderately lobulate but is almost circular in overall outline. In axial-apertural profile, the test appears biconcave because of the depression of the initial spire below the level of the dorsal surfaces of the later chambers. The test is also seen in the axial-apertural view to have a rounded peripheral marginal outline and the later chambers, at least, appear subglobular with little or no differentiation in the degree of inflation for the ventral and dorsal surfaces of the chambers. In ventral aspect, the chambers appear subglobular but with quite deeply depressed, but not sharply incised, intercameral sutures which are radially disposed. The umbilicus is open but is shallow with no clearly marked umbilical shoulders to the surrounding convolution of chambers. The aperture is interiomarginal and extends from the shallow umbilicus to very nearly to the peripheral margin. The aperture is bordered by a well-marked flange-like lip and is a low, only slightly arched, opening. The wall is very finely perforate and the mural-pores do not open into distinct pore-pits, neither are they densely arranged. In optical appearance, the finely and sparsely perforate wall combined with the absence of pore-pits and inter-pore ridges gives the test a smooth, almost polished appearance which is characteristic of the $G$. (T.) compressa (sl) lineage. Maximum diameter of holotype: $0.139 \mathrm{~mm}$ as measured by electron-beam sensor." (Blow, 1979:1049.)

DiagNostiC ChaRACTERS.-Very small-sized species, $<130 \mu \mathrm{m}$ in greatest diameter. Test flattened and compressed with spiral side nearly plane. Axial periphery rounded with slightly conical chambers; chambers nearly flat on spiral side and project at high angle towards umbilicus. Ultimate whorl with 5-6 compressed, oval-shaped chambers; chambers very gradually increasing in size. Umbilicus shallow and broad, open to previous chambers, with sparse pustules on umbilical shoulders of surrounding chambers. Umbilical-extraumbilical aperture a broad, low arch entirely bordered by narrow lip. Wall of 4-7 $\mu \mathrm{m}$ thickness, smooth and perforate. Pores average 1 $\mu \mathrm{m}$ at narrowest point and mostly confined to chamber surfaces away from largely imperforate periphery.

DISCUSSION-This is the first species of the genus Globanomalina to appear in the earliest Danian. In morphology it is very similar to its ancestral species, Hedbergella holmdelensis Olsson, 1964. It differs, however, in that fine pustules are confined to the umbilical and inner spiral areas of the test rather than being sparsely distributed over the entire wall of the test as in H. holmdelensis. In early species of Globanomalina the chamber walls are smoother and generally free of numerous pustules. Pustules are more numerous on the chamber walls of G. pseudomenardii, but these are enhanced by gametogenesis. The possibility that the "pustules" in $G$. archeocompressa are of similar origin needs further investigation. The chambers are somewhat more inflated and the equatorial peripheral margin is more lobulate in $\mathrm{H}$. holmdelensis. Another difference lies in the ontogeny of each species. Six to 7 chambers make up the penultimate whorl in H. holmdelensis, a chamber arrangement typical of ancestral species of Hedbergella in the Cretaceous. In G. archeocompressa, the penultimate whorl is reduced to 5 chambers, which is typical of Globanomalina. The imperforate peripheral margin is a primary derived taxonomic character from $H$. holmdelensis and is present throughout the archeocompressa lineage.

STABLE ISOTOPES.- No data available.

Stratigra Phic Range.--Upper Zone P0 to Zone Plb. Due to the very small size and rare occurrence of this species the upper range is not yet reliably established.

Global Distribution.--Western equatorial Pacific Ocean, coastal Gulf of Mexico, and South Atlantic Ocean (DSDP Site 356).

ORIGIN OF SPECIES.-This species evolved from Hedbergella holmdelensis in late Biochron $\mathrm{P} 0$.

REPOSITORY.-Holotype (BP 37/38) and paratypes (BP 37/7, 37/21, 37/39, 37/49, 37/58, 37/118, 40/12, 40/44, 40/55) deposited in The Natural History Museum, London.

\section{Globanomalina australiformis (Jenkins, 1965)}

\section{Figure 16; Plate 33: Figures 1-13}

Globorotalia australiformis Jenkins, 1965:1112, fig. 11:92-96 [lower Eocene, Waipawan Stage, Middle Waipawan River section, New Zealand].Ludbrook and Lindsay, 1969:367, pl. 1: figs. 4, 5 [middle Eocene, South Australia].

Planorotalites australiformis (Jenkins).-Tjalsma, 1977:495, pl. 2: figs. 10-12 [lower Eocene, DSDP Site 329/32/1: 141-143 cm], fig. 13, [upper Paleocene, DSDP Site 329/33/1: 125-127 cm; Maurice Ewing Bank, South Atlantic Ocean].-Jenkins, 1985:279, fig. 6.8 [holotype refigured].-Huber, 199 lb:440, pl. 6: figs. 17, 18 [Zone A P5, uppermost Paleocene, ODP Hole 738B/23X: 196.93 msbf; Kerguelen Plateau, southern Indian Ocean].

Globorotalia (Planorotalites) australiformis Jenkins in Hornibrook, Brazier, and Strong, 1989:128: fig. 24:15a-c [holotype refigured].

ORIGINAL DESCRIPTION.- - "Test free, sinistrally coiled, small, low trochospiral, biconvex, equatorial periphery quadrilobate; axial periphery rounded in the first 3 chambers of the final whorl, but angled with an incipient keel in the final chamber. Wall calcareous, finely perforate, surface smooth. Chambers compressed, 13 chambers in about $2^{1 / 2}$ whorls, with 5 chambers in the first whorl and 4 in the last, increasing fairly rapidly in size; proloculus diameter approximately $0.01-0.02$ $\mathrm{mm}$. Sutures recurved on spiral side and nearly radial on the umbilical side; slightly depressed on both sides. Umbilicus small, open. Aperture a low arch interiomarginal, extraumbilical-umbilical. Maximum diameter: $0.26 \mathrm{~mm}$." (Jenkins, 1965:1112.)

Diagnostic Characters.- - Small species distinguished by 4 low, conical-shaped chambers in ultimate whorl and acute axial periphery. Earlier chamber walls covered by fine, dense pustules becoming more sparsely distributed on penultimate and ultimate chambers. Axial periphery mostly imperforate, becoming thickened on last one or two chambers. 


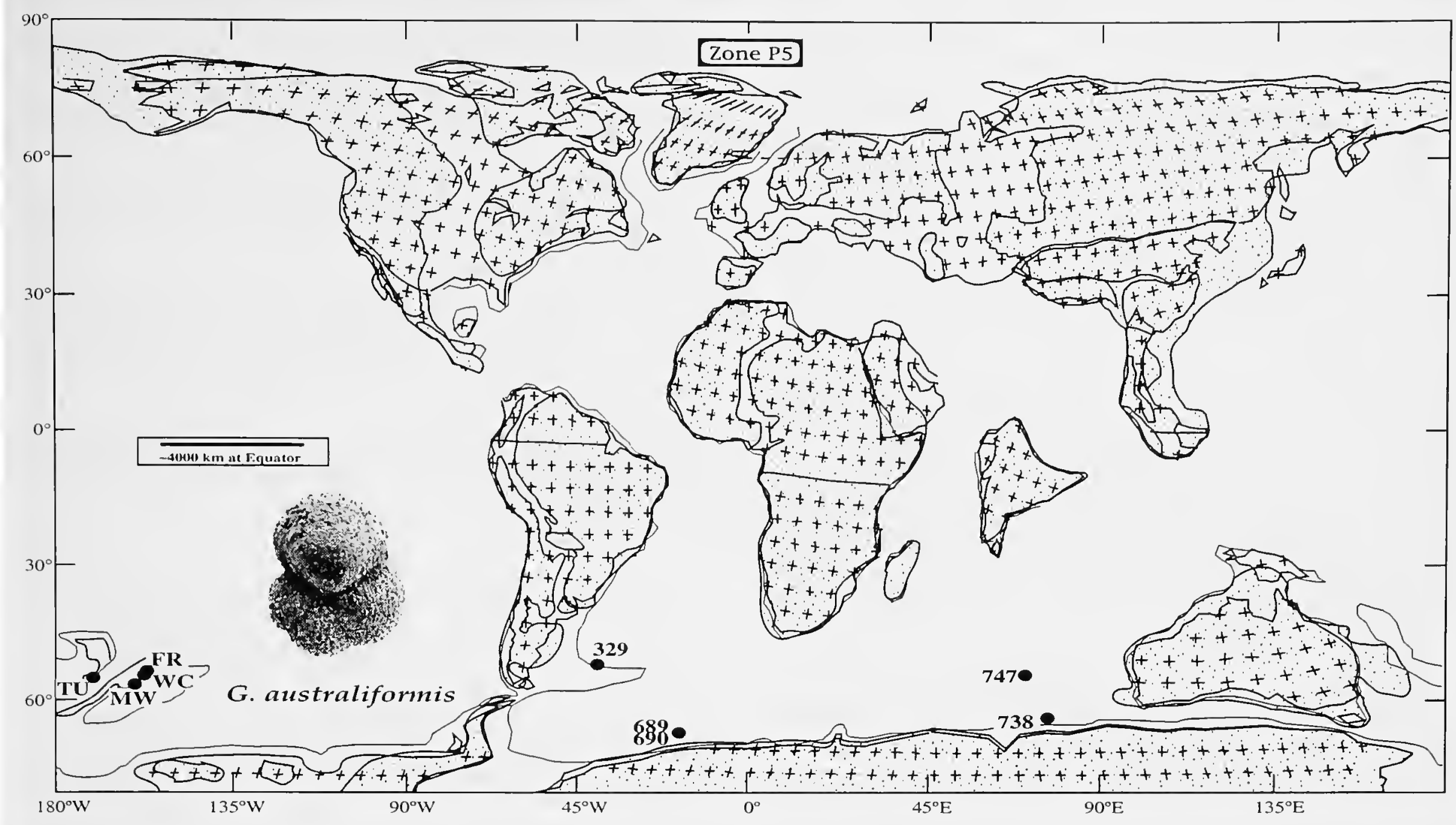

FIGURE 16.-Paleobiogeographic map showing distribution of Globanomalina australiformis (Jenkins) in the upper Paleocene.

DISCUSSION.-The original description of this species by light microscope indicated a smooth, finely perforate wall, but SEM micrographs show a fine coating of pustule-like calcite covering the original wall. It is possible that this coating is of gametogenetic origin, but this possibility needs more study. The species has been reported only in southern latitude sites and may be biogeographically restricted. Blow (1979) suggested that $G$. australiformis may be a cool-water endemic form of the tropical Globorotalia troelseni Loeblich and Tappan morphotype due to its general morphologic similarity. Globorotalia troelseni $(=G$. chapmani Parr, 1938) is a 5-chambered species and does not possess the dense pustulose wall surface of $G$. australiformis. It would appear that $G$. australiformis arose independently as an endemic species in the southern high latitudes. Blow also placed specimens identified as Globorotalia elongata Glaessner, 1937a, by Loeblich and Tappan (1957a) from the Vincentown Formation of New Jersey and from the Velasco Shale of Mexico in synonymy with $G$. australiformis. Those specimens belong to G. chapmani.

STABLE ISOTOPES. - No data available.

STRATIGRAPHIC RANGE.--Lower part of Waipawan Stage to the Porangan Stage; upper Subbotina triloculinoides Zone to the $P$. primitiva Zone (upper Paleocene to lower Eocene).

Global DisTRIBUTION.- Southern middle to high latitudes (Figure 16).
ORIGIN OF SPECIES. - The origin of this species has not been traced. Jenkins (1965) notes that australiformis is closely related to many Paleocene smooth-walled species (of Globanomalina) and that it replaces G. pseudomenardii Bolli, 1957a, in the lower part of the Waipawan Stage. It would appear more closely related to $G$. imitata in having $4-4 \frac{1}{2}$ (mostly 4) chambers in the final whorl and in the dense pustulose wall surface observed in early chambers of this species (see Plate 4: Figures 12, 13, 16; Plate 36: Figures 8, 12).

REPOSITORY.- New Zealand Geological Survey Register No. TF 1503: holotype and two paratypes. Examined by G.J.

\section{Globanomalina chapmani (Parr, 1938)}

\section{Plate 34: Figures 1-7}

Globorotalia chapmani Parr, 1938:87, holotype: pl. 3: fig. 9a,b; topotype: pl. 3: fig. 8 [upper Paleocene (probably Zone P4), Kings Park Shale, Kings Park Bore 1, 1,755 ft, Perth Basin, Western Australia].-McGowran, 1964:85, text-figs. 1-9 [upper Paleocene, Carnarvon Basin, northwestern Australia].-Berggren, Olsson, and Reyment, 1967:277, text-figs. 1, 3:1a-c, 4:1a-c, pl. 1: figs. 1-6 [Zone P4, Vincentown Fm., New Jersey; Boongerooda Greensand, northwestern Australia, text-fig. 1].-Pujol, 1983:657, pl. 3: fig. 3 [upper Paleocene, DSDP Hole 516F/85/1: 40-42 cm; Rio Grande Rise, South Atlantic Ocean].-Haig, Griffin, and Ujetz, 1993:275, pl. 1: figs. 1-3 [holotype ESEM], figs. 4-6 [Part topotype ESEM, from same level as holotype], pl. 2: figs. 1-23 [topotypes, from same level as holotype]. 
Anomalina luxorensis Nakkady, 1951:691, pl. 90: figs. 39-41 [upper Paleocene, Egypt].

Globorotalia membranacea (Ehrenberg).-Subbotina, 1953:205, pl. 16: fig. 12a-c [upper Paleocene, Tarkhankut Peninsula, Crimea] [in part, not pl. 16: figs. 7a-11b, 13]. [Not Planulina membranacea Ehrenberg, 1854.]

Globanomalina ovalis var. lakiensis Haque, 1956:149, pl. 14: fig. 2a-c [upper Paleocene, Pakistan].

Globorotalia elongata Glaessner.-Bolli, 1957a:77, pl. 20: figs. 11-13 [Zone P4, Lizard Springs Fm., Trinidad]. [Not Globorotalia pseudoscitula var. elongata Glaessner, 1937.]

Globorotalia troelseni Loeblich and Tappan, 1957a:196, pl. 60: fig. 4a-c [Zone P4, Nanafalia Fm., Alabama], pl. 63: fig. 5a-c [Zone P4, Velasco Shale, Mexico].

Globorotalia (Globorotalia) ehrenbergi Bolli.-Hillebrandt, 1962:126, pl. 12: fig. 3a-c [Zone D, Paleocene, Reichenhall-Salzburg Basin, AustroGerman border]. [Not Globorotalia ehrenbergi Bolli, 1957a.]

Planorotalites chapmani (Рarr).- - Nederbragt and Van Hinte, 1987:586, pl. 2: figs. 3-10, pl. 3: figs. 4-6 [Zone P4, DSDP Site 605/46/4: $85-89 \mathrm{~cm}$; fig. 3, DSDP Site 605/47/3: 60-62 cm; New Jersey margin] [in part, not pl. 2: figs. 1, 2, 11-16, pl. 3: figs. 1-3, 10-15].-Huber, 1991b:440, pl. 6: figs. 19, 20 [upper Paleocene, ODP Hole 738C/9R: 265.01 msbf; Kerguelen Plateau, Southern Indian Ocean].

ORIGINAL DESCRIPTION.- "Test biconvex, oval, the dorsal surface more convex than the ventral, which is umbilicate; periphery lobulated, peripheral margin rounded; chambers comparatively few, not more than five in the last-formed whorl, each much larger than its predecessor; sutures depressed, not limbate, gently recurved on both sides of the test; wall smooth and punctate, with a silvery lustre; aperture an elongate slit with a slight lip, opening at the base of the last-formed chamber into the umbilical depression. Length up to $0.65 \mathrm{~mm}$. This species belongs to the group of $G$. hirsuta (d'Orbigny) and is perhaps nearest to $G$. hirsuta, which typically has only four chambers to a whorl and with the sutures on the ventral side radial." (Parr, 1938:87.)

Diagnostic Characters. - Species identified by compressed test, pinched periphery with a thickened imperforate band, and rapidly enlarging chambers. Typically 5 , but up to 6 , chambers in ultimate whorl. Test walls smooth with occasional small pustule buildups in umbilical area and on inner spiral area.

DISCUSSION.-Haig et al.'s (1993) illustrations of the holotype, paratypes, and topotypes taken by SEM has clarified the morphologic characters of this species. It is clear from these illustrations that Anomalina luxorensis Nakkady (1951), Globanomalina ovalis var. lakiensis Haque (1956), the form identified by Subbotina (1953, p1. 16: fig. 12a-c) as Globorotalia membranacea (Ehrenberg, 1854), and the form identified by Bolli (1957a, pl. 20: figs. 11-13) as Globorotalia elongata (Glaessner, 1937a) should be placed in the synonomy of $G$. chapmani. In addition, Globorotalia troelseni Loeblich and Tappan (1957a) and the form identified by Hillebrandt (1962, pl. 12: fig. 3a-c) as Globorotalia ehrenbergi Bolli (1957a) are 5-chambered, compressed, smooth-walled forms that can be placed in G. chapmani. Globanomalina chapmani is a common species in upper Paleocene assemblages.
STABLE ISOTOPES.-Globanomalina chapmani has $\delta^{18} \mathrm{O}$ and $\delta^{13} \mathrm{C}$ similar to Parasubbotina varianta, S. triloculinoides, and G. pseudomenardii. The species has distinctly more positive $\delta^{18} \mathrm{O}$ and more negative $\delta^{13} \mathrm{C}$ than Morozovella, Acarinina, and Igorina.

Stratigra PHIC RANGE.-Within Zone P3 to Zone P6.

GLOBAL DiSTRIBUTION.-Worldwide in the middle and high latitudes.

ORIGIN OF SPECIES.-Globanomalina chapmani is a member of the smooth-walled imperforate periphery lineage and evolved from $G$. ehrenbergi (Bolli) in the lower part of Zone P4.

REPOSITORY - Museum collections of the Department of Geology, University of Western Australia, UWA18897. Examined by GJ.

\section{Globanomalina compressa (Plummer, 1926)}

Figure 17; Plate 14: figures 1-3; Plate 32: Figures 11-16; Plate 35: Figures $1-13,17$

Globigerina compressa Plummer, 1926:135, pl. 8: fig. 1 la-c [Zone P2, Wills Point Fm., Midway Group (upper Danian), Navarro Co., Texas].

Globigerina compressa var. compressa Plummer.-Subbotina, 1953:63, pl. 2: figs. 2a-6c [Danian, zone of rotaliform globorotaliids, Elburganian horizon, northern Caucasus].

Globorotalia compressa (Plummer).-Bolli, 1957a:77, pl. 20: figs. 21-23 [lower Paleocene, Lizard Springs Fm., Trinidad].-Bolli and Cita, 1960:20, pl. 32: fig. 3a-c [Globorotalia trinidadensis-Globigerina daubjergensis Zone, Paderno d'Adda section, northern Italy].-Pujol, 1983:656, pl. 2: figs. 3, 4 [lower Paleocene, DSDP Hole 516F/89/2: 119-121 cm; Rio Grande Rise, South Atlantic Ocean] [in part, not pl. 2: fig. 2].

Globorotalia (Globorotalia) compressa (Plummer).-Hillebrandt, 1962:125, pl. 12: fig. la-c [Zone B, lower Paleocene, Reichenhall-Salzburg Basin, Austro-German border].

Globorotalia (Turborotalia) compressa compressa (Plummer).-Blow, 1979:1062, pl. 75: figs. 10, 11 [Zone P1, Lindi area, Tanzania], pl. 78: figs. 5-10 [Zone P2, DSDP Hole 20C/6/4: 72-74 cm; Brazil Basin, South Atlantic Ocean], pl. 248: figs. 1-3 [topotype illustrations], pl. 254: figs. 1-3 [Danian, Denmark], pl. 257: figs. 5-7 [upper Danian, Sweden].

Planorotalites compressus (Plummer).-Huber, 1991c:461, pl. 3: figs. 1, 2 [Zone A P2, ODP Hole 738C/16: 340.93 mbsf; southern Kerguelen Plateau, southern Indian Ocean].

Globanomalina compressa (Plummer)-—Berggren, 1992:563, pl. 1: figs. 14-16 [ODP Hole 747A/19H/CC; Kerguelen Plateau, southern Indian Ocean].

ORIGINAL DESCRIPTION.- -"Test small, rotaliform, closely coiled, somewhat compressed, equally bioconvex; peripheral margin bluntly angular, lobate; chambers increasing gradually, 5 in last-formed whorl, moderately inflated, overlapping on dorsal face; sutures distinctly depressed and strongly curved on the dorsal side; shell wall thin, smooth, finely punctate; aperture a single moderately arched slit protected by a definite flaring flap at base of septal face and extending into the small but distinct umbilical depression.

"Diameter up to $.4 \mathrm{~mm}$.; average $.3 \mathrm{~mm}$." (Plummer, 1926:135.)

DiAGNOSTIC CHARACTERS.-Small, 5-chambered smooth- 


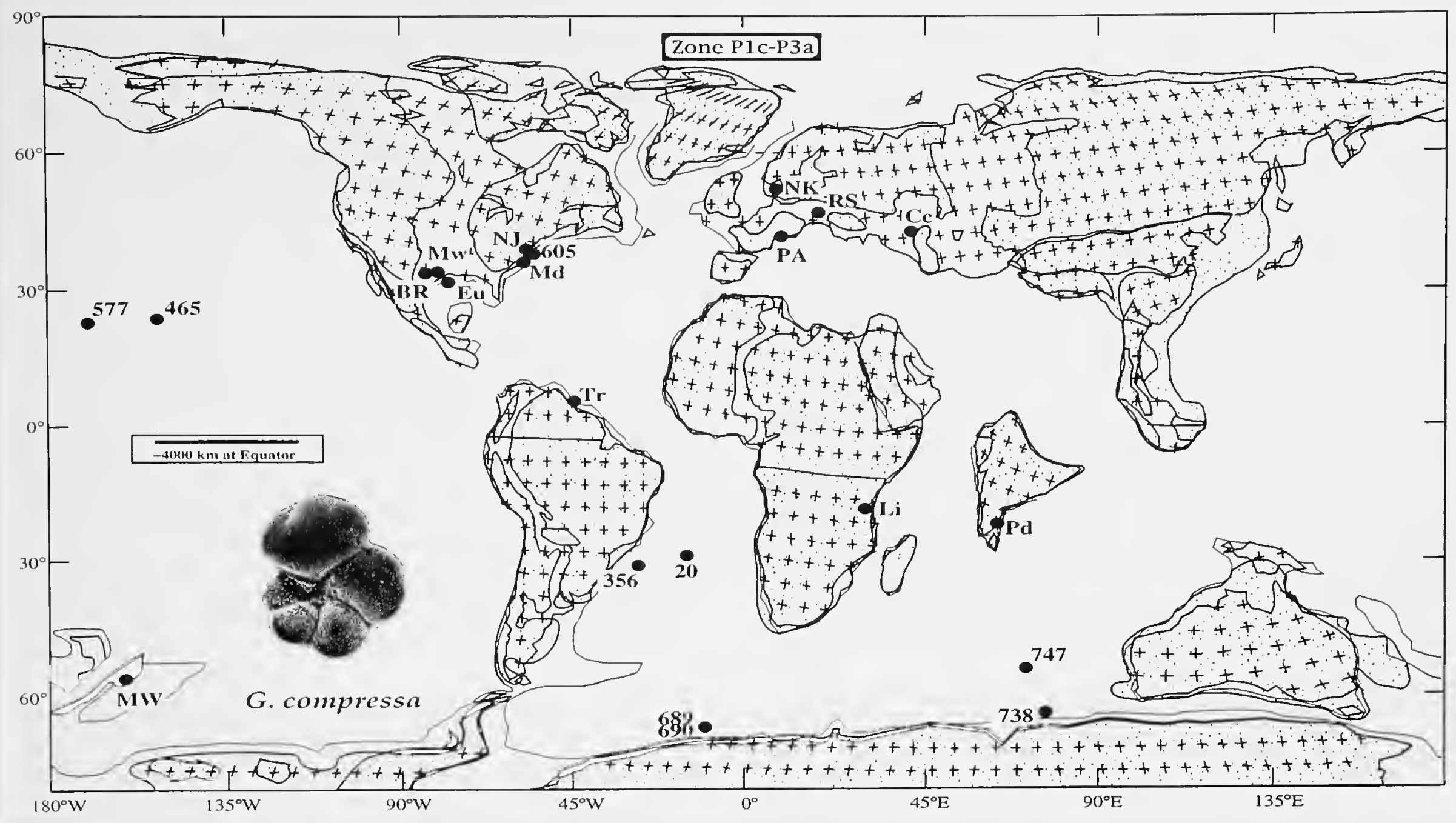

FIGURE 17.-Paleobiogeographic map showing distribution of Globanomalina compressa (Plummer) in Zones $\mathrm{P} 1$ and P2.

walled test, with moderately angular axial periphery, and moderately to strongly developed imperforate peripheral margin. Aperture a low, umbilical-extraumbilical arch, bordered along entirety by narrow, well-defined lip.

DISCUSSION.-Plummer (1926) designated three cotypes to represent her new species and illustrated one view of each (dorsal, edge, and ventral). We have selected one of these cotypes (Plummer, 1926: fig. 11c) as the lectotype for this species (Plate 14: Figures 1-3). The axial view of the lectotype is the view illustrated by Plummer to show the degree of compression of the test and the bluntly angular peripheral margin of the chambers of her new species. The chambers of the two paralectotypes are somewhat more inflated and the axial periphery of the test is somewhat less compressed than in the lectotype. Blow (1979) restricted his identification of $G$. compressa to morphotypes with compressed ogival chambers in axial view in contrast to morphotypes with an inflated rounded axial periphery, which he identified as $G$. cf. compressa or, if the chambers were more fully inflated, as $G$. planocompressa Shutskaya. Our studies separate compressa and planocompressa on the degree of compression/inflation of the chambers and the presence or absence of an imperforate peripheral margin. In the compressa-ehrenbergi-chapmani lineage an imperforate peripheral margin is a distinguishing characteristic, and the degree of compression of chambers in the ultimate whorl may vary from slightly compressed to the compressed ogival shape. In contrast, in the planocompressaimitata-ovalis lineage the chambers in the ultimate whorl are fully inflated and the axial periphery is perforate.

STABLE ISOTOPES.-Globanomalina compressa has $\delta^{18} \mathrm{O}$ and $\delta^{13} \mathrm{C}$ similar to Parasubbotina varianta, S. triloculinoides, and $G$. ehrenbergi. The species has distinctly more positive $\delta^{18} \mathrm{O}$ and more negative $\delta^{13} \mathrm{C}$ than Morozovella and Praemurica.

StratigRaPHIC RANGE.-Zone Plc to Zone P3.

GLOBAL Distribution.-Worldwide in low to high latitudes (Figure 17).

ORIGIN OF SPECIES.-This species shares morphologic similarities with $G$. archeocompressa in the compressed test and in the bluntly angular imperforate peripheral margin. The upper range of $G$. archeocompressa has not been firmly established and, consequently, its linkage with $G$. compressa is, at present, uncertain. We link the two species on the basis of their shared morphologic similarities (Plate 32).

REPOSITORY.-The three cotypes, Walker Museum Collection 33078, Station 23, are designated as follows: lectotype (UC 55091) and paralectotype (UC 33078), Chicago Field Museum; paralectotype (USNM 488563), Cushman Collection, National Museum of Natural History. Examined by BTH and RKO. 


\section{Globanomalina ehrenbergi (Bolli, 1957)}

Plate 14: Figures 4, 8, 12; Plate 35: figures 14-16

Globorotalia membranacea (Ehrenberg). - Cushman and Bermúdez, 1949:34, pl. 6: figs. 16-18 [Paleocene, Cuba]. [Not Planulina membranacea Ehrenberg, 1854.]

Globorotalia ehrenbergi Bolli, 1957a:77, pl. 20: figs. 18-20 [upper Paleocene, Lizard Springs Fm., Trinidad].

Globorotalia haunsbergensis Gohrbandt, 1963:53, pl. 6: figs. 10-12 [Paleocene, north of Salzburg, Austria].

Globorotalia (Turborotalia) haunsbergensis Gohrbandt.-Blow, 1979:1075, pl. 88: figs. 6, 8 [Zone P3, DSDP Hole 47.2/10/1: 72-74 cm; Shatsky Rise, northwestern Pacific Ocean], fig. 9 [Zone P3, Lindi area, Tanzania].

ORIGINAL DESCRIPTION.- "Shape of test low trochospiral, compressed; equatorial periphery strongly lobate; axial periphery acute, last chamber often with a faint keel. Wall calcareous, perforate, surface smooth. Chambers compressed; about 1215 , arranged in 2-3 whorls, the 5 chambers of the last whorl increasing fairly rapidly in size. Sutures on spiral side slightly curved, distinctly depressed; on umbilical side radial, depressed. Umbilicus shallow, open. Aperture a low arch, with a lip; interiomarginal, extraumbilical-umbilical. Coiling random. Largest diameter of holotype $0.28 \mathrm{~mm}$." (Bolli, 1957a:77.)

Diagnostic Characters.-Compressed, smooth-walled test, with chambers moderately increasing in size, often with ultimate chamber smaller than the penultimate one, pinched periphery with thickened imperforate margin (faint keel of Bolli), 5-5 $\frac{1}{2}$ chambers in ultimate whorl.

DisCussion.-Bolli (1957a) erected this species for Paleocene morphotypes that had been referred to Ehrenberg's species. The basis for distinguishing this species from $G$. compressa is the pinched periphery and the thickened imperforate margin, which is more strongly developed than in $G$. compressa. Although Blow (1979) separated G. ehrenbergi from $G$. haunsbergensis, we include morphotypes with a more sharply acute periphery within the range of variation of $G$. ehrenbergi. Blow (1979) drew attention to the more lax coiling of $G$. haunsbergensis morphotypes, which results in a wide, shallow umbilicus. The trend towards a more strongly developed imperforate margin was recognized by Bolli and Blow as a trend towards a true keel, which resulted in the evolution of G. pseudomenardii. Globanomalina chapmani is also allied to $G$. ehrenbergi in having a pinched periphery and a thickened imperforate margin. As in G. pseudomenardii, the rate of chamber-size increase is greater than in G. ehrenbergi.

STABLE ISOTOPES.-Globanomalina ehrenbergi has $\delta^{18} \mathrm{O}$ and $\delta^{13} \mathrm{C}$ similar to Parasubbotina varianta, S. triloculinoides, and $G$. compressa. The species has distinctly more positive $\delta^{18} \mathrm{O}$ and more negative $\delta^{13} \mathrm{C}$ than Morozovella and Igorina.

STRATIGRAPHIC RANGE.-Z Zone P2 to Zone P4.

GLOBAL DISTRIBUTION.-Apparently a worldwide distribution in the low to middle latitudes.

ORIGIN OF SPECIES.-As pointed out by Bolli (1957a) and
Blow (1979), this species is transitional to G. pseudomenardii. It evolved from $G$. compressa by developing a more highly developed imperforate margin and a more sharply angular axial margin.

REPOSITORY.-Holotype (USNM P5060) deposited in the Cushman Collection, National Museum of Natural History. Examined by RKO.

\section{Globanomalina imitata (Subbotina, 1953)}

Plate 10: Figures 12-14; Plate 12: Figures 10-12; PLATE 36: F1GURES 7-12, 16

Globorotalia imitata Subbotina, 1953:206, holotype: pl. 16: fig. 14a-c; paratype: pl. 16: figs. 15a-16c [zone of rotaliform globorotaliids (Danian Stage), Kuban River, northern Caucasus].-Loeblich and Tappan, 1957a:190, pl. 54: fig. 8a-c [Zone P4, Vincentown Fm., New Jersey], pl. 59: fig. 5a-c [Zone P4, Aquia Fm., Maryland], pl. 63: fig. 3a-c [Zone P4, Velasco Fm., Mexico] [in part, not pl. 44: fig. 3a-c, pl. 45: fig. 6a-c, pl. 54: fig. 9a-c].-Olsson, 1960:46, pl. 9: figs. 7-9 [Zone P3b, Hornerstown Fm., New Jersey].

ORIGINAL DESCRIPTION.—“"Shell small, rotaliform, strongly convoluted with a broadly oval outline. Whorls $2^{1 / 2}-3$. The first 2 whorls are considerably smaller than the last. Their diameter comprises on average only one third the diameter of the whole shell. Dorsal side flattened, ventral side convex, subconical. In the centre of the central side there is a very small, hardly discernible umbilicus. The umbilical ends of the chambers are disposed above the rest of the surface of the ventral side, thus forming the apex of a short cone. The peripheral margin is rounded and scalloped. The chambers on the dorsal side are oval and drawn out in the direction of the spiral whereas on the ventral side they are broadly triangular. There are 4 chambers to the last whorl and these show a rapid increase in dimensions. The sutures are recessed, almost straight or slightly curved, on both the dorsal and the ventral sides. Attention should be paid to the shortness of the sutures on the dorsal side as compared with the rather long sutures on the ventral side. The orifice is represented by a straight slit covered by well-defined slender lips. It has the form of an even rectangular cavity extending along the whole length of the marginal suture. The wall is thin, smooth, and in well-preserved specimens lustrous; it is perforated by many small pores. Dimensions: diameter $0.15-0.25 \mathrm{~mm}$, thickness $0.08-0.11$ mm." (Subbotina, 1953:206; translated from Russian.)

DIAGNOSTIC CHARACTERS.-Small smooth-walled test with $4-4^{1} / 2$, occasionally 5 , inflated chambers in ultimate whorl. Chambers ovoid shaped with long axis directed towards umbilicus. In spiral and umbilical views, chambers ovoid shaped, with long axis parallel to coiling spire. Test walls perforate throughout; aperture a high umbilical-extraumbilical arch bordered by thin continuous lip. Adult chambers smoothwalled, but wall covered with fine scattered to dense pustules in early ontogenetic stages possessing anguloconical chambers (Plate 4: Figures 12, 13, 16, Plate 36: Figures 8, 12). 
DISCUSSION.-This is a distinctive species that is often overlooked because of its small size. It belongs to the perforate walled, inflated chamber lineage of planocompressa-imitataovalis. It also appears to have a phylogenetic link to $G$. australiformis (see "Discussion" under this species). The specimens illustrated as imitata by Blow (1979, pl. 81: figs. 8, 9, pl. 83: figs. 1, 2, pl. 88: fig. 5) are distinctly cancellate walled and do not belong to this species but probably belong to Praemurica.

STABLE ISOTOPES.-No data available.

Stratigraphic Range.-Zone P1c to Zone P4.

GLOBAL DisTRIBUTION.-Known from the northern Caucasus, southeast India, and the Atlantic and Gulf of Mexico coastal plains.

ORIGIN OF SPECIES.-This species probably evolved from Globanomalina planocompressa in Zone P1c.

REPOSITORY.-Holotype (No. 4073) and paratypes (Nos. 4074, 4075) deposited in the micropaleontological collections at VNIGRI (378/112), St. Petersburg. Examined by FR.

\section{Globanomalina ovalis Haque, 1956}

\section{PLATE 37: FIGURES 1-15}

Globanomalina ovalis Haque, 1956:147, pl. 14: fig. 3a-c [upper Paleocene, Bed B2, Laki Fm., Pakistan].-Banner, 1989, emended:177, pl. 1: fig. la-c [original drawings of holotype], pl. 1: fig. 2a-c [original drawings of holotype of Globanomalina simplex Haque, 1956], pl. 1: fig. 3a-c [SEM of paratype of $G$. ovalis], pl. 1: fig. 4a-c [original drawings of holotype of Globigerina pseudoiota Homibrook, 1958], pl. 2: fig. la-c [paratype of $G$. ovalis], pl. 2: fig. 2a-e [upper Paleocene, Dannevirke Series, New Zealand], pl. 3: figs. la-2d [upper Paleocene, Dannevirke Series, New Zealand].

Globigerina pseudoiota Homibrook, 1958:34, pl. 1: figs. 16-18 [upper Paleocene, New Zealand]. Banner, 1989, pl. 1: figs. 4a-c, pl. 2: figs. 2a-e, pl. 3, figs. 1a-d, 2a-d.

Globorotalia (Turborotalia) sp. ex interc G. (T.) chapmani Parr and Pseudohastigerina wilcoxensis (Cushman and Ponton).-Blow, 1979:1060, pl. 111: fig. 5 [Moogli Mudstones, Papua, given as Zone P7 = Zone P6a this paper].

ORIGINAL DESCRIPTION.--"Test small, oval, longer than broad, biconvex, nearly bilaterally symmetrical. Periphery sub-acute, broadly rounded, lobate. Dorsal side flat or slightly convex, showing all the chambers. Ventral side completely involute, umbilicate. Chambers distinct, inflated, globose, somewhat overlapping, about 6 in the adult whorl, rather rapidly increasing in size as added; last 2 chambers occupy more that half of the test. Sutures distinct, depressed, somewhat curved on the dorsal side, radial on the ventral. Surface smooth, shiny. Wall calcareous, very finally perforate, built of radially arranged crystals of calcite. Aperture an elongate slit at the base of the last chamber of the outer whorl extending from the periphery to the umbilicus with a narrow lip. Length of figured specimen $0.26 \mathrm{~mm}$; breadth $0.21 \mathrm{~mm}$; thickness $0.14 \mathrm{~mm}$." (Haque, 1956:147.)

DIAGNOSTIC CHARACTERS.-Emended description: "Globanomalina as here defined, with six chambers per whorl initially, sometimes retaining this number in the last-formed whorl but sometimes reducing it to five; the rate of chamber volume increase with chamber addition is approximately the same in each form, so that (a) when the chamber number is reduced (e.g., to five in the last whorl) the spiral side of the test remains completely evolute and flat or slightly convex in shape, or (b) when the final chamber number is not reduced (e.g., is retained at about six in the last whorl) the final chambers overlap slightly onto the spiral side, so that that side becomes incompletely evolute and slightly concave in shape; wall is microperforate, with perforation canaliculi about $1 \mu \mathrm{m}$ in diameter, opening into broadly and bluntly rounded perforation pits about $10 \mu \mathrm{m}$ in diameter (the perforation pits are deeper on the earlier chambers which have had their walls thickened by test growth); maximum diameter achieved is about $0.34 \mathrm{~mm}$." (Banner, 1989:177.)

DISCUSSION.-Banner's (1989) study clarified the taxonomic positon of the genus Globanomalina and the type species ovalis. Banner correctly pointed out that as the number of chambers increase from 5 to 6 in the ultimate whorl the test becomes asymmetrically planispirally arranged. In addition, the aperture, which is a fairly high arch, bordered by a continuous, thin lip, migrates slightly onto the spiral side. The test walls are perforate throughout, and, although Banner described the wall as microperforate, we include G. ovalis in the normal perforate category, which contrasts with microperforate taxa (test walls with pore diameters $0.3-0.45 \mu \mathrm{m}$ in diameter) of the Guembelitridae. As Banner (1989) pointed out in his study, Globigerina pseudoiota Hornibrook (1958) should be regarded as a junior synonym of $G$. ovalis. The form illustrated by Blow (1979, pl. 111: fig. 5) as an intermediate between G. chapmani (Parr) and Pseudohastigerina wilcoxensis (Cushman and Ponton) is a smooth-walled, 6-chambered, nearly planispiral form that has an extraumbilical aperture extending slightly onto the dorsal side. We agree with Blow that this morphology is transitional to Pseudohastigerina, but that it is represented in the species G. ovalis.

STABLE ISOTOPES.-No data available.

STRATIGRAPHIC RANGE.- - Upper Zone P4 to Zone P6.

GLOBAL DISTRIBUTION.-Northern and southern midlatitudes.

ORIGIN OF SPECIES.-This species is a member of the inflated chamber, perforate walled lineage in Globanomalina. Globanomalina ovalis evolved from $G$. imitata in the upper part of Zone $\mathrm{P} 4$ by an increase in the number of chambers in the ultimate whorl from 5 to 6 , a greater degree of inflation of the chambers, and the trend towards planispirality (see Plate 36: Figures 13-15). Although Berggren et al., 1967, and Banner, 1989 , stated that $G$. ovalis derived from G. chapmani, there is a distinct difference in the wall texture between the two species that would appear to preclude a phylogenetic linkage. In the Pondicherry section of southeast India G. ovalis and G. imitata overlap morphologically (Plates 36, 37).

REPOSITORY.-Geological Survey of Pakistan at Quetta, Pakistan. Paratypes (P.42400) at The Natural History Museum, London. 


\section{Globanomalina planocompressa (Shutskaya, 1965)}

\section{Plate 36: Figures 1-6}

Globorotalia compressa (Plummer).-Loeblich and Tappan, 1957a: 188, pl. 40: fig. 5a-c [paratypic by synonymy, type Danian, Ostratorp], pl. 41: fig. 5a-c [Zone P1b, McBryde Fm., Alabama] [in part, not pl. 42: fig. Sa-c, pl. 44: figs. 9, 10].

Globorotalia planocompressa planocompressa Shutskaya, 1965:179, pl. 1: fig. 6a-c [lower Paleocene, northern Caucasus].

Globorotalia (Turborotalia) compressa planocompressa Shutskaya.-Blow, 1979:1067, pl. 68: figs. 4, 8-10 [Zone P1a, DSDP Hole 47.2/11/3: 0-5 cm], pl. 71: figs. 8-10 [Zone P1, DSDP Hole 47.2/1/1: 0-1 cm; Shatsky Rise, northwestern Pacific Ocean].

Globanomalina planocompressa Shutskaya.-Olsson, Hemleben, Berggren, and Liu, 1992:207, pl. 7: figs. 6-8 [Zone Pla, Clayton Basal Sands, Millers Ferry, Alabama].

ORIGINAL DESCRIPTION.- "Test with a subpolygonal lateral outline, strongly compressed along the growth axis. Spire consists of three whorls. Early whorls lie on one level with the surface of the last whorl or rise up slightly above it. In each whorl there are five to six inflated subspherical chambers, rapidly and uniformly increasing in size and arranged freely. Peripherally on the chambers a small papillate projection, directed toward the subsequent chamber, is frequently observed. Last chamber asymmetrical, flattened at the apertural face and slightly shifted toward the umbilical surface. Equatorial outer margin scalloped. Axial outer margin weakly asymmetric, broadly rounded. Sutures deep, straight. Umbilicus narrow. Aperture a semicircular slit located between the umbilicus and the outer margin. Sometimes it is surrounded by a very narrow lip, the width of which is uniform over its whole length. Wall smooth, finely perforate. Surface lustrous or matte. Dimensions of holotype (fig. $5 \mathrm{a}-\mathrm{x}$ ): greatest diameter 0.45 , least diameter 0.32 , height $0.21 \mathrm{~mm}$." (Shutskaya, 1965: 179; translated from Russian.)

DiagNostiC CHARACTERS. - Ultimate whorl with 5 chambers increasing moderately in size. Chambers globular to ovoid shaped, more inflated than $G$. archeocompressa. Pores average $1 \mu \mathrm{m}$ at narrowest point, evenly distributed in chamber walls, but some areas imperforate, especially on parts of wall periphery. Wall thickness 4-7 $\mu \mathrm{m}$.

DISCUSSION.-Although the original types are presumably lost, the meaning of this taxon seems clear from study of the Russian collections, and Blow's (1979) analysis of the species is followed herein. He based his analysis on the specimen figured by Loeblich and Tappan (1957a, pl. 40: fig. 5a-c), which became a paratype of this species when Shutskaya included this specimen in synonymy with her new species. Globanomalina planocompressa is the first member of the planocompressa-imitata-ovalis lineage, a lineage characterized by inflated, perforate-walled chambers.

STABLE ISOTOPES.-Globanomalina planocompressa has $\delta^{18} \mathrm{O}$ and $\delta^{13} \mathrm{C}$ similar to Parasubbotina pseudobulloides, $S$. triloculinoides, and $E$. eobulloides. The species has distinctly more positive $\delta^{18} \mathrm{O}$ and more negative $\delta^{13} \mathrm{C}$ than Praemurica and Woodringina.
Stratigraphic Range.- - Upper Zone P $\alpha$ to Zone Plc.

GLOBAL Distribution.--Known distribution in the northern hemisphere middle and low latitudes.

ORIGIN OF SPECIES.-This species originates in Zone $\mathrm{P} \alpha$ from $G$. archeocompressa by the inflation of chambers and the loss of an imperforate peripheral margin. It, in turn, gives rise to $G$. imitata in Zone Plc.

REPOSITORY.-Holotype No. 3510/1, Moscow, GAN. Examined by FR.

\section{Globanomalina planoconica (Subbotina, 1953)}

Plate 10: Figures 15-17; Plate 34: Figures 8-17

Globorotalia planoconica Subbotina, 1953:210, holotype: pl. 17: fig. 4a-c; paratypes: pl. 17: figs. 5a-6c [zone of conical globorotaliids, lower to middle Eocene (probably lower Eocene), ser. F1, Khieu River, Caucasus].

ORIGINAL DESCRIPTION.- "Shell oval, planoconvex, with flattened dorsal and convex ventral sides. Whorls, 2. The first whorl is poorly distinguished because of its very small size. The second whorl is obvious and consists of 5 or 6 chambers which gradually increase in size. The last chamber is considerably larger than the penultimate one. The peripheral margin is scalloped, acute, and sometimes possesses a narrow keel.

"On the dorsal side the chambers have a semicircular outline, on the ventral side it is triangular. The umbilical ends of the chambers are closely joined together so that there is an open and deep umbilicus.

"The septal sutures are slightly curved and recessed. The orifice is furnished with a slender and narrow lip. In some specimens the orifice appears to extend along the whole of the marginal suture from the umbilicus to the periperal margin and may even extend on to the peripheral margin itself. The wall is thin, smooth, transparent and perforated by fine pores. Dimensions: $0.23-0.26 \mathrm{~mm}$, thickness $0.06-0.08 \mathrm{~mm}$." (Subbotina, 1953:210; translated from Russian.)

DIAGNOSTIC CHARACTERS.-Small highly compressed species with well-developed, thickened, imperforate peripheral margin. Five to 6 , occasionally 7 , chambers in ultimate whorl. Aperture a high umbilical-extraumbilical arch bordered by thin continuous lip. Equatorial periphery rounded in early portions of ultimate whorl, becoming more lobulate with final few chambers.

DISCUSSION.-The specimens identified as this species by Tjalsma (1977) and Huber (1991b) from the South Atlantic and southern Indian oceans, respectively, differ from the holotype (Plate 10: Figures 15-17) by having only five chambers in the ultimate whorl and by the more sharply curved sutures on the spiral side. Tjalsma reported that transitional forms between "planoconica" and G. australiformis occurred at DSDP Site 329 in the upper Paleocene and lower Eocene, suggesting that the former species was derived from the latter. It would appear that these "planoconica" morphotypes may be a different 
species. This possibility needs further investigation. Blow (1979) figured specimens from Zone P10 in a North Atlantic piston core that he identified as G. planoconica. These specimens have 7 to 8 chambers in the ultimate whorl and a high arched aperture that extends slightly over the axial periphery onto the spiral side. He considered these forms ancestral to Pseudohastigerina danvillensis (Howe and Wallace, 1932). Except for the greater number of chambers, Blow's specimens are similar to G. planoconica in that they possess a well-developed imperforate peripheral margin, but they differ in the apertural lip, which widens as a tooth-like projection into the umbilical area. It would appear that these morphotypes may be related to $G$. planoconica. The morphologic range of this species and its relationship to other species in the Eocene needs further study.

STABLE ISOTOPES.- No data available.

STRATIGRAPHIC RANGE.- - Upper Zone P4 to lower Eocene.

GLOBAL DisTRIBUTION.-As discussed above, the taxonomy of this species needs further clarification before its distribution can be reliably plotted. At present, a middle to low latitude distribution is probable.

ORIGIN OF SPECIES.-The strong imperforate peripheral margin allies this species with the chapmani lineage and suggests that it was derived from this species in upper Zone P4.

REPOSITORY.-Holotype (No. 4081) and paratypes (No. 4082, 4083) deposited in the micropaleontological collections at VNIGRI (378/118), St. Petersburg. Holotype examined by FR.

\section{Globanomalina pseudomenardii (Bolli, 1957)}

Figure 18; Plate 14: Figures 5-7; Plate 38: figures 1-16

Globorotalia membranacea (Ehrenberg).-Subbotina, 1953:205, pl. 16: fig. 13a-c [Paleocene, Tarkhankut Peninsula, Crimea] [in part, not pl. 16: figs. 7a-12c]. [Not Planulina membranacea Ehrenberg, 1854.]

Globorotalia pseudomenardii Bolli, 1957a:77, holotype: pl. 20: figs. 14-16; paratype: pl. 20: fig. 17 [Globorotalia pseudomenardii Zone, Lizard Springs Fm., Trinidad].-Loeblich and Tappan, 1957a:193, pl. 47: fig. 4a-c [Zone P4, Salt Mountain Limestone, Alabama], pl. 49: fig. 6a-c [lower Zone P4, Hornerstown Fm., New Jersey], pl. 54: figs. 10a-13c [Zone P4, Vincentown Fm., New Jersey], pl. 59: fig. 3a-c [Zone P4, Aquia Fm., Maryland], pl. 60: fig. 8a-c [Zone P4, Nanafalia Fm., Alabama], pl. 63: fig. la-c [Zone P4, Velasco Fm., Mexico] [in part, not pl. 45: fig. 10a-c].-Bolli and Cita, 1960:26, pl. 33: fig. 2a-c [Globorotalia pseudomenardii Zone, Paderno d'Adda section, northern Italy].

Globorotalia (Globorotalia) pseudomenardii Bolli--Hillebrandt, 1962:126, pl. 12: figs. 5a-6b [upper Paleocene beds of Reichhall-Salzburg Basin, Austria].-Blow, 1979:892, pl. 89: figs. 1-5 [Zone P4, DSDP Hole 21 A/3/5: 74-76 cm; Rio Grande Rise, South Atlantic Ocean], pl. 94: figs. 1-5 [Zone P4, Lindi area, Tanzania], pl. 108: figs. 4-7 [Zone P4, DSDP Hole 20C/6/3: 76-78 cm; Brazil Basin, South Atlantic Ocean], pl. 111: figs. 1-4, pl. 112: figs. 2, 3, 9, 10 [Zone P4, Moogli Mudstones, Papua] [in part, not pl. 105: figs. 3, 7-10].

Planorotalites pseudomenardii Bolli.-Nederbragt and Van Hinte, 1987:587, pl. 1: figs. 1-16 [Zone P4, DSDP Site 605/46/4, 46/6, 46/3, 52/2; New Jersey margin, westem North Atlantic Ocean].-Nocchi et al., 1991:269, pl. 1: figs. 7-9 [Zone P4, ODP Hole 698A/11R/CC; northeast Georgia Rise, South Atlantic Ocean].
ORIGINAL DESCRIPTION.- - "Shape of test very low trochospiral, biconvex; equatorial periphery elongate, lobate, especially so in large specimens; axial periphery angular with distinct keel. Wall calcareous, perforate, surface smooth. Chambers strongly compressed; about 15, arranged in 3 whorls, the 5 chambers of the last whorl increasing rapidly in size. Sutures on spiral side strongly curved, especially so between last chambers of large specimens, depressed; on umbilical side radial, depressed. Umbilicus shallow, open. Aperture a low arch with a lip; interiomarginal, extraumbilical-umbilical. Largest diameter of holotype $0.34 \mathrm{~mm}$., of figured paratype $0.66 \mathrm{~mm} . "$ (Bolli, 1957a:77.)

DiAGNOSTIC CHARACTERS.-Distinct keel, sharply angled axial periphery, spiroconvex test, and narrow umbilicus distinguish species. Number of chambers in the ultimate whorl consistently 5 , but 6 -chambered form rarely observed (Plate 38 : Figure 4).

DISCUSSION.-There is considerable variation in the shape of the equatorial periphery, which varies from fairly smooth to strongly lobulate, depending on the rate of size increase or decrease of the final few chambers in the ultimate whorl.

STABLE ISOTOPES.-Globanomalina pseudomenardii has $\delta^{18} \mathrm{O}$ and $\delta^{13} \mathrm{C}$ similar to Parasubbotina varianta and $S$. velascoensis. The species has distinctly more positive $\delta^{18} \mathrm{O}$ and more negative $\delta^{13} \mathrm{C}$ than Morozovella, Acarinina, and Igorina.

STRATIGRAPHIC RANGE.-Zone P4.

GLOBAL DISTRIBUTION.-Widely reported in the low to middle latitudes (Figure 18).

ORIGIN OF SPECIES.-There is general agreement among workers that $G$. pseudomenardii originated from G. ehrenbergi (= G. haunsbergensis Gohrbandt) by an increase in the test size and the development of a peripheral keel. The species becomes extinct at the top of Zone P4.

REPOSITORY.-Holotype (USNM P5061) and paratype (USNM P5062) deposited in the Cushman Collection, National Museum of Natural History. Examined by BTH and RKO.

\section{Family Truncorotaloididae Loeblich and Tappan, 1961}

\section{(by W.A. Berggren, Ch. Hemleben, R.D. Norris, and R.K. Olsson)}

ORIGINAL DESCRIPTION._- "Primary aperture on the umbilical side, and secondary apertures on spiral side." (Loeblich and Tappan, 1961:309.)

DiAGNOSTIC CHARACTERS.-Test, a low to moderately elevated trochospire, with or without peripheral keel; chambers globular to conical shaped; wall cancellate to muricate, pustule growth moderate to heavy, usually around umbilical area or along a peripheral keel; aperture interiomarginal, umbilicalextraumbilical, with or without lip, may have supplementary apertures.

DISCUSSION.-This family tentatively includes Acarinina, Igorina, Morozovella, and Praemurica. As discussed in "Phylogeny," there are two views among the working group 


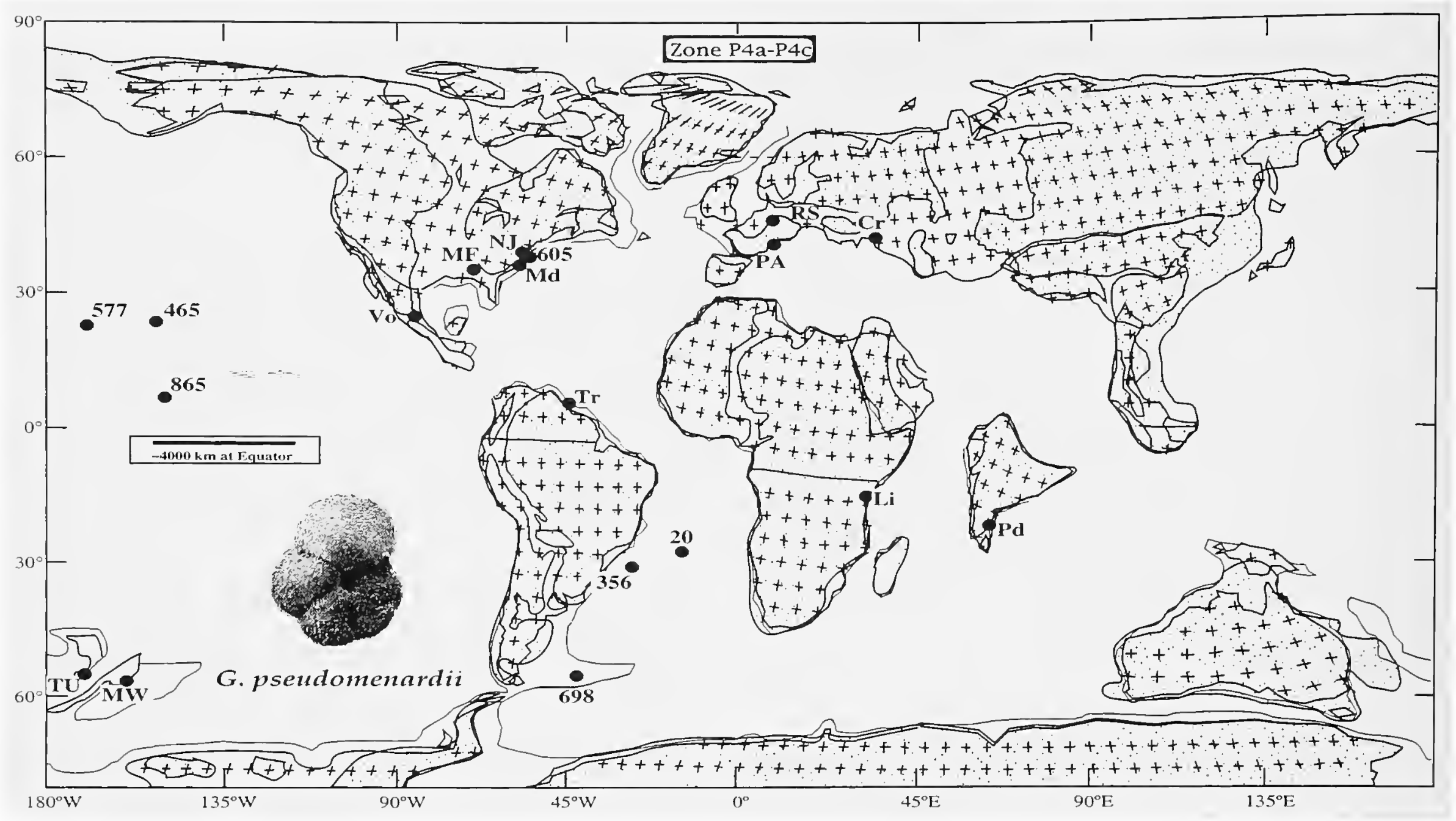

FIGURE 18.-Paleobiogeographic map showing distribution of Globanomalina pseudomenardii (Bolli) in Zone P4.

members on the relationships between these genera (see Figure $5 a, b$ ). The use of this family appears appropriate, for the time being, until these differences are resolved.

\section{Genus Acarinina Subbotina, 1953}

TYPE SPECIES.-Acarinina acarinata Subbotina, 1953 (= junior subjective synonym of Globigerina nitida Martin, 1943).

ORIGINAL DESCRIPTION.- -"Test always strongly inflated, with chambers of the Globigerina type. Dorsal side slightly flattened, strongly convex ventrally. There is always an umbilicus; it may be small and barely discernible or large and very distinct. Peripheral margin without a keel, most frequently rounded. Chambers sometimes closely adjacent to one another, but in many species the chambers are loosely arranged. Aperture slitlike, along the marginal suture, often without a lip. Wall coarsely spinose; on the ventral side, near the umbilicus, the spines are longer than on the remainder of the test." (Subbotina, 1953:219; translated from Russian.)

Diagnostic Characters.--Test, a moderate to low trochospire; chambers ovoid shaped, generally with 4-6 chambers in final whorl, occasionally 7 or more; wall moderately to strongly muricate with moderate to strong pustule growth on umbilical shoulders surrounding aperture; aperture interiomarginal, umbilical-extraumbilical, with or without thin lip.

DiSCUSSION.-The genus Acarinina was erected by Subbotina (1953) to include Paleogene taxa exhibiting morphologic features intermediate between Globigerina and Globorotalia, such as species with rounded chambers, spinose (muricate) test, and an umbilical-extraumbilical aperture. Three groups were originally distinguished:

1. Acarininids with angular chambers (e.g., A. crassaformis);

2. Acarininids with rounded chambers (e.g., A. acarinata);

3. Intermediate acarininids (e.g., A. conicotruncata).

Subsequent authors have questioned the inherent morphological homogeneity of this group by considering Acarinina to be a synonym for taxa as phylogenetically distinct as Turborotalia and Globorotalia. As conceived herein, Acarinina is characterized by rounded to subangular, unkeeled chambers that are covered with coarse pustules (muricae), which become dense, enlarged, and spike-like on the umbilical surface around the aperture. The heavy growth of pustules form deep funnelshaped entrances to the pores and may also partially or completely close the pores. In Paleocene forms, the aperture has a very thin lip or none at all. 
Acarinina coalingensis (Cushman and Hanna, 1927)

\author{
Plate 39: FIGURES $1-16$
}

Globigerina coalingensis Cushman and Hanna, 1927:205, pl. 14: fig. 4 [lower Eocene, California].-Mallory, 1959:46, pl. 34: fig. 6 [lower Eocene, California].

Globoquadrina primitiva Finlay, 1947:291, pl. 8: figs. 129-134.-Hornibrook, 1953:437 [middle Eocene, New Zealand].-Jenkins, 1965:1124, fig. 9 [outline drawing of Finlay's holotype].

Globigerina primitiva (Finlay).-Brönniman, 1952:11, pl. 1: figs. 10-12 [Soldado and Lizard Springs Fms., Trinidad].-Bolli, 1957a:71, pl. 15: figs. 6-8 [Globorotalia rex Zone, Trinidad].

Acarinina triplex Subbotina, 1953:230, pl. 23: figs. 1-5 [holotype from Globorotalia marginodentata Subzone of Globorotalia subbotinae Zone, lower Eocene, Khieu River, Nal'chik, northern Caucasus].-Blow, 1979:963, pl. 97: figs. 8, 9 [Zone P5, Linde area, Tanzania].—Pearson et al., 1993:125, pl. 1: figs. 11, 12 [Zone P11, middle Eocene, DSDP Hole 523, South Atlantic Ocean].-Lu and Keller, 1995:102, pl. 2: figs. 4, 5 [Zone AP 6A, lowermost Eocene; ODP Hole 738C/9R/1: 15-17 cm; Kerguelen Plateau, southern Indian Ocean].

Globigerina inaequispira Subbotina.-Loeblich and Tappan, 1957a:181, pl. 61: fig. 3 [Zone P4, upper Paleocene, Nanafalia Fm., Alabama] [in part, not pl. 49: fig. 2a-c, pl. 52: figs. 1a-2c, pl. 56: fig. 7a-c, pl. 62: fig. 2a-c]. [Not Subbotina, 1953.]

Globorotalia (Acarinina) primitiva (Finlay).-Hillebrandt, 1962:141, pl. 14: figs. 2, 4 [Zone G, lower Eocene, Austria].-Blow, 1979:949, pl. 143: figs. 6-9 [Zone P8, lower Eocene, DSDP Hole 20C/5/4: 77-79 cm; Brazil Basin, South Atlantic Ocean], pl. 249: figs. 1-4 [lower Bortonian, middle Eocene, New Zealand].

Pseudogloboquadrina primitiva (Finlay).-Jenkins, 1965:1124, fig. 9 [nos. 81-83 (holotype) and 84-86; Bortonian, middle Eocene, New Zealand]. Acarinina coalingensis (Cushman and Hanna).-Berggren, 1969b:152, pl. 1: figs. 27-29 [Zone NP 11/12, stratigraphically equivalent to Zone P6/7; lower Eocene 3, Katharinenhof, Fehmarn, northern Germany]._-Huber, 1991b:439, pl. 3: fig. 2 [Zone A P6b/AP7, lower Eocene, ODP Hole 738C/6R: $247.83 \mathrm{msbf}$; Kerguelen Plateau, southem Indian Ocean].—Berggren, 1992:563, pl. 2: fig. 3 [Acarinina wilcoxensis Zone, lower Eocene, ODP Site 749C/10R/1:40-44cm; Kerguelen Plateau, southem Indian Ocean].

Globorotalia (Acarinina) triplex (Subbotina).-Blow, 1979:963, pl. 97: figs. 8, 9 [Zone P5, Lindi area, Tanzania].

Acarinina primitiva (Finlay).—Stott and Kennett, 1990:559, pl. 6: figs. 11, 12 [Zone AP8, lower Eocene, ODP Hole 689B/21H/1: 110-114 cm; Maud Rise, Weddell Sea, Southern Ocean].-Huber, 1991 b:439, pl. 3: fig. 1 [Zone AP10, middle Eocene, ODP Site 738B/15X: $126.70 \mathrm{msbf}$; Kerguelen Plateau, southern Indian Ocean].-Berggren, 1992:563, pl. 2: figs. 4, 5 [Zone P6-7, ODP Hole 748B/18H/3: 80-84 cm; Kerguelen Plateau, southern Indian Ocean].-Lu and Keller, 1993:120, pl. 3: figs. 1, 2 [Zone AP7, lower Eocene, ODP Hole 738C/5R/2: 57-59 cm; Kerguelen Plateau, southern Indian Ocean].--Pearson et al., 1993:125, pl. 1: fig. 19 [Zone P11, middle Eocene, DSDP Hole 523, South Atlantic Ocean].

ORIGINAL DESCRIPTION.- - "Test subglobular, the last three chambers making up nearly the whole periphery of the test, early chambers largely concealed by the ornamentation which is greatest over the early chambers; consisting of large projection bosses with a spinose surface, the succeeding chambers covered with a progressively decreasing ornamentation, the last-formed chamber with only a few short slender spines; aperture small, in the slightly open umbilicus of the ventral side. Diameter $0.60 \mathrm{~mm}$." (Cushman and Hanna, 1927:205.)
Diagnostic Characters.--Robust test, 3-4 chambered final whorl, compact, subquadrate (primitiva morphotype) to subtriangular (coalingensis morphotype), strongly and bluntly muricate test; peripheral margin broadly rounded, less commonly subangular in edge view; chambers arranged at distinct right angles to each other and usually separated by deep, incised sutures (particularly between preantepenultimate and antepenultimate chambers) on umbilical side, and increase rapidly in size; aperture interiomarginal, umbilicalextraumbilical.

DisCUSSION. - There are two basic morphotypes that characterize this robust and strongly muricate species: a form with a triangular-subquadrate appearance characterized by (predominantly) globular chambers (typified by Globigerina coalingensis Cushman and Hanna, 1927, and its junior synonym Acarinina triplex Subbotina, 1953), and a form with a subquadrate to quadrate appearance characterized by straight and circumumbilically pointed, smooth (nonmuricate) globoquadrinid-like chambers (typified by Globoquadrina primitiva Finlay, 1947). These two morphotypes have been synonymized by some workers (Berggren, 1977) and distinguished by others (Pearson et al., 1993; Pearson, 1993). After having considered these forms synonymous, Berggren (1977) distinguished them at Kerguelen Plateau sites based on the perception of their morphologic differences and different stratigraphic ranges (Berggren, 1992). Our work described herein suggests that the earlier interpretation may be more correct. One of us (WAB) has examined topotypic material of A. coalingensis (including the reillustrated holotype, Berggren, 1977, pl. 10), A primitiva, and the holotype and topotypes of $A$. triplex and now believes that these forms belong to a single taxon that exibits a gradual replacement through time of the coalingensis morphotype by the primitiva morphotype. Inasmuch as consistent distinction between these two morphotypes appears impossible, we believe it more appropriate to use a single name for this "taxon" and suggest that authors provide careful descriptions to denote the presence/development of one morphotype relative to the other should this prove useful for biostratigraphic purposes.

STABLE ISOTOPES.-No data available.

STRATIGRAPHIC RANGE.-Zone P4c to Zone P14; coalingensis morphotype dominant over interval of P5-P7/8.

GLOBAL DISTRIBUTION.-Acarinina coalingensis has a cosmopolitan distribution from the tropics to the Southern Ocean and from the open ocean into epicontinental seaways.

ORIGIN OF SPECIES.-We believe that Acarinina coalingensis has its closest affinities with (and is probably a direct descendant of) $A$. nitida from which it differs primarily in its larger and more strongly muricate test, reduced number of chambers, and more pronounced involute coiling. It is also possible that $A$. coalingensis originated from the $A$. subsphaerica-A. mckannai group because these taxa are also characterized by well-developed large muricae on the umbilical surface, 
a feature that would have evolved twice if $A$. coalingensis evolved independently from $A$. nitida.

REPOSITORY.-Museum of the California Academy of Sciences, San Francisco (No. 2548).

\section{Acarinina mckannai (White, 1928)}

Figure 19; Plate 40: Figures 1-16

Globigerina mckannai White, 1928:194, pl. 27: fig. 16a-c [Velasco Fm., Mexico].-Loeblich and Tappan, 1957a:181, pl. 47: fig. 7a-c [Zone P4, Salt Mountain Fm., Alabama], pl. 53: figs. 1a-2c [Zone P4, Vincentown Fm., New Jersey], pl. 57: fig. 8a-c [Zone P4, Aquia Fm., Virginia], pl. 62: figs. 5a-6c [Zone P4, Velasco Fm., Tamaulipas, Mexico], pl. 62: fig. 7a-c [designated lectotype, Columbia University No. 19878, Velasco Fm., Mexico].

Globorotalia mckannai (White).-Bolli, 1957a:79, pl. 19: figs. 16-18 [Globorotalia pseudomenardii Zone, lower Lizard Springs Fm., Trinidad].-Bolli and Cita, 1960:383, pl. 33: fig. 6a-c [Globorotalia velascoensis Zone, Paderno d'Adda, northern Italy].

Globorotalia (Acarinina) mckannai (White).-Hillebrandt, 1962:140, pl. 14: figs. 8a-10c [Zone $\mathrm{F}=$ Globorotalia velascoensis Zone, ReichenhallSalzburg Basin, Austro-German border].-Jenkins, 1971:82, pl. 3: figs. 89-93 [Waipawan Stage, Middle Waipara River section, New Zealand].

Acarinina mckannai (White).-Krasheninnikov and Hoskins, 1973:116, pl. 2: figs. 6-8 [Globorotalia velascoensis Zone, DSDP Site 199/8; Caroline Abyssal Plain, eastern Equatorial Pacific Ocean].-Toumarkine and Luterbacher, 1985:116, text-fig. 18 [3a-c, reillustration of Bolli, 1957a, pl. 19: figs. 16-18; 5a-c, reillustration of holotype from White, 1928; 6a-c, specimen from northern Caucasus illustrated by Shutskaya, 1958] [in part, not $4 \mathrm{a}-\mathrm{c}$, reillustration of holotype of Globogerina subsphaerica Subbotina].-Lu and Keller, 1993:118, pl. 2: figs. 14-16 [Zone AP4, upper Paleocene, ODP Hole 738C/11R/CC; Kerguelen Plateau, southem Indian Ocean].

Muricoglobigerina mckannai (White).-Belford, 1984:13, pl. 22: fig. 408 [upper Paleocene, WABAG Sheet area, Papua, New Guinea].-Stott and Kennett, 1990:559, pl. 3: figs. 7, 8 [Zone AP6, ODP Hole 690B/17H/5: 36-40 cm; Maud Rise, Wedell Sea, Southem Ocean].

Acarinina praecursoria Morozova.-Huber, $1991 \mathrm{~b}: 439$, pl. 1: figs. 3-5 [Zone AP5, ODP Hole 738C/16R: 332.15 mbsf; Kerguelen Plateau, southerm Indian Ocean]. [Not Morozova, 1957.]

ORIGINAL DESCRIPTION.- “Test rotaliform, dorsal side slightly convex, ventral side very convex, umbilicate, periphery rounded; chambers usually six in the last whorl, gradually increasing in size, closely appressed; sutures distinct, deep, not limbate; wall granular or subspinose, very finely perforate; aperture an elongate opening extending from the umbilicus about half way to the peripheral margin. Diameter of type specimen, $0.4 \mathrm{~mm}$; height, $0.3 \mathrm{~mm}$." (White, 1928:194.)

DIAGNOSTIC CHARACTERS. - Test large, $4^{1 / 2} / 2-6$ chambers in final whorl, moderate to low spired, final chamber often curving partly over umbilicus in high-spired variants; strongly muricate on umbilical surface with deep, funnel-shaped entrances to pores over the rest of test; chambers slowly increasing in size in final whorl; peripheral margin rounded, with chambers elongate parallel to coiling axis as well as elongate in direction of coiling; sutures deep, straight, and incised on umbilical surface, gently depressed on spiral side and slightly curved; umbilicus deep and large; aperture interiomarginal, umbilical-extraumbilical without a lip.
DISCUSSION.-Acarinina mckannai is one of the most common and broadly distributed upper Paleocene acarininids and is easily recognized by its large, globular, muricate test with generally 5 to 6 chambers in the final whorl. This species is closely allied with $A$. subsphaerica, and, indeed, complete intergradation exists between them in spire height, umbilical size, and the number of chambers in the final whorl. Shutskaya (1958, 1970a) figured a large number of specimens as $A$. subsphaerica, some of which are clearly referable to $A$. mckannai due to their low spire height.

STABLE ISOTOPES.-Acarinina mckannai has $\delta^{18} \mathrm{O}$ slightly more negative than coexisting morozovellids, such as $M$. velascoensis, and shows no size related trends in $\delta^{18} \mathrm{O}$ (Shackleton et al., 1985). The $\delta^{13} \mathrm{C}$ of $A$. mckannai is much more positive than that of Subbotina and is similar to, or slightly more negative than, that of Morozovella and Igorina (Shackleton et al., 1985).

StRatigraphIC RANGe.-Zone P4a to lower Zone P4c.

GLOBAL DISTRIBUTION.-Acarinina mckannai is a broadly distributed species in the tropical to subtropical oceans. Specimens have been reported from the high southern latitudes (Huber, 1991b), although these are neither as coarsely muricate nor as inflated as typical low-latitude representatives of the species (Figure 19).

ORIGIN OF SPECIES.-Acarinina mckannai evolved from $A$. subsphaerica by a reduction in spire height and an increase in whorl expansion rate. These taxa are the first acarininds to acquire a coarsely pustulose (muricate) ornamentation on the umbilical surface. Acarinina subsphaerica appears before $A$. mckannai in our material and retains the slightly anguloconic test shape of $A$. nitida, suggesting that $A$. subsphaerica is more primitive than $A$. mckannai.

REPOSITORY.-Columbia University Paleontology Collection (No. 19878); collection now at the American Museum of Natural History, New York. Examined by WAB.

\section{Acarinina nitida (Martin, 1943)}

Plate 12: Figures 1-3; Plate 41: Figures 1-16

Globigerina nitida Martin, 1943:115, pl. 7: fig. la-c [Morozovella subbotinae Zone, Lodo Fm., California].

Acarinina acarinata Subbotina, 1953:229, pl. 22: figs. 4, 5, 8, 10 [? figs. 6, 7, 9] [zone of compressed globorotaliids; Globorotalia crassata Subzone = Zone P5 this paper, Khieu River section, Nal'chik, northern Caucasus].Shutskaya, 1970b:118, 228, pl. 27: fig. 13a-c [Acarinina acarinata Zone, Tarkhankut Peninsula, Crimea].-Krasheninnikov and Hoskins, 1973:116, pl. 1: figs. 1-3 [Globorotalia velascoensis Zone, DSDP Site 199/8; Caroline Abyssal Plain, western Pacific Ocean].

Globigerina stonei Weiss, 1955:18, pl. 5: figs. 16-18 [holotype; middle Paleocene, Peru] [in part, not pl. 5: figs. 19-21].

Globorotalia whitei Weiss.-Bolli, 1957a:79, pl. 19: figs. 10-12 [Globorotalia pseudomenardii Zone, lower Lizard Springs Fm., Trinidad]. [Not Weiss, 1955.]

Globigerina cf. G. soldadoensis Brönnimann.-Loeblich and Tappan, 1957a:182, pl. 53: fig. 4a-c [Zone P4, Vincentown Fm., New Jersey]. [Not Brönnimann, 1952.]

Globorotalia (Acarinina) acarinata acarinata (Subbotina).-Blow, 1979:904, fig. 7 [Zone P5 of Blow, 1979 = Subzone P4c this paper; Tanzania]. 


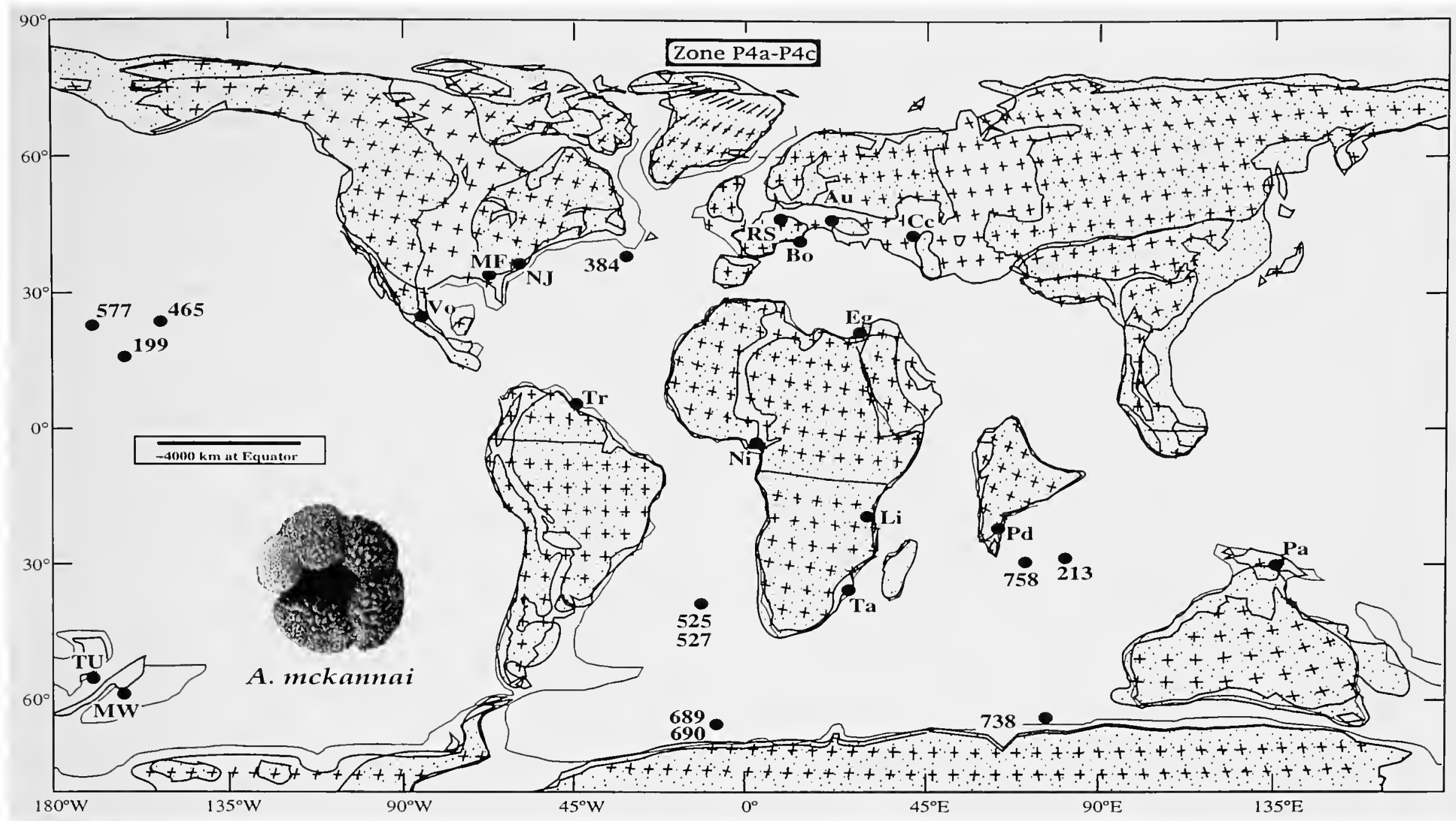

FIGURE 19.-Paleobiogeographic map showing distribution of Acarinina mckannai (White) in Zones P4 and P5.

ORIGINAL DESCRIPTION._-“Test subglobular, more convex ventrally than dorsally; wall calcareous, finely perforate, completely covered with numerous fine papillae giving a granular appearance; periphery broadly rounded, slightly lobulate; all chambers exposed on dorsal side, only last whorl of five visible on ventral side; chambers inflated, increasing rapidly in size as added, last chamber extending slightly beyond previous ones, overhanging on ventral side to form a depressed umbilical area; dorsal sutures more or less distinct, nearly straight, slightly depressed; apertural face of last chamber flat, aperture a narrow slit extending from umbilicus about halfway along base of chamber toward periphery bordered on outer edge by a slight lip. Maximum diameter 0.29 $\mathrm{mm}$; minimum diameter $0.28 \mathrm{~mm}$; maximum thickness 0.28 mm." (Martin, 1943:115.)

DIAGNOSTIC CHARACTERS. - Compact, small, trochospiral, subcircular to subquadrate test with 4 (rarely 5) rounded, tightly packed, radially compressd and axially elongate chambers; early whorls raised above surface of last whorl; surface moderately muricate, particularly on umbilical side, with deep, funnel-shaped entrances to pores.

DISCUSSION.-This form is generally recognized to be a senior synonym of Acarinina acarinata (Subbotina), type species of the genus Acarinina (Stainforth et al., 1975; Luterbacher, 1975b; Berggren, 1977, who compared the holotype of nitida with topotypes of acarinata; Toumarkine and Luterbacher, 1985). It is one of the earliest acarininids appearing together with $A$. subsphaerica at the base of Zone P4. Acarinina nitida represents an intermediate stage between the weakly muricate $A$. strabocella and the more strongly muricate upper Paleocene acarininids. Subbotina (1953) considered that acarinata ranged up to the base of her zone of conical globorotaliids ( $=\mathrm{P} 6 \mathrm{a} / \mathrm{b}$ boundary of this work). Our observations agree more closely with Blow (1979), who indicated its LAD occurs in his Zone P5 or possibly lower P6.

The holotype of Acarinina intermedia Subbotina, 1953 (Plate 12: Figures 4-6), is a poorly preserved specimen with a missing ultimate chamber and an obscured umbilicus. The general morphology of this specimen shows four chambers in the ultimate whorl and heavily muricate umbilical shoulders suggesting a linkage to nitida. Acarinina nitida has also been previously identified under different names (see synonomy) by Weiss (1955), Bolli (1957a), and Loeblich and Tappan (1957a).

STABLE ISOTOPES.-Acarinina nitida has $\delta^{18} \mathrm{O}$ values similar to co-existing morozovellids, such as $M$. velascoensis and $M$. subbotinae, and shows a slight negative size-trend in $\delta^{18} \mathrm{O}$ (D'Hondt et al., 1994). The $\delta^{13} \mathrm{C}$ of $A$. nitida is much more positive than that of Subbotina and is similar to that of Morozovella (D'Hondt et al., 1994).

STRATIGRAPHIC RANGE.-Zone P4a to lower Zone P4c.

GLOBAL DISTRIBUTION.-This form is geographically widespread in (sub)tropical regions and has been reported from high southern latitudes on the Kerguelen Plateau (Huber, 1991b) and 
Maud Rise, Weddell Sea (Stott and Kennett, 1990) at $62^{\circ} \mathrm{S}$ and $65^{\circ} \mathrm{S}$, respectively.

ORIGIN OF SPECIES.-Acarinina nitida is related to unkeeled morozovellids with which the acarininids share a similar ornamentation consisting of deep funnel-shaped entrances to the pores, short, weakly developed muricae at the interpore ridges, deeply incised sutures, and a tendency toward slightly anguloconical chambers in the final whorl. Acarinina nitida is derived from $A$. strabocella from which it differs in having only four chambers in the final whorl, more involute coiling, and a more coarsely muricate surface texture. Bolli (1957a) and Blow (1979) suggested that Globorotalia whitei/A. acarinata, respectively, was the ancestor of $A$. wilcoxensis and we concur.

REPOSITORY.-Holotype (No. 7400) in Stanford University Paleontological Type Collection. Paratypes deposited in the National Museum of Natural History (USNM 559454); the University of California, Berkeley (No. 35066); the American Museum of Natural History (No. MT-1015); the California Academy of Sciences, San Francisco (No. 7877); and the Paleontological Research Institution, Ithaca, N.Y. Paratypes examined by WAB.

\section{Acarinina soldadoensis (Brönnimann, 1952)}

Figure 20; Plate 15: figures 4, 7, 8; Plate 42: figures 1-16

Globigerina soldadoensis Brönnimann, 1952:7, 9, pl. 1: figs. 1-9 [Lizard Springs Fm., Trinidad; type locality of Globigerina velascoensis Zone of Bolli, 1957a:64 = Zone P5 this paper].-Bolli, 1957a:7l, pl. 16: figs. 7-9 [? figs. 10-12] [Globorotalia formosa Zone, upper Lizard Springs Fm., Trinidad]; 1957b:162, pl. 35: fig. 9a-c [Globorotalia palmerae Zone, Navet Fm., Trinidad].

Acarinina clara Khalilov, 1956:250, pl. 5: fig. 4 [upper Paleocene, Akhchakumia, northeastern Azerbaizhan].

Globorotalia (Acarinina) soldadoensis (Brönnimann).- -Hillebrandt, 1962:142, pl. 14: figs. 5, 6 [Zone G = Zone P6 this paper; ReichenhallSalzburg Basin, Austro-German border].-Jenkins, 1971:73, pl. 4, figs. 94-98 [Globigerina triloculinoides Zone, Waipawan Stage, Middle Waipara River section, New Zealand].

Acarinina soldadoensis (Brönnimann).-Berggren, 1971b:76, pl. 5: figs. 1-3 [Morozovella velascoensis Zone, DSDP Hole 20C/6/4: 5-7 cm; South Atlantic Ocean].-Huber, 1991b:439, pl. 2: fig. 16 [Zone AP6a, lower Eocene, ODP Hole 738C/10R: 275.25 msbf; Kerguelen Plateau, southern Indian Ocean].

Muricoglobigerina soldadoensis soldadoensis (Brönnimann).-Blow, 1979:1120, pl. 98: figs. 1-3 [sample FCRM 1670, Zone P5 of Blow, $1979=$ Zone P4c this paper; Lindi area, Tanzania], pl. 107: figs. 1-5 [Zone P6 of Blow, 1979; DSDP Hole 20C/6/3: 76-78 cm; South Atlantic Ocean], pl. 109: fig. 8 [Zone P6, DSDP Hole 47.2/8/4: 78-81 cm], pl. 110: fig. 1 [Zone P6, DSDP Hole 47.2/8/4: 78-81 cm], pl. 124: figs. 1, 3, 5 [Zone P7, DSDP Hole 47.2/8/3: 83-85 cm], pl. 131: figs. 1-3, 6 [Zone P8, DSDP Hole 47.2/8/2: 71-73 cm; Shatsky Rise, northwestern Pacific Ocean].-Stott and Kennett, 1990:559, pl. 3: figs. 1, 4 [Zone AP5, ODP Hole 689B/22X/5: 110-114 cm; Maud Rise, Weddell Sea, Southern Ocean].

ORIGINAL DESCRIPTION.- - The low trochoid test is composed of about two volutions. The four-chambered, occasionally five-chambered adult is lobulate in typical specimens. The spiral side is centrally more or less elevated, the umbilical side is convex. The umbilicus is large and deep showing the arcuate apertures of the latter formed chambers. The subglobular chambers increase gradually in size. They are rounded to slightly flattened peripherally and distinctly elongate in the direction of the axis of the test. At the umbilical side the chambers tend to be somewhat pointed. The end chamber can be smaller than the penultimate one or even rudimentary. Except for the indistinct sutures of the early ontogenetic stage, those of the spiral side are deep and curved in the direction of coiling, or they are oblique giving the impression of an overlapping arrangement of the chambers. The sutures of the umbilical side are straight throughout. The large arcuate apertures of the last formed chambers are provided with minute liplike boarders. The wall are perforate and rather thick. The surface is covered with irregularly distributed papillae which are stronger and more prominent on the early chambers of the adult whorl; they are absent or weakly developed near the aperture of the end chamber. The species is predominantly coiled sinistrally." (Brönnimann, 1952:7.)

DIAGNOSTIC CHARACTERS.-Low trochoid, moderately evolute test of 4-5 moderately to strongly muricate, rounded chambers distinctly elongated in the axis of coiling; final chamber often reduced in size; lobulate periphery; deep and relatively wide umbilicus revealing (in some individuals) earlier chambers and their arcuate foramina; sutures on spiral side deep and curved and/or tangential in direction of coiling, chambers often overlapping.

DISCUSSION.-This taxon is characterized by a test composed of 4 to 5 chambers arranged in a relatively loose (lax) coil, resulting in a relatively open and deep umbilicus and moderate to strong lateral chamber compression (giving an angulate appearance to the peripheral margin of some chambers), which culminates in the descendant angulate species angulosa. Acarinina clara Khalilov (1956) from the upper Paleocene of Azerbaizhan exhibits the typical lobulate test and elongated chamber morphology of $A$. soldadoensis and is herein regarded as a junior synonym of this species.

STABLE ISOTOPES.--No data available.

STRATIGRAPHIC RANGE.-Zone P4c to Zone P9.

GLOBAL DisTribution.-This species has a widespread geographic distribution from equatorial to subantarctic regions (Figure 20).

ORIGIN OF SPECIES.-Acarinina soldadoensis is a sister taxon to A. mckannai from which it differs in being somewhat more evolute and in having more umbilically elongate chambers.

REPOSITORY.--Holotype (USNM 370085) deposited in the Cushman Collection, National Museum of Natural History. Examined by WAB.

\section{Acarinina strabocella (Loeblich and Tappan, 1957)}

Figure 21; Plate 15: figures 1-3; Plate 43: Figures 1-16

Globorotalia angulata (White) var. praepentacamerata Shutskaya, 1956:94, 95, pl. 3: fig. 3 [Acarinina praepentacamarata Zone, Elburgan Fm., Khieu River section, northern Caucasus]. 


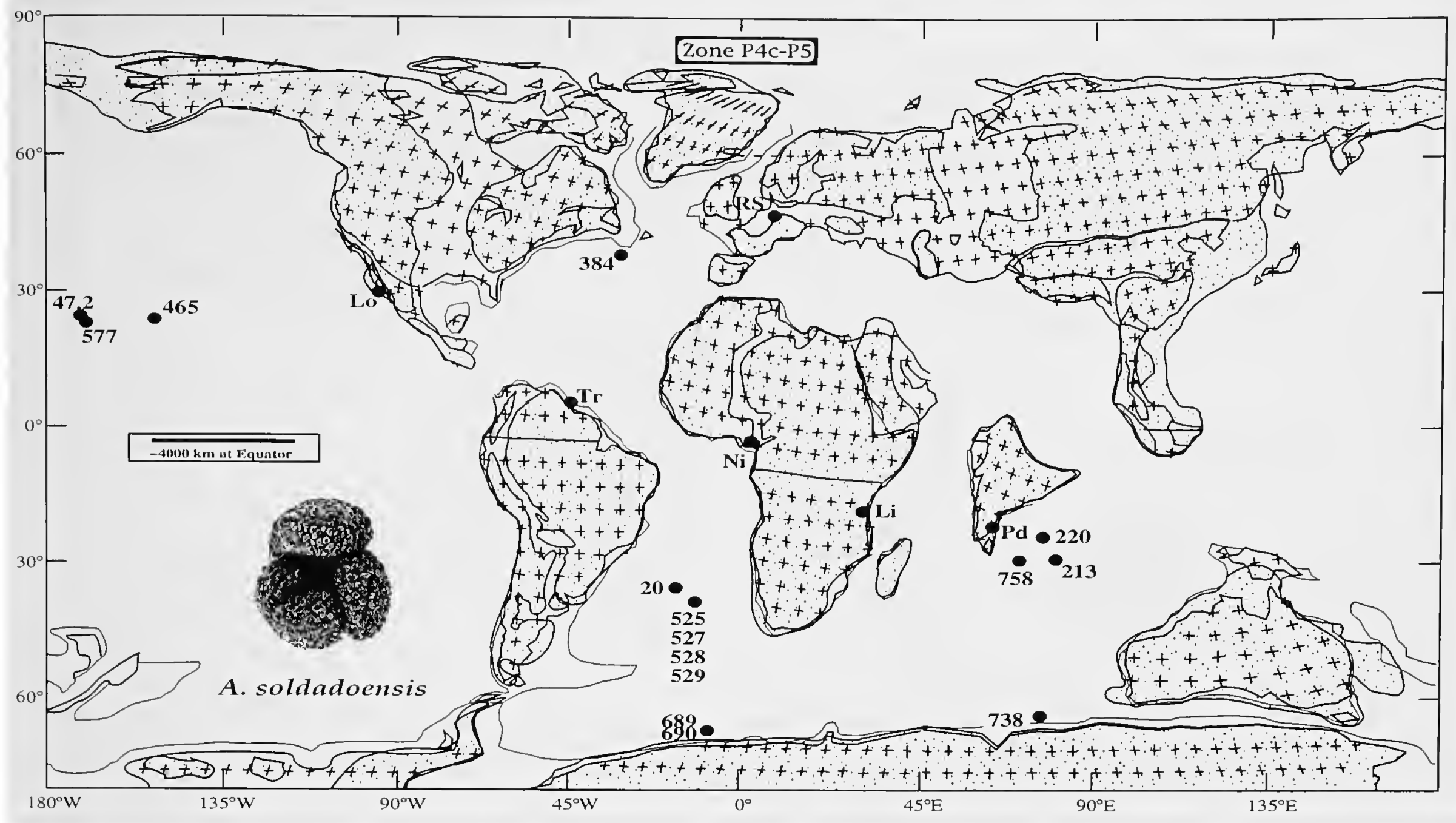

FIGURE 20.-Paleobiogeographic map showing distribution of Acarinina soldadoensis (Brönnimann) in Zones P5 and P6.

Globorotalia strabocella Loeblich and Tappan, 1957a:195, pl. 61: fig. 6a-c [Nanafalia Fm., Alabama].

Globorotalia praepentacamerata Shutskaya.-Luterbacher, 1964:665, pl. 40: fig. 45 [Acarinina tadjikistanensis djanensis Zone, Elburgan Fm., Khieu River, northern Caucasus; topotype determined by Shutskaya].

Acarinina praepentacamerata (Shutskaya).-Shutskaya, 1970b:118-120, pl. 21: figs. 8, 10 [Acarinina praepentacamerata Zone, Chaldzhin Fm., Malyi Balkhan, western Turkmenia], pl. 22: fig. 2 [lower subzone of Acarinina tadjikistanensis djanensis Zone, Lower Danatin Mbr., Malyi Balkhan Ridge, western Turkmenia].-Stott and Kennett, 1990:558, pl. 4: figs. 9, 10 [Zone A4, ODP Hole 689B/23X/1: 108-112 cm; Maud Rise, Weddell Sea, Southern Ocean].-Huber, 1991b:439, pl. 2: figs. 1, 2 [Zone AP5, ODP Hole 738C/l IR: 286.04 msbf; Kerguelen Plateau, southern Indian Ocean].

Globorotalia (Acarinina) strabocella Loeblich and Tappan.--Jenkins, 1971:84, pl. 4: figs. 102-104 [Globigerina triloculinoides Zone, lower Waipawan Stage, New Zealand].

Acarinina praeangulata (Blow).-Huber, 1991a:439, pl. 1, figs. 6, 7 [Zone AP4, ODP Hole 738C/16R: 332.15 mbsf; Kerguelen Plateau, southern Indian Ocean]. [Not Blow, 1979.]

ORIGINAL DESCRIPTION.- “Test free, of medium size, trochospiral, sides moderately convex, umbilical shoulder rounded, umbilicus broad and open, periphery broadly rounded, peripheral outline lobulate; chambers increasing gradually in size as added, of greater breadth than height, 4 per whorl in the early stages, increasing to 5 or 6 per whorl in the adult, early whorls somewhat elevated above the level of the final whorl, each successive chamber on the spiral side added somewhat below the level of that preceding, resulting in an imbricated appearance; sutures distinct, depressed, curved and oblique on the spiral side, radial and nearly straight on the umbilical side; wall calcareous, finely perforate, surface finely spinose, especially on the umbilical side; aperture an interiomarginal, extraumbilical-umbilical opening extending to the periphery.

"Holotype is $0.33 \mathrm{~mm}$ in greatest diameter." (Loeblich and Tappan, 1957a:195.)

DiAGNOSTIC CHARACTERS.-Five to 6 chambered, nearly circular test with weakly lobulate outline; axial periphery broadly rounded to subangular, chambers on umbilical side moderately convex, early whorls on spiral side elevated above later whorl(s); umbilicus usually broad and open exposing earlier whorls; test weakly pustulose (muricate) over entire surface, aperture an interiomarginal, umbilical-extraumbilical slit.

DISCUSSION.-Shutskaya (1956; see also 1970a, 1970b) described Globorotalia angulata var. praepentacamerata from the lower Paleocene of the northern Caucasus and showed that it had a wide distribution in the southwestern part of the former Soviet Union. Luterbacher (1964:665) suggested that Globorotalia strabocella Loeblich and Tappan may be a junior synonym. We agree with this assessment particularly inasmuch as comparison of our material with the holotype of $G$. strabocella at the NMNH shows them to be morphologically 


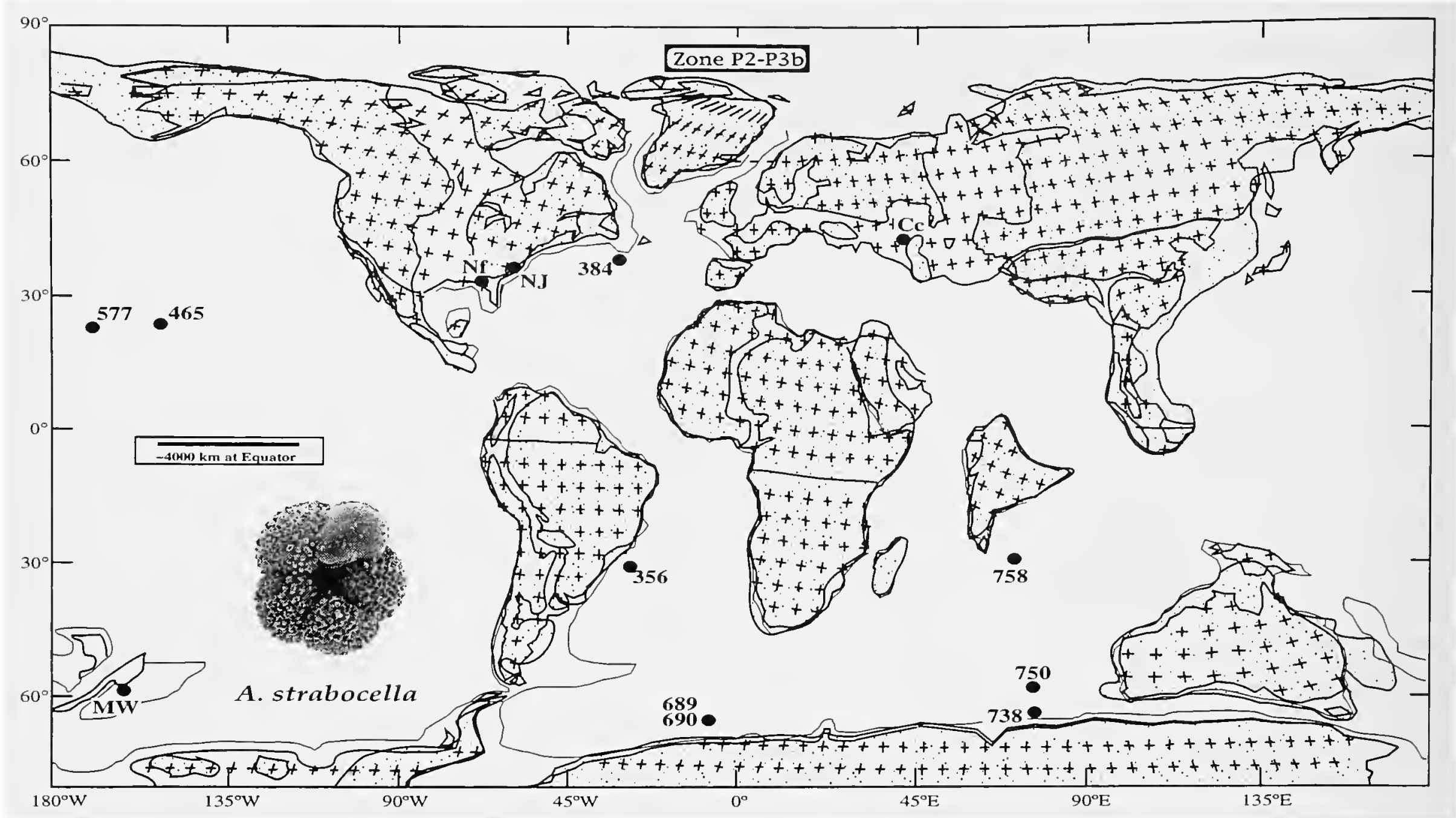

FIGURE 21.-Paleobiogeographic map showing distribution of Acarinina strabocella (Loeblich and Tappan) in Zone P3.

similar. In view of the fact that there is no original (type) material remaining of Shutskaya's taxon (nor of any other taxa that she described, for that matter, with rare exception), we prefer to use the name strabocella for this taxon because of the fact that there is well-preserved type material at a readily accessible museum (the NMNH in Washington), which aids in stabilizing the nomenclature.

Shutskaya (1970b:118, 120, fig. 13) showed that $A$. praepentacamerata is restricted to the $A$. praepentacamerata Zone and the lower subzone of the overlying $A$. tadjikistanensis djanensis Zone in the southwestern part of the former Soviet Union [= Zone P3 (middle part) to ? P4 [lower part)]. This is similar to our observations. The forms referred to A. wilcoxensis strabocella from Zones P6-P8b by Blow (1979:970, pls. $114,129,132,251)$ are considered unrelated to strabocella; they differ in their more evolute coiling, flatter spiral coil, and strongly muricate ornament. They represent a younger, more advanced acarininid morphology than that seen in $A$. strabocella. In fact, we view $A$. strabocella as representing the stem form of the acarininid radiation that occurred at the P3-P4 zonal transition.

STABLE ISOTOPES.-No data available.

STRATIGRAPHIC RANGE.-Zone P3 (lower part) to Zone P4 (lower part).

GLOBAL Distribution.-Northern middle latitudes to the Southern Ocean (Figure 21).
ORIGIN OF SPECIES.-The origin of the first Acarinina species is somewhat obscure. The wall surface of $A$. strabocella is smooth with simple and coalescent pustules (Plate 5: Figure 1) that become more heavily developed on the older part of the test. The origin of this species may be linked with the moderately pustulose Morozovella praeangulata in the lower part of Zone P3 and may have diverged from early forms of this species. Alternatively, A. strabocella may have evolved from Praemurica inconstans by developing a tighter coil and a lower rate of chamber enlargement. In any case, $A$. strabocella represents the stem form of the acarininid radiation. Reduction of the number of chambers in the final whorl and the increased development of muricae are seen in the derivation of $A$. nitida from $A$. strabocella.

REPOSITORY.-Holotype (USNM P5879) and paratypes (USNM CC38526) deposited in the Cushman Collection, National Museum of Natural History. Examined by WAB and RDN.

\section{Acarinina subsphaerica (Subbotina, 1947)}

Figure 22; Plate 15: figures 9, 10; Plate 44: Figures 1-16

Globigerina subsphaerica Subbotina, 1947:108, pl. 5: figs. 26-28 [holotype: Globigerina ex gr. canariensis Zone, Assu River section, northern Caucasus], pl. 5: figs. 23-25 [zone of compressed globorotaliids, Osetiya, 
Assu River section, northern Caucasus]; 1953:59, pl. 2: fig. 15a-c [holotype refigured].-Shutskaya, 1956:91, pl. 3: fig. 1 [holotype from Foraminiferal Bed (F1), zone of compressed globorotaliids, Assu River section, northern Caucasus, also recorded from equivalent levels in Assu River section, Osetiya, northern Caucasus].

Globoconusa quadripartitaformis Khalilov, 1956:249, pl. 5: fig. 3a-c [holotype No. 238, sample 35 (1946), foothills of Malyi Caucasus, Azerbaizhan].

Globigerina chascanona Loeblich and Tappan, 1957a:180, pl. 49: fig. 5a-c [holotype, lower Zone P4, uppermost Hornerstown Fm., New Jersey] [in part, not pl. 49: fig. 4a-c, pl. 61: fig. 8a-c].

Globigerina spiralis Bolli.-Loeblich and Tappan, 1957a:182, pl. 47: fig. 3a-c [Zone P4, Salt Mountain Limestone, Alabama], pl. 49: fig. 3a-c [Zone P4, Hornerstown Fm., New Jersey], pl. 51: figs. 6a-9c [Zone P4, Vincentown Fm., New Jersey], pl. 53: fig. 3a-c [Zone P4, Vincentown Fm., New Jersey]. [Not Bolli, 1957a.]

Acarinina subsphaerica (Subbotina).-Shutskaya, 1958:89, pl. 2: figs. 12-14, pl. 3: figs. 1-3 [all figured specimens from Nal'chik Horizon, Sunzha River section, Groznensk Oblast, northern Caucasus] [in part, not pl. 2: figs. 6-11, pl. 3: figs. 4-21 = Acarinina mckannai]; 1960:249, pl. 2: fig. 8; 1970b:118-120, pl. 2: fig. 8a-c [Acarinina acarinata Zone, Kachan Stage, Belbek River, Bakhchisaray Region, southwestern Crimea], pl. 6: fig. 3a-c [Globorotalia aequa Zone, Bakhchisarayan Stage, Belbek River, Bakhchisaray Region, southwestern Crimea], pl. 26: fig. 3a-c [Acarinina subsphaerica Zone, Nal'chik Region, Khieu River, northern Caucasus].

Acarinina falsospiralis Davidzon and Morozova, 1964:26, 28, pl. 1: fig. 5a-c [upper Paleocene, upper Bukhara Beds, lower Karatag Horizon, Tutkaul Village, Sanglak Range, Tadzhik Depression, Tadzhikistan].

Acarinina microsphaerica Morozova in Morozova, Kozhevnikova, and Kuryleva, 1967:195, pl. 6: figs. 3, 4 [Thanetian Stage, upper Paleocene, Kacha River, Crimea].

Globorotalia (Acarinina) subsphaerica (Subbotina).-Blow, 1979:960, pl. 91: figs. 4-6 [Zone P4, DSDP Hole 21 A/3/6: 74-76 cm; South Atlantic Ocean], pl. 92: figs. 1-3 [Zone P4, DSDP Hole 47.2/9/5: 74-76 cm; Shatsky Rise, northwestern Pacific Ocean].

Muricoglobigerina chascanona (Loeblich and Tappan).-Blow, 1979:1126, pl. 91: figs. 1, 2 [lower Zone P4, DSDP Hole 21A/3/6: 74-76 cm; South Atlantic Ocean], pl. 92: fig. 3 [Zone P4, DSDP Hole 47.2/9/5: 70-72 cm], pl. 93: figs. 7-9, pl. 235: figs. 1-3 [Zone P4, DSDP Hole 47.2/9/3: 70-72 cm], pl. 101: figs. 5, 6 [Zone P5, DSDP Hole 47.2/9/1: 64-66 cm; Shatsky Rise, northwestern Pacific Ocean].

Acarinina chascanona (Loeblich and Tappan).-Huber, 1991b:439, pl. 2: fig. 3 [Zone AP4, ODP Hole 738C/15R: 322.07 msbf; Kerguelen Plateau, southern Indian Ocean] [in part, not pl. 2: fig. 4]. [Not Loeblich and Tappan, 1957a.]

ORIGINAL DESCRIPTION.- “Test small, nearly spherical; viewed from the ventral side, it very often resembles a slightly bursting chestnut. Test consists of three or three and one-half whorls, of which the first two are disproportionately small as compared with the final whorl. In the final whorl there are five to six chambers gradually increasing in size. In the middle of the ventral side there is a small umbilicus. The chambers are trapezoidal on the dorsal side, and triangular on the ventral side; they have a smooth outer surface and adhere closely to one another. Septal sutures depressed, slightly curved in the direction of coiling. Aperture semi-rounded, occupying approximately one-third of the distance between the umbilicus and the periphery. Wall reticulate, finely porous. Average dimensions: greatest diameter $0.27 \mathrm{~mm}$; height $0.25 \mathrm{~mm}$." (Subbotina, 1947:108; translated from Russian.)

DIAGNOSTIC CHARACTERS.-Characterized by strongly elevated spire and tightly coiled, small test giving species a sphaerical, globular shape. Umbilicus narrow, deep, and surrounded by coarse pustules (muricae). Usually with a diminutive final chamber with an arched aperture.

DisCUSSION.-The strongly conical spire and small, tightly coiled muricate test makes this one of the most distinctive taxa of the middle Paleocene. Yet it remains one of the least understood taxa among the acarininids. Although Subbotina described subsphaerica as resembling "a slightly bursting chestnut" (1947:108), she also indicated that the test is "reticulate, finely porous," but she made no mention of its most distinctive character: its high conical spire. In fact, Subbotina (1953:53) retained subsphaerica among her "polythalamous species of Globigerina" characterized by possessing five or more closely packed chambers in the last whorl (together with such taxa as edita Subbotina, compressa Plummer, pseudobulloides Plummer, postcretacea Mjatliuk, and tarchanensis Subbotina and Chutzieva). This oversight is difficult to comprehend and may be partly ascribed to the poor state of preservation (recrystallized tests) of most northern Caucasus Paleocene material. It remained for Shutskaya (1958) to provide the first adequate characterization of this taxon, to clearly illustrate the high degree of variability in this taxon (Shutskaya, 1958, 1970a), in particular, its distinctive high spire, and to transfer it to its appropriate home in the genus Acarinina. In fact, Morozova (1958, fig. 5), in a paper dealing with the morphologic characters important in the classification of Paleogene taxa of the Globigerinidea, observed that the microspheric generation among "globigerinids" typically possess a higher spire and more whorls of chambers than megalospheric forms, and she cited Globigerina subsphaerica Subbotina as a good illustration of this feature.

This taxon has been considered a junior synonym of Acarinina mckannai (White) by some workers (Hillebrandt, 1962; Krasheninnikov and Ponikarov, 1965; Stainforth et al., 1975; Berggren, 1977) because of their supposed similarity. The latter is distinguished by its significantly larger test, relatively low spire, and more evolute coiling pattern resulting in a wide and open umbilicus. In our material, A. mckannai stratigraphically appears somewhat higher/later than $A$. subsphaerica from which we suggest it is descended (cf. Stainforth et al., 1975).

We note that moderately to high-spired morphotypes with surficial morphology/ornament comparable to $A$. subsphaerica occur in upper lower to lower middle Eocene; these may represent a continuation of the late Paleocene acarininid radiation or an independent early Eocene radiation. This issue, however, is beyond the scope of this study. Similar high-spired acarinids, which we regard as synonymous with $A$. subsphaerica, have been described from middle Paleocene deposits in Azerbaizhan, Tadzhikistan, and the Crimea. These include Globoconusa quadripartitaformis Khalilov (1956), Acarinina falsospiralis Davidzon and Morozova (1964), and Acarinina microsphaerica Morozova (1967). Globigerina chascanona Loeblich and Tappan (1957a) is a small, very high-spired pustulose form, which we regard as an immature stage of $A$. 


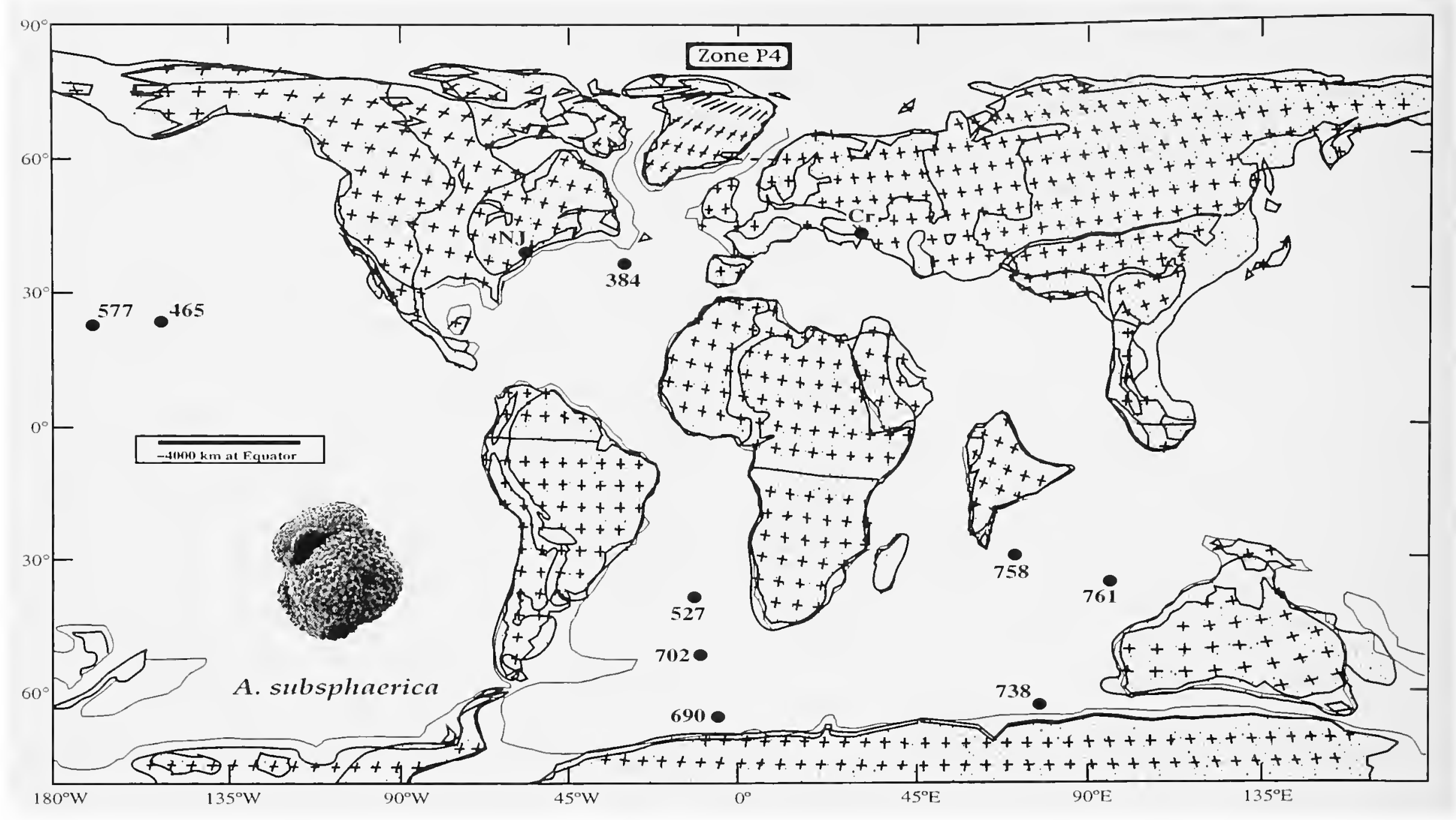

FIGURE 22.-Paleobiogeographic map showing distribution of Acarinina subsphaerica (Subbotina) in Zone P4a.

subsphaerica. Both Blow (1979) and Huber (1991b) noted these small forms, which they placed in chascanona. Larger (adult) forms of $A$. subsphaerica have been identified in middle Paleocene coastal plain deposits from Alabama and New Jersey by Loeblich and Tappan as Globigerina spiralis Bolli.

STABLE ISOTOPES.-No data available.

STRATIGRA PHIC RANGE.--Subzone P4a. We have not found A. subsphaerica associated with $\mathrm{P} 3 \mathrm{~b}$ faunas in any of our material nor have we found it to occur above the middle part of Zone P4 at low latitudes. Indeed, it is the short and distinct stratigraphic range of this taxon that renders it so useful for subdivision of Zone P4. We recognize high-spired acarininids from the upper Paleocene at the high southern latitude ODP Site 690 . (This taxon was recently recorded by Lu and Keller (1995) in younger stratigraphic levels at DSDP Site 577 (Shatsky Rise), northwestern Pacific Ocean and by Huber (1991b) at ODP Site 738, southwestern Kerguelen Plateau (southern Indian Ocean) near the Paleocene/Eocene boundary.)

GLOBAL DISTRIBUTION.--This species appears global in distribution in spite of an apparent bias to a Tethyan distribution, which is probably related to numerous citations in the Russian literature (Figure 22).

ORIGIN OF SPECIES.-Acarinina subsphaerica evolved from A. nitida by an increase in spire height and the development of a coarsely muricate umbilical surface, which is a feature characteristic of all subsequent acarininids. Both $A$. sub- sphaerica and $A$. nitida share an anguloconic, umbilically inflated test as juveniles and, in many of the geologically older examples, a flat or gently domed spiral surface. Acarinina subsphaerica gave rise to $A$. mckannai by an increase in whorl expansion rate.

REPOSITORY.-Holotype in the collections of VNIGRI, St. Petersburg, Russia.

\section{Genus Morozovella McGowran in Luterbacher, 1964}

TYPE SPECIES.-Pulvinulina velascoensis Cushman, 1925.

ORIGINAL DESCRIPTION.-- “Test trochoid, coiling random to strongly preferential; chambers becoming laterally compressed, then more or less conical, during ontogeny, developing an angular margin and sometimes a strongly and irregularly thickened marginal keel, umbilical shoulders may become thickened; surface more or less roughened primilarly, especially at margins; secondarily accentuated so that the test may become coarsely spinose or nodular at margins and on umbilical shoulders. Pores rather coarse and tending to funnel outwards, especially secondarily. Test umbilicate; aperture basal and umbilical, a low rimmed arch surrounded by a poreless area. Paleogene." (McGowran in Luterbacher, 1964:641.)

DIAGNOSTIC CHARACTERS.-Strongly anguloconical chambers throughout ontogeny. Surface texture strongly pustulose 
(muricate) on parts of spire and umbilicus. Most species with muricocarina.

DISCUSSION.-The morozovellids split into two lineages early in their evolution: (1) the M. angulata-M. velascoensis group characterized by the development of muricate adumbilical ridges, a strong muricocarina, and the absence of muricae on parts of the chamber surfaces; and (2) the M. apanthesma$M$. subbotinae group whose members are initially unkeeled and entirely covered with fine, thin muricae.

\section{Morozovella acuta (Toulmin, 1941)}

\section{Plate 45: Figures 1-14}

Globorotalia wilcoxensis Cushman and Ponton var. acuta Toulmin, 1941:608, pl. 82: figs. 6-8 [Zone P4, Salt Mountain Limestone, Wilcox Group, Alabama].-Cushman and Renz, 1942:12, pl. 3: fig. 2a-c [Zone P4, Soldado Fm., Trinidad].-Cushman, 1944a:48, 49, pl. 8: fig. 5a,b [Zone P3b, Naheola Fm., Alabama]; 1944b:15, pl. 2: fig. 16a,b [Zone P5, Bashi Fm., Wilcox Group, Alabama].-Shifflett, 1948:73, pl. 4: fig. 23a-c [Zone P4, Aquia Fm. Maryland].

Globorotalia velascoensis (Cushman) var. parva Rey, 1954:209, pl. 12: fig. la,b [Zone P4, Sample TB 450, Well No. 11, Koudiat Bou-Khelif, near Ouezzane, northern Morocco].

Globorotalia acuta Toulmin.-Loeblich and Tappan, 1957a:185, pl. 47: fig. 5a-c [Zone P4, Salt Mountain Limestone, Wilcox Group, Alabama], pl. 55: figs. 4a-5c [Zone P4, Vincentown Fm., New Jersey], pl. 58: fig. 5a-c [Zone P4, Aquia Fm., Virginia].-Aubert, 1962:54, pl. I: fig. 3a-c [Zone P4, Koudiat Bou Khelif, Morocco].-Luterbacher, 1964:686-689, text-fig. 101a-c [Zone P4, El Quss Abu Said, Farafrah Oasis, Egypt], text-figs. 102a-104c [Zone P5, Velasco Fm., Ebano, eastern Mexico].

Globorotalia velascoensis parva Rey.-Bolli and Cita, 1960:392-393, pl. 35: fig. 5a-c [Zone P4, Paderno d'Adda, northern Italy],-Aubert, 1963:54, pl. 1: fig. 2a-c [Zone P4, N. Morocco].

Globorotalia velascoensis acuta (Toulmin).-Shutskaya, 1970a:119-120, pl. 27: fig. 1la-c [Acarinina acarinata Zone, Kachan Stage, Tarkhankut Peninsula, Crimea], pl. 28: fig. 4a-c, pl. 29: fig. 9a-c [Globorotalia aequa Zone, Bakhchisarayan Stage, Tarkhankut Peninsula, Crimea].

Globorotalia (Morozovella) acuta Toulmin.-Jenkins, 1971:106, pl. 9: figs. 205-207 [Globigerina triloculinoides Zone = Zone P4 this paper, Waipawan D Stage, Middle Waipara River section, New Zealand].

Globorotalia (Morozovella) velascoensis parva Rey.-Jenkins, 1971:106, 107, pl. 9: figs. 211-213 [Globigerina triloculinoides Zone = Zone P4 this paper, Waipawan Stage, Middle Waipara River section, New Zealand].-Blow, 1979:1030, 1031, pl. 95: figs. 3-6 [Zone P5, Sample FRCM 1670, Lindi area, Tanzania].

Morozovella acuta (Toulmin).-Toumarkine and Luterbacher, 1985:111, text-fig. 14 (7, reillustration of holotype; 8, reillustration of Loeblich and Tappan, 1957a, pl. 55: fig. 4a-c, from the Vincentown Fm., New Jersey; incorrectly ascribed to the Salt Mountain Fm., Alabama].

ORIGINAL DESCRIPTION.- - "Test trochiform, plano-convex, dorsal side flat, ventral side strongly convex, deeply umbilicate, periphery strongly lobate, acute, and bounded by a thick flange; chambers distinct, about $4^{1 / 2}$ in the last whorl, increasing regularly in size as added; sutures distinct, on the dorsal side slightly curved, limbate, slightly if at all depressed, on the ventral side radiate, depressed; wall roughened with minute, low spinose processes, especially along the peripheral border; aperture an arched opening on the ventral side of the final chamber extending from the peripheral flange to the umbilicus. Length $0.46 \mathrm{~mm}$; width $0.37 \mathrm{~mm}$; thickness 0.24 mm." (Toulmin, 1941:608).

DIAGNOSTIC CHARACTERS.-Conicotruncate, distinctly muricocarinate test with (typically) 5 chambers in last whorl; intercameral sutures radial, depressed on umbilical side and strongly recurved and tangential, distinctly ornamented on, and flush with, spiral side; periumbilical collar weakly to moderately well-ornamented with muricae; umbilicus (typically) wide and open but narrow in more tightly coiled individuals; aperture interiomarginal, umbilical-extraumbilical with (typically) well-developed, triangular, circumumbilical "teeth."

DisCussion.-Considerable controversy surrounds the characterization and recognition of this, and closely related, forms of the velascoensis group. The "typical" M. acuta is generally believed to be distinguishable from $M$. velascoensis in its average smaller size, more rapid increase in chamber growth, proportionately larger final chamber, more subdued periumbilical ornamentation, and reduced number of chambers in the final whorl (Loeblich and Tappan, 1957a; Luterbacher, 1964; Blow, 1979). Other authors (Bolli, 1957a; Hillebrandt, 1962; Proto Decima and Zorzi, 1965, among others) believe these (and other) forms are linked by continuous gradations and consider them synonymous.

At the same time, another commonly cited form is Globorotalia velascoensis parva (auct. non) that we believe shares a close morphologic relationship with $M$. acuta. Whether the forms illustrated by various authors as parva are, indeed, referable to Rey's taxon is a moot point, however. Luterbacher (1964) showed that the typical parva from the type sample from Morocco has four large, nearly equal-sized chambers in the final whorl, slightly raised and beaded sutures on the spiral side, and a relatively narrow umbilicus lacking the periumbilical ornament characteristic of the velascoensisacuta forms. We concur with his analysis that forms identified as parva by Bolli and Cita (1960), Gartner and Hay (1962), and Gohrbandt (1963) differ from the type-level specimens of parva by possessing a heavy keel and a flat spiral side. The individuals illustrated by Aubert (1962) as velascoensis parva (pl. 1: fig. 2a-c) and acuta (pl. 1: fig. 3a-c), respectively, from Koudiat Bou Khelif, Morocco, are virtually identical, and the individual illustrated as acuta by Blow (1979, pl. 104: fig. 2) is virtually indistinguishable from the one he figured on pl. 95: fig. 6 as parva. We believe that the two morphotypes parva (auct) and acuta are virtually indistinguishable in late Paleocene assemblages.

STABLE ISOTOPES.-Morozovella acuta has $\delta^{18} \mathrm{O}$ and $\delta^{13} \mathrm{C}$ similar to other species of Morozovella (M. occlusa, $M$. velascoensis). Morozovella acuta has more positive $\delta^{13} \mathrm{C}$ and more negative $\delta^{18} \mathrm{O}$ than Subbotina spp. (Shackleton et al., 1985).

StRATIGRAPHIC RANGE.-Zone P4b to Zone P5 (top). Several authors suggest that $M$. acuta occurs somewhat higher than $M$. velascoensis. We record its lowest occurence in Zone $\mathrm{P} 4 \mathrm{~b}$ and have not found it to extend above $M$. velascoensis at 
DSDP Site 213 (Indian Ocean). Shutskaya (1970a) gave the range of $M$. acuta as extending from the $A$. acarinata Zone (= Subzone P4b this paper) to the top of the $G$. aequa Zone (= top of Zone P5 this paper), which is, essentially, the same as observed herein.

Global Distribution.-Morozovella acuta is an essentially subtropical to tropical form with somewhat narrower biogeographic distribution than velascoensis (see also Loeblich and Tappan, 1957a).

ORIGIN OF SPECIES.-This species evolved from $M$. velascoensis through a reduction in umbilical size and ornament and chamber number.

REPOSITORY.-Three paratypes (USNM CC38526) deposited in the Cushman Collection, National Museum of Natural History. Examined by WAB and RDN.

\section{Morozovella acutispira (Bolli and Cita, 1960)}

\section{Plate 46: Figures $1-15$}

Globorotalia californica Smith, 1957:190, pl. 28: figs. 22a-23c [homonym]. [Not Globorotalia californica Cushman and Todd, 1946.]

Globorotalia acutispira Bolli and Cita, 1960:15, pl. 33: fig. 3a-c [Zone P4, Paderno d'Adda, northern ltaly].

Globorotalia kolchidica Morozova, 1961:17, pl. 2: fig. 2a-c [Zone Ms1 IV(?) (Cibicides lectus Zone $=$ Zone P3 this paper, upper part), Khokodz' River section, Crimea].

Globorotalia sp. aff. G. kolchidica Morozova.-Luterbacher, 1964:668, text-figs. 61, 62 [Globorotalia pusilla Zone, Gubbio section, central Apennines, ltaly].

Globorotalia sp. aff. G. acutispira Bolli and Cita.-Shutskaya, 1970b:118120, pl. 25: fig. 7a-c [upper subzone of Acarinina tadjikistanensis djanensis Zone, Olen Platform, boring 210, 517-527 m, Kachan Stage, Tarkhankut Peninsula, Crimea].

Globorotalia (Morozovella) occlusa acutispira (Bolli and Cita).-Belford, 1984:9, pl. 17: figs. 14-21 [upper Paleocene, WABAG Sheet, Papua, New Guinea].

ORIGINAL DESCRIPTION.- -"Test trochospirally coiled, the dimensions medium for the genus, constituted of 11-12 regularly and rapidly increasing chambers, with 4 in number in the last whorl. Chambers petaloid, bordered by a very large and projecting banded keel; spiral suture arcuate and retroversed; umbilical sutures depressed and radial; umbilical cavity very small and tight. Aperture slender, interiomarginal, extraumbilical-umbilical. Wall finely punctate. The peculiar characteristic of this species, from which is derived the specific name we intentionally selected, stems from the exceptional height of the spire corresponding to the initial whorl; this confers a biconvex profile to Globorotalia acutispira, characterized by a particularly sharp rise, quite angular, from the opposite side to that of the ultimate chamber. The spire thus rises to occupy an eccentric position with respect to the center of the fossil figure, which causes the noticeable increase in height of the chambers constituting the ultimate whorl." (Bolli and Cita, 1960:15; translated from Italian.)

DIAGNOSTIC CHARACTERS.-Lenticular to subcircular, plano-convex to biconvex test with apiculate early whorls and lobulate outline, 4-6 chambers in last whorl; umbilical sutures radial, slightly curved, depressed; spiral sutures curved, raised and ornamented by the extension of the strongly muricate keel; chambers tend to be flattened along the peripheral margin; aperture a low, interiomarginal, umbilical-extraumbilical arch extending from a narrow, deep umbilicus.

DisCUSSION.-This species has been little used in the literature on Paleocene morozovellids. The distinctive character of this form is the raised early part of the test containing the neanic chambers; this feature can vary considerably among individuals in a given sample. Our studies support the diagnosis of Blow (1979) of a biconvex test with a very narrow umbilicus linking it with M. occlusa. If Globorotalia californica Smith, 1957, is indeed a homonym of Globorotalia californica Cushman and Todd, 1946 (according to Blow, 1979), and a senior synonym of Globorotalia acutispira Bolli and Cita, 1960, it should be renamed, although we can agree (provisonally) with Blow that this may be unnecessary.

A closely related, if not identical, morphospecies is $M$. kolchidica (Morozova). Morozova (1961) referred to the flat or weakly convex central part of the spiral side of the test, which we have confirmed by examinaton of the holotype (3510/12 in the micropaleontological collections of GAN, Moscow). Comparison with the refigured holotype of $M$. acutispira Bolli and Cita (in Luterbacher, 1964, text-fig. 72a-c) reveals two virtually identical forms. Blow's (1979) interpretation of $M$. kolchidica as a junior synonym of $G$. (M.) formosa gracilis Bolli is considered anomalous and incorrect (although the two forms are clearly homeomorphic in the same manner as are $M$. velascoensis and $M$. caucasica). Morozovella kolchidica was described from (and is characteristic of) Zone P3 (as well as Zone $\mathrm{P} 4$ ); $M$. gracilis was described from (and is characteristic of) Zone P6 (as well as Zone P7). Morozovella acutispira is also homeomorphic with $M$. marginodentata (Subbotina), but the latter bears a consistently more massive muricocarina and lacks the apiculate early portion of the test (see also Berggren, 1977).

Illustrated on Plate 11: Figures 13-15 is a specimen from the collections of Shutskaya (no. 645) in VNIGRI (St. Petersburg), which is probably referable to $M$. acutispira. Although the slide containing this specimen is labeled as Globorotalia angulata var. kubanensis Shutskaya, the illustration of the holotype resembles $M$. conicotruncata (Subbotina); however, because the holotype in Moscow is lost, the identity of this taxon cannot be determined. Further confusing the taxonomic status of Shutskaya's taxon is the other specimen from the same slide (no. 645) illustrated on Plate 11: Figures 10-12. This specimen is probably referable to $M$. apanthesma.

STABLE ISOTOPES.-The $\delta^{13} \mathrm{C}$ of Morozovella acutispira is similar to that of coexisting morozovellids but is more positive than that of Subbotina and Globanomalina. The $\delta^{18} \mathrm{O}$ of $M$. acutispira is lighter than that of Globanomalina and Subbotina (Berggren and Norris, 1997). 
StRatigra PHIC RANGE.-Near the Zone P3/P4 boundary to the top of Zone P4b.

GLOBAL DISTRIBUTION.-The geographic distribution of this morphospecies appears characteristic of subtropical to tropical regions as does that of occlusa.

ORIGIN OF SPECIES.-This morphospecies is closely related to, and probably evolved from, $M$. pasionensis by an increase in spire height, development of a biconvex test, a decrease in the number of chambers in the final whorl, and a decrease in the size of the umbilicus. Morozovella acutispira is closely related to $M$. occlusa as herein described.

REPOSITORY.-Holotype (No. 1278) in the micropaleontological collections of the Laboratory of Micropaleontology, Institute of Paleontology, University of Milan.

\section{Morozovella aequa (Cushman and Renz, 1942)}

\section{Plate 15: Figures 11, 12, 15; Plate 47: Figures 1-16}

Globorotalia crassata (Cushman) var. aequa Cushman and Renz, 1942:12, pl. 3: fig. 3a-c [near base Globorotalia subbotinae Zone, Soldado Fm., Trinidad].

Globorotalia lacerti Cushman and Renz, 1946:47, pl. 8: figs. 11, 12 [lower zone of Lizard Springs Fm., Ravine Ampelu, Lizard Springs area, southeastem Trinidad].

Globorotalia (Truncorotalia) crassata (Cushman) var. aequa Cushman and Renz.-Cushman and Bermúdez, 1949:37, pl. 7: figs. 7-9 [near San Ramon, about $900 \mathrm{~m}$ SW of Carretera San Ramon, Pinar del Rio Province, Cuba; Bermúdez Sta. 536].

Globorotalia praenartanensis Shutskaya, 1956:98, pl. 3: fig. 5a-c [Acarinina acarinata Zone, Nal'chik Horizon, lower part of Abazin Formation, Kuban River Basin, central pre-Caucasus].-Luterbacher, 1964:671, text-fig. 73a-c [topotypes from Acarainina acarinata Zone, Kuban River section, northern Caucasus].

Globorotalia aequa Cushman and Renz.-Bolli, 1957a:74, pl. 17: figs. 1-3, pl. 18: figs. 13-15 [Globorotalia velascoensis Zone = Zone P5 this paper; upper Lizard Springs Fm., Trinidad].-Loeblich and Tappan, 1957a:186, pl. 59: fig. 6a-c [Zone P4, Aquia Fm., Virginia], pl. 64: fig. 4a-c [Zone P4, Velasco Fm., Tamaulipas, Mexico] [in part, not pl. 46: figs. 7a-8c $(?=M$. angulata $)$, pl. 50: fig. 6a-c, pl. 55: fig. 8a-c].-Bolli and Cita, 1960:377, 378, pl. 33: fig. 5a-c [Zone P4, Paderno d'Adda section, northern Italy]. - Luterbacher, 1975b:64, pl. 2: figs. 22-24 [Globorotalia subbotinae Zone], pl. 2: figs. 28-30 [Globorotalia pseudomenardii Zone, Possagno section, Treviso Province, northem Italy].

Globorotalia angulata (White).-Loeblich and Tappan, 1957a:187, pl. 48: fig. 2a-c [Zone P4, Salt Mountain Limestone, Alabama], pl. 58: fig. 2a-c [Aquia Formation, Virginia] [in part, not pl. 45: fig. 7a-c, pl. 50: fig. 4a-c, pl. 55: figs. 2a-c, 6a-7c, pl. 64: fig. 5a-c]. [Not White, 1928.]

Globorotalia (Truncorotalia) aequa aequa (Cushman and Renz).Hillebrandt, 1962:133, 134, pl. 13: fig. la-c [Zone F = Zone P5 this paper, Bad Reichenhall-Salzburg Basin, Austro-German border].

Globorotalia (Morozovella) aequa bullata Jenkins, 1965:1110, fig. 10, no. 87-91 [Globigerina triloculinoides Zone, lower Waipawan Stage, Middle Waipara River section, New Zealand]; 1971:100, pl. 7: figs. 172-176 [reillustration of holotype and paratype specimens].

Globorotalia loeblichi El-Naggar, 1966:218-220, pl. 23: fig. 1a-c [Globigerina wilcoxensis Zone $=$ Zone $\mathrm{P} 6$ this paper, sample S 68 , Thebes Calcareous Shale, Thebes Fm., Gebel Owaina section].

Truncorotaloides (Morozovella) aequus (Cushman and Renz).-McGowran, 1968:190, pl. 1: figs. 3-7 [Planorotalites simplex Zonule, Boongerooda Greensand, Cape Range, Australia], figs. 8-12 [Truncorotaloides $(A$.) mckannai Zonule, Boongerooda Greensand, Cape Range, Australia].
Globorotalia (Morozovella) aequa aequa Cushman and Renz.-Jenkins, 1971:100, pl. 7: figs. 167-169 [Globigerina triloculinoides Zone, Middle Waipara River section, New Zealand], figs. 170, 171 [Globigerina triloculinoides Zone, lower part of type Waipawan Stage, Te Uri Stream section, New Zealand].-Blow, 1979:975-977, pl. 96: figs. 4-9, pl. 218: figs. 1-6 [Zone P5 of Blow, 1979; Sample FCRM 1670, Lindi area, Tanzania], pl. 99: fig. 5 [Zone P5 of Blow, 1979; DSDP Hole 47.2/9/1: 64-66 cm; Shatsky Rise, northwestern Pacific Ocean], pl. 102: figs. 6, 9, 10, pl. 103: fig. 1, pl. 211: figs. 3-5 [Zone P6 of Blow, 1979; DSDP Hole 20C/6/3: 76-78 cm; Brazil Basin, South Atlantic Ocean], pl. 118: figs. 8-10, pl. 21 1: figs. 1, 2 [Zone P7 of Blow, 1979; DSDP Hole 47.2/8/3: 83-85 cm; Shatsky Rise, northwestern Pacific Ocean].

Morozovella aequa (Cushman and Renz).-Berggren, 1971b:76, pl. 5: fig. 6 [Morozovella velascoensis Zone $=$ Zone P5 this paper, DSDP Hole 20C/6/4: 5-7 cm; Brazil Basin, South Atlantic Ocean].-Snyder and Waters, 1985:446, pl. 7: figs. 5-7 [Zone P4/5, DSDP Site 549/16/5: 57-60 cm; Pendragon Escarpment, Goban Spur, northeastern Atlantic Ocean].-[not Lu and Keller, 1995:102, pl. 1: fig. 15 (Zone P3, DSDP Site 577/11/3: 19-21 $\mathrm{cm}$; Shatsky Rise, northwestern Pacific Ocean)].-[not Stott and Kennett, 1990:560, pl. 6: figs. 13-15 (Zone A. 6, ODP Hole 690B/16H/7: 36-40 cm; Maud Rise, Weddell Sea, Southem Ocean (? = Acarinina wilcoxensis))].

Acarinina aequa (Cushman and Renz).-Tjalsma, 1977:508, pl. 3: fig. 13 [Morozovella velascoensis Zone, DSDP Site 329/32/4: 107-109 cm; Maurice Ewing Bank, South Atlantic Ocean].

Globorotalia (Morozovella) aequa lacerti (Cushman and Renz).-Blow, 1979:977-979, pl. 138: figs. 1-3 [Zone P8b of Blow, $1979=$ Zone P7 this paper; DSDP Hole 20C/5/5: 72-74 c m; Brazil Basin, South Atlantic Ocean], pl. 115: fig. 6 [Zone P7 of Blow, 1979 = Zone P6b this paper; Sample RS 80, Kilwa area, Tanzania, as ex interc $G .(M$.$) aequa lacerti-G. (M$. subbotinae].

Globorotalia (Morozovella) aequa tholiformis Blow, 1979:979-981, p1. 102: figs. 7, 8 [Zone P6 of Blow, 1979; DSDP Hole 20C/6/3: 76-78 cm; Brazil Basin, South Atlantic Ocean], pl. 119: figs. 1, 2 [holotype], fig. 3 [Zone P7 of Blow, 1979; DSDP Hole 47.2/8/3: 82-85 cm], pl. 125: figs. 1, 2, pl. 127: figs. 8, 9, pl. 129: fig. 6 [Zone P8a of Blow, 1979; DSDP Hole 47.2/8/2: 71-73 cm], pl. 133: fig. 9 [Zone P8b of Blow, 1979; DSDP Hole 47.2/8/1: 77-79 cm; Shatsky Rise, northwestern Pacific Ocean].

ORIGINAL DESCRIPTION.- "Variety differing from the typical in the much smoother surface, and the chambers especially in the later ones, broader and more arcuate.

"Holotype of variety (Cushman Coll. No. 38210) from the Midway Eocene, Soldado Formation, Soldado Rock, Trinidad, B.W.I. Coll. Dr. H.G. Kugler (sample K. 2950)." (Cushman and Renz, 1942:12.)

DIAGNOSTIC CHARACTERS.-Subquadrate, plano-convex, muricocarinate test with moderately lobulate peripheral outline and 4 (less commonly 5) chambers in last whorl; intercameral sutures on umbilical side straight, radial; raised, curved on spiral side; umbilicus narrow, bordered by low apertural slit extending nearly to periphery; test surface generally covered with muricae, particularly on umbilical shoulder and along peripheral margin.

DISCUSSION.-This taxon has a complicated and intricate taxonomic history due, in no small part, to the (minor) morphologic variability (and resulting complex nomenclature) ascribed to this species (see discussion by Blow, 1979:975982). Cushman and Renz (1942) described a subquadrate, planoconvex, carinate morozovellid from the terminal Paleocene of Trinidad, which has come to serve as the central type of 
a plexus of late Paleocene to early Eocene forms generally linked by the features listed in the diagnosis above; however, we see little justification, or utility, in using these minor morphologic differences in distinguishing the forms listed in the synonymic list above.

STABLE ISOTOPES.-Morozovella aequa has more positive $\delta^{13} \mathrm{C}$ and more negative $\delta^{18} \mathrm{O}$ than Subbotina and Globanomalina and a similar isotopic signature to coexisting morozovellids, such as $M$. velascoensis ( $\mathrm{Lu}$ and Keller, 1996; Berggren and Norris, 1997).

StRatigraPhic Range.-Zone P4c to Zone P7.

GLOBAL DISTRIBUTION.-Morozovella aequa is a geographically widespread species, having been recorded from areas circumscribed by latitudes $50^{\circ} \mathrm{N}$ (Goban Spur, northeastern Atlantic Ocean; Snyder and Waters, 1985) and 50 ${ }^{\circ}$ (Falkland Plateau; Tjalsma, 1977); it occurs as far south as nearly $60^{\circ}$ (Kerguelen Plateau; Berggren, 1992) during the brief early Eocene (Zone P6) temporal excursion of (sub)tropical morozovellids.

ORIGIN OF SPECIES.-Morozovella aequa evolved from $M$. apanthesma through concomitant reduction in the number of chambers and the development of both more involute coiling (resulting in a more closed umbilicus) and a peripheral muricocarina. We have observed this transition both in our material and particularly at DSDP Site 384 , where it occurs at the base of Zone P4c together with the appearance of various acarininid taxa of the soldadoensis and primitivalcoalingensis plexus in the younger part of Chron C25r. We have not found this form in lower parts of the stratigraphic record (cf. Blow, 1979; Lu and Keller, 1995).

REPOSITORY.- Holotype (USNM CC38210) deposited in the Cushman Collection, National Museum of Natural History. Examined by WAB and RDN.

\section{Morozovella angulata (White, 1928)}

Figure 23; PLATE 48: FigURES 1-16

Globigerina angulata White, 1928:191, pl. 27: fig. 13 [Zone P4, Velasco Fm., Mexico].

Globorotalia angulata (White)-Glaessner, 1937b:383, pl. 4: figs. 35a-c; ? 36a-c $(?=M$. aequa), fig. 37a-c (M. conicotruncata) [upper Paleocene, Anapa section, Goryachi Kliutch Fm. and Il'sk, northwestern Caucasus; lower part of Sumgait Group, southeastern Caucasus, lower Foraminiferal Beds of Dagestan].-Bykova, 1953:82-86, text-figs. 7a-1lc ["Montian Stage," western Turkmenia].- Shutskaya, 1956:92, 93, text-fig. 1, pl. 3: fig. 2a-c [Elburgan Fm., Khieu River section, central Caucasus].-Bolli, 1957a: 74, pl. 17: figs. 7-9 [Globorotalia pusilla Zone, lower Lizard Springs Fm., Trinidad].-Loeblich and Tappan, 1957a:187, pl. 50: fig. 4a-c [Zone P3b, Hornerstown Fm., New Jersey, cf. Blow, 1979:985], pl. 64: fig. 5a-c [Zone P4, Velasco Fm., Mexico, cf. Blow, 1979:986] [in part, not pl. 45: fig. 7a-c, pl. 48: fig. 2a-c (= M. aequa (Cushman and Renz)), pl. 55: figs. 2a-c, 6a-7c (probably transitional to $M$. apanthesma (Loeblich and Tappan)), pl. 58: fig. 2a-c $(=M$. aequa (Cushman and Renz))].-Bolli and Cita, 1960:376, 377, pl. 35: fig. 8a-c [Globorotalia pusilla Zone, Paderno d'Adda section, northern Italy].-Olsson, 1960:44, pl. 8: figs. 14-16 [Zone P3b, Hornerstown Fm., New Jersey].-Toumarkine and Luterbacher, 1985:111, text-fig. 14: 5a-c [holotype reillustrated], text-fig. 14: 6a-c [reillustration of
Bolli, 1957a, pl. 17: figs. 10-12 "transitional form between Globorotalia uncinata Bolli, new species and Globorotalia angulata (White)"].

Globorotalia (Truncorotalia) angulata (White).-Hillebrandt, 1962:131, 132, pl. 13: figs. $14 \mathrm{a}-15 \mathrm{c}$ [Zone $\mathrm{D}=\mathrm{G}$. pusilla Zone, Richenhall-Salzburg Basin, Austro-German border].

Truncorotaloides (Morozovella) angulatus (White).-McGowran, 1968:190, pl. 1: figs. 13-18 [middle Paleocene, Boongerooda Greensand, Australia].

Globorotalia (Morozovella) angulata (White).-Blow, 1979:984, pl. 86: figs. 7-9 [figs. 7, 8, given as $G$. (M.) cf. angulata], pl. 87: fig. 1 [Zone P3, DSDP Hole 47.2/10/1: 72-74 cm; Shatsky Rise, northwestern Pacific Ocean].

Morozovella protocarina Corfield, 1989:98, pl. 1: figs. 1-12 [Zone P3, DSDP Site 577/1 1/6: 30-31 cm; Shatsky Rise, northwestern Pacific Ocean].

ORIGINAL DESCRIPTION.- "Test rotaliform, dorsal side flat, ventral side convex, umbilicate, periphery sharply angled; chambers few, usually four or five in the last whorl, inflated, rapidly increasing in size; sutures distinct, curved, deep, not limbate; wall granular or subspinose, very finely perforate; aperture an elongate opening extending from the umbilicus almost to the peripheral margin and sometimes provided with a narrow lip. Diameter of type specimen, $0.35 \mathrm{~mm}$.; height, 0.25 mm." (White, 1928:191.)

DiagnostiC CHARACTERS.-Muricate, nonspinose anguloconical test, spiral side flat, early chambers slightly elevated, 10-12 chambers arranged in $2 \frac{1}{2}$ whorls, 4-6 chambers in final whorl, periphery lobulate, (sub)acute, imperforate band (muricocarina) developed along peripheral margin; weak circumumbilical collar formed around narrow, deep umbilicus by elevated chambers, particularly last chamber; sutures depressed, straight, radial on umbilical side, strongly recurved on spiral side; aperture, low, interiomarginal, umbilicalextraumbilical low arch with weakly developed lip.

DISCUSSION.-Blow (1979:984) drew a distinction between peripherally muricocarinate (angulata) and (putatively ancestral) non-carinate (praeangulata) morphotypes of the early angulata lineage. Following Blow (1979) in this distinction, we maintain both morphotaxa in the genus Morozovella (contra Pearson, 1993).

Considerable confusion and misidentification has surrounded this taxon, not the least because of the long (about 50 year) sequestration of the White collection at Columbia University, which ended with its rediscovery by $\mathrm{T}$. Saito and its subsequent transfer to the American Museum of Natural History in the early 1980s. We have followed Blow (1979) in adopting the concept of angulata sensu Bolli (1957a) in identifying this form. We regard Morozovella protocarina Corfield (1989) as falling within this concept of $M$. angulata. Our studies, however, support the range of $M$. angulata given by Bolli (1957a) (Zone P3 to middle part of Zone P4) rather than that of Blow (1979) (Zone P3 to basal Zone P5).

STABLE ISOTOPES.-Morozovella angulata has more negative $\delta^{18} \mathrm{O}$ and more positive $\delta^{13} \mathrm{C}$ than Parasubbotina and Subbotina (Douglas and Savin, 1978; Boersma and Premoli Silva, 1983; Shackleton et al., 1985). The species displays a distinct trend toward increased $\delta^{13} \mathrm{C}$ with increased test size and little or no trend in $\delta^{18} \mathrm{O}$ with size (Shackleton et al., 1985). 


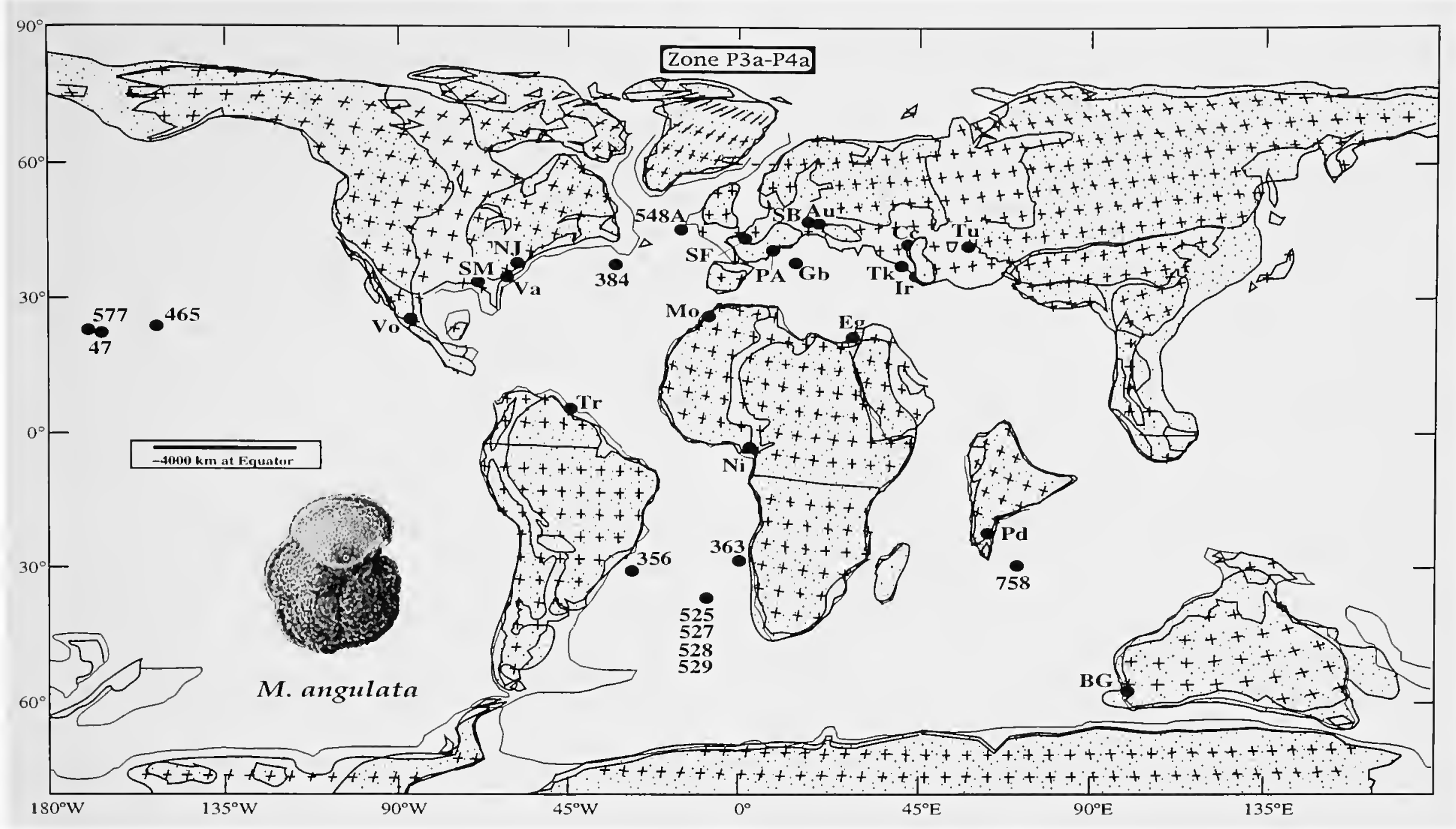

FIGURE 23.-Paleobiogeographic map showing distribution of Morozovella angulata (White) in Zones P3 and P4.

STRATIGRA PHIC RANGE.-Zone P3 to lower Zone P4.

GLOBAL DISTRIBUTION.-This form is essentially restricted to (sub)tropical to temperate regions (circumscribed by $50^{\circ} \mathrm{N}$ and $\mathrm{S}$ latitudes); it has not been reliably reported from high northern or southern (subantarctic) regions (Figure 23).

ORIGIN OF SPECIES.-This species evolved from Morozovella praeangulata (Blow) at or near the Zone $\mathrm{P} 2 / 3$ transition by elaboration of the muricae, development of a peripheral muricocarina, and establishment of anguloconical chambers throughout the last whorl.

REPOSITORY.-Columbia University Paleontology Collection (No. 19876), collection now at the American Museum of Natural History, New York.

\section{Morozovella apanthesma (Loeblich and Tappan, 1957)}

\section{Plate 17: Figures 1-3; Plate 49: Figures 1-15}

Globorotalia apanthesma Loeblich and Tappan 1957a:187, pl. 48: fig. la-c [Zone P4, Salt Mountain Limestone, Clarke Co., Alabama], pl. 55: fig. 1a-c [Zone P4, Vincentown Fm., New Jersey], pl. 58: fig. 4a-c (paratype), pl. 59: fig. la-c (holotype) [Zone P4, Aquia Fm., Virginia].

Globorotalia (Morozovella) apanthesma Loeblich and Tappan.-Jenkins, 1971:102, pl. 8: figs. 186-188 [Globigerina triloculinoides Zone, Waipawan Stage, Middle Waipara River section, New Zealand].-Belford, 1984:9, pl. 16: figs. 1-8 [Zone P4, Papua, New Guinea].

? Globorotalia (Morozovella) apanthesma Loeblich and Tappan.-Blow,
1979:988, pl. 251: fig. 2 [Zone P7 of Blow, 1979 = Zone P6 this paper; Sample HK 1831, type level of $G$. rex Zone, "Carmen Jones Ravine," tributary of Cascas River, southern Trinidad].

Acarinina apanthesma (Loeblich and Tappan).-Huber, 1991b:446, pl. 4: figs. 1, 2 [Zone AP4, ODP Hole 738C/16R: 332.15 mbsf; Kerguelen Plateau, southern Indian Ocean].

Not Morozovella apenthesma [sic] Lu and Keller, 1995:102, pl. 1: figs. 18, 19 [Zone P3b/P4x of Lu and Keller; DSDP Site 577/11/2: 52-54 cm; Shatsky Rise, northwestern Pacific Ocean].

ORIGINAL DESCRIPTION.- "Test free, trochospiral, planoconvex, umbilicoconvex, with rather wide, deep and open umbilicus, periphery subacute, peripheral outline lobulate; chambers hemispherical, flattened to gently convex and appearing lunate in side view from the spiral side, strongly inflated to subangular on the umbilical side, 4 to 5 in the final whorl, commonly somewhat obliquely overlapping earlier chambers, the forward margin of each chamber protruding slightly above the general level of the spiral side, the posterior margin of the succeeding chamber beginning at a slightly lower level; sutures distinct, strongly curved and slightly depressed on the spiral side, radial and strongly depressed on the umbilical side, wall calcareous, rather coarsely perforate, surface spinose, most strongly on the umbilical side; aperture interiomarginal, extraumbilical-umbilical, a broad arched opening, with a narrow bordering lip present in well-preserved specimens. 
"Hypotypes range from 0.23 to $0.45 \mathrm{~mm}$. in diameter and from 0.15 to $0.33 \mathrm{~mm}$. in thickness." (Loeblich and Tappan, 1957a:187-188.)

DiAGNOSTIC CHARACTERS.-Planoconvex, umbilicoconvex, test with lobulate, weakly muricocarinate periphery; 4-5 chambers in last whorl, inflated to subangular on umbilical side, moderately convex, triangular (lunate) in edge view; intercameral sutures on umbilical side depressed, radially curved and slightly depressed on spiral side; umbilical side distinctly muricate, coarsely perforate on spiral side; umbilicus relatively narrow, deep; aperture an interiomarginal, umbilical-extraumbilical arch with narrow, continuous intraperiumbilical lip.

DISCUSSION.-Blow (1979) drew attention to an important distinction within this plexus: apanthesma exhibits the essentially quadrate chamber pattern of the related (and descendant) aequa in the early whorls, whereas angulata (and related forms) retains the more "vorticiform," strongly recurved, early whorl pattern. In view of these, and other pertinent observations based on personal observations of type material (Blow, 1979), it is strange that he presented, almost as an afterthought, only a single, spiral view of a form assigned to apanthesma from (his) Zone P7 (= Zone P6 this paper) whose affinities are somewhat hard to evaluate. Earlier this species was considered a junior synonym of $M$. conicotruncata (Subbotina) by Luterbacher (1964) and of M. angulata (White) by Berggren (1977).

Illustrated on Plate 11: Figures 10-12 is a specimen from the collections of Shutskaya (no. 645) in VNIGRI (St. Petersburg) that is probably referable to $M$. apanthesma. Although the slide containing this specimen is labeled as Globorotalia angulata var. kubanensis Shutskaya, the illustration of the holotype resembles $M$. conicotruncata (Subbotina). Because the holotype in Moscow is lost, the identity of this taxon cannot be determined. Further confusing the taxonomic status of Shutskaya's taxon is the other specimen from the same slide (no. 645) illustrated on Plate 11: Figures 13-15. This specimen is probably referable to $M$. acutispira.

STABLE ISOTOPES.-Limited isotopic data suggest $M$. apanthesma is similar in $\delta^{18} \mathrm{O}$ and $\delta^{13} \mathrm{C}$ to other morozovellids and has a more positive $\delta^{13} \mathrm{C}$ and more negative $\delta^{18} \mathrm{O}$ than coexisiting Globanomalina and Subbotina (Lu and Keller, 1996; Berggren and Norris, 1997).

STRATIGRA PHIC RANGE.-Zone P3b to Zone P4c.

GLOBAL Distribution.--Northern middle latitudes to the Southern Ocean.

ORIGIN OF SPECIES.-Morozovella apanthesma and its descendants, $M$. aequa and $M$. subbotinae, differ from the $M$. angulata-M. velascoensis group in possessing a relatively even distribution of fine muricae (pustules) over the surface of the test in contrast to the development of muricae-free surfaces between the murcorcarina and adumbilical ridges in the $M$. velascoensis plexus. Morozovella apanthesma shares charac- teristics intermediate between $M$. praeangulata (its antecedent) and $M$. aequa (its descendant). The former is generally somewhat smaller (contra Loeblich and Tappan, 1957a; see also Jenkins, 1971), with more subdued muricate wall texture and more strongly recurved chambers when seen from the spiral surface. Compared to its ancestor, $M$. aequa exhibits a reduced number of chambers and a more anguloconical test.

REPOSITORY.-Holotype (USNM P5860) and paratypes (USNM P5868, P5861, P5862) deposited in the Cushman Collection, National Museum of Natural History. Examined by WAB, RDN, and RKO.

\section{Morozovella conicotruncata (Subbotina, 1947)}

Plate 11: Figures 10-15; Plate 50: Figures 1-15

Globorotalia conicotruncata Subbotina, 1947:115, pl. 4: figs. 11-13 [holotype, zone of "Danian Foraminifera," Assu River section, northern Caucasus], pl. 9: figs. 9-11 [zone of "Danian Foraminifera," Khieu River section, Nal'chik, northern Caucasus].-Luterbacher, 1964:660, text-fig. 40 [zone of rotalid globorotaliids, Khieu River section, northern Caucasus], text-figs. 41, 42 [as $G$. angulata abundocamerata: topotypes from Globorotalia pusilla pusilla Zone, lower Lizard Springs Fm., Trinidad], text-figs. 46-49 [Globorotalia pseudomenardii Zone], text-fig. 51 [Globorotalia pusilla pusilla Zone, Gubbio section, central Apennines, Italy]; 1975a:726, pl. 1: figs. 6, 7 [Globorotalia pusilla pusilla Zone, DSDP Site 305/14/CC; Shatsky Rise, northwestern Pacific Ocean].-Pujol. 1983:645, pl. 2: fig. 8 [Zone P3 (mid-part), DSDP Hole 516F/87/4: 43-44 cm; Rio Grande Rise, South Atlantic Ocean].

Acarinina conicotruncata (Subbotina).-Subbotina, 1953:220. pl. 20: fig. 5a,b [zone of rotalid globorotaliids, Foraminiferal Beds, Suite F1 (lower part), Khieu River, Nal'chik, northern Caucasus], pl. 20: fig. 6a-c [holotype reillustrated], pl. 20: fig. 7a-c [specimen reillustrated from Subbotina, 1947, pl. 9: figs. 9-11, same sample as holotype], pl. 20: fig. 8a-c [same sample as fig. 7a-c] [in part, not pl. 20: figs. 10a-12c].

Globorotalia angulata (White) var. kubanensis Shutskaya, 1956:93, pl. 3: fig. 4a-c [holotype No. 3525/19, GAN, Bed 6, Marl, Elburgan Fm., Kuban River Section, northern Caucasus].

Globorotalia angulata abundocamerata Bolli, 1957a:74, pl. 17: figs. 4-6 [Globorotalia pusilla pusilla Zone, lower Lizard Springs Fm., Trinidad].Bolli and Cita, 1960:379, pl. 35: figs. 6a-c [Globorotalia pusilla pusilla Zone, Paderno d'Adda section, northern Italy].

Globorotalia (Truncorotalia) angulata Hillebrandt, 1962:131, pl. 13: figs. 14a-15c [Zone D = correlative with upper part of Globorotalia pusilla pusilla Zone, Reichenhall-Salzburg Basin, Austro-German border]. [Not White, 1928.]

Globorotalia kubanensis (Shutskaya).-Shutskaya, 1970b:118-120, pl. 21: fig. la-c [Acarinina praepentacamerata Zone, Malyi Balkhan Ridge, Chaal'dzhin Group, western Turkmenia].

Morozovella conicotruncata (White).-Berggren, 1971b:74, pl. 4: figs. 8, 9 [Zone P4, DSDP Hole 20C/6/5: 8-10 cm], figs. 10-14 [Zone P4, DSDP Hole 20C/6/4: 100-102 cm; Brazil Basin, South Atlantic Ocean].-Snyder and Waters, 1985:446, pl. 8: figs. 4, 5 [Zone P4/5, DSDP Site 549/16/4: $57-60 \mathrm{~cm}$ ], fig. 6 [DSDP Site 549/16/5: $57-60 \mathrm{~cm}$; northeast Atlantic Ocean].

Globorotalia (Morozovella) angulata conicotruncata (White).-Blow, 1979:986, pl. 87: fig. 3 [Zone P3, DSDP Hole 47.2/10/1: 72-74 cm; Shatsky Rise, northwestern Pacific Ocean].

ORIGINAL DESCRIPTION.- - "Test a truncated cone. There are two whorls. Dorsal side flat except in the slightly raised central portion occupied by the first whorl; ventral side strongly 
convex, sloping toward the dorsal side at an angle of about $50^{\circ}$ to $60^{\circ}$. Umbilicus open, deep, not very broad for Globorotalia. Periphery broadly lobate, acute, not keeled. The final whorl usually consists of five chambers which are alate on the dorsal side and triangular on the ventral side. Each chamber of the first whorl is approximately one-half the size of the corresponding chamber of the second whorl. The chambers increase very slowly in size within each whorl, so that each pair of adjacent chambers seems to be equal. One of the characteristic features is the uniform thickness (the dorsoventral elongation), due to which their umbilical ends are almost in the same plane. The chambers adhere closely to one another. Septal sutures on the dorsal side simple, arcuately curved, depressed; on the ventral side, they diverge radially from the umbilicus to the periphery, in the form of straight, strongly depressed furrows. Spiral sutures weakly lobate, nearly smooth, depressed, most often indistinct. Aperture slitlike, very weakly curved to nearly straight, extending from the umbilicus to approximately half-way between the umbilicus and the periphery on the ventral side. Wall densely covered with short and relatively thick spines, usually larger on the ventral side than on the dorsal side. Final chamber usually smoother. Spines most distinct at the periphery." (Subbotina, 1947:115; translated from Russian.)

DIAGNOSTIC CHARACTERS.-Subcircular, moderately lobulate, low trochospiral test with 5-7 subangular, inflated, essentially equidimensional chambers in last whorl, spiral side flat to slightly convex in early whorls; umbilical sutures straight to weakly curved, radial, incised; spiral sutures distinctly curved, incised; axial periphery (sub)acute, peripheral muricocarina variable, generally fused on early chambers of last whorl whereas later chambers generally subrounded (although muricocarinae fuse consistently along peripheral margin on individuals of this form as it transforms into $M$. velascoensis in Zone $\mathrm{P} 3 \mathrm{~b}$ ); umbilicus narrow, deep; aperture a low interiomarginal, umbilical-extraumbilical slit.

Discussion.-This is a distinct middle Paleocene planoconvex morozovellid species characterized by 5-7 equidimensional chambers in the last whorl. Our studies support Blow's (1979) observation that this form appears virtually simultaneously with typical angulata-types (cf. Bolli, 1957a); however, we do not agree with the extended range given this taxon by Blow (1979) of mid-Zone P3 through Zone P4, extending possibly into Zone P5. Our studies support, rather, the range given by Bolli (1957a) of its extension into the lower part of the Globorotalia pseudomenardii Zone.

STABLE ISOTOPES.-Morozovella conicotruncata has $\delta^{13} \mathrm{C}$ similar to M. angulata and more positive than Subbotina and Globanomalina (Boersma and Premoli Silva, 1983; Berggren and Norris, 1997). The $\delta^{18} \mathrm{O}$ of $M$. conicotruncata is slightly lighter than $M$. angulata in samples from DSDP Site 384 (Berggren and Norris, 1997) and is distinctly lighter than coexisting Globanomalina and Subbotina (Boersma and Premoli Silva, 1983; Berggren and Norris, 1997).
Stratigra Phic Range.-Zone P3 to lower Zone P4.

GLOBAL DISTRIBUTION.-As with its closely related sister taxon angulata, this form has a predominantly tropical to temperate distribution ( $<45^{\circ} \mathrm{N}$ and $\mathrm{S}$ ) and has not been reliably reported from high northern or southern (subantarctic) latitudes. It is a common and distinct form in our material and is observed to grade into $M$. velascoensis in Subzone P3b.

ORIGIN OF SPECIES.-This morphospecies evolved from Morozovella angulata (White) in the lower part of Zone P3 by the development of a distinctly planoconvex test, a more open umbilicus than $M$. angulata, and a characteristic low rate of chamber enlargement, which results in equidimensional chambers throughout the final whorl.

REPOSITORY.-Holotype (No. 3085) and paratypes (Nos. $2178,4085,4086,4087,4099$ ) deposited in the micropaleontological collections at VNIGRI, St. Petersburg, Russia. Examined by WAB.

\section{Morozovella gracilis (Bolli, 1957)}

\section{PLATE 54: FIGURES 13-15}

Globorotalia formosa gracilis Bolli, 1957a:75, pl. 18: figs. 4-6 [Globorotalia rex Zone, Trinidad Leasholds, Ltd., well Guayaguayare 159, core 3,707-13', upper Lizard Springs Fm., Trinidad].--Luterbacher, 1964:692, text-fig. $115 \mathrm{a}-\mathrm{c}$ [topotypes, Globorotalia rex Zone, Trinidad], text-fig. 117a-c [Globorotalia formosa formosa/Globorotalia subbotinae Zone, sample leve] G-58, Gubbio section, central Apennines, Italy], text-fig. 105a-c [Globorotalia velascoensis Zone, Ebano, eastern Mexico, as $G$. sp. aff. formosa gracilis], text-figs. 106a-107c [Globorotalia velascoensis Zone, sample level G-74, Gubbio section, central Apennines, Italy].-Shutskaya, 1970b:118-120, pl. 14: fig. 8a-c [Globorotalia subbotinae Zone, ChurukSu, Kacha River section, Bakhchissaray region, Bakhchissarayan Stage, southwestern Crimea].-Luterbacher, 1975a:727, pl. 2: fig. 7a-c [DSDP Site 313/13/4: 71-73 cm; Mid-Pacific Mountains, North Pacific Ocean]; 1975b:65, pl. 4: figs. 10-12 [Globorotalia subbotinae Zone, Possagno section, Trevisiano Province, Italy].

Globorotalia bollii El-Naggar, 1966:202-203, pl. 22: fig. 6a-d [Globigerina wilcoxensis Zone, Thebes Calcareous Shale, Gebel Aweina, Egypt] [in part, not pl. 22: fig. 5a-d (holotype $=M$. subbotinae $($ Morozova))].

Globorotalia (Morozovella) gracilis Bolli.-Jenkins, 1971:105, pl. 9: figs. 202-204 [Globigerina wilcoxensis Zone, Middle Waipara River section, Waipawan Stage, New Zealand].

Morozovella gracilis (Bolli).-Berggren, 197lb:76, pl. 5: figs. 7, 8 [Morozovella subbotinae Zone, DSDP Hole 20C/5/6: 100-102 cm; South Atlantic Ocean].-Huber, 1991b:440, pl. 4: fig. 8 [Zone AP6A, ODP Hole 738C/10R, 277.78 mbsf; Kerguelen Plateau, southern Indian Ocean].-Lu and Keller, 1995:102, pl. 1: fig. 9 [Zone P6bx of Lu and Keller = Zone P6a this paper; DSDP Site 577/9/6: $53-55 \mathrm{~cm}$; Shatsky Rise, northwestern Pacific Ocean].

Globorotalia (Morozovella) subbotinae gracilis Bolli.-Blow, 1979:10211024, pl. 111 : figs. 9, 10, pl. 112: fig. 1 [Zone P7 of Blow, 1979; sample KRE 83F, Moogli Mudstone, Kagua Inlier, Kagua, Papua, New Guinea], pl. 115: figs. 7-10, pl. 223: figs. 3, 4 [Zone P7 of Blow, 1979; sample RS 80, Kilwa area, Tanzania], pl. 120: figs. 1-9, pl. 121: figs. 1-8 [Zone P7 of Blow, 1979; DSDP Hole 47.2/8/3: 83-85 cm; Shatsky Rise, northwestern Pacific Ocean], ? pl. 249: figs. 8, 9 [Globorotalia pseudomenardii Zone, sample/ specimens collected by L.W. LeRoy as topotypic Discorbina simulatilis Schwager, 1883, and presented to R. Wright Barker; Maqfi section, Farafrah Oasis, Egypt]. 
Morozovella formosa gracilis (Bolli).-Snyder and Waters, 1985:446-447, pl. 8: figs. 7-9 [Zone P7, DSDP Site 549/12/4: $47-50 \mathrm{~cm}$; Pendragon Escarpment, Goban Spur, northeastern Atlantic Ocean].-Toumarkine and Luterbacher, 1985:12, text-fig. 15: 12a-c [reillustration of holotype of Bolli, 1957a].

ORIGINAL DESCRIPTION.--"Shape of test very low trochospiral, spiral side almost flat or slightly convex, umbilical side distinctly convex; equatorial periphery lobate; axial periphery angular with a faint keel ornamented with spines. Wall calcareous, perforate, surface distinctly spinose. Chambers angular, inflated; about 12 , arranged in $2^{1 / 2}-3$ whorls, the 5 or 6 chambers of the last whorl increasing rapidly in size. Sutures on the dorsal side slightly curved to oblique, slightly depressed; on umbilical side radial, distinctly depressed. Umbilicus fairly narrow, deep, open. Aperture a low arch; interiomarginal, extraumbilical-umbilical. Coiling between 90 and 100 percent dextral. Largest diameter of holotype $0.50 \mathrm{~mm}$." (Bolli, 1957a:75.)

DiagNoSTIC ChARACTERS.-Planoconvex to moderately biconvex test, with lobulate peripheral margin ornamented with well-developed muricocarina; 5-6 essentially equidimensional chambers in last whorl; umbilical intercameral sutures radial, straight, depressed; on spiral side, sutures strongly curved, distinctly muricate except for penultimate/ultimate chamber suture, which is straight giving cuneiform shape to final chamber (not unlike the shape in Acarinina triplex); umbilical surface covered with muricae, spiral side weakly muricate except for concentration of muricae along intercameral sutures and peripheral margin of ultimate whorl; small sutural openings along margin/junction of ultimate/penultimate whorl resulting from chamber addition along topographically separated/elevated muricate edges; umbilicus narrow, deep; aperture a low interiomarginal, umbilical-extraumbilical arch extending towards, but not to, the peripheral margin.

DISCUSSION.-Morozovella gracilis occupies a morphologic/phylogenetic position intermediate between $M$. subbotinae and M. formosa (see also Pearson, 1993). It differs from the former in the increased number of chambers (5-6) in the final whorl, which is associated with a looser (more evolute) coiling mode, and in the elevated spiral intercameral sutures. Morozovella formosa is characterized by a further increase in size and number of chambers (6-8) in the last whorl and concomitant increase in the width of the umbilicus. Like most other morozovellids, particularly those morphotypes closely associated with the aequa-subbotinae-gracilis-marginodentataformosa plexus, it has a complicated taxonomic history, which is discussed in Berggren (1977) and Blow (1979). Globorotalia bolli El-Naggar (1966), it appears, includes morphotypes of this plexas. We regard his pl. 22: fig. 6a-d as a morphotype of $M$. gracilis, in contrast to the holotype (pl. 22: fig. 5a-d), which is a morphotype of $M$. subbotinae.

STABLE ISOTOPES.-No data available.

Stratigraphic Range.-Z Zone P5 to Zone P6b.
Global Distribution.-This is a geographically widespread morphospecies recorded from (predominantly) (sub)tropical biogeographies. It occurs as far south as nearly $60^{\circ}$ at ODP Sites 738 (Huber, 1991b) and 747 (Berggren, 1992) on the Kerguelen Plateau, southern Indian Ocean, as part of the earliest Eocene extra-tropical excursion of morozovellids.

ORIGIN OF SPECIES.- This species evolved from M. subbotinae through a reduction in spire height and an increase in the number of chambers.

REPOSITORY.- Holotype (USNM P5055) deposited in the Cushman Collection, National Museum of Natural History. Examined by $\mathrm{WAB}$ and $\mathrm{RDN}$.

\section{Morozovella occlusa (Loeblich and Tappan, 1957)}

Plate 17: figures 4-6; Plate 51: figures 1-15

? Discorbina simulatilis Schwager, 1883:120, pl. 29: fig. 15a-d [? Zone P4, Farafra Oasis, Egypt].

Globorotalia occlusa Loeblich and Tappan, 1957a:191, pl. 55: fig. 3a-c [Zone P4, Vincentown Fm., New Jersey], pl. 64: fig. 3a-c [holotype, Zone P4, Velasco Shale, Tamaulipas, Mexico].-Luterbacher, 1964:690, text-figs. $112 \mathrm{a}-113 \mathrm{c}$ [Globorotalia velascoensis Zone, Velasco Fm., Ebano, eastem Mexico], text-fig. 114a-c [Globorotalia velacoensis Zone, Gubbio section, central Apennines, Italy].

Globorotalia crosswicksensis Olsson, 1960:47, pl. 10: figs. 7-9 [Zone P3b, Hornerstown Fm., New Jersey].

Globorotalia (Truncorotalia) velascoensis occlusa Loeblich and Tappan.Hillebrandt, 1962:139, pl. 13: figs. 22, 24, 25 [Zone F = Zone P4/5 this paper], pl. 13: figs. 23, 26 [Zone D = Globorotalia pusilla pusilla Zone (upper part), Reichenhall-Salzburg Basin, Austro-German border].

Globorotalia (Morozovella) occlusa Loeblich and Tappan.-Jenkins, 1971:106, pl. 9: figs. 208-210 [Subbotina triloculinoides Zone, Waipawan Stage, Middle Waipara River section, New Zealand].-Blow, 1979:1007, pl. 90: figs. 7, 10 [lower part of Zone P4, DSDP Hole $21 \mathrm{~A} / 3 / 6: 74-76 \mathrm{~cm}$; South Atlantic Ocean], pl. 95: figs. 7-10, pl. 96: figs. 1-3 [Zone P5, sample FCRM. 1670, Lindi area, Tanzania], pl. 213: fig. 6, pl. 214: figs. 1-6, pl. 215: figs. 5, 6, pl. 103: figs. 4-6, pl. 108: figs. 9, 10 [Zone P6, lower part, DSDP Hole 20C/6/3: 76-78 cm; Brazil Basin. South Atlantic Ocean], pl. 118: figs. 1-7 [Zone P7, DSDP Hole 47.2/8/3: 83-85 cm; Shatsky Rise, northwestern Pacific Ocean].-Belford, 1984:9, pl. 17: figs. 6-14 [upper Paleocene, WABAG Sheet area, Papua, New Guinea].

Globorotalia (Morozovella) occlusa cf. occlusa Loeblich and Tappan.-Blow, 1979:1007, pl. 92: figs. 5, 6 [Zone P4, DSDP Hole 47.2/8/3: 83-85 cm; Shatsky Rise, northwestern Pacific Ocean].

Globorotalia (Morozovella) occlusa crosswickensis Olsson.-Blow, 1979:1011, pl. 88: figs. 1, 2, pl. 213: figs. 1, 2 [upper part of Zone P3, DSDP Hole 47.2/10/1: 72-74 cm; Shatsky Rise, northwestern Pacific Ocean], pl. 90: figs. 3-6, 8, 9, pl. 213: figs. 3-5, pl. 215: figs. 1-4 [lower part of Zone P4, DSDP Hole 21A/3/6: 74-76 cm; South Atlantic Ocean].

Morozovella simulatilis (Schwager).-Snyder and Waters, 1985:470, pl. 9: figs. 7-9 [Zone P4/5, DSDP Site 549/16/4: $57-60 \mathrm{~cm}$; northeastern Atlantic Ocean].

ORIGINAL DESCRIPTION.- “Test free, of medium size, trochospiral, spiral side flat, umbilical side convex with a very small and deep umbilicus, periphery keeled, peripheral outline entire to slightly lobulate; chambers gradually increasing in size, 4 to 5 , rarely 6 , in the final whorl, of greatest thickness at the umbilical shoulder immediately adjacent to the narrow umbilicus, umbilical shoulder subacutely rounded; sutures 
distinct, curved and oblique, thickened and flush to slightly elevated on the spiral side; radial and moderately depressed on the umbilical side; wall calcareous, finely perforate, surface smooth except for the thickened sutures on the spiral side and the peripheral keel which may be marginally nodose to hirsute, umbilical side with a somewhat granular appearance, particularly in the early region of the final whorl; aperture an interiomarginal, umbilical-extraumbilcal arch with a distinct lip above.

"Greatest diameter of holotype $0.45 \mathrm{~mm}$." (Loeblich and Tappan, 1957a:191.)

DIAGNOSTIC CHARACTERS.-Plano-convex to low biconvex, nearly circular test, 4-6 (rarely up to 8) chambers in last whorl, coalescing in a circular, subacute, weakly to moderately muricate umbilical shoulder and forming a narrow, deep umbilicus; umbilical sutures depressed, radial; elevated and beaded, tangentially curved on spiral side; sutures between final and penultimate whorl coarsely muricate; periphery distinctly muricocarinate; aperture an interiomarginal, umbilical-extraumbilical arch.

DisCUSSION.-The enhanced, expanded concept of $M$. occlusa applied by Hillebrandt (1962) to include biconvex forms with 5-8 chambers is followed herein (see also Gohrbandt, 1963; Luterbacher, 1964; Samanta, 1970). Blow (1979) interpreted this form as a morphologically and phylogenetically advanced (descendant) form of $M$. crosswicksensis Olsson, which was said to generally lack the circumumbilical muricate coronet present in $M$. occlusa. The former was described from Zone P3b (Hornerstown Fm., New Jersey); the latter was described from the Velasco Fm. (Zone P4) and is characteristic of Zones P4 and P5. We include crosswicksensis in the concept of the taxon occlusa; it bears a similar relationship to that observed in the Acarinina coalingensis/ triplex (earlier rounded periphery)-primitiva (later angular periphery) morphotypic series.

STABLE ISOTOPES.-Morozovella occlusa has $\delta^{13} \mathrm{C}$ and $\delta^{18} \mathrm{O}$ similar to coexisting $M$. velascoensis and Acarinina mckannai and more positive $\delta^{13} \mathrm{C}$ and more negative $\delta^{18} \mathrm{O}$ than Subbotina spp. (Shackleton et al., 1985; Lu and Keller, 1996).

STRATIGRAPHIC RANGE.-Top of Zone P3b (typical crosswicksensis); Zone P4-P5 (typical occlusa).

GLOBAL DISTRIBUTION.-This species is widespread in the low to middle latitudes.

ORIGIN OF SPECIES.-This species probably evolved from $M$. pasionenesis by a decrease in umbilical size, development of a biconvex test, and reduction of the muricate, sharp adumbilical ridges to lightly muricate, gently rounded surfaces around the umbilicus. Morozovella occlusa is a sister species to M. acutispira, with which it shares the biconvex test shape and relatively constricted umbilicus.

REPOSITORY.-Holotype (USNM P5874) and paratypes (USNM P5866) deposited in the Cushman Collection, National Museum of Natural History. Examined by WAB, RDN, and RKO.

\section{Morozovella pasionensis (Bermúdez, 1961)}

\section{Plate I7: Figures 7-9; Plate 52: Figures 1-15}

Pseudogloborotalia pasionensis Bermúdez, 196I:1346, pl. 16: figs. 8a,b [sample G-58, Rio de Pasion, El Petén, Guatemala].

Globorotalia pasionensis (Bermúdez).-Luterbacher, 1964:690, text-fig. I08a-c [topotype, Rio de la Pasion, El Petén, Guatemala], text-figs. I09a-I 10c [Globorotalia aequa Zone, Gubbio section, central Apennines, Italy], text-fig. $111 \mathrm{a}-\mathrm{c}$ [Globorotalia velascoensis Zone, Velasco Fm., Ebano, eastern Mexico; as G. sp. aff. pasionensis].-Samanta, 1970:629, figs. 11, 12 [Zone P4/5, upper Marlstone unit, Pondicherry Formation, India].

Globorotalia velascoensis caucasica Glaessner-El-Naggar, 1966:242, pl. 19: fig. 6a-c [Globorotalia velascoensis Zone, Gebel Aweina, Egypt]. [Not Glaessner, 1937a.]

ORIGINAL DESCRIPTION.- - "Test trochoid, planoconvex, dorsal side plane or slightly convex and ventral side strongly convex, peripheral border lobulate and keeled but not sharp; chambers in two spiral whorls; all visible on the dorsal side and on the ventral side only the six or seven of the last whorl which gradually increase in size, sutures of the chambers depressed, slightly oblique on the dorsal side and radial on the ventral side; umbilicus large where one can see some of the chambers of the primary portion of the test; wall thin, completely covered by short spines; aperture as a narrow groove at the base of the septal face of the last chamber. Diameter $0.50 \mathrm{~mm}$; height 0.25 mm." (Bermúdez, 1961:1346; translated from Spanish.)

DIAGNOSTIC CHARACTERS: Relatively large, low umbilicoconvex test with flat spiral side, distinctly lobulate, heavily keeled periphery; generally 5-7 (but up to 10 , particularly in younger, Zone P4c-P5 horizons) relatively equidimensional chambers in final whorl, but with insertion of smaller chambers between larger chambers in some individuals; intercameral sutures depressed, radial on umbilical side; curved, moderately retorse, raised and beaded on spiral side; umbilicus wide but shallow, periumbilical collar only weakly developed; aperture a low slit extending along peri-intraumbilical margin to peripheral margin of last chamber.

DISCUSSION.-This highly variable taxon differs from the closely related $M$. velascoensis in having a more loosely coiled, less vaulted angulo-conical test and a widely varying number of chambers. The chambers may be either essentially equidimensional, or there may be smaller, kummeform-like chambers inserted in the normal chamber progression of the last whorl. Morozovella pasionensis also has a relatively wider and shallower umbilicus and a more weakly ornamented periumbilcial collar.

Basic analyses of this taxon were made by Luterbacher (1964) and Blow (1979). The latter observed that the "holotype" individual of Pseudogloborotalia pasionensis Bermúdez at the National Museum of Natural History is coiled in a direction (sinistral) opposite to that of the photograph (dextral) of the "holotype" (Bermúdez, 1961, pl. 16: fig. 8a,b); however, it is the specimen (identified as Pseudogloborotalia velascoensis (Cushman)) illustrated on pl. 16: fig. $11 \mathrm{a}, \mathrm{b}$ (and 
not that illustrated as fig. 8a,b), which is the holotype of pasionensis and which was examined by Blow and ourselves in the Cushman Collection (USNM 639063). The holotype of $P$. pasionensis shows characters similar to $P$. velascoensis, which indicate its close relationship with that tax on, but it has a low conical test as opposed to the high conical test typical of $P$. velascoensis. Luterbacher (1964) provided a revised and amplified description of this species based on topotypes supplied by Bermúdez. The analyses of Blow and Luterbacher are essentially compatible, with the exception that Luterbacher (1964) recorded 5-7 chambers as typical of this form, whereas Blow (1979) noted 9-10 (and occasionally up to 12) chambers in the final whorl.

STABLE ISOTOPES.-Morozovella pasionensis has $\delta^{13} \mathrm{C}$ and $\delta^{18} \mathrm{O}$ similar to coexisting $M$. velascoensis and Acarinina mckannai and more positive $\delta^{13} \mathrm{C}$ and more negative $\delta^{18} \mathrm{O}$ than Subbotina spp. (Shackleton et al., 1985; Lu and Keller, 1996).

STRATIGRAPHIC Range.-Zone P3b to Zone P5. Luterbacher (1964) considered "pasionensis" restricted to the Globorotalia aequa Zone (= Zone P6a this paper), whereas Blow (1979) considered it restricted to (his) Zone P5 (i.e., prior to the appearance of $M$. subbotinae) with questionable or sporadic occurrences in (his) Zones P4 and P6. In our studies, we have found that $M$. pasionensis appears slightly higher or later than the initial appearance of $M$. velascoensis in Zone $\mathrm{P} 3 \mathrm{~b}$, and that it ranges throughout Zones P4 and P5. We have not observed it ranging into post- $M$. velascoensis (Zone P5) levels. It was ancestral to M. acutispira and M. occlusa, which appear in the terminal part of Zone P3b.

GLOBAL DISTRIBUTION.-Our observations agree with those of Blow (1979) that $M$. pasionensis had an essentially tropical (but not necessarily solely equatorial Pacific Ocean) distribution.

ORIGIN OF SPECIES.-This species probably evolved from $M$. velascoensis through a reduction in spire height, a decrease in the ornament around the umbilicus, and an increase in the number of chambers.

REPOSITORY.- Holotype (USNM 639063) deposited in the Cushman Collection, National Museum of Natural History. Examined by WAB, RDN, and BTH.

\section{Morozovella praeangulata (Blow, 1979)}

\section{Plate 53: FIGURES 1-13}

Transitional form between Globorotalia uncinata Bolli and Globorotalia angulata (White).-Bolli, 1957a:74, pl. 17: figs. 10-12 [Zone P3, lower Lizard Springs Fm., Trinidad].

? Acarinina quadratoseptata Davidzon and Morozova, 1964:28, 30, pl. 2: fig. la-c [holotype], figs. 2a-3c [Zone P2/3 equivalent, upper part of the Chaaldzha Fm. ("transitional beds"), Kizilcheshme well, Kyurendag, Turkmenia] [in part, not text-fig. la-c (= Acarinina mckannai (White))].

Globorotalia (Acarinina) praeangulata Blow, 1979:942-944, pl. 82: figs. 5, 6 [Zone P2, Sample DB 176, type locality of Globorotalia uncinata Zone, near Pointe a Pierre, southern Trinidad], pl. 83: fig. 6 [Zone P2, DSDP Hole 47.2/10/3: 18-20 cm], pl. 84: figs. 1, 7, pl. 212: figs. 1, 2 [holotype], fig. 8
[Zone P3, DSDP Hole 47.2/10/2: 80-82 cm; Shatsky Rise, northwestern Pacific Ocean].

ORIGINAL DESCRIPTION.- "The test is comprised of about 11-12 chambers coiled in a low, but comparatively lax, trochospire with $5^{1 / 2}$ chambers visible in the last convolution of the test. In dorsal aspect, the chambers are longer tangentially than radially broad with the dorsal intercameral sutures strongly recurved to vorticiform in the earlier parts of the last convolution; the dorsal intercameral sutures are distinctly incised and are not pseudolimbate but are weakly muricate (see Plate 212: fig. 1). The equatorial profile is lobulate and the peripheral margin does not bear a continuous muricocarina. However, the peripheral margin is strongly muricate (cf. Plate 212: figs. 1 and 2) but the muricae are not fused or coalesced together. In axial-aperture profile, the test is plano-conic (cf. paratype in Plate 84: fig. 8) with the dorsal side nearly flat and the ventral side strongly vaulted; the peripheral margin is seen to be subacute in this axial-apertural aspect. In ventral aspect, the umbilicus is open and deep and the ventral intercameral sutures are radially disposed and quite deeply incised. The primary aperture opens from the umbilicus to about two-thirds of the way towards the periphery. The wall is muricate with a peripheral concentration of muricae. Maximum diameter of holotype $0.32 \mathrm{~mm}$. ." (Blow, 1979:942.)

DIAGNOSTIC CHARACTERS.-Planoconvex, moderately lobulate test with 5-6 tangentially elongate chambers in last whorl; umbilical sutures straight to weakly curved, depressed/ incised; spiral intercameral sutures incised, weakly muricate, strongly recurved; peripheral margin strongly muricate but not muricocarinate; umbilicus narrow, deep with aperture an interiomarginal, umbilical-extraumbilical slit (bordered by a distinct intraperiumbilical lip in well-preseved specimens) extending nearly to the peripheral margin.

DISCUSSION.-Examination of the holotype (3514/6) and several paratypes of Acarinina quadratoseptata Davidzon and Morozova, 1964, in the micropaleontological collections of GAN in Moscow suggests that this form may be a senior synonym of $M$. praeangulata Blow. We retain the name praeangulata in this work, however, for the reasons given below. The holotype and one of the paratypes (3514/7) of quadratoseptata are characterized by 5 chambers in the last whorl and slightly (but distinctly) curved sutures sloping to a rounded to subangular, lobulate, noncarinate periphery. In both specimens, the early whorls are obscured, the tests are poorly preserved (strongly recrystallized), and the last chamber for each is missing. Paratype $3514 / 8$ has a quadrate test and flat early whorls, and the chambers of its last whorl slope toward a distinctly subangular periphery. The test of this paratype is homeomorphic with the Pliocene noncarinate Globorotalia crassaformis. The remaining paratype (3514/9) is distinctly different, as it comes from a different locality and stratigraphic level, and it is referable to Acarinina mckannai. The drawing of this specimen is misleading and gives the impression of a 
morozovellid. A further problem lies in the fact that the specimens coil in the opposite direction to what is shown in the illustrations. The negatives were apparently retouched and printed backwards.

The Russian authors compared their new species with Acarinina pentacamerata Morozova, 1961, and A. praecursoria Morozova, 1961. Although believing that quadratoseptata may indeed be a senior synonym of praeangulata by 15 years, the fact that the type material of quadratoseptata is very poorly preserved and has been virtually ignored in Soviet/Russian literature (it was not mentioned by Shutskaya, 1970a, 1970b, in her comprehensive review of Paleocene-lower Eocene planktonic foraminifera) leads us to retain the name praeangulata for this morphospecies.

STABLE ISOTOPES.-Morozovella praeangulata has $\delta^{13} \mathrm{C}$ and $\delta^{18} \mathrm{O}$ values similar to $M$. angulata and more positive $\delta^{13} \mathrm{C}$ and more negative $\delta^{18} \mathrm{O}$ values than Subbotina spp. (Shackleton et al., 1985).

Stratigra Phic Range.-Zone P2 to Zone P3a.

GLOBAL Distribution.-The few localities where this species has been identified suggests a low to middle latitude distribution.

ORIGIN OF SPECIES.-Bolli (1957a) proposed that Globorotalia (= Morozovella) angulata was derived from Globorotalia (= Praemurica) uncinata. He illustrated a form (pl. 17: figs. 10-12) that he considered transitional between $M$. uncinata and M. angulata. Blow (1979) accepted Bolli's proposed phylogeny and selected this specimen as a paratype to support his documentation of $M$. praeangulata as the stem form of the morozovellid lineage. The transition to $M$. praeangulata would have involved the development of a more pronounced conicotruncate test and concomitant change toward equidimensional (as opposed to tangentially elongate) chambers, as well as formation of a thicker (and ultimately) muricocarinate peripheral margin. This has been the traditional view of the origin of Morozovella. An alternate view, as noted in "Wall Texture, Classification, and Phylogeny," is that the wall texture of $M$. praeangulata developed with pustule buildup on a smooth "globorotaliid" surface in contrast to the praemuricate wall texture of uncinata. In this view $M$. praeangulata originated from a smooth-walled Globanomalina, such as $G$. imitata, which has pustules covering the walls of early formed anguloconical chambers (Plate 4: Figures 11-13, 16, Plate 36: Figures 8-12). These chambers are similar to those observed in the modern Globorotalia scitula (Plate 3: Figure 8), which was a stem form for several globorotaliid lineages in the Neogene. Thus, the initial step in the evolution of M. praeangulata would have involved the suppression of the later stages of ontogeny by speeding up the rate of maturation and the development of a more pustulose, conicotruncate adult test. This change in the timing of maturation would account for the small size of the early forms of $M$. praeangulata.

REPOSITORY.-Holotype (BP Cat. No. 38/15) and paratypes (BP Cat. Nos. 33/3, 33/9, 38/6, 38/14, 38/16, 41/54) deposited in the micropalentological collections at The Natural History
Museum, London. Paratype (USNM P5074) deposited in the Cushman Collection, National Museum of Natural History. Paratype (USNM P5074) examined by WAB and RDN.

\section{Morozovella subbotinae (Morozova, 1939)}

Figure 24; PLATE 54: FIGURES 1-12

Globorotalia subbotinae Morozova, 1939:80, pl. 2: figs. 16, 17 [upper Paleocene, base of section at cemetary at Asankozha, left bank of Emba River, S part of Emba oil field, Kazakh S.S.R. (= Kazakhstan)].-Shutskaya, 1956:98, 99, pl. 4: fig. 4 [Globorotalia subbotinae Zone, Cherkessk Formation, Nal'chik, northern Caucasus] [in part, not pl. 4: fig. 3a,b; ? = Acarinina wilcoxensis].-Luterbacher, 1964:676, text-figs. 85a-86c, 89a90c [Globorotalia aequa Zone, Gubbio section, central Apennines, Italy], text-fig. 88a-c [Globorotalia formosa formosa/Globorotalia subbotinae Zone, Gubbio section, central Apennines, Italy].-Shutskaya, 1970a:119, pl. 13: fig. 6a-c, pl. 14: fig. 6a-c [Globorotalia subbotinae Zone, Churuk-Su, Kacha River section, Bakchissarayan Stage, Bakhchissaray area, southwestem Crimea], pl. 38: fig. 9a-c [Globorotalia subbotinae Zone, Malyi Balkhan Ridge, middle Danian Fm., western Turkmenia].—Luterbacher, 1975a:732, pl. 2: fig. 2a,b [Globorotalia formosa formosa Zone, DSDP Site 305/12/CC; Shatsky Rise, northwestem Pacific Ocean]; 1975b:65, pl. 2: figs. 31-33 [Globorotalia subbotinae Zone, Possagno section, Trevisiano Province, Italy].

Globorotalia rex Martin, 1943:117, pl. 8: fig. 2a-c [Zone P6, Lodo Fm., Lodo Gulch, Fresno Co., California].-Bolli, 1957a:75, pl. 18: figs. 10-12 [Globorotalia rex Zone, upper Lizard Springs Fm., Trinidad].

Globorotalia (Truncorotalia) aequa simulatilis (Schwager).-Hillebrandt, 1962:134, 135, pl. 13: figs. 6a-c, 7, 8a-c [Zone G, Reichenhall-Salzburg Basin, Austro-German border]. [Not Schwager, 1883.]

Globorotalia bollii El-Naggar, 1966:202, pl. 22: fig. 5a-d [Globorotalia wilcoxensis Zone, Thebes Calcareous Shale, Gebel Aweina, Egypt] [in part, not pl. 22: fig. 6a-d (= M. gracilis (Bolli))].

Globorotalia nartanensis Shutskaya, 1970b:118-120, p1. 15: figs. 2a-c, 8a-c [Globorotalia subbotinae Zone, Churuk-Su, Kacha River section, Bakhchissarag region, Bakhchissarayan Stage, southwestern Crimea]. [Not Globorotalia nartanensis Shutskaya, 1956:96-98, pl. 54: fig. 2a-c $(=$ M. lensiformis Subbotina, 1953).]

Globorotalia (Morozovella) aequa rex Martin.-Jenkins, 1971:101, 102, pl. 7: figs. 180-182 [Globigerina wilcoxensis Zone, Waipawan Stage, Middle Waipara River section, New Zealand].

Morozovella subbotinae (Morozova).-Berggren, 1971b:76, pl. 5: figs. 10, 11 [Globorotalia subbotinae Zone, DSDP Hole 20C/5/6: 100-102 cm; Brazil Basin, South Atlantic Ocean].-Snyder and Waters, 1985:442, 443, pl. 9: figs. 10-12 [DSDP Hole 548A/28/3: 70-74 cm; Goban Spur, northeastern Atlantic Ocean].-Toumarkine and Luterbacher, 1985:112, text-fig. 15:9a-c [reillustration of holotype of Globorotalia rex Martin, 1943], text-fig. 15:10a-c [reillustration of holotype of Globorotalia subbotinae Morozova, 1939], text-fig. 15:11a-c [reillustration of specimen from northwestern Crimea identified by Subbotina, 1953, pl. 17: fig. 13a-c as Globorotalia crassata Cushman].-Huber, 1991b:440, pl. 4: fig. 9 [Zone AP6A, ODP Hole 738C/10R: 277.78 mbsf; Kerguelen Plateau, southern Indian Ocean].Lu and Keller, 1993:123, pl. 4: fig. 19 [their Morozovella subbotinae Subzone of Zone AP5A/Planorotalites australiformis Zone of Stott and Kennett, 1990; ODP Hole 738C/11/1R: 15-17 cm; Kerguelen Plateau, southern Indian Ocean]; 1995:102, pl. 1: figs. 11-13 [their Subzone P6bx, DSDP Site 577/9/6: 53-55 cm; Shatsky Rise, northwestern Pacific Ocean].

Globorotalia (Morozovella) subbotinae subbotinae (Morozova).-Blow, 1979:1018-1021, pl. 102: figs. 1-5, pl. 219: figs. 1-4 [Zone P6 of Blow, 1979; DSDP Hole 20C/6/3: 76-78 cm; Brazil Basin, South Atlantic Ocean], pl. 111: figs. 6-8 [Zone P7 of Blow, 1979, Sample KRE 83F, Moogli Mudstones, Kagua, Papua, New Guinea], pl. 115: figs. 3-5 [Zone P7 of Blow, 1979, Sample RS 80, Kilwa area, Tanzania; also pl. 115: fig. 6 as 
Globorotalia (Morozovella) sp. specimen ex interc G. (M.) aequa lacerti Cushman and Renz and $G$. (M.) subbotinae subbotinae Morozova], pl. 119: figs. 4-10, pl. 219: figs. 5, 6, pl. 220: figs. 1-6, pl. 222: figs. 1-7 [Zone P7 of Blow, 1979, DSDP Hole 47.2/8/3: 82-85 cm], pl. 127: figs. 6, 7 [Zone P8a of Blow, 1979, DSDP Hole 47.2/8/2: 71-73 cm], pl. 123: fig. 8 [Zone P8b of Blow, 1979, DSDP Hole 47.2/8/1: 77-79 cm; Shatsky Rise, northwestern Pacific Ocean], pl. 103: figs. 2, 7, 9, pl. 223: figs. 1, 2 [Zone P6 of Blow, 1979, DSDP Hole 20C/6/3: 76-78 cm; Brazil Basin, South Atlantic Ocean].

ORIGINAL DESCRIPTION.--_"Test lenticular, composed of $2-2^{1 / 2}$ spiral whorls. Peripheral margin acute, lobulate, with a keel and fine, irregular denticulations. Dorsal side slightly convex, ventral side conical, the side inclined at an angle of $25-30^{\circ}$ to the dorsal side. Umbilicus narrow but deep. In the last whorl, there are 4-5 chambers rapidly increasing in size. Sutures deep near the umbilicus, becoming shallower toward the periphery. Wall thin, spinose. Aperture in the form of a narrow slit, extending from the umbilicus to the peripheral margin.

"Dimensions.—Diameter, $0.36 \mathrm{~mm}$; thickness, $0.20 \mathrm{~mm}$." (Morozova, 1939:80; translated from Russian.)

Diagnostic Characters.-Relatively large (to $0.5 \mathrm{~mm}$ maximum diameter), planoconvex to weakly biconvex test with moderately lobulate, strongly/thickly keeled periphery; $4-4 \frac{1}{2}$ chambers in last whorl, generally covered with muricae on umbilical side, spiral side relatively smooth; umbilical and spiral intercameral sutures weakly curved, tangential on spiral side yielding trapezoidal-shaped chambers; circumumbilical chamber tips weakly ornamented by muricae and surrounding deep, narrowly open umbilicus; aperture a low, umbilicalextraumbilical slit extending almost to periphery and bordered by weak lip.

DISCUSSION.-This robust species is a characteristic element of latest Paleocene and early Eocene planktonic assemblages. Morozovella subbotinae has had a convoluted taxonomic history. It is generally agreed by specialists that Globorotalia subbotinae Morozova, 1939, is a senior synonym of Globorotalia rex Martin, 1943 (see Berggren, 1977; Blow, 1979, for discussions). In the (former) Soviet Union this taxon was identified with (the middle Eocene) Globorotalia crassata, Cushman, 1925 (nomen non conservandum, fide Blow, $1979=$ Morozovella spinulosa (Cushman, 1927b)) (see Subbotina, 1947, 1953).

Blow (1979) drew attention to the close similarities between M. subbotinae (Morozova), M. marginodentata (Subbotina), and $M$. gracilis (Bolli). In fact, he separated $M$. gracilis from $M$. subbotinae at the subspecies level based on the increase in chamber number (from $4^{1 / 2}$ in subbotinae to $5^{1 / 2}-6$ in gracilis), which is associated with the development of a somewhat more evolute coiling mode and more vorticiform spiral intercameral sutures in $M$. gracilis, and on the slightly different (shorter) stratigraphic range of $M$. gracilis. The development of a strongly dentate (fimbriate) muricocarina (marginodentata) on some morphotypes was regarded as an ecophenotypic variation within the subbotinae plexus of morphotypes. He considered this indicative of high productivity, and $M$. marginodentata was, accordingly, identified only as a variant of $M$. subbotinae (cf. Berggren, 1971b, who had suggested earlier that $M$. marginodentata might be synonymous, an ecophenotypic variant of $M$. gracilis).

STABLE ISOTOPES.-Morozovella subbotinae has $\delta^{13} \mathrm{C}$ and $\delta^{18} \mathrm{O}$ similar to $M$. velascoensis and Acarinina nitida and has more positive $\delta^{13} \mathrm{C}$ and more negative $\delta^{18} \mathrm{O}$ than Subbotina triangularis (D'Hondt et al., 1994). Morozovella subbotinae displays a pronounced increase in $\delta^{13} \mathrm{C}$ with increased test size but little corresponding change in $\delta^{18} \mathrm{O}$ (D'Hondt et al., 1994).

STRATIGRAPHIC RANGE.-Zone P5 to Zone P6b.

GLOBAL DISTRIBUTION.-Morozovella subbotinae is a geographically widespread morphospecies. It is recorded in (sub)tropical assemblages in Atlantic, Indo-Pacific, and typical Tethyan biogeographies and as far south as $60^{\circ}$ in association with the early Eocene (Zone P6) extra-tropical excursion of carinate morozovellids on the Kerguelen Plateau (Huber, 1991b, ODP Site 738; Berggren, 1992, ODP Site 747) (Figure 24).

ORIGIN OF SPECIES.-Morozovella subbotinae evolved from $M$. aequa through the enhanced development of peripheral muricocarina, a heightened anguloconical umbilical side, and an increase in test size.

REPOSITORY.-Holotype (Slide No. 700) deposited in the micropaleontological collections at VNIGRI, St. Petersburg, Russia.

\section{Morozovella velascoensis (Cushman, 1925)}

Figure 25; Plate 17: figures 10-12; Plate 55: figures 1-15

Pulvinulina velascoensis Cushman, 1925:19, pl. 3: fig. 5a-c [Velasco Fm., San Luis Potosi, Tampico Embayment, eastem Mexico].

Globorotalia velascoensis (Cushman).-White, 1928:281, pl. 38: fig. 2a-c [Velasco Shale Fm., eastem Mexico].-Cushman and Renz, 1946:47, pl. 8: figs. 13, 14 [lower Lizard Springs Fm., Trinidad].-Subbotina, 1947:123, pl. 7: figs. 9-11 [Globortalia velascoensis Zone, Sunzha River section, northern Caucasus], pl. 9: figs. 21-23 [Globorotalia velascoensis Zone, Kuban River section, northern Caucasus].-Le Roy, 1953:33, pl. 3: figs. 1-3 [Maqfi section, Egypt].-Haque, 1956:181, pl. 24: fig. 2a-c [upper Paleocene, Nammal Gorge, Salt Range, Pakistan].-Bolli, 1957a:76, pl. 20: figs. 1-4 [Globorotalia pseudomenardii Zone, lower Lizard Springs Fm., Trinidad].-Loeblich and Tappan, 1957a:196, pl. 64: figs. la-2c [Zone P4, Velasco Fm., Tamaulipas, Mexico].-Bolli and Cita, 1960:391, pl. 35: fig. 7a-c [Globorotalia pseudomenardii Zone, Paderno d'Adda section, northern Italy].-Said and Kerdany, 1961:330, pl. 1: fig. 10a-c [lower Esna Shale Fm., Western Desert, Egypt].-Shutskaya, 1970b:118-120, pl. 23: fig. 3a-c, pl. 24: fig. 5a-c [Acarinina tadjikistanensis djanensis Subzone, Kachan Stage, Tarkhankut Peninsula, Crimea, Olenev Platform, Boring 210, $517-527 \mathrm{~m}$ ], pl. 25: fig. 5a-c [same zone as above, but from boring 229, 637-641 m], pl. 27: fig. 12a-c [Acarinina acarinata Zone, Kachan Stage, Tarkhankut Peninsula, Crimea], pl. 29: fig. 8a-c [Globorotalia aequa Zone, Bakhchissarayan Stage, Tarkhankut Peninsula, Crimea].-Luterbacher, 1975a:726, pl. 1: fig. 8a,b [Globorotalia pseudomenardii Zone, DSDP Site 305/14/1: 135-138 cm; Shatsky Rise, northwestern Pacific Ocean].-Pujol, 1983:644, pl. 3: fig. 9 [Zone P5, DSDP Hole 516F/84/5: 13-15 cm; Rio Grande Rise, southwestern Atlantic Ocean]. 


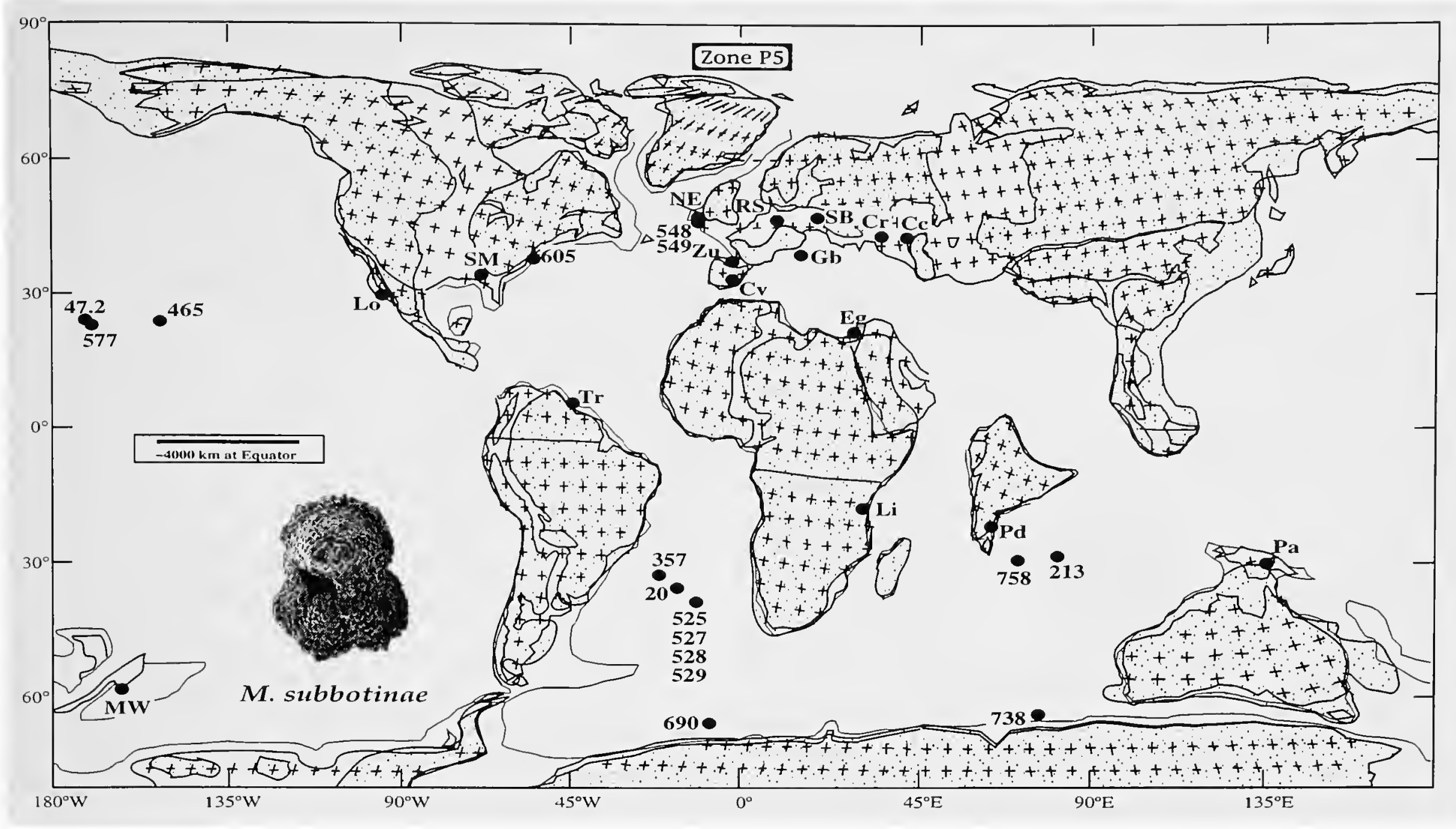

FIGURE 24.-Paleobiogeographic map showing distribution of Morozovella subbotinae (Morozova) in Zones P5 and P6.

Pseudogloborotalia velascoensis (Cushman).—Bermúdez, 1961:1349, pl. 16: fig. 1 la,b [Velasco Station, Tampico-San Luis Potosi Railway, Mexico].

Globorotalia (Truncorotalia) velascoensis velascoensis (Cushman).Hillebrandt, 1962:169, pl. 13: figs. 16-21 [Zone D = Globorotalia pusilla pusilla Zone (upper part), Reichenhall-Salzburg Basin, Austro-German border].

Truncorotaloides (Morozovella) velascoensis (Cushman).-McGowran, 1968: 190, pl. 2: fig. 1 [Velasco Fm., Ebano, Mexico].

Globorotalia (Morozovella) velascoensis velascoensis (Cushman).--Jenkins, 1971:107, pl. 9: figs. 214-216 [Globigerina triloculinoides Zone, Waipawan Stage, Middle Waipara River section, New Zealand].-Blow, 1979:1029, pl. 92: fig. 7 [Zone P4, DSDP Hole 47.2/9/3: 70-72 cm; Shatsky Rise, northwestern Pacific Ocean], pl. 94: figs. 6-9, pl. 95: figs. 1, 2, pl. 216: figs. 1-8, pl. 217: figs. 1-6 [Zone P5, Samples FCRM. 1670, Lindi area, Tanzania], pl. 99: figs. 3, 4 [Zone P5, DSDP Hole 47.2/9/1: 64-66 cm; Shatsky Rise, northwestern Pacific Ocean].-Belford, 1984:10, pl. 1: fig. 2, pl. 19: figs. 1-12 [upper Paleocene, Wabag Sheet area, Papua, New Guinea]. Morozovella velascoensis (Cushman).-Toumarkine and Luterbacher, 1985: 109, text-figs. 11, 12 [fig. 11: reillustration of Bolli, 1957a, pl. 20: figs. 1-3; fig. 12: reillustration of holotype from Cushman, 1925, pl. 3, fig. 5a-c].

ORIGINAL DESCRIPTION.- "Test plano-convex, the dorsal side flat or even slightly concave, ventral side very much produced, periphery carinate, subacute, the series of which surround a depressed umbilical area; about seven chambers in the last-formed coil; sutures distinct, on the dorsal side curved, marked by a series of small, bead-like processes, the periphery of each with a slightly raised carina which marks also the line of coiling in the central portion, ventral side with the sutures nearly radiate, straight, much depressed, surface roughened with very minute, low spinose processes which rather uniformly cover the entire test; aperture elongate, narrow, on the ventral side [of] the last-formed chamber extending from near the periphery almost to the umbilical area." (Cushman, 1925:19.)

DIAGNOSTIC CHARACTERS.-Relatively large (maximum diameter $>0.5 \mathrm{~mm}$ ), robust, plano-convex, nearly circular, moderately lobulate test composed of about 15-16 chambers arranged in $2^{1 / 2}-3$ whorls; last whorl with 6-7 (rarely 8) anguloconical chambers whose tips surround moderately open umbilicus; umbilicus surmounted by an "adumbilical" or circum-umbilical rim ("collar") of fused muricae; umbilical sutures radial, depressed, moderately to strongly curved, raised and beaded on spiral side; wall finely perforate, distinctly muricocarinate periphery, but spiral chamber surfaces often nearly free of muricae; aperture a low, interiomarginal, umbilical-extraumbilical arch.

DisCUSSION.-This is the type species of the genus Morozovella McGowran (in Luterbacher, 1964) and one of the most characteristic and easily recognized Paleocene morozovellids. It has been assigned to various genera and subgenera over the past half century but would appear to have found a suitable home in the genus Morozovella as defined by McGowran in Luterbacher (1964; see also McGowran, 1968). 


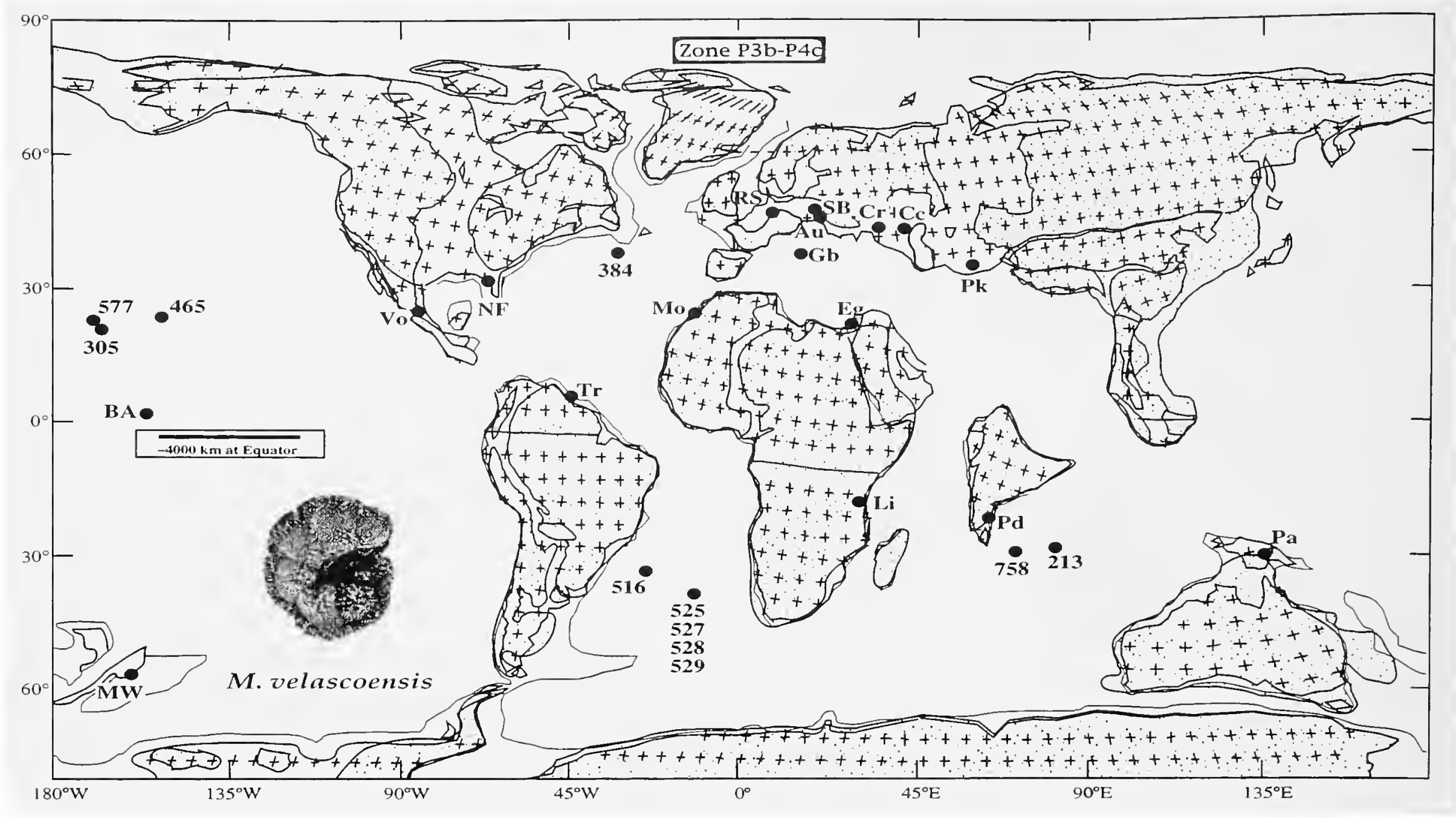

FIGURE 25.-Paleobiogeographic map showing distribution of Morozovella velascoensis (Cushman) in Zones P4 and P5.

This species has been confused with the heterochronously isomorphic form $M$. caucasica (Glaessner) (see Subbotina, 1953, pl. 19: figs. 1a-2c, who identified strongly muricocarinate and circumumbilically muricate forms from the lower Eocene zone of conical globorotaliids of the northern Caucasus as G. velascoensis; see also El-Naggar, 1966, who was equally confused by the distinctions between these two taxa, and Blow, 1979 , for clarification of the problems associated with separation and recognition of these two forms).

STABLE ISOTOPES.-Morozovella velascoensis has $\delta^{13} \mathrm{C}$ similar to coexisting species of Morozovella and Acarinina and more positive $\delta^{13} \mathrm{C}$ and more negative $\delta^{18} \mathrm{O}$ than Subbotina (Boersma and Premoli Silva, 1983; Shackleton et al., 1985; D'Hondt et al., 1994). Morozovella velascoensis displays a pronounced increase in $\delta^{13} \mathrm{C}$ with increased test size but little corresponding change in $\delta^{18} \mathrm{O}$ (D'Hondt et al., 1994). This species typically has more negative $\delta^{18} \mathrm{O}$ than all other analyzed species of Morozovella (Berggren and Norris, 1997).

STRATIGRA PHIC RANGE.-Zone P3b to Zone P5 (top).

GLOBAL DISTRIBUTION.-Morozovella velascoensis has a wide geographic distribution but is a predominantly (sub)tropical to temperate form; it has not been recorded from high northern or southern (subantarctic) latitudes $\left(>45^{\circ} \mathrm{N}\right.$ or $\mathrm{S}$ ). The disappearance of this taxon is a distinct biostratigraphic event that is used to define the boundary between Zones P5 and
P6, which occurs in mid-Chron C24r, and is closely correlative with the Paleocene/Eocene boundary as denoted in the Belgian and/or London-Hampshire Basin(s) of northwestern Europe (Berggren and Aubry, 1996) (Figure 25).

ORIGIN OF SPECIES.-This species evolved from Morozovella conicotruncata (Subbotina) within Subzone P3b by the acquisition of coarsely muricate adumbilical ridges, the complete loss of muricae on the spiral chamber surfaces and between the murcrocarina and umbilical collar, as well as the formation of a thick, coarsely muricate mucrocarina.

REPOSITORY.-Holotype (USNM CC4347) deposited in the Cushman Collection, National Museum of Natural History. Examined by WAB and RDN.

\section{Genus Igorina Davidzon, 1976}

TYPE SPECIES.-Igorina tadjikistanensis (Bykova, 1953).

ORIGINAL DESCRIPTION.- - Test free, bilaterally convex. Equatorial outline round, slightly undulate. Axial outline takes the form of a bilateral cone with variable vertex angles. Chambers on spiral side alate, on umbilical side triangular. Umbilicus small or absent. Aperture a slit at the base of the septal surface of the last chamber. Surface of chambers smooth or almost uniformly covered with small spines." (Davidzon, 1976:197; translated from Russian.) 
Diagnostic Characters.-Test small, biconvex, may have a peripheral keel; chambers, ovoid or low conical in shape, 5-6 in final whorl; wall, coarsely cancellate, praemuricate, often with a thick, encrusted pustulose layer covering the praemuricate wall; aperture, interiomarginal, umbilicalextraumbilical, a low arch bordered by a thin lip.

DISCUSSION.-As Pearson (1993:212) observed, the group of "biconvex, muricate morozovellids" (see Boersma and Premoli Silva, 1983; Premoli Silva and Boersma, 1989)including the pusilla-laevigata, convexa, and broedermanni plexus of forms - is probably distinct from Acarinina and mainstream morozovellids. He considered these forms inappropriately placed in Igorina Davidzon (Loeblich and Tappan, 1988), inasmuch as the type species of the latter, Globorotalia tadjikistanensis Bykova, was considered an enigmatic, biconvex morozovellid from the upper part of Zone P3a, and probably is related to conicotruncata. Recent examination and SEM reillustration of the holotypes of Globorotalia tadjikistanensis Bykova (pl. 11: figs. 4-6) and Globorotalia convexa Subbotina (pl. 11: figs. 1-3), however, have shown these forms to be synonymous, with tadjikistanensis having priority.

Igorinids are characterized by their small, coarsely cancellate tests, evolute coiling, and distinctive blunt, praemuricate surface texture. We believe that the Igorinids evolved from Praemurica about the time of appearance of the first morozovellids ( $M$. praeangulata, $M$. angulata). Like many globigerininid groups, the igorinids show a trend toward chamber compression and development of a peripheral keel, but this trend is reversed in the Eocene with the evolution of the I. broedermanni group.

\section{Igorina albeari (Cushman and Bermúdez, 1949)}

Figure 26; Plate 16: Figures 1-6; Plate 56: Figures 1-16

Globorotalia albeari Cushman and Bermúdez, 1949:33, pl. 6: figs. 13-15 [holotype from stratigraphic level within subsequently described (1957) Globorotalia pseudomenardii Zone, Madruga Fm., Cuba].-Cifelli and Belford, 1977:100, pl. 1: figs. 4-6 [holotype reillustrated].

Globorotalia pusilla laevigata Bolli, 1957a:78, pl. 20: figs. 5-7 [Globorotalia pseudomenardii Zone, Lizard Springs Fm., Trinidad].-Bolli and Cita, 1960:27, pl. 32: fig. 6a-c [Globorotalia pseudomenardii Zone, Paderno d'Adda, northern Italy].-Hillebrandt, 1962:128, 129, pl. 11: fig. 17a-c [Globorotalia pseudomenardii Zone, Reichenhall-Salzburg Basin, AustroGerman border].-McGowran, 1965:63, pl. 6: fig. 4 [upper Paleocene, stratigraphically equivalent to Globorotalia pseudomenardii Zone, Dilwyn Clay, Rivernook Mbr., Pebble Point, Australia].

Globorotalia pseudoscitula Glaessner.-Loeblich and Tappan, 1957a:193, pl. 46: fig. 4a-c [Zone P3, Coal Bluff Fm., Midway Group, Gulf Coast, Alabama], pl. 53: fig. 5a-c [Zone P4, Vincentown Fm., New Jersey], pl. 59: fig. 2a-c [Zone P4, Aquia Fm., Aquia Creek, Maryland/Virginia], pl. 63: fig. 6a-c [Zone P4, Velasco Fm., Tamaulipas, Mexico] [in part, not pl. 48: fig. 3a-c (= Igorina pusilla (Bolli))]. [Not Glaessner, 1937.]

Globorotalia (Globorotalia) albeari Cushman and Bermúdez.-Blow, 1979:883, pl. 92: figs. 4, 8, 9, pl. 93: figs. 1-4 [Zone P4, DSDP Hole 47.2/9/3: 70-72 cm; Shatsky Rise, northwestern Pacific Ocean].

ORIGINAL DESCRIPTION.- - "Test very small for the genus, strongly biconvex, dorsal side showing all the coils and ventral side only the last-formed whorl, periphery somewhat rounded; chambers not very distinct, 9 to 10 in the last-formed whorl, only slightly inflated ventrally, increasing very gradually in size as added; sutures fairly distinct but only slightly depressed except in the last whorl on the ventral side, rather strongly recurved on the dorsal side; wall slightly spinose, coarsely perforate; aperture an elongate opening on the ventral side of the last-formed chamber extending from nearly the inner end to the periphery and with a distinct thin lip. Diameter 0.30-0.32 mm; thickness $0.20 \mathrm{~mm}$." (Cushman and Bermúdez, 1949:33.)

DIAGNOSTIC CHARACTERS.-Moderately to strongly biconvex, essentially circular, cancellate, pustulose test with 6-8 chambers in final whorl; intercameral sutures on umbilical side radial to weakly recurved yielding triangular-shaped chambers; strongly recurved and exhibiting distinct limbation on the spiral side, particularly between the last 3-4 chambers, yielding trapezoidal-shaped chambers; peripheral margin distinctly carinate, particularly on last chambers of final whorl; aperture a low interiomarginal, umbilical-extraumbilical arch extending towards, but not to, the peripheral margin.

DISCUSSION.-Comparison of the type specimens (Plate 16: Figures 1-6) of Globorotalia albeari Cushman and Renz, 1946, and G. pusilla laevigata Bolli, 1957a, by Blow (1979) and Berggren (1960, 1965, 1968, 1969a, 1977) have confirmed the suspicions previously raised by Postuma (1971) of the synonymy of these two forms. Most notable is the presence of a distinct peripheral carina in this taxon that was not shown in the holotype illustration by Cushman and Renz (1946) nor, surprisingly, in the refiguration of the holotype by Cifelli and Belford (1977). We have observed a wide range of variation in the degree of convexity of the spiral side in this taxon and have tried to convey this variation in Plate 56: Figures 1-16. The umbilical side is generally less convex than the spiral side, and the final chamber is often flattened and smoother (less pustulose) than the remainder of the test.

STABLE ISOTOPES.-Igorina albeari has $\delta^{13} \mathrm{C}$ more negative than Acarinina and Morozovella but more positive than Subbotina and Globanomalina. The $\delta^{18} \mathrm{O}$ of $I$. albeari is more negative than Subbotina and Globanomalina but is more positive than Morozovella (Berggren and Norris, 1997).

StRatigRaPhIC RANGE.-Zone P3a/P3b boundary to Zone P4.

GLOBAL DISTRIBUTION.-Igorina albeari is predominantly tropical to subtropical, low latitude, in distribution. It has not been recorded from high southern latitudes at appropriate stratigraphic levels (Stott and Kennett, 1990), although Huber (1991b) recorded/illustrated a form (pl. 3: figs. 18, 19) similar to albeari (as pusilla) from a biostratigraphic level (Zone AP5 near the Paleocene/Eocene boundary) in ODP Hole 738C (Kerguelen Plateau, southern Indian Ocean). From our experience with Russian literature and the comparative material in the collection at WHOI, it would appear that this taxon has not been recorded or is not present in the Caucasus-Crimean Paleocene (Figure 26). 


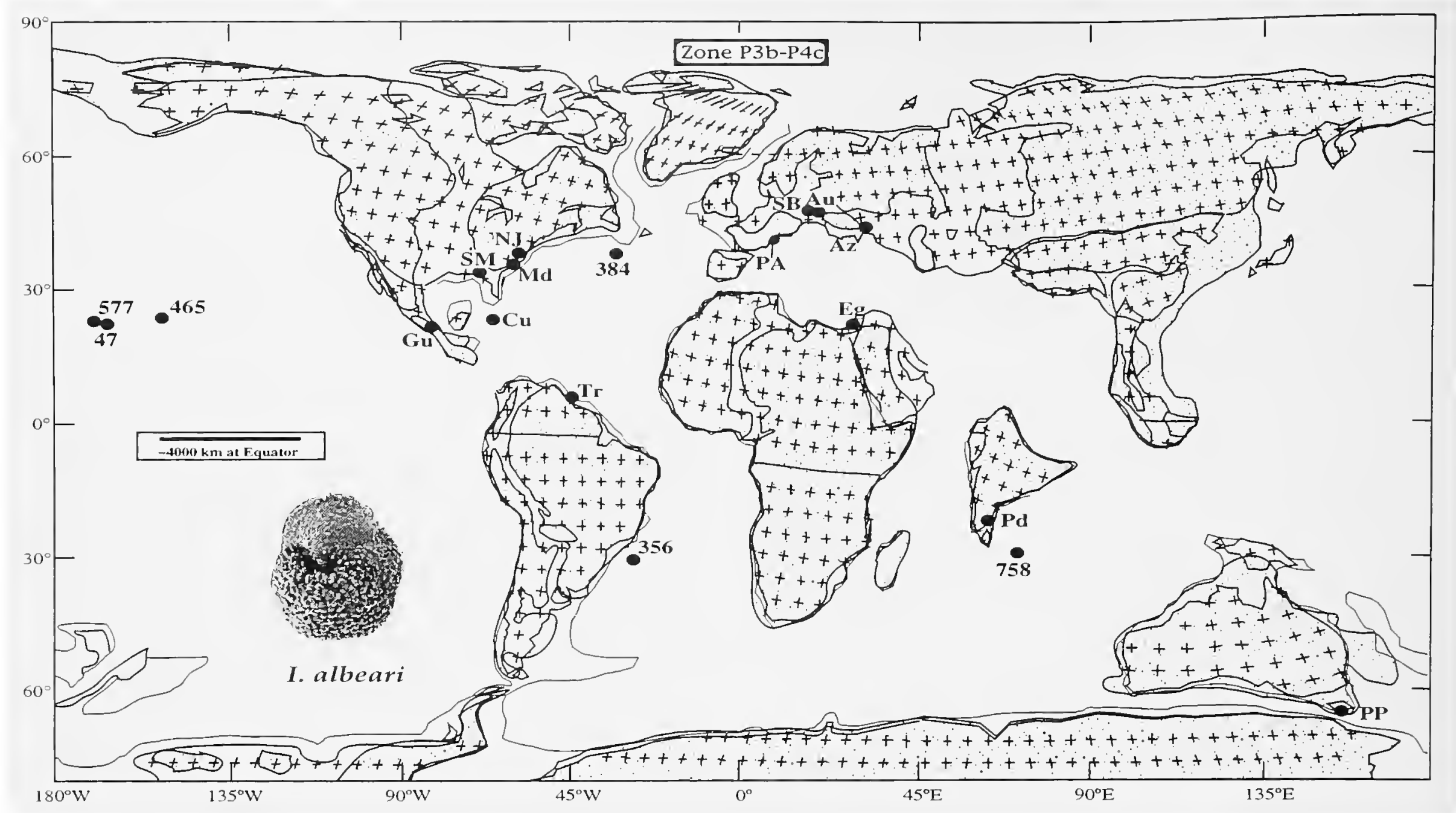

FIGURE 26.-Paleobiogeographic map showing distribution of Igorina albeari (Cushman and Bermúdez) in Zones $\mathrm{P} 3$ and $\mathrm{P} 4$.

ORIGIN OF SPECIES.-Igorina albeari is derived from $I$. pusilla by the development of compressed chambers and a keel on one or more chambers in the final whorl.

REPOSITORY.-Holotype (USNM CC47413) deposited in the Cushman Collection, National Museum of Natural History. Examined by WAB, RDN, and BTH.

\section{Igorina pusilla (Bolli, 1957)}

FigURE 27; Plate 16: Figures 7-9; Plate 57: Figures 1-16

Globorotalia pusilla pusilla Bolli, 1957a:78, pl. 20: figs. 8-10 [Globorotalia pusilla pusilla Zone, Guayaguayare Well 159, Trinidad Leasholds, Ltd., Lizard Springs Fm., Trinidad].-Bolli and Cita, 1960:388, 389, pl. 34: fig. 4a-c [Globorotalia pusilla pusilla Zone, Paderno d'Adda, northern Italy].

Planorotalites tauricus Morozova, 1961:16, pl. 2: fig. 3 [Acarinina indolensis Subzone $\left(\mathrm{Dn}_{2} 11 \mathrm{I}^{1}\right)$, Michurino Substage, Urukh River, northern Caucasus]. Globorotalia (Globorotalia ?) pusilla pusilla Bolli.--Hillebrandt, 1962:128, pl. 11: fig. 18a,b [Globorotalia pusilla pusilla Zone, Reichenhall-Salzburg Basin, Austro-German border].

Globorotalia pusilla pusilla (?) Bolli--Shutskaya, 1970b:2 18, pl. 22: fig. 3a-c [lower subzone of Acarinina tadjikistanensis djanensis Zone, lower Danatin Formation, Malyi Balkhan Ridge, western Turkmenia].

Globorotalia pusilla Bolli.-Pujol, 1983:652, pl. 2: figs. 12, 13 [Globorotalia pusilla Zone, DSDP Hole 516F/86/4: 6-9 cm; Rio Grande Rise, South Atlantic Ocean].

Morozovella pusilla pusilla (Bolli).-Snyder and Waters, 1985:446, 449, 460, pl. 8: figs. 15-17 [Morovozella pusilla pusilla Zone, DSDP Site 549/20/5: 18-20 cm; northeastern Atlantic Ocean].
Planorotalites pusilla pusilla (Bolli).--Toumarkine and Luterbacher, 1985:108, fig. 12:13a-c [holoype reillustrated], fig. 12:14a-c [Zone P3, DSDP Hole 144A/3/4: 120-122 cm; South Atlantic Ocean].

ORIGINAL DESCRIPTION.- "Shape of test low trochospiral, biconvex, compressed; equatorial periphery nearly circular, slightly lobate; axial periphery acute to subacute. Wall calcareous, perforate, surface smooth. Chambers compressed; $12-16$, arranged in $2^{1 / 2}-3$ whorls, the 5-6 chambers of the last whorl increasing moderately in size. Sutures on spiral side strongly curved, slightly depressed; on umbilical side radial, depressed. Umbilicus narrow, open. Aperture a low arch, with narrow lip; interiomarginal, extraumbilical-umbilical. Coiling random. Largest diameter of holotype $0.24 \mathrm{~mm}$." (Bolli, 1957a:78.)

DIAGNOSTIC CHARACTERS.-Relatively small (generally $<0.25 \mathrm{~mm}$ in diameter), essentially circular, biconvex, cancellate, pustulose test with 5-6 chambers in last whorl; intercameral sutures on umbilical side radial, depressed, on spiral side moderately to strongly curved, depressed/weakly incised; axial periphery subacute and non-carinate; umbilicus narrow, shallow, aperture an interiomarginal, umbilicalextraumbilical arch extending towards, but not reaching, the periphery.

DISCUSSION.-Igorina pusilla is the earliest representative of the biconvex, praemuricate igorinids. The small, biconvex 


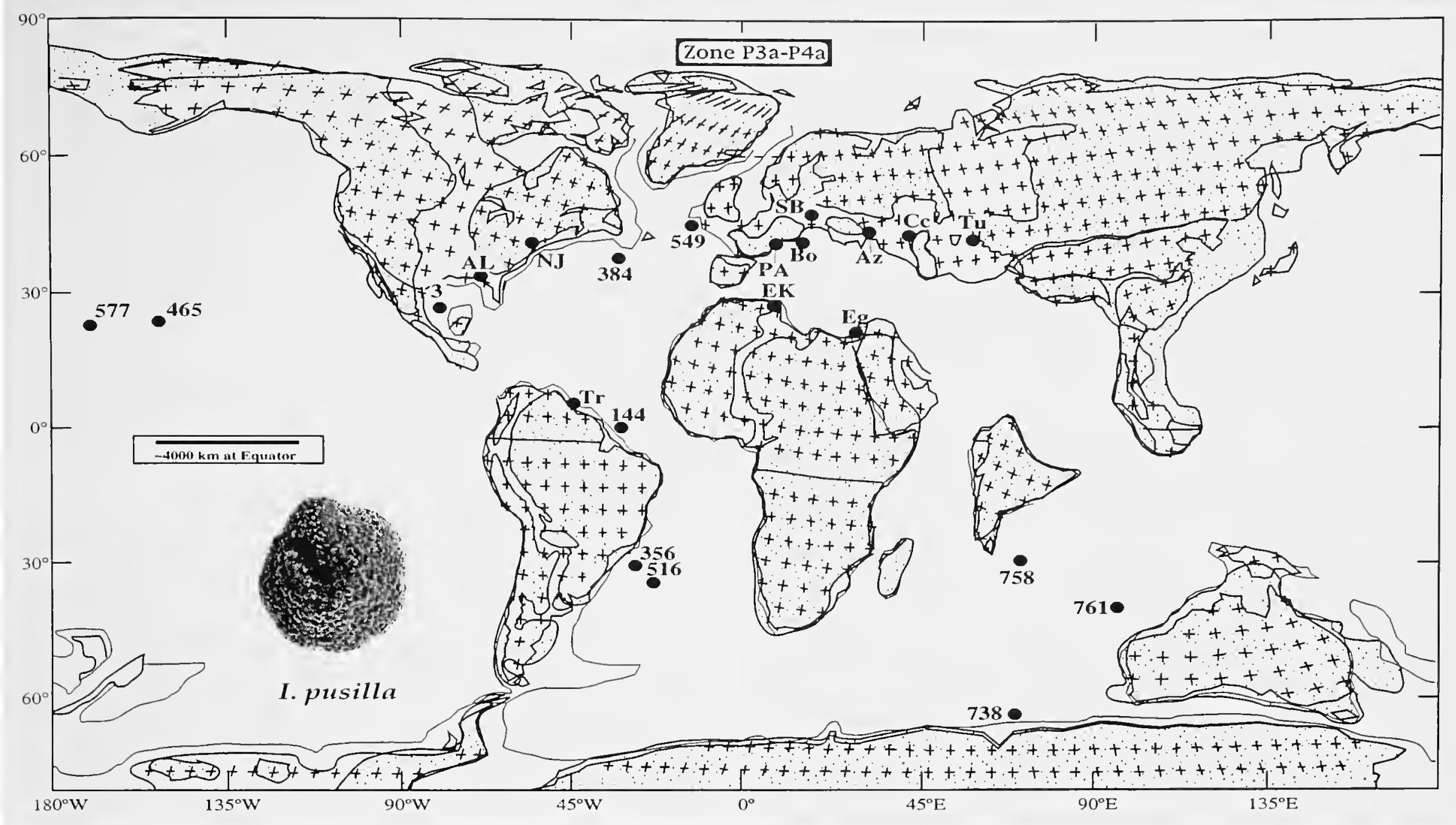

FIGURE 27.-Paleobiogeographic map showing distribution of Igorina pusilla (Bolli) in Zones P3 and P4.

test, deep funnel-shaped entrances to the pores, and distinctly praemuricate surface serves to differentiate this form (and its descendants) from the mainline morozovellids and suggests that $I$. pusilla represents the founding species of a separate lineage among early Paleogene planktonic foraminifera. There appears to be little confusion in the identification of this species. We note, however, that Planorotalites tauricus Morozova (1961) is a middle Paleocene igorinid species from the northern Caucacus that we regard as synonymous with $I$. pusilla.

STABLE ISOTOPES.-No data available.

StRatigra PHIC RANGE.-Zone P3a to Zone P3b (lower part).

GLOBAL DisTRIBUTION.-Igorina pusilla has been recorded from predominantly low latitude (sub)tropical locations (Figure 27).

ORIGIN OF SPECIES.-We believe that the igorinids are derived from the nonkeeled, praemuricate forms of the inconstans-uncinata plexus as previously suggested by Pearson (1993). Although the exact pattern of ancestry has not been worked out, Igorina pusilla is probably derived from forms similar to $P$. inconstans or $P$. uncinata by development of more involute coiling. This transformation may have occurred through the suppression of the later stages of ontogeny by speeding up the rate of maturation. This change in the timing of maturation would account for the small size of mature igorinids.

REPOSITORY.-Holotype (USNM P5064) deposited in the Cushman Collection, National Museum of Natural History. Examined by $\mathrm{WAB}, \mathrm{RDN}$, and $\mathrm{BTH}$.

\section{Igorina tadjikistanensis (Bykova, 1953)}

\section{Plate 11: Figures 1-9; Plate 58: Figures 1-12}

Globorotalia tadjikistanensis Bykova, 1953:86, pl. 3: fig. 5a-c [Globorotalia tadjikistanensis Zone, Suzakian Stage, southern part of Tadzhik Basin, Ak-Tau, Kazakhstan; given as Eocene].-Leonov and Alimarina, 1960:53, pl. 7: figs. 1, 2, 7 [upper part Globorotalia tadjikistanensis Subzone, eastern facies, Khieu River section, northern Caucasus], figs. 3, 4, 7 [lower part Globorotalia tadjikistanensis Subzone, eastern facies, Khieu River section, northern Caucasus].--Luterbacher, 1964:52, text-fig. 52a-c [Globorotalia pusilla pusilla Zone, Gubbio section, central Apennines, Italy].

Globorotalia convexa Subbotina, 1953:209, pl. 17: fig. 2a-c [holotype], fig. 3a-c [zone of conical globorotaliids, Foraminiferal Layer, Series F1, Khieu River, Nal'chik, northern Caucasus].--Loeblich and Tappan, 1957a:188, pl. 48: fig. 4a-c [Zone P4, Vincentown Fm., New Jersey], pl. 50: fig. 7a-c [Zone P4, Homerstown Fm., New Jersey], pl. 53: figs. 6a-8c [Zone P4, Aquia Fm., Maryland], pl. 57: figs. 5a-6c [Zone P4, Salt Mountain Limestone, Alabama], pl. 63: fig. 4a-c [Zone P4, Velasco Fm., Tamaulipas, Mexico].-Pujol, 1983:644, pl. 3: figs. 1, 2 [Zone P3, DSDP Hole 516F/88/2: 102-103 cm; Rio Grande Rise, South Atlantic Ocean].

Truncorotaloides (Morozovella) convexus (Subbotina)-McGowran, 1968:192, pl. 2: figs. 11-14 [Truncorotaloides (Acarinina) mckannai zonule, Boongerooda Greensand, Australia]. 
Globorotalia (Acarinina) convexa Subbotina.-Jenkins, 1971:81, pl. 3: figs 79-83 [Globigerina (Subbotina) triloculinoides Zone, type Teurian, Te Uri Stream section, New Zealand].-Blow, 1979:920, pl. 85: figs. 2-7 [Zone P3, DSDP Hole 47.2/10/2: $80-82 \mathrm{~cm}$ ], pl. 88: figs. 3, 4 [upper part of Zone P3, DSDP Hole 47.2/10/1: 72-74 cm], pl. 100: figs. 3, 5-9 [Zone P5, DSDP Hole 47.2/9/1: 64-66 cm; Shatsky Rise, northwestern Pacific Ocean].

Globorotalia (Acarinina) convexa cf. convexa Subbotina.-Blow, 1979:92I, pl. I00: figs. 1, 2, 4 [Zone P5, DSDP Hole 47.2/9/1: $64-66 \mathrm{~cm}$; Shatsky Rise, northwestern Pacific Ocean].

Globorotalia (Morozovella) tadjikistanensis Bykova-Belford, 1984:10, pl.

I8: figs. I8-23 [upper Paleocene, Wabag Sheet, Papua, New Guinea].

Morozovella convexa (Subbotina).-Stott and Kennett, 1990:560, pl. 3: figs. 5,

6 [Zone AP3, near AP3/4 boundary, ODP Hole 690B/19H/4: 36-40 cm; Maud Rise, Weddell Sea, Southern Ocean].

ORIGINAL DESCRIPTION.- - Test rounded in outline, biconvex, with a weakly sloping, convex evolute side, and an arched, cone-shaped, strongly convex ventral side. Peripheral margin weakly lobate. The spiral consists of about three whorls with six to eight chambers per whorl. On the ventral side, the umbilical ends of the chambers converge, usually forming a small, shallow umbilicus. The chambers on the dorsal side in the first one and one-half whorls are barely discernible; in the last one to one-half whorls they are rather low, flat, and curved. On the ventral side the chambers are triangularly curved, rather distinctly convex, and increase slightly in size as they are added. The septal sutures on the dorsal side are tapered. In the final one and one-half whorls they are slightly depressed. On the ventral side the sutures are depressed and curved. Apertural face not distinct. The aperture is not distinguishable. The wall is rough, covered with short, thin spines. Dimensions of holotype: large diameter $0.32 \mathrm{~mm}$; small diameter $0.28 \mathrm{~mm}$; thickness $0.20 \mathrm{~mm}$." (Bykova, 1953:86; translated from Russian.)

Diagnostic Characters. - Relatively small $(<0.25 \mathrm{~mm}$ in diameter), nonspinose, biconvex, ovate to subcircular, moderately lobulate, densely and finely praemuricate test with 5-7 (rarely up to 9-10) chambers in last whorl; axial periphery subrounded to subacute, noncarinate; umbilical intercameral sutures curved, depressed, spiral sutures depressed, strongly recurved, tangential to inner whorl, often obscured by dense murical network; umbilicus small, shallow as a result of tight coiling mode, surrounded by an irregularly wavy umbilical shoulder formed by undulating periumbilical chamber apices; aperture a low, narrow interiomarginal, umbilicalextraumbilical slit bordered by a distinct lip and extending towards, but not reaching, the peripheral margin.

DISCUSSION.-This taxon is a distinct component of late Paleocene and earliest Eocene assemblages. Recent examination and SEM reillustration of the holotype specimen of the taxon tadjikistanensis (Plate 11: Figures 4-6) and convexa (Plate 11: Figures 1-3), described originally from the upper Paleocene of Kazakhstan (Bykova, 1953) and from the zone of conical globorotaliids (= Zones P6-P8) in the Kuban River section near Nal'chik, in the northern Caucasus (Subbotina, 1953), respectively, has shown the two forms to be conspecific, with the former having priority. We essentially follow the interpretation of Blow (1979), although unlike Blow we include certain forms illustrated by Loeblich and Tappan (1957a) from the synonymy of this species. We also include the multichambered variety identified as cf. convexa in this taxon, which presages its descendant $I$. broedermanni Cushman and Bermúdez.

STABLE ISOTOPES.-Igorina tajikistanensis has $\delta^{18} \mathrm{O}$ slightly lighter than coexisting $M$. velascoensis at equivalent sizes and has distinctly more negative $\delta^{18} \mathrm{O}$ than Subbotina (Shackleton et al., 1985; Berggren and Norris, 1997). The $\delta^{13} \mathrm{C}$ of I. tajikistanensis displays a strong increase in $\delta^{13} \mathrm{C}$ with increased size, which is similar to Acarinina and Morozovella (Berggren and Norris, 1997).

STRATIGRA PHIC RANGE.-Zone P3b to Zone P7.

GLOBAL DISTRIBUTION.-Igorina tadjikistanensis was broadly distributed in tropical and subtropical latitudes.

ORIGIN OF SPECIES.-This species probably evolved from $I$. pusilla in middle to upper Zone P3 by developing a more involute coiling mode, increasing the number of chambers in the final whorl, and developing a dense, finely praemuricate ornament. Igorina tadjikistanensis differs from I. albeari in being generally smaller, lower spired, and without a peripheral keel.

REPOSITORY.- Holotype (No. 2794-a) and paratype (No. 2794-a) deposited the micropaleontological collections at VNIGRI, St. Petersburg, Russia. Examined by FR.

\section{Genus Praemurica Olsson, Hemleben, Berggren, and Liu, 1992}

TYPE SPECIES.-Globigerina (Eoglobigerina) taurica Morozova, 1961.

ORIGINAL DESCRIPTION.- "Test very low trochospiral with 10-15 chambers, and with 5-6, but occasionally more in the ultimate whorl. The chambers which are globular to slightly ovoid in shape increase very gradually in size. The arrangement of chambers in the coil is nearly planispiral although the last one or two chambers may be shifted slightly towards the umbilicus. The aperture is interiomarginal, umbilical to extraumbilical, a low to high arch which is bordered by a narrow lip that often is somewhat wider in the umbilical area. The umbilicus can vary from narrow and deep to fairly broad and wide but is open to the previous chambers. The wall is weakly to strongly cancellate and nonspinose." (Olsson, Hemleben, Berggren, and Liu, 1992:202.)

Diagnostic Characters.-Test very low trochospiral, $5-6$, up to 8 in some species, globular to oval chambers in last whorl that increase slowly to moderately in size; periphery moderately to distinctly lobulate; nonspinose, cancellate wall texture weakly developed; aperture an interiomarginal, umbilical-extraumbilical low to high rounded arch, bordered by a thin lip. 
DisCUSSION.-The wall texture of Praemurica (Plate 6: Figures 2-4) is similar to that observed in the modern Neogloboquadrina dutertrei (d'Orbigny) (Plate 5: Figures 9, 10). Elongate subparallel ridges, often with an orientation towards the aperture, are connected by shorter less welldeveloped ridges that are thicker and broader on one side. This gives the test a cancellate wall texture, which is herein termed praemuricate. It is the first distinctive nonspinose, pustulose wall texture to evolve in the phylogeny of the early Paleocene planktonic foraminifera.

\section{Praemurica inconstans (Subbotina, 1953)}

Figure 28; Plate 10: Figures 4-8; Plate 14: Figures 13, 14; Plate 59: FIGURES $1-16$

Globigerina inconstans Subbotina, 1953:58, pl. 3: figs. 1, 2 [holotype, fig. 1; both specimens from zone of rotaliform globorotaliids, Elburgan Fm., Kuban River, northern Caucasus = middle part of Acarinina inconstans Zone of Leonova and Alimarina, 1960].-Berggren, 1965:291, text-fig. 9:3, 4 [Zone P2, Mexia Clay member, Wills Point Fm., Midway Group, Mexia, Texas].

Globigerina schachdagica Khalilov, 1956:246, pl. 1: fig. 3 [holotype: Danian Stage, Zeid, northwestern Azerbaidzhan].

Acarinina praecursoria Morozova, 1957:1111, text-fig. 1 [Danian, Khokodze River, northern Caucasus].

Globorotalia trinidadensis Bolli, 1957a:73, pl. 16: figs. 19-21 [holotype], figs. 22, 23 [Globorotalia trinidadensis Zone, lower Lizard Springs Fm., Trinidad].

Transitional form between Globorotalia pseudobulloides (Plummer) and Globorotalia uncinata Bolli.-Bolli, 1957a:74, pl. 17: figs. 16-18 [Globorotalia uncinata Zone, lower Lizard Springs Fm., Trinidad].

Globorotalia (Acarinina) inconstans (Subbotina).-Leonov and Alimarina, 1960, pl. 3: figs. 1-3, 5-8 [Globorotalia inconstans Subzone: figs. 1, 7, Podkhoomok River section; figs. 2-6, Khieu River; fig. 8, Urukh River, northern Caucasus].

Globorotalia scabrosa Bermúdez, 1961:1196, 1197, pl. 5: fig. 5 [Petromex Well, $200 \mathrm{~m}$, La Palma 56, Panuco, Veracruz, Mexico].

Globigerina scobinata Bermúdez 1961:1197, pl. 5: fig. 6 [Madruga Fm., Madruga, Havana Province, Cuba].

Globorotalia (Globorotalia) inconstans (Subbotina).-Hillebrandt, 1962:130, pl. 12: figs. 7, 8 [Zone B, Reichenhall-Salzburg Basin, Austro-German border].

Globorotalia inconstans (Subbotina).-Luterbacher, 1964:650: figs. 19-23 [figs. 19, 23, topotypes from zone of rotaliform globorotaliids, upper part of Elburgan Fm., Kuban River, northern Caucasus; figs. 20, 22, Globorotalia trinidadensis Zone, Gubbio section, central Apennines, Italy].

Globigerina arabica El-Naggar, 1966:157, 158, pl. 18: fig. 6 [holotype from Sample 30, Gebel Owaina, Globorotalia compressa/Globigerina daubjergensis Zone, upper Danian, Nile Valley, Egypt].

Acarinina inconstans inconstans (Subbotina).-Shutskaya, 1970b:108, pl. 6: figs. 4, 5 [middle part Acarinina inconstans Zone: fig. 4, western Turkmenia, Malyi Balkhan; fig. 5, Elburgan Fm., northem Caucasus].

Globorotalia (Turborotalia) inconstans (Subbotina).-Blow, 1979:1080, pl. 71: figs. 6, 7 [Zone P1, DSDP Hole 47.2/1/1: top], pl. 75: figs. 4-7 [Zone P1, Lindi area, Tanzania], pl. 76: figs. 3, 6, 7 [Zone P2, DSDP Hole 47.2/10/6: 69-71 cm], fig. 10 [Zone P2, Hole 47.2/10/5: 70-72 cm], pl. 77: fig. 1 [Zone P2, DSDP Hole 20C/6/4: 72-74 cm; Brazil Basin, South Atlantic Ocean], pl. 81: figs. 1, 2 [Zone P2, DSDP Hole 47.2/10/4: 83-85 cm; Shatsky Rise, northwestern Pacific Ocean], pl. 233: figs. 4, 5 [Zone P1, Lindi area, Tanzania].

Subbotina inconstans (Subbotina).- -Stott and Kennett, 1990:559, pl. 2: figs. 5, 6 [Subzone AP lb, upper Danian, ODP Hole 690C/14X/2: 36-40 cm; Maud Rise, Weddell Sea, Southern Ocean].
Morozovella inconstans (Subbotina).-Berggren, 1992:564, pl. 1: figs. 12, 13 [Subzone Plc, ODP Hole 747A/19H/CC: Kerguelen Plateau, southern Indian Ocean].

ORIGINAL DESCRIPTION.- - "Test with round or broadly oval outline consisting of $2-2^{1 / 2}$ whorls to the spiral. Peripheral margin rounded, weakly lobulate. The early whorls are disproportionately small relative to the last whorl. They (the whorls) are situated either on the same plane as the last whorl or even below it. The last whorl contains 5-6 chambers which increase gradually in size; the last chamber is often considerably larger than the others. However, there are some individuals in which the last three chambers are of equal size.

"Dorsal side very strongly compressed, ventral side convex, in certain forms conical. There is a well-defined, shallow umbilicus in the middle of the ventral side. Chambers spherical, closely packed together. The outline of the dorsal side of the chambers is rounded and that of the ventral side is either rounded or triangular.

"Sutures simple, curved in the form of an arc. On the ventral side they radiate from the umbilicus. Aperture slit-like, situated along the marginal suture. Walls smooth, often finely cancellate. Dimensions: diameter $0.35-0.45 \mathrm{~mm}$, thickness 0.12 0.20 mm." (Subbotina, 1953:58; translated from Russian.)

DiAGNOSTIC CHARACTERS.-Nonspinose, subcircular to broadly elongate-oval, moderately lobulate, 5-7 chambered, cancellate test; peripheral margin rounded to weakly subangular, chambers in early whorls tightly coiled, rapidly expanding in final whorl; sutures radial, straight to weakly curved in early forms, more strongly curved and weakly incised in more advanced forms; aperture an interiomarginal, umbilicalextraumbilical slit with distinct, lipped rim.

DISCUSSION.-The extensive synonymy above reflects our current understanding and interpretation of this taxon. A variety of morphotypes have been ascribed to inconstanstrinidadensis-praecursoria over the past 40 years and assigned to the genera Globigerina, Globorotalia, Acarinina, Subbotina, and Turborotalia. We include this form in the genus Praemurica following the demonstration by Olsson et al. (1992) of a phylogenetically distinct and homogenous lower Paleocene cancellate, nonspinose lineage. One of us (WAB) has examined the type specimens of inconstans, praecursoria, trinidadensis, and schachdagica and the synonymic listing above is based to a large extent on those studies. The wide range of variation ascribed herein to this morphospecies unifies forms sharing the characteristics of a cancellate, nonspinose test intermediate between the pseudoinconstans-taurica morphology and the typically anguloconical, nonkeeled uncinata morphology.

STABLE ISOTOPES.-Praemurica inconstans has more positive $\delta^{13} \mathrm{C}$ and more negative $\delta^{18} \mathrm{O}$ than Subbotina and Globanomalina but has a similar isotopic signature to $P$. taurica (Boersma and Premoli Silva, 1983; Berggren and Norris, 1997). There is a pronounced increase in $\delta^{13} \mathrm{C}$ with increased size in $P$. inconstans (Kelley et al., 1996). 


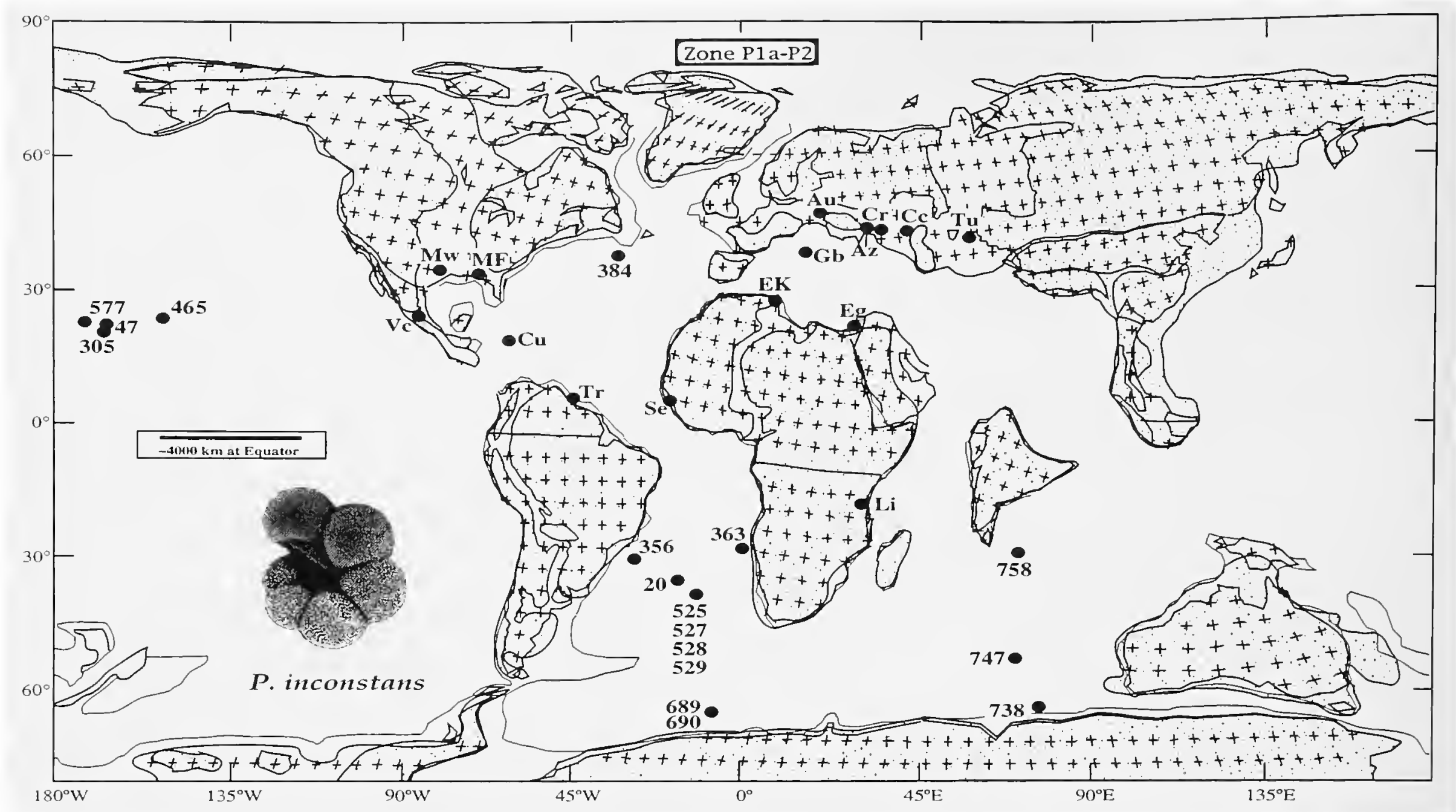

FIGURE 28.-Paleobiogeographic map showing distribution of Praemurica inconstans (Subbotina) in Zone P2.

Stratigra Phic Range.-Zone P1c to lower Zone P3.

GLOBAL DISTRIBUTION.-A cosmopolitan species in northern and southern hemisphere sections (Figure 28).

ORIGIN OF SPECIES.-This morphospecies evolved from Praemurica pseudoinconstans by the development of umbilical-conical chambers in morphologically advanced forms, development of incised umbilical sutures, and an increase in the number of chambers in the final whorl.

REPOSITORY.-Holotype (No. 3992) and paratype (No. 3993) deposited in the micropaleontological collections at VNIGRI, St. Petersburg, Russia. Examined by WAB.

\section{Praemurica pseudoinconstans (Blow, 1979)}

\section{Plate 60: Figures $1-13$}

Globorotalia pseudobulloides (Plummer).--Loeblich and Tappan, 1957a:192, pl. 40: fig. 9a-c [paratype, Pine Barren Mbr., Clayton Fm., Alabama] [in part]. [Not Plummer, 1926.]

Globorotalia (Turborotalia) pseudoinconstans Blow, 1979:1 105, pl. 67: fig. 4 [holotype: Zone P $\alpha$, DSDP Hole 47.2/11/3: 148-150 cm], pl. 67: fig. 3 [paratypes: Zone P $\alpha$, DSDP Hole 47.2/11/3: 148-150 cm], pl. 69: fig. 4 [paratypes: Zone P1, DSDP Hole 47.2/11/3: 0-5 cm; Shatsky Rise, northwestern Pacific Ocean].

"Morozovella" inconstans (Subbotina).-Huber, 199lc:46l, pl. 3: figs. 11, 12 [Zone APlb, ODP Hole 738C/19R: 365.22 mbsf; Kerguelen Plateau, southern Indian Ocean]. [Not Subbotina, 1953.]
Praemurica pseudoinconstans (Blow).-Olsson, Hemleben, Berggren, and Liu, 1992:202, pl. 6: figs. 1, 4 [Zone Pa, Clayton Basal Sands, Millers Ferry, Alabama]: figs. 2, 3, 5-8 [Zone Pla, Pine Barren Mbr., Clayton Fm., Millers Ferry, Alabama].

ORIGINAL DESCRIPTION.- "The comparatively small test is coiled in a low, fairly lax, trochospire with 6 complete chambers visible in the last convolution of the test together with a small part of a seventh chamber and about 12-14 chambers comprising the spire. In dorsal aspect, the chambers are sensibly equidimensional, inflated and subglobular, with quite distinctly incised dorsal intercameral sutures; these intercameral sutures are radially disposed. In ventral aspect, the chambers are inflated, subglobular, but are slightly more embracing and appressed than as seen in dorsal aspect. The chambers increase evenly, but only slowly, in size as added in the progression of the trochospire. The umbilicus is widely open, moderately deep and clearly delimited by the umbilical shoulders of the last convolution of chambers. The primary aperture is slit-like near the umbilicus but widens to become highly arched at, or near to, the peripheral margin of the test; the aperture is bordered by a strongly developed flap-like lip proximally, which extends into the umbilical depression. Distally, the lip of the aperture is more rim-like and is less broad than seen proximally. Within the umbilicus, relict apertures are present for chambers prior to the last and their 
apertural lips are confluent with the lip of the ultimate chamber. The equatorial profile is subcircular to slightly elongate in the direction of the diameter which bisects the final chamber; the equatorial profile is also moderately lobulate. The axialapertural profile shows an equally biconvex test with rounded peripheral margins. The wall texture of the test is finely and densely perforate and, over the earlier chambers of the last whorl, the mural-pores open into small pore-pits. The interpore ridges show a meandriform pattern which is characteristic. Maximum diameter of holotype $0.328 \mathrm{~mm}$. as measured by electron beam sensor." (Blow, 1979:1105.)

DIAGNOSTIC CHARACTERS.-Ultimate whorl with 5-51/2 chambers of which first few increasing in size gradually, final few increasing in size more rapidly; last chamber slightly offset toward umbilicus in some specimens. Aperture a high rounded arch, bordered by a narrow lip broadening toward umbilicus; aperture not as pronounced as P. taurica. Cancellate wall texture weakly developed, difficult to view with light microscope, especially in poorly preserved specimens. Pores about 1 $\mu \mathrm{m}$ in diameter at narrowest point, positioned at bases of cancellate ridges. Walls about $4 \mu \mathrm{m}$ thick, overall test size up to $300 \mu \mathrm{m}$ across.

DISCUSSION.-Praemurica pseudoinconstans is a fairly common species that may be confused with the less common Parasubbotina pseudobulloides (Plummer). Indeed, Blow (1979) carefully distinguished the two species and selected as a paratype a specimen from the Clayton Formation, Alabama, previously identified by Loeblich and Tappan (1957a) as $P$. pseudobulloides. The chambers in $P$. pseudobulloides increase more rapidly in size and are more inflated than in $P$. pseudoinconstans. Parasubbotina pseudobulloides is spinose in contrast to $P$. pseudoinconstans, which is nonspinose. The meandriform pattern of the interpore ridges noted by Blow (1979) is due to the Neogloboquadrina dutertrei-like wall texture observed in this species under SEM. In this type of wall texture, the pores are often not isolated from one another by interpore ridges as in $P$. pseudobulloides. Except for their general appearance, the two wall textures are fundamentally different.

STABLE ISOTOPES.-No data available.

StratigraPhic Range.-Zone P $\alpha$ to Zone P2.

GLOBAL DISTRIBUTION.-Originally described from DSDP Site 47, Shatsky Rise, northwestern Pacific Ocean. It also occurs in Alabama and in the South Atlantic Ocean at DSDP Site 356.

ORIGIN OF SPECIES.-Evolved from Praemurica taurica in middle Biochron $\mathrm{P} \alpha$ by increasing the rate of expansion of the last few chambers in the ultimate whorl.

REPOSITORY.-Holotype (BP Cat. No. 37/134) and paratypes (BP Cat. No. 37/135, 40/7) deposited in the micropaleontological collections at The Natural History Museum, London. Paratype (USNM P5724) deposited in the Cushman Collection, National Museum of Natural History. Paratype (USNM P5724) examined by WAB and RKO.

\section{Praemurica taurica (Morozova, 1961)}

Figure 29; Plate 10: figures 1-3; Plate 61: Figures 1-15

Globigerina (Eoglobigerina) taurica Morozova, 1961:10, pl. 1: fig. 5a-c [lower Danian Stage (Uylin Substage), Dn 1 I Zone, Globigerina (Eoglobigerina) taurica Zone, Tarkhankut Peninsula, Crimea].

Morozovella taurica (Morozova).-Berggren, 1992:564, pl. 1: figs. 9-11 [Danian, ODP Hole 747C/3H/2: 22-24 cm; Kerguelen Plateau, southern Indian Ocean].

Praemurica taurica (Morozova).-Olsson, Hemleben, Berggren, and Liu, 1992:202, pl. 5: figs. 1-8 [Zone P1a, Pine Barren Mbr., Clayton Fm., Millers Ferry, Alabama].

ORIGINAL DESCRIPTION.—."Test with a subpolygonal lateral outline, strongly compressed along the growth axis. Spire consists of three whorls. Early whorls lie on one level with the surface of the last whorl or rise up slightly above it. In each whorl there are five to six inflated subspherical chambers, rapidly and uniformly increasing in size and arranged freely. Peripherally on the chambers a small papillate projection, directed toward the subsequent chamber, is frequently observed. Last chamber asymmetrical, flattened at the apertural face and slightly shifted toward the umbilical surface. Equatorial outer margin scalloped. Axial outer margin weakly asymmetric, broadly rounded. Sutures deep, straight. Umbilicus narrow. Aperture a semicircular slit located between the umbilicus and the outer margin. Sometimes it is surrounded by a very narrow lip, the width of which is uniform over its whole length. Wall smooth, finely perforate. Surface lustrous or matte.

"Dimensions of holotype (fig. 5a-c): greatest diameter 0.45, least diameter 0.32 , height $0.21 \mathrm{~mm}$.

"Variability: The form of the test, changing from oval to rounded, and the number of chambers in a whorl are not constant. Tests are predominant in which the last whorl there are five to six chambers, but are encountered with four and a half, seven, or eight chambers to a whorl.

"Comparison: From the near species Globigerina cretacea d'Orbigny, 1840, and G. edita Subbotina, 1949, this species differs by its flatter, low test, the often oval outlines, more flattened spiral side, greater number (5-6) of chambers in the last whorl, the asymmetrical shape of the last chamber, which stands above the umbilicus, and the small umbilical aperture." (Morozova, 1961:10; translated from Russian.)

DiAGNOSTIC CHARACTERS. - Characterized by a very low trochospiral test with 5-6, occasionally more, chambers in ultimate whorl. Globular to slightly ovoid chambers increase very gradually in size with last one or two occasionally slightly shifted towards umbilicus. Umbilical-extraumbilical aperture a low to high arch bordered by narrow lip broadening towards umbilicus and becoming somewhat triangular in shape. In well-preserved specimens, lips from previous chambers project as small flaps into fairly wide, broad umbilicus having a deep depression. Cancellate structure weakly developed. 


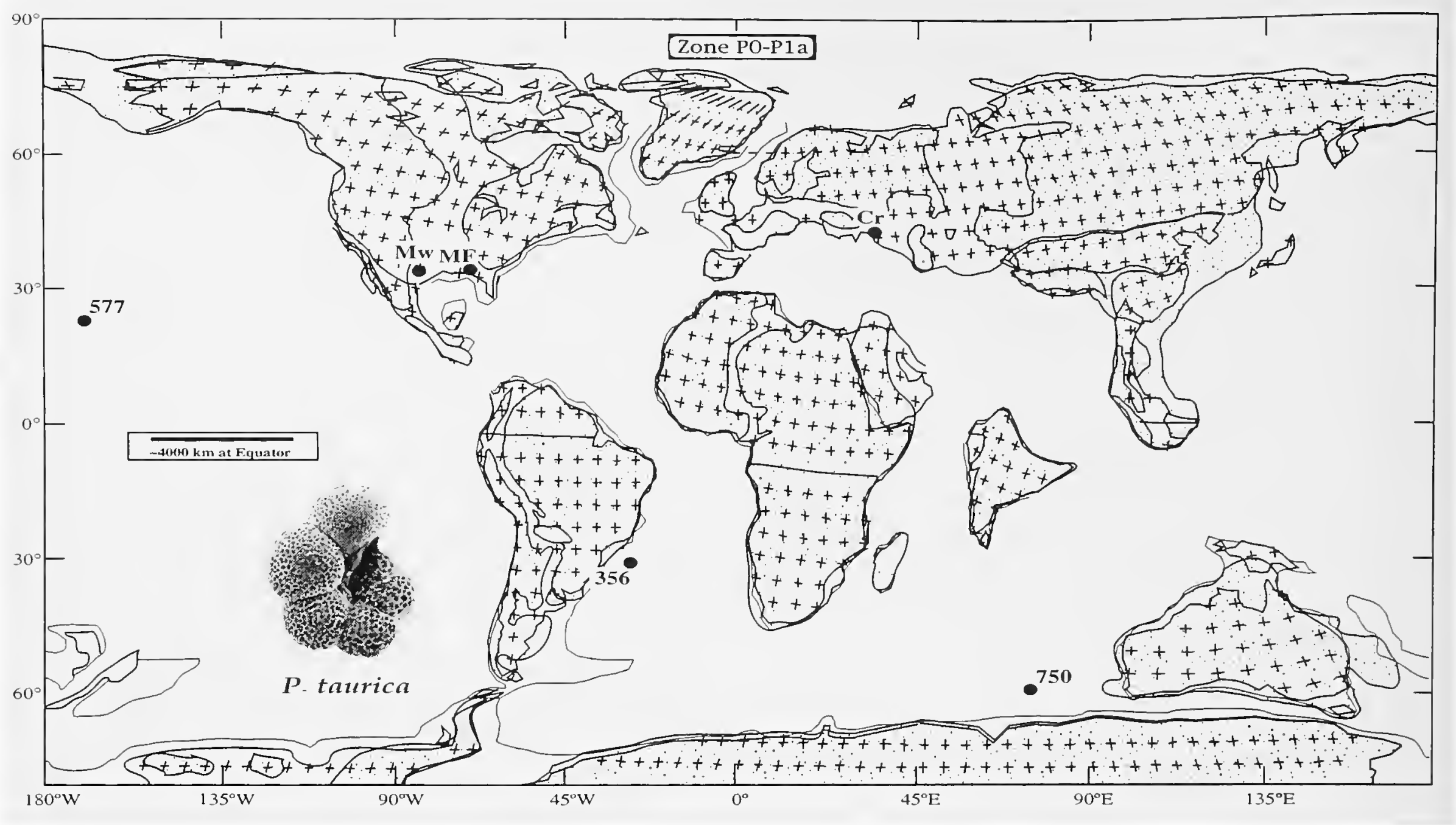

FIGURE 29.-Paleobiogeographic map showing distribution of Praemurica taurica (Morozova) in Zone P1.

DISCUSSION.-This is the first species of Praemurica to evolve from Hedbergella monmouthensis in the basal Danian. It is fairly commmon in Zone P $\alpha$. Although the cancellate wall texture is weakly developed, it is distinctive under SEM, being nearly identical to the living species Neogloboquadrina dutertrei. Praemurica taurica is a stem form of an important lineage leading to $P$. uncinata.

STABLE ISOTOPES.-Praemurica taurica has more positive $\delta^{13} \mathrm{C}$ and more negative $\delta^{18} \mathrm{O}$ than Subbotina and Globanomalina in the late Danian, but all these taxa have similar isotopic signatures in the earliest Danian (Berggren and Norris, 1997). There is a pronounced increase in $\delta^{13} \mathrm{C}$ with increased size in $P$. taurica among small specimens (up to $\sim 200 \mu \mathrm{m}$; D'Hondt and Zachos, 1993) but a weak trend above this size (Norris, 1996).

STRATIGRA PHIC RANGE.- Upper Zone P0 to Zone Plb; ? P1C.

Global Distribution.-Worldwide in the high to low latitudes (Figure 29).

ORIGIN OF SPECIES.-This species evolved from Hedbergella monmouthensis in late Biochron P0. It is the stem form of the praemuricate pseudoinconstans-inconstans-uncinata lineage of the lower Paleocene (Danian) Zones P1 and P2.

REPOSITORY.-Holotype (No. 3510/1) deposited at GAN, Moscow. Examined by FR.

\section{Praemurica uncinata (Bolli, 1957)}

Figure 30; Plate 10: Figures 9-11; Plate 14: Figures 9-11; PLATE 62: FIGURES $1-16$

Globorotalia uncinata Bolli, 1957a:74, pl. 17: figs. 13-15 [Globorotalia uncinata Zone, lower Lizard Springs Fm., Trinidad].-Luterbacher. 1964:655, 657, fig. 30a-c [Globorotalia uncinata Zone, level G-85, Gubbio section, central Apennines, Italy], fig. 31a-c [topotype, Trinidad].-Said and Sabry, 1964:385, 386, pl. 1: fig. 12a-c [Globorotalia uncinata Zone, Esna Shale, Gebel Aweina, Egypt].-Berggren, 1965:294, text-fig. 9 (5a-c) [Globorotalia uncinata Zone, Mexia Clay Mbr., Wills Point Fm., Mexia, Texas].-Toumarkine, 1978:692, 693, pl. 1: fig. 16 [Globorotalia uncinata Zone, DSDP Site 363/17/1: 87-89 cm; Walvis Ridge, South Atlantic Ocean].-Pujol, 1983:645, 652, pl. 2: fig. 1 [Globorotalia uncinata Zone, DSDP Hole 516F/87/7: 39-40 cm; Rio Grande Rise, South Atlantic Ocean]. Acarinina indolensis Morozova, 1959:1116, text-fig. 1 [Danian, Globoconusa daubjergensis/Acarinina indolensis Zone, northwestern Crimea].

Globorotalia uncinata uncinata Bolli.-El-Naggar, 1966:240, pl. 18: fig. la-c, pl. 19: fig. 2a-c [samples S.34 and S.36, respectively, both Globorotalia uncinata Zone, lower Esna Shale, Gebel Oweina, Egypt].

Acarinina inconstans uncinata (Bolli).-Shutskaya, 1970a:1 10, pl. 6: fig. la-c [holotype refigured], fig. 2a-c [middle part of Acarinina inconstans Zone, Elburgan Fm., Kuban River, northern Caucasus], fig. 3a-c [lower part of Globigerina trivialis-Globoconusa daubjergensis-Globorotalia compressa Zone, northern Osetiya, Urukh River, northern Caucasus]; 1970b:118-120, pl. 19: figs. 7a-c, 10a-c [Acarinina inconstans Zone, Elburgan Fm., Kuban River, Cherkessk region, northern Caucasus].

Globorotalia (Acarinina) praecursoria praecursoria (Morozova).-Blow, 1979:944-947, pl. 76: figs. 4, 8, 9, pl. 81: fig. 3 [Zone P2, DSDP Hole 
47.2/10/5: 70-72 cm], pl. 77: figs. 2-5 [Zone P2, DSDP Hole 20C/6/4 72-74 cm; Brazil Basin, South Atlantic Ocean], pl. 82: figs. 1-3 [Zone P2, recollection of Globorotalia uncinata type locality, Trinidad], pl. 84: fig. 2, pl. 85: fig. 9 [Zone P3, DSDP Hole 47.2/10/2: 80-82 cm; Shatsky Rise, northwestern Pacific Ocean]. [Not Morozova, 1961.]

Morozovella uncinata (Bolli).--Snyder and Waters, 1985:448, 449, pl. 10: figs. 1, 2 [Globorotalia uncinata Zone, DSDP Site 550/37/5: 59-61 cm; Porcupine Abyssal Plain, northeastern Atlantic Ocean].

ORIGINAL DESCRIPTION._- "Shape of test low trochospiral, spiral side almost flat or slightly convex, umbilical side distinctly convex; equatorial periphery distinctly lobate; axial periphery rounded to subangular. Wall calcareous, perforate, surface finely spinose. Chambers subangular, inflated, laterally compressed; 12-15, arranged in about $2^{1 / 2}$ whorls, the 5-6 chambers of last whorl increasing moderately in size. Sutures on spiral side strongly curved, depressed; on umbilical side radial, depressed. Umbilicus fairly narrow, deep, open. Aperture a low arch; interiomarginal, extraumbilical-umbilical. Coiling random. Largest diameter of holotype $0.35 \mathrm{~mm}$." (Bolli, 1957a:74.)

DiAGNOSTIC CHARACTERS.--Nonspinose, weakly cancellate, elongate-oval, plano-convex to moderately high spired, moderately lobulate test with 5-8 chambers in last whorl; chambers occasionally so loosely coiled as to form secondary spiral apertures between them; sutures on umbilical side radial, depressed, on spiral side incised and strongly recurved yielding typically trapezoidal-shaped chambers; axial periphery subangular, noncarinate but with rugose muricae often situated along peripheral margin of early chambers of last whorl; umbilicus typically narrow, deep, bordered by weakly developed circumumbilical shoulder formed by raised periumbilical chamber extensions; aperture a narrow interiomarginal, umbilicalextraumbilical arch extending to peripheral margin.

DisCussion.-Blow (1979) argued the case for including uncinata Bolli, 1957a, as a junior synonym of praecursoria Morozova, 1957. Our examination of the holotypes of both of these forms leads us to reject this interpretation. Rather, we interpret praecursoria as an advanced, atypically large endmember of inconstans that is characterized by rounded chambers and an axial periphery, and we reserve for uncinata those forms exhibiting the typical anguloconical (but noncarinate) test with distinctly incised and recurved spiral intercameral sutures. Acarinina indolensis Morozova (1959) is a small form of $P$. uncinata with five chambers in the final whorl but, nevertheless, exhibits the characteristic morphology of this species.

STABLE ISOTOPES.-Praemurica uncinata has more positive $\delta^{13} \mathrm{C}$ and more negative $\delta^{18} \mathrm{O}$ than Subbotina and Globanomalina and has an isotopic signature similar to that of Morozovella praeangulata (Shackleton et al., 1985; Berggren and Norris, 1997). There is a pronounced increase in $\delta^{13} \mathrm{C}$ with increased size in P. uncinata (Kelly et al., 1996; Norris, 1996).

STRATIGRAPHIC RANGE.-Zone P2 to lower Zone P3.

Global DisTRIBUTION.-This taxon has been widely reported in the literature from predominantly low latitude (sub)tropical localities. Shutskaya (1970a, 1970b) recorded it from several localities in the northern Caucasus. This species does not appear to occur in high southern latitudes (Stott and Kennett, 1990; Huber, 1991b), and we have not found it in our examination of material from the southern part of the Indian Ocean (Figure 30).

ORIGIN OF SPECIES.-This species evolved from Praemurica inconstans at the base of Zone P2 by extension of the umbilically conical chambers into most of the final whorl, and by the formation of blunt pustules around the umbilicus and on the initial chambers of the final whorl.

REPOSITORY.- Holotype (USNM P5048) deposited in the Cushman Collection, National Museum of Natural History. Examined by WAB and RDN.

\section{Family GuembelitriIDAE Montanaro Gallitelli, 1957}

(by S. D'Hondt, C. Liu, and R.K. Olsson)

Guembelitriinae Montanaro Gallitelli, 1957:136 [subfamily]. Guembelitriidae El-Naggar, 1971:431 [nomen translatum ex subfamily].

ORIGINAL DESCRIPTION.- "Test triserial; chambers globular; aperture basal, arched, simple." (Montanaro Gallitelli, 1957:136.)

Diagnostic Characters.-Original description of foraminiferal tests assignable to subfamily Guembelitriinae does not apply to all members of family Guembelitriidae. Tests of guembelitriid foraminifera either triserial (Guembelitria spp.), trochospiral (Parvularugoglobigerina spp., Globoconusa spp.), or nearly triserial in initial whorl and approximately biserial in later whorls (Woodringina spp.). Chambers usually globular or subglobular, increasing gradually in size. Aperture usually a loop-shaped arch, often slightly infolded on one side, marked by a fine lip. Surface texture microperforate, smooth to pustulous; when present, pustules or small mounds generally perforated by one or more pores ("pore-mounds") (Guembelitria, Parvularugoglobigerina, Woodringina) or peripherally associated with pores (Globoconusa).

Discussion.-Montanaro Gallitelli (1957) emended the family Heterohelicidae Cushman, 1927a, by creating the subfamily Guembelitriinae for the triserial genera Guembelitria Cushman, 1933, and Guembelitriella Tappan, 1940. Loeblich and Tappan (1957a) assigned Woodringina Loeblich and Tappan, 1957, to the Guembelitriinae, implicitly modifying the definition of the Guembelitriinae to include forms that are triserial in the first whorl and biserial in later whorls. El-Naggar (1971) raised the Guembelitriiidae to family status, and Blow (1979) explicitly broadened its definition to include morphotypes with biserial and trochospiral stages.

The assignment of biserial Woodringina species to the Guembelitriidae rests on the hypothesis that Woodringina species were derived from Guembelitria cretacea Cushman, 1933. This phylogenetic hypothesis is a subset of the broader 


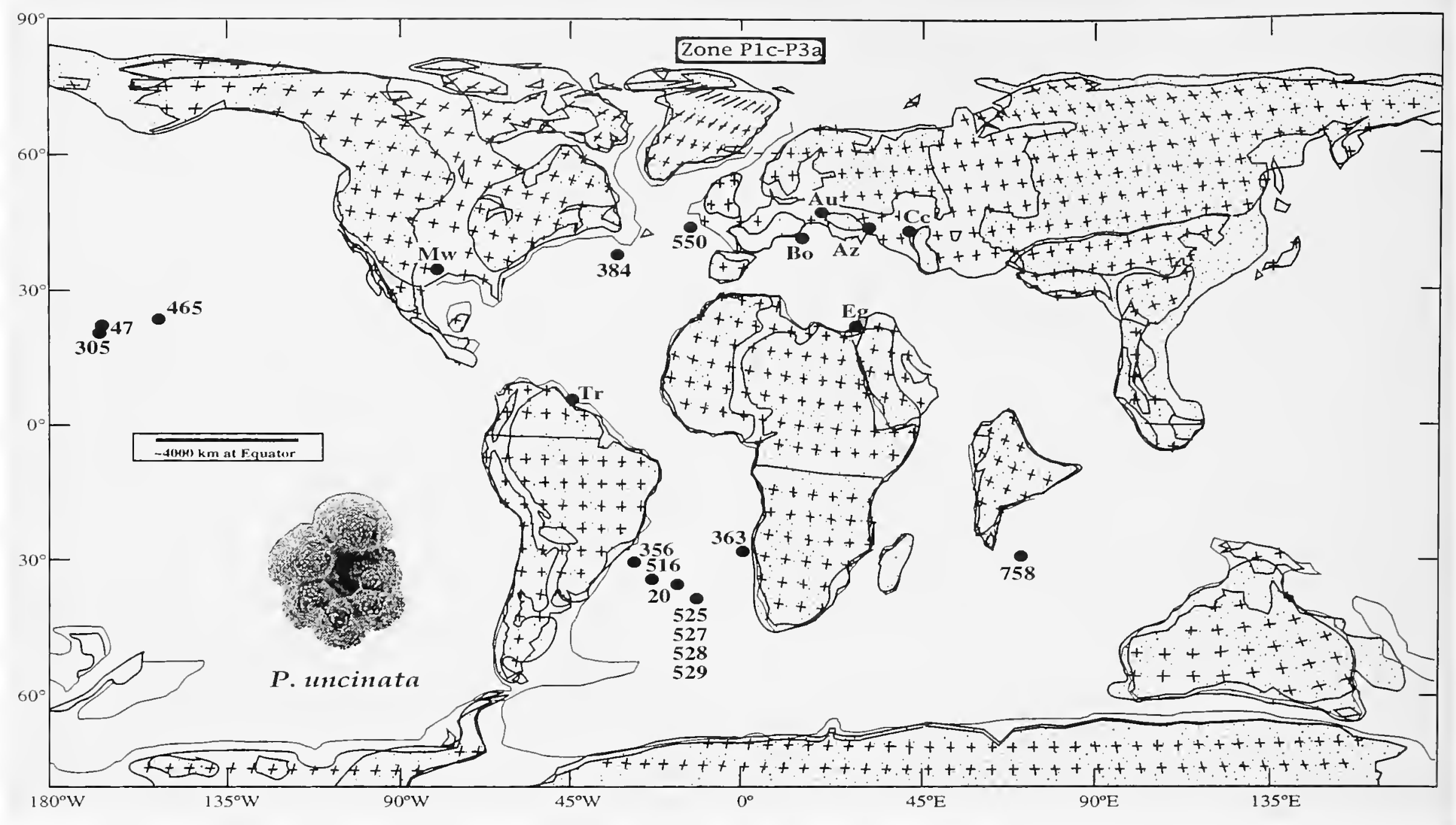

FIGURE 30.-Paleobiogeographic map showing distribution of Praemurica uncinata (Bolli) in Zone P2.

hypothesis that Chiloguembelina midwayensis (Cushman, 1940), is lineally derived from Guembelitria cretacea Cushman, 1933, via Woodringina claytonensis Loeblich and Tappan, 1957 (Olsson, 1970, 1982; Premoli Silva, 1977; Li and Radford, 1991; Olsson et al., 1992; Liu and Olsson, 1992). This broader hypothesis is supported by cladistic analysis, based on shared apertural, surface textural, and juvenile characters (D'Hondt, 1991). Given the apparent phylogenetic relationship of Chiloguembelina midwayensis to Guembelitria cretacea, the Guembelitriidae constitutes a paraphyletic family because it does not include descendent species assigned to the Chiloguembelinidae. The relationship of many post-Paleocene microperforate taxa (i.e., Cassigerinella Pokorny, 1955, Corrosina Thalmann, 1956, and Gallitellia Loeblich and Tappan, 1986) to the Guembelitriidae remains largely unexplored.

Recent studies have documented morphologic intergradation and shared surface-textural and apertural characteristics between Guembelitria cretacea and members of the trochospiral genera Parvularugoglobigerina Hofker, 1978, and Globoconusa Khalilov, 1956 (D'Hondt and Keller, 1991; Liu and Olsson, 1992; Olsson et al., 1992) (Plates 63-68). These demonstrate the general validity of several recent phylogenetic hypotheses for the origin of the latter genera (Olsson, 1970, 1982; Premoli Silva, 1977; Smit, 1982; Olsson et al., 1992). On this basis, we assign both Parvularugoglobigerina and Globoconusa to the Guembelitriidae.
Among the primary morphologic characters that unite the Guembelitriidae is a close surface-textural association of pores and pustules (Liu and Olsson, 1992; Olsson et al., 1992) (Plates 63-68). Where the pores directly perforate the surface mounds (or pustules), these perforated mounds are commonly referred to as "pore-mounds." Interspecimen and intraspecimen variation in surface texture from smooth to pore-mound is exhibited by Guembelitria cretacea, Woodringina claytonensis, and Parvularugoglobigerina species (D'Hondt and Keller, 1991; Liu and Olsson, 1992; Olsson et al., 1992) (Plates 63-68). The degree of pore-mound expression within a specimen appears ontogenetically variable, with the ultimate chamber often exhibiting more weakly developed pore-mounds than immediately preceding chambers (Liu and Olsson, 1992) (Plates 63-68). Furthermore, the pustules (pore-mounds) are often asymmetrically perforate (Plate 63: Figure 6, Plate 65: Figure 6, Plate 67: Figure 14).

The phyletic relationship of Parvularugoglobigerina, Globoconusa, Woodringina, and Chiloguembelina to Guembelitria cretacea indicates that both trochospiral and biserial chamber arrangements divergently evolved within the planktonic foraminifera (Olsson, 1982; Smit, 1982; D'Hondt, 1991; Liu and Olsson, 1992). Such relationships have clearly not been accounted for by taxonomic schemes, which separate serial and trochospiral morphotypes at the superfamily level (i.e., Loeblich and Tappan, 1988). 


\section{Genus Guembelitria Cushman, 1933}

Chiloguembelitria Hofker, 1978:60.

TYPE SPECIES.—Guembelitria cretacea Cushman, 1933.

ORIGINAL DESCRIPTION.- "Test similar to Gümbelina, but triserial; wall calcareous, finely perforate; aperture large, at the inner edge of the last-formed chamber." (Cushman, 1933:37.)

DiAGNOSTIC CHARACTERS.-Test small and triserial. Aperture bordered by a distinct lip and often slightly asymmetric. Wall structure microperforate; surface texture of wellpreserved specimens characterized by presence of poremounds.

DISCUSSION.-Confusion remains over the taxonomic status of Chiloguembelitria, which Loeblich and Tappan (1988) retained as a valid genus and Kroon and Nederbragt (1990) suggested is a junior synonym of Guembelitria. This confusion is exacerbated by the absence of a designated holotype for Chiloguembelitria or its type species, Chiloguembelitria danica Hofker, 1978. Nonetheless, it appears that no morphological characters consistently distinguish Chiloguembelitria spp. from Guembelitria spp. The original description and illustration of $C$. danica Hofker, 1978, resembles Guembelitria cretacea Cushman, 1933, in its apertural characteristics and its consistent triseriality (Plate 63). The absence of distinct chiloguembelitriid characters indicates that, as suggested by Kroon and Nederbragt (1990), Chiloguembelitria danica Hofker, 1978, is a junior synonym of Guembelitria cretacea Cushman, 1933.

\section{Guembelitria cretacea Cushman, 1933}

Figure 31; Plate 8: Figures 1-3; Plate 13: Figure 3; PLATE 63: FIGURES 1-12

Guembelitria cretacea Cushman, 1933:37, pl. 4: fig. 12a,b [upper Maastrichtian, Navarro Fm., Texas].-Olsson, 1970:601, pl. 91: figs. 4, 5 [upper Maastrichtian, Redbank Fm., New Jersey].-Smith and Pessagno, 1973:15, pl. 1: figs. 1-8 [upper Maastrichtian, Corsicana Fm., Texas].--Keller, 1989:319, figs. 1-1, 1-2 [lower Danian, Brazos River, Texas].—D'Hondt, 1991:172, pl. 1: figs. 1, 3, 5, 6 [Zone P $\alpha$, DSDP Site 577/12/5: 94-96 cm; Shatsky Rise, northwestem Pacific Ocean], figs. 2, 4 [lower Danian, Brazos River, Texas], pl. 2: fig. 2 [Zone Pa, DSDP Site 577/12/5: 94-96 cm; Shatsky Rise, northwestem Pacific Ocean], fig. 3 [Zone P $\alpha$, DSDP Site 528/31/CC: 14-15 cm; Walvis Ridge, South Atlantic Ocean].-D'Hondt and Keller, 1991:93, pl. 3: fig. 1 [Zone P $\alpha$, DSDP Site 577/12/5: 115-117 cm; Shatsky Rise, northwestem Pacific Ocean].-Liu and Olsson, 1992:341, pl. 1: figs. 1, 2 [Zone P $\alpha$, Pine Barren Mbr., Clayton Fm., Millers Ferry, Alabama].

Guembelitria irregularis Morozova, 1961:17, pl. 1: fig. 9 [Danian, Tarkhankut, Crimea].-D'Hondt, 1991:172, pl. 1: fig. 7 [Zone P $\alpha$, DSDP Site 577/12/5: 94-96 cm; Shatsky Rise, northwestem Pacific Ocean].

Chiloguembelitria danica Hofker, 1978:60, pl. 4: fig. 14 [holotype: Danian, DSDP Hole 47.2, sample depth unknown; Shatsky Rise, northwestern Pacific Ocean].-Loeblich and Tappan, 1988:452, pl. 484: figs. 3-6 [holotype], figs. 7, 8 [Danian, DSDP Hole 47.2, sample depth unknown; Shatsky Rise, northwestern Pacific Ocean].

Guembelitria (?) trifolia (Morozova).-Blow, 1979:1384, pl. 61: fig. 9 [Zone P $\alpha$, DSDP Hole 47.2/11/5: 148-150 cm; Shatsky Rise, northwestem Pacific Ocean]. [Not Globigerina (Eoglobigerina) trifolia Morozova, 1961.]
Guembelitria azzouzi Salaj, 1986:49, pl. 1: figs. 1-6, pl. 2: fig. 1 [base of Danian, El Haria, Tunisia].

Guembelitria besbesi Salaj, 1986:50, pl. 1: figs. 7-9 [base of Danian, El Haria, Tunisia].

Guembelitria trifolia (Morozova).-Keller, 1989:319, figs. 3-3, 3-4 [lower Danian, Brazos River, Texas].—D'Hondt and Keller, 1991:93, pl. 3: fig. 2 [Zone P $\alpha$, DSDP Site 577/12/5: 115-117 cm; Shatsky Rise, northwestern Pacific Ocean]. [Not Globigerina (Eoglobigerina) trifolia Morozova, 1961.]

ORIGINAL DESCRIPTION.- - "Test small, triserial; chambers globular, nearly spherical; sutures much depressed; wall smooth, finely perforate; aperture large, semicircular or semi-elliptical at the inner margin of the last-formed chamber. Length of holotype $0.20 \mathrm{~mm}$.; breadth $0.17 \mathrm{~mm}$." (Cushman, 1933:37.)

DiAGNOSTIC CHARACTERS.-Test small, triserial, composed of globular chambers with strongly depressed sutures. Aperture bordered by distinct lip; aperture often slightly asymmetric due to infolding of lip along one side of aperture (as in Woodringina and Chiloguembelina). Wall structure microperforate; surface texture often characterized by blunt poremounds; i.e., mounds marked by one or more pores (Plate 63: Figure 6).

DISCUSSION.-As discussed previously, Chiloguembelitria danica Hofker, 1978, appears to be a high-spired form of Guembelitria cretacea Cushman, 1933. Similarly, the primary characters of Guembelitria irregularis Morozova, 1961 (Plate 8: Figures 1-3), and Guembelitria azzouzi Salaj, 1986, are indistinguishable from those of Guembelitria cretacea. In contrast, Guembelitria dammula Voloshina, 1961 (Plate 12: Figures 7-9), appears to differ from Guembelitria cretacea sensu stricto by its three-chamber series being aligned more strictly parallel to its axis of test coiling. Closer examination of the type population of $G$. dammula may be necessary to determine whether it should be reduced to a junior synonym of G. cretacea or retained as a separate taxon.

Salaj (1986) designated a short-spired earliest Paleocene form of Guembelitria as G. besbesi. Other authors have identified that short-spired form of Guembelitria as Guembelitria (?) trifolia (Morozova) or Guembelitria trifolia (Morozova) (Blow, 1979; Keller, 1989; D'Hondt, 1991). The latter designations are incompatible with our interpretation of Globigerina (Eoglobigerina) trifolia Morozova, 1961, as a variant of Globoconusa daubjergensis (Brönnimann, 1953) (Plate 8: Figures 4-6). In any case, the short-spired Guembelitria morphotype intergrades with $G$. cretacea sensu stricto (Plate 63). The former differs from the latter only in having a shorter spire. Along with $G$. cretacea sensu stricto, the short-spired morphotype is present in uppermost Maastrichtian near-shore sequences (D'Hondt, 1991) and is abundant in lowermost Paleocene planktonic foraminiferal assemblages (D'Hondt and Keller, 1991). The stratigraphic and biogeographic association of these intergrading morphotypes suggests that the short-spired form (= Guembelitria besbesi Salaj, 1986) is a morphologic variant of $G$. cretacea. 


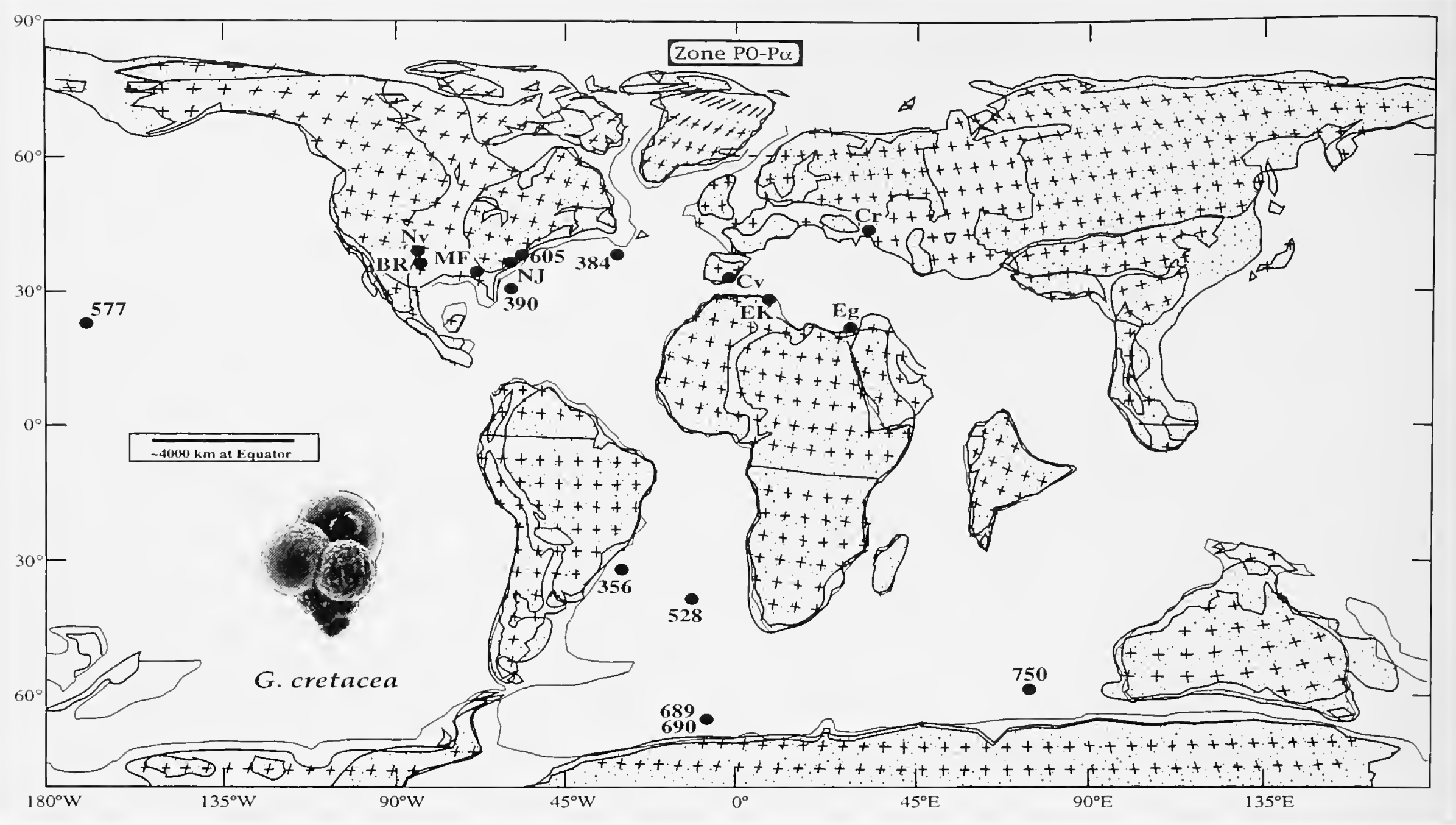

FIGURE 31.-Paleobiogeographic map showing distribution of Guembelitria cretacea Cushman in the Danıan.

STABLE IsOTOPES.-Biogeographic and oxygen isotopic data suggest that $G$. cretacea inhabited a near-surface planktonic niche (Boersma et al., 1979; Boersma, 1984a; D’Hondt and Zachos, 1993).

STRATIGRA PHIC RANGE.-Maastrichtian to Zone Plb.

GLOBAL Distribution.-During the Maastrichtian, $G$. cretacea was generally limited to near-shore environments and only rarely was present in the open ocean (Davids, 1966; Olsson, 1970; Smith and Pessagno, 1973). Immediately following the Cretaceous/Tertiary boundary event, G. cretacea radiated into the open ocean, where it was abundant at low and middle latitudes (Olsson, 1970; Smit and van Kempen, 1987; D'Hondt and Keller, 1991; Liu and Olsson, 1992). In Zone P0 and lower Zone $\mathrm{P} \alpha$ it was a cosmopolitan planktonic foraminiferal taxon. Biogeographic and oxygen isotopic data suggest that $G$. cretacea inhabited a near-surface planktonic niche (Boersma et al., 1979; Boersma, 1984a; D'Hondt and Zachos, 1993) (Figure 31).

ORIGIN OF SPECIES.-Unknown.

REPOSITORY.-Holotype (USNM CC19022) deposited in the Cushman Collection, National Museum of Natural History. Examined by SD, CL, and RKO.

\section{Genus Globoconusa Khalilov, 1956}

Globastica Blow, 1979:1231.
TYPE SPECIES.-Globoconusa conusa Khalilov, $1956=$ Globigerina daubjergensis Brönnimann, 1953.

ORIGINAL DESCRIPTION.- - "Test high conical, turret-like, tapering toward the initial end. Dorsal side strongly convex, with a conical spire, its apex at the initial chamber. The height of the cone exceeds the diameter of its base or is nearly equal to it. On the dorsal side all whorls are visible, in general represented by semispherical chambers; on ventral side subspherical chambers are observed only in the last whorl." (Khalilov, 1956:249; translated from Russian).

Diagnostic Characters.- -Test tiny, low to high trochospire of 2-21/2 whorls; each whorl comprised of 3-4 inflated, subglobular chambers. Wall calcareous, microperforate, with distinctly hispid surface; pustules often peripherally associated with a small pore (and vice-versa). Aperture a very small, low arch, with umbilical position. Test sometimes marked by one or more small supplementary apertures on spiral side.

DisCUSSION.-Globoconusa conusa Khalilov, 1956, is widely considered to be a junior synonym of Globigerina daubjergensis Brönnimann, 1953 (Loeblich and Tappan, 1964, 1988; Khalilov, 1967; Morozova et al., 1967, Olsson, 1970; Premoli Silva, 1977; Hofker, 1978; Smit, 1982; Toumarkine and Luterbacher, 1985; Brinkhuis and Zachariasse, 1988; Stott and Kennett, 1990; D'Hondt and Keller, 1991; Huber, 1991b; Li and Radford, 1991; Liu and Olsson, 1992; Olsson et al., 1992). A different opinion was held by Blow (1979), who noted 
that Khalilov's (1956:249) type description of Globoconusa conusa differs from the holotype of $G$. daubjergensis in some respects (i.e., the test of $G$. conusa was originally described as "strongly thickened" and "covered with small, dense pits"). On this basis, Blow (1979) created the generic designation Globastica for Globigerina daubjergensis and related forms.

\section{Globoconusa daubjergensis (Brönnimann, 1953)}

Figure 32; Plate 8: figures 4-6; Plate 15: figures 13, 14; PLATE 64: FIGURES 1-12

Globigerina daubjergensis Brönnimann, 1953:340, text-fig. 1 [Danian, Daubjerg Quarry, Denmark].

Globoconusa conusa Khalilov, 1956:249, pl. 5: fig. 2a-c [Danian, northeastern Azerbaidzhan].-Blow, 1979:1386, pl. 257: fig. 10 [Danian, DSDP Hole 20C/6/4: 72-74 cm; Brazil Basin, South Atlantic Ocean], fig. 11 [Thanet Sands, Reculver, Kent, England].

Globigerinoides daubjergensis (Brönnimann).-Loeblich and Tappan, 1957a:184, pl. 40: fig. la-c [upper Danian, Sweden], pl. 40: fig. 8a-c [Zone P1, Pine Barren Mbr., Clayton Fm., Alabama], pl. 41: fig. 9a-c [Zone P1c, McBryde Mbr., Clayton Fm., Alabama], pl. 42: figs. 6a-7c [Zone P1c, Brightseat Fm., Maryland], pl. 43: fig. la-c [Zone P1, Kincaid Fm., Texas], pl. 44: figs. 7, 8a-c [Zone P2, Wills Point Fm., Texas].—Olsson, 1960:43, pl. 8: figs. 4-6 [Zone P1, basal Hornerstown Fm., New Jersey].

Globigerina kozlowskii Brotzen and Pożaryska, 1961:162, pl. 1: figs. 1-14, p1. 2: figs. 1-17, pl. 3: figs. 1a-2c [Danian, Pamietowo, Poland].

Globigerina (Eoglobigerina) trifolia Morozova, 1961:12, pl. 1: fig. 1 [Danian, Tarkhankut, Crimea].

Globoconusa tripartita Morozova et al., 1967:193, pl. 5: figs. 4-6 [Danian, Kopet-Dagh, Crimea].

Globoconusa daubjergensis gigantea Bang, 1969:65, pl. 4: figs. 1-3b [type Danian, Denmark].

Globoconusa daubjergensis (Brönnimann).-Olsson, 1970:601, pl. 92: fig. 2a,b [lower Danian, Pine Barren Mbr., Clayton Fm., Millers Fenry, Alabama], figs. 5a-6b [Danian, basal Hornerstown Fm., New Jersey].Keller, 1993:1, pl. 3: figs. 1-3 [Danian, ODP Hole 690C/15/1: 19-21 cm], pl. 4: figs. 11-13 [Danian, Hole 690C/15/1: 121-123 cm; Weddell Sea, Southern Ocean].

Globastica daubjergensis (Brönnimann).-Blow, 1979:1235, pl. 74: figs. 7-9 [Zone P1, DSDP Hole 47.2/11/2: 148-150 cm; Shatsky Rise, northwestern Pacific Ocean], pl. 256: figs. 1-9 [Zone D2, Danian, Karlstrup, Denmark], p1. 257: figs. 3, 4 [upper Danian, Ostratorp, Sweden].

ORIGINAL DESCRIPTION.- “The specimens are very small for the genus [Globigerina]. The outline of the trochoid test is distinctly lobulate. The spiral side is pointed in the initial portion. The umbilicus is small and shallow. The final whorl, the dominant portion of the test, consists of 3 to 4 gradually in size increasing subglobular chambers. The sutures of the final whorl are strongly incised, those of the early test are not clearly visible. The extremely small, subcircular aperture opens into the shallow umbilical depression. The rough surface is covered by minute irregularly distributed spines. The thin walls are finely perforate. The direction of coiling is undetermined, 11 out of 19 specimens are coiling to the right hand side.

"The maximum diameter of the tests varies from $0.125 \mathrm{~mm}$ to $0.2 \mathrm{~mm}$, average $0.15 \mathrm{~mm}$. The height of the test is \pm 0.12 $\mathrm{mm}$ and the aperture has a diameter of $\pm 0.02 \mathrm{~mm}$. Common in sample 38." (Brönnimann, 1953:340.)
Diagnostic ChaRacters.-Test characterized by microperforate wall structure, with outer surface covered by abundant small pustules. Wide variation in spire height; some specimens marked by relatively low trochospire, others display relatively high spire (similar to short-spired Guembelitria cretacea). Occasionally exhibits small secondary (intercameral) apertures; both primary and secondary apertures sometimes covered by bullae.

DISCUSSION.-The morphology of $G$. daubjergensis has been described in detail by several authors (Brönnimann, 1953; Loeblich and Tappan, 1957a; Troelsen, 1957; Blow, 1979). Troelsen (1957:120) recognized two forms as end-member morphologic variants of Globigerina daubjergensis Brönnimann, noting that the two variants "grade imperceptibly into each other." One of these contains four chambers in each whorl, whereas the other is a three-chambered form (Eoglobigerina trifolia Morozova, 1961, Globigerina tripartita Morozova et al., 1967, and Globastica sp. Type 1 of Blow, 1979). Blow (1979:1244) suggested that the three-chambered form "is one of three later differentiates from the basic Globastica daubjergensis-morphotype." Close examination of lowermost Paleocene sequences, however, suggests that the first appearance of the three-chambered morphotype preceded that of the fourchambered morphotype (D'Hondt and Keller, 1991).

Some specimens assigned to the three-chambered morphotype appear morphologically intermediate between Guembelitria cretacea and Globoconusa daubjergensis (Plate 63: Figures 7-9). The existence of such intermediate forms in lowermost Paleocene sediments has often been interpreted to demonstrate the evolution of $G$. daubjergensis from $G$. cretacea (Olsson, 1970, 1982; Premoli Silva, 1977; Smit, 1977, 1982; Li and Radford, 1991; Liu and Olsson, 1992).

Blow (1979:1235) suggested that $G$. daubjergensis, $G$. daubjergensis gigantea, and G. kozlowskii should probably be considered as only subspecifically related. Bang (1969) proposed the subspecies designation Globoconusa daubjergensis gigantea for morphotypes of $G$. daubjergensis that are marked by an umbilical bulla and secondary bullae in intercameral sutures. The holotype illustration of Globigerina kozlowskii Brotzen and Pożaryska (1961) has a higher initial spire and tighter coiling mode than the holotype of $G$. daubjergensis. Nonetheless, the former falls within the range of morphologic variability of the latter. Hence, G. kozlowskii is a junior synonym of $G$. daubjergensis.

Recrystallization renders the holotype of Postrugoglobigerina praedaubjergensis Salaj difficult to unambiguously identify (Salaj, 1986, pl. 3: fig. 7); however, Salaj (1986) considered Postrugoglobigerina praedaubjergensis immediately ancestral to $G$. daubjergensis, and the only other illustrated specimen assigned to $P$. praedaubjergensis is a Globoconusa daubjergensis specimen (Salaj, 1986, pl. 3: figs. 8,9 ).

STABLE ISOTOPES.-Although its abundance in near-shore sequences indicates a near-surface planktic habitat (Troelsen, 


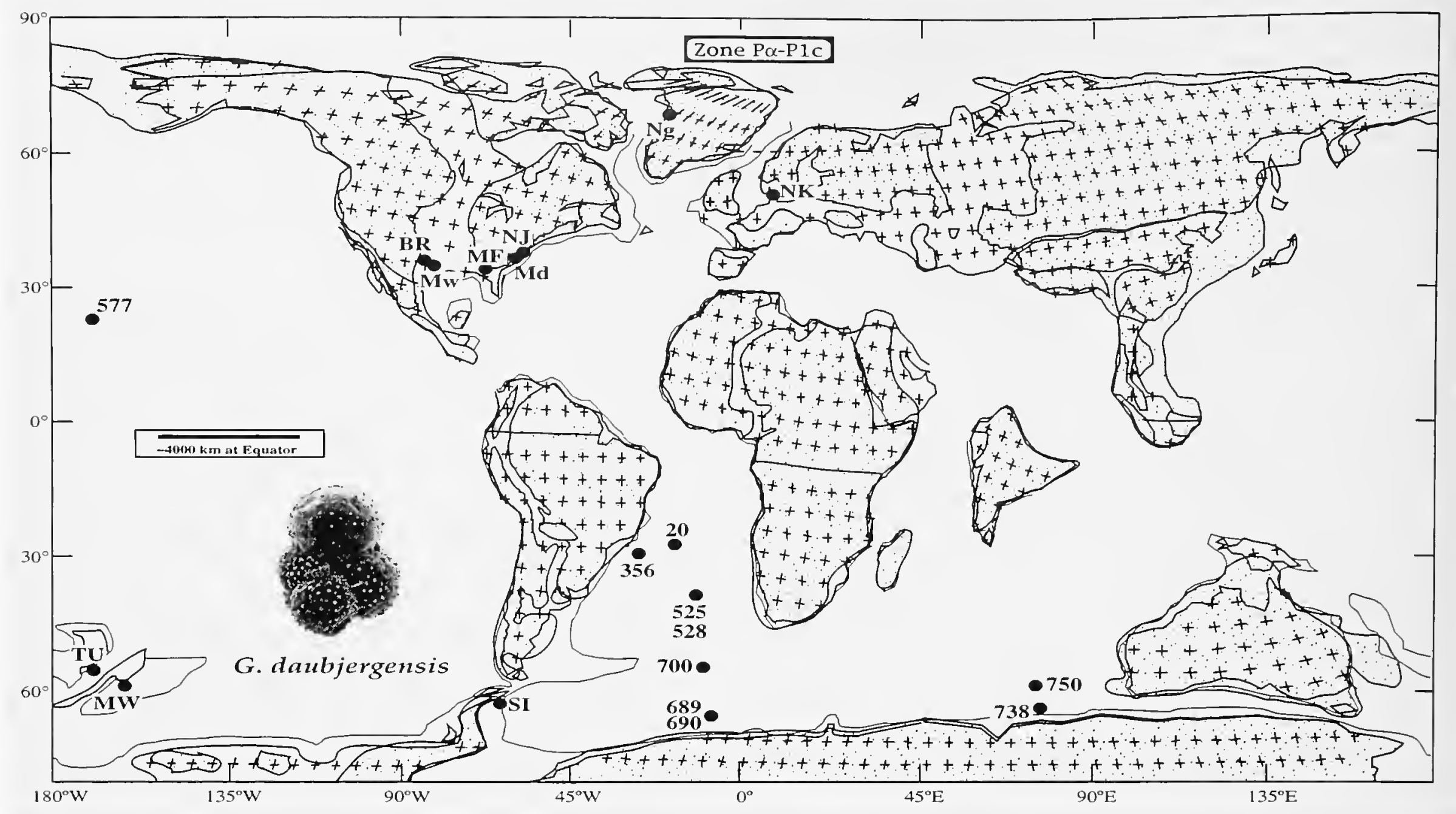

FIGURE 32.-Paleobiogeographic map showing distribution of Globoconusa daubjergensis (Brönnimann) in Zones $\mathrm{P} \alpha$ and $\mathrm{Pl}$.

1957; Keller, 1989; Liu and Olsson, 1992), its oxygen isotopic signature and open-marine abundance patterns suggest a preference for relatively cool water masses (Premoli Silva and Boersma, 1989; D'Hondt and Keller, 1991; Liu and Olsson, 1992; D'Hondt and Zachos, 1993).

StRATIGRA PHIC RANGE.-Basal Zone Pa to Zone Plc.

GLOBAL DistRIBUTION.-Globoconusa daubjergensis was abundant in high-latitude and near-shore planktonic foraminiferal assemblages (Troelsen, 1957; Keller, 1989; Premoli Silva and Boersma, 1989; Liu and Olsson, 1992). It was rare in low-latitude open-marine environments (Premoli Silva and Boersma, 1989; D'Hondt and Keller, 1991; Liu and Olsson, 1992) (Figure 32).

ORIGIN OF SPECIES.-Globoconusa daubjergensis is considered to be a direct descendent of Guembelitria cretacea (Bang, 1969; Olsson, 1970, 1982; Premoli Silva, 1977; Smit, 1977, 1982; Li and Radford, 1991; Liu and Olsson, 1992).

REPOSITORY.-Holotype (USNM CC64879) deposited in the Cushman Collection, National Museum of Natural History. Examined by SD, CL, and RKO.

\section{Genus Parvularugoglobigerina (Hofker, 1978), emended}

Postrugoglobigerina Salaj, 1986:52.

TYPE SPECIES. - Globigerina eugubina Luterbacher and Premoli Silva, 1964.
ORIGINAL DESCRIPTION.- -"Very small species with 3-6 chambers in the last-formed whorl; at the dorsal side all chambers visible; at the ventral side only those of the last-formed coil; chambers globular, with sutures depressed on both sides; umbilical cavity very small; walls thin, consisting of one lamella, with small pustules in between the pores; often the pustules are found in rows, as in Rugoglobigerina. Pores fine, pipelike, at the surface ending in a funnel, as in some species they end in pits of the wall. Aperture an umbilicalextraumbilical, crescent-like opening, with slightly thickened border, or a narrow poreless lip." (Hofker, 1978:60.)

DIAGNOSTIC CHARACTERS.-Original description inaccurate, especially with respect to surface texture. Test typically small, with moderate to flat trochospire consisting of $2^{1 / 2}$ whorls of globular or subglobular chambers. Chambers gradually increase in size; $3^{1 / 2}-7$ chambers in each whorl, separated by radial and depressed sutures on both spiral and umbilical sides. Umbilicus closed. Aperture umbilical to extraumbilical, ranging from comma-shaped arch to long narrow opening extending up apertural face in nearly equatorial position. Aperture bordered by a slight lip. Surface texture microperforate, pustulous or smooth; when pustulous, wellpreserved parvularugoglobigerinids exhibit pore-mound surface texture characteristic of guembelitriid taxa. Pores do not end in pits; pustules not aligned. 
DISCUSSION.-As noted by several previous authors, Hofker's (1978) description of Parvularugoglobigerina eugubina (Luterbacher and Premoli Silva) does not accurately describe Globigerina eugubina Luterbacher and Premoli Silva, 1964 (Bang, 1979; Brinkhuis and Zachariasse, 1988; Loeblich and Tappan, 1988; Liu and Olsson, 1992; Olsson et al., 1992). Nonetheless, the genus Parvularugoglobigerina was erected with Globigerina eugubina Luterbacher and Premoli Silva, 1964, as the type species, and it remains the generic label for that species and related forms (Hofker, 1978; Brinkhuis and Zachariasse, 1988; Loeblich and Tappan, 1988; Olsson et al., 1992).

The type species of Postrugoglobigerina is Postrugoglobigerina hariana Salaj, 1986. Because Postrugoglobigerina hariana Salaj, 1986, is a junior synonym of Globigerina eugubina Luterbacher and Premoli Silva, 1964, Postrugoglobigerina Salaj, 1986, is a junior synonym of Parvularugoglobigerina Hofker, 1978.

Parvularugoglobigerinids generally resemble woodringinids in their surface texture and apertural characteristics.

\section{Parvularugoglobigerina alabamensis (Liu and Olsson, 1992)}

\section{PLATE 65: FIGURES $1-6$}

Guembelitria? alabamensis Liu and Olsson, 1992:341, pl. 2: figs. 1-7 [Zone Pla, Pine Barren Mbr., Clayton Fm., Millers Ferry, Alabama]

ORIGINAL DESCRIPTION.- - "Test small, 110-160 $\mu \mathrm{m}$ in height and 90-135 $\mu \mathrm{m}$ in largest diameter, height-width ratio $1.0-1.2 ; 10-13$ globular or spherical chambers arranged in a high trochospire, triserial in the early and trochospiral in the later ontogenetic stage, with 3 to 4 , mostly $3^{1 / 2}$ to 4 chambers in the last formed whorls; sutures deeply incised; umbilicus open, narrow and shallow; aperture semicircular, high, with a distinct narrow but thick lip, umbilical, symmetrically situated at the base of the last formed chamber. Wall microperforate, early chambers have intensive small pore mounds, later chambers are covered with dense blunt pustules and less frequent pore-mounds." (Liu and Olsson, 1992:341.)

DIAGNOSTIC CHARACTERS. - Typically characterized by $2^{1 / 2}$ whorls, each composed of 3-4 inflated subglobular chambers, increasing slowly in size. Aperture low, centrally located, umbilical, marked by a distinct lip. Sometimes characterized by presence of pore-mounds (Plate 65: Figure 6).

DISCUSSION.-Parvularugoglobigerina alabamensis differs from Guembelitria cretacea by possessing $3^{1 / 2-4}$ (rather than 3 ) chambers in the outer whorl. It resembles $G$. cretacea in its apertural characteristics and presence of pore-mounds. Parvularugoglobigerina alabamensis sensu stricto differs from Parvularugoglobigerina extensa in having a less elongate aperture that does not extend extraumbilically.

STABLE ISOTOPES.- No data available.

StratigraPhic RANGE.-Zone P $\alpha$ to Zone P3b.

GLOBAL DISTRIBUTION.-Similar to Parvularugoglobigerina eugubina.
ORIGIN OF SPECIES.-This species evolved from Guembelitria cretacea. Parvularugoglobigerina alabamensis appears as a morphologically intermediate form between $G$. cretacea and Parvularugoglobigerina extensa Blow. For example, the apertural characteristics of $P$. alabamensis more closely resemble those of $G$. cretacea than do those of typical $P$. extensa (compare Plates 63 and 65); however, the exact phylogenetic relationship of Parvularugoglobigerina alabamensis to Parvularugoglobigerina extensa is unclear, in part because the first known occurrence of $P$. extensa is stratigraphically lower than the first known occurrence of $P$. alabamensis. It appears likely that either $P$. alabamensis evolved from $G$. cretacea independently of $P$. extensa (Liu and Olsson, 1992) or $P$. alabamensis was ancestral to $P$. extensa, but the known stratigraphic record of $P$. alabamensis is incomplete. The first hypothesis is stratigraphically simpler, but evolutionarily more complex, than the second because the former necessarily entails iterative evolution of four-chambered parvularugoglobigerine morphotypes from $G$. cretacea.

TYPE LOCALITY.-Forty feet above the base of the Clayton Fm. at Millers Ferry, Alabama.

REPOSITORY.- Holotype (USNM 460338) and paratypes (USNM 460339-460342) deposited in the Cushman Collection, National Museum of Natural History. Examined by SD, $\mathrm{CL}$, and RKO.

\section{Parvularugoglobigerina eugubina (Luterbacher and Premoli Silva, 1964)}

Figure 33; Plate 66: FIGURES 1-12; Plate 67: Figures 1-14

Globigerina anconitana Luterbacher and Premoli Silva, 1964:107, pl. 2: fig. 3a-c [Globigerina eugubina Zone, Gubbio, central Appenines, ltaly].

Globigerina eugubina Luterbacher and Premoli Silva, 1964:105, pl. 2: fig. 8a-c [Globigerina eugubina Zone, Gubbio, central Appenines, Italy].Premoli Silva and Bolli, 1973:526, pl. 7: figs. 2-5 [Globigerina eugubina Zone: figs. 2-4, DSDP Site 152/10/1: $127-130 \mathrm{~cm}$; fig. 5, DSDP Site 152/10/CC; Nicaragua Rise, Caribbean Sea].-Smit, 1982:339, pl. 1: figs. 1-20, pl. 2: figs. 1-8 [Zone P $\alpha$, Gredero, southeastern Spain].-Keller, 1988:257, pl. 3: figs. 8-10 [Zone P $\alpha$, El Kef, Tunisia]; 1989:321, pl. 6: figs. 3, 6 [Zone P $\alpha$, Brazos River, Texas].

Globigerina sabina Luterbacher and Premoli Silva, 1964:108, pl. 2: fig. 6a-c [Globigerina eugubina Zone, Gubbio, central Appenines, ltaly].

Globigerina umbrica Luterbacher and Premoli Silva, 1964:106, pl. 2: fig. 2a-c [Globigerina eugubina Zone, Gubbio, central Appenines, Italy].

Globorotalia (Turborotalia) cf. hemisphaerica (Morozova).-Blow, 1979:1077, pl. 64: fig. 8 [Zone P $\alpha$, DSDP Hole 47.2/11/3: 148-150 cm; Shatsky Rise, northwestern Pacific Ocean].

Globorotalia (Turborotalia) longiapertura Blow, 1979:1085, pl. 56: figs. 3, 4 [Zone P $\alpha$, DSDP Hole 47.2/11/6: 148-150 cm], pl. 58: figs. 3-5 [Zone P $\alpha$, DSDP Hole 47.2/11/5: 148-150 cm], pl. 63: figs. 1-9 [Zone P $\alpha$, DSDP Hole 47.2/11/4: 148-150 cm], pl. 68: fig. 3 [Zone P $\alpha$, DSDP Hole 47.2/11/3: 148-150 cm], pl. 72: fig. 1 [given as Zone P1, DSDP Hole 47.2/11/1: 148-150 cm; Shatsky Rise, northwestern Pacific Ocean].

Globorotalia (Turborotalia)? cf. pentagona (Morozova).-Blow, 1979:1088, pl. 64: fig. 1 [Zone P $\alpha$, DSDP Hole 47.2/11/4: 148-150 cm; Shatsky Rise, northwestern Pacific Ocean].

Globorotalia (Turborotalia) cf. tetragona (Morozova).-Blow, 1979:1113, pl. 64: fig. 7 [Zone P $\alpha$, DSDP Hole 47.2/11/3: 148-150 cm; Shatsky Rise, northwestern Pacific Ocean] [in part, not pl. 67: fig. 5]. 
Postrugoglobigerina hariana Salaj, 1986:53, pl. 3: figs. 1-3, 5 [base of Danian, El Haria, Tunisia].

Globigerina cf. edita (Subbotina).--Keller, 1988:257, pl. 3: fig. 18 [Zone P $\alpha$, El Kef, Tunisia].

Globigerina (Eoglobigerina) hemisphaerica Morozova.—Keller, 1988:257, pl. 3: figs. 6, 7, 11 [Zone P $\alpha$, El Kef, Tunisia]. [Not Globigerina (Eoglobigerina) hemisphaerica Morozova, 1961.]

Globigerina (Eoglobigerina) taurica Morozova.-Keller, 1988:257, pl. 3: figs. 4, 5 [Zone P $\alpha$, El Kef, Tunisia]. [Not Globigerina (Eoglobigerina) taurica Morozova, 1957.]

Parvularugoglobigerina eugubina (Luterbacher and Premoli Silva).-D'Hondt and Keller, 1991:96, pl. 4: figs. 4-6 [Zone P $\alpha$, DSDP Site 577/12/5: 115-117 cm; Shatsky Rise, northwestern Pacific Ocean].-Liu and Olsson, 1992:345, pl. 3: figs. 1-11 [Zone P $\alpha$, Pine Barten Mbr., Clayton Fm., Millers Ferry, Alabama]. [Not Hofker, 1978:60, pl. 2: figs. 6-10, pl. 3: figs. 1, 2.]

Parvularugoglobigerina longiapertura (Blow).-D'Hondt and Keller, 1991:96, pl. 4: figs. 7, 8 [Zone P $\alpha$, DSDP Site 577/12/5: 115-117 cm; Shatsky Rise, northwestern Pacific Ocean].

Parvularugoglobigerina morphotype 3, D'Hondt and Keller, 1991:93, pl. 3: figs. 10, 11 [Zone P $\alpha$, DSDP Site 577/12/5: 115-117 cm; Shatsky Rise, northwestern Pacific Ocean].

Parvularugoglobigerina cf. eugubina (Luterbacher and Premoli Silva).-Liu and Olsson, 1992:345, pl. 3: fig. 12 [Zone P $\alpha$, Pine Barren Mbr., Clayton Fm., Millers Ferry, Alabama].

ORIGINAL DESCRIPTION.--"Test very small, trochospiral; umbilical side flat, spiral side almost flat; the initial part of the spire is slightly raised relative to the final whorl. Composed of 12 to 14 globular chambers, disposed in $2 \frac{1}{2} 2$ whorls; the final whorl contains 6 chambers that increase gradually in size. The final chamber occupies about $1 / 4$ to $1 / 5$ of the test's surface. The periphery is lobate. Sutures depressed and radial on the umbilical side, depressed and slightly arcuate on the spiral side. Umbilicus quite large. Aperture at the base of the final chamber in an umbilical position. Surface slightly rugose.

Dimensions:

$\begin{array}{llll}\text { holotype } & \begin{array}{l}\text { length } \\ \text { width } \\ \text { depth }\end{array} & \begin{array}{l}0.13 \mathrm{~mm} \\ 0.095 \mathrm{~mm}\end{array} & \\ & & 0.06 \mathrm{~mm} . & \\ \text { paratypes } & & \text { A } & \text { B } \\ & \begin{array}{l}\text { length } \\ \text { width }\end{array} & 0.11 \mathrm{~mm} & 0.13 \mathrm{~mm} \\ & \text { depth } & 0.045 \mathrm{~mm} & 0.11 \mathrm{~mm} \\ & & 0.055 \mathrm{~mm} . "\end{array}$

(Luterbacher and Premoli Silva, 1964:105; translated from Italian.)

DiAGNOSTIC CHARACTERS. - Test a small trochospire with $2^{1 / 2}$ whorls, each whorl with $4 \frac{1}{2}-8$ inflated subglobular chambers; chambers increasing slowly in size; first and last whorls usually with same number of chambers. Spire height low to moderate. Test wall microperforate, well-preserved specimens sometimes exhibit surficial pore-mounds (Plate 67: Figure 14). Aperture elongate, marked by thickened rim; apertural position ranges from umbilical to nearly peripheral (Plates 66, 67). Individual specimens sometimes exhibit dorsal aperture (Plate 66: Figure 6) or both dorsal and umbilical apertures on final chamber (Plate 66: Figure 9); some showing more than one dorsal aperture.
Discussion.-Premoli Silva and Bolli (1973) declared Globigerina umbrica Luterbacher and Premoli Silva, 1964, and Globigerina sabina Luterbacher and Premoli Silva, 1964, to be junior synonyms of Globigerina eugubina Luterbacher and Premoli Silva, 1964. This broadened the concept of eugubina to include moderately spired forms with $41 / 2$ chambers in the final whorl (Globigerina sabina) and forms with 7 chambers in the final whorl (Globigerina umbrica). We also include in this broadened concept Globigerina anconitana Luterbacher and Premoli Silva (1964), a species that was described from the same assemblage as these species. Smit (1982) first noted that Globorotalia longiapertura Blow, 1979, is a junior synonym of Globigerina eugubina Luterbacher and Premoli Silva.

Following Premoli Silva and Bolli (1973) and Smit (1982), we treat several intergrading morphotypes as variants of $P$. eugubina (Plates 66, 67). These include a moderately spired form with 41/2-5 chambers (Plate 66: Figures 1, 2, Plate 67: Figures 13,14$)$ in each whorl (= Globigerina sabina Luterbacher and Premoli Silva, 1964; Globorotalia (Turborotalia) longiapertura paratypes of Blow, 1979, Plate 63: Figures 1-3; Parvularugoglobigerina morphotype 3 of D'Hondt and Keller, 1991; Parvularugoglobigerina cf. eugubina of Liu and Olsson, 1992) and a relatively low-spired form characterized by 5-8 chambers per whorl (Plate 66: Figures 7, 8, 10-12, Plate 67: Figures $1,3,10,12)$ that has an apertural extension from the umbilicus to a near peripheral location and slightly more embracing chambers with less deeply incised sutures (the longiapertura morphotype of Blow, 1979).

Globigerina minutula Luterbacher and Premoli Silva, 1964, was described along with Globigerina eugubina from the Gubbio section. The holotype drawing of $G$. minutula illustrates a very low trochospiral, 3-chambered form, which closely resembles Plate 65: Figure 13 that was selected from the type level. The specimen is completely recrystallized so that it is uncertain whether it is a microperforate or normal perforate taxon. Consequently, given its generalized morphology, we cannot accurately identify this taxon.

Although badly preserved, the type specimen of Postrugoglobigerina hariana Salaj, 1986, is indistinguishable from Parvularugoglobigerina eugubina. The holotype of $P$. hariana is a low trochospiral form with a pore-mound surface texture, five globular chambers in each of two whorls, a low rate of chamber expansion, and a "narrow slot-like interiomarginal umbilical aperture at the base of the last chamber" (Salaj, 1986:53). Consequently, Postrugoglobigerina hariana Salaj, 1986 , is regarded as a junior synonym of Parvularugoglobigerina eugubina (Luterbacher and Premoli Silva, 1964). In addition, we include in $P$. eugubina a number of forms identified by Blow (1979) and Keller (1988) to various species of cancellate Danian species (see synonomy). The illustrations of Blow and Keller clearly show a microperforate wall structure; therefore, these identifications are incorrect. The general morphology of their illustrated forms falls within the broadened concept of $P$. eugubina. 


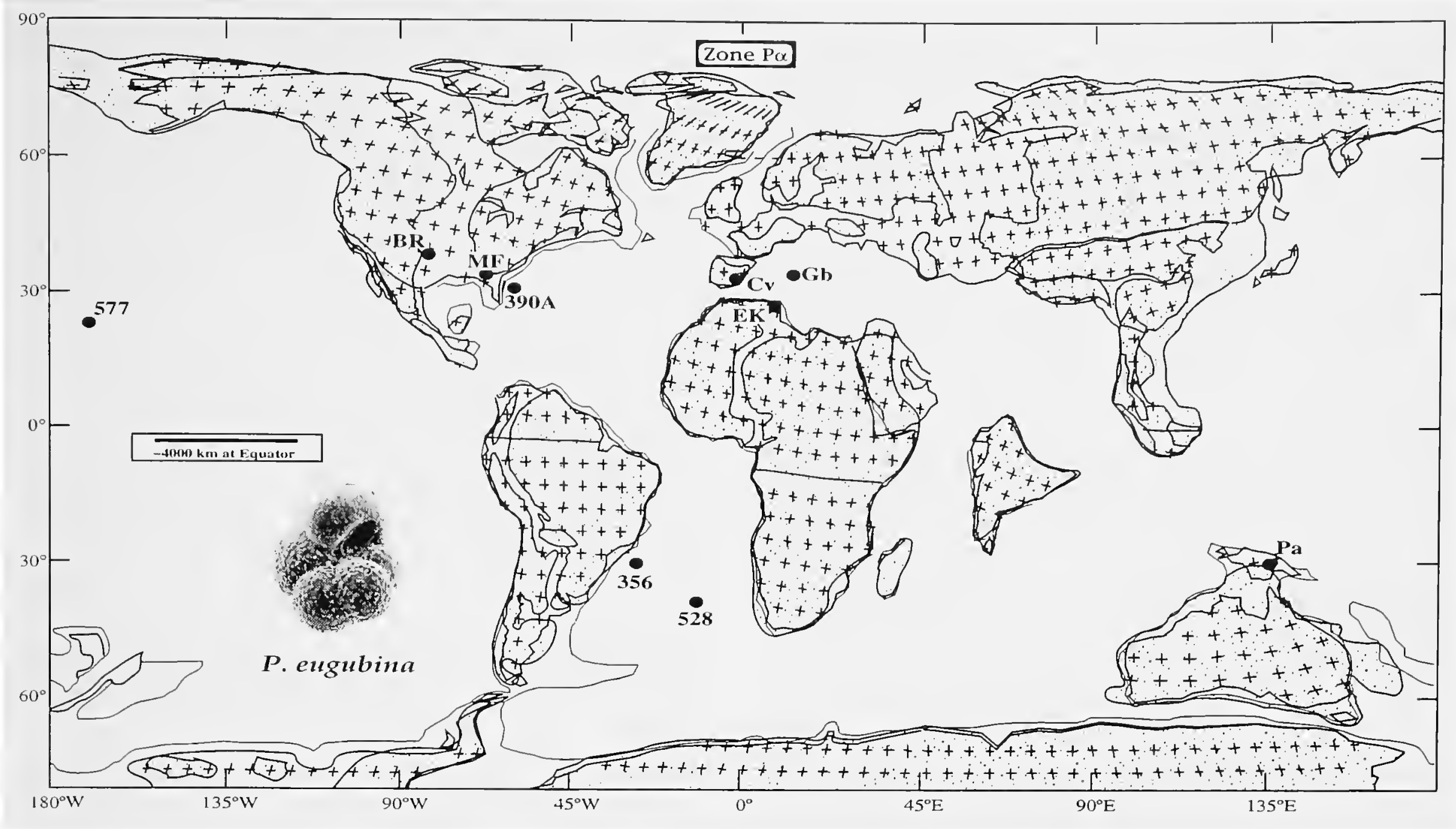

FIGURE 33.-Paleobiogeographic map showing distribution of Parvularugoglobigerina eugubina (Luterbacher and Premoli Silva) in Zone P $\alpha$.

STABLE ISOTOPES.-Oxygen isotopic data suggest that $P$. eugubina occupied a slightly deeper or cooler-season planktic niche than co-occurring $G$. cretacea and Woodringina spp. (Boersma et al., 1979; Boersma, 1984a; D'Hondt and Zachos, 1993).

\section{StRatigraPHIC RANGE.-Zone P $\alpha$.}

GLOBAL DisTrIBUTION.-Biogeographic data indicate that $P$. eugubina was a low to middle latitude taxon with an open-ocean affinity (Premoli Silva and Bolli, 1973; Premoli Silva and Boersma, 1989; D'Hondt, 1991; D'Hondt and Keller, 1991; Liu and Olsson, 1992) (Figure 33).

ORIGIN OF SPECIES.-This species evolved from Guembelitria cretacea via Parvularugoglobigerina extensa at the base of Zone P $\alpha$.

REPOSITORY.-Holotype (No. C20532) and paratype (Nos. C20554, C20555) are deposited in the Basel Museum of Natural History, Switzerland.

\section{Parvularugoglobigerina extensa (Blow, 1979)}

\section{Plate 65: FIGURES 7-13}

Woodringina hornerstownensis group, Premoli Silva and Bolli, 1973:538, 540, pl. 6: fig. 10, pl. 7: fig. 1 [Globigerina eugubina Zone, DSDP Site 150/10/2: $78-50 \mathrm{~cm}$; Caribbean Sea]. [Not Olsson, 1960.]

Eoglobigerina? extensa Blow, 1979:1220, pl. 69: fig. 7 [Zone P1, DSDP Hole 47.2/11/3: 0-5 cm], pl. 74: figs. 1, 2 [Zone P1, DSDP Hole 47.2/11/3: $148-150 \mathrm{~cm}$; Shatsky Rise, northwestern Pacific Ocean].
Eoglobigerina? fodina Blow, 1979:1221, pl. 57: figs. 5, 6 [Zone P $\alpha$, DSDP Hole 47.2/1 1/5: 148-150 cm; Shatsky Rise, northwestern Pacific Ocean].

Globigerina minutula Luterbacher and Premoli Silva.-Smit, 1982:338, pl. 3: figs. 3-6 [Zone Pa, Gredero, southeastern Spain]. [Not Luterbacher and Premoli Silva, 1964.]

Globoconusa conusa (Khalilov).-Keller, 1988:257, pl. 3: figs. 12-14 [Zone P0b, El Kef, Tunisia]; 1989:319: figs. 3, 9-11 [Zone Pa, Brazos River, Texas]. [Not Khalilov, 1956.]

Parvularugoglobigerina morphotype 1, D'Hondt and Keller, 1991:93, pl. 3: figs. 3-5, 7-10 [figs. 3, 4, 7-10, Zone P $\alpha$, DSDP Site 577/12/5: 115-117 cm; Shatsky Rise, northwestern Pacific Ocean; fig. 5, lower Danian, Brazos River, Texas].

Parvularugoglobigerina morphotype 2, D'Hondt and Keller, 1991:96, pl. 41: figs. 1, 2 [Zone P $\alpha$, DSDP Site 577/12/5: $115-117 \mathrm{~cm}$; Shatsky Rise, northwetern Pacific Ocean].

Parvularugoglobigerina aff. eugubina (Luterbacher and Premoli Silva).-Liu and Olsson, 1992:345, pl. 2: figs. 8-11 [Zone Pa, Pine Barren Mbr., Clayton Fm., Millers Ferry, Alabama].

ORIGINAL DESCRIPTION.- - "The small test is coiled in a distinct, tightly expressed, trochospire with 9-10 chambers comprising the spire and four chambers in the last whorl. In dorsal aspect, the chambers are inflated, closely appressed, closely-set and quite strongly embracing and the dorsal intercameral sutures are subradially to sinuously disposed. The dorsal and ventral intercameral sutures are depressed to moderately incised. In ventral aspect, the chambers are inflated, subglobular, but embracing. The umbilicus is closed and the aperture extends from the umbilicus extensively towards the 
anterior side of the last chamber and is a widely open, almost rectangular, opening bordered by a weakly developed but thickened porticus. The equatorial profile is strongly lobulate but almost circular in outline whilst the axial profile shows the distinct early trochospire and subglobular nature of the later chambers. The wall is very finely perforate and the mural-pits are very widely and sparsely developed; the mural pores do not open into pore pits but the wall bears fine pustules which may be the bases of normal spines. Maximum diameter of holotype $0.198 \mathrm{~mm}$. as measured electronically. The name extensa derives adjectively from the extensive nature of the aperture." (Blow, 1979:1220.)

Diagnostic ChaRACTERS. - Characterized by $2^{1 / 2}$ whorls, each composed of $3^{1 / 2}-4$ inflated subglobular chambers, increasing slowly in size. Aperture centrally located, umbilical-extraumbilical, marked by distinct lip, often elongate, and often asymmetrically oriented. Test wall microperforate. Despite original description, pustules are not bases of normal spines but guembelitriid pustules typically either perforated by pores (pore-mounds) or peripherally associated with pores.

DisCUSSION.-Parvularugoglobigerina extensa is a moderately high-spired form and is morphologically intermediate between Guembelitria cretacea and Parvularugoglobigerina eugubina. Parvularugoglobigerina extensa primarily differs from $G$. cretacea sensu stricto by possessing $31 / 2-4$ (rather than 3 ) chambers in the outer whorl and by typically having an elongate aperture that extends extraumbilically.

Eoglobigerina? fodina Blow, 1979, was originally described as characterized by a small but open umbilicus and a circular aperture "extending from the opening in a slightly oblique manner, into the terminal face of the last chamber" (Blow, 1979:1221). The name fodina was derived from the Latin word for pit or tunnel and applied to the apertural shape, which was described as looking like the entrance to a London Underground Railway tunnel (Blow, 1979:1221). The slight differences between the holotypes of extensa and fodina result from elongation of the former's aperture toward the umbilicus. Given the extreme plasticity of apertural morphology and location in related taxa (i.e., Parvularugoglobigerina eugubina and Woodringina species), such minor differences appear insufficient to maintain extensa and fodina as separate taxa. Consequently, we have reduced Eoglobigerina? fodina Blow, 1979, to a junior synonym of Parvularugoglobigerina extensa (Blow, 1979). In addition, the 31/2-4 chambered inflated subglobular, microperforate forms described by Premoli Silva and Bolli (1973), Smit (1982), Keller (1988), D'Hondt and Keller (1991), and Liu and Olsson (1992) under various names (see synonomy) are placed in $P$. extensa.

Although Blow (1979:1220) provisionally placed extensa and fodina in the genus Eoglobigerina, he recognized their microperforate structure as quite "distinct from the normal perforate, cancellate or reticulate, wall of the eobulloidestrivialis-edita group." On that basis, he expressed doubt that assignment of those forms to Eoglobigerina would be maintained in future studies. On the basis of wall structure and texture, Blow (1979) suggested that extensa and fodina (= extensa) were more closely related to Globastica (= Globoconusa) daubjergensis than to any other species assigned to Eoglobigerina. He further hypothesized that "either fodina or extensa might be ancestral to daubjergensis or, alternatively the various forms only share a common ancestor" (Blow, 1979:1221). The latter interpretation is consistent with the present hypothesis that Globoconusa daubjergensis and Parvularugoglobigerina extensa both evolved directly from Guembelitria cretacea (Olsson, 1970, 1982; Premoli Silva, 1977; Smit, 1982; Liu and Olsson, 1992; Olsson et al., 1992).

STABLE ISOTOPES.-No data available.

StRatigra PHIC Range.- - Upper Zone P0 through Zone P $\alpha$. GLOBAL DistribuTION.- Similar to Parvularugoglobigerina eugubina.

ORIGIN OF SPECIES.-This species evolved from Guembelitria cretacea.

REPOSITORY.-Holotype (BP Cat. No. 39/60) and paratype (BP Cat. No. 40/24) are deposited at The Natural History Museum, London. Examined by GJ.

\section{Genus Woodringina Loeblich and Tappan, 1957}

TYPE SPECIES.-Woodringina claytonensis Loeblich and Tappan, $1957 b$.

ORIGINAL DESCRIPTION.- -"Test free, early stage with a single whorl of three chambers, followed by a biserial stage; chambers inflated; wall calcareous, radial in structure, finely perforate; aperture a low arched slit, bordered above by a slight lip. Family Heterohelicidae. Paleocene. Monotypic." (Loeblich and Tappan, 1957b:39.)

DiagNOSTIC CHARACTERS.-Tests contain an initial whorl of 3 chambers, later whorls of 2 chambers each. Test wall microperforate, marked by a guembelitriid surface texture (smooth walled or bearing perforate pustules). Aperture usually asymmetrically positioned and thin apertural lip infolded on one side.

DISCUSSION.-Although Woodringina remains limited to the Paleocene, it is no longer monotypic. It was assigned to the subfamily Guembelitriinae by Loeblich and Tappan (1957b). Elevation of the subfamily Guembelitriinae to the family Guembelitriidae (El-Naggar, 1971; Blow, 1979; Loeblich and Tappan, 1988) removed it from the family Heterohelicidae.

\section{Woodringina claytonensis Loeblich and Tappan, 1957}

Plate 13: Figures 6-8; Plate 68: Figures 1-6

Woodringina claytonensis Loeblich and Tappan, 1957b:39: fig. la-d [lower Danian, Pine Barren Mbr., Clayton Fm., Alabama]; 1957a:178, pl. 40: fig. 6 [holotype reillustrated].-D'Hondt, 1991:172, pl. 1: figs. 8, 11, 12 [figs. 8, 12, DSDP Site 577/12/5: 94-96 cm; fig. 11, lower Danian, Brazos River, Texas], pl. 2: figs. 4, 12 [DSDP Site 577/12/5: 94-96 cm; Shatsky Rise, northwestern Pacific Ocean].-Liu and Olsson, 1992:341, pl. 1: figs. 4-6 
[Zone P $\alpha$, Pine Barren Mbr., Clayton Fm., Millers Ferry, Alabama].MacLeod, 1993:61, pl. 3: figs. 8-14 [ODP Hole 690C/15X/2: 28-30 cm; Maud Rise, Southem Ocean].

Woodringina hornerstownensis Olsson.-Keller, 1988:257, pl. 3: fig. 15 [Zone $\mathrm{P} \alpha$, El Kef, Tunisia]; 1989:319: figs. 3-6 [lower Danian, Brazos River, Texas]. [Not Woodringina hornerstownensis Olsson, 1960.]

Woodringina kelleri MacLeod, 1993:63, pl. 4: figs. 1-3 [Danian, DSDP Site 577A/12/2: 44-46 cm; Shatsky Rise, northwestern Pacific Ocean].

Woodringina cf. kelleri MacLeod, 1993:63, pl. 3: figs. 4, 5, 12 [Zone Pa, El Kef, Tunisia].

ORIGINAL DESCRIPTION._-“Test free, tiny, flaring rapidly; early stage with a single whorl of three chambers (reduced 'triserial'), commonly followed by three or more, rarely up to five, pairs of biserial chambers, the plane of biseriality slightly twisted in development; chambers few in number, subglobular, increasing rapidly in size; sutures distinct, constricted; wall calcareous, finely perforate and very finely hispid; aperture a low arched slit bordered above by a slight lip, somewhat asymmetrical in position.

"Length of holotype $0.15 \mathrm{~mm}$.; greatest breadth $0.12 \mathrm{~mm}$. Other specimens range from 0.12 to $0.22 \mathrm{~mm}$. in length." (Loeblich and Tappan, 1957b:39.)

DIAGNOSTIC CHARACTERS.--In general, original description accurately describes diagnostic features of $W$. claytonensis, except for description of microperforate wall as hispid. Some specimens smooth-walled (Loeblich and Tappan, 1988), others characterized by presence of scattered pore-mounds (Plate 68: Figure 6). In other respects, species highly variable morphologically, with apertural height varing from high to low. Twisted plane of biseriality, apertural asymmetry, and triseriality of the first whorl more strongly pronounced in some specimens than in others within same assemblages.

DISCUSSION.-MacLeod (1993:92) described Woodringina kelleri as distinguished from Woodringina claytonensis by the former's "laterally compressed adult chambers, and ... its large elongate aperture that is surrounded by a well-developed discontinuous apertural rim;" however, the final chambers of both holotypes are similarly subglobular in edge and plan view (compare MacLeod, 1993, pl. IV: figs. 1-3 to Loeblich and Tappan, 1957b, pl. 39: fig. 1; see also Plate 13: Figures 6, 7). The only other figured specimen identified by MacLeod (1993) as $W$. kelleri also lacks laterally compressed chambers and closely resembles the $W$. claytonensis holotype in the shape of its final chambers (compare D'Hondt, 1991, pl. 2: fig. 4 to Loeblich and Tappan, 1957b, pl. 39: fig. 1). Comparison of the respective apertural characteristics of $W$. claytonensis and $W$. kelleri is complicated by the absence of $W$. claytonensis paratype specimens and the physical obstruction of the $W$. claytonensis holotype aperture. Nonetheless, the $W$. claytonensis holotype also appears to have a large elongate aperture surrounded by a well-developed, discontinuous apertural rim (Plate 13: Figure 7). The aperture of the $W$. kelleri holotype (Plate 13: Figure 8) does appear to be more centrally located than that of the $W$. claytonensis holotype. This difference appears insufficient to warrant maintenance of $W$. kelleri as a separate taxon, given the pronounced variability in position, height, and number of apertures exhibited by otherwise similar specimens in populations of Woodringina and other guembelitriid genera (i.e., Guembelitria and Parvularugoglobigerina). Hence, we consider Woodringina kelleri MacLeod, 1993, a junior synonym of Woodringina claytonensis Loeblich and Tappan, 1957.

STABLE ISOTOPES. - The stable isotopic signature of this species suggests an affinity for relatively warm near-surface water masses (D'Hondt and Zachos, 1993).

Stratigra Phic Range.-Basal Zone P $\alpha$ to Zone Plb.

GLOBAL DISTRIBUTION.--Woodringina claytonensis was most abundant in low-latitude open-ocean assemblages (D'Hondt and Keller, 1991; Liu and Olsson, 1992). It was rare in high-latitude open-marine environments (Liu and Olsson, 1992).

ORIGIN OF SPECIES.-This species is considered to have descended from Guembelitria cretacea (Olsson, 1970, 1982; Smit, 1977, 1982; D'Hondt, 1991; Li and Radford, 1991; Olsson et al., 1992; Liu and Olsson, 1992). D'Hondt (1991) and Liu and Olsson (1992) illustrated forms that are morphologically intermediate between Guembelitria cretacea Cushman, 1933, and Woodringina claytonensis Loeblich and Tappan, 1957. Such morphotypes are triserial in early whorls and biserial in later whorls (Guembelitria irregularis Morozova, 1961, of D'Hondt, 1991) (Plate 63: Figure 12; Plate 68: Figure 5).

REPOSITORY.-Holotype (USNM P5685) deposited in the Cushman Collection, National Museum of Natural History. Examined by SD, CL, and RKO.

\section{Woodringina hornerstownensis Olsson, 1960}

Figure 34; Plate 13: figures 4, 5; Plate 68: figures 7-14

Woodringina hornerstownensis Olsson, 1960:29, pl. 4: figs. 18, 19 [Zone P3b, Homerstown Fm., New Jersey].-D'Hondt, 1991:172, pl. 2: figs. 5-8 [figs. 5, 8, Zone P1a, DSDP Site 577/12/4: $34-36 \mathrm{~cm}$; Shatsky Rise, northwestem Pacific Ocean; figs. 6, 7, Zone P3b, Hornerstown Fm., New Jersey].—Liu and Olsson, 1992:341, pl. 1: fig. 8 [Midway Group, Plummer Stop 14, Kaufman Co., Texas].—MacLeod, 1993:63, pl. 4: figs. 6, 7, 11, 13 [lower Danian, El Kef, Tunisia].

Chiloguembelitria taurica Morozova.-Keller, 1988:257, pl. 3: fig. 3 [Zone $\mathrm{P} \alpha$, El Kef, Tunisia]. [Not Chiloguembelitria taurica Morozova, 1961.]

ORIGINAL DESCRIPTION.--“"Test small, elongate, slightly twisted, rather rapidly tapering, about twice as long as broad. Initial end consists of whorl of three chambers, rest of test consists of biserial arrangement of chambers. Wall smooth, surface of last two chambers may be finely spinose, especially near the aperture. Chambers numerous, somewhat inflated, wider than high, increasing more rapidly in width than height as added. Sutures distinctly depressed, nearly at right angles to axis of test. Aperture a low arch at one side of final chamber, directed inward, with a small lateral flange along the periphery. Length $0.15 \mathrm{~mm}$. Width 0.10 to $0.15 \mathrm{~mm}$." (Olsson, 1960:29.) 
DIAGNOSTIC CHARACTERS. - Test wall microperforate; aperture marked by a thin lip. Apertural position and height somewhat variable. Biserial portion of test distinctly twisted, although less so than $W$. claytonensis. Woodringina hornerstownensis distinguished from $W$. claytonensis by "the elongate tapering test and the almost straight sutures" (Olsson, 1960:29). Woodringina hornerstownensis often with six or more pairs of biserial chambers, whereas $W$. claytonensis usually limited to five or fewer.

DISCUSSION.-The holotype illustration and description of Chiloguembelina taurica Morozova, 1961, closely resembles W. hornerstownsis Olsson, 1960. Chiloguembelina taurica was originally described as being characterized by a "high narrow test, weakly compressed bilaterally, its height two to three times the width. Lateral outlines at first subtriangular, later almost parallel" (Morozova, 1961:18). The test of C. taurica is formed of 10-12 spheroidal chambers, and its intercameral sutures are almost straight. Although not visible in the holotype illustrations, the aperture of $C$. taurica was described as semicircular and basal (Morozova, 1961). Based on its type illustration and description, Chiloguembelina taurica Morozova, 1961, should be considered a possible junior synonym of Woodringina hornerstownensis Olsson, 1960. The holotype illustrations and descriptions of Heterohelix gradata Khalilov, 1967, and Heterohelix gradata normalis Khalilov, 1967, also closely resemble Woodringina hornerstownensis Olsson, 1961. Heterohelix gradata normalis was originally described as being characterized by an elongate "wedge-shaped [test], gradually broadening toward the obliquely trimmed-off apertural end ... chambers biserially arranged, in each offset row there are 6-8 spherical chambers.... Aperture semilunate, much shifted from the median frontal position and shielded on one side by a moderately protruding lip" (Khalilov, 1967:173). From this description $H$. gradata normalis is indistinguishable from $W$. hornerstownensis in general test morphology. Furthermore, it appears to share the asymmetry of apertural shape and position that is diagnostic of Woodringina and related taxa. Heterohelix gradata sensu stricto was distinguished from $H$. gradata normalis by its last 4-10 chambers being much larger than the preceding chambers (Khalilov, 1967). It also appears to share the chamber shape, adult chamber arrangement, and apertural asymmetry of $W$. hornerstownensis. Given the general congruence of their original illustrations and descriptions with $W$. hornerstownensis, Heterohelix gradata Khalilov and $H$. gradata normalis Khalilov should be considered possible junior synonyms of $W$. hornerstownensis Olsson, 1960. The original descriptions of $H$. gradata and $H$. gradata normalis stated that the tests of these taxa are covered with large pores (Khalilov, 1967). If so, these taxa are distinguishable from $W$. hornerstownensis on the basis of wall structure. Close examination of wall structure and other relevant characters (i.e., the presence or absence of initial triseriality) in type populations of $H$. gradata and $H$. gradata normalis are necessary to conclusively define the taxonomic status of these taxa relative to $W$. hornerstownensis.
STABLE ISOTOPES.-Biogeographic and stable isotopic data suggest an open-ocean, warm shallow-water habitat for $W$. hornerstownensis, similar to that of $W$. claytonensis (D'Hondt and Keller, 1991; Liu and Olsson, 1992; D'Hondt and Zachos, 1993).

StRATIGRA PHIC RANGE.-Zone P $\alpha$ to Zone P3b.

Global Distribution.-Widespread in high and low latitudes (Figure 34).

ORIGIN OF SPECIES.-This species is generally considered to have descended from Guembelitria cretacea via $W$. claytonensis (Olsson, 1970, 1982; Smit, 1977, 1982; D'Hondt, 1991; Li and Radford, 1991; Olsson et al., 1992; Liu and Olsson, 1992).

REPOSITORY.-Holotype (USNM 626457) deposited in the Cushman Collection, National Museum of Natural History. Unfigured paratypes deposited at Princeton University (No. 81038) and Rutgers University (No. 5026). All specimens examined by $\mathrm{SD}, \mathrm{CL}$, and RKO.

\section{Family Chiloguembelinidae Reiss, 1963}

\author{
(by S. D'Hondt and B.T. Huber)
}

ORIGINAL DESCRIPTION.- -"Trochospirally coiled with two chambers per coil arranged around an elongated axis. Test usually twisted. Aperture single, an interiomarginal asymmetrical low to high arch, bordered by an asymmetrically situated flap which is often protruding and platelike, or terminal, situated on a short neck. No distinct toothplates. Ornamentation if present consisting of inflational papillae or short spines." (Ruess, 1963:55.)

DIAGNOSTIC CHARACTERS.- - Small test comprised of biserially arranged chambers, often with a slightly twisted coiling axis. Intercameral sutures distinct, depressed, and often somewhat oblique. Wall calcareous and microperforate with smooth to pustulous surface texture. Aperture arched, rimmed by narrow lip, and generally infolded on one side of ultimate chamber. Many Chiloguembelina species with well-developed flap or flange bordering aperture along infolded side.

Discussion.-As noted in the discussion of the Guembelitriidae, the Chiloguembelinidae appears to be a monophyletic or paraphyletic family descended from Guembelitria cretacea via Woodringina claytonensis (Olsson, 1970, 1982; Premoli Silva, 1977; Smit, 1982; D'Hondt, 1991; Li and Radford, 1991; Liu and Olsson, 1992; Olsson et al., 1992). It is generally believed that this family was monophyletic throughout the Paleocene. It's post-Paleocene status is less clear, as the relationships of Chiloguembelina to such late Paleogene and Neogene taxa as Streptochilus Brönnimann and Resig, 1971, and Cassigerinella Pokorny, 1955, is presently uncertain.

Reiss (1963) originally assigned both Chiloguembelina and Zeauvigerina to the Chiloguembelinidae. Given the Late Cretaceous occurrence of Zeauvigerina (Huber and Boersma, 1994) and the earliest Paleocene derivation of Chiloguembelina from a guembelitriid ancestor, retention of this assignment 


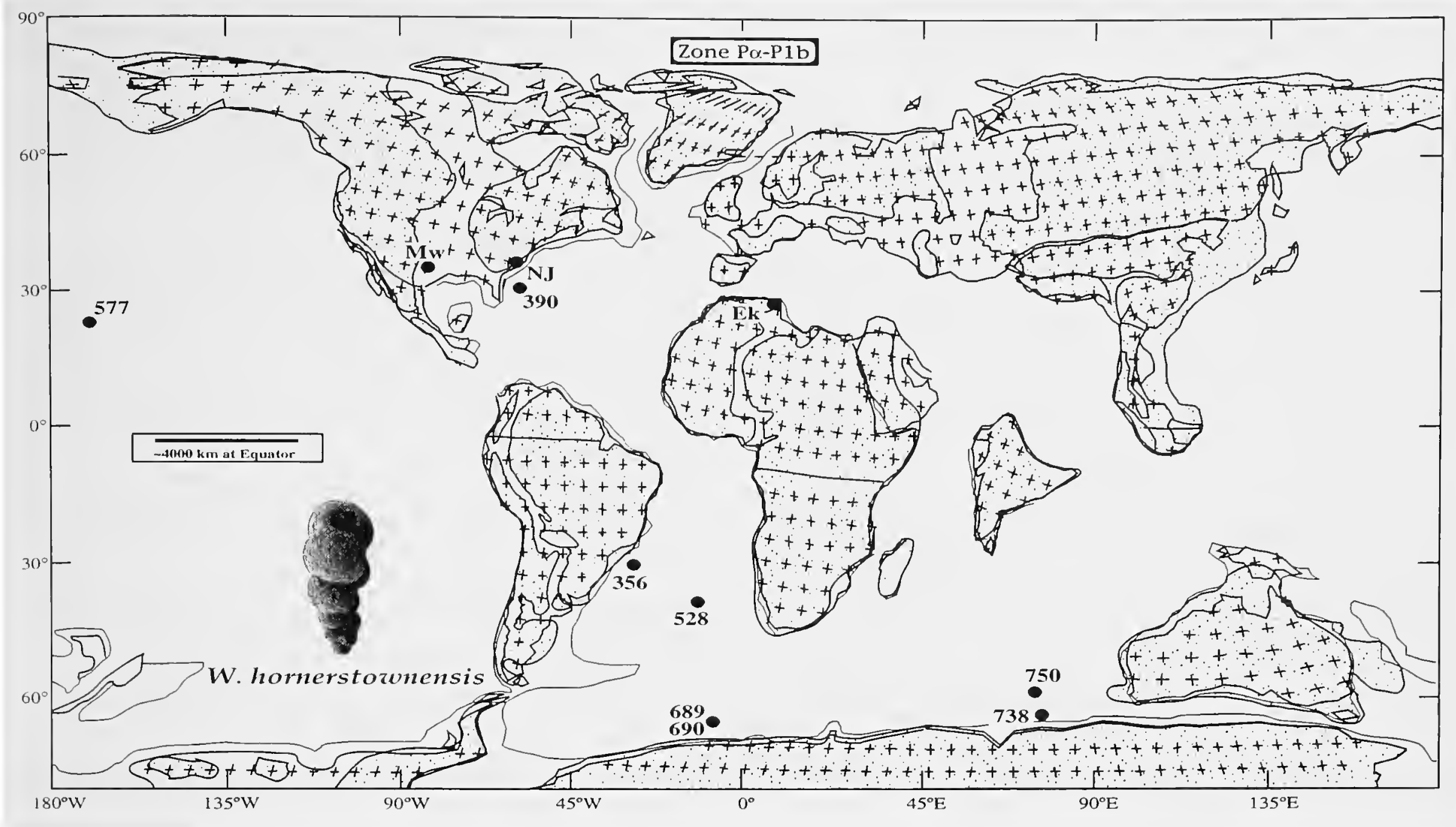

FIGURE 34.-Paleobiogeographic map showing distribution of Woodringina hornerstownensis Olsson in Zones P1 to P3.

would render the Chiloguembelinidae a polyphyletic group. On these grounds, Zeauvigerina should no longer be assigned to the Chiloguembelinidae.

\section{Genus Chiloguembelina Loeblich and Tappan, 1956}

TYPE SPECIES. - Chiloguembelina midwayensis (Cushman, 1940).

ORIGINAL DESCRIPTION. - "Test free, flaring; inflated chambers biserially arranged, with a tendency to become somewhat twisted; sutures distinct, depressed; wall calcareous, finely perforate, radial in structure, surface smooth to hispid; aperture a broad low arch bordered with a pronounced neck-like extension of the chamber; commonly this forms a more strongly developed flap at one side, so that the aperture appears to be directed toward one of the flat sides of the test." (Loeblich and Tappan, 1956:340.)

DIAGNOSTIC CHARACTERS.-The original description is diagnostic of many Chiloguembelina species (i.e., Chiloguembelina midwayensis (Cushman, 1940), C. crinita (Glaessner, 1937b), and C. morsei (Kline, 1943)). The diagnostic characters of Chiloguembelina species include the microperforate surface texture, slight twisting of the coiling axis, and infolding of the apertural lip on one side. The apertural flap noted by Loeblich and Tappan (1956) and Reiss (1963) characterizes $C$. midwayensis and closely related taxa (C. morsei and C. crinita). This flap is located on the apertural side that is not infolded and results from extension of the apertural lip (and its trailing chamber wall) over the preceding chamber. The apertural infolding and opposing flap render the chiloguembelinid aperture distinctly asymmetric with respect to the plane of biserial symmetry. This apertural asymmetry and twisting of the coiling axis are much reduced in the late Paleocene taxa Chiloguembelina trinitatensis (Cushman and Renz, 1942) and Chiloguembelina wilcoxensis (Cushman and Ponton, 1932). Apertural asymmetry is variably expressed in C. wilcoxensis; although apertural asymmetry occurs in early ontogeny, the apertures of terminal chambers appear to be symmetric in some C. wilcoxensis specimens and asymmetric in others (Plate 70: Figures 11, 12, 16, 17).

DISCUSSION.-The microperforate surface texture, apertural asymmetry, and twisted coiling axis are the primary features that unite Chiloguembelina species with woodringinids and other Paleocene descendants of Guembelitria cretacea. The biserial first whorl of Chiloguembelina species distinguishes them from Woodringina species.

Beckmann (1957) proposed that Gümbelina trinitatensis Cushman and Renz and Gümbelina wilcoxensis Cushman and Ponton descended from Chiloguembelina crinita (Glaessner). On this basis, Beckmann (1957) assigned trinitatensis and wilcoxensis to the genus Chiloguembelina. 
Chiloguembelina crinita (Glaessner, 1937)

Plate 69: FiguRES $1-8$

Gümbelina crinita Glaessner, 1937b:383, pl. 4: fig. 34a,b [Paleocene, beds from Gorjatschij Kljutsch].

Chiloguembelina crinita (Glaessner).-Beckmann, 1957:89, text-figs. 14 (1-4), pl. 21: fig. 4a,b [Globorotalia pseudomenardii and Globorotalia velascoensis Zones (Zones P4 and P5), lower Lizard Springs Fm., Trinidad].-Loeblich and Tappan, 1957a:178, pl. 49: fig. 1 [upper Paleocene, Hornerstown Fm., New Jersey], pl. 51: figs. 1a-3 [Vincentown Fm., New Jersey], pl. 56: fig. la,b [Aquia Fm., Maryland], pl. 60: fig. 6 [Nanafalia Fm., Alabama], pl. 62: fig. 1 [Velasco Fm., Mexico].-MacLeod, 1993:66, pl. 6: figs. 1, 2, 5, 6 [lower Zone P6, ODP Hole 738C/10R/4: 34-36 $\mathrm{cm}$; Kerguelen Plateau, southern Indian Ocean]. [Not Huber, 199lb:448, pl. 6: figs. 2, 3; 199lc:461, pl. 2: figs. 3, 4.]

ORIGINAL DESCRIPTION.- “"Test small, built up with about 10-15 spherical or oval-shaped, distinct, separated chambers. The spire of the initial chambers in existing specimens is not distinctly recognizable. The ratio of chamber width to the length varies strongly. The largest diameter of the last chamber is offset from the biserial plane. Consequently, the last chamber diagonally overlies the previous one, the median suture on both sides are not opposite each other and the test appears thereby somewhat distorted. The aperture opens not in the usual case towards the edge of the test, but in a direction which lies between the edge and the side of the test. In extreme cases, it is directed even along the suture of the last chamber in side view. The aperture is moderate in width, but high, half rounded and enclosed along the margin. The test surface in many specimens is covered by fine granulations, but in spite of their minuteness especially on the periphery, [there are] distinctly visible sharp tiny protuberances.

"Measurements.- length 0.17-0.22 mm.; width 0.10-0.15 mm.; thickness 0.05-0.1 mm." (Glaessner, 1937b:383; translated from German.)

DiagnostiC ChaRACTERS.-Test biserial throughout, exhibiting characteristic chiloguembelinid apertural asymmetry; aperture marked by narrow lip, infolded on one side, and expanded into distinct apertural flange on opposite side. As noted by Beckmann (1957) and Loeblich and Tappan (1957a), later chambers subglobular. Sutures distinct and depressed. Test microperforate and last chambers finely hispid.

DISCUSSION.-The later chambers of Chiloguembelina crinita specimens are much higher and more inflated than those of $C$. midwayensis and $C$. morsei. These differences are readily observable, as late-stage chambers of $C$. crinita appear subglobular in edge and plan views.

STABLE ISOTOPES.-No data available.

STRATIGRA PHIC RANGE.--Lower Zone P4 to lower Zone P6.

GLOBAL DISTRIBUTION.-Cosmopolitan.

ORIGIN OF SPECIES.-Chiloguembelina crinita is believed to have evolved from C. midwayensis (Beckmann, 1957).

REPOSITORY.-Holotype deposited in the Collections of the Institute for Fuel-Research of the Academy of the Sciences of Russia (Paleontology Division), Moscow.

\section{Chiloguembelina midwayensis (Cushman, 1940)}

Figure 35; Plate 13: Figures 9, I0, 12, 13; Plate 69: Figures 16-22

Gümbelina midwayensis Cushman, 1940:65, pl. 11: fig. 15 [Paleocene, Sumter Co., Alabama].-Cushman and Todd, 1946:58, pl. 10: fig. 15 [Paleocene, Arkansas].-Cushman, 1951:37, pl. 11: figs. 7, 8 [Paleocene, Alabama, Arkansas, and Texas].

Chiloguembelina midwayensis (Cushman)._Loeblich and Tappan, 1957a:179, pl. 41: fig. 3 [Danian, Clayton Fm., Alabama], pl. 43: fig. 7a,b [Wills Point Fm., Texas], pl. 45: fig. 9a,b [Porters Creek Clay, Alabama].-D’Hondt, 1991:173, pl. 2: fig. 13 [Zone P $\alpha$, DSDP Site 528/31/CC: 14-15 cm; Walvis Ridge, South Atlantic Ocean], fig. 14 [Zone P $\alpha$, DSDP Site 577/12/5: 34-36 cm; Shatsky Rise, northwestern Pacific Ocean]. [Not Olsson, 1970:601, pl. 91: fig. 8.-MacLeod, 1993:66, pl. 6: figs. 3, 4, 7-I0.-Huber and Boersma, 1994:282, pl. 3: fig. 3a-d.]

Chiloguembelina midwayensis midwayensis (Cushman).-Beckmann, 1957:90, text-fig. 14 (24-27), pl. 21: fig. 1a,b [Globorotalia trinidadensis through Globorotalia velascoensis Zones, lower Lizard Springs Fm., Trinidad].

Chiloguembelina midwayensis strombiformis Beckmann, 1957:90, text-fig. 14 (28-31), pl. 21: fig. 6a-c [Globorotalia pseudomenardii and Globorotalia velascoensis Zones, lower Lizard Springs Fm., Trinidad].

ORIGINAL DESCRIPTION.- “Test small, compressed, usually twice as long as broad, rapidly tapering, with the greatest breadth formed by the last pair of chambers, periphery rounded throughout, lobulate; chambers with breadth and height about equal, slightly overlapping, inflated, increasing rapidly in height as added; sutures distinct, depressed, very slightly curved, wall finely spinose; aperture high, arched, with distinct lateral flanges [sic]. Length 0.18-0.22 mm.; breadth 0.10-0.12 mm.; thickness 0.05 mm." (Cushman, 1940:65.)

DiaGNOSTIC CharaCters. - Test small, compressed in thickness (depth), and rapidly tapering. Early chambers subspherical, successive chambers increase more rapidly in breadth than in height. Late-stage chambers cross the coiling axis and overlap immediately preceding chamber. In holotype, overlap so pronounced that maximum breadth of final chamber nearly equal to maximum breadth of test (Plate 13: Figures 9, 10). Holotype's surface covered with numerous small pustules; however, last two chambers contain few pustules. Contrary to the original description, aperture of each chamber with only one distinct lateral flange (the chiloguembelinid "flap" of Loeblich and Tappan, 1956) (Plate 69: Figures 16-22).

DISCUSSION.-Chiloguembelina midwayensis strombiformis Beckman, 1957, was erected as a Paleocene subspecies of Chiloguembelina midwayensis (Cushman, 1940). The chambers of the $C$. midwayensis strombiformis holotype (Plate 13: Figures 12, 13) expand much more rapidly in depth (thickness) than do those of $C$. midwayensis sensu stricto; in late-stage chambers of $C$. midwayensis sensu stricto, chamber breadth consistently exceeds chamber depth.

STABLE ISOTOPES.-The stable isotopic signature of $C$. midwayensis suggests that this species inhabited a deeperwater or cooler-season habitat than most co-occurring taxa (Boersma and Premoli Silva, 1983; D'Hondt and Zachos, 1993). 


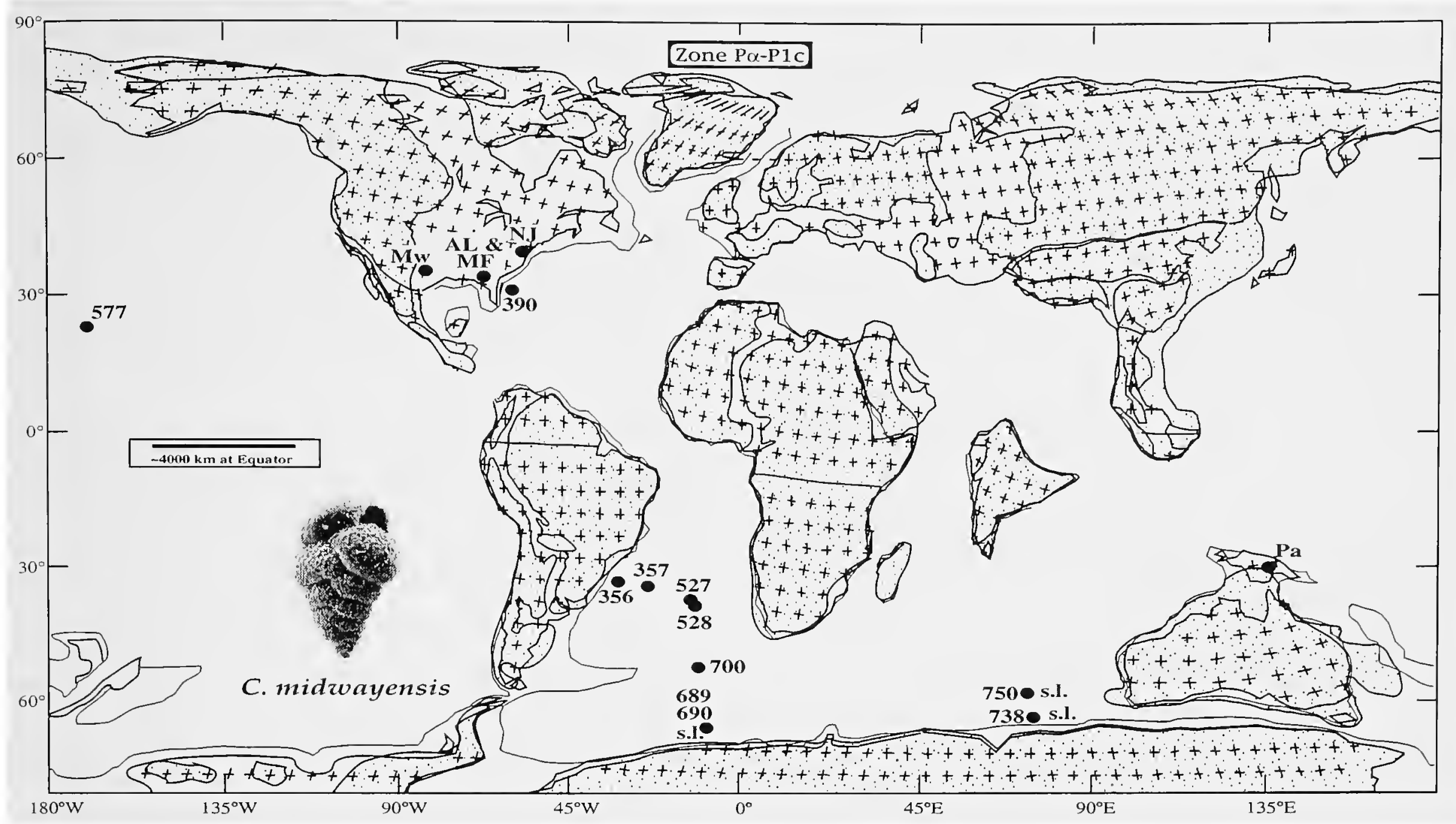

FIGURE 35.-Paleobiogeographic map showing distribution of Chiloguembelina midwayensis (Cushman) in the Danian. "s.l." refers to sensu lato forms found at high latitude sites.

StratigraPhiC Range.-Zone P $\alpha$ (D'Hondt, 1991) to Zone P5 (Beckman, 1957; Boersma, 1984b).

GLOBAL DISTRIBUTION.-Chiloguembelina midwayensis occurred at low and middle latitudes (Beckmann, 1957; Boersma, 1984b; D’Hondt and Keller, 1991; Liu and Olsson, 1992) (Figure 35).

ORIGIN OF SPECIES.-Chiloguembelina midwayensis evolved from C. morsei (Kline) (D’Hondt, 1991).

REPOSITORY.-Holotype (USNM CC35715) deposited in the Cushman Collection, National Museum of Natural History. Examined by SD, BTH, CL, and RKO.

\section{Chiloguembelina morsei (Kline, 1943)}

Plate 13: figures 14, 15; Plate 69: figures 9-15

Gümbelina morsei Kline, 1943:44, pl. 7: fig. 12 [Danian, Porters Creek Clay, Clay Co., Mississippi].

Chiloguembelina morsei (Kline).-Loeblich and Tappan, 1957a:179, pl. 40: fig. 2a,b [Danian, Erslev, Mors, Denmark], pl. 41: fig. 4 [Clayton Fm., Alabama], pl. 42: fig. 1a,b [Brightseat Fm., Maryland], pl. 43: fig. 2 [Kincaid Fm., Texas], pl. 43: fig. 6a,b [Wills Point Fm., Texas]. [Not Huber, 1991a:448, pl. 6: figs. 6, 7.]

Chiloguembelina midwayensis (Cushman).-MacLeod, 1993:66, pl. 6: figs. 3, 4 [Danian, DSDP Hole 577A/12/2: 44-46 cm; Shatsky Rise, northwestern Pacific Ocean].

ORIGINAL DESCRIPTION.-_"Test small, about twice as long as broad, regularly tapering, with greatest breadth at apertural end, periphery rounded and lobulate; chambers with breadth greater than height, inflated, increasing rapidly in size, especially in breadth; sutures distinct, depressed; wall finely but distinctly spinose; aperture high, arched, with distinct lateral flanges [sic]." (Kline, 1943:44.)

DiAGNOSTIC CHARACTERS. - Test biserial throughout. Sutures distinct and depressed; basal sutures separating earliest chambers subhorizontal, those separating later chambers oblique. Successive chambers overlap, particularly in late ontogeny. Initial chambers subspherical. Chamber breadth increases more rapidly than chamber depth, with successive chambers exhibiting a greater breadth to depth ratio than predecessor, consequently, maximum breadth of each latestage chamber greater than its maximum depth. Surface of holotype test marked by numerous small pustules; pustules less abundant on final chambers. Aperture of each chamber exhibiting only one distinct lateral flange.

DISCUSSION.-The gross morphology of Chiloguembelina morse $i$ is very similar to that of Chiloguembelina midwayensis. Loeblich and Tappan (1957a) suggested that $C$. morsei can be distinguished from $C$. midwayensis sensu stricto by the former's narrower test, more globular chambers, and more deeply constricted sutures. The two taxa are most readily distinguished by the narrowness of their tests; the chambers of 
C. morsei expand less rapidly in breadth than those of $C$. midwayensis. Consequently, the periphery of the former defines a more acute angle $\left(\sim 50^{\circ}\right)$ than that of the latter $\left(\sim 60^{\circ}\right)$. Forms intermediate between $C$. morsei and $C$. midwayensis have been illustrated as $C$. midwayensis by D'Hondt (1991:173, pl. 2: figs. 13, 15).

STABLE ISOTOPES. - No data available.

StRatigra PHIC RANGE.-Zone P $\alpha$ (D'Hondt, 1991) to Subzone P1c (Boersma, 1984b).

Global Distribution.-Low and middle latitudes (Boersma, 1984b; D'Hondt and Keller, 1991).

ORIGIN OF SPECIES. - Chiloguembelian morsei evolved from a Woodringina species in Zone P $\alpha$ (D'Hondt, 1991; Liu and Olsson, 1992).

REPOSITORY.-Holotype (USNM 487301) deposited in the Cushman Collection, National Museum of Natural History. Examined by SD, BTH, and RKO.

\section{Chiloguembelina subtriangularis Beckmann, 1957}

Plate 13: Figures 17, I8; Plate 70: Figures 1-7

Chiloguembelina subtriangularis Beckmann, 1957:91, text-fig. 15 (39-42), pl. 2I: fig. 5a,b [Paleocene, Globorotalia pusilla pusilla Zone, lower Lizard Springs Fm., Trinidad].- Said and Kerdany, 1961:331, pl. 2: fig. 6 [Paleocene, lower part of Esna Shale, Farafra Oasis, Egypt].

ORIGINAL DESCRIPTION.- “Test small, subtriangular, pointed at the base, compressed, with a subangular periphery. Chambers biserial, very slightly inflated. Sutures nearly horizontal, slightly depressed, at least in the later stages. Wall smooth. Aperture commonly slightly eccentric, semicircular to subquadrangular, may have a slight collar." (Beckmann, 1957:91.)

Diagnostic Characters.-Test small, biserial with a subangular periphery, subtriangular in side view. Chambers increasing nearly twice as rapidly in breadth than in height, slightly inflated, successive chambers slightly overlapping previous chambers, sutures somewhat depressed and nearly straight, forming a low angle with the growth axis. Aperture a low, asymmetrically positioned, interiomarginal arch surrounded by a lip that narrows toward center of chamber. Length $140-220 \mu \mathrm{m}$.

DISCUSSION.-This species is easily distinguished from other chiloguembelinids by its subtriangular test with a subangular periphery.

STABLE ISOTOPES. - No data available.

Stratigra PHIC Range.-Zone P1c to Zone P3.

GLobal Distribution.- Reported from the low to middle latitudes worldwide.

ORIGIN OF SPECIES.-Beckmann (1957) suggested that $C$. subtriangularis descended from $C$. midwayensis during the Paleocene.

REPOSITORY.- Holotype (USNM P5783), figured paratypes (USNM P5784A-D), and unfigured paratypes (USNM P5785) deposited in the Cushman Collection, National Museum of Natural History. Examined by SD and BTH.

\section{Chiloguembelina trinitatensis (Cushman and Renz, 1942)}

Plate 13: figures 11, 16; Plate 70: figures 8-10, 14

Gümbelina trinitatensis Cushman and Renz, 1942:8, pl. 2: fig. 8 [Paleocene, Soldado Fm., Trinidad].

Chiloguembelina trinitatensis (Cushman and Renz).-Beckmann, 1957:91, text-fig. 15 (43-45), pl. 21: fig. 7a,b [Globorotalia velascoensis Zone, Lizard Springs Fm., Trinidad].

ORIGINAL DESCRIPTION.--"Test slightly longer than broad, moderately compressed, rapidly tapering, greatest breadth formed by the last-formed pair of chambers, periphery rounded, lobulate; chambers with breadth and height about equal, the last-formed pair in the adult usually much larger than the remainder of the test; sutures distinct, depressed, straight, nearly at right angles to the elongate axis; wall smooth or slightly hispid, aperture high, arched. Length of holotype 0.27 $\mathrm{mm}$; breadth $0.20 \mathrm{~mm}$; thickness $0.15 \mathrm{~mm}$." (Cushman and Renz, 1942:8.)

DiAGNOSTIC CHARACTERS.-Distinguished by biserial test with chambers increasing uniformly in breadth and height, and symmetrically centered, low-arched aperture surrounded by narrow, equidimensional lip.

DISCUSSION.-The holotype of this species differs from $C$. crinita by having an aperture that is symmetrically positioned on the chamber face, and it differs from $C$. wilcoxensis by its smaller size and slower, more continuous chamber-size increase. The holotype has been extensively recrystallized so the primary wall texture is difficult to discern.

STABLE ISOTOPES.-No data available.

STRATIGRAPHIC RANGE.-Zone P5 to lower Zone P6a. In Trinidad, Beckman (1957) recorded C. trinitatensis only in the Morozovella velascoensis Zone (= Zone P5), but observations by $\mathrm{BTH}$ suggest it ranges from Zone P5 to Zone P6a at DSDP Site 152.

Global DistRibution.-Reported primarily from lowlatitude, near-shore marine sections.

ORIGIN OF SPECIES.-Beckmann (1957) suggested that $C$. trinitatensis descended from $C$. crinita during the Paleocene, but see discussion under $C$. wilcoxensis.

REPOSITORY.-Holotype (USNM CC38198) deposited in the Cushman Collection, National Museum of Natural History. Examined by BTH.

\section{Chiloguembelina wilcoxensis (Cushman and Ponton, 1932)}

Plate 13: figures 19, 20; Plate 70: figures 11-13, 15-18

Gümbelina wilcoxensis Cushman and Ponton, 1932:66, pl. 8: figs. 16, 17 [lower Eocene, Wilcox Fm., Ozark, Alabama].

Chiloguembelina wilcoxensis (Cushman and Ponton).-Beckmann, 1957:92, text-fig. 15 (49-58), pl. 21: figs. 10, 12, 13 [upper Paleocene to lower Eocene, Lizard Springs Fm., Trinidad].-Huber, 1991 b:440, pl. 6: figs. 4, 5 
[Zone AP6a, early Eocene, ODP Hole 738C/8R: 264.35 mbsf; Kerguelen Plateau, southern Indian Ocean].

ORIGINAL DESCRIPTION.—-"Test biserial, periphery broadly rounded; chambers distinct, much inflated, increasing very rapidly in the adult so that the last four chambers make up a very considerable amount of the entire test; sutures distinct, depressed; wall distinctly papillate throughout; aperture a low opening at the base of the last-formed chamber in the median line. Length $0.45 \mathrm{~mm}$; breadth $0.35 \mathrm{~mm}$; thickness $0.25 \mathrm{~mm}$." (Cushman and Ponton, 1932:66.)

DiAGNOSTIC CHARACTERS.-Distinguished by large test size, broadly rounded periphery, rapid chamber-size increase in initial portion of test, and symmetrically centered, low-arched to semicircular aperture surrounded by an equidimensional lip.

Discussion.-The final chamber in adult Chiloguembelina wilcoxensis may be normalform to strongly kummerform. The aperture on the final chamber may be a symmetrical low to moderately high semicircular arch, centered on the chamber face, and bordered by an equidimensional lip (Plate 70: Figures 11,12 ), or they may be slightly asymmetrical, off-centered on the final chamber face, and bordered by an inequidimensional lip that is slightly infolded on one side (Plate 70: Figure 16).

The symmetrical shape and positioning of the aperture and equidimensional bordering lip on adult specimens of $C$. wilcoxensis are reminiscent of the Cretaceous Heterohelicidae. Dissection of adult tests with symmetrical apertures in the center of the final chamber, however, reveal that the apertures on pre-adult chambers are asymmetrical in position and shape and the bordering lip is infolded on one side (Plate 70: Figure 12). Apertural asymmetry in early ontogeny is taken to represent a primitive feature shared with the chiloguembelinid stock; whereas apertural symmetry in adult specimens is considered a derived character that first appeared in $C$. trinitatensis. Chiloguembelina wilcoxensis differs from this species by its larger, less tapering test.

STABLE ISOTOPES.-No data available.

STRATIGRA PHIC RANGE.-Zone P4 to Zone P6a. The FAD of $C$. wilcoxensis is not well-constrained in published deep-sea records because many authors have not differentiated the chiloguembelind species. In Trinidad, Beckmann (1957) recorded the FAD of $C$. wilcoxensis in the Globorotalia pseudomenardii Zone (= Zone P4), with an uncertain occurrence within the lower part of this zone, and the LAD at the top of the Globorotalia velascoensis Zone (= Zone P5). Observations by BTH of high-latitude samples from ODP Sites 698, 700 , and 738 indicate that the FAD of this species is in the middle of Zone AP4 ( Zone P4) and its LAD in Zone AP6a ( Zone P6a).

GLOBAL DisTRIBUTION.- Reported from low to high latitudes worldwide.

ORIGIN OF SPECIES.-Although Beckmann (1957) suggested that $C$. wilcoxensis descended from $C$. crinita during the late Paleocene, it is more likely that $C$. wilcoxensis was derived from $C$. trinitatensis during the late Paleocene because $C$. wilcoxensis and $C$. trinitatensis are more similar morphologically, and the study of Caribbean DSDP Site 152 indicates that the first occurrence of $C$. trinitatensis is older than that of $C$. wilcoxensis (B. Huber, pers. observ., 1995). Both species have a similar pustulose wall texture suggesting that they are phylogenetically related (Plate 70, compare Figures 14 and 18).

REPOSITORY.-Holotype (USNM 16218) deposited in the Cushman Collection, National Museum of Natural History. Examined by BTH.

\section{Family Heterohelicidae Cushman, 1927}

$$
\text { (by B.T. Huber) }
$$

ORIGINAL DESCRIPTION. - “"Test in the more primitive forms planospiral in the young, later becoming biserial, in the more specialized genera the spiral stage and even the biserial stage may be wanting and the relationships shown by other characters; wall calcareous, perforate, ornamentation in higher genera bilaterally symmetrical; aperture when simple, usually large for the size of the test, without teeth, in some forms with apertural neck and phialine lip." (Cushman, 1927:59.)

DiAGNOSTIC CHARACTERS. - Test with biserial arrangement of alternating chambers, final arrangement either multiple or uniserial; chambers, globular to ovoid in shape; wall smooth or striated with fine to coarse parallel ridges; aperture, a low, symmetrical arch, usually at base of ultimate chamber, may be terminal, may have accessory sutural apertures.

DISCUSSION.- Only simple, biserial forms survived into the Cenozoic. The latter portion of the test often becomes uniserial.

\section{Genus Rectoguembelina Cushman, 1932}

TYPE SPECIES.-Rectoguembelina cretacea Cushman, 1932.

ORIGINAL DESCRIPTION.- - "Test with the early chambers arranged in a biserial manner similar to Guembelina, later chambers uniserial and rounded in transverse section; chambers all inflated, distinct; sutures distinct, depressed; wall calcareous, thin, very finely perforate; aperture in the early stages similar to Guembelina in the adult terminal, rounded, with a distinct neck." (Cushman, 1932:6.)

DIAGNOSTIC CHARACTERS.-Transition from biserial to uniserial portion of test very abrupt, occurring after first four or more pairs of biserial chambers, without an intervening interval of gradually increasing chamber overlap. Apertures on biserial portion interiomarginal with a small, narrow arch; apertures on uniserial chambers terminal, circular, and aligned in rectilinear fashion, without lip or toothplate. Wall calcareous, microperforate; surface smooth to finely pustulose.

DisCUSSION-Glaessner (1936) and Montanaro Gallitelli (1957) considered Rectoguembelina to be a junior synonym of Tubitextularia Sulc (type species = Pseudotextularia bohemica Sulc, 1929), whereas Loeblich and Tappan (1964, 1988) 
synonymized both of these genera under Bifarina Parker and Jones (type species $=$ Dimorphina saxipara Ehrenberg, 1854). Comparison of the type species of Rectoguembelina with the type species of Bifarina and Tubitextularia, however, reveals significant differences. The holotype illustration of Dimorphina saxipara, which is a cross-sectional view, shows a tubular extension between the apertures of successive uniserial chambers (Loeblich and Tappan, 1988, pl. 491: fig. 4), and the apertures on the uniserial chambers of Pseudotextularia bohemica are described and illustrated as alternating from one side of the chamber to the other (Sulc, 1929, pl. 1: figs. 6-16); however, the uniserial apertures of $R$. cretacea lack any tubular extensions and are terminal in position. Rectoguembelina cretacea also differs from $P$. bohemica and $D$. saxipara by having a greater number of chambers, which are less globular and more distinctly biserial prior to the onset of the uniserial growth stage. Based on comparison of the type species, Tubitextularia is retained as a junior synonym of Bifarina, whereas Rectoguembelina is resurrected to accomodate the distinctly different $R$. cretacea.

The holotype and paratypes of Rectoguembelina texana Cushman and $R$. trinitatensis Cushman and Renz are more appropriately assigned to Bifarina because the biserial stage is only represented by two to four very globular chambers, the wall texture is hispid rather than smooth, and the apertures on the uniserial chambers alternate from one side to the other prior to the final chamber. Presently, $R$. cretacea is the only species placed in Rectoguembelina.

Rectoguembelina differs from Zeauvigerina by having several, rather than one, fully uniserial chambers following the biserial stage. The early ontogeny of both taxa are similar though, as the biserial chambers have an asymmetrically positioned aperture surrounded by a narrow, equidimensional lip.

StRatigra PHIC RANGE.-Maastrichtian through Zone P2.

GLOBAL DISTRIBUTION.- - Low to middle latitudes.

ORIGIN OF GENUS.-Probably derived from the same Laeviheterohelix stock that gave rise to the Zeauvigerina plexus.

\section{Rectoguembelina cretacea Cushman, 1932}

Plate 13: Figures 1, 2; Plate 71: Figures 24-26

Rectogümbelina cretacea Cushman 1932:6, pl. 1: figs. 11, 12 [upper Maastrichtian, Arkadelphia Clay, Hope, Arkansas].

Tubitextularia laevigata Loeblich and Tappan, 1957a:180, pl. 41: fig. 6 [lower Paleocene, McBryde Limestone Mbr., Clayton Fm., Wilcox Co., Alabama].

ORIGINAL DESCRIPTION.--"Test consisting of two unequal portions, the early portion consisting of several pairs of globular chambers arranged as in Guembelina, the adult stage uniserial, formed usually by three subglobular or slightly pyriform chambers, slightly overlapping, the apertural end extended out into a tapering neck; sutures distinct, depressed; wall smooth, translucent, very finely perforate; aperture circular, at the end of the tubular neck. Length $0.25-0.35 \mathrm{~mm}$; breadth 0.08-0.10 mm; thickness 0.05-0.07 mm." (Cushman, 1932:6.)

Diagnostic Characters.-Distinguished by small, elongate biserial to uniserial test, usually with 2-4 uniserial chambers arranged in rectilinear fashion and bearing simple, terminal, round to oval-shaped aperture on short neck.

DISCUSSION.-The Paleocene holotype of $T$. laevigata Loeblich and Tappan is very similar to the $R$. cretacea holotype (Plate 13: Figures 1,2) except for the presence of more globular chambers in the uniserial growth stage. Paleocene specimens of Rectoguembelina from DSDP Site 357, however, bear uniserial chambers that range in shape from the globular forms of the $T$. laevigata holotype to forms identical to the $R$. cretacea holotype (Plate 71: Figures 24-26). It is on this basis that $T$. laevigata is considered a junior synonym of $R$. cretacea.

STABLE ISOTOPES.-Stable isotopic evidence that $R$. cretacea inhabited upper surface waters is presented in Huber and Boersma $(1994$, table $1 ;=T$. laevigata). The oxygen isotopic data reveal that $R$. cretacea was more than $1.5 \%$ more negative than the co-occurring benthic species Nuttalites truempyi, and it was more than $0.5 \%$ more negative than three other planktonic species (Globoconusa daubjergensis, Globanomalina compressa, and Globanomalina sp.).

STRATIGRAPHIC RANGE.-Mastrichtian through Zone P2.

GLOBAL DISTRIBUTION.--This species has a very irregular distribution, occurring only in near-shore sediments during the Maastrichtian and in offshore sediments at several deep sea sites during the Paleocene, ranging from the low to middle latitudes.

ORIGIN OF SPECIES.-The origin of $R$. cretacea is uncertain, but test dissections have revealed that apertures in the biserial growth stage are asymmetrically positioned and partially surrounded by a narrow lip of equidimensional thickness, which is identical to the apertures on biserial chambers of Zeauvigerina waiparaensis. This suggests that Rectoguembelina and Zeauvigerina shared a common phylogenetic stock, and Laeviheterohelix is suggested as the most closely related ancestral taxon based on similarities discussed in Huber and Boersma (1994).

REPOSITORY.-Holotype (USNM CC16308) deposited in the Cushman Collection, National Museum of Natural History. Examined by BTH.

\section{Genus Zeauvigerina Finlay, 1939}

TYPE SPECIES.-Zeauvigerina zelandica Finlay, 1939.

ORIGINAL DESCRIPTION.- "Genus similar to Eouvigerina in size, biserial arrangement of most chambers and spout-like uvigerine aperture, but differing in first and last stages. The early chambers show not the slightest trace, even in the microspheric form, of spiroplectine coiling; the final chambers have no tendency to become irregularly triserial, the whole test being regularly bolivine throughout. 
"The general similarities to Eouvigerina (especially of the aspera and gracilis type, which have somewhat the same ornament) are so marked that close relationship must surely exist. If so, the elision of the theoretical coiled early chambers and the more settled and compact development throughout is probably due to the later appearance in time of this genus, Eouvigerina proper being an Upper Cretaceous form, while the New Zealand development is Upper Middle Eocene." (Finley, 1939:541.)

Diagnostic CharaCters.-Distinguished by biserial chamber arrangement with tendency in adult specimens toward development of uniserial final chamber with near terminal or terminal, oval-shaped aperture, partially or entirely surrounded by thickened, equidimensional lip. In pre-adult chambers, aperture a low, interiomarginal arch partially bordered by narrow, equidimensional lip. Wall calcareous, microperforate; surface smooth to finely pustulose.

DISCUSSION.-There has been some disagreement about the suprageneric classification of Zeauvigerina and whether or not this is a planktonic or benthic taxon. In his original description of this genus, Finlay (1939) noted similarities in chamber arrangement and morphology of the necked aperture between Zeauvigerina and the benthic taxon Eouvigerina and suggested a strong likelihood that these were closely related. Following Finlay's (1939) comments, Loeblich (1951) emended the definition of Eouvigerina to accomodate Zeauvigerina as a junior synonym. This classification was later adopted in Loeblich and Tappan (1964). In their more recent classification of foraminifera, Loeblich and Tappan (1988) resurrected the genus Zeauvigerina but placed it in the benthic superfamily Loxostomatacea without an explanation for this reallocation. In contrast, Finlay (1947) noted that broken specimens of $Z$. teuria resemble Gümbelina (= Chiloguembelina) and suggested that Zeauvigerina was probably planktonic. Beckmann (1957) further noted that the necked, terminal aperture occurs only in the final chamber, and the earlier apertures are interiomarginal, semicircular, and eccentric in position, similar to Chiloguembelina, whereas the earlier chambers in Eouvigerina have tubular projections usually connected by a thin, band-like structure. Consequently, Beckmann (1957) and Reiss (1963) considered Zeauvigerina to be closely related to Chiloguembelina. This classification was followed by Jenkins $(1965,1971)$ and other subsequent workers until Huber and Boersma (1994) placed Zeauvigerina in the Heterohelicidae based on biometric and stratophenetic evidence. The generic description of Zeauvigerina was modified by the latter authors to accomodate wholly biserial forms of $Z$. waiparaensis (Jenkins, 1965) and " $Z$." virgata (Khalilov, 1967).

Zeauvigerina has been variously interpreted as having inhabited a plantonic or benthic habitat by various authors. The only stable isotopic data published for species of this genus were presented by Huber and Boersma (1994), who favored an interpretation of a planktic mode of life for Z. aegyptiaca, but suggested a benthic habitat or a deep-dwelling planktic habitat for Z. waiparaensis. These authors preferred the latter interpretation based on relative abundance counts of $Z$. waiparaensis that were greater than the relative abundance of all benthic species combined in pelagic carbonate samples they studied.

STRATIGRAPHIC RANGE.-Zeauvigerina waiparaensis, the oldest species assigned to Zeauvigerina, first occurs just below the base of the Abathomphalus mayaroensis Zone at ODP Site 750 in the Antarctic Indian Ocean and DSDP Site 208 in the southwestern Pacific Ocean. This genus has not been recorded elsewhere until the lower Danian at ODP Site 690 (Maud Rise) and DSDP Site 528 (Walvis Ridge) in the South Atlantic Ocean and in New Zealand. Zeauvigerina zelandica, which has the highest range of the zeauvigerinids, last occurs in the Kaiatan Stage (upper Eocene) in New Zealand.

Global Distribution.-Worldwide in high to low latitudes.

ORIGIN OF GENUS.-Probably derived from Laeviheterohelix (Heterohelicidae) during the late Campanian or early Maastrichtian.

\section{Zeauvigerina aegyptiaca Said and Kenawy, 1956}

Figure 36a; Plate 71: Figures 19, 20

Zeauvigerina aegyptiaca Said and Kenawy, 1956:141, pl. 4: fig. 1 [Paleocene, Esna Shale, measured section at Nekhl, $29^{\circ} 50^{\prime} \mathrm{N}, 33^{\circ} 34^{\prime} \mathrm{E}$, northern Sinai, Egypt].-Beckmann, 1957:92, text-fig. 15 (59-62), pl. 21: figs. 9a,b, 11 [upper Paleocene, Lizard Springs Fm., Trinidad].--Huber and Boersma, 1994:271, pl. 2: figs. 6-8 [upper Paleocene, DSPD Site 98/12/1: 119-120 $\mathrm{cm}$; Blake Plateau, western North Atlantic Ocean].

ORIGINAL DESCRIPTION.- -"Test small, about twice as long as broad, gradually broadening from the subacute initial end to the point of greatest breadth, which is slightly above the middle, after which the sides become parallel; periphery slightly rounded, in transverse section some what rectangular; biserial throughout; chambers broader than high, indistinct; sutures indistinct, slightly depressed; wall smooth; aperture rounded, at the end of a short but distinct neck, with a weakly-developed lip. Length $0.3 \mathrm{~mm}$; breadth $0.2 \mathrm{~mm}$." (Said and Kenawy, 1956:141.)

DIAGNOSTIC CHARACTERS.- Test variable in shape and size, length $150-370 \mu \mathrm{m}$, with elliptical to moderately tapering outline and rounded periphery. Most specimens biserial with uniserial final chamber and a terminal aperture produced on short neck with a poorly to well-developed surrounding lip. Less common forms biserial throughout with off-centered interiomarginal aperture.

DisCUSSION.-Unlike the late Paleocene higher latitude zeauvigerinids, $Z$. aegyptiaca usually produces a final uniserial chamber with a distinct neck and bordering rim or lip, but, within the population of $Z$. aegyptiaca, there are a few uniserial specimens lacking a neck. These are very similar to $Z$. teuria Finlay from New Zealand and may have been derived from that species during the late Paleocene. 


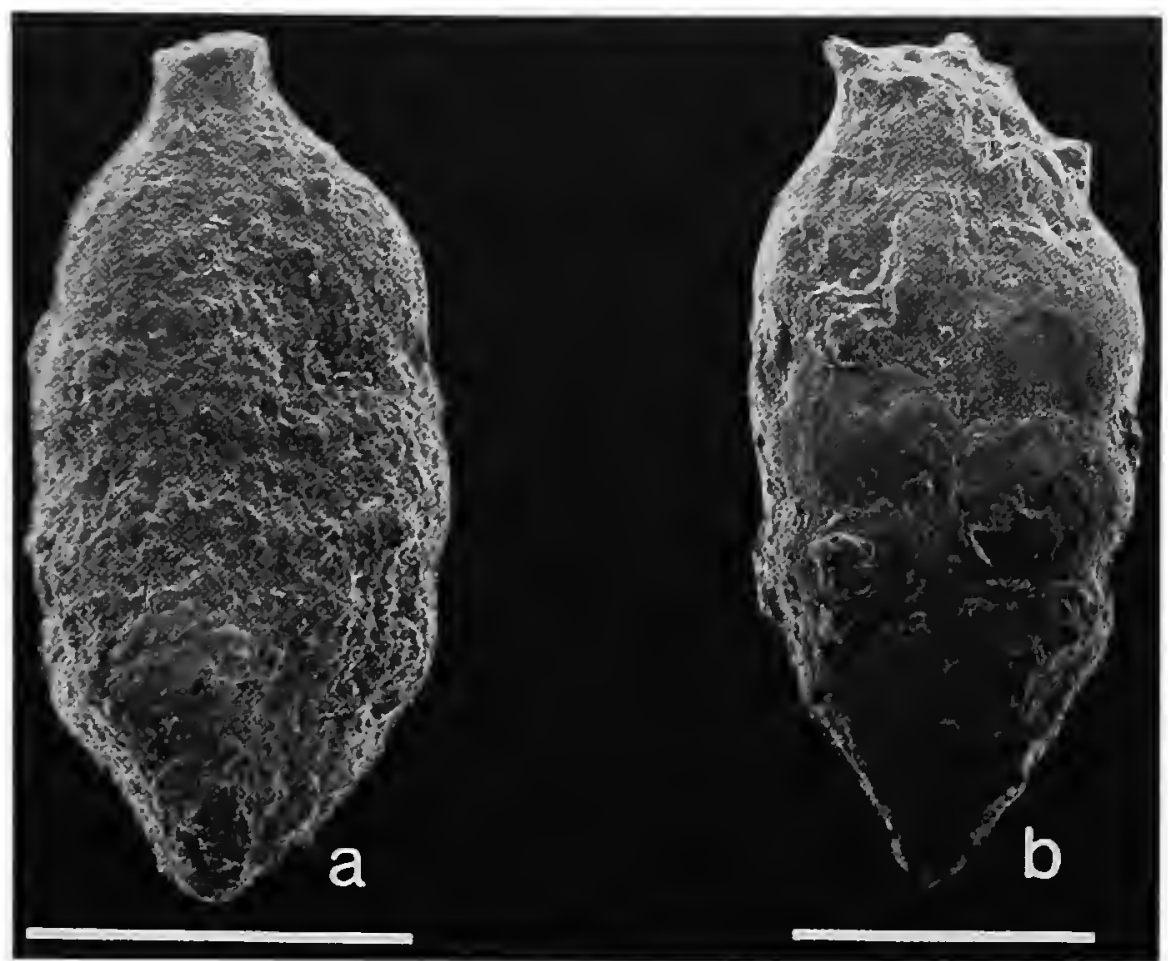

FIGURE 36.-Primary types of Zeauvigerina: a, Zeauvigerina aegyptiaca Said and Kenawy, holotype, USNM P4091, side view; b, Zeauvigerina teuria Finlay, paratype, USNM 689029, side view. (Scale bars $=100 \mu \mathrm{m}$.)

Ontogenetic growth patterns of $Z$. aegyptiaca were characterized for populations from DSDP Site 98 and for two of Beckmann's (1957) USNM hypotypes (Huber and Boersma, 1994: fig. 8). The growth trajectories show two patterns: one group includes specimens from DSDP Site 98 that are smaller than $200 \mu \mathrm{m}$ and the other group, which includes the Trinidad hypotypes and several DSDP Site 98 specimens, reaches nearly $300 \mu \mathrm{m}$ in length, has a more rapid chamber growth rate, and attains cross-sectional chamber areas that are more than twice the maximum values of the smaller forms. The former group shows growth patterns that are nearly identical to those of $Z$. waiparaensis (Jenkins, 1965). Because some intermediate forms also occur in the DSDP Site 98 populations, all of these forms are considered the same species.

Whereas the apertural necks and bordering rims are rather weakly developed in most $Z$. aegyptiaca specimens, these features are very pronounced on some forms (e.g., Plate 71: Figure 20). Some of the latter specimens closely resemble $Z$. zelandica Finlay, which was described from the Eocene in New Zealand. Biometric comparison of $Z$. aegyptiaca and $Z$. zelandica may reveal that these species are synonymous.

STABLE ISOTOPES.-Stable isotopic data for Zeauvigerina aegyptiaca were reported in Huber and Boersma (1994, table 1). The $\delta^{18} \mathrm{O}$ values for this species are very close to co-existing Chiloguembelina strombiformis $(=C$. midwayensis), intermediate between the benthic Nuttalites truempyi and the planktic $S$. triloculinoides, but considerably more negative $\left(>1 \%\right.$ ) than $A$. mckannai. The $\delta^{13} \mathrm{C}$ values are much closer to co-occurring planktonic species than to $N$. truempyi.

STRATIGRAPHIC RANGE.-Said and Kenawy (1956) identified Z. aegyptiaca from the Paleocene Esna Shale of Sinai and noted two occurrences of this species within the underlying Maastrichtian chalk. The Cretaceous occurrence of Zeauvigerina, however, was not confirmed in subsequent studies of Maastrichtian sediments underlying the Esna Shale at other sites in Egypt (Said and Kerdany, 1961; Said and Sabry, 1964). In fact, Said and Sabry (1964) stated that Z. aegyptiaca is a Landenian (upper Paleocene) index species, but they did not mention a previous occurrence in Maastrichtian sediments elsewhere. Zeauvigerina aegyptiaca was also reported by Beckmann (1957) from the lower Lizard Springs Formation in Trinidad, ranging from the Globorotalia pseudomenardii Zone through the G. velascoensis Zone (upper Paleocene), and by McGowran (1964) from the Kings Park Shale (Paleocene) in Western Australia. This species also occurs in upper Paleocene sediments from DSDP Sites 95 and 98 on Blake Plateau.

GLOBAL DisTRIBUTION.-Worldwide in the middle to low latitudes.

ORIGIN OF SPECIES.-This species is probably derived from Z. teuria Finlay during the late Paleocene (Huber and Boersma, 1994).

REPOSITORY.-Holotype (USNM P4091) deposited in the Cushman Collection, National Museum of Natural History (Figure 36a). Examined by BTH.

\section{Zeauvigerina teuria Finlay, 1947}

\section{F1GURE $36 b$}

Zeauvigerina teuria Finlay, 1947:276, pl. 4: figs. 49-54 [Paleocene, type Teurian Te Uri Stream section, Porangahau Survey District, New Zealand].-Jenkins, 1971:70, pl. 1: figs. 22, 23 [holotype reillustrated], figs. 24-26 [topotypes].-Webb, 1973:543, pl. 2: figs. 3, 4 [Paleocene, DSDP Site 208/30/1: 112-114 cm; Lord Howe Rise, Tasman Sea]. [Not Huber, 1991b:461, pl. 2: fig. 2.]

ORIGINAL DESCRIPTION.- - "Large for the genus, $1^{1 / 2}$ times length of zelandica, but more than twice its full size, stouter and thicker. Final chamber with flattish top instead of tapering to spout aperture, otherwise similar in chamber arrangement, proportions, and sutures. Very finely and densely roughened all over by minute papillae instead of actual fine, sharp spines. Aperture normal, at end of a short thick central tubular neck with distinct rim. Size, $0.45 \mathrm{~mm}$.

"Broken specimens are easily confused with Gümbelina, which has more spherical chambers, deeper sutures, and when unbroken the characteristic quarter-moon-shaped aperture. It is quite probable, however, that Zeauvigerina was derived from Gümbelina and was pelagic. In the overlying Waipawan [Paleocene] superficially similar specimens are all true Gümbelina, the accompanying Zeauvigerina being the much smaller zelandica and the smooth parri." (Finlay, 1947:276.)

DiAGNOSTIC ChARACTERS.-Distinguished from $Z$. parri and $Z$. waiparaensis by larger size and presence of necked aperture, and from $Z$. zelandica Finlay by absence of rim surrounding terminal aperture. 
DISCUSSION.-Although Jenkins (1971) considered $Z$. aegyptiaca to be a junior synonym of $Z$. teuria, comparison of USNM paratypes indicates that these are distinct species. Zeauvigerina aegyptiaca has a more spherical final chamber and a terminal aperture that is produced on a longer neck and is surrounded by a narrow rim. It is not clear from the scattered reports of these latter two species whether their stratigraphic and biogeographic ranges overlap or are separated by significant gaps.

STABLE ISOTOPES.-No data available.

STRATIGRAPHIC RANGE.- This species occurs in the middle Teurian Stage (Danian) in New Zealand (Jenkins, 1971) and was reported in Danian sediments at DSDP Site 208 (Webb, 1973).

Global Distribution.-Reported only from the middle latitudes in the Southern Hemisphere (New Zealand, DSDP Sites 208, and 277).

ORIGIN OF SPECIES.-This species probably derived from $Z$. waiparaensis (Jenkins) during the Danian (Huber and Boersma, 1994).

REPOSITORY.- Holotype and three paratypes (Register No. TF 1245) in the collections of the New Zealand Geological Survey. Paratype (USNM 689029) deposited in the Cushman Collection, National Museum of Natural History (Figure 36b). Examined by BTH.

\section{Zeauvigerina waiparaensis (Jenkins, 1965)}

Figure 37; Plate 71: FIGURES 1-18

Chiloguembelina waiparaensis Jenkins, 1965:1095, pl. 1: figs. 1-6 [Danian, Teurian Stage, Globigerina (Globigerina) pauciloculata Zone, Middle Waipara River section, New Zealand]; 1971:68, pl. 1: figs. 10-15 [holotype and paratypes reillustrated].-Huber, 1991c:461, pl. 2: figs. 5, 6 [lower Paleocene, ODP Hole 738C/20R: 376.00 mbsf; Kerguelen Plateau, southern Indian Ocean].

Heterohelix glabrans (Cushman).-Webb, 1973:543, pl. 1: fig. 4 [upper Maastrichtian, DSDP Site 208/33/4: 128-130 cm; Lord Howe Rise, Tasman Sea]. [Not Cushman, 1938.]

Zeauvigerina waiparaensis (Jenkins).-Huber and Boersma, 1994:276, pl. 1: figs. 1-10 [fig. la,b, topotype; figs. 2-8, 10, Abathomphalus mayaroensis Zone, ODP Hole $750 \mathrm{~A} / 16 \mathrm{R} / 1: 130-131 \mathrm{~cm}$; fig. 9, Globotruncanella havanensis Zone, ODP Hole 750A/19R/1: 118-120 cm; Kerguelen Plateau, southern Indian Ocean], pl. 2: figs. 1-5, 10a,b [fig. la,b, late Paleocene, ODP Hole $738 \mathrm{C} / 13 \mathrm{C} / \mathrm{CC}$; figs. 2-5c, ODP Hole $738 \mathrm{C} / 21 \mathrm{R} / \mathrm{CC}$; fig. 10a,b, ODP Hole $750 \mathrm{~A} / 17 \mathrm{R} / 1: 52-54 \mathrm{~cm}$; both Abathomphalus mayaroensis Zone, Kerguelen Plateau, southem Indian Ocean].

ORIGINAL DESCRIPTION.- - "Test free, small, elongate, biserial, tapering towards the prolocular end, compressed. Chambers subglobular, 17, the first 7 increasing slowly in size and the last 10 increasing more rapidly in size. Wall calcareous, finely perforate. Sutures subparallel in side view, slightly depressed, distinct. Aperture terminal, oval-shaped, symmetrical, with its open end towards the penultimate chamber. Length of holotype $0.26 \mathrm{~mm}$." (Jenkins, 1965:1095.)

DIAGNOSTIC CHARACTERS.-Distinguished by small, irregular outline of test, uneven biserial chamber addition, and terminal, oval-shaped aperture on mature specimens. Equidimensional, narrow lip partially surrounds and folds into aperture.

DISCUSSION.-Biometric study of this taxon revealed considerable variability in chamber arrangement and apertural positioning (Huber and Boersma, 1994). This resulted in the recognition of a sensu stricto form and four forma, including forma improcera, forma palmula, forma prolata, and forma velata, which are considered ecophenotypes or ontogenetic variants. The sensu stricto phenotype conforms to the original holotype description. Tracings of $\times$-radiograph images reveal a relatively uniform growth rate up to the ninth or tenth chamber (or test length of about $\sim 90 \mu \mathrm{m}$ ). This growth stage is followed by a series of chambers that have a diminished rate of size increase and are somewhat erratic in their growth pattern. Zeauvigerina waiparaensis sensu stricto begins to increase chamber overlap only in the last one or two chambers, and some chambers become nearly uniserial in position and have a nearly terminal aperture (e.g, Plate 71: Figures 1-4). The ultimate chambers of forms included in $Z$. waiparaensis sensu stricto are invariably smaller than the penultimate chambers, unlike specimens included in $Z$. waiparaensis forma improcera and $Z$. waiparaensis forma prolata. Dissection of the ultimate and earlier chambers of $Z$. waiparaensis sensu stricto reveals apertures that are quite different from the nearly terminal final chamber aperture; the aperture on the juvenile chambers is a small, semicircular arch oriented to the front of the test, off-centered, and interiomarginally positioned (Plate 71: Figures 11, 12). As with the ultimate chamber, an equidimensional, narrow lip partially borders the apertures of juvenile chambers. These features clearly distinguish taxa included in the Zeauvigerina plexus from species included in Chiloguembelina, which has a flange-like lip that is inequally broadened on one side of a narrow and highly arched aperture and that is oriented to the side of the test.

The forma improcera (Plate 71: Figures 13-15) and forma prolata (Plate 71: Figures 7,8) are biserial throughout and have interiomarginal, low-arched apertures. These are both considered immature growth forms of $Z$. waiparaensis (Huber and Boersma, 1994). Forma velata (Plate 71: Figures 17, 18) differs from the other $Z$. waiparaensis by having a uniserial final chamber with a terminally positioned aperture. Dissection of forma velata (Plate 71: Figure 18) reveals an interiomarginal aperture identical to the improcera and prolata forma.

STABLE ISOTOPES.-Zeauvigerina waiparaensis sensu lato yields stable isotopic values that are close to benthic foraminifer values and consistently more positive in $\delta^{18} \mathrm{O}$ and more negative in $\delta^{13} \mathrm{C}$ than co-occurring planktonic taxa (Huber and Boersma, 1994). A planktic habitat was inferred by Huber and Boersma (1994) based on relative abundance counts of $Z$. waiparaensis, which were greater than the relative abundance of all benthic species combined in the pelagic carbonate samples that they studied. 


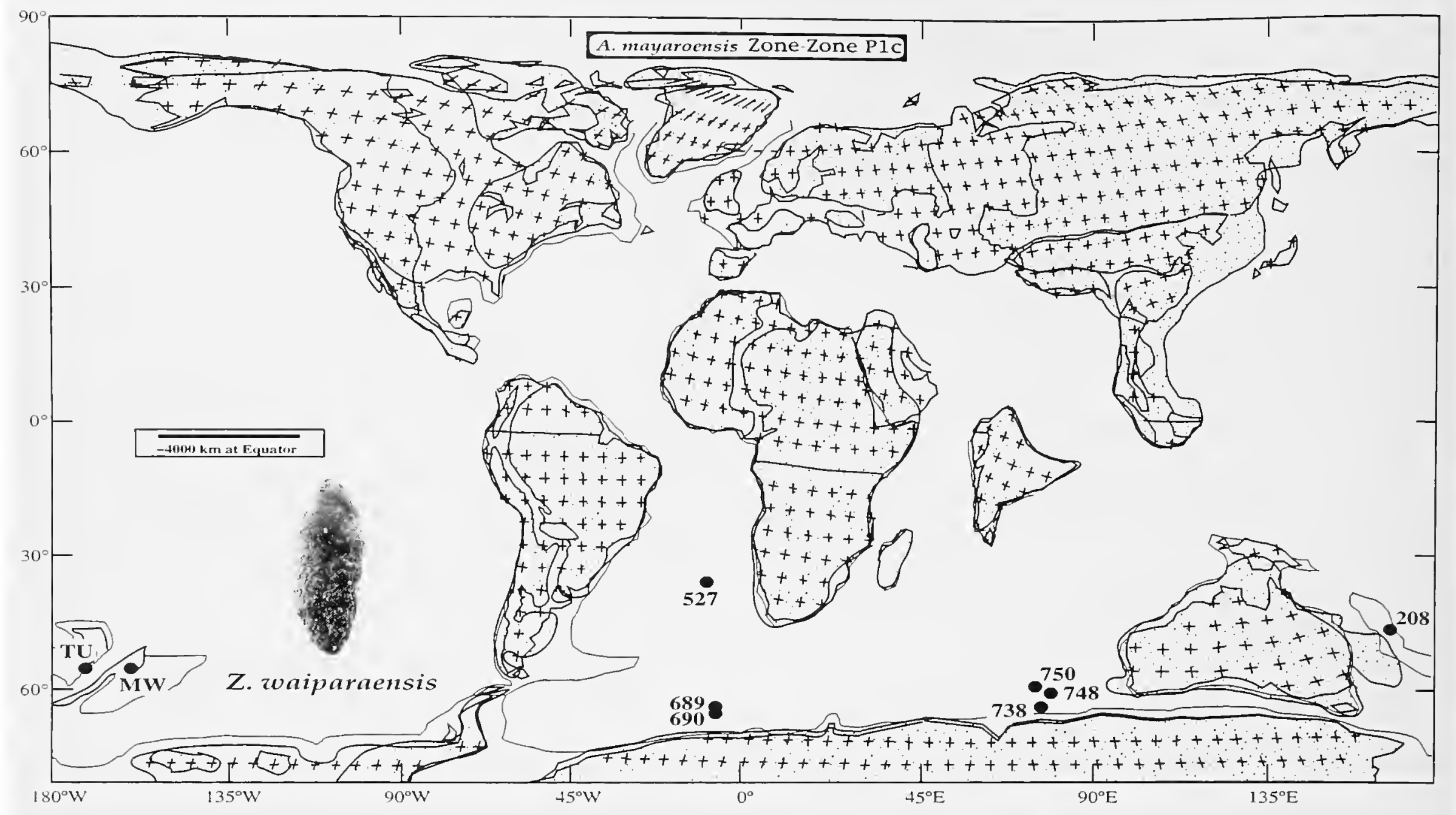

FIGURE 37.-Paleobiogeographic map showing distribution of Zeauvigerina waiparaensis (Jenkins) in the Danian.

STRATIGRA PHIC RANGE.-Zeauvigerina waiparaensis sensu stricto was described by Jenkins (1965) from Teurian (Danian) sediments in New Zealand. On the Kerguelen Plateau (ODP Sites 738 and 750) and Lord Howe Rise (DSDP Site 208), the improcera, prolata, velata, and sensu stricto forma first appear in the middle Maastrichtian, just below the base of the Abathomphalus mayaroensis Zone. These range into, but not above, the Danian in New Zealand and at the deep sea sites. Forma palmula has a separate range, first occurring in the upper Paleocene and last occurring in the lower Eocene.

Global Distribution.--Restricted to the Pacific and Indian Ocean sectors of the Southern Ocean during the late Maastrichtian, but the sensu stricto forma is present at DSDP Site 528 in the Angola Basin in only two samples: at the top of the Maastrichtian as contaminants (having the color of the Paleocene forams), and in the lowest Danian (528/31/CC) at the $\mathrm{K} / \mathrm{T}$ boundary. Zeauvigerina waiparaensis does not range farther into the Paleocene at this location and has not been found in Cretaceous or Paleocene levels at the adjacent DSDP Site 527 (Figure 37).

ORIGIN OF SPECIES.-The origin of this species is uncertain, but Huber and Boersma (1994) surmised that Laeviheterohelix was the most likely ancestor because of the similarities in wall texture, chamber morphology, and apertural features.

REPOSITORY.-Holotype and two paratypes (Register No. TF 1495) in the collections of the New Zealand Geological Survey.

\section{"Zeauvigerina" virgata (Khalilov, 1967)}

\author{
Plate 71: FiguRES 21-23
}

Heterohelix virgata Khalilov, 1967:174, fig. 9a,b [Village of Zeid, northeastern Azerbaidzhan]

"Zeauvigerina" virgata (Khalilov)--Huber and Boersma, 1994:279, pl. 2: figs. 9a-c, 1la-c [lower Paleocene, ODP Hole 750A/11R/2: 40-42 cm; Kerguelen Plateau, southern Indian Ocean].

ORIGINAL DESCRIPTION.- “Test long, compressed bilaterally, slowly becoming broader toward the apertural end; initial end bluntly compressed, while the apertural end is obliquely cut off. At the apertural end the rows of chambers are much shifted with respect to one another. Chambers spherical, alternating in two rows, forming moderate zigzags along the depressed spiral suture. Often the initial end of the test is planispiral. Chambers gradually increase in size toward the apertural end. Septal sutures depressed, slightly curved. Aperture semilunate, placed somewhat further on relative to the frontal plane of the second row of chambers. Wall calcareous, rows of pores are observed on the surface. Along the length of the test the number of pores in each row on the chambers exceeds 3 to 5." (Khalilov, 1967:174; translated from Russian.)

Diagnostic CHARACTERS.--Test elongate with very uniform chamber addition, biserial throughout; aperture interiomarginal, bordered by an equidimensional, thickened rim or lip. 
DISCUSSION, - Examination of the holotypes of Heterohelix oculis Khalilov (labeled $H$. ocutus on the holotype slide) and $H$. virgata Khalilov (first called Heterohelix parallelus, then revised on the slide) revealed two species that are similar in most features. The holotype of $H$. oculis is smaller in size, is generally thinner side to side, and has a twisted initial portion, rounder chambers, finer and fewer chambers, and a less scalloped outline. The holotype of H. oculis resembles the type figure, but the aperture is not visible; however, the holotype of $H$. virgata shows less similarity to the type figure, as the strongly slanted sutures and distinctive aperture shown in the illustration are obscured in the holotype. Nonetheless, the Southern Ocean forms illustrated herein are most similar to the holotype of $H$. virgata.

This species resembles Chiloguembelina by having biserial chambers with an off-centered, asymmetrical aperture, but it differs from it in that the aperture is forward facing and the apertural lip is of uniform thickness throughout. It is tentatively placed in "Zeauvigerina" because it resembles the immature growth forms of $Z$. waiparaensis (forma prolata) in test coiling, test elongation, chamber number, absence of overlap of sequential chambers, and in the rounded aperture oriented to the front of the test (e.g., compare Plate 71: Figures 6-8 with Plate 71: Figures 21, 22). Biometric analysis by Huber and Boersma (1994) revealed that "Z." virgata can be distinguished from $Z$. waiparaensis by its greater rate of chamber inflation that begins half way up the test. SEM illustrations show that the lip of " $Z$." virgata extends fully around the aperture (Plate 71: Figure 23) in contrast to the partial lip of $Z$. waiparaensis (Plate 71: Figures 5, 16). Although intermediate forms were not found, Huber and Boersma (1994) suggested that " $Z$." virgata may have been derived from $Z$. waiparaensis sensu lato during the Danian. If this can be proven, then the species "Z." virgata and its relatives belong in the genus Zeauvigerina.

STABLE ISOTOPES.-No data available.

STRATIGRAPHIC RANGE.- - "Zeauvigerina" virgata was first identified from the upper Danian of the lower Caucasus where it is a rare component of faunas in the Zeid section (Khalilov, 1967). These faunas probably belong to upper Danian Zone Pld, but the full range of " $Z$." virgata in the Caucasus is not currently known. Southern Ocean populations of " $Z$." virgata range from about Zone $\mathrm{P} 1 \mathrm{~b}$ into Zone $\mathrm{P} 3 \mathrm{a}$, and rare specimens are found to the top of the Paleocene.

Global Distribution.-Reported from the Caucasus and the Southern Ocean.

ORIGIN OF SPECIES. - Similarity between mature specimens of "Z." virgata and immature forms of $Z$. waiparaensis suggests the former was derived from the latter during the early Paleocene (Huber and Boersma, 1994).

REPOSITORY.-Holotype no. 638 at the Institute of Geology of the Academy of Sciences of Azerbaidzhan, Baku. 


\section{Literature Cited}

Alimarina, V.P.

1962. Nekotorye osobennosti razvitiya planktonnykh foraminifer $v$ rannem paleogene Severnogo Kavkaza [Observations on the Evolution of Planktonic Foraminifera in the Early Paleogene of the Northern Caucasus]. Byulleten Moskovskogo Obshchestva Ispytatelei Prirody, Otdel Geologicheskii, 37:128-129. [In Russian.]

1963. Nekotorye osobennosti razvitiya planktonnykh foraminifer $v$ svyazi $s$ zonalny ras'cheleniem nizhnogo paleogene sever nogo Kavkaza [Some Peculiarities in the Development of Planktonic Foraminifera and the Zonation of the Lower Paleogene of the Northern Caucasus]. Voprosy Mikropaleontologii, Akademiya Nauk SSSR, 7:158-195. [In Russian.]

Aubert, J.

1962. Les Globorotalia de la région prérifaine (Muroc septentrional). Notes et Memoires du Service Géologique Maroc, 22:1-156.

Bang, I.

1969. Planktonic Foraminifera and Biostratigraphy of the Type Danian. In P. Brönnimann and H.H. Renz, editors, Proceedings of the First International Conference on Planktonic Microfossils, 1:58-65. Geneva.

1979. Foraminifera from the Type Section of the eugubina Zone Compared with Those from the Cretaceous/Tertiary Boundary Localities in Jylland, Denmark. Danmarks Geologiske Undersogelse Arbog, 1979:139-165.

Banner, F.T.

1989. The Nature of Globanomalina Haque, 1956. Journal of Foraminiferal Research, 19:171-184.

Barron, E.J.

1987. Global Cretaceous Paleogeography: International Geologic Correlation Programme Project 191. Palaeogeography, Palaeoclimatology, Palaeoecology, 59:207-216.

Beckmann, J.P.

1957. Chiloguembelina Loeblich and Tappan and Related Foraminifera from the Lower Tertiary. In A.R. Loeblich, Jr., and collaborators, Studies in Foraminifera. Bulletin of the United States National Museum, 215:83-95.

Belford, D.J.

1967. Paleocene Planktonic Foraminifera from Papua and New Guinea. Bureau of Mineral Resources, Australia, Bulletin, 92:1-33.

1984. Tertiary Foraminifera and Age of Sediments, Ok Tedi-Wabag, Papua, New Guinea. Bulletin, Bureau of Mineral Resources, Geology, and Geophysics, Australia, 216:1-52.

Benjamini, C., and Z. Reiss

1979. Wall-hispidity and -perforation in Eocene Planktonic Foraminifera. Micropaleontology, 7:141-150.

Berggren, W.A.

1960. Paleogene Biostratigraphy and Planktonic Foraminifera of the SW Soviet Union: An Analysis of Recent Soviet Investigations. Stockholm Contributions in Geology, 6:63-125.

1962. Some Planktonic Foraminifera from the Maestrichtian and Type Danian Stages of Southern Scandinavia. Stockholm Contributions in Geology, 9(1): 106 pages.

1965. Some Problems of Paleocene-Lower Eocene Planktonic Foraminiferal Correlations. Micropaleontology, 11:278-300.

1968. Phylogenetic and Taxonomic Problems of Some Tertiary Planktonic Foraminiferal Lineages. Tulane Studies in Geology and Paleontology, 6:1-22.

1969a. Rates of Evolution in Some Cenozoic Planktonic Foraminifera. Micropaleontology, 15:351-365. 1969b. Paleogene Biostratigraphy and Planktonic Foraminifera of Northwestern Europe. In P. Brönnimann and H.H. Renz, editors, Proceedings of the First International Conference on Planktonic Microfossils, 1:121-160.

1971a. Multiple Phylogenetic Zonations of the Cenozoic Based on Planktonic Foraminifera. In A. Farinacci, editor, Proceedings of the II Planktonic Conference, 1:41-56. Rome: Edizioni Tecnoscienza.

197lb. Paleogene Planktonic Foraminiferal Faunas on Legs I-IV (Atlantic Ocean), JOIDES Deep Sea Drilling Program-a Synthesis. In A. Farinacci, editor, Proceedings of the II Planktonic Conference. 1:57-77. Rome: Edizioni Tecnoscienza.

1977. Atlas of Palaeogene Planktonic Foraminifera: Some Species of the Genera Subbotina, Planorotalites, Morozovella, Acarinina and Truncorotaloides. In A.T.S. Ramsay, editor, Oceanic Micropaleontology, pages 205-300. London: Academic Press.

1992. Paleogene Planktonic Foraminifera Magnetobiostratigraphy of the Southern Kerguelen Plateau (Sites 747-749). In S.W. Wise, Jr., R. Schlich et al., Proceedings of the Ocean Drilling Program, Scientific Results, 120:551-569. College Station, Texas: Ocean Drilling Program.

Berggren, W.A., and M.-P. Aubry

1996. A Late Paleocene-Early Eocene NW European and North Sea Magnetobiochronologic Correlation Network. In R.W.O'B. Knox, R.M. Corfield, and R.E. Dunnay, editors, Correlation of the Early Paleogene in Northwest Europe. Geological Society, Special Publication, 101:309-352.

Berggren, W.A., D.V. Kent, C.C. Swisher, III, and M.-P. Aubry

1995. A Revised Cenozoic Geochronology and Chronostratigraphy. In W.A. Berggren, D.V. Kent, M.-P. Aubry, and J. Hardenbol, editors, Geochronology, Time Scales and Global Stratigraphic Correlations. Society of Economic Paleontologists and Mineralogists, Special Publication, 54:129-212.

Berggren, W.A., and K.G. Miller

1988. Paleogene Tropical Planktonic Foraminiferal Biostratigraphy and Magnetobiochronology. Micropaleontology, 34:362-380.

Berggren, W.A., and R.D. Norris

1993. Origin of the Genus Acarinina and Revisions to Paleocene Biostratigraphy. [Abstract.] Geological Society of America, Abstracts with Programs, 24:A359.

1997. Taxonomy and Biostratigraphy of (Sub)tropical Paleocene Planktonic Foraminifera. Micropaleontology, Supplement 1, 43:1-116.

Berggren, W.A., R.K. Olsson, and R.A. Reyment

1967. Origin and Development of the Foraminiferal Genus Pseudohastigerina Banner and Blow, 1959. Micropaleontology, 13:265-288.

Bermúdez, P.J.

1961. Contribucion al estudio de las Globigerinidea de la region Caribe-Antillana (Paleocene-Reciente). Boletin de Geologia (Venezuela), Publicacion Especial, 3 (Congres Geologia Venezolano, 3d. Caracas, 1959, Mem. 3):1119-1393.

Blow, W.H.

1979. The Cainozoic Globigerinida. 1413 pages. Leiden, The Netherlands: E.J. Brill.

Boersma, A.

1984a. Campanian through Paleocene Paleotemperature and Carbon Isotope Sequence and the Cretaceous-Tertiary Boundary in the Atlantic Ocean. In W.A. Berggren and J.A. van Couvering, editors, Catastrophes and Earth History, pages 247-278. Princeton, New Jersey: Princeton University Press. 
1984b. Cretaceous-Tertiary Planktonic Foraminifers from the SouthEastern Atlantic, Walvis Ridge Area, Deep Sea Drilling Project Leg 74. In T.C. Moore, P.D. Rabinowitz et al., Initial Reports of the Deep Sea Drilling Project, 74:501-524. Washington, D.C.: U.S. Government Printing Office.

Boersma, A., and I. Premoli Silva

1983. Paleocene Planktonic Foraminiferal Biogeography and Paleoceanography of the Atlantic Ocean. Micropaleontology, 29:355-381.

Boersma, A., N.J. Shackleton, M. Hall, and Q. Given

1979. Carbon and Oxygen Isotope Variations at DSDP Site 384 (North Atlantic) and Some Paleotemperatures and Carbon Isotope Variations in the Atlantic Ocean. In B.E. Tycholke, P.R. Vogt et al., Initial Reports of the Deep Sea Drilling Project, 43:695-717. Washington, D.C.: U.S. Government Printing Office.

Bolli, H.M.

1957a. The Genera Globigerina and Globorotalia in the Paleocene-Lower Eocene Lizard Springs Formation of Trinidad, B.W.I. In A.R. Loeblich, Jr., and collaborators, Studies in Foraminifera. Bulletin of the United States National Museum, 215:61-82.

1957b. Planktonic Foraminifera from the Eocene Navet and San Fernando Formations of Trinidad, B.W.I. In A.R. Loeblich, Jr., and collaborators, Studies in Foraminifera. Bulletin of the United States National Museum, 215:155-172.

1966. Zonation of Cretaceous to Pliocene Marine Sediments Based on Planktonic Foraminifera. Boletin Informativo Asociación Venezolana de Geologia, Mineria y Petróleo, 9:3-32.

Bolli, H.M., and M.B. Cita

1960. Globigerine e Globorotalie del Paleocene di Paderno d'Adda (Italia). Rivista Italiana di Paleontologia e Stratigrafia, 66:361408.

Brinkhuis, H., and W.J. Zachariasse

1988. Dinoflagellate Cysts, Sea Level Changes and Planktonic Foraminifera Across the Cretaceous-Tertiary Boundary at El Haria, Northwest Tunisia. Marine Micropaleontology, 13:153-191.

Brönnimann, $\mathrm{P}$.

1952. Trinidad Paleocene and Lower Eocene Globigerinidae. Bulletins of American Paleontology, 34: 34 pages.

1953. Note on Planktonic Foraminifera from Danian Localities of Jutland, Denmark. Eclogae Geologicae Helvetiae, 45:339-341.

Brönnimann, P., and N.K. Brown, Jr.

1958. Hedbergella, a New Name for a Cretaceous Planktonic Foraminiferal Genus. Journal of the Washington Academy of Sciences, 48:15-17.

Brönnimann, P., and J. Resig

1971. A Neogene Globigerinacean Biochronologic Time-scale of the Southwestern Pacific. In E.L. Winterer, W.R. Reidel et al., Initial Reports of the Deep Sea Drilling Project, 7:1235-1409. Washington, D.C.: U.S. Government Printing Office.

Brotzen, F., and K. Pożaryska

1961. Foraminifères du Paléocène et de l'Eocène inférieur en Pologne septentrionale; remarques paléogéographiques. Revue de Micropaléontologie, 4:155-166.

Brummer, G.J.A., Ch. Hemleben, and M. Spindler

1986. Planktonic Foraminiferal Ontogeny and New Perspectives for Micropaleontology. Nature, 319:50-52.

Bykova, N.K.

1953. Foraminifery suzakskogo yarusa Tadzhikskoi depressii [Foraminifera of the Suzakh Stage of the Tadzhik Depression]. Trudy Vsesoyuznogo Neftyanogo Nauchno-Issledovat'skogo GeologoRazvedochnogo Instituta (VNIGRI), Mikrofauna SSSR, Sbornik, 6:5-103. [In Russian.]

Carpenter, W.B., W.K. Parker, and T.R. Jones

1862. Introduction to the Study of the Foraminifera. 139 pages. London: Ray Society Publications.
Cifelli, R., and D.J. Belford

1977. The Types of Several Species of Tertiary Planktonic Foraminifera in the Collections of the U.S. National Museum of Natural History. Journal of Foraminiferal Research, 7:100-105.

Corfield, R.M.

1989. Morozovella protocarina: A New Species of Palaeocene Planktonic Foraminferida. Journal of Micropaleontology, 8(1):97-102.

Cushman, J.A.

1925. Some New Foraminifera from the Velasco Shale of Mexico. Contributions from the Cushman Laboratory for Foraminiferal Research, 1:18-23.

1927a. An Outline of a Re-classification of the Foraminifera. Contributions from the Cushman Laboratory for Foraminiferal Research, 3:1105.

1927b. New and Interesting Foraminifera from Mexico and Texas. Contributions from the Cushman Laboratory for Foraminiferal Research, 3:111-119.

1932. Rectogümbelina, a New Genus from the Cretaceous. Contributions from the Cushman Laboratory for Foraminiferal Research, 8:4-7.

1933. Some New Foraminiferal Genera. Contributions from the Cushman Laboratory for Foraminiferal Research, 9:32-38.

1938. Cretaceous Species of Guembelina and Related Genera. Contributions from the Cushman Laboratory for Foraminiferal Research, 14:2-28.

1940. Midway Foraminifera from Alabama. Contributions from the Cushman Laboratory for Foraminiferal Research, 16:51-73.

1944a. A Paleocene Foraminiferal Fauna from the Coal Bluff Marl Member of the Naheola Formation of Alabama. Contributions from the Cushman Laboratory for Foraminiferal Research, 20:29-49.

1944b. A Foraminiferal Fauna of the Wilcox Eocene, Bashi Formation, from near Yellow Bluff, Alabama. American Journal of Science, 242:7-18.

1951. Paleocene Foraminifera of the Gulf Coastal Region of the United States and Adjacent Areas. United States Geological Survey Professional Paper, 232: 75 pages.

Cushman, J.A., and P.J. Bermúdez

1949. Some Cuban Species of Globorotalia. Contributions from the Cushman Laboratory for Foraminiferal Research, 25:26-45.

Cushman, J.A., and G.D. Hanna

1927. Foraminifera from the Eocene near San Diego, California. Transactions of the San Diego Society of Natural History, 5:45-64.

Cushman, J.A., and G.M. Ponton

1932. An Eocene Foraminiferal Fauna of Wilcox Age from Alabama. Contributions from the Cushman Laboratory for Foraminiferal Research, 8:51-72.

Cushman, J.A., and H.H. Renz

1942. Eocene, Midway, Foraminifera from Soldado Rock, Trinidad. Contributions from the Cushman Laboratory for Foraminiferal Research, 18:1-14.

1946. The Foraminiferal Fauna of the Lizard Springs Formation of Trinidad, British West Indies. Special Publications of the Cushman Laboratory for Foraminiferal Research, 18: 48 pages.

Cushman, J.A., and R. Todd

1946. A Foraminiferal Fauna from the Paleocene of Arkansas. Contributions from the Cushman Laboratory for Foraminiferal Research. 22:45-65.

Davids, $\mathrm{R}$.

1966. A Paleoecologic and Paleo-biogeographic Study of Maastrichtian Planktonic Foraminifera. 241 pages. Doctoral dissertation, Rutgers University, New Brunswick, New Jersey.

Davidzon, R.M.

1976. Novyy paleogenovyy rod planktonnykh foraminifer [A New Paleogene Planktonic Foraminiferal Genus]. Trudy, Vsesoyuznyi Nauchno-Issledovatel'skii Geologorazvedochnyi Neftyanoi Institut (VNIGNI), Tadzhikskoe Otdelenie, 183:197-198. [In Russian.] 
Davidzon, R.M., and V.G. Morozova

1964. Planktonnye i bentosnye izvestkovye foraminifery Bucharskikh sloev (Paleotsen) Tadzhikskoi depressii [Planktonic and Benthonic Calcareous Foraminifera of the Bukhara Beds (Paleocene) of the Tadzhik Depression.] Paleontologicheskiy Zhurnal, 3:23-29. [1n Russian.]

D'Hondt, S.

1991. Phylogenetic and Stratigraphic Analysis of Earliest Paleocene Biserial and Triserial Planktonic Foraminifera. Journal of Foraminiferal Research, 21:170-183.

D'Hondt, S., and G. Keller

1991. Some Patterns of Planktic Foraminiferal Assemblage Tur nover at the Cretaceous-Tertiary Boundary. Marine Micropaleontology, 17:77118.

D'Hondt, S., and J.C. Zachos

1993. On Stable Isotopic Variation and Earliest Paleocene Planktonic Foraminifera. Paleoceanography, 8:527-547.

D'Hondt, S., J.C. Zachos, and G. Schultz

1994. Stable Isotopic Signals and Photosymbiosis in Late Paleocene Planktic Foraminifera. Paleobiology, 20:391-406.

Douglas, R.G., and S.M. Savin

1978. Oxygen Isotopic Evidence for the Depth Stratification of Tertiary and Cretaceous Planktic Foraminifera. Marine Micropaleontology, 3:175-196.

Ehrenberg, C.G.

1854. Mikrogeologie. 374 pages. Leipzig: L. Voss.

El-Naggar, Z.R.

1966. Stratigraphy and Planktonic Foraminifera of the Upper CretaceousLower Tertiary. Bulletin of the British Museum (Natural History), Geology, supplement 2: 291 pages.

1971. On the Classification, Evolution, and Stratigraphical Distribution of the Globigerinacea. In A. Farinacci, editor, Proceedings of the II Planktonic Conference, 1:421-476. Rome: Edizioni Tecnoscienza.

Finlay, H.J.

1939. New Zealand Foraminifera: Key Species in Stratigraphy, No. 2. Transactions of the Royal Society of New Zealand, 69:309-329.

1947. New Zealand Foraminifera: Key Species in Stratigraphy, No. 5. New Zealand Journal of Science and Technology, 28:259-292.

Fox, S.K., and R.K. Olsson

1969. Danian Planktonic Foraminifera from the Cannonball Formation, North Dakota. Journal of Paleontology, 43:1397-1404.

Gandolfi, R.

1942. Ricerche micropaleontologiche e stratigrafiche sulla scaglia e sul flysch Cretacici dei Dintorni di Balerna (Canton Ticino). Rivista Italiana di Paleontologia, Memoria, 4: 160 pages.

Gartner, S., Jr., and W.W. Hay

1962. Planktonic Foraminifera from the Type Ilerdian. Eclogae Geologicae Helvetiae, 55:553-575.

Glaessner, M.F.

1936. Die Foraminiferengattungen Pseudotextularia und Amphimorphina. Problems in Paleontology, Moscow University Laboratory of Paleontology, 1:116-134.

1937a. Planktonische Foraminiferen aus der Kreide und dem Eozän und ihre stratigraphische Bedeutung. Studies in Micropaleontology, Publications of the Laboratory of Paleontology. Moscow University, $1: 27-52$.

1937b. Studien über Foraminiferen aus der Kreide und dem Tertiär des Kaukasus. Problems in Paleontology, Moscow University Laboratory of Paleontology, 2-3:349-410.

Gohrbandt, K.H.A.

1963. Zur Gliederung der Paläogen im Helvetikum nördlich Salzburg nach planktonischen Foraminiferen, I. Teil: Paleozän und tiefstes Untereozän. Mitteilungen der Geologischen Gesellschaft in Wien, 56:1116.
Haig, D.W., B.J. Griffin, and B.F. Ujetz

1993. Redescription of Type Specimens of Globorotalia chapmani Parr from the Upper Paleocene, Western Australia. Journal of Foraminiferal Research, 23:275-280.

Haque, A.F.M.M.

1956. The Foraminifera of the Ranikot and the Laki of the Nammal Gorge, Salt Range. Memoirs of the Geological Survey of Pakistan, Palaeontologia Pakistanica, 1:1-300.

Hemleben, $\mathrm{Ch}$

1969. Zur Morphogenese planktonischer Foraminiferen. Zitteliana, 1:91113.

Hemleben, Ch., A.H.W. Bé, O.R. Anderson, and S. Tuntivate-Choy

1977. Test Morphology, Organic Layers and Chamber Formation of the Planktonic Foraminifer Globorotalia menardii (d'Orbigny). Journal of Foraminiferal Research, 7:1-25.

Hemleben, Ch., I. Breitinger, and W. Deuser

1985. Field and Laboratory Studies on Some Globorotaliid Species from the Sargasso Sea off Bermuda. Journal of Foraminiferal Research, 15:254-272.

Hemleben, Ch., D. Mühlen, R.K. Olsson, and W.A. Berggren

1991. Surface Texture and the First Occurrence of Spines in Planktonic Foraminifera from the Early Tertiary. Geologisches Jahrbuch, 128:117-146.

Hemleben, Ch., M. Spindler, and O.R. Anderson

1989. Modern Planktonic Foraminifera. 363 pages. New York: Springer.

Hillebrandt, A. von

1962. Das Paleozän und seine Foraminiferenfauna im Becken von Reichenhall und Salzburg. Bayerische Akademie der Wissenschaften, 108: 181 pages.

Hofker, J.

1978. Analysis of a Large Succession of Samples through the Upper Maastrichtian and the Lower Tertiary of Drill Hole 47.2, Shatsky Rise, Pacific, Deep Sea Drilling Project. Journal of Foraminiferal Research, 8:46-75.

Hornibrook, N. de B.

1953. Faunal Migrations to New Zealand, I: Immigration of Foraminifera to New Zealand during the Upper Cretaceous and Tertiary. New Zealand Journal of Science and Technology, 34:436-444.

1958. New Zealand Upper Cretaceous and Tertiary Foraminiferal Zones and Some Overseas Correlations. Micropaleontology, 4:25-38.

Hornibrook, N. de B., R.C. Brazier, and C.P. Strong

1989. Manual of New Zealand Permian to Pleistocene Foraminiferal Biostratigraphy. New Zealand Geological Survey Paleontological Bulletin, 56: 175 pages.

Howe, H.V., and W.E. Wallace

1932. Foraminifera of the Jackson Eocene at Danville Landing on the Ouachita, Catahoula Parish, Louisiana. Geology Bulletin, Department of Conservation, Louisiana Geological Survey, 2:7-118.

Huber, B.T.

1990. Maestrichtian Planktonic Foraminifer Biostratigraphy of the Maud Rise (Weddell Sea, Antarctica): ODP Leg 113 Holes 689B and 690C. In P.F. Barker, J.P. Kennett et al., Proceedings of the Ocean Drilling Program, Scientific Results, 113:489-513. College Station, Texas: Ocean Drilling Program.

1991a. Planktonic Foraminifer Biostratigraphy of Campanian-Maestrichtian Sediments from Sites 698 and 700, Southern South Atlantic. In P.F. Ciesielski, Y. Kristoffersen et al., Proceedings of the Ocean Drilling Program, Scientific Results, 114:281-298. College Station, Texas: Ocean Drilling Program.

1991b. Paleocene and Early Neogene Planktonic Foraminifer Biostratigraphy of Sites 738 and 744, Kerguelen Plateau (Southern Indian Ocean). In J. Barron, B. Larsen et al., Proceedings of the Ocean Drilling Program, Scientific Results, 119:427-449. College Station, Texas: Ocean Drilling Program. 
1991c. Maestrichtian Planktonic Foraminifer Biostratigraphy and the Cretaceous/Tertiary Boundary at Hole 738C (Kerguelen Plateau, Southern Indian Ocean). In J. Barron, B. Larsen et al., Proceedings of the Ocean Drilling Program. Scientific Results, 119:451-465. College Station, Texas: Ocean Drilling Program.

1994. Ontogenetic Morphometrics of Some Late Cretaceous Trochospiral Planktonic Foraminifera from the Austral Realm. Smithsonian Contributions to Paleobiology, 77: 85 pages.

Huber, B.T., and A. Boersma

1994. Cretaceous Origin of Zeauvigerina and Its Relationship to Paleocene Biserial Planktonic Foraminifera. Journal of Foraminiferal Research, 24:268-287.

Jenkins, D.G.

1965. Planktonic Foraminiferal Zones and New Taxa from the Danian to Lower Miocene of New Zealand. New Zealand Journal of Geology and Geophysics, 8:1088-1126.

1971. New Zealand Cenozoic Planktonic Foraminifera. Palaeontological Bulletin, New Zealand Geological Survey, 42: 278 pages.

1985. Southern Mid-Latitude Paleocene to Holocene Planktic Foraminifera. In H.M. Bolli, J.B. Saunders, and K. Perch-Nielsen, editors, Plankton Stratigraphy, pages 263-282. Cambridge: Cambridge University Press.

Keller, G.

1988. Extinction, Survivorship, and Evolution across the Cretaceous/ Tertiary Boundary at El Kef. Marine Micropaleontology, 13:239263.

1989. Extended Cretaceous/Tertiary Boundary Extinctions and Delayed Population Change in Planktonic Foraminifera from Brazos River, Texas. Paleoceanography, 4:287-332.

1993. The Cretaceous-Tertiary Boundary Transition in the Antarctic Ocean and Its Global Implications. Marine Micropaleontology, 21:1-45.

Kelly, D.K., A.J. Arnold, and W.C. Parker

1996. Paedomorphosis and the Origin of the Paleocene Planktonic Foraminiferal Genus Morozovella. Paleobiology, 22:266-281.

Khalilov, D.M.

1956. O pelagicheskoy faune foraminifer Paleogenovykh otlozheniy Azerbaydzhana [Pelagic Foraminifera of the Paleogene Deposits of the Azerbaizhan SSR]. Trudy Instituta Geologii, Akademiya Nauk Azerbaidzhanskoi SSR, 17:234-255. [In Russian.]

1967. Mikrofauna i stratigrafiya paleogenovykh otlozheniy Azerbaydzhana, chast' II [Microfauna and Stratigraphy of Paleogene Strata of Azerbaydzhan, Part 2]. 216 pages. Baku, Azerbaydzhan: Akademiya Nauk Azerbaidzhanskoi SSR Instituta Geologii. [In Russian.]

Kline, V.H.

1943. Clay County Fossils: Midway Foraminifera and Ostracoda. Mississippi State Geological Survey Bulletin, 53:1-98.

Krasheninnikov, V.A.

1965. Zonal naya stratigrafiya Paleogenovykh otlozhenii [Zonal Stratigraphy of Paleogene Deposits]. International Geological Congress, $21 \mathrm{st}$ Norden, 1960, Doklady Soviet Geologists, Problem 16: Problems of Cenozoic Stratigraphy, 12D:37-61. Moscow: Akdemiya Nauk SSSR. [In Russian.]

1969. Geograficheskoe i stratgraficheskoe raspredelenie planktonnykh foraminifer $v$ otlozheniyakh Paleogena tropicheskoi i subtropicheskoi oblastei [Geographical and Stratigraphical Distribution of Planktonic Foraminifers in Paleogene Deposits of Tropical and Subtropical Areas]. Izdatelstvo "Nauka," Moscow, Akademiya Nauka SSSR, 184 pages. [In Russian.]

Krasheninnikov, V.A., and R.H. Hoskins

1973. Late Cretaceous, Paleogene and Neogene Planktonic Foraminifera. In B.C. Heezen, I.D. McGregor et al., Initial Reports of the Deep Sea Drilling Project, 20:105-203. Washington, D.C.: U.S. Government Printing Office.
Krasheninnikov, V.A., and V.P. Ponikarov

1965. Zonal Stratigraphy of Paleogene Deposits in the Nile Valley. Papers, Geological Survey and Mining Resources Department, United Arab Republic, Cairo, 132:1-26.

Kroon, D., and A.J. Nederbragt

1990. Ecology and Paleoecology of Triserial Planktic Foraminifera. Marine Micropaleotology, 16:25-38.

Leonov, G.P., and V.P. Alimarina

1960. Stratigrafiya i planktonnye foraminifery "perekhodnykh" ot mela k paleogeny sloev tsentral'nogo Predkavkazya [Stratigraphy and Plantonic Foraminifera of the Cretaceous-Paleogene "Transition" Beds of the Central Part of the North Caucasus]. In Problema V: Granitsa melovoi i paleogenovoi sistem. Mezhdunarodnyi Geologicheskii Kongress, XXI Sessiya, Doklady Sovetskikh Geologov, Izdatelstvo Akademiya Nauk, pages 29-60. [In Russian.]

Leroy, L.W.

1953. Biostratigraphy of the Maqfi Section, Egypt. Geological Society of America, Memoir, 54:1-73.

Li, Q., and S.S. Radford

1991. Evolution and Biogeography of Paleogene Microperforate Planktonic Foraminifera. Palaeogeography, Palaeoclimatology, Palaeoecology, 83:87-115.

Liu, C.

1993. Uppermost Cretaceous-Lower Paleocene Stratigraphy and Turnover of Planktonic Foraminifera Across the Cretaceous/Paleogene Boundary. 181 pages. Doctoral dissertation, Rutgers University, New Brunswick, New Jersey.

Liu, C., and R.K. Olsson

1992. Evolutionary Adaptive Radiation of Microperforate Planktonic Foraminifera Following the K/T Mass Extinction Event. Journal of Foraminiferal Research, 22:328-346.

1994. On the Origin of Danian Normal Perforate Planktonic Foraminifera from Hedbergella. Journal of Foraminiferal Research, 24:61-74.

Loeblich, A.R., Jr.

1951. Coiling in the Heterohelicidae. Contributions from the Cushman Foundation for Foraminiferal Research, 2:106-110.

Loeblich, A.R, Jr., and H. Tappan

1956. Chiloguembelina, a New Tertiary Genus of the Heterohelicidae (Foraminifera). Journal of the Washington Academy of Sciences, 46:340.

1957a. Planktonic Foraminifera of Paleocene and Early Eocene Age from the Gulf and Atlantic Coastral Plains. In A.R. Loeblich, Jr., and collaborators, Studies in Foraminifera. Bulletin of the United States National Museum, 215:173-198.

1957b. Woodringina, a New Foraminiferal Genus (Heterohelicidae) from the Paleocene of Alabama. Journal of the Washington Academy of Sciences, 47:39-40.

1961. Suprageneric Classification of the Rhizopodea. Journal of Paleontology, 35:245-330.

1964. Sarcodina Chiefly "Thecamoebians" and Foraminiferida. In R.C. Moore, editor, Treatise on Invertebrate Paleontology, Part C, Protista (2): 900 pages, 653 text-figures. Lawrence, Kansas: University of Kansas Press.

1986. Some New and Revised Genera and Families of Hyaline Calcareous Foraminiferida (Protozoa). Transactions of the American Microscopical Society, 105:239-265.

1988. Foraminiferal Genera and Their Classification. 2 volumes, 970 pages, 847 plates. New York: Van Nostrand and Reinhold Company.

Lu, G., and G. Keller

1993. The Paleocene-Eocene Transition in the Antarctic Indian Ocean: Inference from Planktic Foraminifera. Marine Micropaleontology, 21:101-142.

1995. Planktic Foraminiferal Faunal Turnovers in the Subtropical Pacific during the Late Paleocene to Early Eocene. Journal of Foraminiferal Research, 25:97-116. 
1996. Separating Ecological Assemblages Using Stable Isotope Signals: Late Paleocene to Early Eocene Planktic Foraminifera, DSDP Site 577. Journal of Foraminiferal Research, 26:103-112.

Ludbrook, N.H., and J.M. Lindsay

1969. Tertiary Foraminiferal Zones in South Australia. In P. Brönnimann and H.H. Renz, editors, Proceedings of the First International Conference on Planktonic Microfossils, 2:366-374.

Luterbacher, H.P.

1964. Studies in Some Globorotalia from the Paleocene and Lower Eocene of the Central Apennines. Eclogae Geologicae Helvetiae, 57:631730.

1975a. Paleocene and Early Eocene Planktonic Foraminifera Leg 32, Deep Sea Drilling Project. In R.L. Larson, R. Moberly et al., Initial Reports of the Deep Sea Drilling Project, 32:725-728. Washington, D.C.: U.S. Government Printing Office.

1975b. Planktonic Foraminifera of the Paleocene and Early Eocene, Possagno Section. Schweizerische Paläntologische Abhandlungen, 97:57-67, plates 1-4.

Luterbacher, H.P., and I. Premoli Silva

1964. Biostratigrafia del limite Cretaceo-Terziario nell'Appenino centrale. Rivista Italiana di Paleontologia e Stratigrafia, 70:67-128.

MacLeod, N.

1993. The Maastrichtian-Danian Radiation of Triserial and Biserial Planktic Foraminifera: Testing Phylogenetic and Adaptational Hypotheses in the (Micro)Fossil Record. Marine Micropaleontology, 21:47-100.

Mallory, V.S.

1959. Lower Tertiary Biostratigraphy of the California Coast Ranges. 146 pages. Tulsa, Oklahoma: American Association of Petroleum Geologists.

Martin, L.T.

1943. Eocene Foraminifera from the Type Lodo Formation, Fresno County, California. Stanford University Publications, Geological Sciences, 3:93-125.

McGowran, B.

1964. Foraminiferal Evidence for the Paleocene Age of the King's Park Shale (Perth Basin, Western Australia). Journal of the Royal Society of Western Australia. 47:81-86.

1965. Two Paleocene Foraminiferal Faunas from the Wangerrip Group, Pebble Point Coastal Section, Western Australia. Proceedings of the Royal Society of Victoria, 79:9-74.

1968. Reclassificatiion of Early Tertiary Globorotalia. Micropaleontology, 14:179-198.

Montanaro Gallitelli, E.

1957. A Revision of the Foraminiferal Family Heterohelicidae. In A.R. Loeblich, Jr., and collaborators, Studies in Foraminifera. Bulletin of the United States National Museum, 215:133-154.

Morozova, V.G.

1939. K stratigraphii verchnego mela i paleogena Embenskoi oblasti po faune foraminifer [On the Stratigraphy of the Upper Cretaceous and Paleogene of the Embe Region According to the Foraminiferal Fauna]. Byulleten Moskovskogo Obshchestva Ispytatelei Prirody, Otdel Geologicheskii, 17:59-96. [In Russian, includes an English summary.]

1957. Nadsemeistvo foraminifer Globigerinidea superfam. nova i nekotori yevo predstaviteli [Foraminiferal Superfamily Globigerinidea, Superfamily nov., and Some of Its Representatives]. Doklady Akademiya Nauk SSSR, 114(5):1109-1111. [In Russian.]

1958. $\mathrm{K}$ sistematike $\mathrm{i}$ morfologii paleogenovykh predstavitelei nadsemeistva Globigerinidea [Addition to the Systematics and Morphology of the Paleogene Members of the Superfamily Globigerinidea]. Voprosy Mikropaleontologii, 114:22-52. [In Russian.]

1959. Stratigrafiya Datsko-Montskikh otlozhenii Kryma po foraminiferam [Stratigraphy of the Danian-Montian Deposits of the Crimea According to the Foraminifera]. Doklady Akademiya Nauk SSSR, 124:1113-1116. [In Russian.]
1960. Zonal'naya stratigrafiya Datsko-Monstkikh otlozhenii CCCR i granitsa mela c paleogenom [The Paleocenoses of Danian-Montian Foraminifera and Their Stratigraphic and Paleogeographic Importance]. In Problema V: Granitsa melovoi i paleogenovoi sistem. Mezhdunarodnyi Geologicheskii Kongress, XXI Sessiya, Doklady Sovetskikh Geologov, Izdatelstvo Akademiya Nauk, pages 83-100. [In Russian.]

1961. Datsko-Montskie planktonnye foraminifery yuga SSSR [DanianMontian Planktonic Foraminifera of the Southern USSR]. Paleontologicheskiy Zhurnal, 2:8-19. [In Russian.]

Morozova, V.G., G.E. Kozhevnikova, and A.M. Kuryleva

1967. Datsko-Paleotsenovye Raznofatsial'nye otlozheniya Kopet-Daga i metody ikh korrelyatsii po foraminiferam [Danian-Paleocene Heterofacial Deposits of Kopet-Dag and Methods of Their Correlation According to the Foraminifers]. Trudy Geologicheskogo Instituta, Akademiya Nauk SSSR, 157:1-208. [In Russian.]

Nakkady, S.E.

1951. A New Foraminiferal Fauna from the Esna Shales and Upper Cretaceous Chalk of Egypt. Journal of Paleontology, 24:675-692.

Nederbragt, A.J., and J.E. Van Hinte

1987. Biometric Analysis of Planorotalites pseudomenardii (Upper Paleocene) at Deep Sea Drilling Site 605, Northwestern Atlantic. In J.E. Van Hinte, S.W. Wise et al., Initial Reports of the Deep Sea Drilling Project, 93:577-592. Washington, D.C.: U.S. Government Printing Office.

Nocchi, M., E. Amici, and I. Premoli Silva

1991. Planktonic Foraminiferal Biostratigraphy and Paleoenvironmental Interpretation of Paleocene Faunas from the Subantarctic Transect, Leg 114. In P.F. Ciesielski, Y. Kristoffersen et al., Proceedings of the Ocean Drilling Program, Scientific Results, 114:233-279. College Station, Texas: Ocean Drilling Program.

Norris, R.D.

1996. Symbiosis as an Evolutionary Innovation in the Radiation of Paleocene Planktic Foraminifera. Paleobiology, 4:461-480.

Olsson, R.K.

1960. Foraminifera of Latest Cretaceous and Earliest Tertiary Age in the New Jersey Coastal Plain. Journal of Paleontology, 34:1-58.

1964. Late Cretaceous Planktonic Foraminifera from New Jersey and Delaware. Micropaleontology, 10:157-188.

1970. Planktonic Foraminifera from Base of Tertiary, Millers Ferry, Alabama. Journal of Paleontology, 44:598-604.

1982. Cenozoic Planktonic Foraminifera: A Paleobiogeographic Summary. In T.W. Broadhead, editor, Foraminifera Notes for a Short Course (organized by M.A. Buzas and B.K. Sen Gupta). University of Tennessee Department of Geological Sciences Studies in Geology. 6:127-147.

Olsson, R.K., and Ch. Hemleben

1996. Phylogeny of Normal Perforate Paleocene Planktonic Foraminifera Based on Wall Texture. [Abstract.] North American Paleontology Conference, Washington, D.C., Abstracts with Program, page 294.

Olsson, R.K., Ch. Hemleben, W.A. Berggren, and C. Liu

1992. Wall Texture Classification of Planktonic Foraminifera Genera in the Lower Danian. Journal of Foraminiferal Research, 22:195-213.

Parker, F.L.

1962. Planktonic Foraminiferal Species in Pacific Sediments. Micropaleontology, 8:219-254

Parr, W.J.

1938. Upper Eocene Foraminifera from Deep Borings in King's Park, Perth, Western Australia. Journal of the Royal Society of Western Australia, 24:69-101.

Pearson, P.N.

1993. A Lineage Phylogeny for the Paleogene Planktonic Foraminifera. Micropaleontology, 39:193-232. 
Pearson, P.N., N.J. Shackleton, and M.A. Hall

1993. The Stable Isotope Paleoecology of Middle Eocene Planktonic Foraminifera and Multi-species Integrated Isotope Stratigraphy, DSDP Site 522, South Atlantic. Journal of Foraminiferal Research. 23:123-140.

Plummer, H.J.

1926. Foraminifera of the Midway For mation in Texas. University of Texas Bulletin, 2644: 206 pages.

Pokon'y, V.

1955. Cassigerinella boudecensis n. gen., n. sp. (Foraminifera, Protozoa) z Oligocénu zdánického flyse [Cassigerinella boudecensis $\mathrm{n}$. gen., $\mathrm{n}$. sp. (Foraminifera, Protozoa) from the Oligocene of the Zdanice Flysch]. Vestnik Ustredniho Ustavo Geologického, 30:136-140. [In Czech.]

Postuma, J.A.

1971. Manual of Planktonic Foraminifera. 420 pages. Amsterdam: Elsevier Publishing Co.

Premoli Silva, I.

1977. The Earliest Tertiary Globigerina eugubina Zone: Paleontological Significance and Geographical Distribution. Memorias del Segundo Congreso Latinoamericano de Geologia, 3, Special Publication, 7:1541-1555.

Premoli Silva, I., and A. Boersma

1989. Atlantic Paleogene Planktonic Foraminiferal Bioprovincial Indices. Marine Micropaleontology, 14:357-371.

Premoli Silva, I., and H.M. Bolli

1973. Late Cretaceous to Eocene Planktonic Foraminifera and Stratigraphy of Leg 15 Sites in the Caribbean Sea. In N.T. Edgar, J.B. Saunders et al., Initial Reports of the Deep Sea Drilling Project, 15:499-547. Washington, D.C.: U.S. Government Printing Office.

Proto Decima, F., and P. Zorzi

1965. Studio micropaleontologico-stratigrafico della serie CretaceoTerziaria del Molinetto di Pederroba (Treviggiano occidentale). Memorie degli Istituti di Geologia e Mineralogia dell'Università di Padova, 25: 44 pages.

Pujol, C.

1983. Cenozoic Planktonic Foraminiferal Biostratigraphy of the Southwestern Atlantic (Rio Grande Rise): Deep Sea Drilling Project Leg 72. In P.F. Barker, D.A. Johnson et al., Initial Reports of the Deep Sea Drilling Project, 72:623-673. Washington, D.C.: U.S. Government Printing Office.

Reiss, $\mathrm{Z}$.

1957. The Bilamellidae, nov. superfamily, and Remarks on Cretaceous Globorotaliids. Contributions from the Cushman Foundation for Foraminiferal Research, 8:127-145.

1963. Reclassification of Perforate Foraminifera. Bulletin of the Geological Survey of Israel, 35:1-111.

Rey, M.

1954. Description de quelques espèces nouvelles de Foraminiferes dans le Nummulitique nord-marocain. Bulletin de la Société Géologique de France, series 6, 4:209-211.

Said, R., and A. Kenaway

1956. Upper Cretaceous and Lower Tertiary Foraminifera from Northern Sinai, Egypt. Micropaleontology, 2:105-173.

Said, R., and M.T. Kerdany

1961. The Geology and Micropaleontology of the Farafra Oasis, Egypt. Micropaleontology, 7:317-336.

Said, R., and H. Sabry

1964. Planktonic Foraminifera from the Type Locality of the Esna Shale in Egypt. Micropaleontology, 10:375-395.

Salaj, J.

1986. The New Postrugoglobigerina praedaubjergensis Zone at the Base of the Stratotype of the Marine Paleocene (E1 Kef, Tunisia). Geologicky Zbornik, Geologica Carpathica, 37:35-58.
Samanta, B.K.

1970. Planktonic Foraminifera from the Early Tertiary Pondicherry Formation of Madras, South India. Journal of Paleontology, 44:605-641.

Schwager, $\mathrm{C}$.

1883. Die Foraminiferen aus den Eocaenablagerungen der libyschen Wüste und Aegyptens. Palaeontographica, 30:79-153.

Scotese, C.R., and C.R. Denham

1988. Terra Mobilis: Plate Tectonics for the Macintosh. Austin, Texas: Earth in Motion Technologies. [Computer program.]

Shackleton, N.J., R.M. Corfield, and M.A. Hall

1985. Stable Isotope Data and the Ontogeny of Paleocene Planktonic Foraminifera. Journal of Foraminiferal Research, 15:321-336.

Shifflett, E.

1948. Eocene Stratigraphy and Foraminifera of the Aquia Formation. Maryland Department of Geology. Mines and Water Resources Bulletin, 3:1-93.

Shutskaya, E.K.

1953. Raschlenenie kubanskogo i elburganskogo gorizontov Severnogo Kavkaza po globigerinam [The Subdivision of the Kuban and Elburgan Horizons of the Northern Caucusus by Means of the Globigerinids]. Byulleten Moskovskogo Obshchestva Ispytatelei Prirody, new series, volume 58, Otdel Geologicheskii, 28:71-79. [In Russian.]

1956. Stratigrafiya nizhnikh gorizontov paleogena Tsentral'nogo Predkavkaz'ya po foraminiferam [Stratigraphy of the Lower Horizons of the Paleogene in the Central Precaucasus According to the Foraminifera]. Trudy Instituta Geologii, Akademiya Nauk SSSR, 164(70):3-114. [In Russian.]

1958. Izmenchivosti nekotorikh nizhnepaleogenovikh plannktonikh foraminifer sever nogo Kavkaza [Variations of Some Lower Paleogene Planktonic Foraminifers of the Northern Caucasus]. Voprosyi Mikropaleontologii, Akademiya Nauk SSSR, 2:84-90. [In Russian.]

1960. Stratigrafiya i fatsii nizhnego paleogena Predkavkazya [Stratigraphy and Facies of the Lower Paleogene of the Precaucasus]. 104 pages. Vsesoyuznyi Nauchno-Issledovatel'skii Geologorazvedochnyi Neftyanoi Institut (VNIGNI). Moscow: Gostoptekhizdat. [ln Russian.]

1962. Foraminifery datskogo yarusa i paleotsena fatsii otrtogo morya Kryma, Predkavkazya i Zakaspiya [Foraminifera of the Danian and Paleocene in Pelagic Facies of Crimea, Precaucasus and Transcaspian Region]. Byulleten Moscovskogi Obshchestva Ispytatelei Prirody, Otdel Geologicheskii. 37:126-127. [In Russian.]

1965. Filogeneticheskie vzaimootnoscheniya vidov gruppy Globorotalia compressa Plummer v datskom vekhe i paleotzenovoi epokhe [On the Phylogenetic Relations of the Species of the Globorotalia compressa Plummer-group during Danian Time and the Paleocene Epoch]. Voprosyi Mikropaleontologii, Akademiya Nauk SSSR, 9:173-188. [In Russian.]

1970a. Morfologicheskie grupirovki vidov rodov Globigerina i Acarinina v nizhnei chasti paleogena Kryma, Predkavkazya i zapada Srednei Azii i ipisanie vidov [Morphological Groups of Species of the Genera Globigerina and Acarinina in the Lower Part of the Paleogene in the Crimea, Precaucasus and Western Part of Central Asia as Well as Description of Genera]. In E.K. Shutskaya, editor, Stratigrafiya i paleontologiya Mezozoiskikh i Paleogenovykh otlozhenii Srednei Azii. Trudy, Vsesoyuznyi Nauchno-Issledovatel'skii Geologorazvedochnyi Neftyanoi Institut (VNIGNI), 69:79-134. [In Russian.]

1970b. Stratigrafiya, foraminifery i paleogeografiya nizhnego paleogena Kryma, predkavkaz'ya i zapadnoi chadsti srednei azii [Stratigraphy, Foraminifera and Paleogeography of the Lower Paleogene in the Crimea, Precaucasus and the Western Part of Central Asia]. Trudy, Vsesoyuznyi Nauchno-Issledovadetel'skii Geologorazvedochnyi Neftyanoi Institut (VNIGNI), 70: 256 pages. [In Russian.] 
Sliter, W.V.

1976. Cretaceous Foraminifers from the Southwestern Atlantic Ocean, Leg 36, Deep Sea Drilling Project. In P.F. Barker, E.W.D. Dalziel et al., Initial Reports of the Deep Sea Drilling Project, 36:519-573. Washington, D.C.: U.S. Government Printing Office.

Smit, J.

1977. Discovery of a Planktonic Foraminiferal Association between the Abathomphalus mayaroensis Zone and the Globigerina eugubina Zone at the Cretaceous/Tertiary Boundary in the Barranco del Gredero (Caravaca, SE Spain): A Preliminary Report, I and II Koninklijke Nederlandse Akadamie van Wetenschappen, Proceedings, section $\mathrm{B}, 80: 280-301$.

1982. Extinction and Evolution of Planktonic Foraminifera after a Major Impact at the Cretaceous/Tertiary Boundary. In L.T. Silver and P.H. Schultz, editors, Geological Implications of Impacts of Large Asteroids and Comets on the Earth. Geological Society of America. Special Paper, 190:329-352.

Smit, J., and Th.M.G. van Kempen

1987. Planktonic Foraminifers from the Cretaceous/Tertiary Boundary at DSDP Sea Drilling Project Site 605, North Atlantic. In J.E. Van Hinte, S.W. Wise et al., Initial Reports of the Deep Sea Drilling Project, 93:549-553. Washington, D.C.: U.S. Government Printing Office.

Smith, B.Y.

1957. Lower Tertiary Foraminifera from Contra Costa County California University of California Publications in Geological Sciences, 32:1-190.

Smith, C.C., and E.A. Pessagno

1973. Planktonic Foraminifera and Stratigraphy of the Corsicana Formation (Maestrichtian) North-central Texas. Special Publication of the Cushman Foundation for Foraminiferal Research, 12: 68 pages.

Snyder, S.W., and V.J. Waters

1985. Cenozoic Planktonic Foraminiferal Biostratigraphy of the Goban Spur Region, Deep Sea Drilling Project Leg 80. In P.C. de Graciannsky, C.W. Poag et al., Initial Reports of the Deep Sea Drilling Project, 80:439-472. Washington, D.C.: U.S. Government Printing Office.

Stainforth, R.M., J.L. Lamb, H. Luterbacher, J.H. Beard, and R.M. Jeffords

1975. Cenozoic Planktonic Foraminiferal Zonation and Characteristics of Index Forms. University of Kansas Paleontological Contributions, Article, 62: 425 pages.

Steineck, P.L., and R.L. Fleisher

1978. Towards the Classical Evolutionary Reclassification of Cenozoic Globigerinacea (Foraminiferida). Journal of Paleontology, 52:618635.

Stott, L.D., and J.P. Kennett

1990. Antarctic Paleogene Planktonic Foraminifer Biostratigraphy: ODP Leg 113, Sites 689 and 690. In P.F. Barker, J.P. Kennett et al., Proceedings of the Ocean Drilling Program, Scientific Results, 113:549-569. College Station, Texas: Ocean Drilling Program.

Stratigraphic Commission

1963. [Decision of the Permanent Interdepartmental Stratigraphic Commission on the Paleogene of the USSR.] Sovetskaya Geologiya, 6:145-151. [In Russian.]

Subbotina, N.N

1947. Foraminifery datskikh i paleogenovykh otlozhenii severnogo Kavkaza [Foraminifera of the Danian and Paleogene Deposits of the Northern Caucasus]. In Mikrofauna neftyanykh mestorozhdenii Kavkaza, Emby I Srednei Azii. Trudy, Vsesoyuznyi NauchnoIssledovatel'skii Geologorazvedochnyi Neftyanoi Institut (VNIGNI), 1:39-160. [In Russian.]

1950. Mikrofauna i stratigrafiya Elburganskogo Gorozonta Goriathego Klyitcha [Microfauna and Stratigraphy of the Elburgan Horizon and the Goryatchy Klijutch Horizon]. Trudy Vsesoyuznego Neftyanogo Nauchno-Issledovatel'skogo Geologo-Razvedochnogo Instituta (VNIGRI), Mikrofauna SSSR, Sbornik, 51:5-112. [In Russian.]
1953. Iskopaemye foraminifery SSSR (Globigerinidy, Khantkenininidy i Globorotaliidy) [Fossil Foraminifera of the USSR (Globigerinidae, Hantkeninidae and Globorotaliidae)]. Trudy Vsesoyznogo Neftyanogo Nauchno-Issledovatel'skogo Geologo-Razvedochnogo Instituta (VNIGRI), 76: 296 pages. [In Russian.]

Sulc, $J$.

1929. Contributions à connaissance de la morphologie des foraminiferes Vestnik Státniho Geologického Ústavu Ceskoslovenské Republiky, 5:142-149.

Tappan, $\mathrm{H}$

1940. Foraminifera from the Grayson Formation of Northern Texas, Journal of Paleontology, 14:93-126.

Tjalsma, R.C.

1977. Cenozoic Foraminifera from the South Atlantic, DSDP Leg 36. In P.F. Barker, I.W.D. Dalziel et al., Initial Reports of the Deep Sea Drilling Project, 36:493-518. Washington, D.C.: U.S. Government Printing Office.

Thalman, H.E.

1956. Bibliography and Index to New Genera, Species and Varieties of Foraminifera for the Year 1954. Journal of Paleontology, 30:352388

Toulmin, L.D.

1941. Eocene Smaller Foraminifera from the Salt Mountain Limestone of Alabama. Journal of Paleontology, 15:567-611.

Toumarkine, $\mathrm{M}$

1978. Planktonic Foraminiferal Biostratigraphy of the Paleogene of Sites 360 to 364 and the Neogene of Sites 362A, 363, and 364 Leg 40. In H.M. Bolli, W.B.F. Ryan et al., Initial Reports of the Deep Sea Drilling Project, 40:679-721. Washington, D.C.: U.S. Government Printing Office.

Toumarkine, M., and H.-P. Luterbacher

1985. Paleocene and Eocene Planktic Foraminifera. In H.M. Bolli, J.B. Saunders, and K. Perch-Nielsen, editors, Plankton Stratigraphy, pages 87-154. Cambridge: Cambridge University Press

Troelsen, J.C

1957. Some Planktonic Foraminifera of the Type Danian and Their Stratigraphic Importance. In A.R. Loeblich, Jr., and collaborators, Studies in Foraminifera. Bulletin of the United States National Museum, 215:125-132.

Van Eijden, A.J.M., and J. Smit

1992. Eastern Indian Ocean Cretaceous and Paleogene Quantitative Biostratigraphy. In J. Weissel, J. Peirce, E. Taylor, J. Alt et al., Proceedings of the Ocean Drilling Program, Scientific Results, 121:77-124. College Station, Texas: Ocean Drilling Program.

Voloshina, A.M.

1961. Nekotorye novye vidy Verkhiemelovykh foraminifer VolynoPodol'skoy plity [Some New Species of Upper Cretaceous Foraminifera from the Volhyn-Podol Platform]. Paleontologicheskii Sbornik, L'vovskogo Geologicheskogo Obshchestva, 1:71-81. [In Russian.]

Webb, P.N.

1973. Upper Cretaceous-Paleocene Foraminifera from Site 208 (Lord Howe Rise, Tasman Sea), DSDP, Leg 21. In R.E. Burns, J.E. Andrews et al., Initial Reports of the Deep Sea Drilling Project, 21:541-573. Washington, D.C.: U.S. Government Printing Office.

Weiss, L.

1955. Foraminifera from the Paleocene Pale Greda Formation of Peru. Journal of Paleontology, 29:1-21.

White, M.P.

1928. Some Index Foraminifera of the Tampico Embayment of Mexico, Part I and Part II. Journal of Paleontology, 2:177-215, 280-317.

Ziegler, P.A.

1982. Geological Atlas of Western and Central Europe. Pages 1-22. Amsterdam: Elsevier Publishing Co. 
Plates 


\section{PLATE 1}

\section{Spinose and Nonspinose Wall Texture}

FIGURE 1.-Globorotalia hirsuta (d'Orbigny), nonspinose smooth wall surface with scattered pustules, notice the size gradient of pustule distribution from the ultimate to the antiprepenultimate chambers (bar $=200 \mu \mathrm{m}$ ). Recent, plankton net catch, off Bermuda.

FIGURE 2.-Globorotalia menardii (Parker, Jones, and Brady), cross section of bilamellar wall, primary organic membrane (POM) spans across the pore cross section; during life the pore is closed by this organic layer in addition to organic pore fillings ( $\mathrm{bar}=10 \mu \mathrm{m}$ ). Recent, plankton net catch, Indian Ocean.

FIGURE 3.-Globigerinoides ruber (d'Orbigny), overall view of early adult stage showing spines implanted in test wall $(\mathrm{bar}=100 \mu \mathrm{m})$. Recent, plankton net catch off Barbados, Caribbean Sea.

FIGURE 4.-Globigerinoides sacculifer (Brady), cross section showing POM and remanents of pore plate, organic pore lining, and terraced pore structure with plate-like crystals. Rather fine-grained crystals form the wall (bar $=2 \mu \mathrm{m})$. Recent, plankton net catch, Indian Ocean.

FIGURE 5.-Globorotalia menardii (Parker, Jones, and Brady), keel with small and medium-sized pustules growing on a very smooth surface (bar $=20 \mu \mathrm{m}$ ). Recent, Eltanin cruise 15 sample.

FIGURE 6.-Globorotalia truncatulinoides (d'Orbigny), tangential view and cross section of pustules showing layering indicating that pustules grow as part of the test wall $(\mathrm{bar}=5 \mu \mathrm{m})$. Recent. DSDP Site $1 / 1 / 1: 1-4 \mathrm{~cm}$.

FIGURE 7.-Globigerinoides ruber (d'Orbigny), cross section of wall showing broken spine that is separated from the wall. POM with part of the pore plate, inner organic lining $(1 \mathrm{OL})$, and organic pore lining $(\mathrm{bar}=5 \mu \mathrm{m})$. Recent, plankton net catch, South Pacific Ocean.

FIGURE 8. -Globigerina praebulloides Blow, cross section of spine hole containing mold of a spine (bar $=2$ $\mu \mathrm{m})$. Upper Eocene, DSDP Hole 362A/7/5: 24-26 cm; Walvis Ridge, eastern South Atlantic Ocean.

FIGURE 9.-Globigerinoides sacculifer (Brady), overall view of surface of test showing regular cancellate structure with spines and spine holes $(\mathrm{bar}=100 \mu \mathrm{m})$. Recent, plankton net catch off Barbados, Caribbean Sea.

FIGURE 10. Subbotina linaperta (Finlay), overall view of surface of test showing same cancellate surface texture as above with spine holes $(\mathrm{bar}=100 \mu \mathrm{m})$. Upper Eocene, DSDP Hole 362A/7/5: 24-26 cm; Walvis Ridge, eastern South Atlantic Ocean.

FIGURE 11.-Globigerinoides ruber (d'Orbigny), showing a less regular cancellate surface texture than $G$. sacculifer or S. linaperta. Note spine holes (bar $=100 \mu \mathrm{m})$. Recent, plankton net catch off Barbados, Caribbean Sea.

FIGURE 12.-Globigerina bulloides d'Orbigny, showing a more pitted surface due to rather isolated spine bases. Note spine holes in spine bases ( $b a r=100 \mu \mathrm{m}$ ). Recent, sediment trap off Bermuda, North Atlantic.

FIGURE 13.-Globigerina praebulloides Blow, same as Figure 8, above, but showing a rather thick wall (bar $=$ $100 \mu \mathrm{m})$. Upper Eocene, DSDP Hole 362A/7/5: 24-26 cm; Walvis Ridge, eastem South Atlantic Ocean.

FIGURE 14.-Globigerinoides sacculifer (Brady), enlarged view of test wall showing spine holes left by the resorption of spines during gametogenesis $(\mathrm{bar}=10 \mu \mathrm{m})$. Recent, plankton net catch off Barbados, Caribbean Sea.

FIGURE 15.-Globigerinoides ruber (d'Orbigny), enlarged view of test wall showing spine holes and some gametogenic calcification (bar $=10 \mu \mathrm{m}$ ). Recent, plankton net catch off Barbados, Caribbean Sea.

FIGURE 16.-Globigerina bulloides d'Orbigny, enlarged view of test wall showing spine holes (bar $=40 \mu \mathrm{m}$ ). Recent, plankton net catch, middle North Atlantic Ocean.

FIGURE 17.-Globigerinoides sacculifer (Brady), juvenile specimen showing a globorotaliid test with a smooth wall and a few spines $(\mathrm{bar}=20 \mu \mathrm{m})$. Live specimen, Barbados.

FIGURE 18.-Globigerinoides sacculifer (Brady), showing crystal growth in surface view (bar $=20 \mu \mathrm{m}$ ). Live specimen, Barbados.

FIGURE 19.-Globigerinoides sacculifer (Brady), enlargement of Figure 18 showing the pore resorption (bar $=5$ $\mu \mathrm{m})$.

FIGURE 20.-Globigerinoides sacculifer (Brady), detail of cancellate structure of the pore funnel with plate-like crystal growth and spines (bar $=10 \mu \mathrm{m})$. Recent, Eltanin cruise 15 sample. 


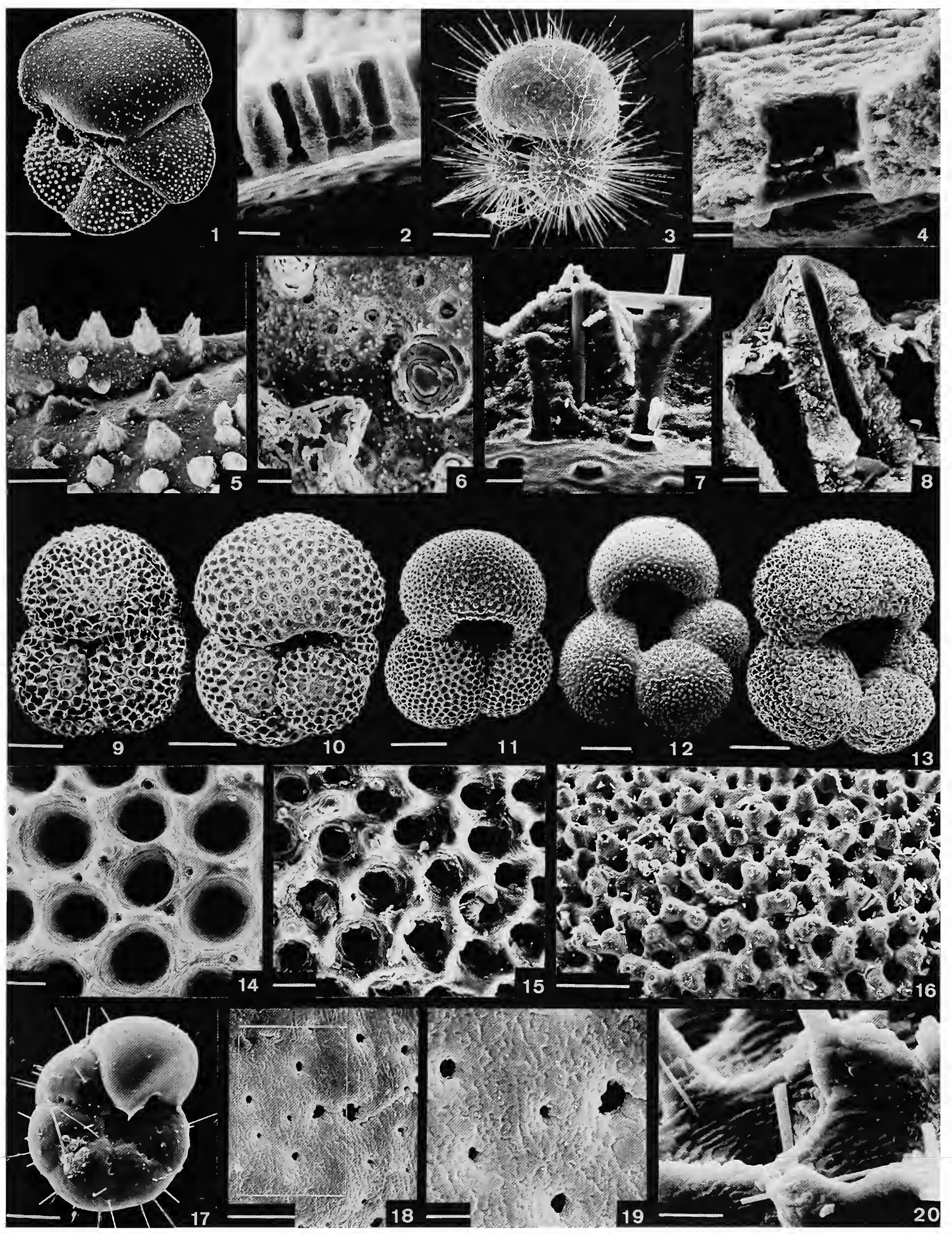




\section{PLATE 2}

\section{Gametogenetic Calcification (Spinose Wall Texture)}

FIGURE 1.-Globigerinoides ruber (d'Orbigny), view of test wall showing a cancellate structure with spines on the interpore ridges $(\mathrm{bar}=10 \mu \mathrm{m})$. Recent, plankton net catch, off Bermuda.

FIGURE 2.-Globigerinoides sacculifer (Brady), view of test wall showing gametogenic calcification covering the spine holes (bar $=10 \mu \mathrm{m}$ ). Live specimen, off Bermuda.

FIGURE 3.-Subbotina linaperta (Finlay), view of test wall showing spine holes and incipient gametogenic calcification $(\mathrm{bar}=20 \mu \mathrm{m}$ ). Upper Eocene, DSDP Hole 362A/7/5: 24-26 cm; Walvis Ridge, eastern South Atlantic Ocean.

FIGURE 4.-Subbotina linaperta (Finlay), view of test wall showing different stages of gametogenetic calcification $(\mathrm{bar}=20 \mu \mathrm{m}$ ). Upper Eocene, DSDP Hole 362A/7/5: 24-26 cm; Walvis Ridge, eastern South Atlantic Ocean.

FIGURE 5.-Subbotina linaperta (Finlay), enlarged view of test wall showing partial gametogenetic overgrowth of a spine hole (bar $=4 \mu \mathrm{m})$. Upper Eocene, DSDP Hole 362A/7/5: 24-26 cm; Walvis Ridge, eastern South Atlantic Ocean.

FIGURE 6.-Subbotina cancellata Blow, view of test wall showing gametogenic calcification covering the spine holes $($ bar $=10 \mu \mathrm{m})$. Paleocene, Zone P4, DSDP Site 549/20/5: 20-22 cm; Goban Spur, eastern North Atlantic.

FIGURES 7-9.-Parasubbotina pseudobulloides (Plummer): 7, view of test wall showing a cancellate surface texture with spine holes and rather heavy corrosion; 8, spine holes and gametogenic calcification; 9, well-preserved specimen showing typical gametogenic calcification $($ bar $=10 \mu \mathrm{m})$. Paleocene, Zone P2, Midway Group, Texas, sample 8030.

FIGURE 10.-Globigerinoides ruber (d'Orbigny), view of test wall showing a less well-developed cancellate surface texture with gametogenic calcification ( $b a r=10 \mu \mathrm{m}$ ). Recent, plankton net catch, off Bermuda.

FIGURES 11-13.-Eoglobigerina eobulloides Morozova: 11, view of test wall showing cancellate wall texture, spine holes, and gametogenic calcification; 12, corroded surface (lower left) and gametogenic calcification; 13 , well-preserved specimen showing rather thick gametogenic calcification (bar $=10 \mu \mathrm{m})$. Paleocene, Zone Pa, Core 226, samples 8, 21, 84, respectively, Millers Ferry, Alabama.

FIGURE 14.-Globigerina praebulloides Blow, view of test wall showing spine holes and spine bases (bar $=10$ $\mu \mathrm{m})$. Upper Eocene, DSDP Hole 362A/7/5: 24-26 cm; Walvis Ridge, eastem South Atlantic Ocean.

FIGURES 15, 16.-Subbotina triangularis (White), views of test wall showing spine holes, spine bases, and gametogenic calcification. Compare to Figure $11(\mathrm{bar}=10 \mu \mathrm{m})$. Paleocene, Zone P4, Glendola Well, New Jersey, sample 286-287 feet. 

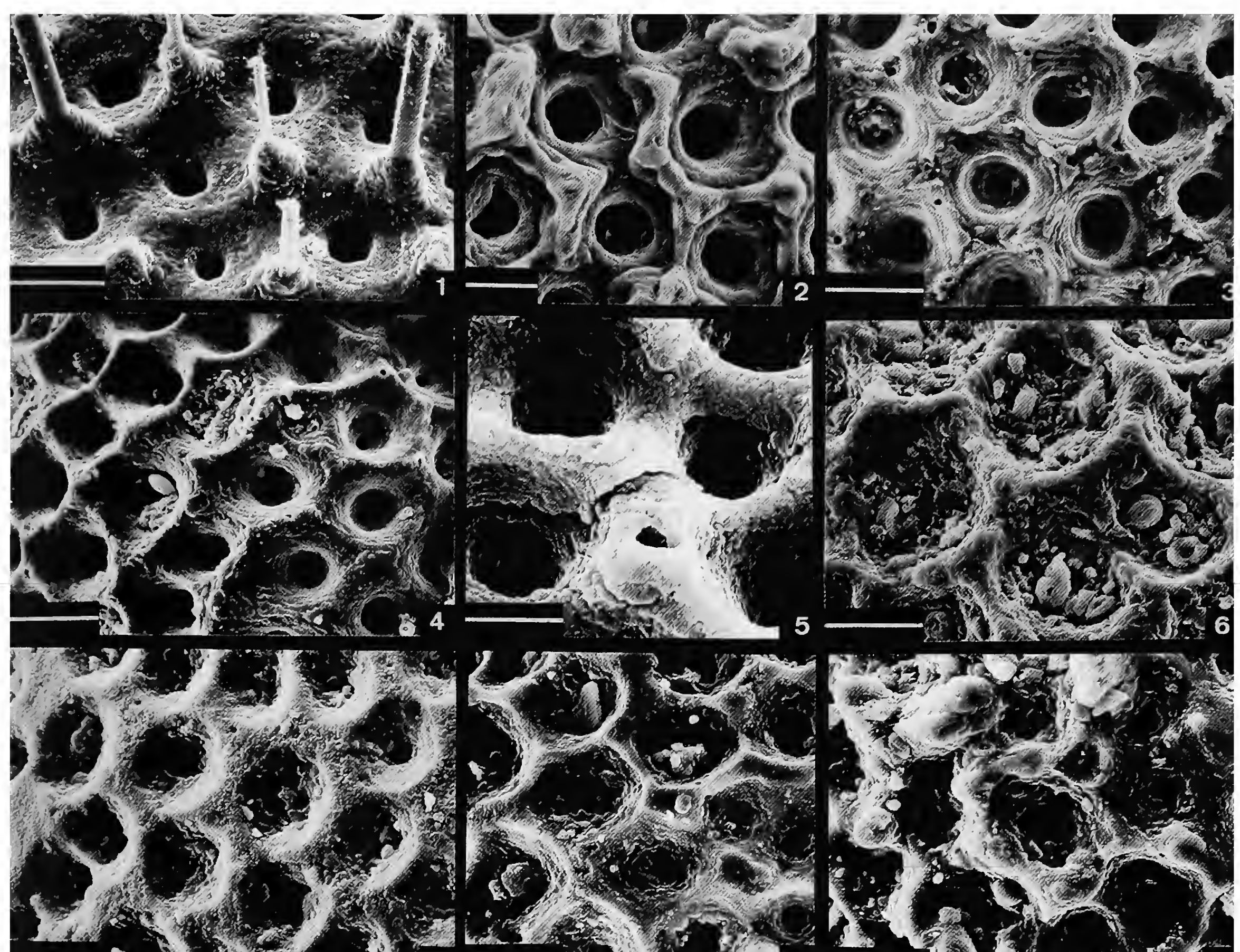

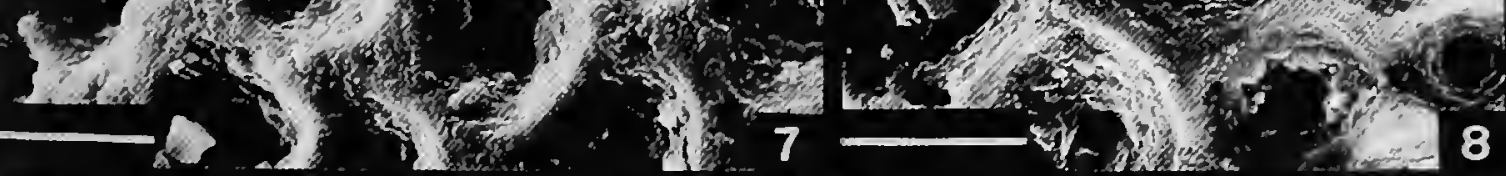

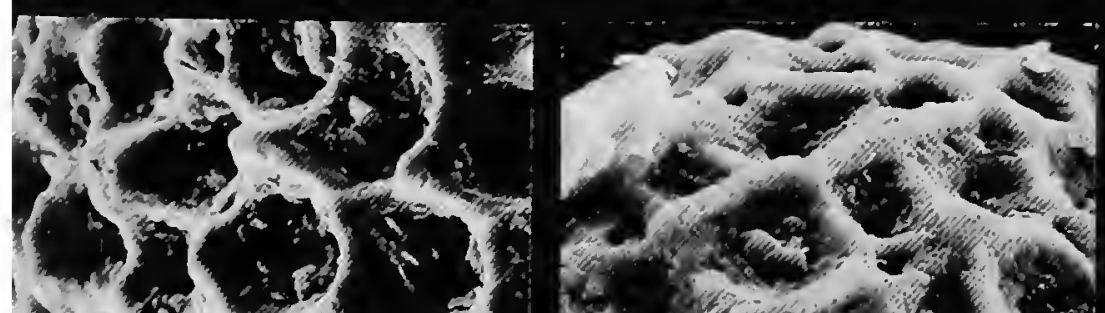

P.2.
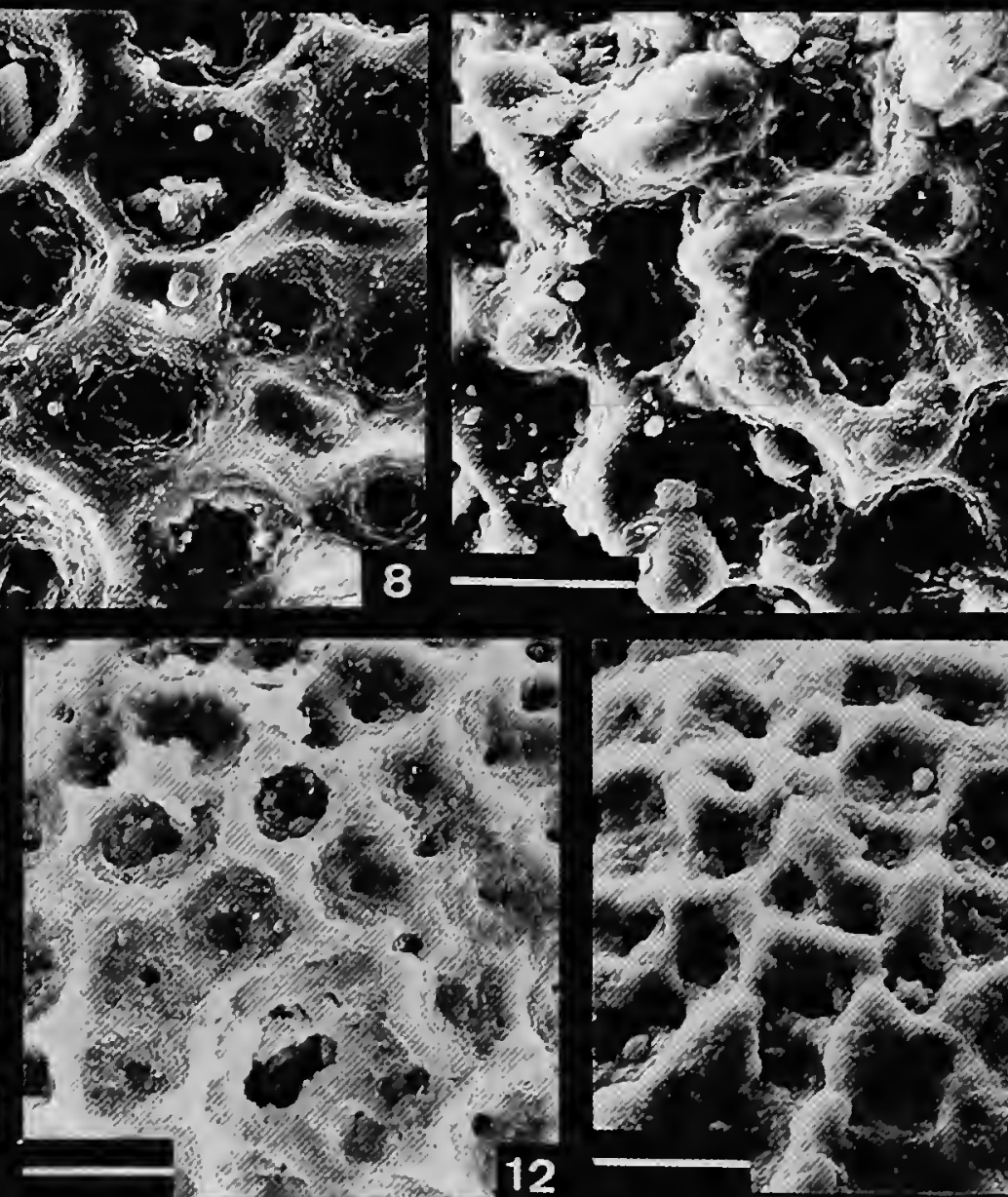

3

,

s. $-1+28$

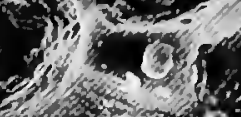
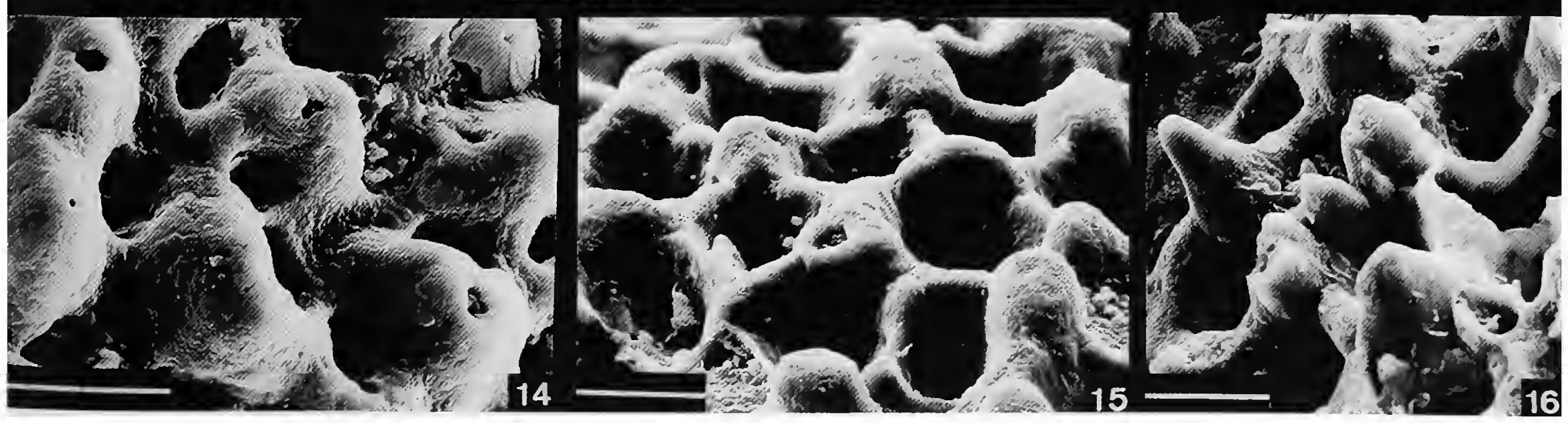


\section{PLATE 3}

\section{Nonspinose (Globorotaliid) Wall Texture}

FIGURE 1.-Globorotalia scitula (Brady), overall view of a thin-walled test showing smooth surface and scattered pustules in umbilical area $(\mathrm{bar}=100 \mu \mathrm{m})$. Recent, sediment trap, off Barbados.

FIGURE 2.-Globorotalia truncatulinoides (d'Orbigny), overall view of a medium thick-walled test showing heavier pustule growth on the older chambers (bar $=200 \mu \mathrm{m}$ ). Recent, sediment trap, off Bermuda.

FIGURE 3.-Globorotalia inflata (d'Orbigny), overall view of a medium thick-walled test showing pustules of various ages on all chambers $(\mathrm{bar}=100 \mu \mathrm{m})$. Recent, plankton net catch, western South Atlantic Ocean.

FIGURE 4. Globorotalia inflata (d'Orbigny), overall view of test showing a final layer of thick pustule growth (bar $=100 \mu \mathrm{m})$. Recent, plankton net catch, off Bermuda.

FIGURE 5.-Globorotalia truncatulinoides (d'Orbigny), enlarged view of chamber surface with young small pustules $(\mathrm{bar}=10 \mu \mathrm{m})$. Recent, North Atlantic Ocean.

FIGURE 6.-Globorotalia inflata (d'Orbigny), enlarged view of tangential section of a thin-layered wall covering a previously formed wall, indicating superposition of various calcification events (bar $=4 \mu \mathrm{m}$ ). Recent, plankton net catch, off Bermuda.

FIGURE 7.-Globorotalia inflata (d'Orbigny), enlarged view of tangential section of test wall showing consecutive pustule growth that leads to a bumpy layered wall $(\mathrm{bar}=20 \mu \mathrm{m})$. Recent, plankton net catch, Chain 35, Station 89.

FIGURE 8.-Globorotalia scitula (Brady), enlarged view of 3rd and 4th chambers of Figure 1 showing distribution of pustules and covering of pores by growth of pustules (bar $=20 \mu \mathrm{m})$. Recent, sediment trap, off Barbados.

FIGURE 9.-Globorotalia truncatulinoides (d'Orbigny), enlarged view of test wall showing several generations of pustule growth and an increase in wall thickness by pustule growth (bar $=40 \mu \mathrm{m}$ ). Recent, plankton net catch, South Atlantic Ocean.

Figures 10,11.-Globorotalia inflata (d'Orbigny): 10, enlarged view of test wall showing outermost pustules and the beginning of calcite crust growth (bar $=20 \mu \mathrm{m}$ ); 11 , additional calcification on top of pustules (bar = $4 \mu \mathrm{m})$. Recent, plankton net catch, off Bermuda.

FIGURE 12.-Globorotalia truncatulinoides (d'Orbigny), cross section of test wall showing the normal wall and a layered pustule $(\mathrm{bar}=20 \mu \mathrm{m})$. Recent, DSDP Site 2/4/2: 149-151 cm; Gulf of Mexico.

FIGURE 13. - Globorotalia truncatulinoides (d'Orbigny), branching pustules (bar $=40 \mu \mathrm{m}$ ). Recent, DSDP Site 2/4/2: 149-151 cm; Gulf of Mexico.

FIGURES 14-16.-Globorotalia menardii (Parker, Jones, and Brady): 14, cross section of test wall showing the normal wall and the beginning of the calcite crust (elongated crystals); 15, early stage of keel development showing the doubling of the wall; at this stage the keel contains a few pores that do not function (bar $=10 \mu \mathrm{m}$ ). Recent, DSDP Site 2/4/2: 149-151 cm; Gulf of Mexico. 16, medium stage of keel development showing the layering of the keel $(\mathrm{bar}=10 \mu \mathrm{m})$. Recent, DSDP Site 1/1/1: $1-4 \mathrm{~cm}$; Gulf of Mexico. 

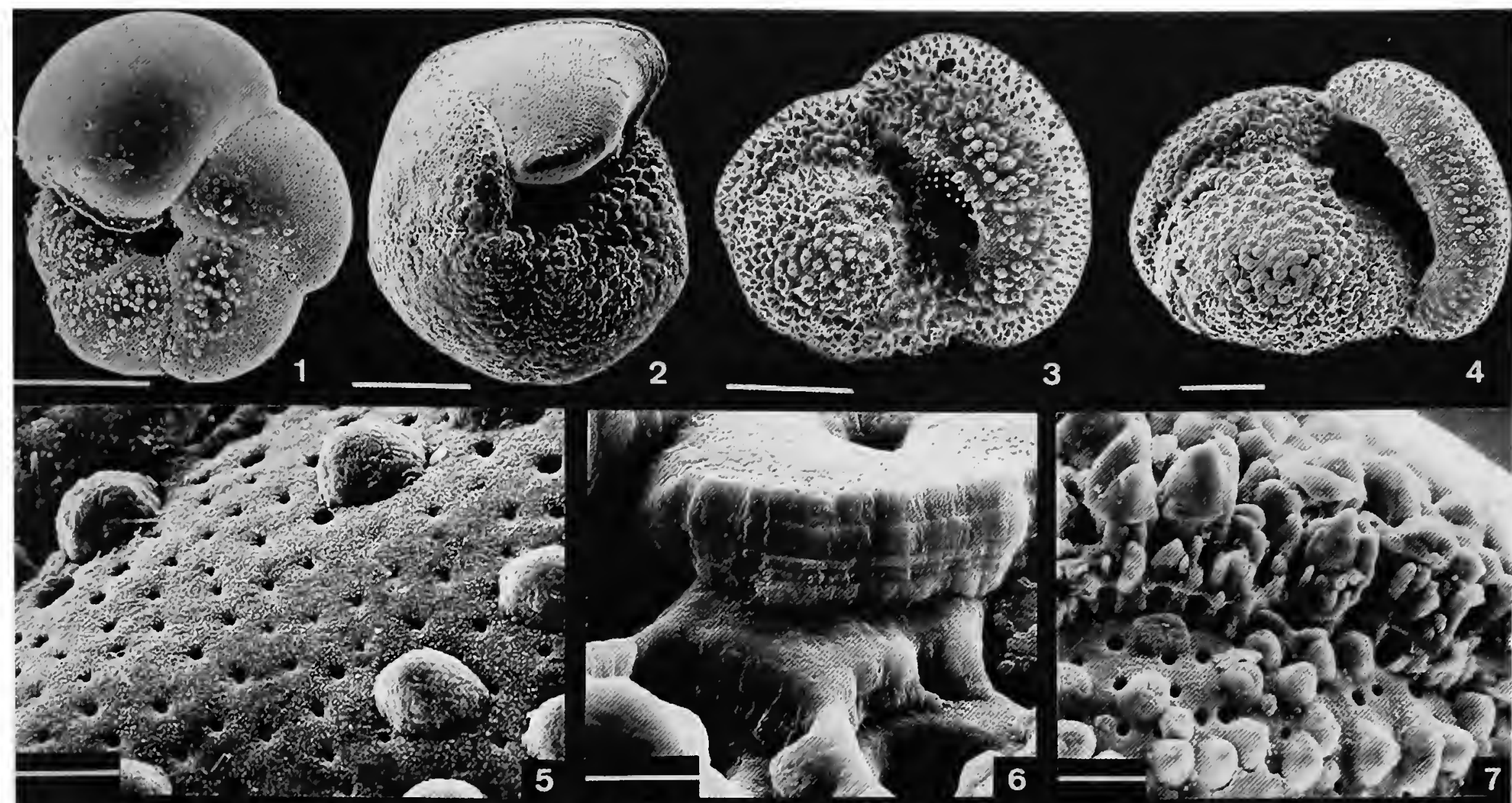
40

PQ"

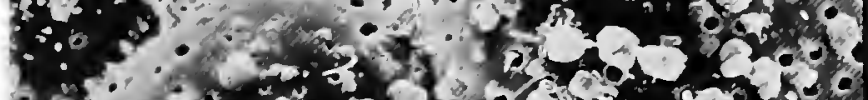

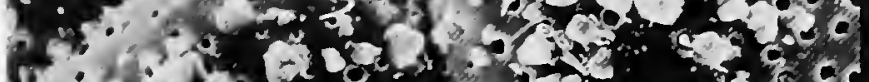
(1)

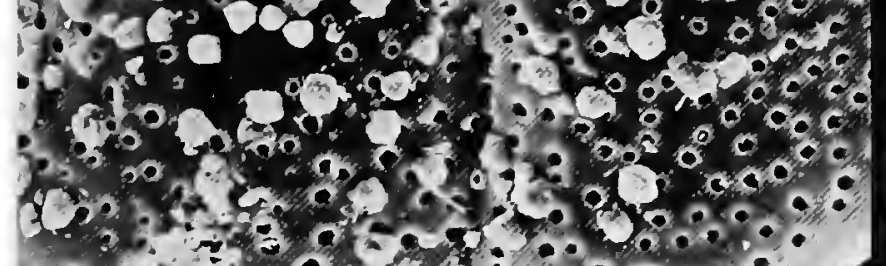

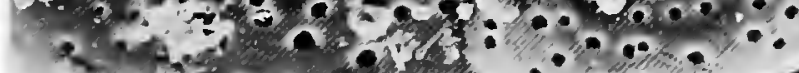

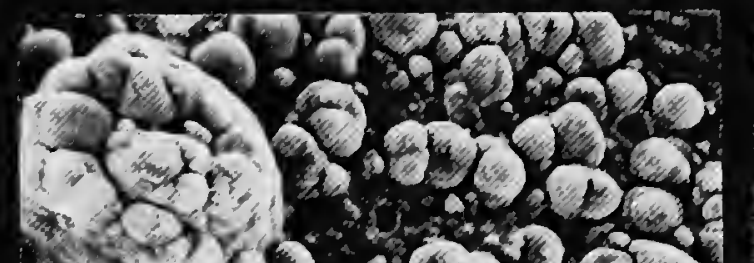

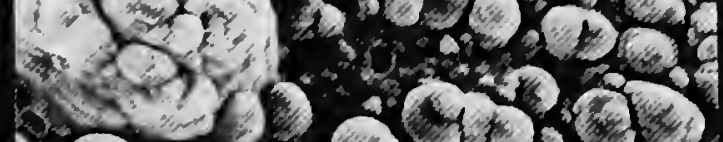

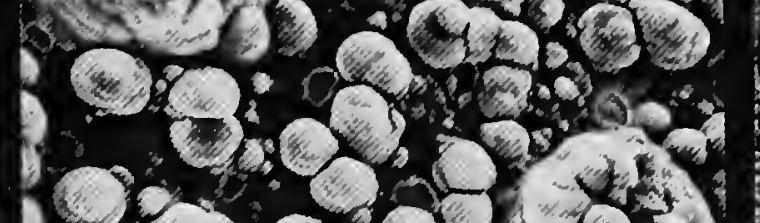

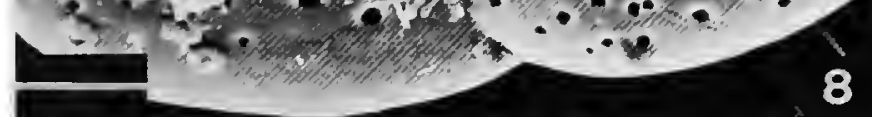
(-2)

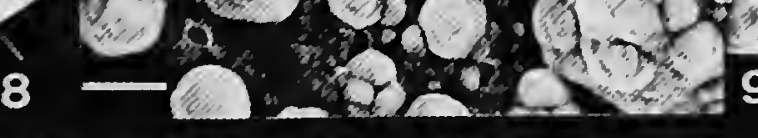
$-2 x+2=10$
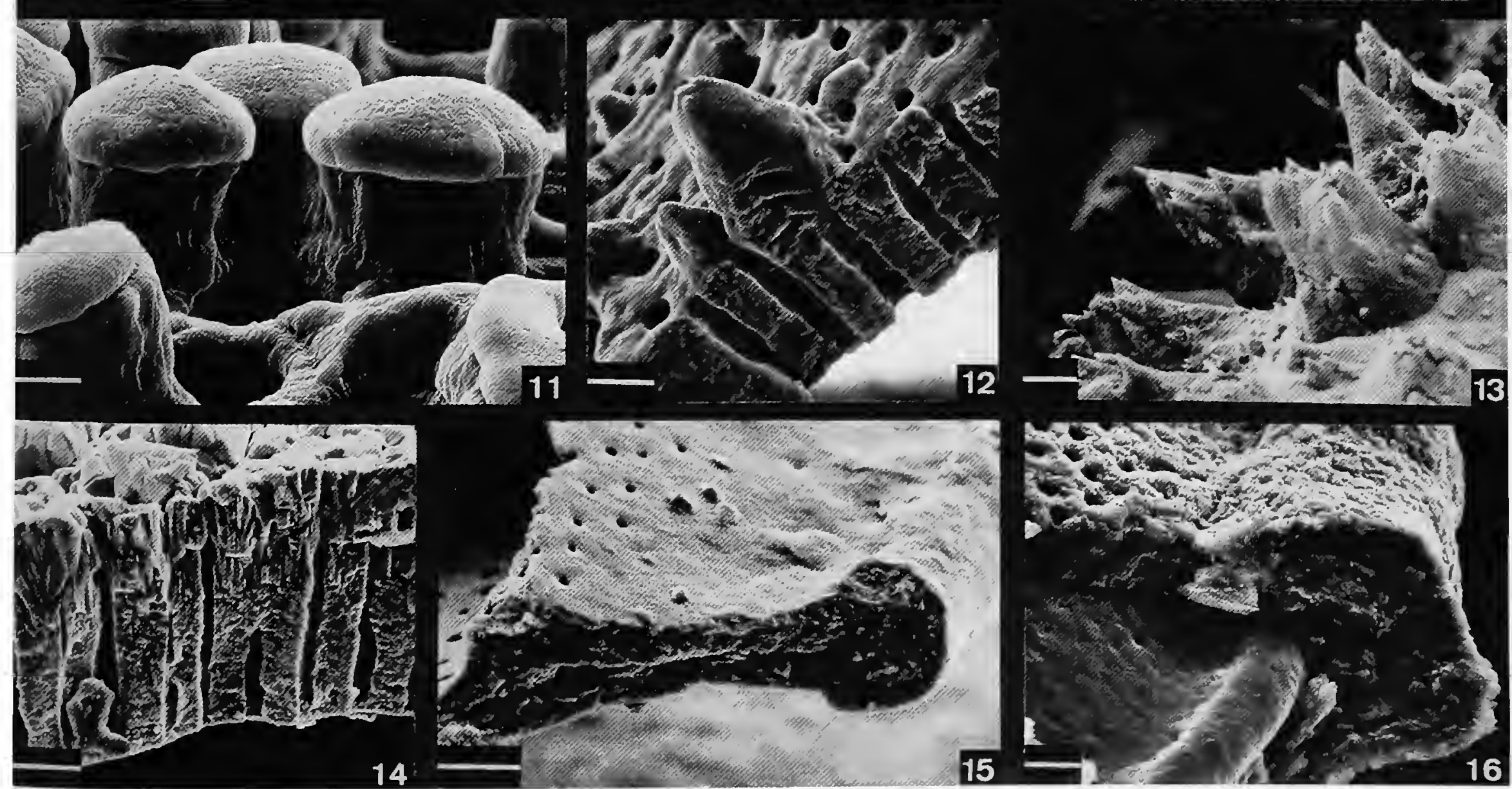


\title{
PLATE 4
}

\author{
Nonspinose (Globorotaliid) Wall Texture, Cretaceous and Paleocene
}

FIGURES 1-3.-Hedbergella holmdelensis Olsson: 1, overall view of test showing a smooth wall with pustule distribution resembling Globorotalia scitula (Brady) $(\mathrm{bar}=50 \mu \mathrm{m}) ; 2$, enlarged view of 3 rd chamber showing overgrowth of pores by pustules (bar $=5 \mu \mathrm{m}$ ); 3 , pustule growth covering wall surface on 5 th chamber (bar $=$ $5 \mu \mathrm{m})$. Topotype, upper Maastrichtian, Navesink Formation, New Jersey.

FIGURES 4, 5.-Globanomalina archeocompressa (Blow): 4, overall view of test showing a smooth surface with a pustule distribution similar to G. scitula (Brady) and H. holmdelensis Olsson (bar $=20 \mu \mathrm{m}$ ); 5, enlarged view of wall showing a smooth surface and some small pustules in front of the aperture (bar $=10 \mu \mathrm{m}$ ). Paleocene, Zone Pla, DSDP Site 356/29/1: 70-72 cm; São Paulo Plateau, South Atlantic Ocean.

FIGURES 6, 7.-Globanomalina planocompressa (Shutskaya): 6, overall view of test showing a very smooth surface and no pustules $(\mathrm{bar}=50 \mu \mathrm{m}) ; 7$, closeup view of 3rd chamber $(\mathrm{bar}=10 \mu \mathrm{m})$. Paleocene, Zone Plc, Mexia Clay, Texas.

FIGURE 8.-Globanomalina chapmani (Рап), enlarged view of test wall showing smooth surface and some pores in the imperforate peripheral band $(\mathrm{bar}=10 \mu \mathrm{m})$. Paleocene, Zone P4, Glendola Well, New Jersey, sample 286-287 feet.

FIGURES 9, 10.-Globanomalina pseudomenardii (Bolli): 9, cross section of test wall showing the layered wall and the trace of the POM (primary organic membrane) and pustule exhibiting the same morphology as in globorotaliid species (bar $=2 \mu \mathrm{m}$ ), Paleocene, Zone P4, Whitesville Well, New Jersey, sample 210-215 feet. 10 , view of surface layer on top of keel and of pustules of various generations (bar $=10 \mu \mathrm{m}$ ), Paleocene, Zone P4, Glendola Well, New Jersey, sample 286-287 feet.

FiguRES 11-13, 16.-Globanomalina imitata (Subbotina): 11, enlarged view of test wall showing typical globorotaliid pustules $(\mathrm{bar}=10 \mu \mathrm{m}) ; 12$, chambers of the inner whorl showing conical inner chambers with rounded and sharp-tipped pustules $(\mathrm{bar}=20 \mu \mathrm{m}) ; 13$, enlarged view of inner chamber of Figure 12 showing pustules $(\mathrm{bar}=10 \mu \mathrm{m}$ ); Paleocene, Zone P4, Whitesville Well, New Jersey, sample 210-21 5 feet. 16, enlarged view of inner chamber showing same pustule development as in Figure $12(\mathrm{bar}=10 \mu \mathrm{m})$, Paleocene, Zone P4, DSDP Site 384/7/CC; southeast Newfoundland Ridge, North Atlantic Ocean.

FIGURE 14.-Morozovella praeangulata (Blow), enlarged view of test wall showing pustules growing on a smooth "globorotaliid" surface (bar $=20 \mu \mathrm{m}$ ). Paleocene, Zone P3b, DSDP Site 527/28/6: 30-32 cm; Walvis Ridge, eastern South Atlantic Ocean.

FIGURE 15.-Morozovella velascoensis (Cushman), enlarged view of test wall showing different sized pustules growing on a smooth "globorotaliid" surface $(b a r=20 \mu \mathrm{m}$ ). Paleocene, Zone P5, DSDP Site 213/16/1: 104 cm; Wharton Basin, eastern Indian Ocean. 


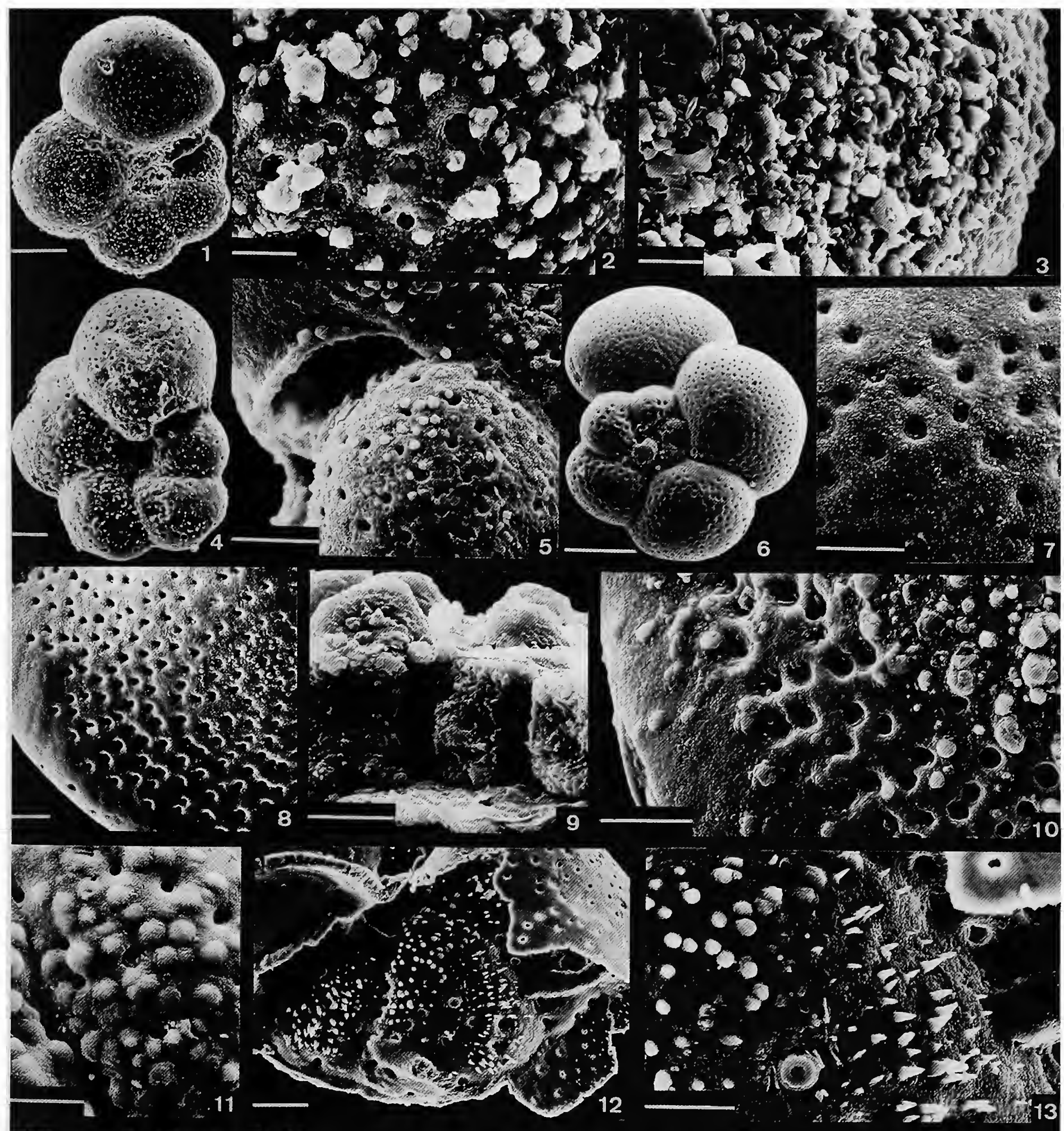

Gone.

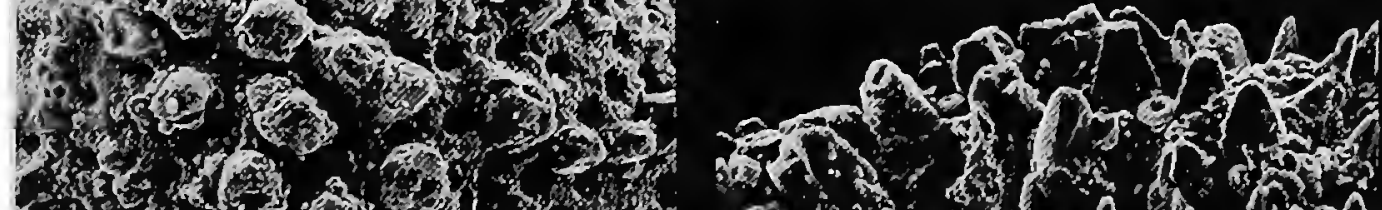

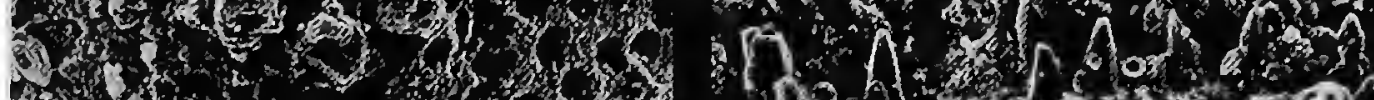

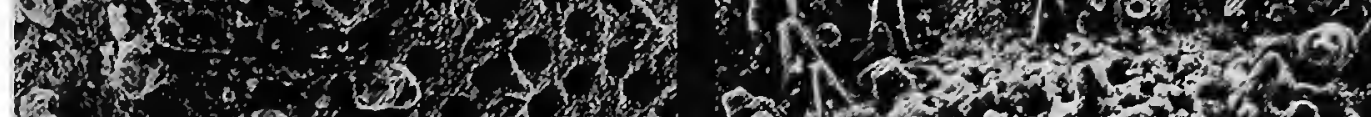
s. $x \rightarrow$ 19. (1)

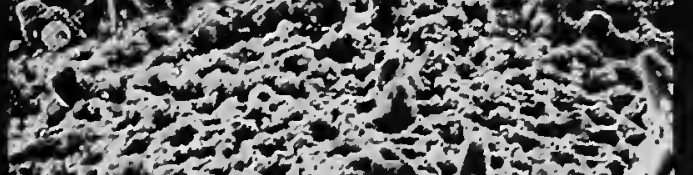

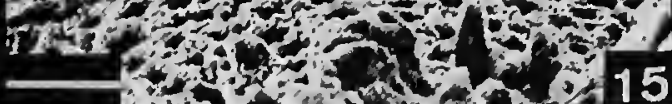

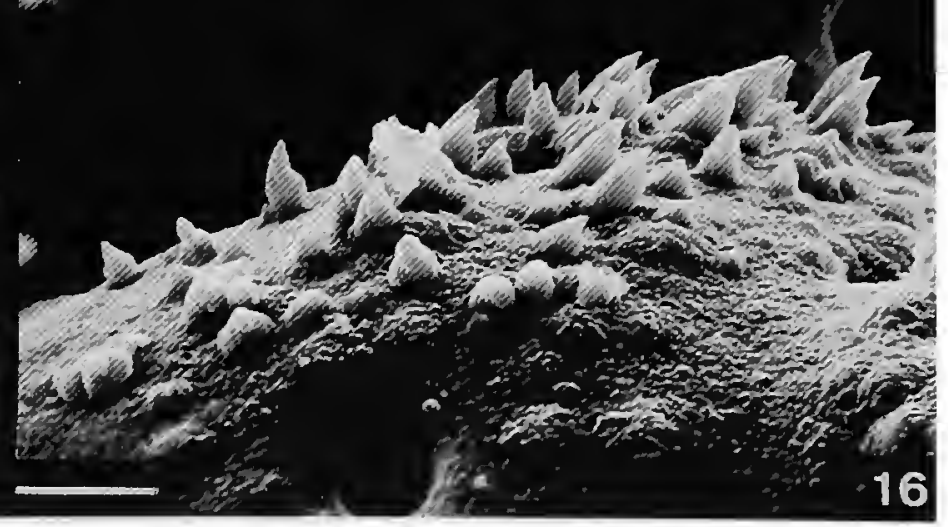




\section{PLATE 5}

\section{Acarinina and Praemurica Wall Texture}

FIGURE 1.-Acarinina strabocella (Loeblich and Tappan), enlarged view of test wall showing a smooth (globorotaliid) surface with simple and coalescent pustules $(\mathrm{bar}=10 \mu \mathrm{m})$. Paleocene, Zone P2, DSDP Site 356/25/5: 148-150 cm; São Paulo Plateau, South Atlantic Ocean.

FIGURE 2.-Acarinina nitida (Martin), enlarged view of test wall showing a smooth (globorotaliid) surface with simple and coalescent pustules, similar to Figure 1; wall texture, pustule morphology, and distribution is typical of extant globorotaliids (bar $=20 \mu \mathrm{m}$ ). Paleocene, Zone P4, DSDP Site 384/8/1: 136-138 cm; southeast Newfoundland Ridge, North Atlantic Ocean.

FIGURE 3.-Acarinina mckannai (White), enlarged view of test wall showing heavy, coalescing pustule growth on a smooth (globorotaliid) surface; wall texture, pustule morphology, and distribution is typical of extant globorotaliids (bar $=20 \mu \mathrm{m}$ ). Paleocene, Zone P4, DSDP Site 384/6/CC; southeast Newfoundland Ridge, North Atlantic Ocean.

FIGURE 4.--Acarinina subsphaerica (Subbotina), enlarged view of test wall showing heavy pustule growth; wall texture, pustule morphology, and distribution is typical of extant globorotaliids (bar $=20 \mu \mathrm{m}$ ). Paleocene, Zone P4, DSDP Site 465/5/1: 65-67 cm; Hess Rise, central Pacific Ocean.

FIGURES 5-8.-Neogloboquadrina dutertrei (d'Orbigny), overall view of thin (Figure 5), medium (Figures 6, 7), and thick (Figure 8) walled specimens showing development of globoquadrinid wall texture by growth and coalescing of pustules to form a cancellate wall texture. A calcite crust is formed in the final stage (Figure 8). (Figure 5: bar $=50 \mu \mathrm{m}$; Figures 6-8: bar $=100 \mu \mathrm{m}$.) Recent, plankton net catch, eastern North Atlantic.

FIGURES 9-11.-Neogloboquadrina dutertrei (d'Orbigny): 9, 10, enlarged views of test wall of same specimen showing pores separated by elongated, subparallel ridge-like structures, which are connected by short, less developed ridges, thereby forming the cancellate wall texture. (Figure 9: bar $=20 \mu \mathrm{m}$; Figure 10: bar $=10$ $\mu \mathrm{m}$.) Recent, sediment trap, off Barbados. 11, two enlarged views of test wall of single specimen showing gametogenetic calcification and early formation of a calcite crust. The wall thickens as the individual sinks to deeper water, e.g., deep chlorophyll maximum. (Bars $=20 \mu \mathrm{m}$ and $5 \mu \mathrm{m}$, respectively.) Recent, plankton net catch, off Bermuda.

FIGURES 12-15.-Hedbergella monmouthensis (Olsson), views of test wall showing the development and distribution of pustules on a smooth surface: 12 , overall view of specimen (bar $=40 \mu \mathrm{m}) ; 13$, enlarged view of ultimate chamber with small scattered pustules; 14 , enlarged view of penultimate chamber showing growth and coalescing of pustules; 15 , enlarged view of 4th chamber showing coalescing of pustules around pores, which is an initial step toward the development of a cancellate wall texture. (Figures 13-15: bars $=10 \mu \mathrm{m}$.) Topotype, upper Maastrichtian, Redbank Formation, New Jersey.

FiguREs 16-18,-Praemurica taurica (Morozova): 16, overall view of test showing the globoquadrinid-type (praemuricate) wall texture (bar $=40 \mu \mathrm{m}) ; 17$, enlarged view of test wall of another specimen showing the praemuricate cancellate wall (bar $=10 \mu \mathrm{m}) ; 18$, enlarged view of test wall of another specimen showing elongate, subparallel ridges connected by short, less developed ridges surrounding the pores (bar $=10 \mu \mathrm{m}$ ). Paleocene, Zone Pla, Millers Ferry, Alabama, core 225, Figures 16, 17, from sample 216 and Figure 18 from sample 194. 

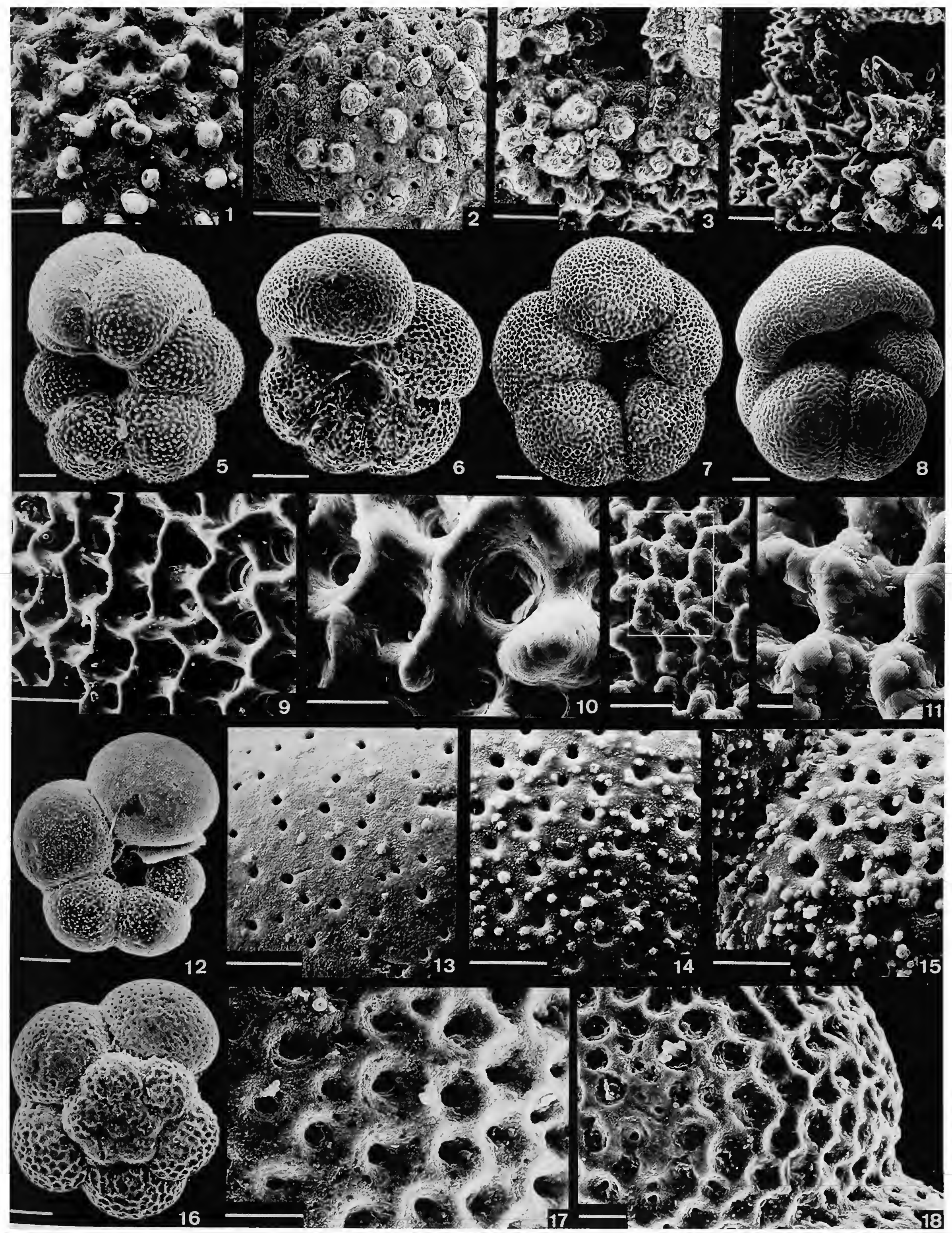


\section{PLATE 6}

\section{Praemurica and Microperforates}

FIGURES 1-4.-Praemurica pseudoinconstans (Blow): 1, overall view of test showing the globoquadrinid-type (praemuricate) wall texture (bar $=40 \mu \mathrm{m}$ ); 2, 4, enlarged view of 6th and 3rd chambers, respectively, showing the typical praemuricate wall texture of elongate, subparallel ridges connected by shorter, less developed ridges surrounding the pores, and showing light gametogenetic calcification (bar $=10 \mu \mathrm{m}$ ); 3 , enlarged view of another specimen showing the praemuricate wall texture $(\mathrm{bar}=10 \mu \mathrm{m}$ ). Paleocene, Zone Pla, Millers Ferry, Alabama, core 225, sample 194.

FIGURE 5.-Igorina pusilla (Bolli), enlarged view of test wall showing the praemuricate wall texture (bar $=10$ $\mu \mathrm{m})$. Paleocene, Zone P4, Glendola Well, New Jersey, sample 286-287 feet.

FIGURE 6.-Igorina albeari (Cushman and Bermúdez), enlarged view of test wall showing the typical praemuricate wall texture of subparallel ridges connected by shorter, less developed ridges surrounding the pores $(\mathrm{bar}=20 \mu \mathrm{m})$. Paleocene, Zone P3b, DSDP Site 356/24/2: 92-94 cm; São Paulo Plateau, South Atlantic Ocean.

FIGURES 7-10.-Globigerinita glutinata (Egger): 7, overall view of early adult form showing microperforate wall and scattered small pustules (bar $=100 \mu \mathrm{m}) ; 8$, mature adult form showing heavy pustulose wall texture and bulla with scattered small pustules (bar $=100 \mu \mathrm{m}$ ); 9, enlarged view of test wall of another specimen showing microperforate wall with multifaceted pustules covering pores $(\mathrm{bar}=20 \mu \mathrm{m}) ; 10$, enlarged view of test wall of another specimen showing microperforate wall with small rounded pustules overgrowing pores (bar $=5 \mu \mathrm{m})$. Recent, plankton net sample, North Atlantic Ocean.

FIGURES 11, 12.-Globoconusa daubjergensis (Brönnimann): 11, overall view of test showing microperforate wall with scattered pustules (bar $=50 \mu \mathrm{m}$ ); 12, enlarged view of another specimen showing microperforate wall with sharp-pointed pustules (bar $=10 \mu \mathrm{m}$ ). Paleocene, Zone Plc, Brightseat Formation, Maryland.

FIGURES 13, 14. Chiloguembelina crinita (Glaessner): 13, overall view of test showing microperforate wall covered with coarse rounded pustules (bar $=50 \mu \mathrm{m}) ; 14$, enlarged view of 3rd chamber showing microperforate wall and rounded pustules overgrowing pores $(\mathrm{bar}=10 \mu \mathrm{m})$. Paleocene, Zone P4, Whitesville Well, New Jersey, sample $180-185$ feet.

FIGURES 15-18. - Chiloguembelina morsei (Kline): 15-17, overall view and enlarged views of test wall showing microperforate texture with coarse multifaceted pustules overgrowing pores (compare to Figure 9) (Figure 15: bar $=40 \mu \mathrm{m}$; Figures 16, 17: bar $=10 \mu \mathrm{m}$ ). Paleocene, Zone P2, DSDP Site 356/24/2: 92-94 cm; São Paulo Plateau, South Atlantic Ocean. 18, enlarged view of test wall, partially recrystallized, showing multifaceted pustules $(\mathrm{bar}=20 \mu \mathrm{m})$. Paleocene, ODP Hole 690B/16/5: 76-80 cm; Maud Rise, Southern Ocean. 


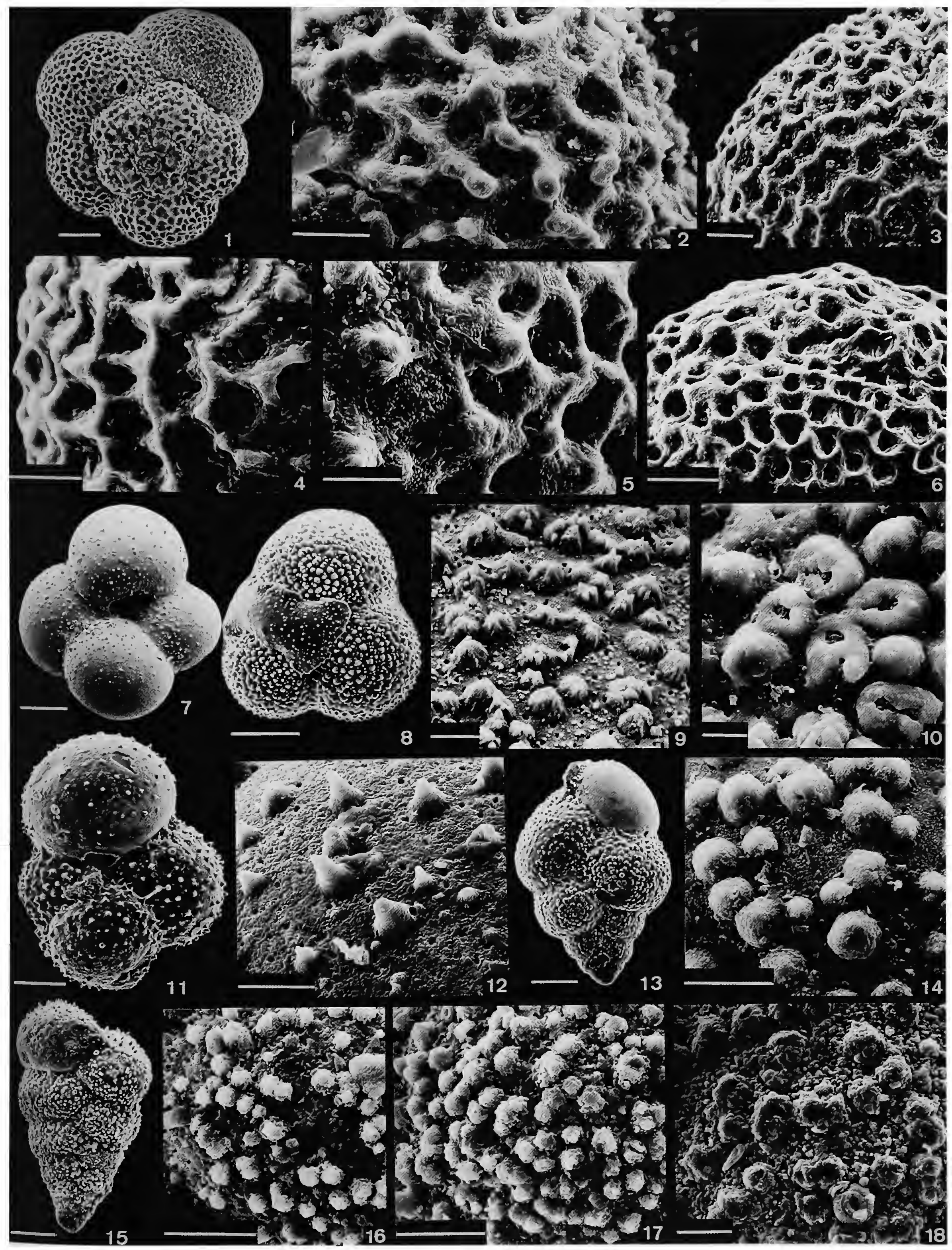




\section{PLATE 7}

\section{Diagenesis}

FIGURES 1, 2.- Subbotina cancellata Blow, overall view and enlarged view of recrystallized and corroded specimen; diagenesis obscures original wall texture, although a spine hole is visible in center of picture (Figure 1: $\mathrm{bar}=40 \mu \mathrm{m}$; Figure 2: bar $=10 \mu \mathrm{m}$ ). Paleocene, Zone P2, DSDP Hole 398D/39/4: 145-147 cm; western Iberian continental margin, eastern North Atlantic Ocean.

FIGURE 3.-Eoglobigerina edita (Subbotina), enlarged view of test wall showing corrosion and dissolution (bar $=4 \mu \mathrm{m})$. Paleocene, Zone Pa, Millers Ferry, Alabama, core 226, sample 8.

FIGURE 4.-Subbotina trivialis (Subbotina), enlarged view of heavily recrystallized and overgrown test wall showing euhedral calcite crystals closing off pores, although a spine hole is still visible in center of picture (bar $=20 \mu \mathrm{m})$. Paleocene, Zone P1, DSDP Hole 390A/l 1/4: 80-82 cm; Blake-Bahama Basin, North Atlantic Ocean.

FIGURES 5, 6.-Parasubbotina pseudobulloides (Plummer), enlarged views of corroded and recrystallized test wall; diagenesis has nearly obliterated original wall texture, but a few spine holes are preserved (Figure 5: bar $=10 \mu \mathrm{m}$; Figure 6: bar $=4 \mu \mathrm{m}$ ). Paleocene, Zone Pla, Millers Ferry, Alabama, core 226, sample 85 .

FIGURE 7.-Acarinina strabocella (Loeblich and Tappan), enlarged view of recrystallized wall showing fine subhedral crystals; recrystallized pustules show euhedral crystal surfaces $(\mathrm{bar}=10 \mu \mathrm{m})$. Paleocene, Zone P3, ODP Hole 750A/1 1/1: 149-150 cm; southern Kerguelen Plateau, Southern Ocean.

FIGURE 8.-Praemurica inconstans (Subbotina), enlarged view of recrystallized and overgrown test wall, showing closed off pores and obscured original wall texture $(\mathrm{bar}=10 \mu \mathrm{m})$. Paleocene, Zone P Ic, DSDP Site 577/12/1: 49-51 cm; Shatsky Rise, western Pacific Ocean.

FIGURE 9. - Subbotina $\mathrm{cf}$. triangularis (White), enlarged view of partially dissolved wall showing calcitic pore linings that are visible due to dissolution $(\mathrm{bar}=10 \mu \mathrm{m}$ ). Paleocene, Zone P5, DSDP Site $2 / 3 / 16$; Wharton Basin, eastern Indian Ocean.

FIGURE 10.- Subbotina cf. velascoensis (Cushman), enlarged view of cross section showing recrystalled wall with overgrowth on inner wall, but POM is still visible $($ bar $=10 \mu \mathrm{m}$ ). Paleocene, Zone P2, DSDP Site 398D/39/4: 145-147 cm; western lberian continental margin, eastern North Atlantic Ocean.

FIGURE 11. Subbotina sp., enlarged view of heavily recrystallized wall (bar $=4 \mu \mathrm{m}$ ). Paleocene, Zone $P \alpha$, DSDP Site 577/12/5: 113-114 cm; Shatsky Rise, western Pacific Ocean.

FIGURE 12.-Subbotina triangularis (White), enlarged view of cross section showing heavily recrystallized wall completely obscuring the original wall texture $($ bar $=10 \mu \mathrm{m})$. Paleocene, Zone P4, DSDP Site 549/20/2: 69-71 cm; Goban Spur, eastern North Atlantic Ocean.

FIGURES 13, 14.-Parvularugoglobigerina eugubina (Luterbacher and Premoli Silva), overall view and enlarged view showing completely recrystallized test wall; original microperforate wall is obscured (Figure 13: bar $=40$ $\mu \mathrm{m}$; Figure 14: bar $=10 \mu \mathrm{m}$ ). Paleocene, Zone P $\alpha$, DSDP Site 577/12/5: 125-126 cm; Shatsky Rise, western Pacific Ocean.

FIGURE 15.-Chiloguembelina wilcoxensis (Cushman and Ponton), enlarged view of recrystallized wall showing recrystallized pustules; microperforate wall is obscured $(\mathrm{bar}=10 \mu \mathrm{m})$. Paleocene, ODP Hole 690B/16/5: 76-80 cm; Maud Rise, Southern Ocean. 

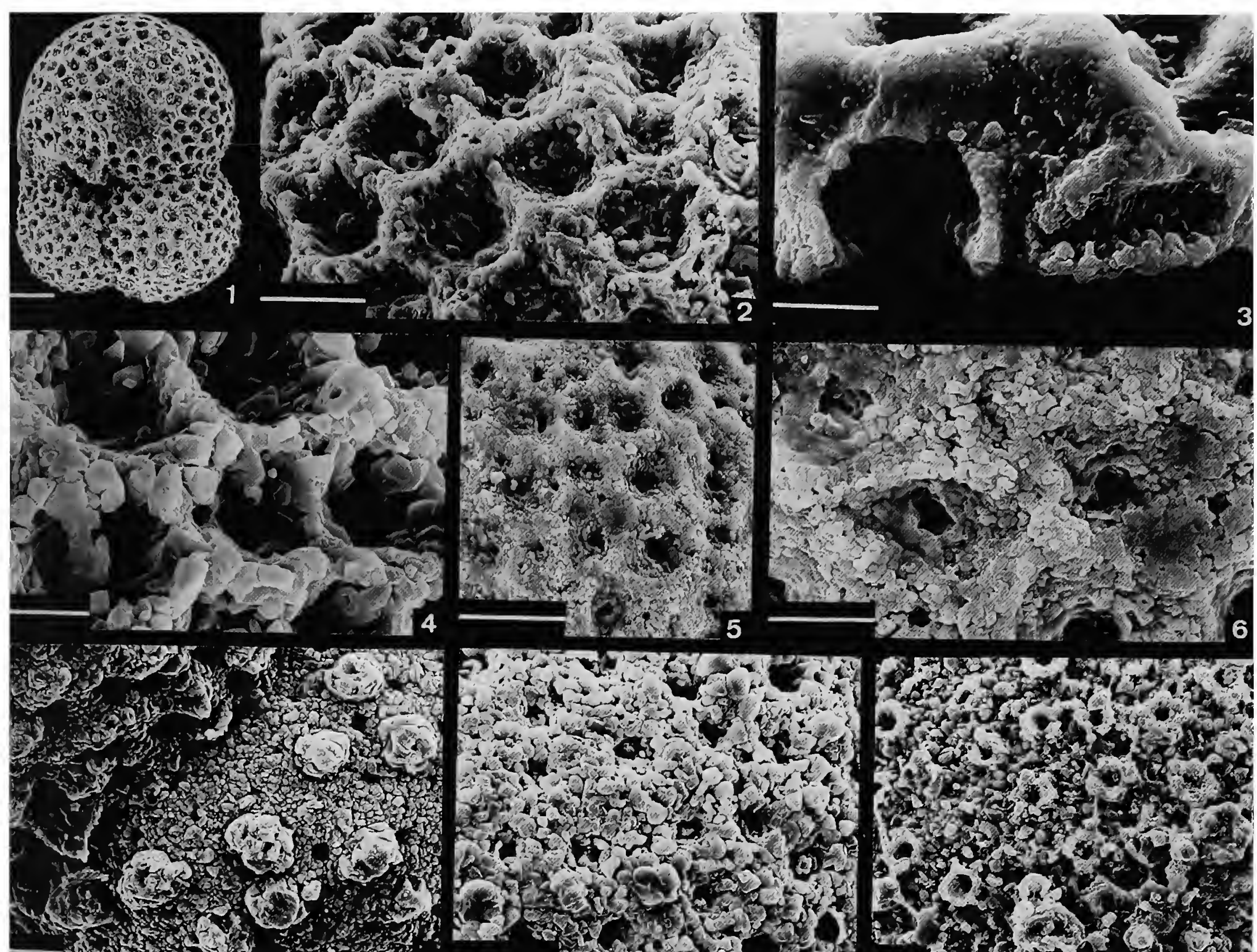
4.

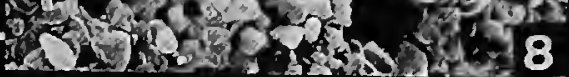

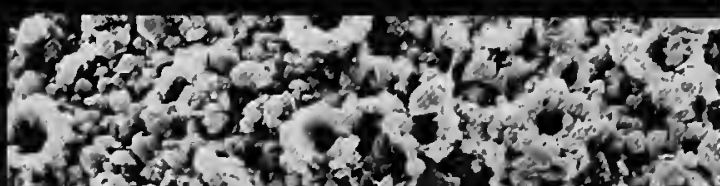
350 .

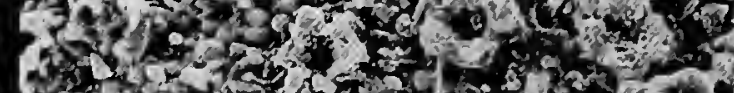

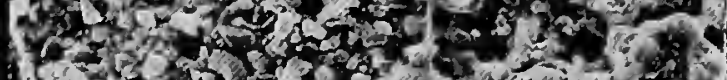

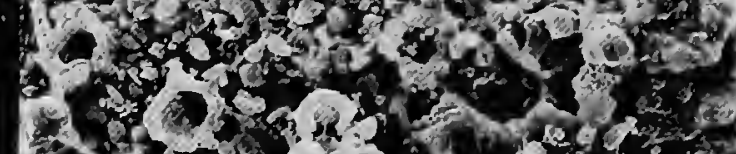
and and

\section{(2)} $3^{2}-x^{2}-1$

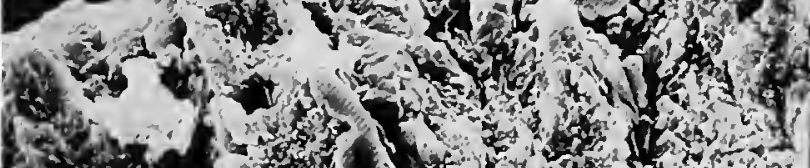

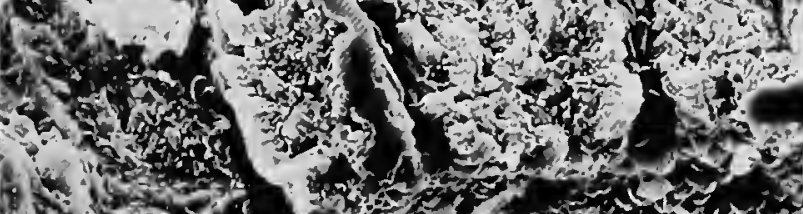
(1)

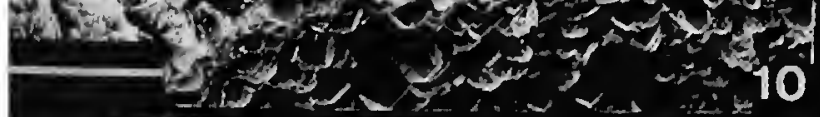

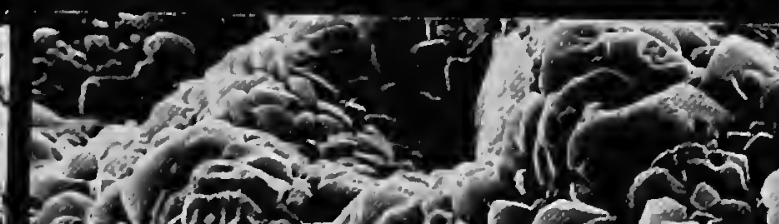

and (1) ,

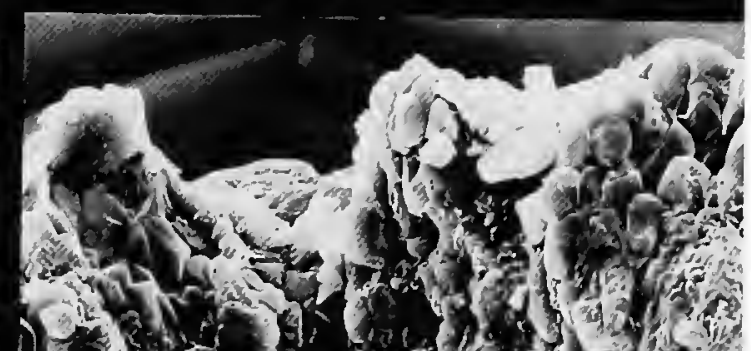

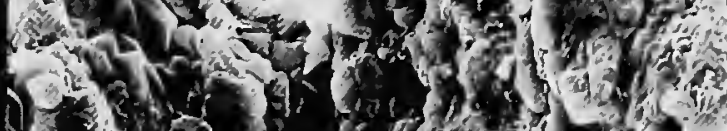
1023

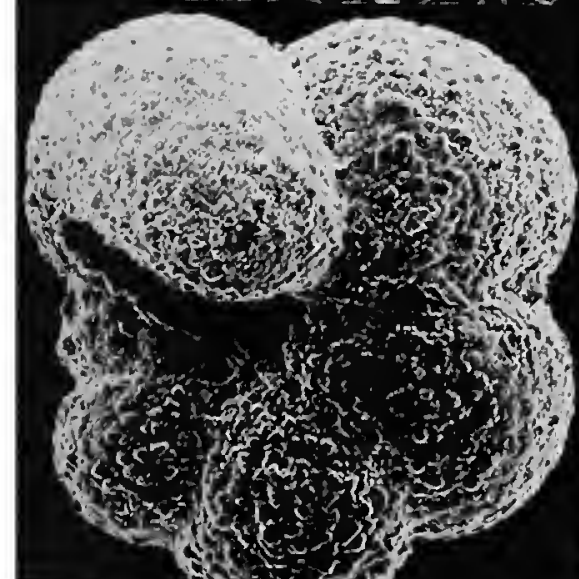

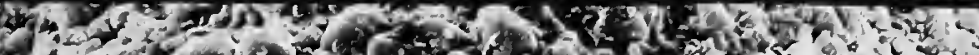

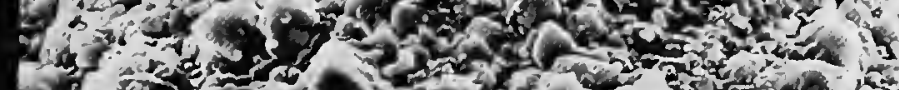

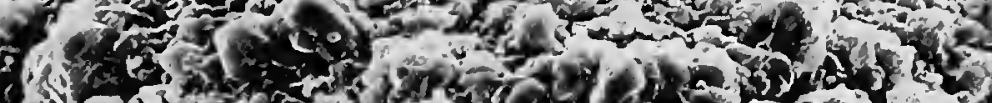

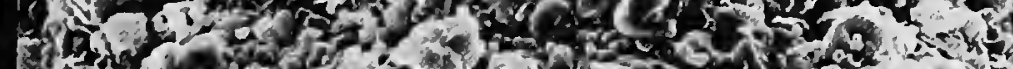

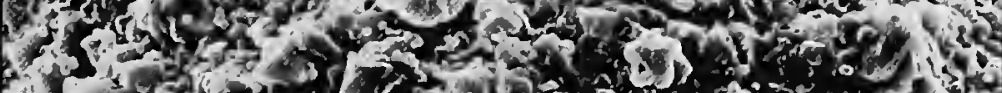

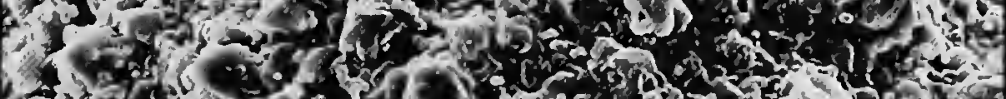

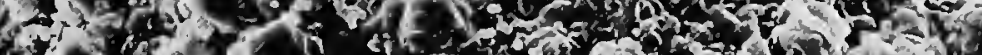

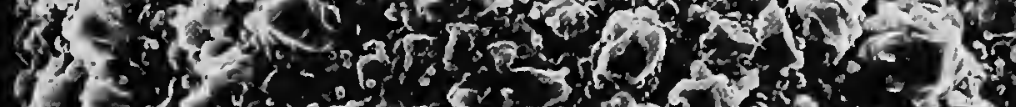
Sor and

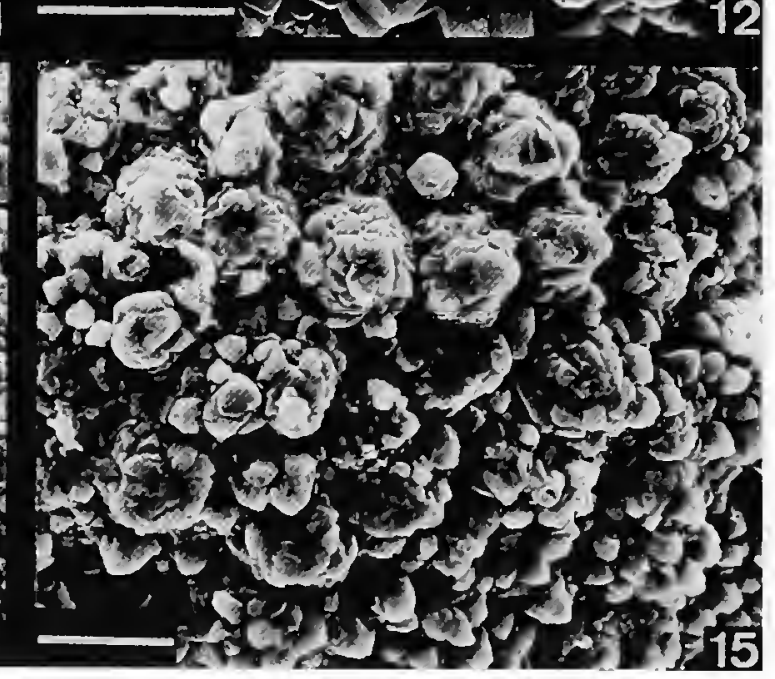




\section{PLATE 8}

\section{Russian Primary Type Specimens}

(bars $=100 \mu \mathrm{m}$ )

FIGURES 1-3.-Guembelitria irregularis Morozova, 1961:17, pl. 1: fig. 9, holotype no. 3510/13a, Moscow GAN; Danian, Tarkhankut, Crimea. See "Discussion" for Guembelitria cretacea.

FiguRES 4-6.-Globigerina (Eoglobigerina) trifolia Morozova, 1961:12, pl. 1: fig. 1, holotype no. 3510/4, Moscow GAN; Danian, Tarkhankut, Crimea. See "Discussion" for Globoconusa daubjergensis.

FIGURES 7-9.-Acarinina multiloculata Morozova, 1961:15, pl. 2: fig. 5, holotype no. 3510/10, Moscow GAN; Montian, Balka Nasypkoiskaya, Crimea. Probably a reworked specimen of Hedbergella planispira (Tappan, 1940).

FIGURES 10-12.-Globigerina (Eoglobigerina) eobulloides Morozova, 1959:1115, text-fig. la-c, holotype no. 3508/1, Moscow GAN; Danian, Tarkhankut, Crimea. See Eoglobigerina eobulloides.

FIGURES 13-15.-Globigerina (Eoglobigerina) hemisphaerica Morozova, 1961:11, pl. 1: fig. 4, holotype no. 3510/3, Moscow GAN; Danian, Tarkhankut, Crimea. See "Discussion" for Eoglobigerina edita.

FIGURES 16-18.-Globigerina (Eoglobigerina) theodosica Morozova, 1961:11, pl. 1: fig. 6, holotype no. 3510/2, Moscow GAN; Danian, Tarkhankut, Crimea. See "Discussion" for Eoglobigerina edita. 

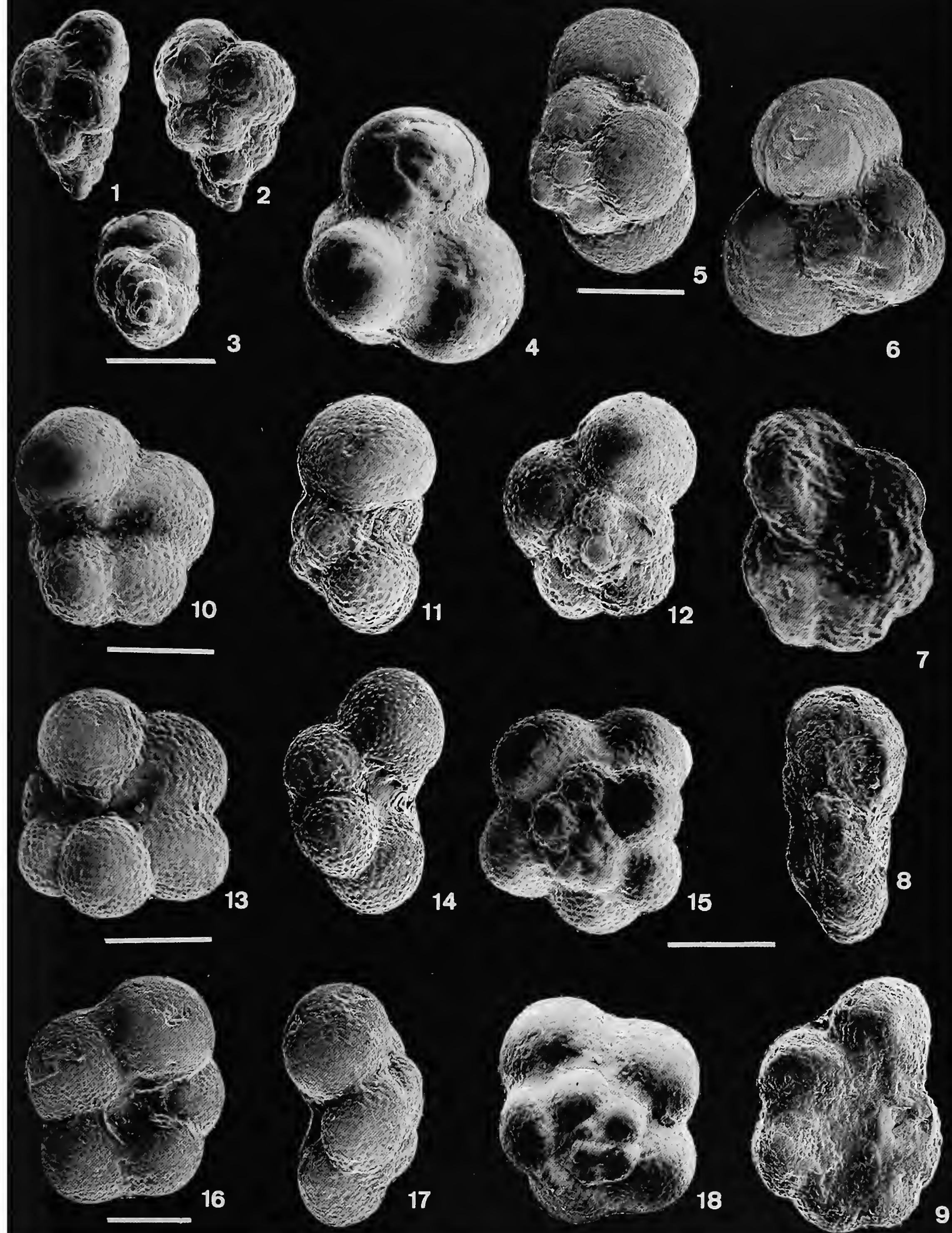

18

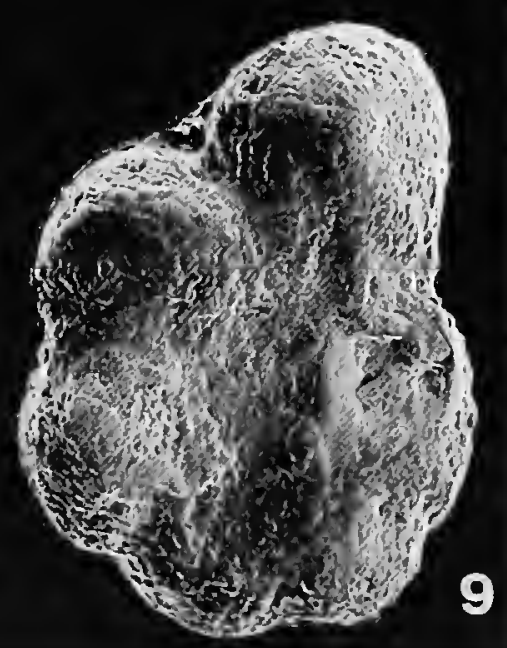




\title{
PLATE 9
}

\section{Russian Primary Type Specimens}

\author{
$($ bars $=100 \mu \mathrm{m})$
}

FIGURES 1-3.-Globigerina (Eoglobigerina) tetragona Morozova, 1961:13, pl. 1: fig. 2, holotype no. 3510/5, Moscow GAN; Danian, Pre-Caspian Basin, Novouzensk. See "Discussion" for Eoglobigerina edita.

FIGURES 4-6.-Globigerina (Eoglobigerina) pentagona Morozova, 1961:13, pl. 1: fig. 3, holotype no. 3510/6, Moscow GAN; Danian, Tarkhankut, Crimea. See "Discussion" for Eoglobigerina edita.

FIGURES 7-9.—Globigerina fringa Subbotina, 1953:62, pl. 3: fig. 3, holotype no. 2175, St. Petersburg VNIGRI (323/39); Danian, Pecten horizon, Azov-Black Sea flysch, Anapa, Caucasus. See "Discussion" for Subbotina cancellata.

FIGURES 10-12.—Globigerina trivialis Subbotina, 1953:64, pl. 4: fig. 4a-c, holotype no. 4004, St. Petersburg VNIGRI (378/30); Elburgan Fm., Kuban River section, northern Caucasus. See Subbotina trivialis.

FIGURES 13-15.-Globigerina (Globigerina) microcellulosa Morozova, 1961:14, pl. 1: fig. 11, holotype no. 3510/7, Moscow GAN; Danian, Tarkhankut, Crimea. See "Discussion" for Subbotina triloculinoides.

FIGURES 16-18.-Globigerina varianta Subbotina, 1953:63, pl. 3: fig. 5a-c, holotype no. 3994, St. Petersburg VNIGRI (378/20); zone of rotaliform Globorotalia, Elburgan Fm., Kuban River section, northern Caucasus. See Parasubbotina varianta. 


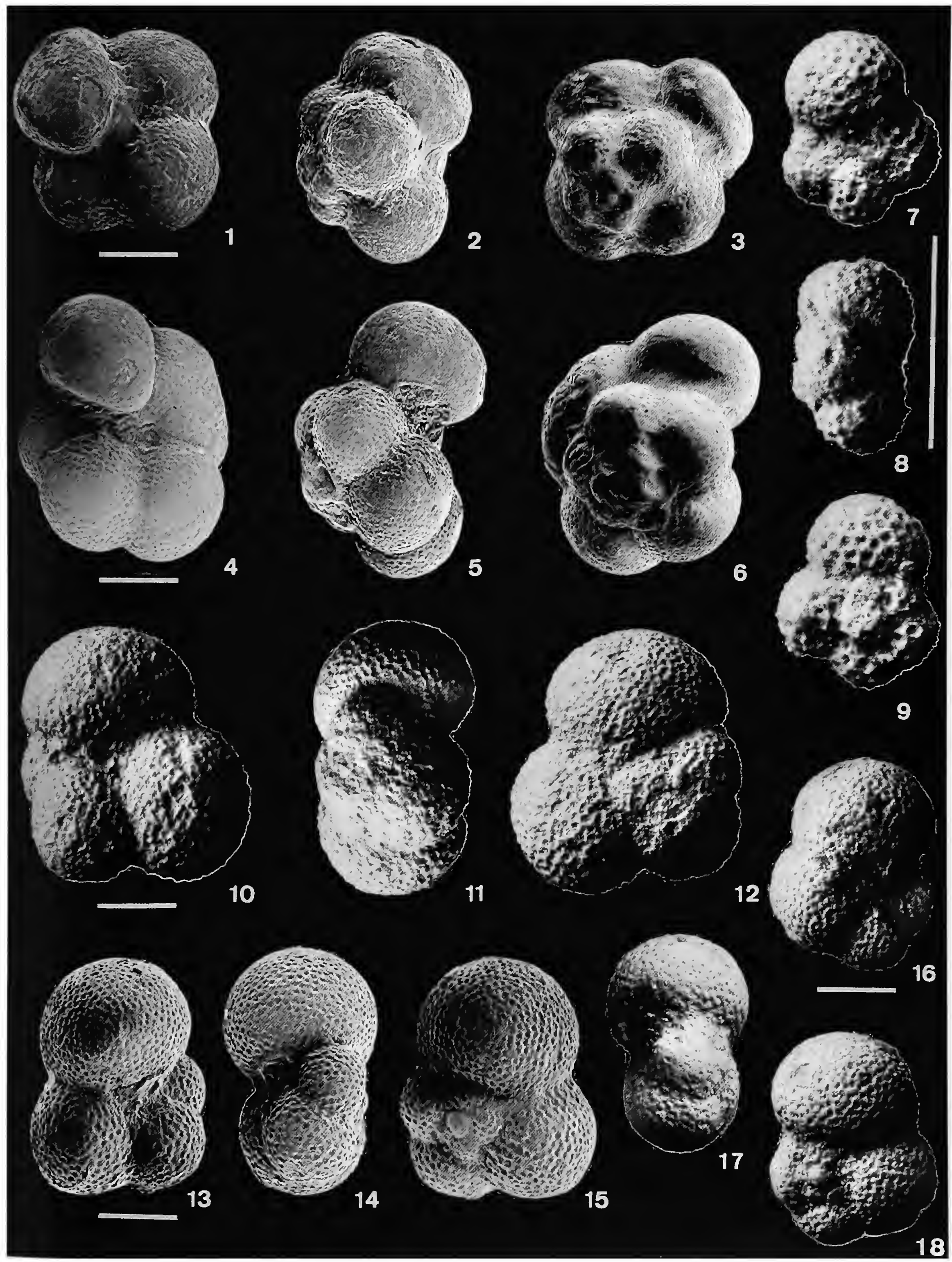




\title{
PLATE 10
}

\author{
Russian Primary Type Specimens \\ $($ bars $=100 \mu \mathrm{m})$
}

Figures 1-3.-Globigerina (Eoglobigerina) taurica Morozova, 1961:10, pl. 1: fig. 5, holotype no. 3510/1, Moscow GAN; Danian, Tarkhankut Peninsula, Crimea. See Praemurica taurica.

FIGURES 4-6.-Globigerina inconstans Subbotina, 1953:58, pl. 3: fig. 1, holotype no. 3992, St. Petersburg VNIGRI (378/18); zone of rotaliform globorotaliids, Elburgan Fm., Kuban River, northern Caucasus. See Praemurica inconstans.

Figures 7, 8.-Acarinina praecursoria Morozova, 1957:1111, text-fig. 1, holotype no. 3507/1, Moscow GAN; Danian, Khokhodz' River, northem Caucasus. See "Discussion" for Praemurica inconstans and for Praemurica uncinata.

FIGURES 9-11.-Acarinina indolensis Morozova, 1959:1116, text-fig. 1, holotype no. 3508/2, Moscow GAN; Danian, Tarkhankut Peninsula, Crimea. See "Discussion" for Praemurica uncinata.

FIGURES 12-14.-Globorotalia imitata Subbotina, 1953:206, pl. 16: fig. 14a-c, holotype no. 4073, St. Petersburg VNIGRI (378/112); zone of rotaliform globorotaliids (Danian?), Elburganian horizon, Kuban River, northern Caucasus. See Globanomalina imitata.

FiguRES 15-17.-Globorotalia planoconica Subbotina, 1953:210, pl. 17: fig. 4a-c, holotype no. 4081, St. Petersburg VNIGRI (378/118); zone of conical globorotaliids, lower to middle Eocene (probably lower Eocene), Series F1, Khieu River, Caucasus. See Globanomalina planoconica. 


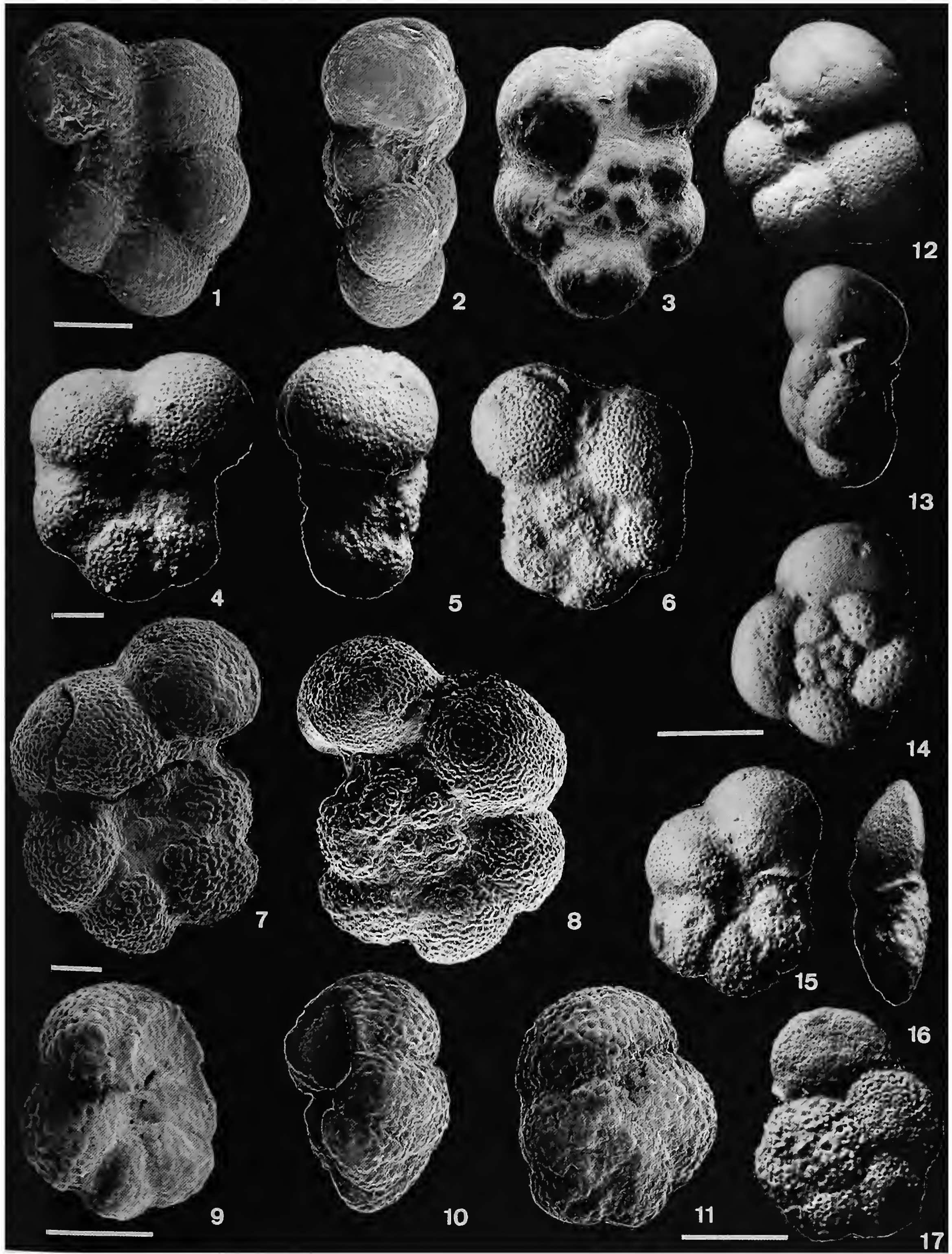




\title{
PLATE 11
}

\section{Russian Primary Type Specimens}

\author{
(bars $=100 \mu \mathrm{m})$
}

FIGURES 1-3.-Globorotalia convexa Subbotina, 1953:209, pl. 17: fig. 2a-c, holotype no. 4079, St. Petersburg VNIGRI (378/116); zone of conical globorotaliids, lower to middle Eocene (probably lower Eocene), Series F1, Khieu River, Caucasus. See "Discussion" for Igorina tadjikistanensis.

FIGURES 4-6.-Globorotalia tadjikistanensis Bykova, 1953:86, pl. 3: fig. 5a-c, holotype no. 2794-a (upper specimen), St. Petersburg VNIGRI (350/10); Suzakian Stage (middle Paleocene), Ak-Tau, southern part of Tadzhik Basin, Kazakhstan. See "Discussion" for Igorina tadjikistanensis.

FIGURES 7-9.-Globorotalia tadjikistanensis Bykova, 1953:86, paratype no. 2794-a (middle specimen), St. Petersburg VNIGRI (350/10); Suzakian Stage (middle Paleocene), Ak-Tau, southern part of Tadzhik Basin, Kazakhstan. See Igorina tadjikistanensis.

FIGURES 10-15.-Globorotalia angulata (White) var. kubanensis Shutskaya, 1956, specimens from remaining collections of Shutskaya (no. 645-32), St. Petersburg VNIGRI; zone of Acarinina conicotruncata. PCI (middle Paleocene), Khieu River, Caucasus. Holotype in Moscow is lost, hence the identity of this taxon cannot be determined. Further confusing the taxonomic status of this taxon is the specimen represented by Figures 10-12, which is probably referable to Morozovella apanthesma (Loeblich and Tappan), and the specimen represented by Figures 13-15, which is probably referable to Morozovella acutispira (Bolli and Cita). The holotype figure, in contrast, resembles Morozovella conicotruncata (Subbotina). 


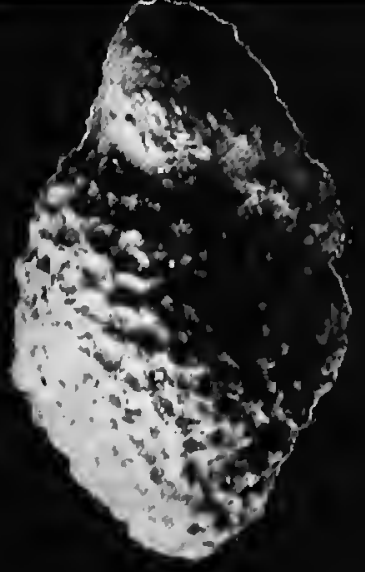

2

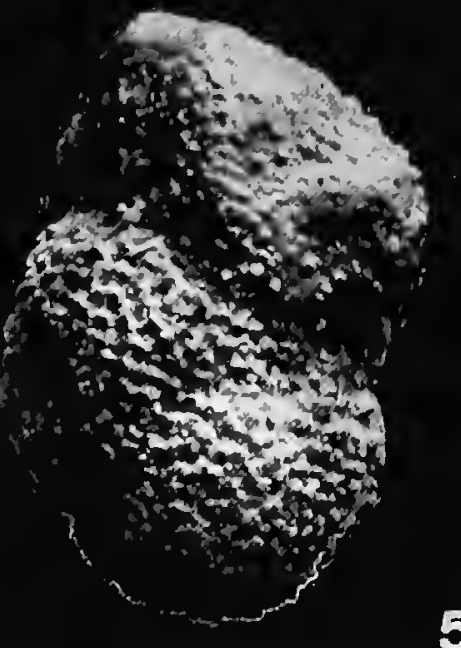

4
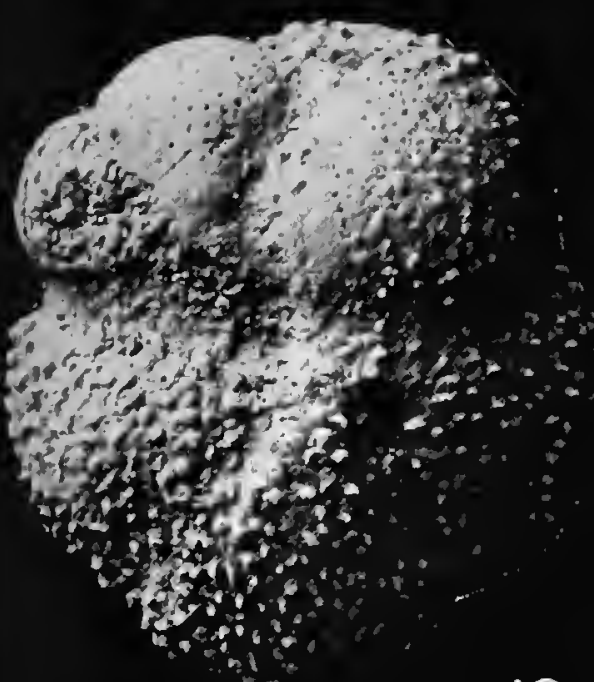

10
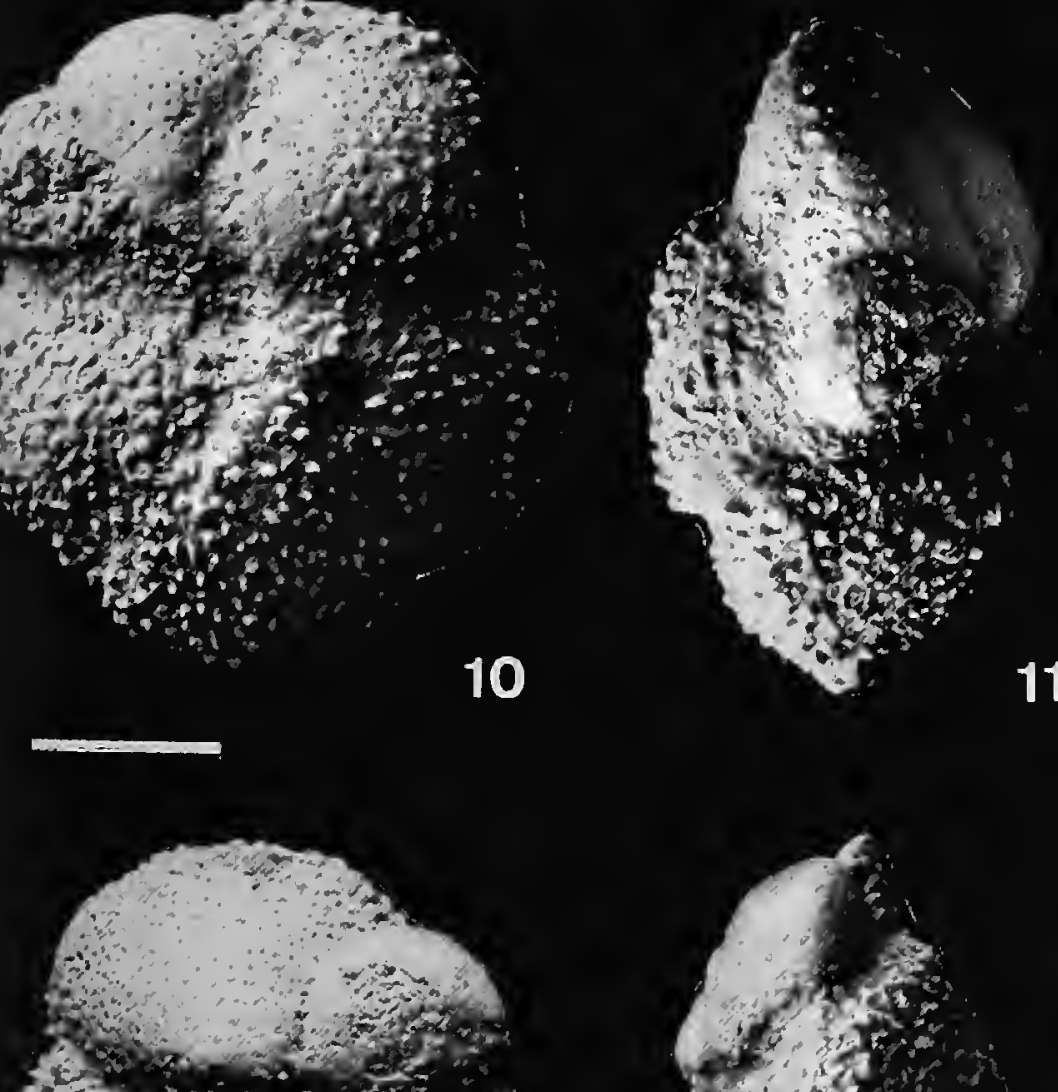

cot

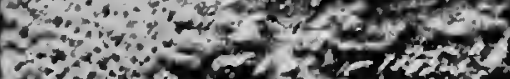

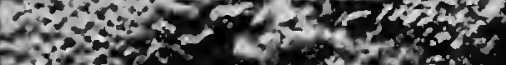

1.0.

8.

13

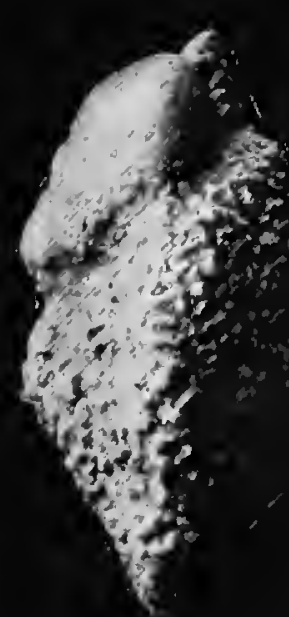

5

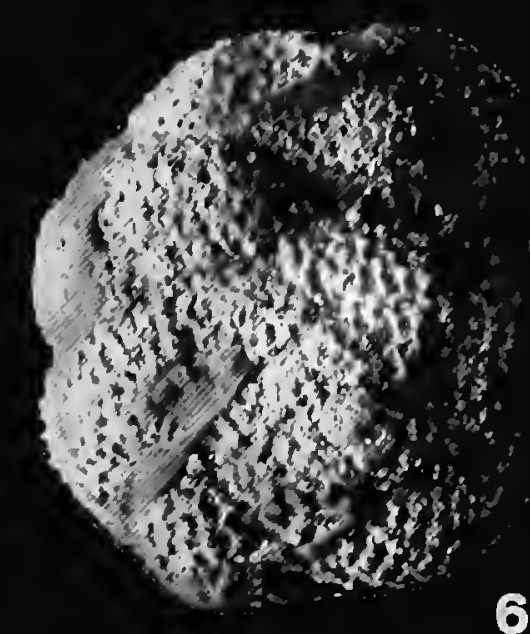

6
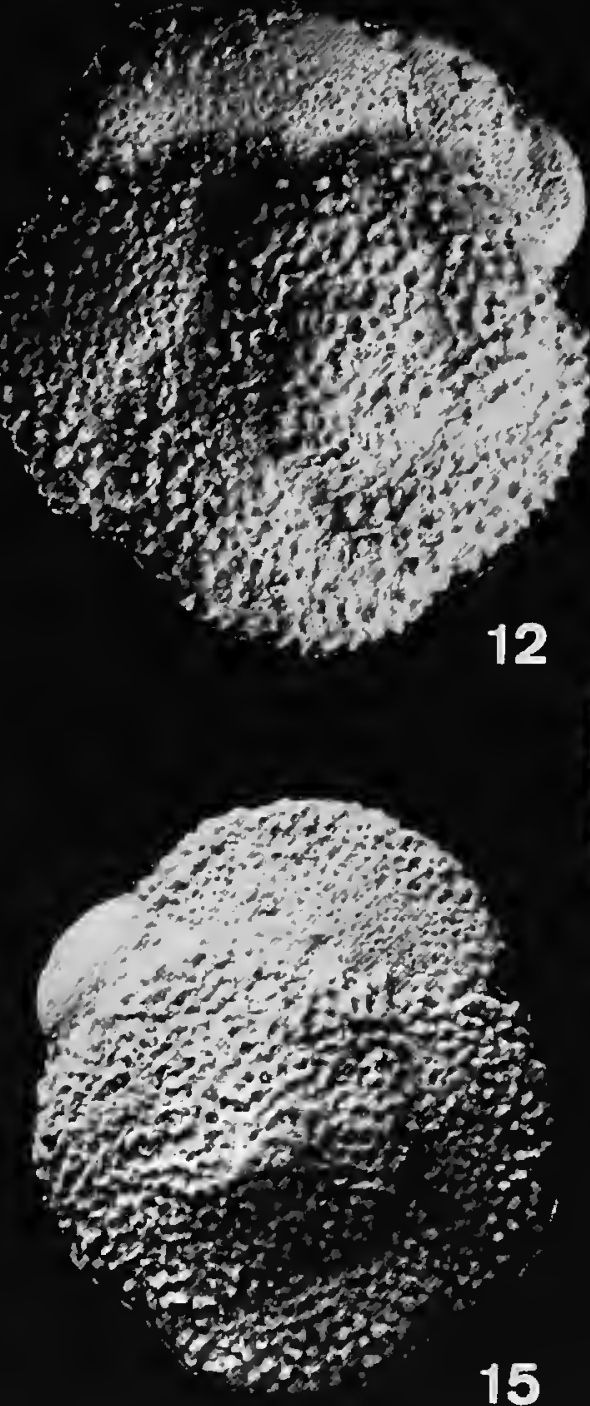

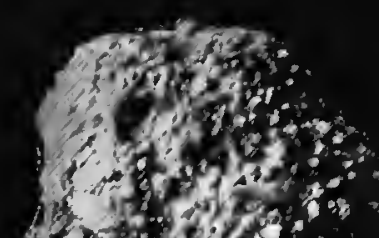

3

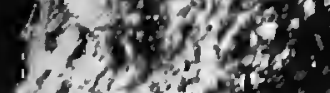

is and of

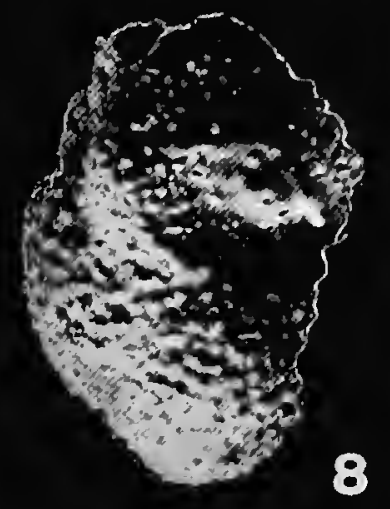

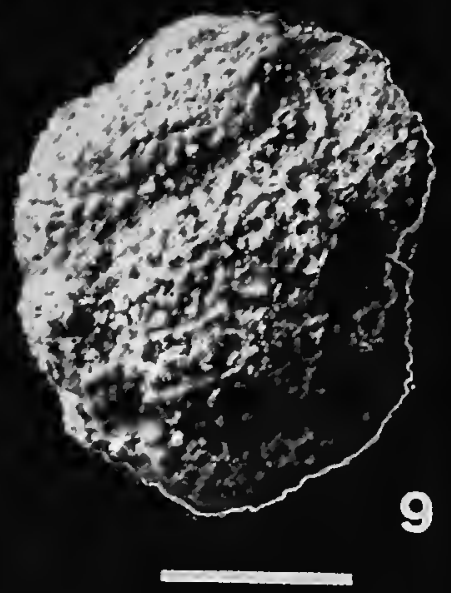




\title{
PLATE 12
}

\section{Russian Primary Type Specimens}

\author{
(bars $=100 \mu \mathrm{m})$
}

FIGURES 1-3.-Acarinina acarinata Subbotina, 1953:229, pl. 22: fig. 5, paratype no. 4129. St. Petersburg VNIGRI (378/160); zone of compressed globorotaliids, Paleocene-lower Eocene, Series FI, Khieu River, Caucasus. See "Discussion" for Acarinina nitida.

FIGURES 4-6.-Acarinina intermedia Subbotina, 1953:227, pl. 20: fig. 15, holotype no. 4095, St. Petersburg VNIGRI (378/124); zone of compressed globorotaliids, Paleocene?, Goryache Klynch horizon, Kuban River, Caucasus. See "Discussion" for Acarinina nitida.

FIgures 7-9.-Guembelitria dammula Voloshina, 1961, hypotype; Paleocene, P0, Bjala (K/T section no. 2b, 1-2 cm above boundary), Bulgaria. See "Discussion" for Guembelitria cretacea.

FIGURES 10-12.-Globanomalina imitata (Subbotina, 1953), hypotype; Paleocene, Plb/c, Bjala (K/T section no. 2b, sample Sum 24/12), Bulgaria. See Globanomalina imitata. 


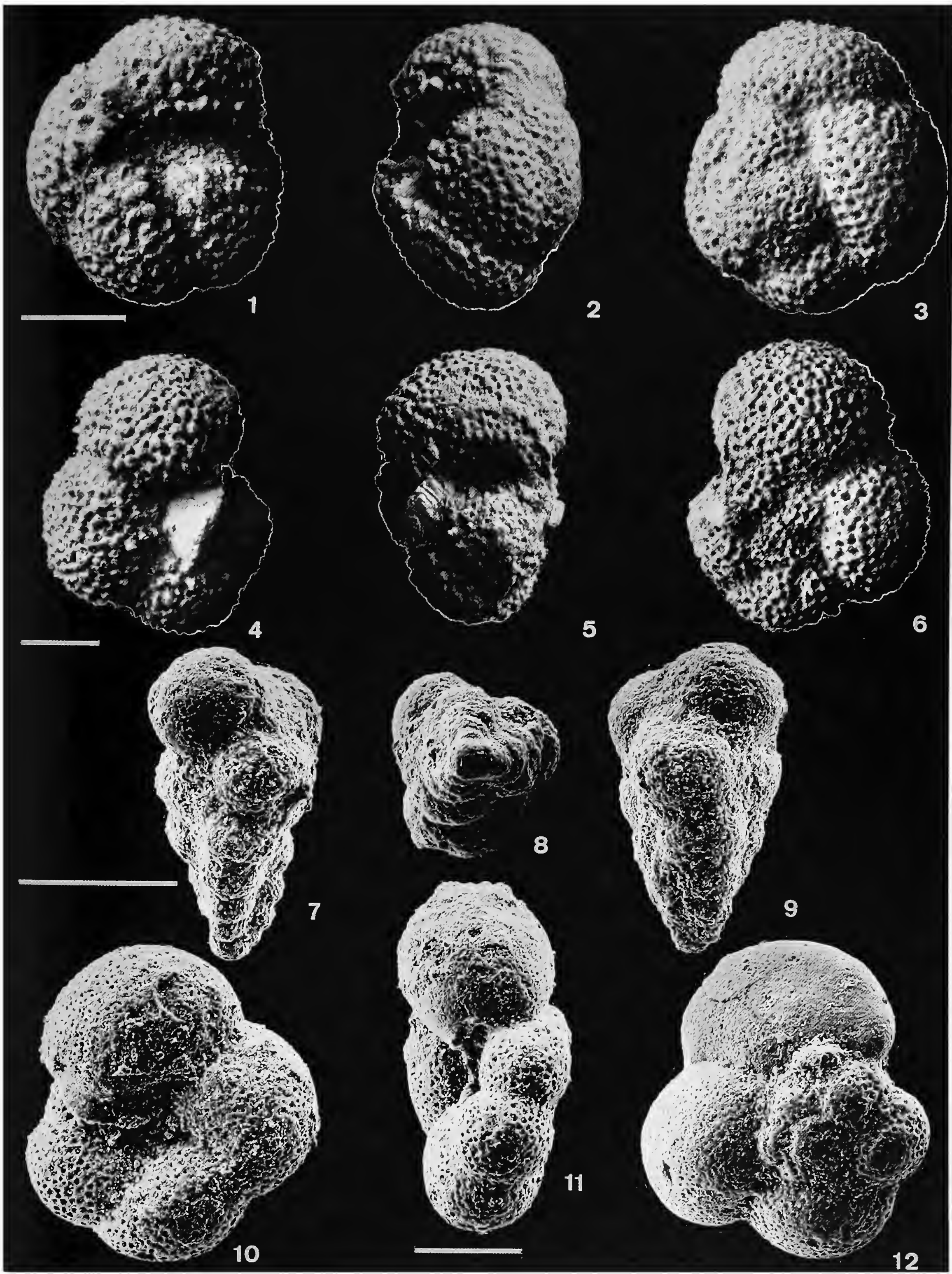




\section{PLATE 13}

\section{USNM Primary Type Specimens}

$($ bars $=50 \mu \mathrm{m})$

FIGURE 1.-Rectogümbelina cretacea Cushman, 1932, holotype, USNM CC16308; upper Maastrichtian, Arkadelphia Clay, Hope, Arkansas.

FIGURE 2.-Tubitextularia laevigata Loeblich and Tappan, 1957 (= Rectoguembelina cretacea Cushman), holotype, USNM P5820; lower Paleocene, McBryde Limestone Mbr., Clayton Fm., Wilcox Co., Alabama.

FIGURE 3.-Guembelitria cretacea Cushman, 1933, holotype, USNM CC19022; upper Maastrichtian, Navarro Fm., Texas.

FIGURES 4, 5.-Woodringina hornerstownensis Olsson, 1960, holotype, USNM 626457; Zone P3b. Hornerstown Fm., New Jersey.

FiguRES 6, 7.-Woodringina claytonensis Loeblich and Tappan, 1957, holotype, USNM P5685; lower Danian, Pine Barren Mbr., Clayton Fm., Alabama.

FIGURE 8. -Woodringina kelleri MacLeod, 1993 (= Woodringina claytonensis Loeblich and Tappan); Zone Pa, DSDP Site 577A/12/2: 44-46 cm; Shatsky Rise, northwestern Pacific Ocean.

FIGURES 9, 10.-Gümbelina midwayensis Cushman, 1940, holotype, USNM CC35715; basal Midway Fm., Sumter Co., Alabama.

FIGURES 11, 16. Gümbelina trinitatensis Cushman and Renz, 1942, holotype, USNM CC38198; Paleocene, Soldado Fm., Trinidad.

FIGURES 12, 13.-Chiloguembelina midwayensis strombiformis Beckmann, 1957 (= Chiloguembelina midwayensis (Cushman)), holotype, USNM P5771; Globorotalia pseudomenardii Zone, Lizard Springs Fm., Trinidad.

FIguREs 14, 15.-Gümbelina morsei Kline, 1943, holotype, USNM 487301; Danian, Porters Creek Clay, Clay Co., Mississippi.

FIGURES 17, 18.-Chiloguembelina subtriangularis Beckmann, 1957, holotype, USNM P5783; Globorotalia pusilla pusilla Zone, lower Lizard Springs Fm., Trinidad.

FIGURES 19, 20.-Gümbelina wilcoxensis Cushman and Ponton, 1932, holotype, USNM 16218; Wilcox Fm., Ozark, Alabama. 


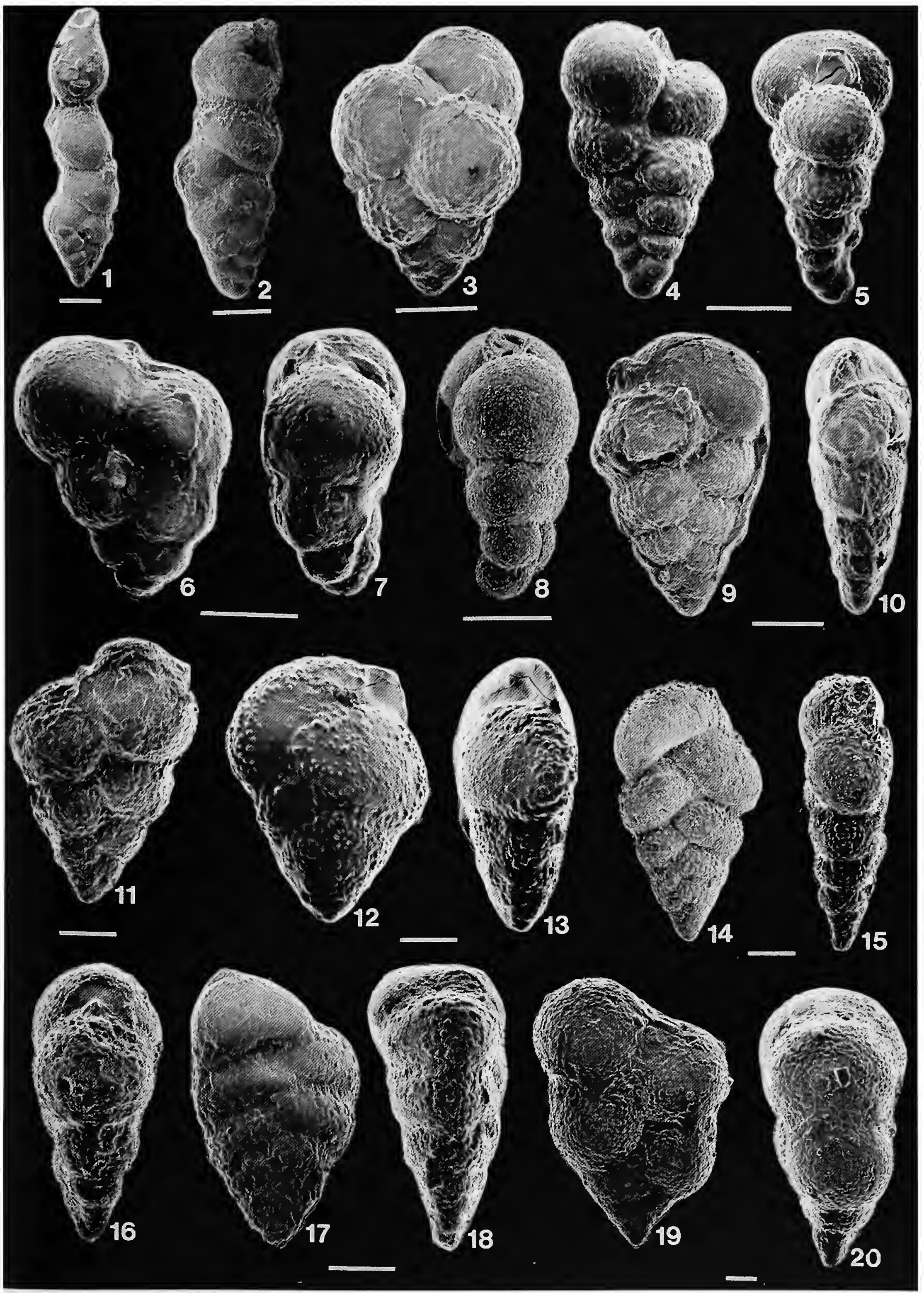




\section{PLATE 14}

\section{USNM Primary Type Specimens}

$$
\text { (bars }=50 \mu \mathrm{m} \text { ) }
$$

FIGURES 1-3.-Globigerina compressa Plummer, 1926, lectotype, Chicago Field Museum UC55091; upper Danian, Zone P2, Wills Point Fm., Midway Group, Navarro Co., Texas.

FIGURES 4, 8, 12.-Globorotalia ehrenbergi Bolli, 1957, holotype, USNM P5060; upper Paleocene, Lizard Springs Fm., Trinidad.

FIGURES 5-7.-Globorotalia pseudomenardii Bolli, 1957, holotype, USNM P5061; Globorotalia pseudomenardii Zone, Lizard Springs Fm., Trinidad.

FIGURES 9-11.-Globorotalia uncinata Bolli, 1957, holotype, USNM P5048; Globorotalia uncinata Zone, lower Lizard Springs Fm., Trinidad.

FIGURES 13, 14.-Globorotalia trinidadensis Bolli, 1957 (= Praemurica inconstans (Subbotina)). holotype, USNM P5044; Globorotalia trinidadensis Zone, lower Lizard Springs Fm., Trinidad.

FIGURES 15, 16. -Globigerina triloculinoides Plummer, 1926, paratype, USNM 370088; Zone P2, Wills Point Fm., Midway Group, Navarro Co., Texas, Plummer station 23. 


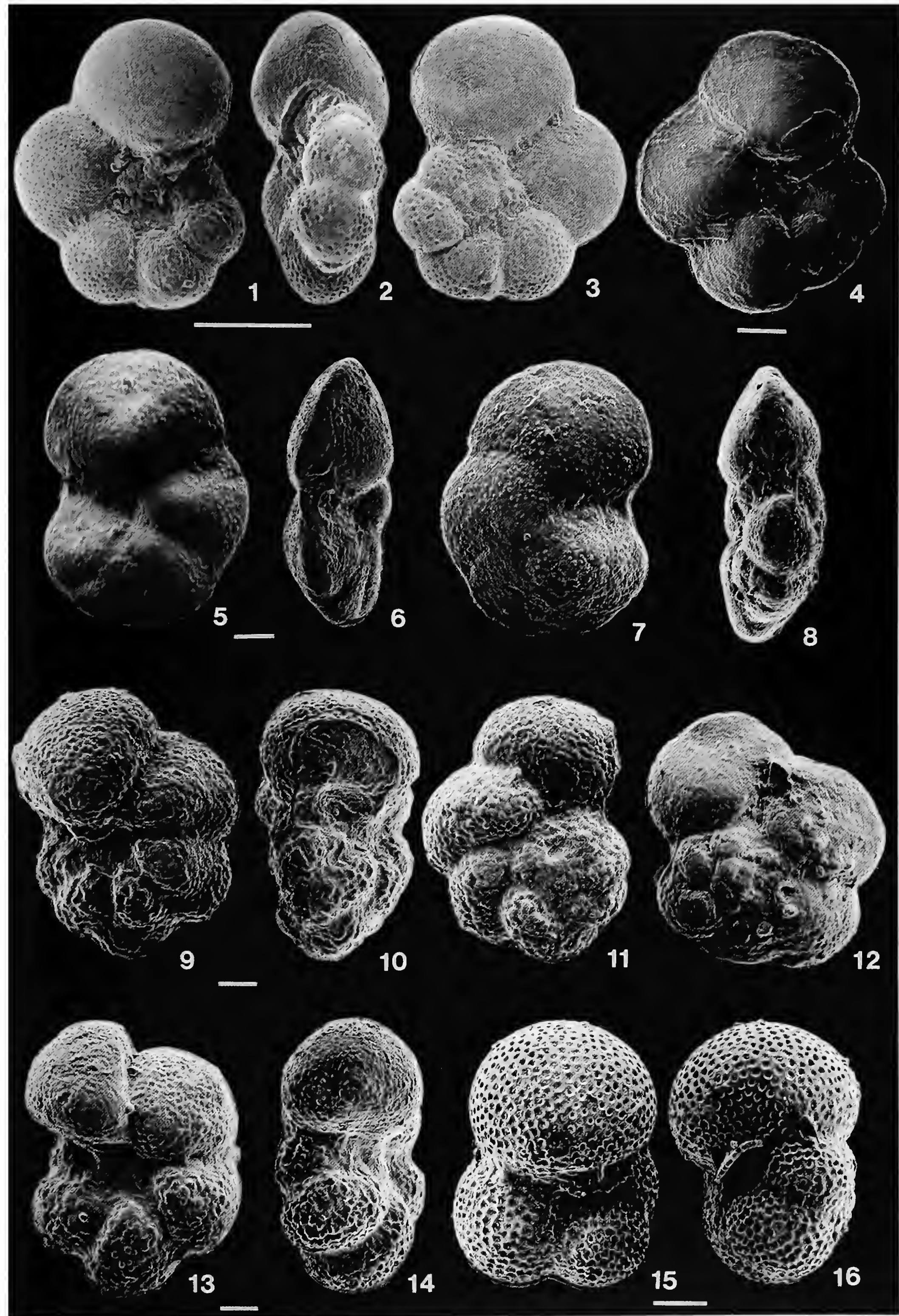




\section{PLATE 15}

\section{USNM Primary Type Specimens}

$$
(\text { bars }=50 \mu \mathrm{m})
$$

FIGURES 1-3.-Globorotalia strabocella Loeblich and Tappan, 1957, holotype, USNM P5879; Nanafalia Fm., Alabama.

FIGURES 4, 7, 8.-Globigerina soldadoensis Brönnimann, 1952, holotype, USNM 370085; Lizard Springs Fm., Trinidad; type locality of Globorotalia velascoensis Zone of Bolli, 1957a = Zone P5.

FIgURES 5, 6.-Globigerina aquiensis Loeblich and Tappan, holotype, USNM P5839; Aquia Fm., Aquia Creek, Virginia.

FIGURES 9, 10.-Globigerina chascanona Loeblich and Tappan, 1957 (= Acarinina subsphaerica (Subbotina)), holotype, USNM P5842; Zone P4, uppermost Hornerstown Fm., New Jersey.

FIGURES 11, 12, 15.-Globorotalia crassata (Cushman) var. aequa Cushman and Renz, 1942, holotype, USNM CC38210; near base of Globorotalia subbotinae Zone, Soldado Fm., Trinidad.

FIGURES 13, 14.-Globigerina daubjergensis Brönnimann, 1953, holotype, USNM CC64879; Danian, Daubjerg Quarry, Denmark. 

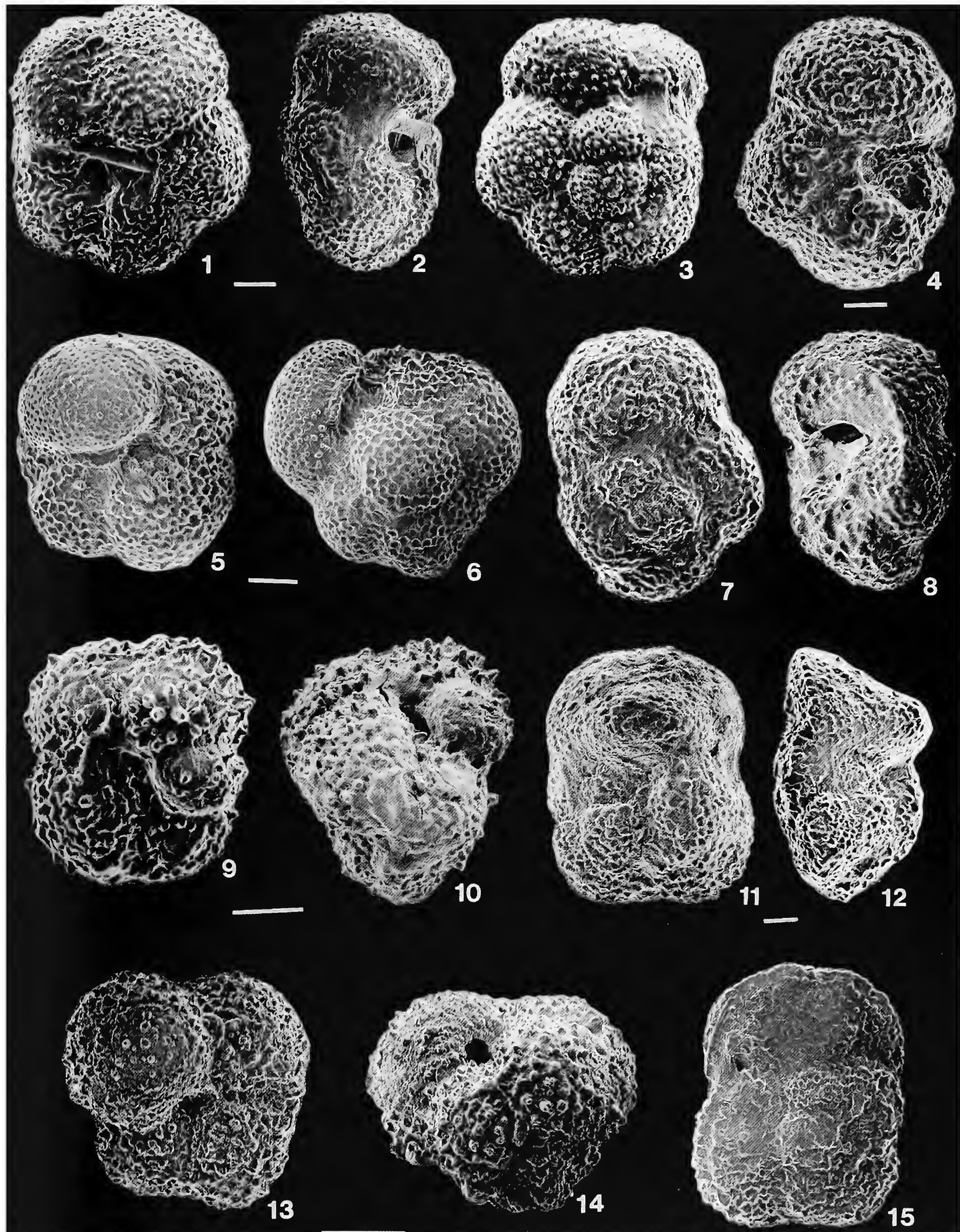


\section{PLATE 16}

USNM Primary Type Specimens

$($ bars $=50 \mu \mathrm{m})$

FIGURES 1-3.-Globorotalia albeari Cushman and Bermúdez, 1949, holotype, USNM CC47413; Globorotalia pseudomenardii Zone, Madruga Fm., Cuba.

FIGURES 4-6.-Globorotalia pusilla laevigata Bolli, 1957 (= Igorina albeari (Cushman and Bermúdez)), holotype, USNM P5065; Globorotalia pseudomenardii Zone, Lizard Springs Fm., Trinidad.

FIGURES 7-9.-Globorotalia pusilla pusilla Bolli, 1957, holotype, USNM P5064; Globorotalia pusilla pusilla Zone, Guayaguayare Well 159, Trinidad Leasholds, Ltd., Lizard Springs Fm., Trinidad.

FIGURES 10-12.-Globigerina spiralis Bolli, 1957, holotype, USNM P5030; Globorotalia uncinata Zone, lower Lizard Springs Fm., Trinidad. 


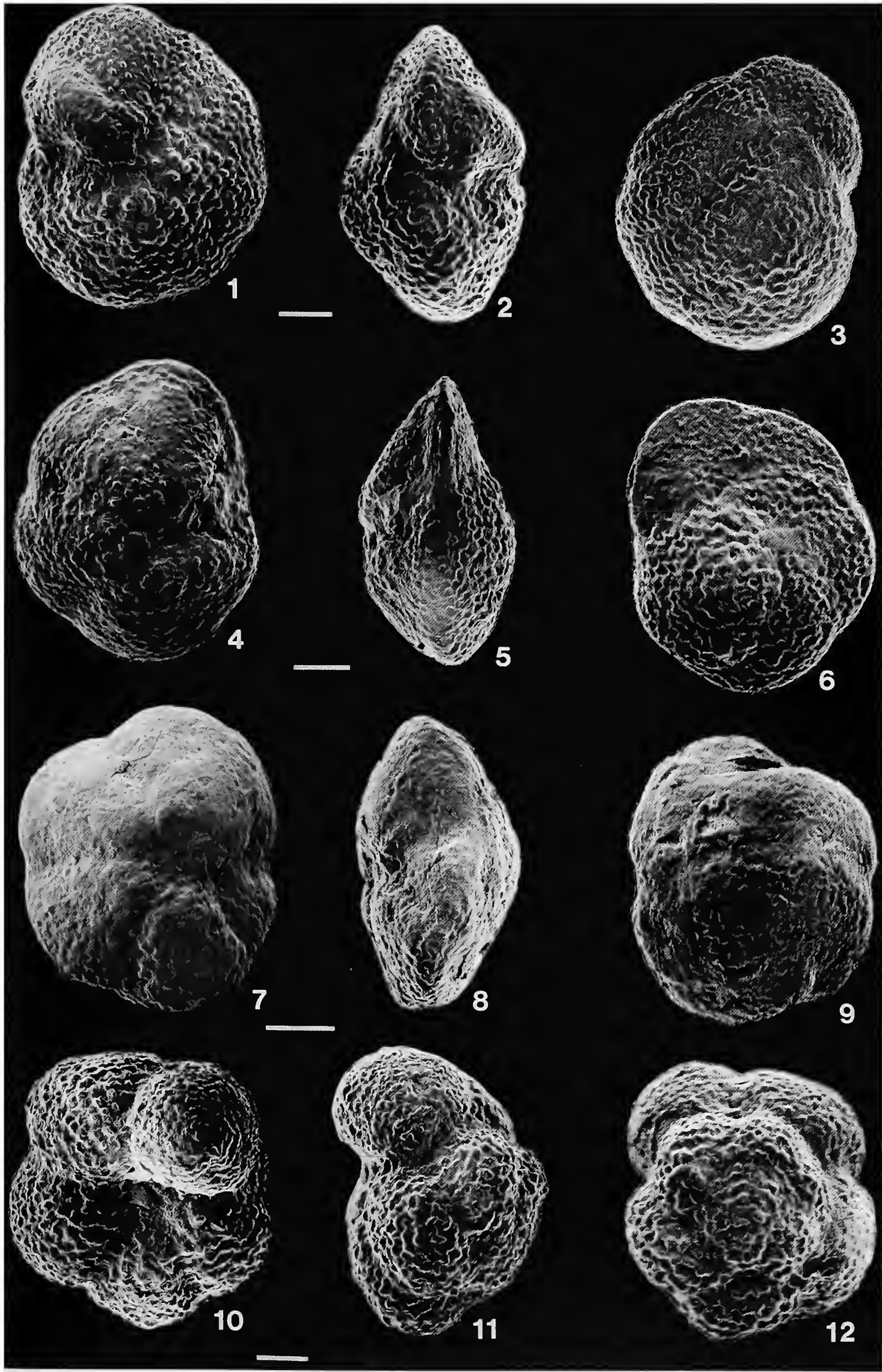




\section{PLATE 17}

\section{USNM Primary Type Specimens}

$$
\text { (bars }=50 \mu \mathrm{m} \text { ) }
$$

FlGURES 1-3.-Globorotalia apanthesma Loeblich and Tappan, 1957, holotype, USNM P5860; Zone P4, Aquia Fm., Virginia.

FlGURES 4-6.-Globorotalia occlusa Loeblich and Tappan, 1957, holotype, USNM P5874; Zone P4, Velasco Shale, Tamaulipas, Mexico.

FlGURES 7-9.-Pseudogloborotalia pasionensis Bermúdez, 1961, holotype, USNM 639063; sample G-58, Rio de Pasion, El Petèn, Guatemala.

FIGURES 10-12.-Pulvinulina velascoensis Cushman, 1925, holotype, USNM CC4347; Velasco Fm., San Luis Potosi, Tampico Embayment, eastern Mexico. 


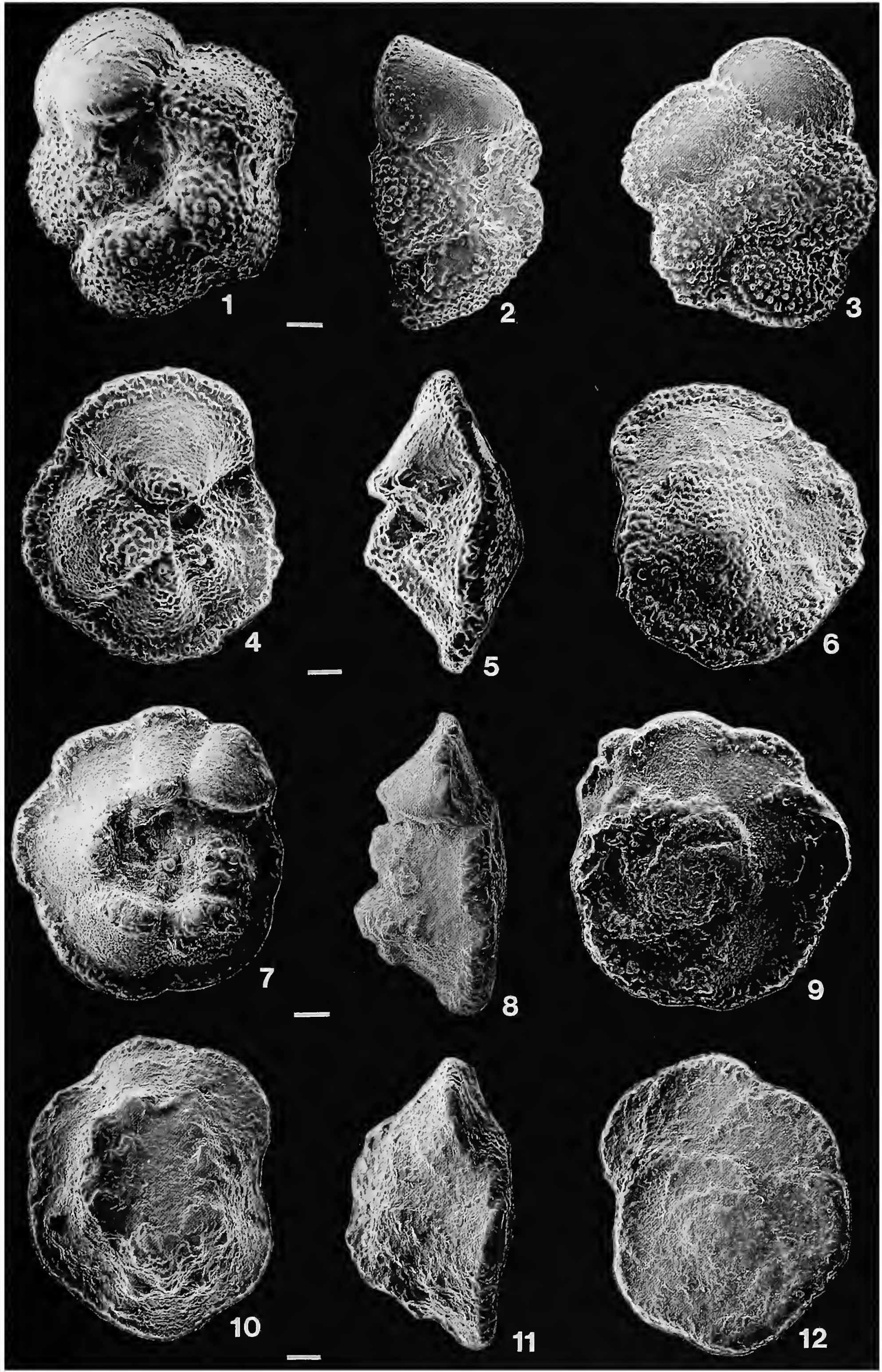




\section{PLATE 18}

Eoglobigerina edita (Subbotina, 1953)

(Figures 1-14: bars $=50 \mu \mathrm{m}$; Figure 15: bar $=20 \mu \mathrm{m}$; Figure 16: bar $=10 \mu \mathrm{m}$ )

FIGURE 1.-Zone P $\alpha$, Millers Ferry, Alabama, core 226, sample 85.

FIGUREs 2, 3, 5, 6.-Zone Pla, DSDP Site 356/28/2: 144-145 cm; São Paulo Plateau, South Atlantic Ocean.

Figures 4, 15, 16.-Zone Pla, Millers Ferry, Alabama, core 225, sample 194; Figures 15, 16, views of wall texture of 3rd chamber of Figure 4.

FIGURE 7.-Zone Pla, Millers Ferry, Alabama, core 225, sample 216.

FIGURES 8-14.-Zone Plc, Brightseat Fm., Maryland. 


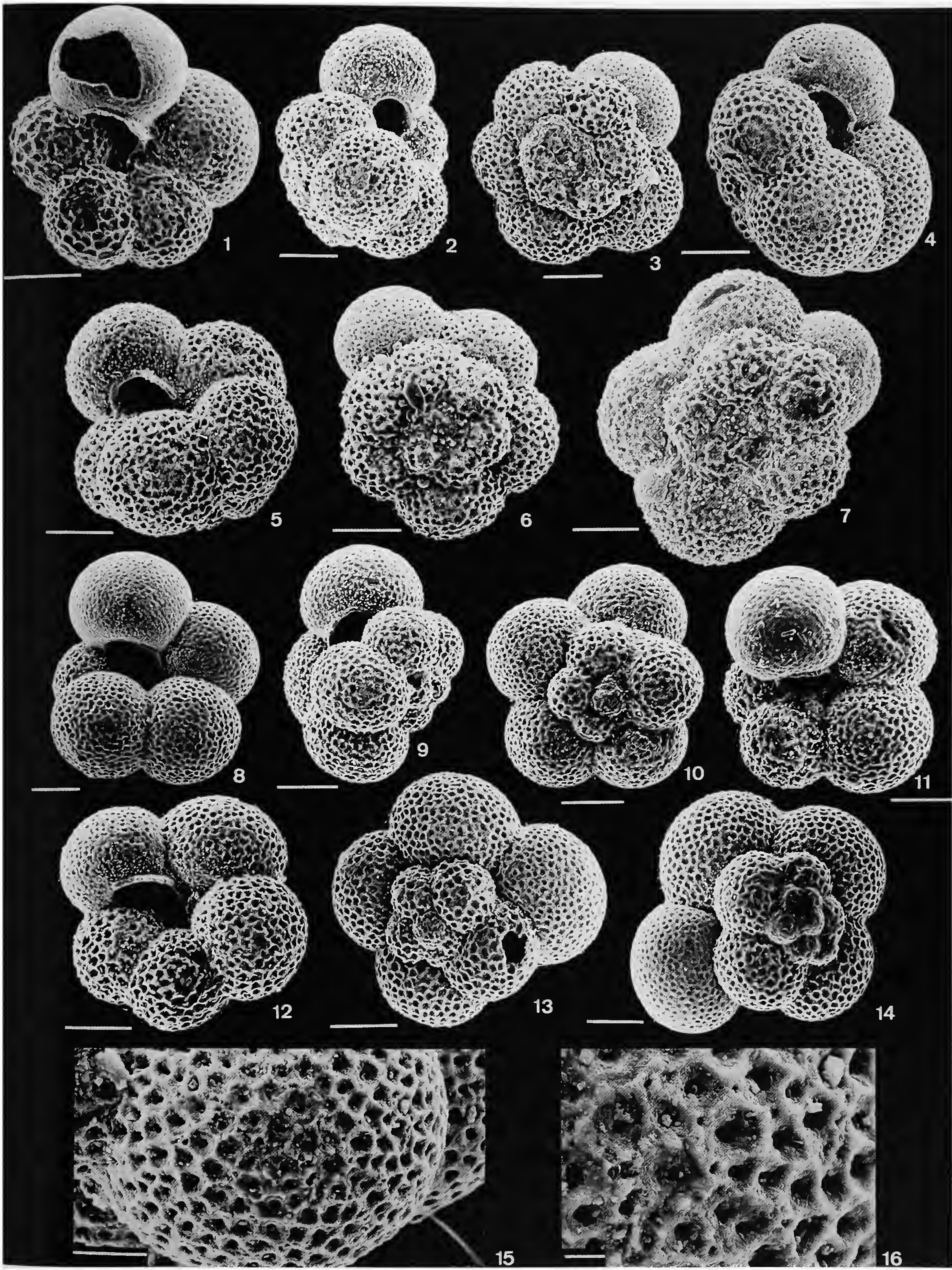




\section{PLATE 19}

Eoglobigerina eobulloides Morozova, 1959

(Figures 1-12: bars $=50 \mu \mathrm{m}$; Figures 13, 15: bars $=10 \mu \mathrm{m} ;$ Figure 14: bar $=4 \mu \mathrm{m}$ )

Figures 1, 2, 5, 13-15.-Zone P $\alpha$, Millers Ferry, Alabama, core 226, sample 85; Figures 13-15, views of 3rd chamber of Figure 5 showing spinose cancellate wall texture.

Figures 3, 7, 11, 12.-Zone P1a, Millers Ferry, Alabama, core 226, sample 216.

FIGURES 4, 6.-Zone P1a, DSDP Hole 350A/11/4: 80-82 cm; Greenland.

FiguRE 8.-Zone P0, Millers Ferry, Alabama, core 225, sample 349.

Figure 9.-Zone P $\alpha$, Millers Ferry, Alabama, core 226, sample 84.

FIGURE 10.-Zone Plc, Brightseat Fm., Maryland. 


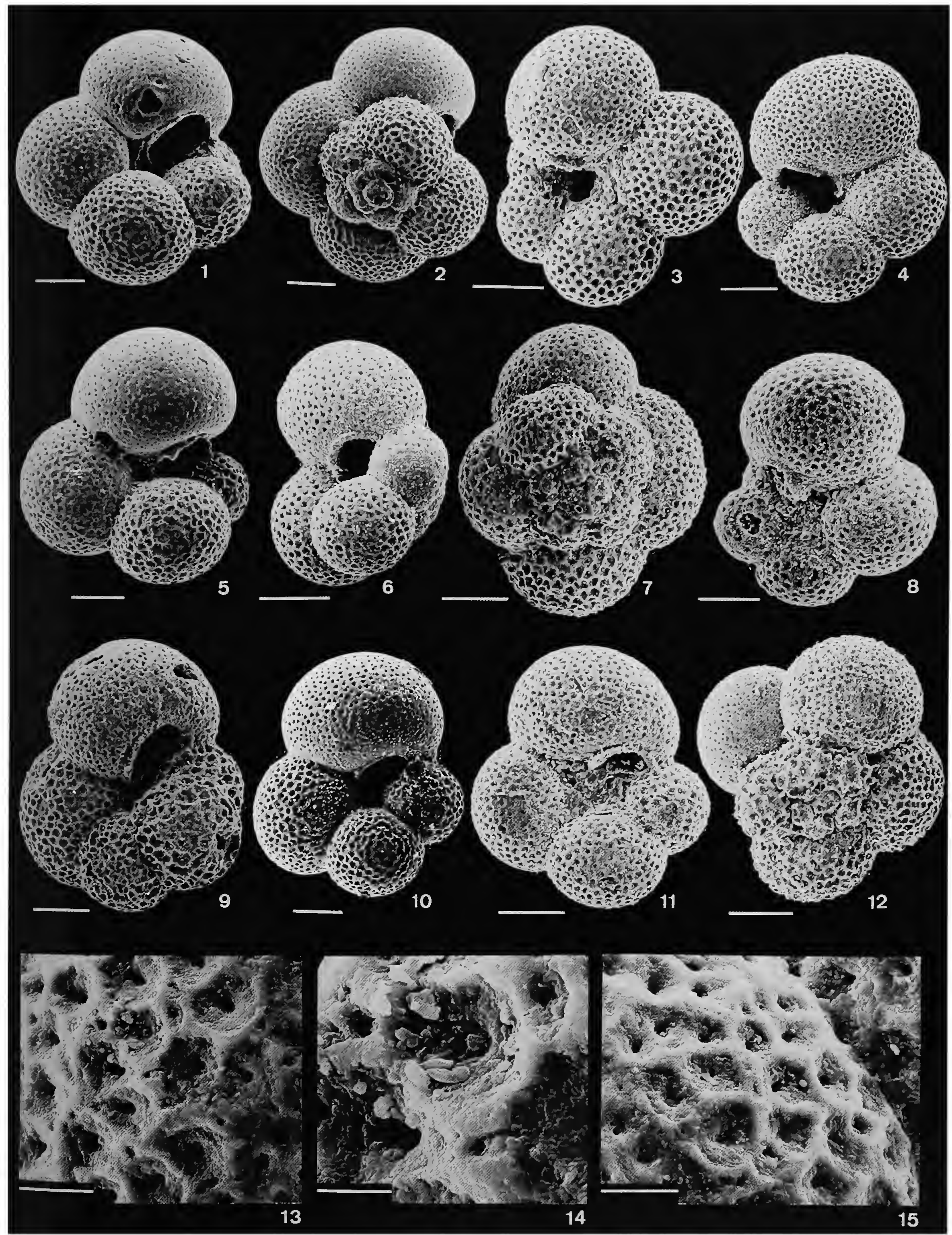




\section{PLATE 20}

\section{Eoglobigerina spiralis (Bolli, 1957)}

(Figures 1-9, 11: bars $=50 \mu \mathrm{m}$; Figure 10: bar $=4 \mu \mathrm{m}$ )

Figures 1-6, 10.-Zone PIc, Midway Fm., Texas, Plummer station 14; Figure 10, view of 5th chamber of Figure 5 showing spinose wall texture.

FIGURES 7-9.-Zone P2, DSDP Site 356/25/5: 109-111 cm.

FIGURE 11.-Zone P2, DSDP Site 356/26/4: 30-32 cm; São Paulo Plateau, South Atlantic Ocean. 


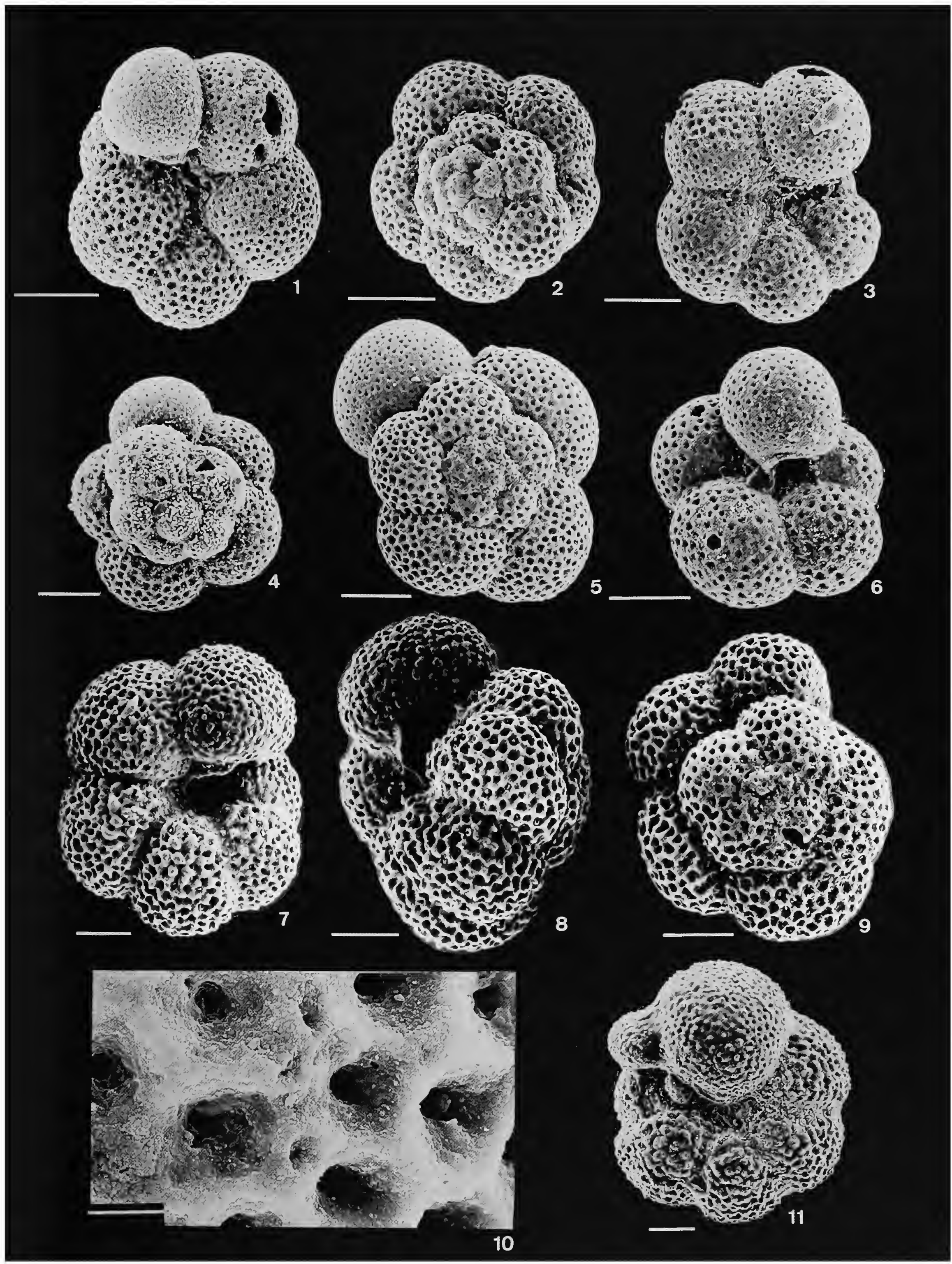




\section{PLATE 21}

\section{Parasubbotina pseudobulloides (Plummer, 1926)}

(Figures 1-11: bars $=50 \mu \mathrm{m}$; Figures $12-15$ : bars $=5 \mu \mathrm{m}$ )

Figures 1-4, 8, 12.-Zone P2, Midway Group, Texas, sample 8030; Figure 12, view of 2nd chamber of Figure 4 showing cancellate spinose wall texture.

Figures 5, 9.-Zone Pla, Millers Ferry, Alabama, surface sample 30 feet.

Figures 6, 10, 11, 13, 14.-Zone P1a, Millers Ferry, Alabama, core 225, sample 216; Figures 13, 14, views of 4th chamber of Figure 6 showing cancellate spinose wall texture.

Figures 7, 15.-Zone P1a, Millers Ferry, Alabama, core 226, sample 85; Figure 15, view of 2nd chamber of Figure 7 showing cancellate spinose wall texture. 


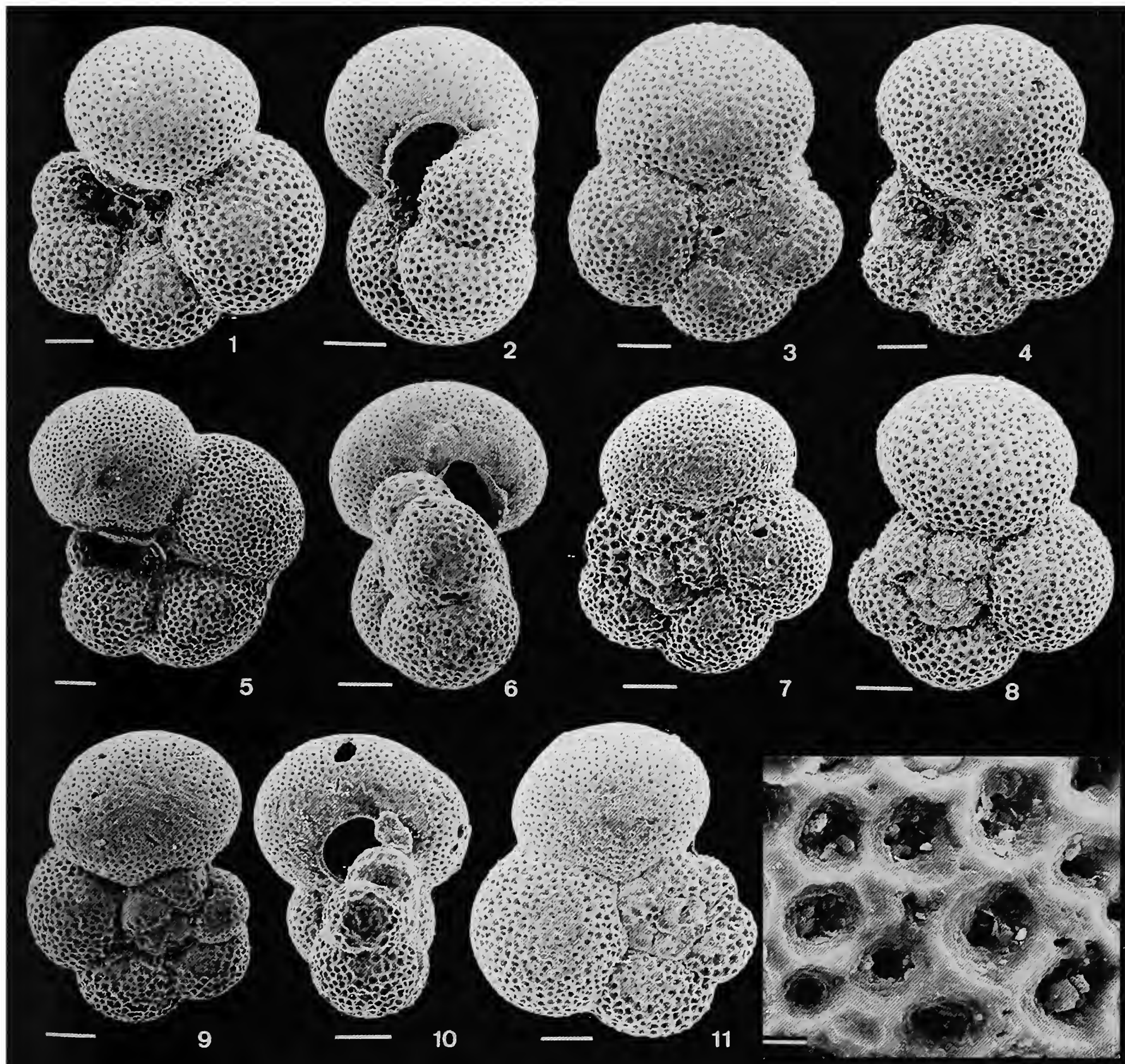

12

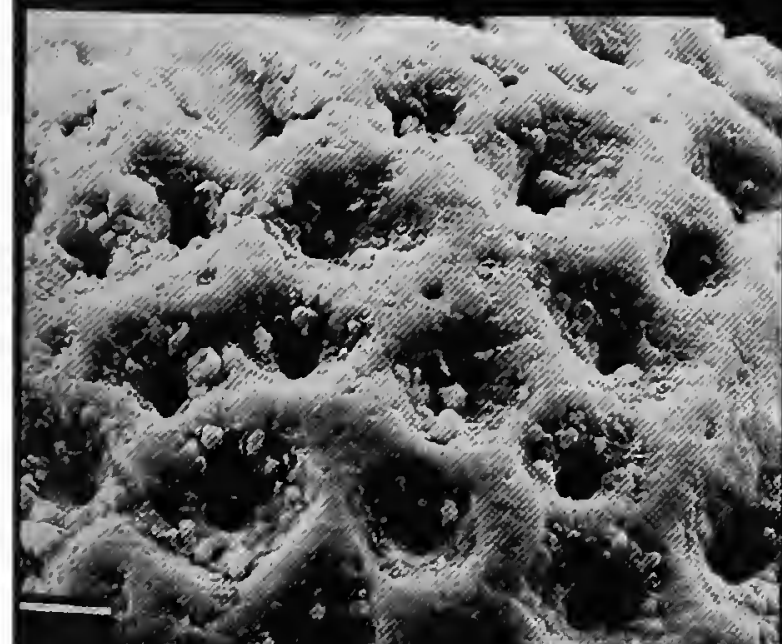

13

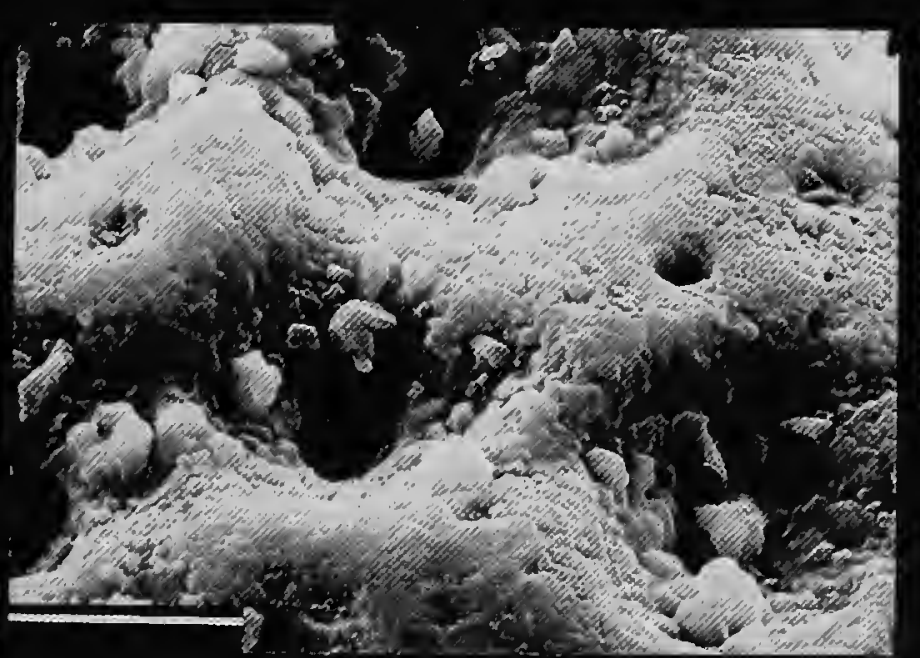

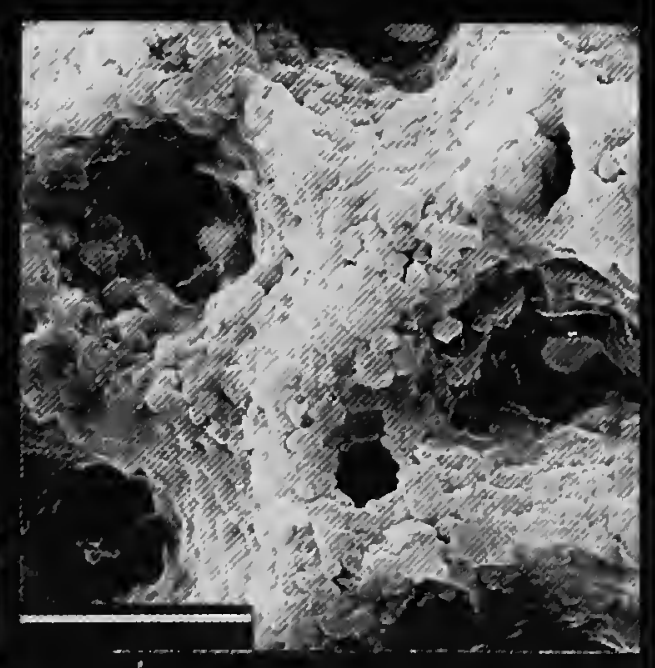




\section{PLATE 22}

\section{Parasubbotina aff. pseudobulloides (Plummer, 1926)}

(Figures 1-3: bars $=50 \mu \mathrm{m} ;$ Figures 4, 5: bars $=10 \mu \mathrm{m}$ )

FIGURES 1-5.-Zone P $\alpha$, Millers Ferry, Alabama, core 226, sample 85; Figures 4, 5, views of 2nd chamber of Figure 3 showing weakly developed cancellate spinose wall texture, slightly recrystallized.

Parasubbotina varianta (Subbotina, 1953)

(Figures 6-13: bars $=50 \mu \mathrm{m}$; Figures 14, 15: bars $=10 \mu \mathrm{m}$; Figure 16: bar $=4 \mu \mathrm{m}$ )

Figures 6-8, 10-12, 14-16.-Zone P2, DSDP Site 356/25/5: 148-150 cm; São Paulo Plateau, South Atlantic Ocean; Figure 14 (view of 2nd chamber of Figure 6) and Figure 15 (view of 3rd chamber of Figure 12), showing cancellate spinose wall texture.

FIGURE 9.-Zone P1c, Mexia Clay Mbr., Midway Group, Texas.

FIGURE 13.-Zone Pla, Millers Ferry, Alabama, core 225, sample 194. 


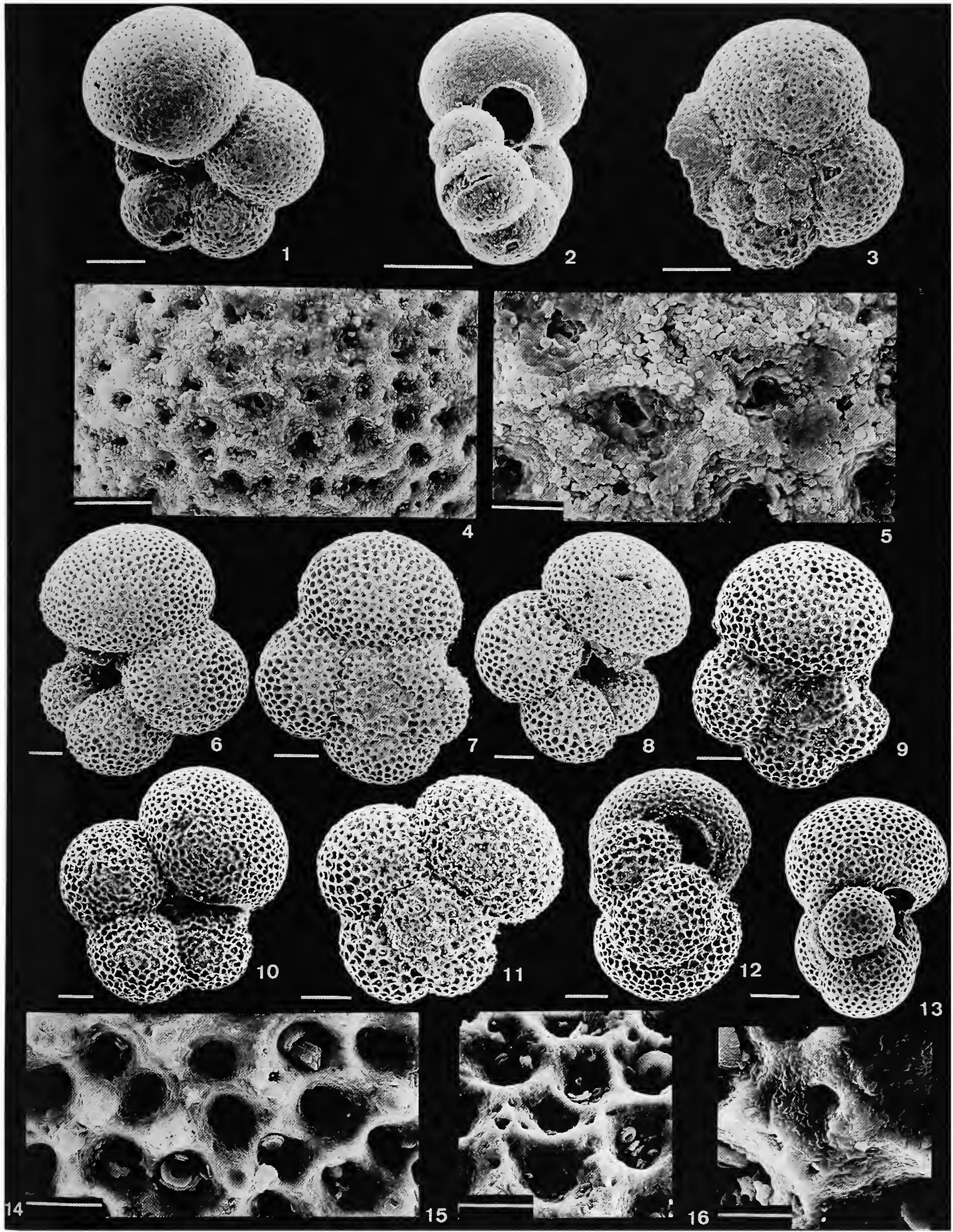




\section{PLATE 23}

\section{Parasubbotina variospira (Belford, 1984)}

(Figures 1-14, 16: bars $=100 \mu \mathrm{m}$; Figure 15: bar $=200 \mu \mathrm{m}$ )

Figures $1-10,13,15,16$. Zone P3, DSDP Site 384/10/CC.

Figures 11, 12, 14.-Zone P3, DSDP Site 384/9/CC; southeast Newfoundland Ridge, North Atlantic Ocean. 

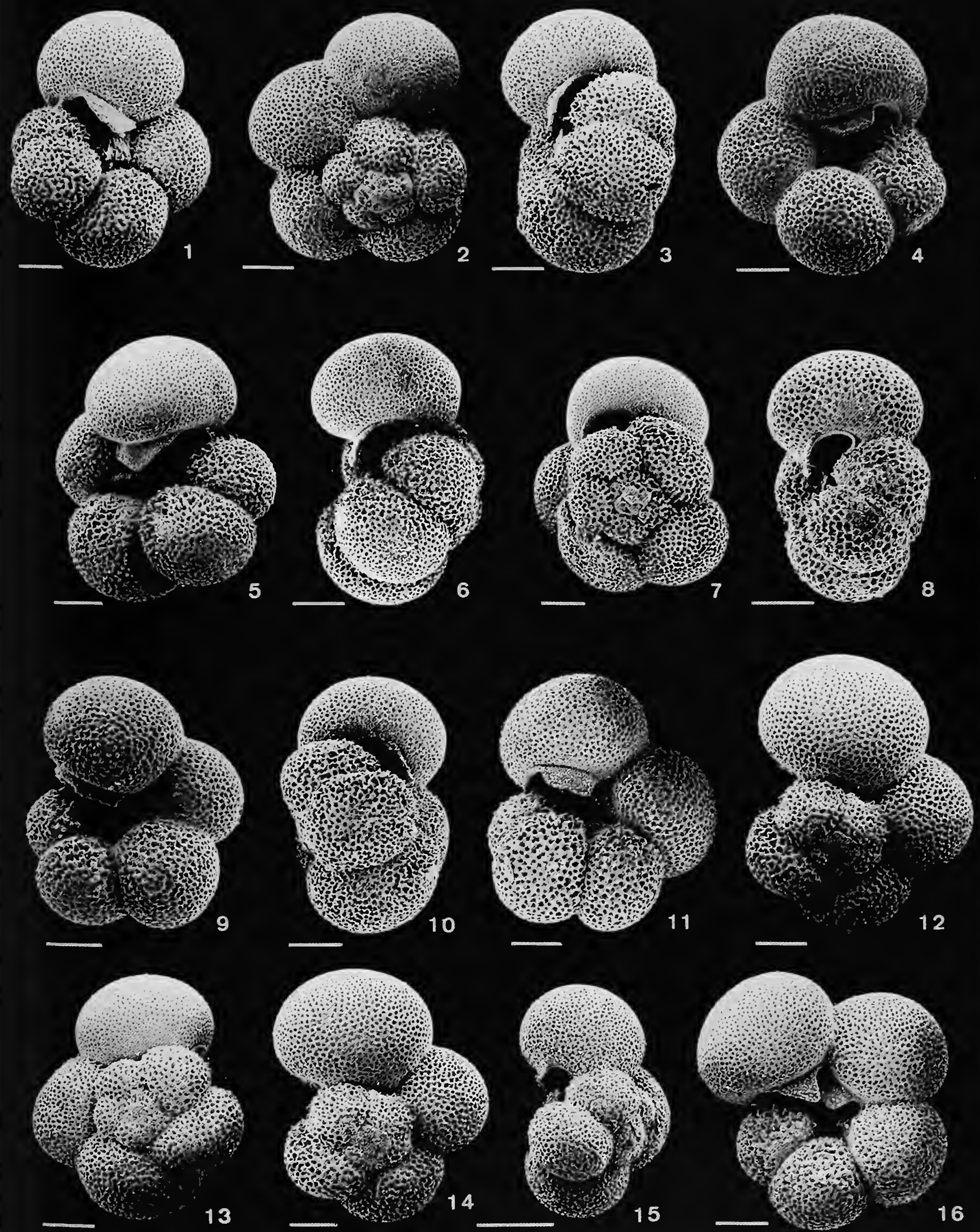


\section{PLATE 24}

\section{Subbotina cancellata Blow, 1979}

$$
\text { (bars }=100 \mu \mathrm{m})
$$

FIGURES 1-12.-Zone Plc, DSDP Site 356/26/3: 90-92 cm; São Paulo Plateau, South Atlantic Ocean.

FIGURE 13. - Zone P4, Vincentown Fm., Glendola Well, New Jersey, sample 286-287 feet.

FIGURE 14.-Zone P4, DSDP Site 549/20/5: 20-22 cm; Goban Spur, eastern North Atlantic Ocean. 

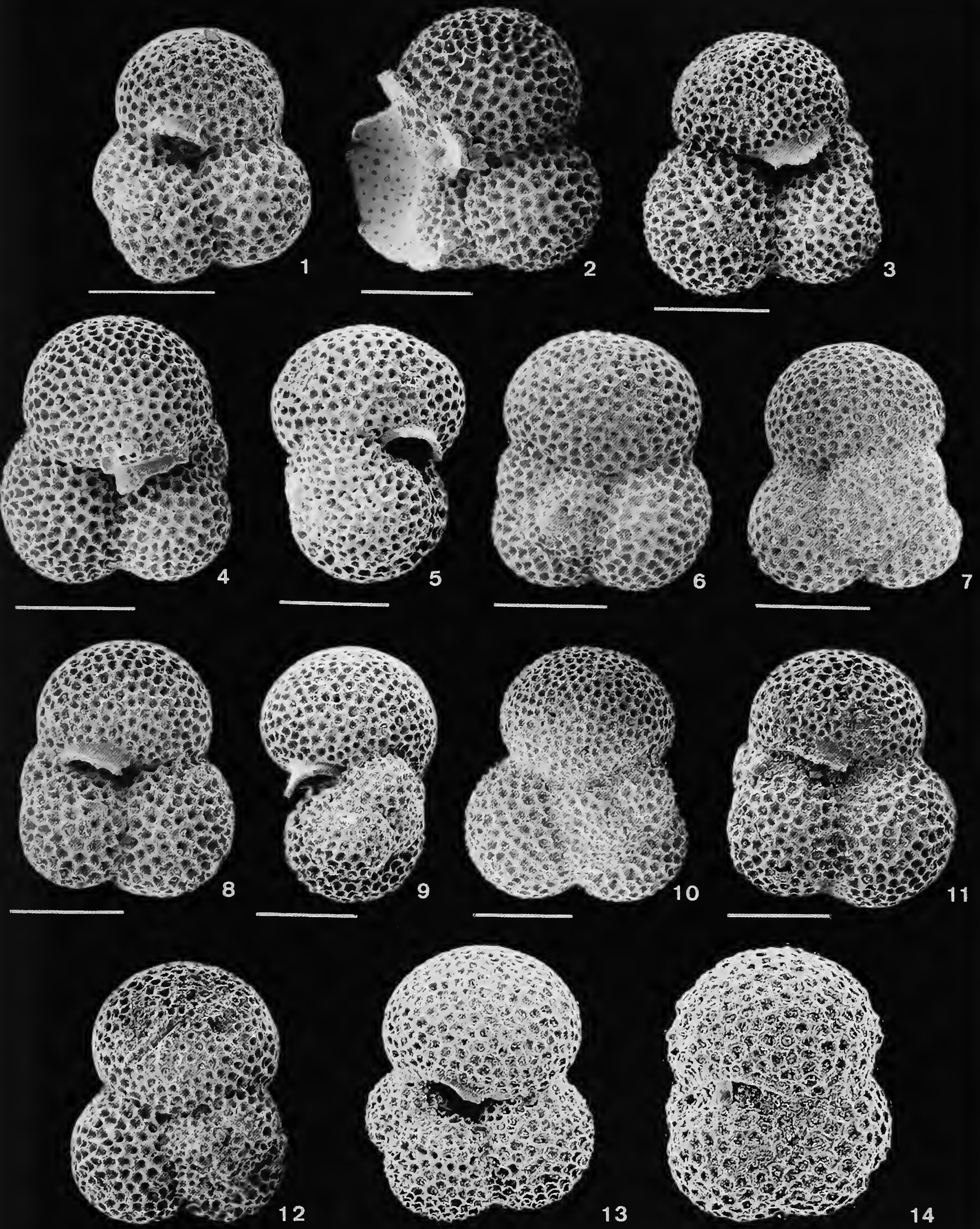


\section{PLATE 25}

\section{Subbotina cancellata Blow, 1979}

(Figures 1-14: bars $=50 \mu \mathrm{m}$; Figure 15: $\mathrm{bar}=10 \mu \mathrm{m}$ )

FIGURES 1-15.-Morphotypes showing a range of variation in the number of chambers in the final whorl and in the coarseness of the cancellate wall texture; Figure 7 shows transitional morphology to Subbotina trivialis (Subbotina, 1953). See "Discussion" under S. cancellata on the relationship with Globigerina fringa Subbotina, 1950. Zone P1c, DSDP Site 356/27/6: 38-40 cm; São Paulo Plateau, South Atlantic Ocean. 

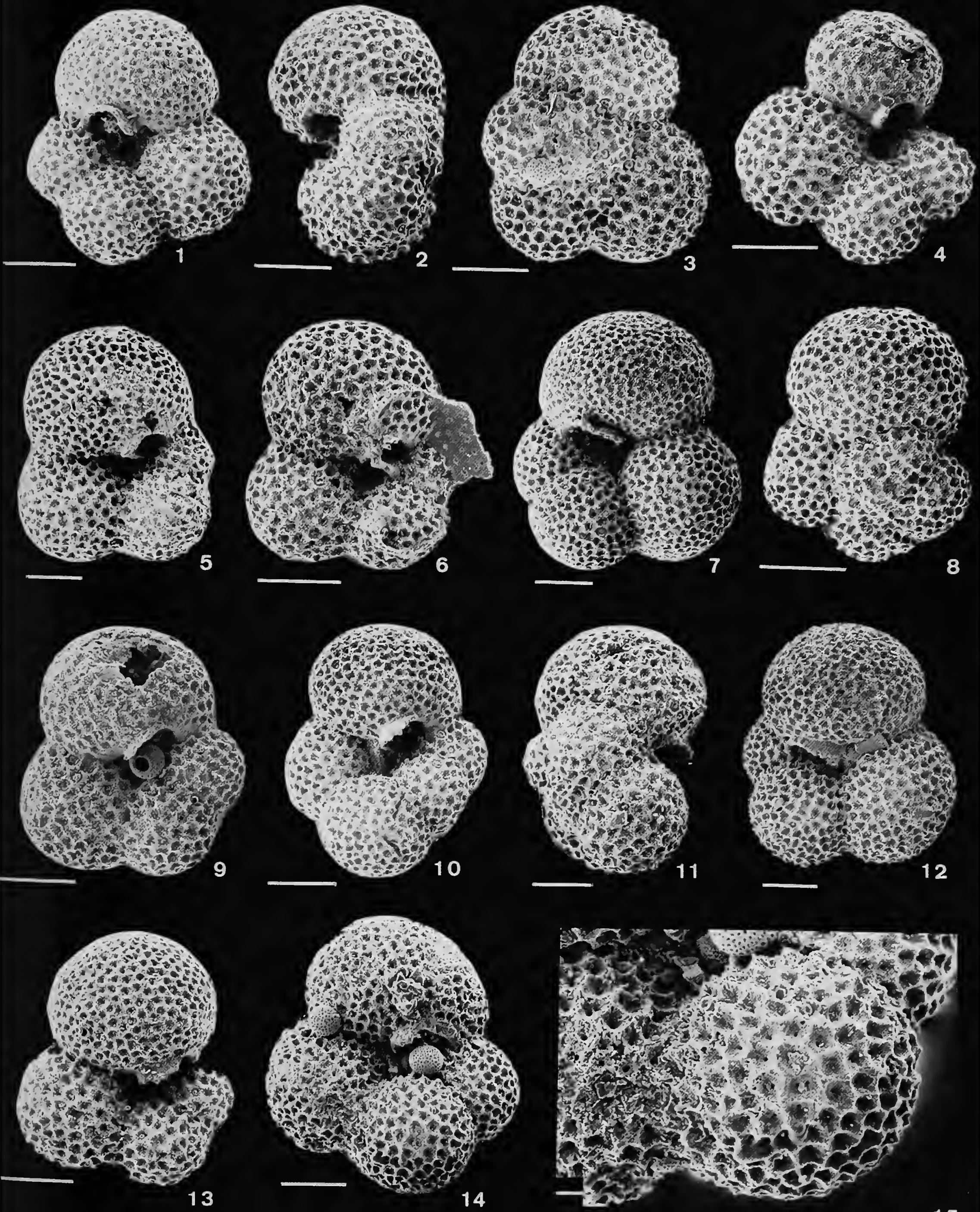


\section{PLATE 26}

Subbotina triangularis (White, 1928)

(Figures 1-11: bars $=100 \mu \mathrm{m} ;$ Figure 12: bar $=10 \mu \mathrm{m} ;$ Figure 13: bar $=4 \mu \mathrm{m}$ )

Figures 1, 3, 7, 8, 12, 13.-Zone P4, Vincentown Fm., Glendola Well, New Jersey, sample 286-287 feet; Figure 12 (view of 3rd chamber of Figure 11) and Figure 13 (view of 2nd chamber of Figure 8) showing spinose wall texture.

Figures 2, 4-6, 9, 11.-Zone P4, Velasco Fm., Tamaulipas, Mexico.

FIgURE 10.-Upper Paleocene, Khieu River, foraminifer beds. 

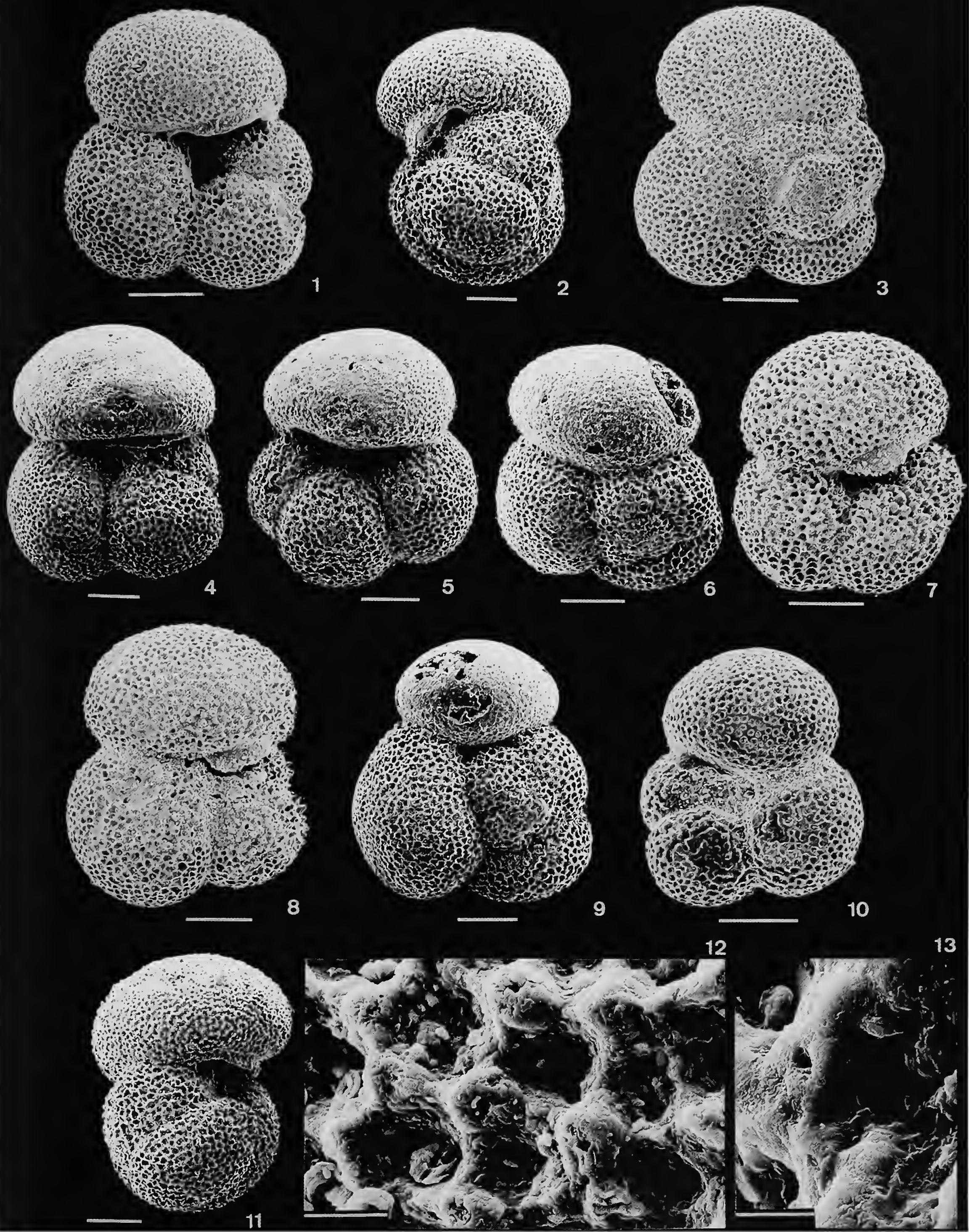


\section{PLATE 27}

\section{Subbotina triloculinoides (Plummer, 1926)}

(Figures 1-11: bars $=50 \mu \mathrm{m}$; Figures 12, 13: bars $=5 \mu \mathrm{m}$ )

FIGURE 1.-Zone P4, DSDP Site 549/20/2: 69-71 cm

Figures 2, 6, 7.-Zone Plc, Mexia Clay Mbr., Midway Group, Texas.

FigurEs 3, 10.-Zone P1b, Eureka Core, Gulf of Mexico, sample 6817-6817.5 feet.

Figures 4, 9, 12, 13.-Zone Plc, Wills Point Fm., Milam Co., Texas; Figure 12, view of 2nd chamber of Figure 9 showing cancellate spinose wall texture; Figure 13, view of spine hole on interpore ridge.

FIGURE 5.-Zone P1b, Eureka Core, Gulf of Mexico, sample 6820-6820.5 feet.

FIGURE 8.-Zone P1, DSDP Hole 390A/1 1/4: 80-82 cm; Blake-Bahama Basin, North Atlantic Ocean.

FIGURE 11.-Zone P4, DSDP Site 549/20/5: 20-22 cm; Goban Spur, eastern North Atlantic Ocean. 

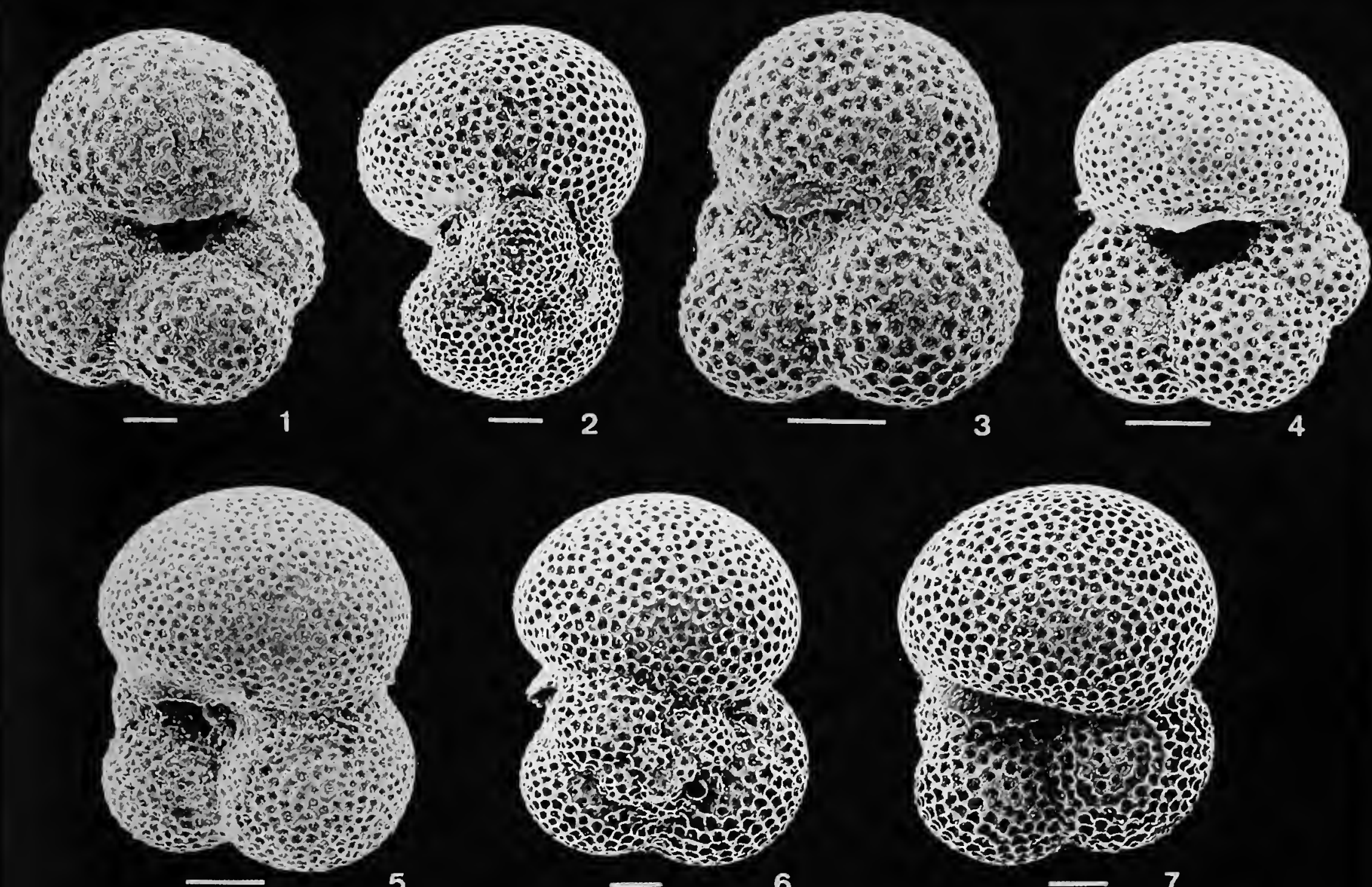

6

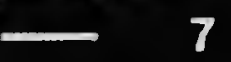

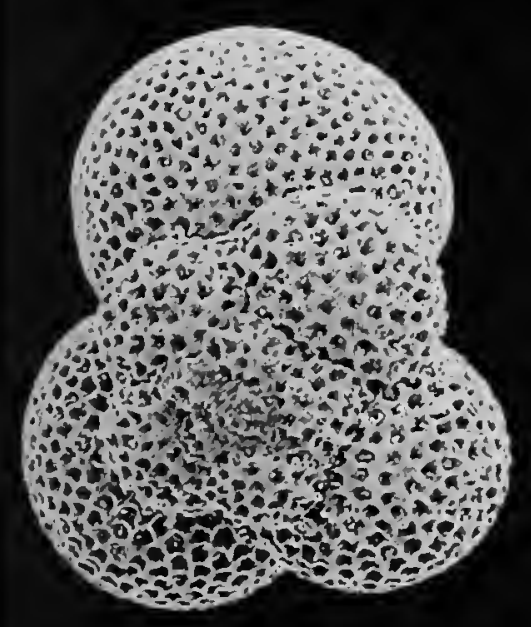

8

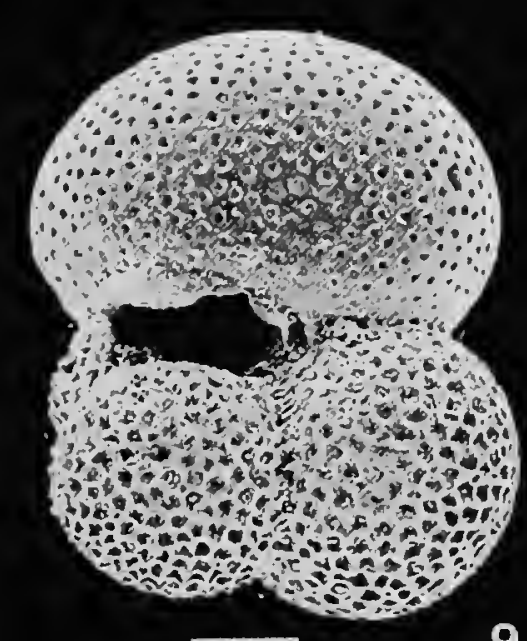

9
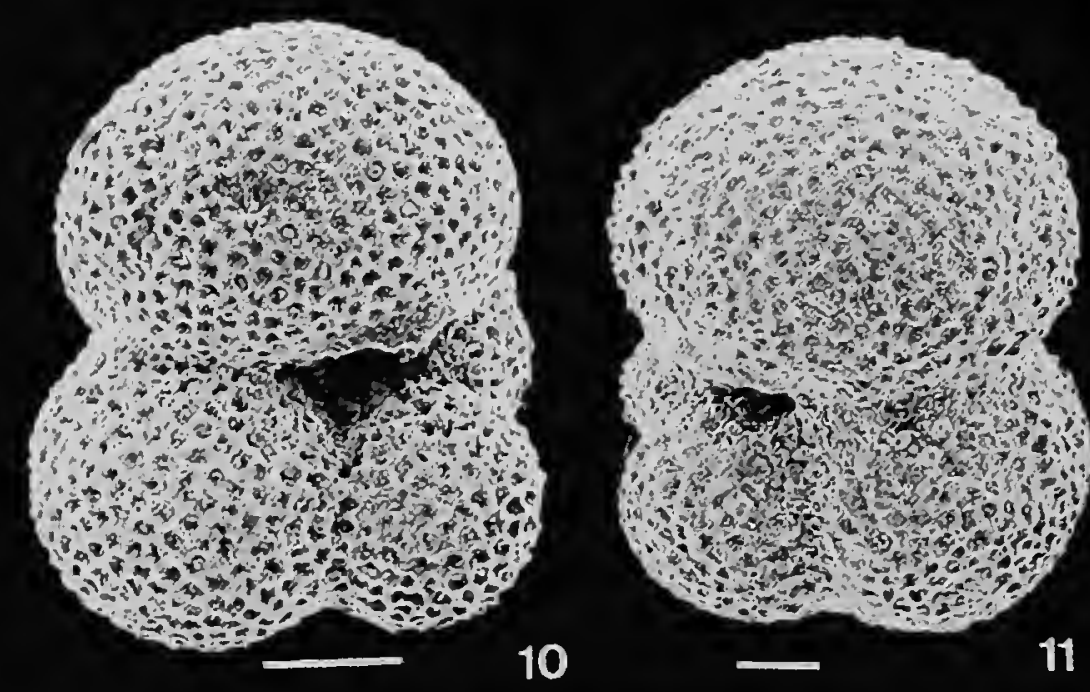
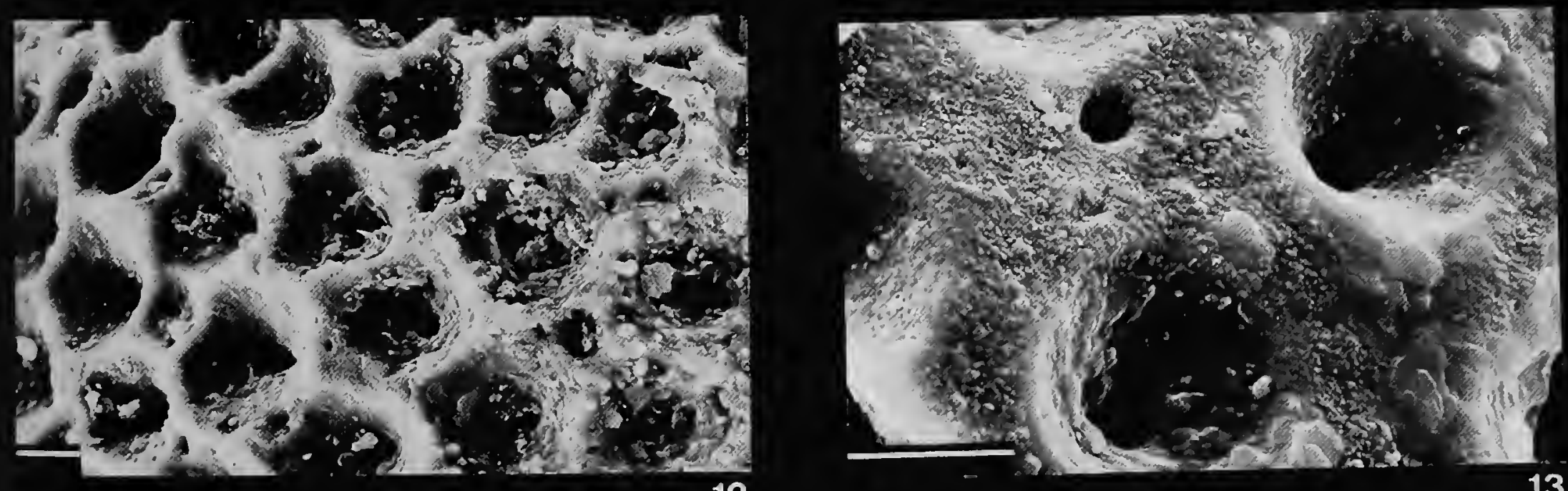


\section{PLATE 28}

Subbotina trivialis (Subbotina, 1953)

(Figures 1-11: bars $=100 \mu \mathrm{m} ;$ Figure 12: bar $=10 \mu \mathrm{m} ;$ Figure 13: bar $=4 \mu \mathrm{m}$ )

Figure 1.-Zone P1c, upper Midway, Milam Co., Texas, sample 8030.

Figures 2, 5, 9.-Zone P1, DSDP Hole 390A/1 1/4: 80-82 cm; Maud Rise, Southern Ocean.

Figures 3, 10, 12, 13.-Zone Pla, Millers Ferry, Alabama, core 225, sample 194; Figures 12, 13, views of wall of Figure 10 showing cancellate spinose wall texture.

FigurE 4,-Zone P1a, Eureka Core, Gulf of Mexico, sample 6826.5-6827.0 feet.

Figures 6-8, 11.-Zone Pla, DSDP Site 356/28/2: 144-145 cm; São Paulo Plateau, South Atlantic Ocean. 

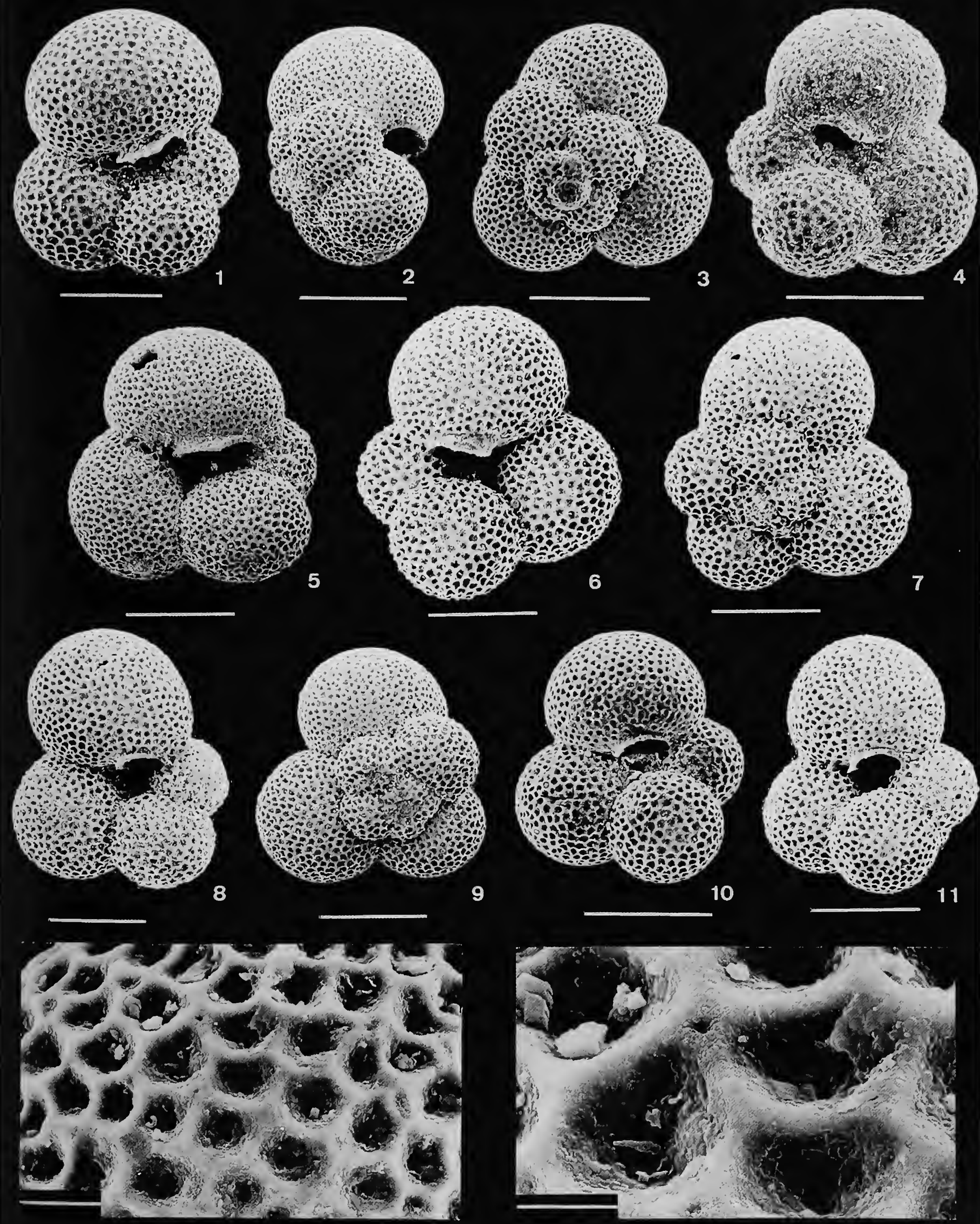


\section{PLATE 29}

\section{Subbotina velascoensis (Cushman, 1925)}

(Figures 1-10, 12: bars $=100 \mu \mathrm{m}$; Figure 11: bar $=10 \mu \mathrm{m}$ )

Figures 1, 3-6, 10.—Zone P4, Velasco Fm., Tamaulipas, Mexico.

Figures 2, 8, 9, 11, 12.-Zone P4, Glendola Well, New Jersey, sample 286-287 feet; Figure 11, view of wall of Figure 8 showing cancellate spinose wall texture.

Figure 7.-Zone P4, Nerinea Fm., Pondicherry, South India. 

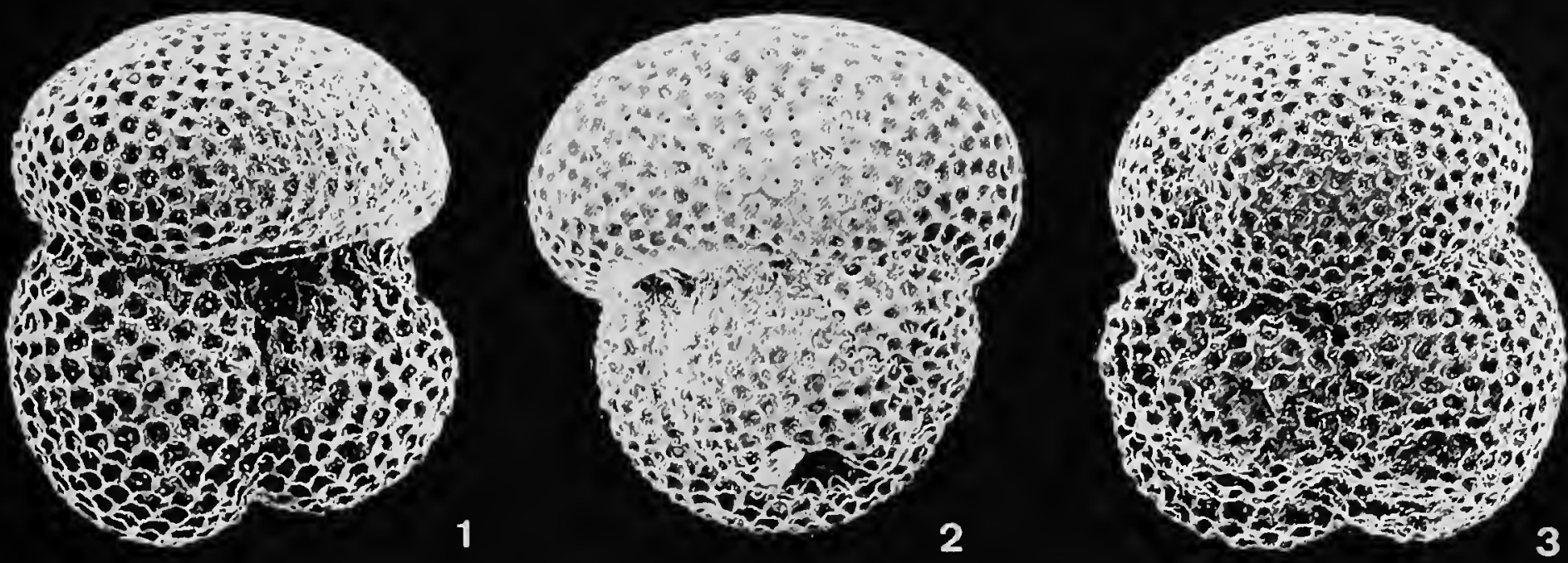

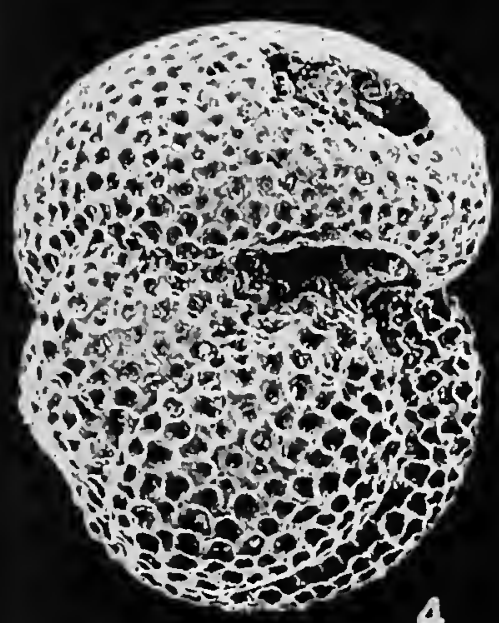

4

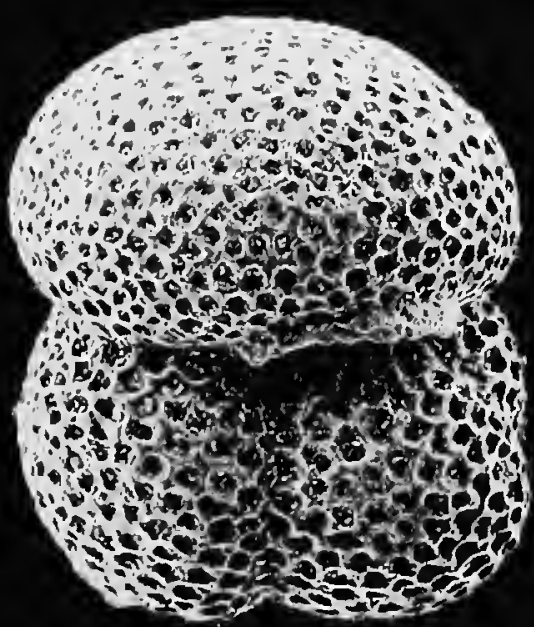

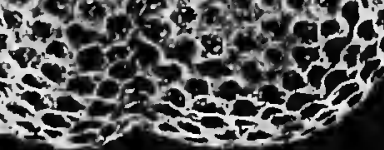

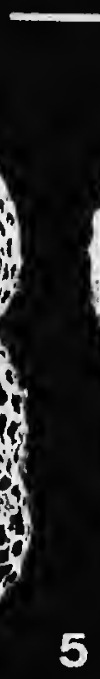

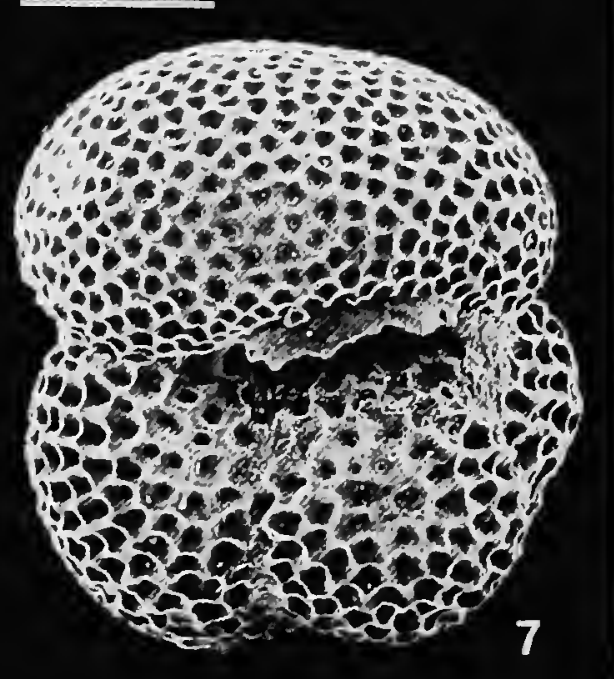
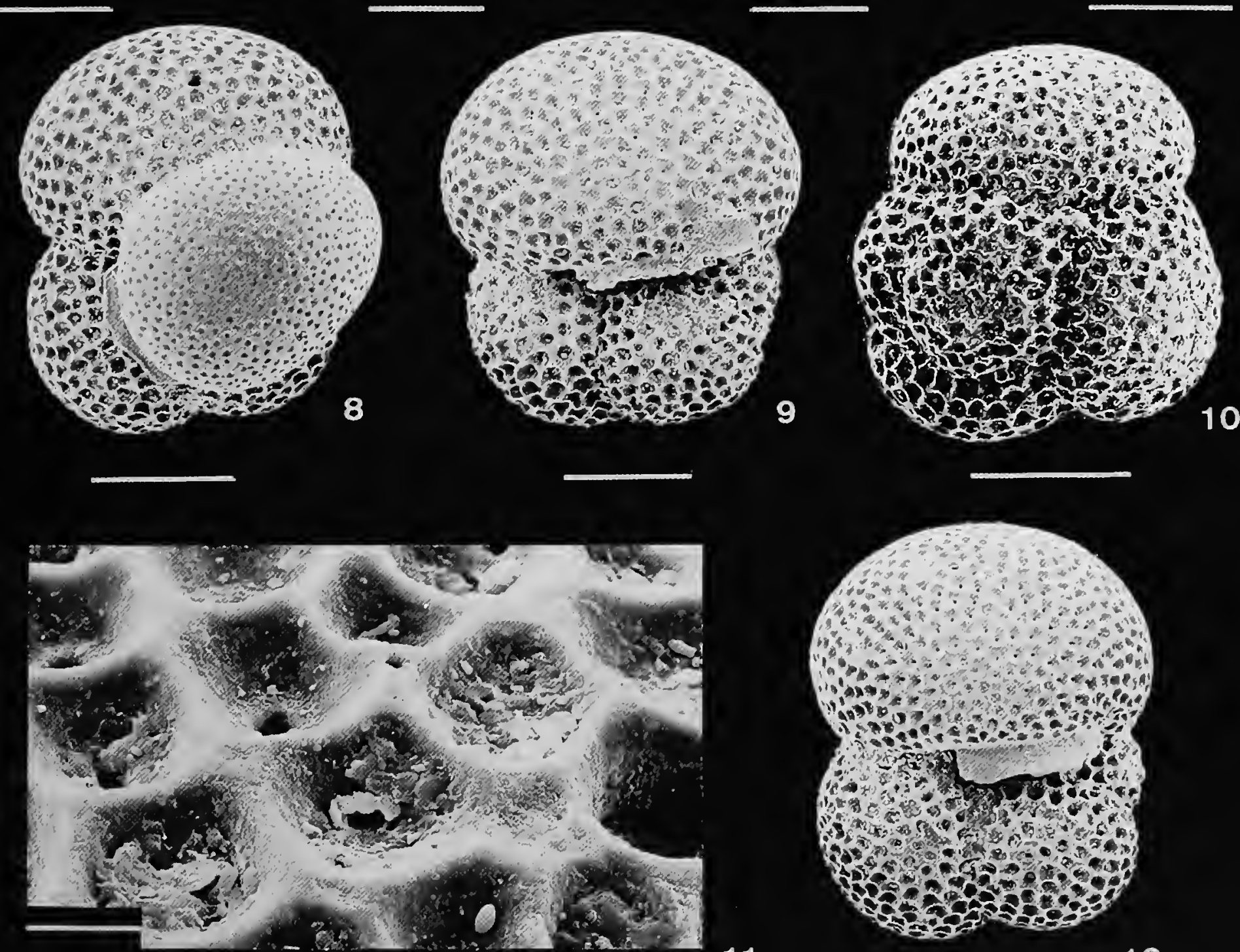


\section{PLATE 30}

\section{Hedbergella holmdelensis Olsson, 1964}

$$
(\text { bars }=50 \mu \mathrm{m})
$$

FIGURES 1-16.-Topotypes, upper Maastrichtian, Navesink Fm., New Jersey.

FigURE 17.-Zone P0, Millers Ferry, Alabama, core 225, sample 346. 

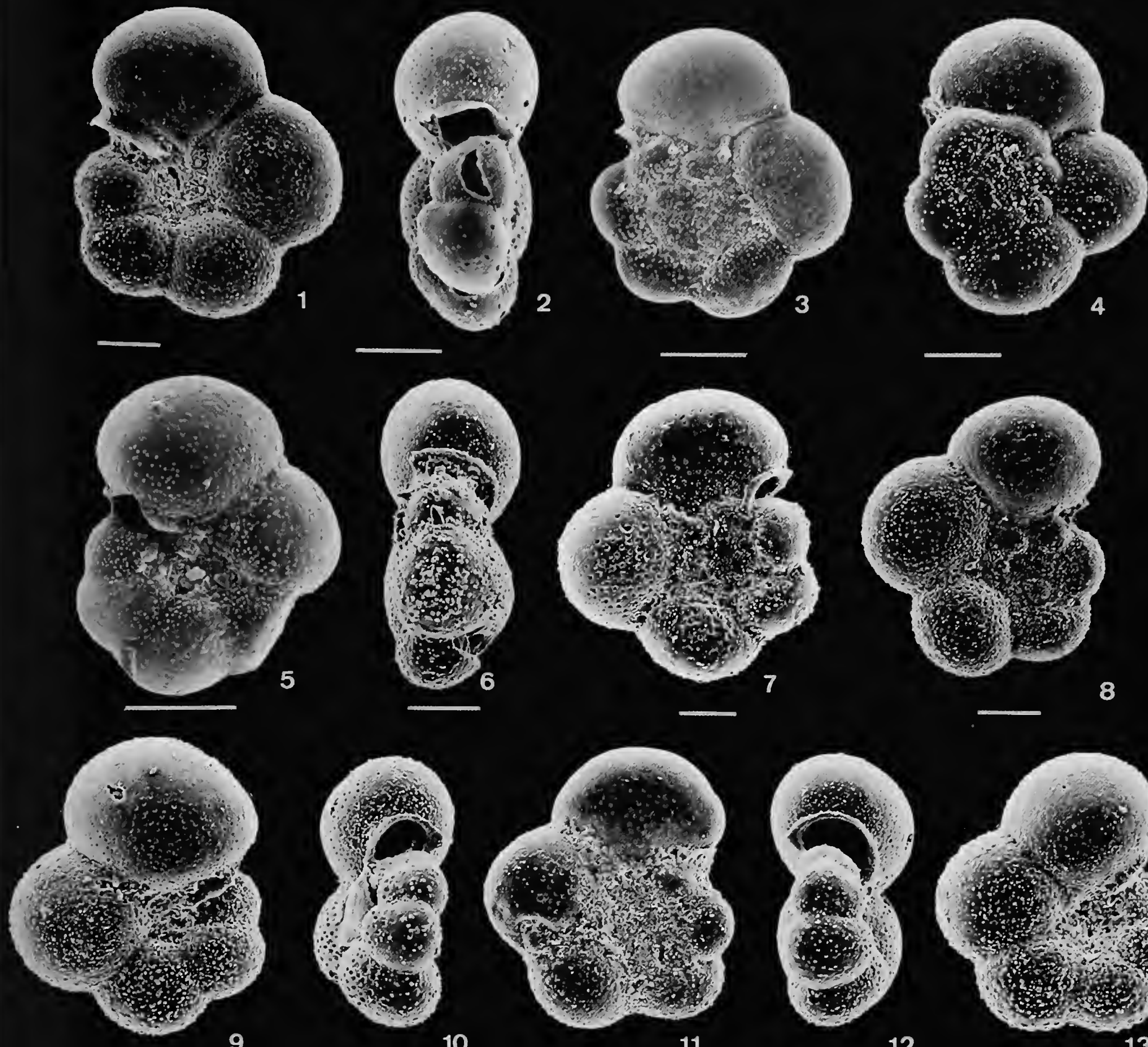

12

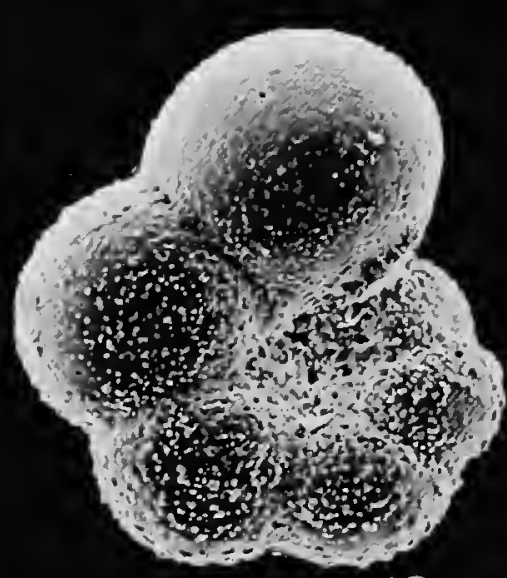

13

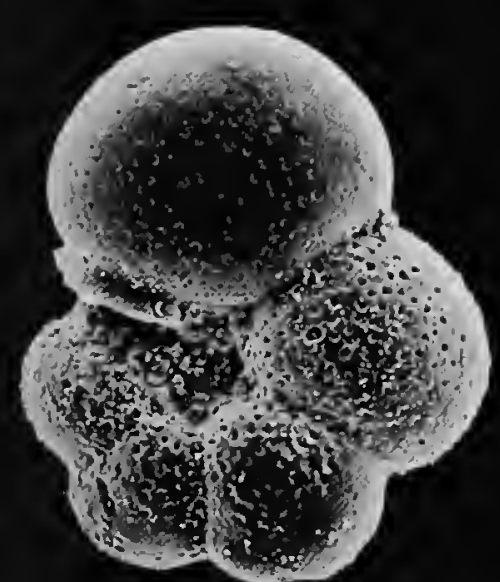

14

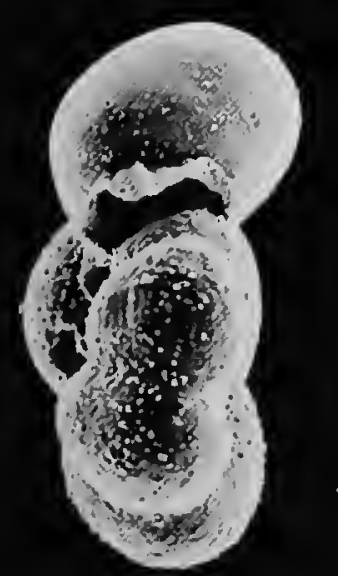

15
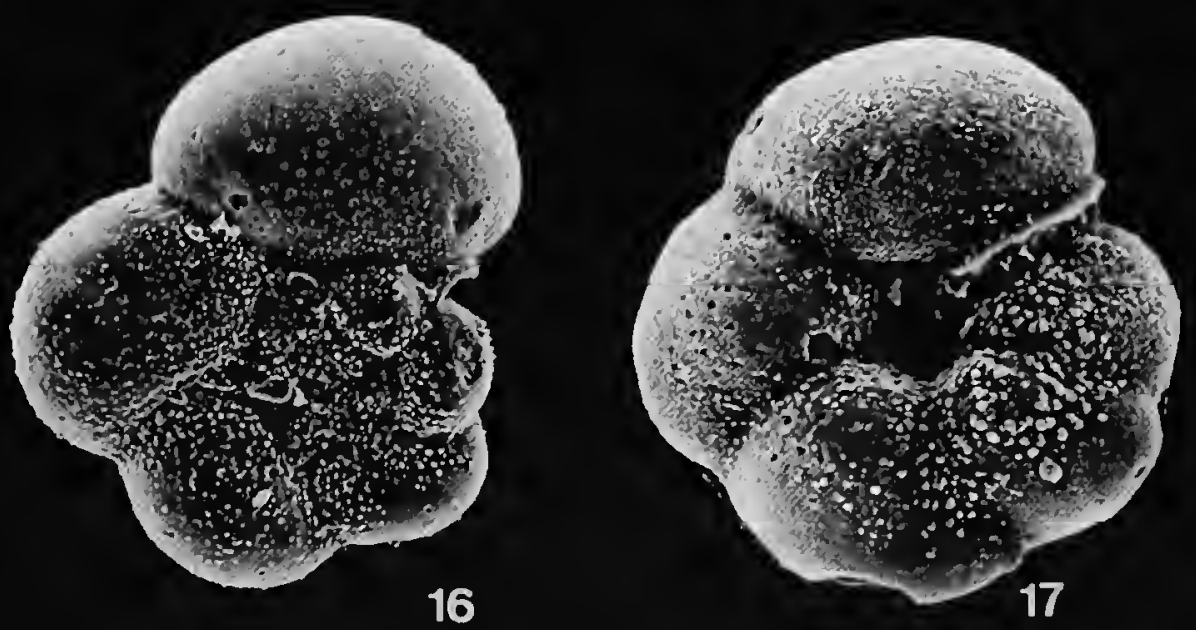


\section{PLATE 31}

\section{Hedbergella monmouthensis (Olsson, 1960)}

(Figures 1-6, 8-13: bars $=50 \mu \mathrm{m} ;$ Figures 7, 14: bars $=10 \mu \mathrm{m} ;$ Figure 15: bar $=4 \mu \mathrm{m}$ )

FIgURES 1-11.-Topotypes, upper Maastrichtian, Redbank Fm., New Jersey; Figure 7, enlarged view of apertural lips of Figure 1.

FiguRES 12-15.-Zone P0, Millers Ferry, Alabama, core 225, sample 346; Figures 14, 15, views of wall of Figure 13 showing development of primitive pore pits. 

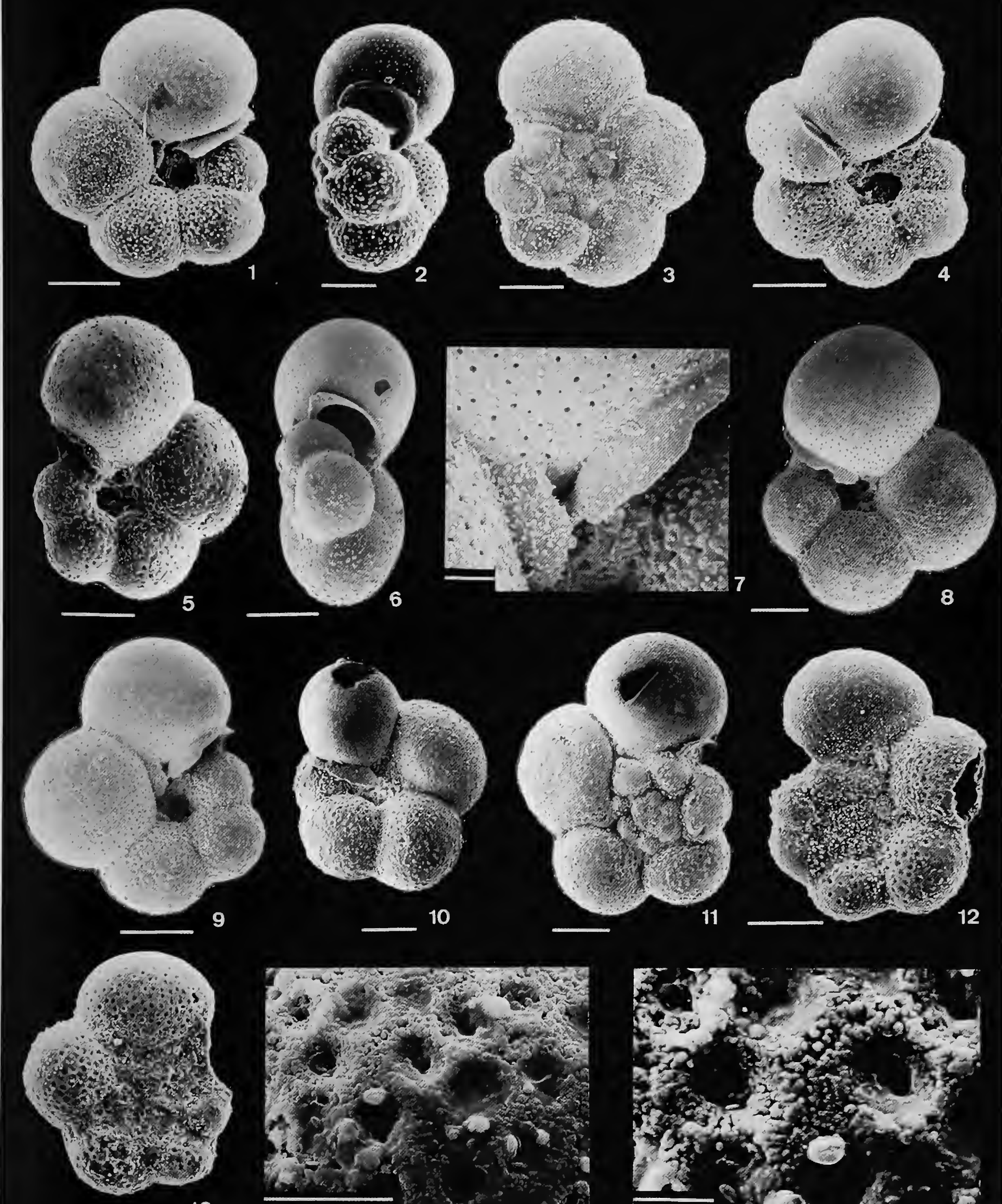

13

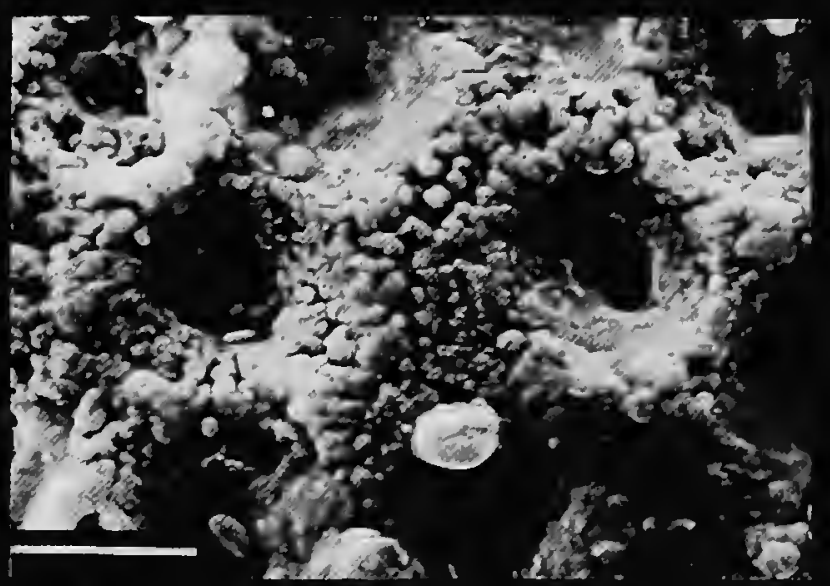




\section{PLATE 32}

Globanomalina archeocompressa (Blow, 1979)

$$
\text { (bars }=10 \mu \mathrm{m})
$$

FIGURES 1-9.-Zone P0, Millers Ferry, Alabama, core 225, sample 342.

FIGURE 10.-Zone P0, Millers Ferry, Alabama, core 225, sample 346.

\section{Globanomalina compressa (Plummer, 1926)}

$$
(\text { bars }=100 \mu \mathrm{m})
$$

FigurES 11-13, 15, 16. - Zone Plc, DSDP Site 356/26/3: 90-92 cm; São Paulo Plateau, South Atlantic Ocean. FIGURE 14.-Zone P2, DSDP Hole 398D/39/4: 100-102 cm; western Iberian continental margin, eastern North Atlantic Ocean. 

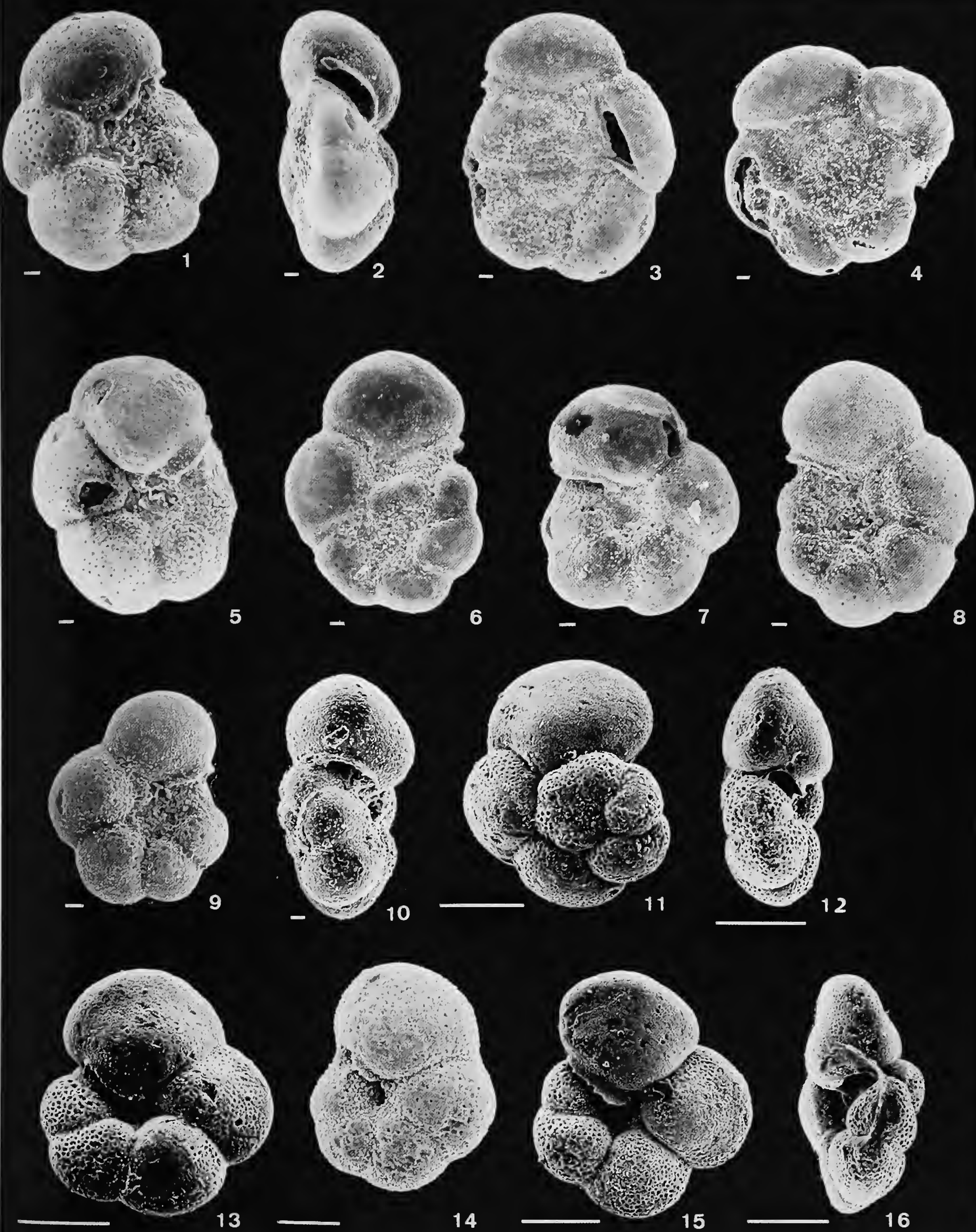

14 


\section{PLATE 33}

Globanomalina australiformis (Jenkins, 1965)

(Figures 7, 10, 11, 13: bars $=100 \mu \mathrm{m}$; Figures $1-4,6:$ bars $=40 \mu \mathrm{m}$; Figures 8 , 9: bars $=50 \mu \mathrm{m}$; Figures 5, 12: bars $=10 \mu \mathrm{m}$ )

FIGURES 1-6.-Topotypes, Subbotina triloculinoides Zone, N141/910N.2, Waipara, New Zealand; Figure 5, view of 3 rd chamber of Figure 3 showing wall texture.

FIgURES 8, 9.-Lower Paleocene, ODP Hole 738B/23X/CC; Kerguelen Plateau, southern Indian Ocean.

Figures 7, 10-13.-Zone Plc, ODP Hole 747C/2R/4: 90-92 cm; Kerguelen Plateau, souther n Indian Ocean; Figure 12, view of 4 th chamber of Figure 13 showing wall texture. 

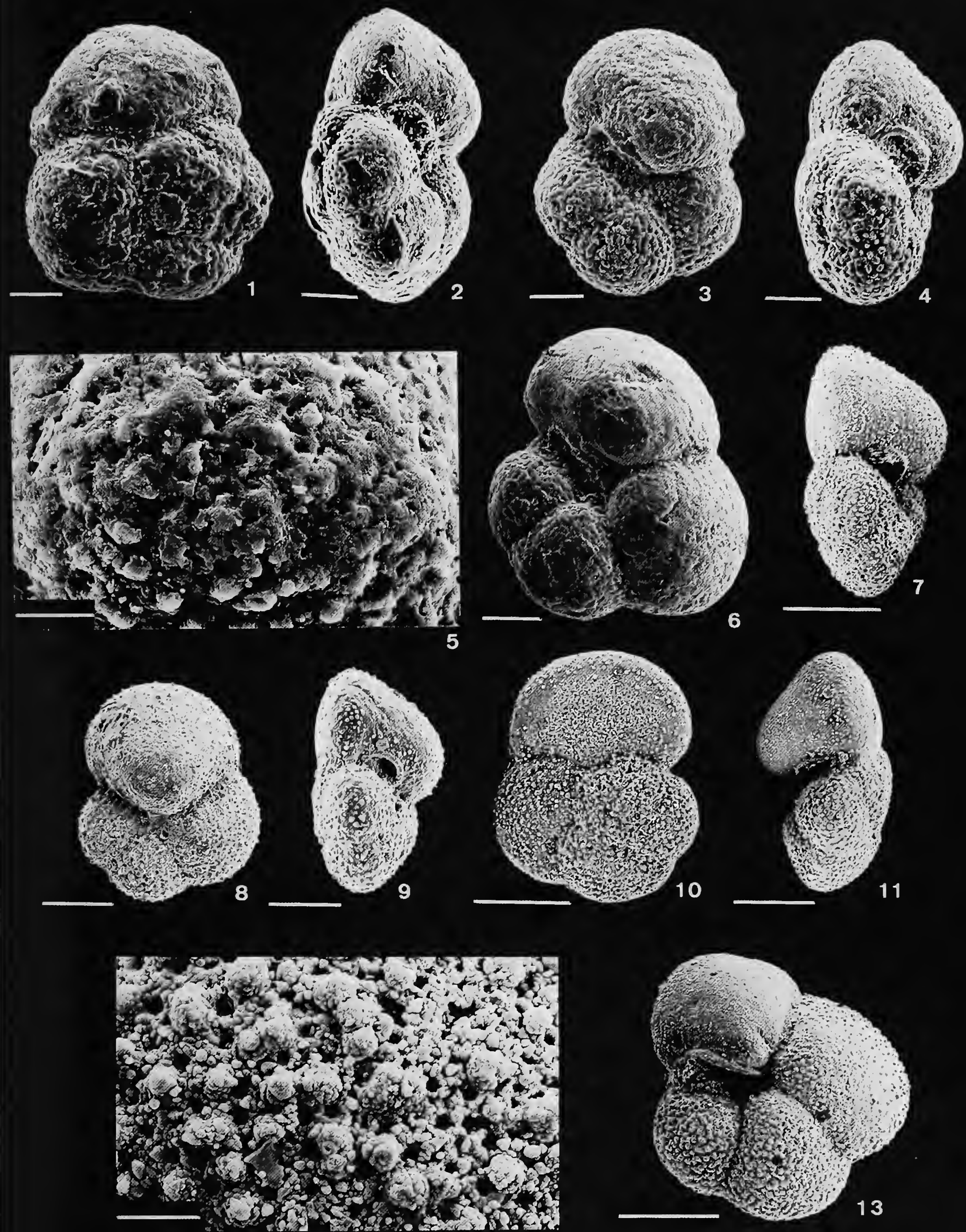


\section{PLATE 34}

Globanomalina chapmani (Parr, 1938)

$$
(\text { bars }=50 \mu \mathrm{m})
$$

FiguRES 1, 2, 5, 6.-Zone P4, Vincentown Fm., Glendola Well, New Jersey, sample 286-287 feet. FIGURE 4.-Zone P4, Vincentown Fm., Whitesville Well, New Jersey, sample 215-220 feet. FIgUREs 3, 7.-Zone P4, Nerinea Fm., Pondicherry, South India, sample PT14.

\section{Globanomalina planoconica (Subbotina, 1953)}

$$
(\text { bars }=50 \mu \mathrm{m})
$$

FIgURES 8-17.-Zone P4, Velasco Fm., Tamaulipas, Mexico, John Cruz Collection, sample 17. 

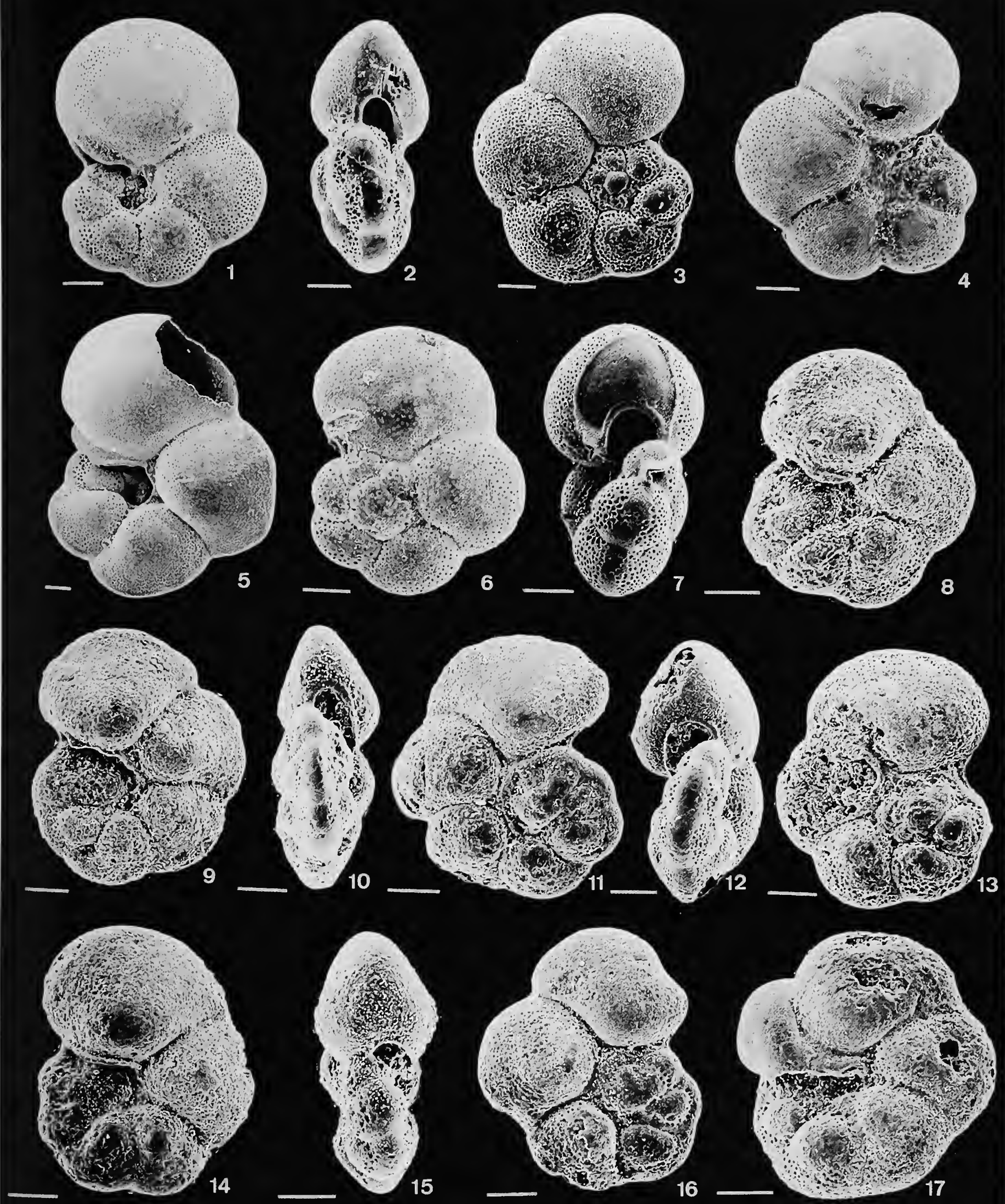


\section{PLATE 35}

Globanomalina compressa (Plummer, 1926)

(Figures 1-3, 5-13, 17: bars $=100 \mu \mathrm{m} ;$ Figure 4: bar $=40 \mu \mathrm{m}$ )

Figures 1, 3, 5, 7, 11,-Zone Plc, Mexia Clay Mbr., Midway Group, Texas.

FIGURE 4.-Zone P2, Wills Point Fm., Texas.

Figures 2, 6, 8-10.-Zone Plc, Brightseat Fm., Maryland.

Figures 12, 13, 17.-Zone PIc, DSDP Site 356/26/3: 90-92 cm; São Paulo Plateau, South Atlantic Ocean.

Globanomalina ehrenbergi (Bolli, 1957)

$$
\text { (bars }=100 \mu \mathrm{m})
$$

Figures 14-16.-Zone P1c, Mexia Clay Mbr., Midway Group, Texas. 


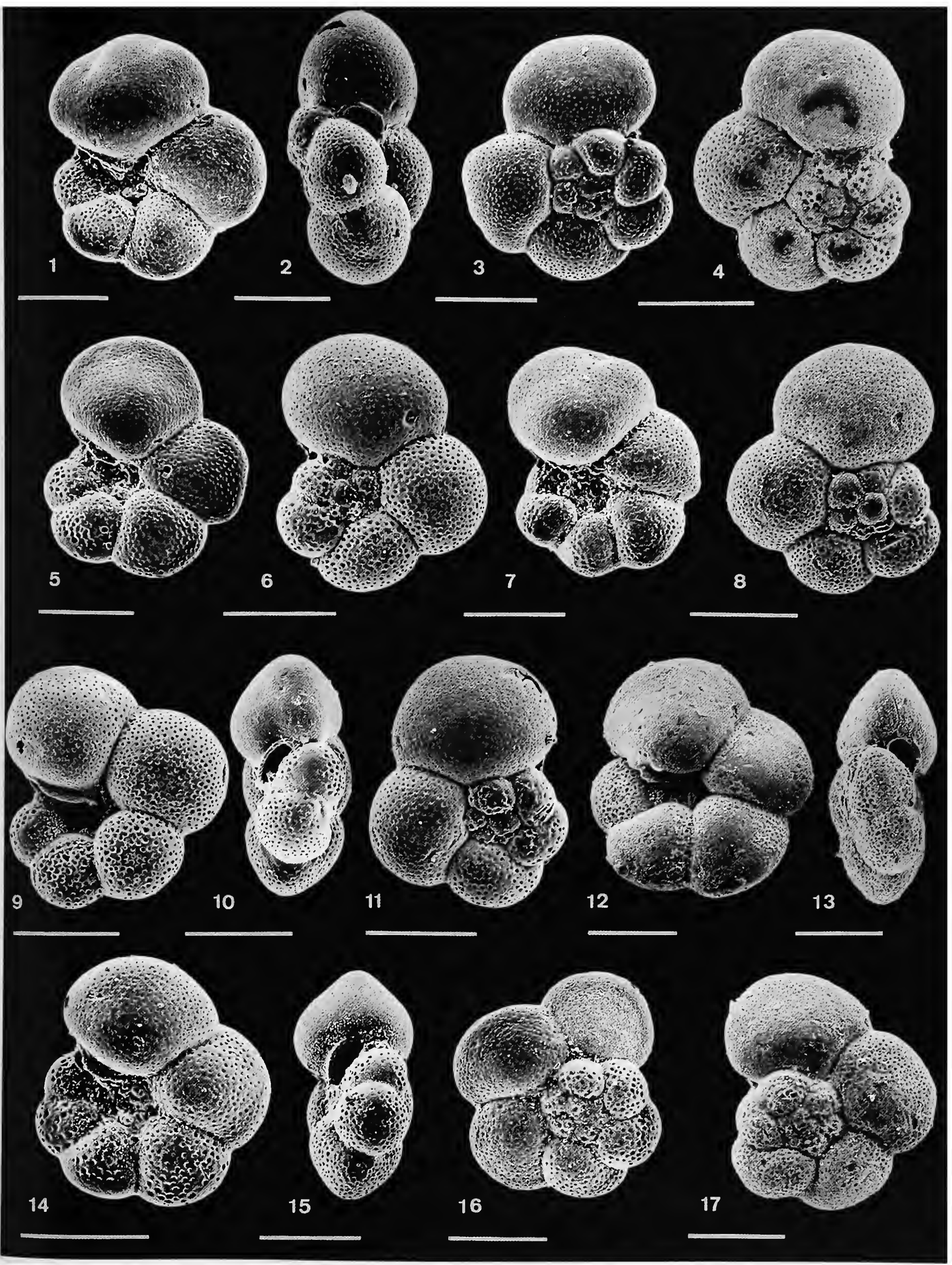




\section{PLATE 36}

\section{Globanomalina planocompressa (Shutskaya, 1965)}

(Figures 1-4: bars $=40 \mu \mathrm{m}$; Figures 5, 6: bars $=100 \mu \mathrm{m}$ )

FiguRE 1.-Zone Pla, Millers Ferry, Alabama, core 225, sample 194.

Figures 2, 3, 6.-Zone Pla, Millers Ferry, Alabama, surface sample 30 feet.

FIGURE 4.-Zone Plb, Eureka Core, Gulf of Mexico, sample 6817-6817.5 feet.

FIGURE 5.-Zone Plc, Brightseat Fm., Maryland.

\section{Globanomalina imitata (Subbotina, 1953)}

(Figures 8-13, 15, 16: bars $=40 \mu \mathrm{m}$; Figures 7, 14: bars $=100 \mu \mathrm{m}$ )

Figures 7, 16.-Zone Plc, Mexia Clay Mbr., Midway Group, Texas.

Figures 8-12.-Zone P4, Vincentown Fm., Whitesville Well, New Jersey, sample 210-215 feet; Figure 12, view showing inner whorl of conical-shaped chambers with pustulose surface.

FIGURES 13-15.-Globanomalina aff. imitata transitional to G. ovalis, Zone P4, Nerinea Fm., Pondicherry, South India, sample PT 14. 

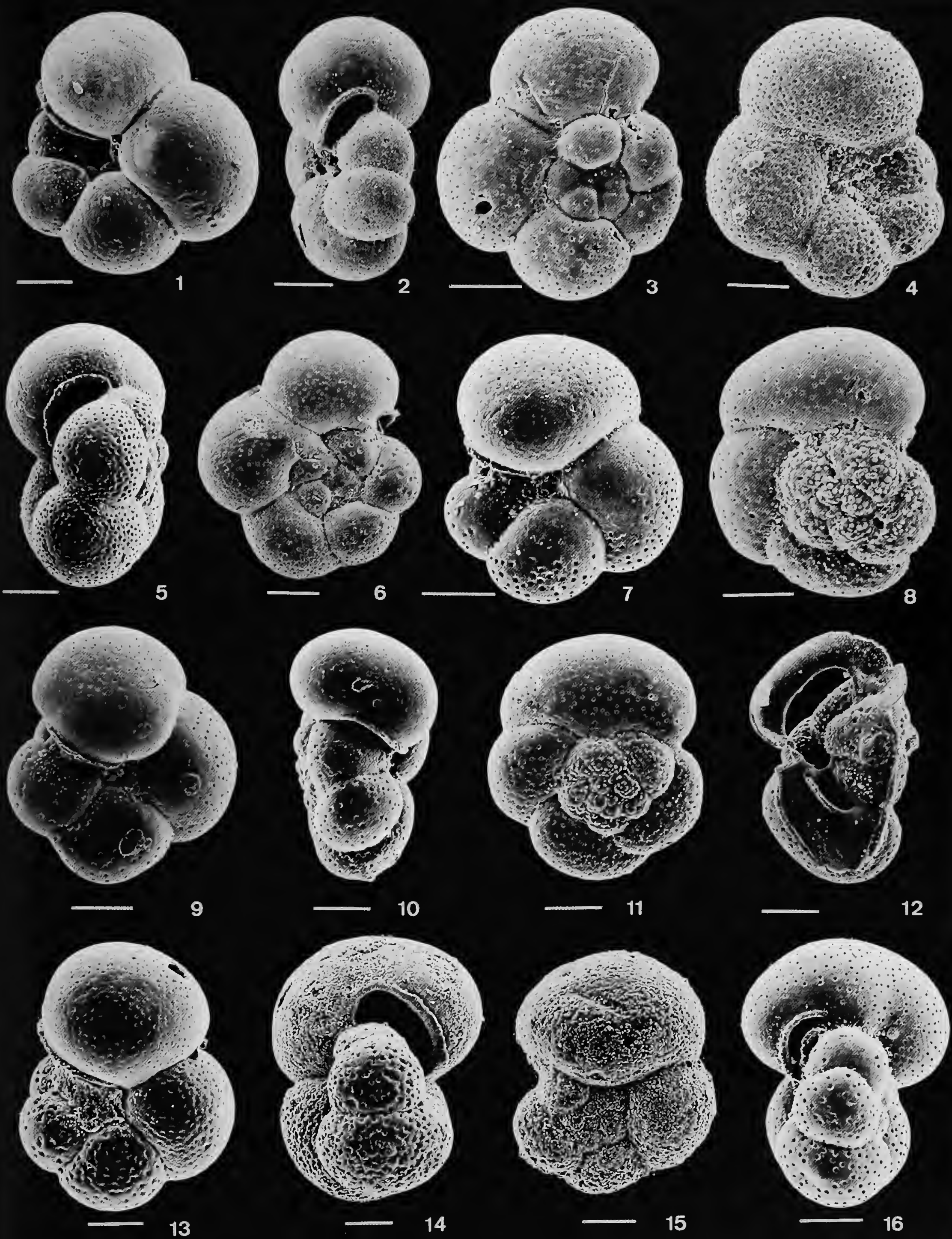


\section{PLATE 37}

Globanomalina ovalis Haque, 1956

$$
\text { (bars }=50 \mu \mathrm{m})
$$

Figures 1-15.-Zone P4, Nerinea Fm., Pondicherry, South India, sample PT14. 

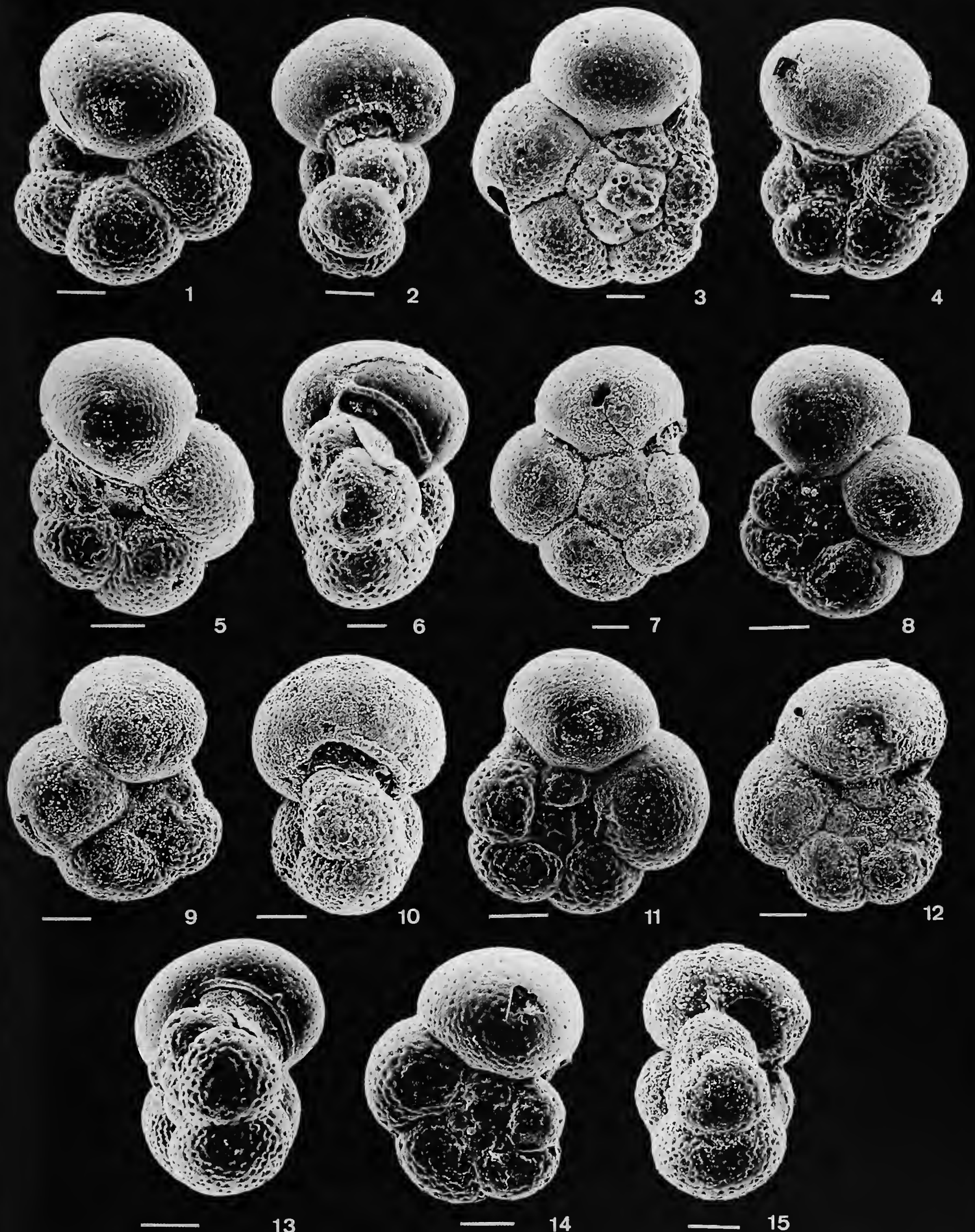

11
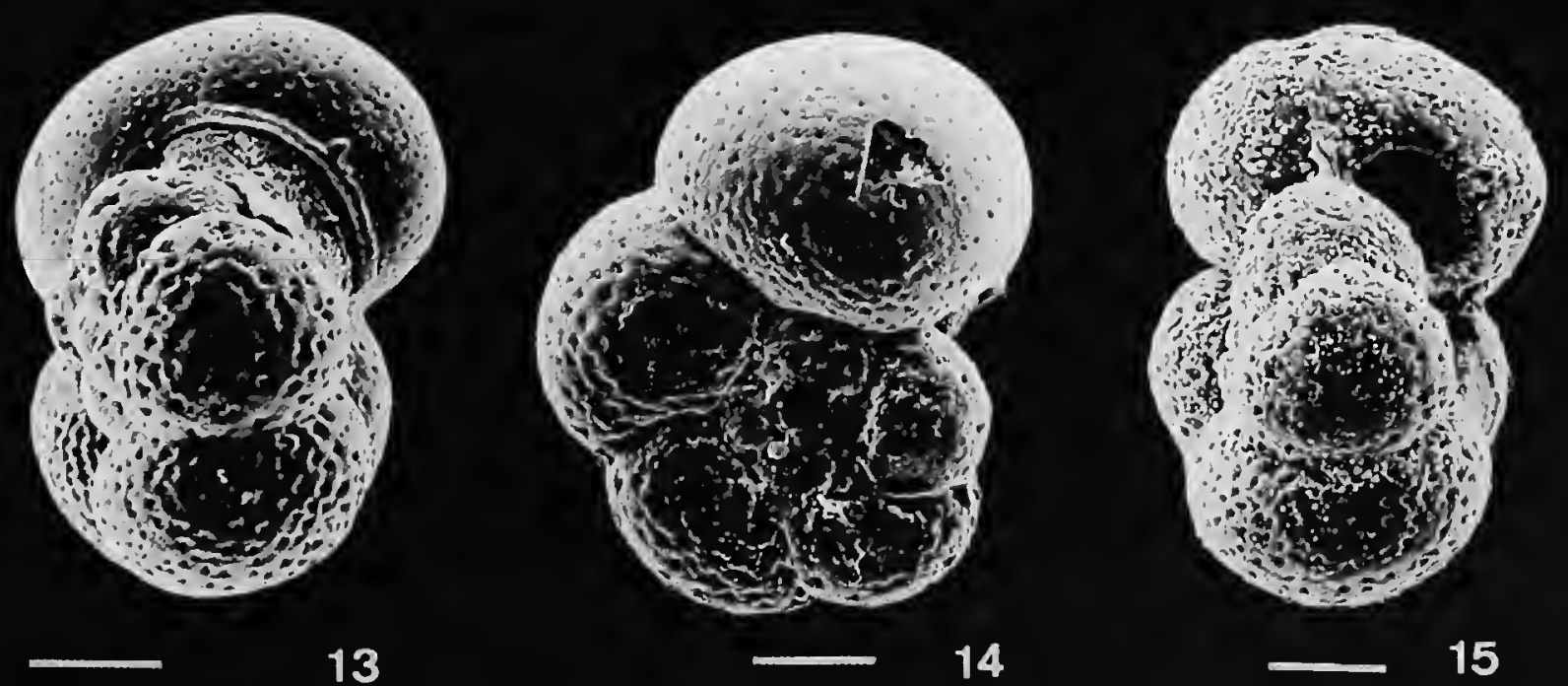

14 


\section{PLATE 38}

Globanomalina pseudomenardii (Bolli, 1957)

$$
(\text { bars }=50 \mu \mathrm{m})
$$

FigurES 1-7.-Zone P4, Velasco Fm., Tamaulipas, Mexico.

Figures 8, 10-16.-Zone P4, Vincentown Fm., Glendola Well, New Jersey, sample 286-287 feet.

FIGURE 9.-Zone P4, Nerinea Fm., Pondicherry, South India, sample PT14. 

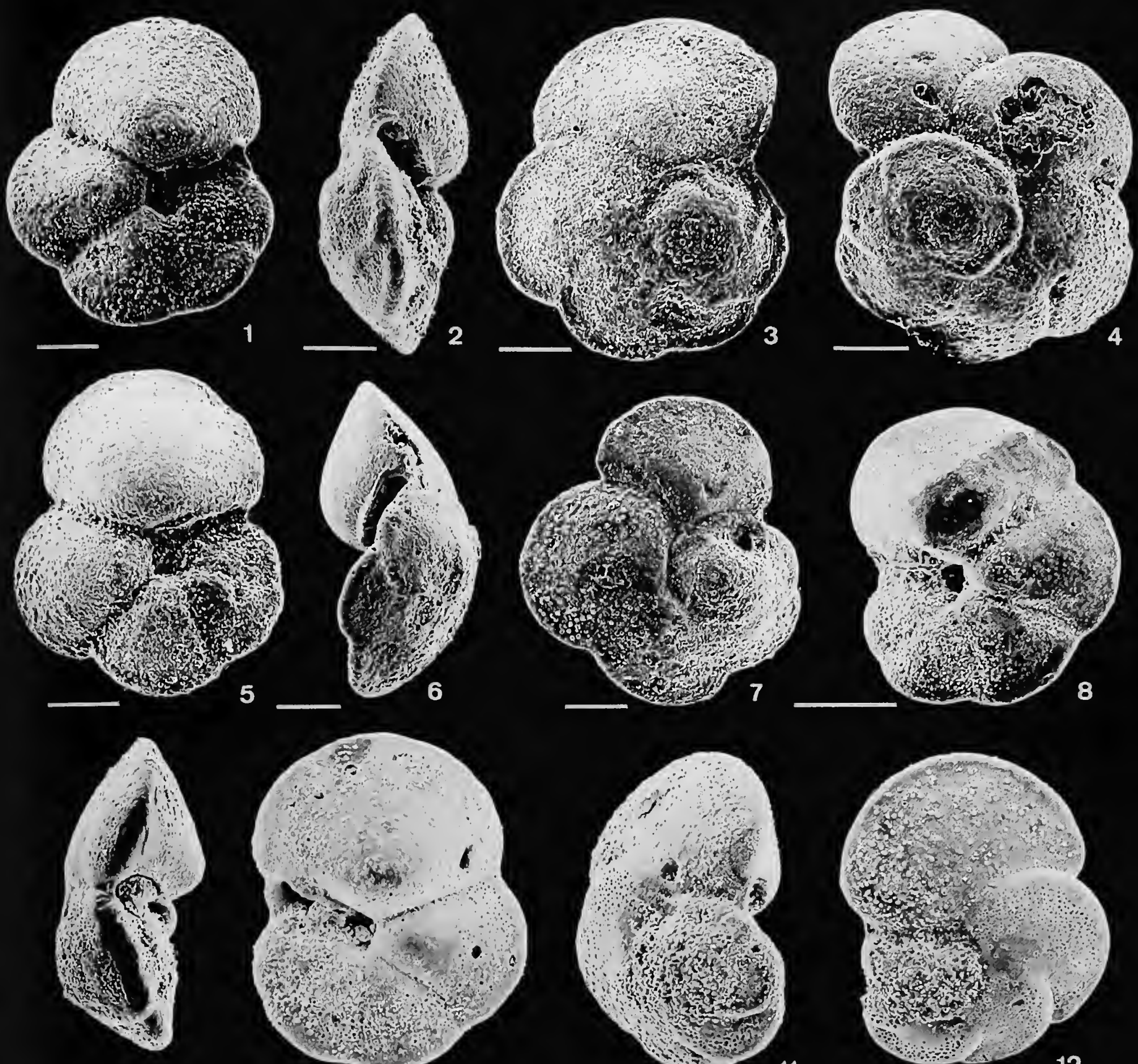

9
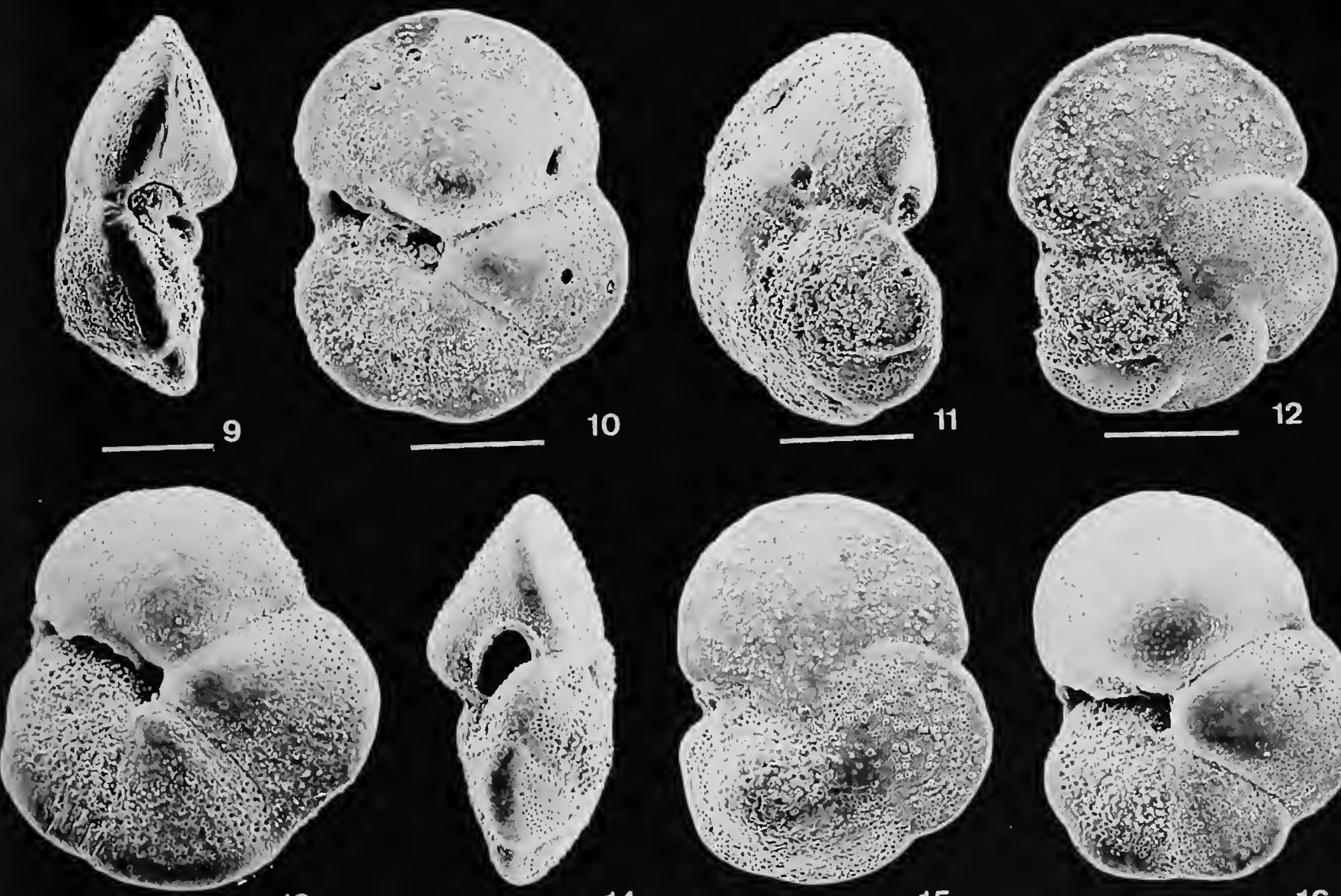

13
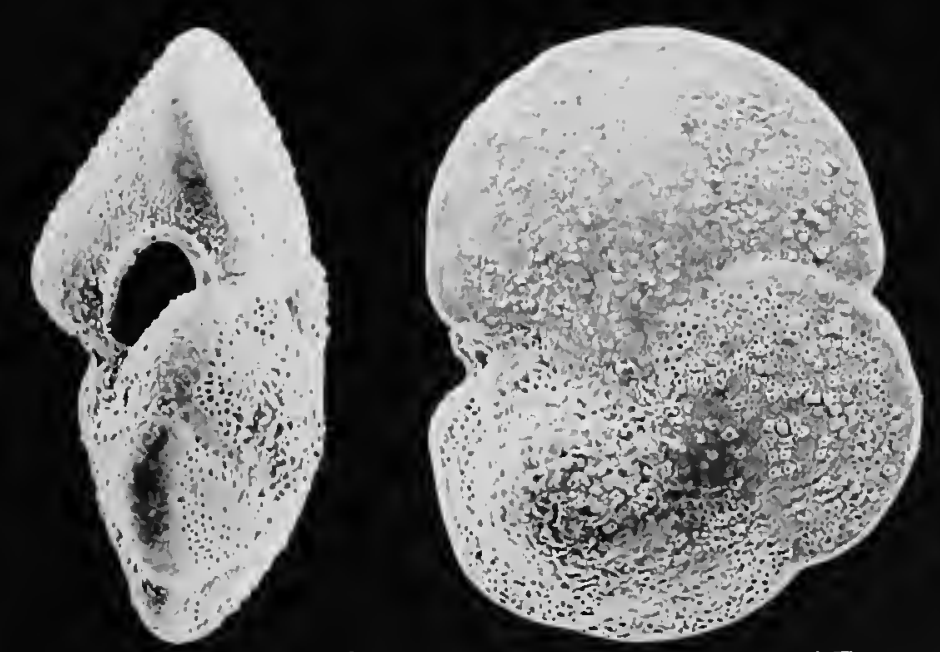

15

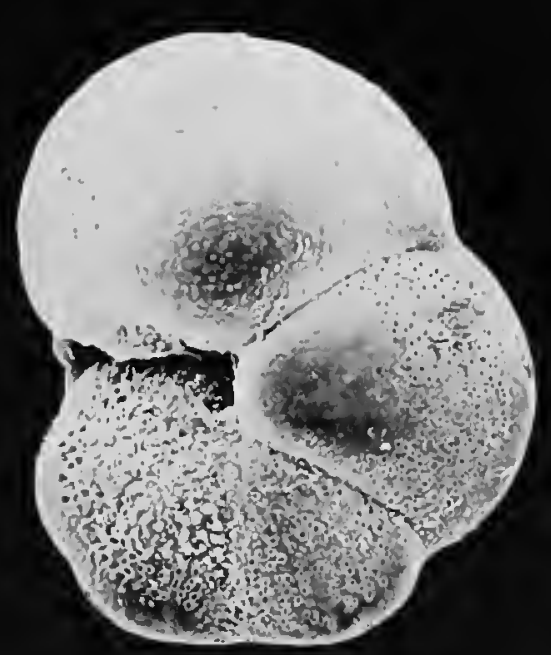

16 


\section{PLATE 39}

Acarinina coalingensis (Cushman and Hanna, 1927)

$$
\text { (bars }=100 \mu \mathrm{m} \text { ) }
$$

Figures 1, 4, 13-15.-Zone P5, DSDP Site 465/3/1: 59-61 cm; Hess Rise, central North Pacific Ocean. Figures 2, 3, 8, 12, 16.-Zone P5, DSDP Hole 20C/6/4: 17-19 cm; Brazil Basin, South Atlantic Ocean. FigURES 5-7, 9-11.-Zone P5, ODP Hole 758A/28/1: 50-52 cm; Ninetyeast Ridge, Indian Ocean. 

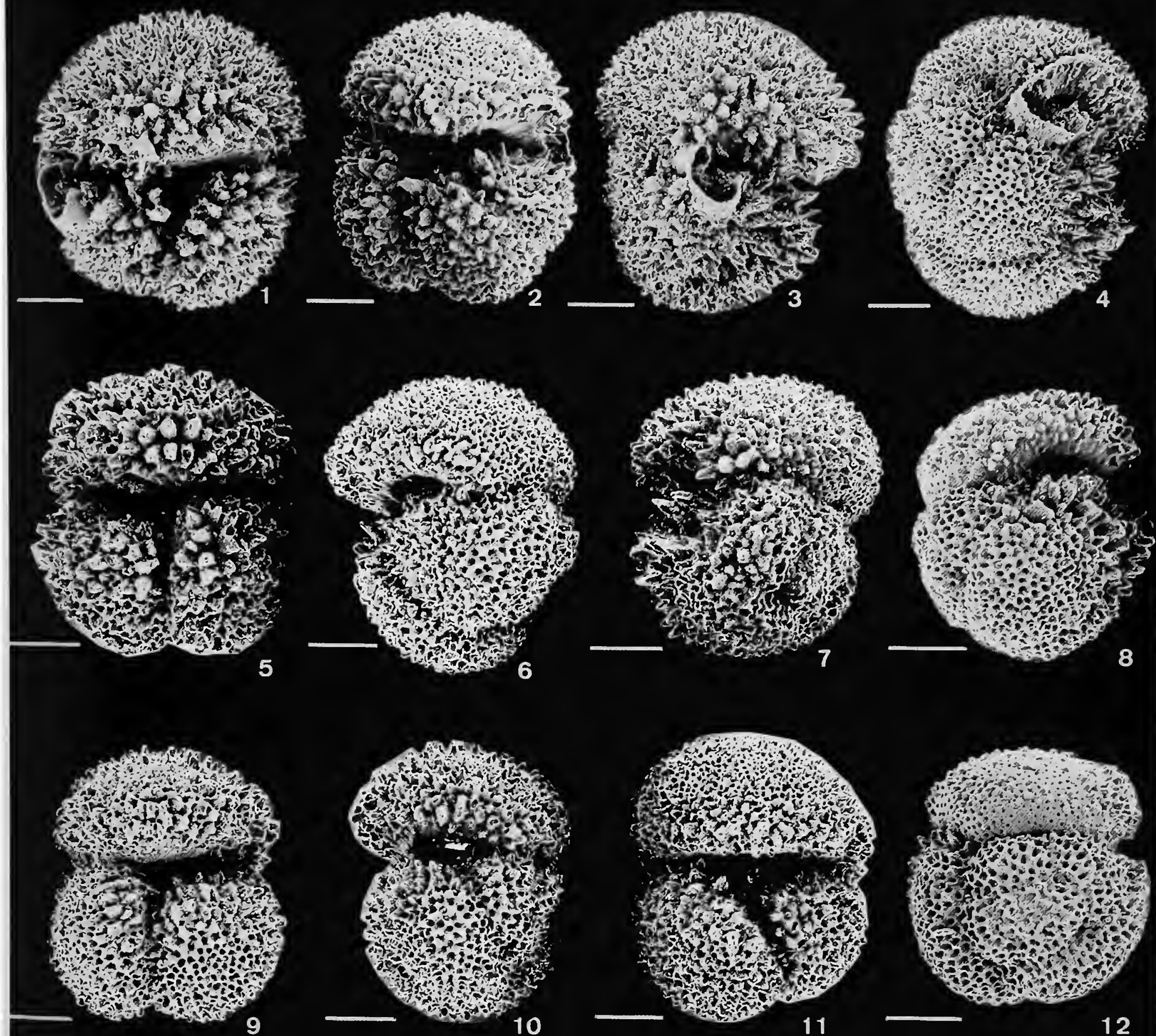

10

11
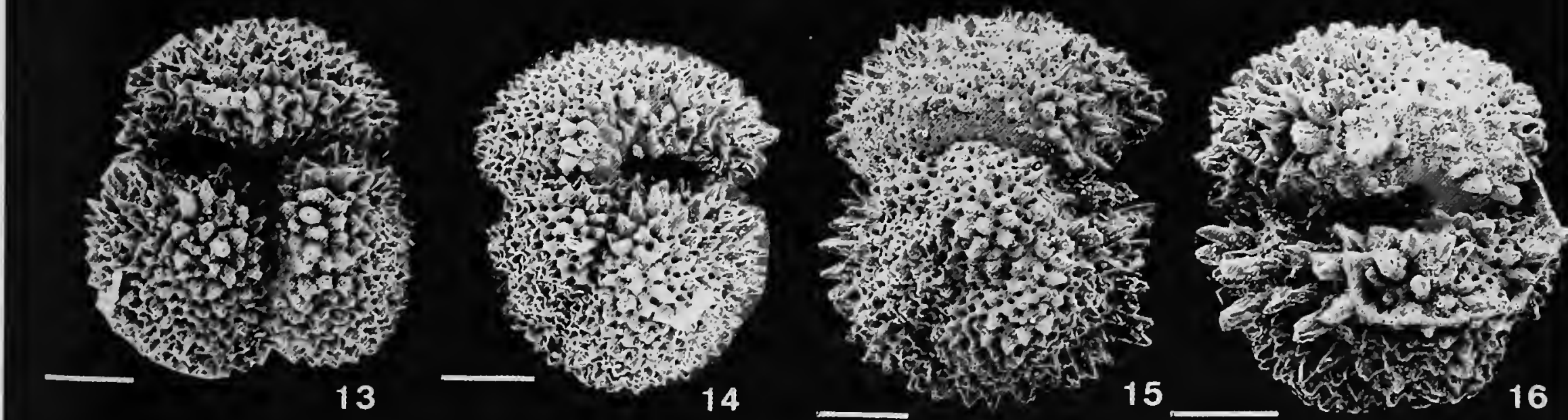


\section{PLATE 40}

Acarinina mckannai (White, 1928)

$$
\text { (bars }=100 \mu \mathrm{m})
$$

FIGURES 1-4.-Zone P4, DSDP Site 465/4/3: 62-64 cm; Hess Rise, central North Pacific Ocean.

FIgUREs 5-7.-Zone P4, DSDP Site 384/6/CC; southeast Newfoundland Ridge, North Atlantic Ocean.

FIGURE 8.-Zone P4, DSDP Site 384/7/1: 60-62 cm; southeast Newfoundland Ridge, North Atlantic Ocean.

FIGURES 9-11.-Zone P4, DSDP Site 527/27/1: 30-32 cm; Walvis Ridge, South Atlantic Ocean.

FIGURES 12, 16.-Zone P4, ODP Hole 758A/28/5: 50-52 cm; Ninetyeast Ridge, Indian Ocean.

FIGURE 13.-Late Paleocene, ODP Hole 738C/16R/1: 55-60 cm; Kerguelen Plateau, southern Indian Ocean.

Figures 14, 15.-Zone P4, Vincentown Fm., Glendola Well, New Jersey, sample 219-221 feet. 

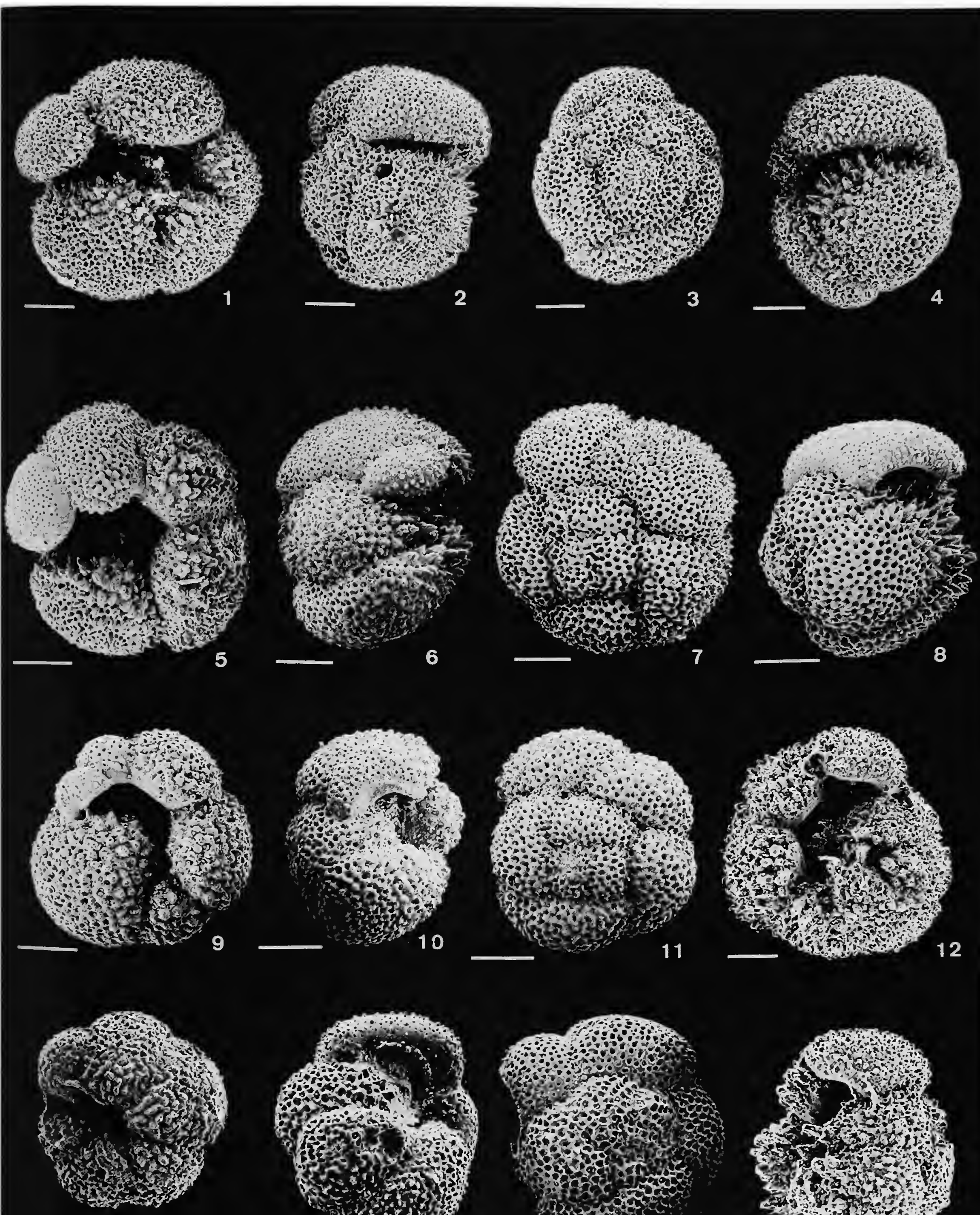

13
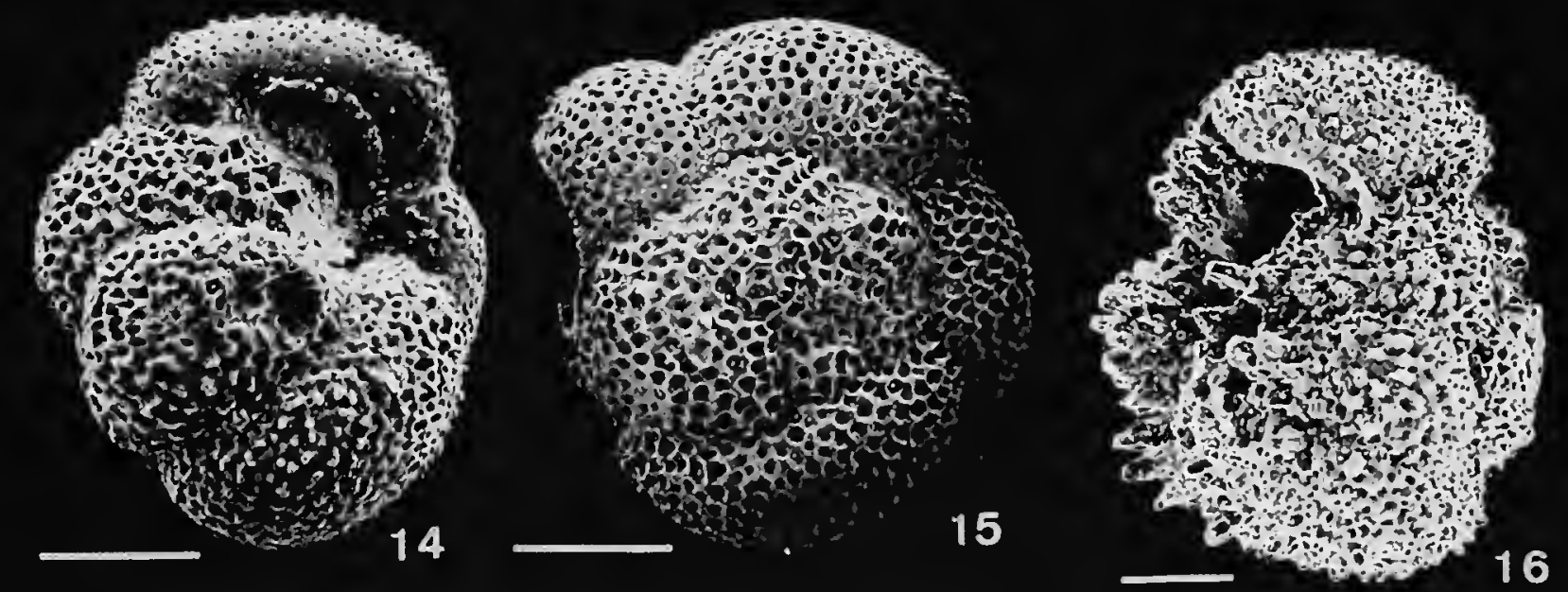


\section{PLATE 41}

Acarinina nitida (Martin, 1943)

(Figures 1-4, 7, 10: bars $=40 \mu \mathrm{m}$; Figures 13-15: bars $=50 \mu \mathrm{m}$; Figures 5, 6, 8, 9, 11, 12, 16: bars $=100 \mu \mathrm{m}$ ) FIGURES 1-3, 7.-Zone P4, DSDP Site 384/9/2: 136-138 cm.

Figures 4, 10.-Zone P4, DSDP Site 384/8/4: 136-138 cm; southeast Newfoundland Ridge, North Atlantic Ocean.

Figures 5, 8, 9, 11, 12.-Zone P4, Vincentown Fm., Glendola Well, New Jersey, sample 219-221 feet.

FIGURE 6.-Zone P5, ODP Hole 758A/28/3: 50-52 cm; Ninetyeast Ridge, Indian Ocean.

FIGURE 13.-Lower Eocene, ODP Hole 738C/10R: 277.78 mbsf.

FigurEs 14, 15.-Lower Eocene, ODP Hole 738C/10R/3: 98-102 cm; Kerguelen Plateau, southern Indian Ocean.

FIGURE 16.-Upper Paleocene, ODP Hole 690B/25/3: 90-92 cm; Maud Rise, Southern Ocean. 

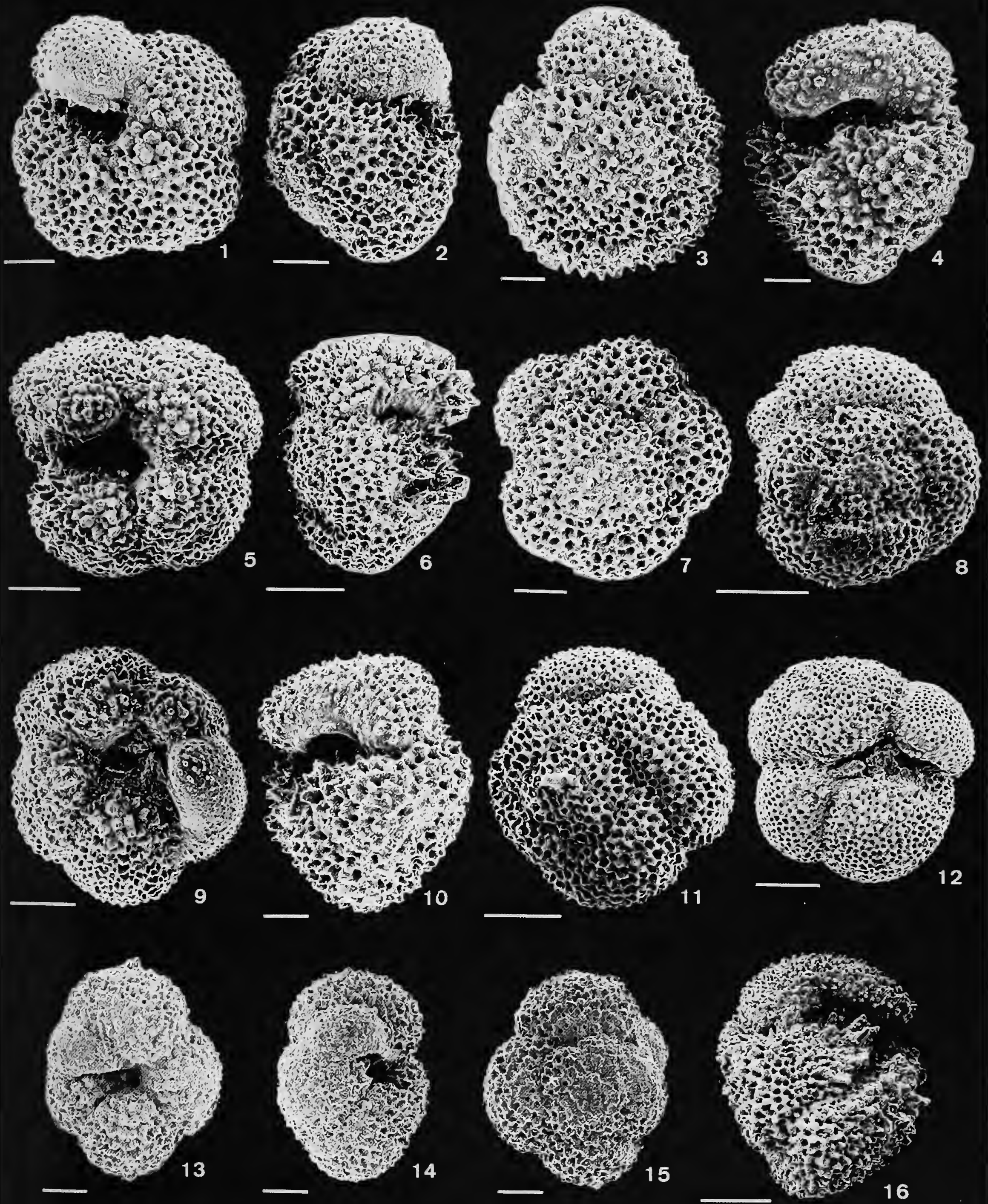


\section{PLATE 42}

Acarinina soldadoensis (Brönnimann, 1952)

$$
\text { (bars }=100 \mu \mathrm{m} \text { ) }
$$

FIGURES 1-3.-Zone P4, DSDP Site 465/4/4: 62-64 cm.

FIGURE 4.-Zone P5, ODP Hole 758A/28/3: 50-52 cm.

FIGURES 5-7.-Zone P6a, DSDP Hole 20C/3/1: 1-19 cm; Brazil Basin, South Atlantic Ocean.

FIgURES 8, 12-14.-Zone P5, DSDP Site 465/3/1: 59-61 cm; Hess Rise, central North Pacific Ocean.

FIGURES 9-11.-Zone P5, DSDP Site 213/16/1: 104-106 cm; eastern Indian Ocean.

Figures 15, 16.-Zone P4, ODP Hole 758A/28/5: 50-52 cm; Ninetyeast Ridge, Indian Ocean. 


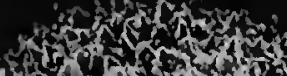

to 80120

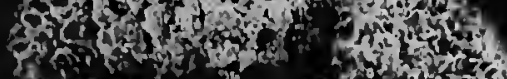

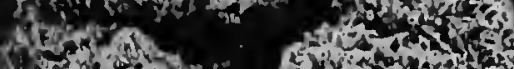
$\rightarrow 15$ ards 13 0 . $\sin 30$

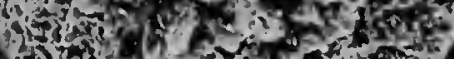
(1) 3 , N 1 .

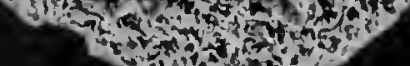

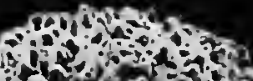
cistickstor c.

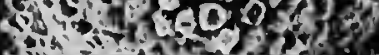
(iv) 104 ene dy Wetcon

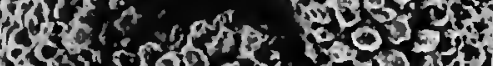

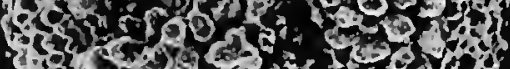
sis 20504

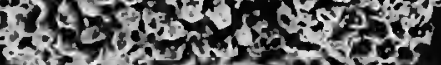

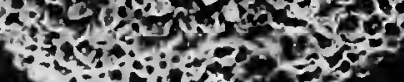

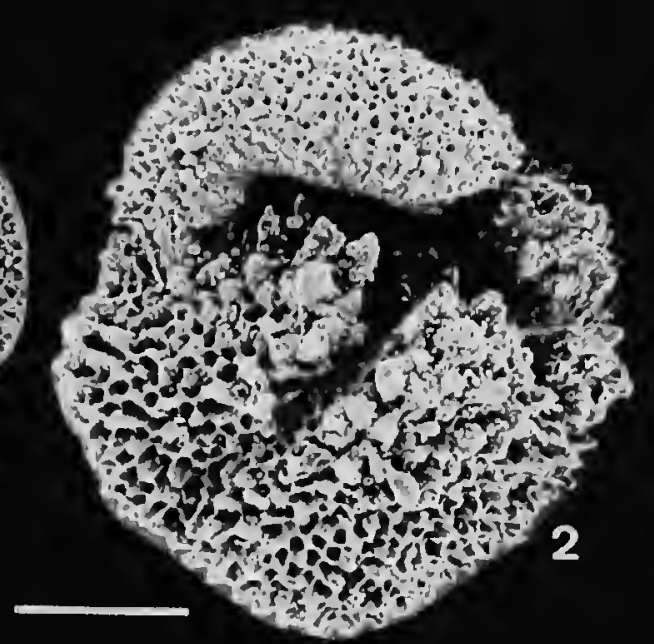

W

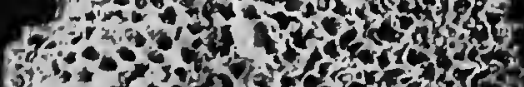

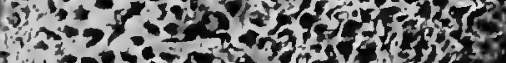
45030125

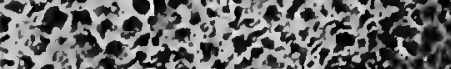
P. átar

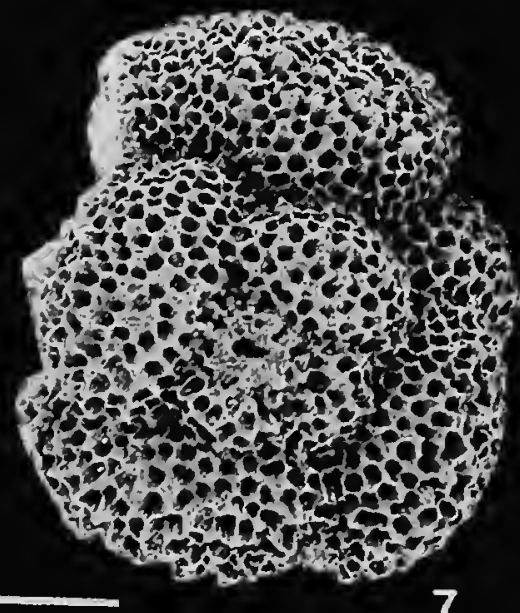
6

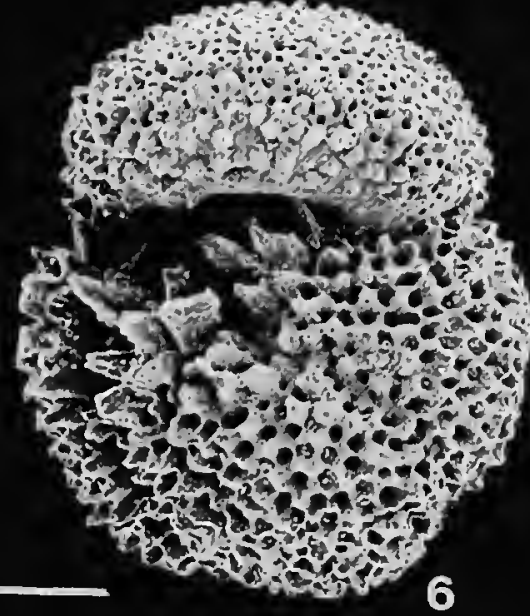

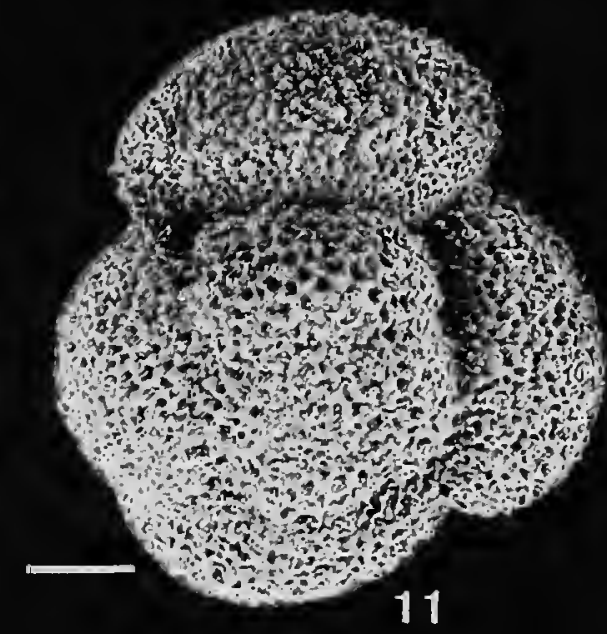

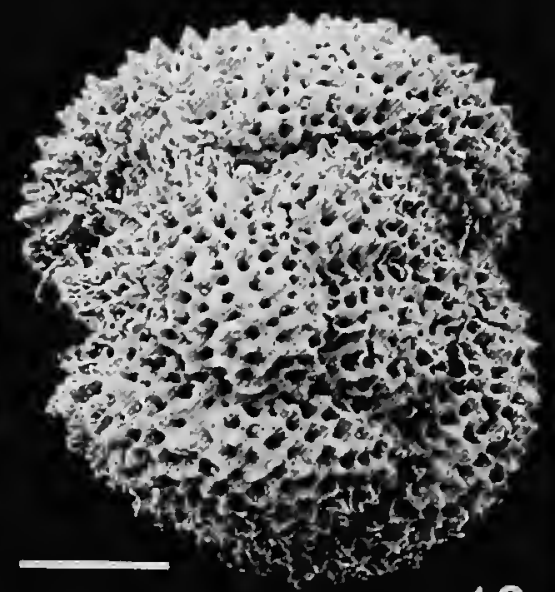

12

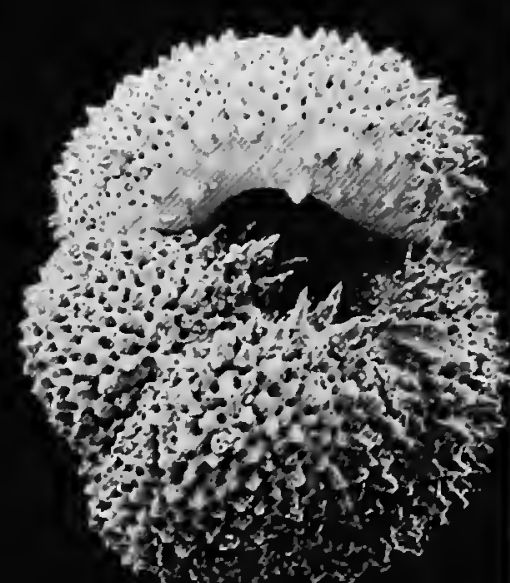

8

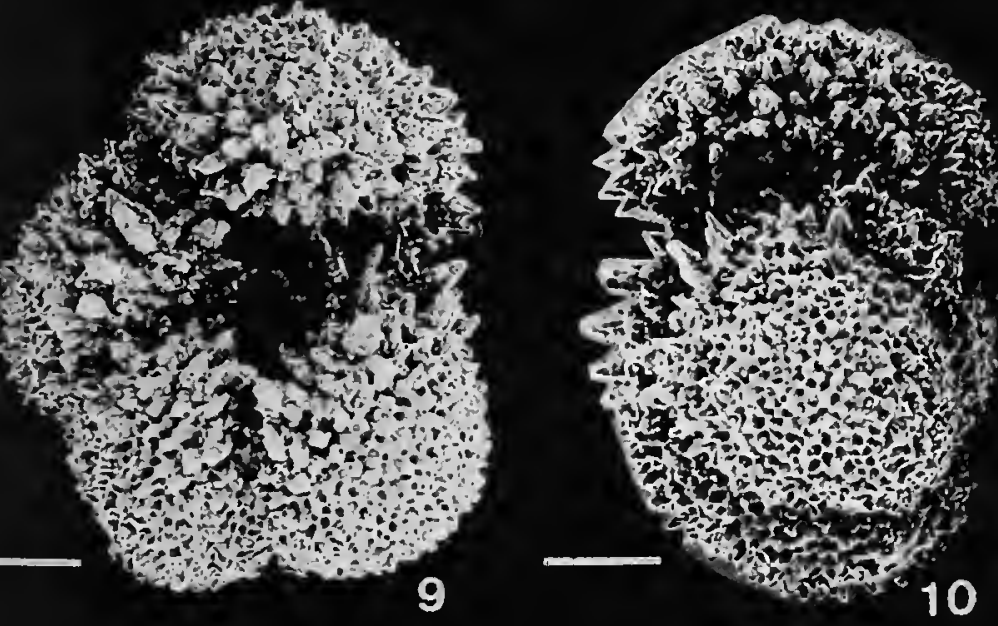

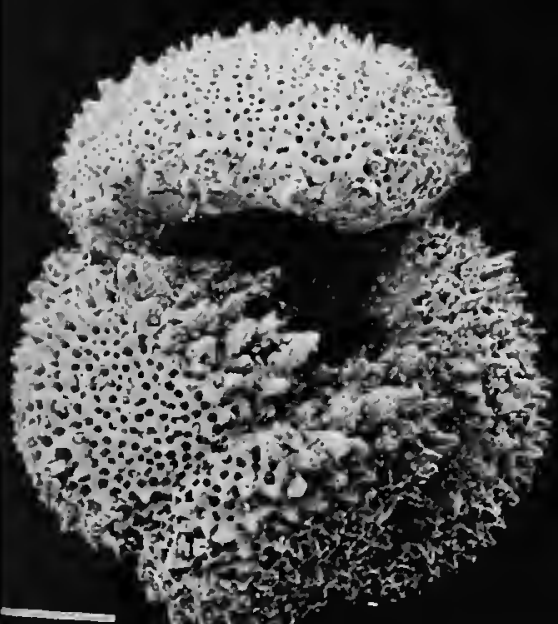

13
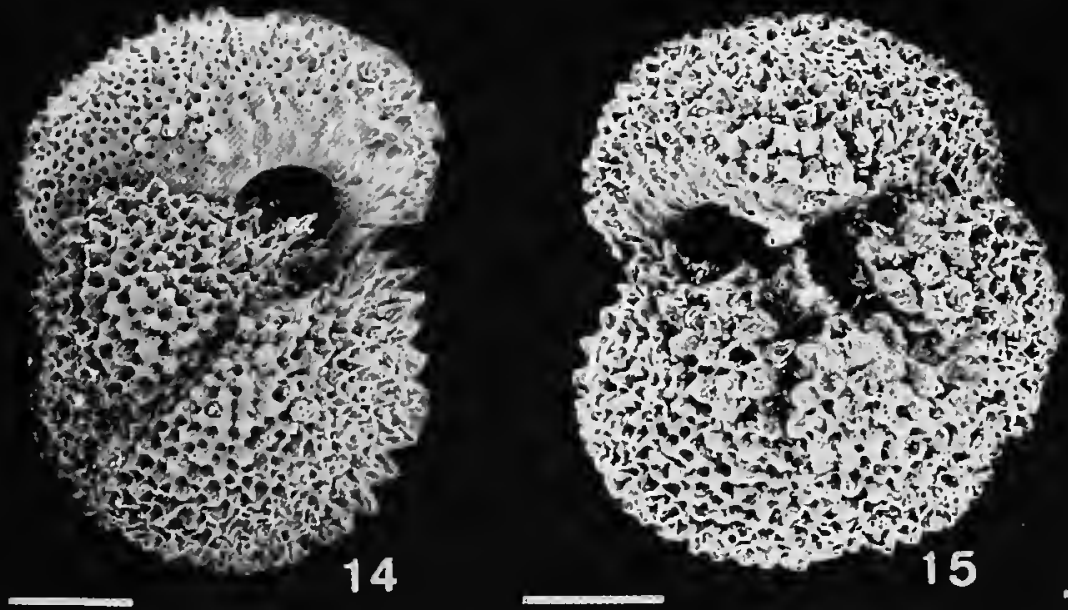


\section{PLATE 43}

Acarinina strabocella (Loeblich and Tappan, 1957)

(Figures 1, 2, 5: bars $=40 \mu \mathrm{m}$; Figures 3, 4, 6-16: bars $=100 \mu \mathrm{m}$ )

FigurE 1.-Zone P3b, Hornerstown Fm., New Jersey, NJT 12-1A.

Figures 2, 3, 13.-Zone P2, DSDP Site 356/25/5: 148-150 cm; São Paulo Plateau, South Atlantic Ocean.

FIGURES 4, 7, 8, 10, 11, 14, 16.-Zone P2, ODP Hole 750A/11/2: 19-21 cm.

FIGURES 5, 6, 9, 12.-Zone P2/3, ODP Hole 750A/11/1: 149-150 cm; Kerguelen Plateau, southern Indian Ocean.

FIGURE 15.-Zone P3, DSDP Site 384/9/6: $136-138 \mathrm{~cm}$; southeast Newfoundland Ridge, North Atlantic Ocean. 




\title{
PLATE 44
}

\section{Acarinina subsphaerica (Subbotina, 1947)}

\author{
$($ bars $=100 \mu \mathrm{m})$
}

FIGURES 1, 5, 16.-Zone P4, DSDP Site 384/7/CC; southeast Newfoundland Ridge, North Atlantic Ocean.

FIGURES 2, 3, 8, 10, 13.-Zone P4, DSDP Site 465/5/1: 65-67 cm.

FIGURE 4.-Upper Paleocene, ODP Hole 738C/15R: 322.07 mbsf; southern Kerguelen Plateau, Southern Ocean.

FIGURES 6, 7.-Zone P4, DSDP Site 527/27/1: 30-32 cm; Walvis Ridge, South Atlantic Ocean.

FIgURES 9, 11.-Zone P5, ODP Hole 758A/28/3: 50-52 cm; Ninetyeast Ridge, Indian Ocean.

FIGURE 12.-Zone P4, ODP Hole 761 B/17/6: 49-51 cm; Wombat Plateau, eastern Indian Ocean.

Figures 14, 15.-Zone P4, DSDP Site 465/4/4: 62-64 cm; Hess Rise, central North Pacific Ocean. 

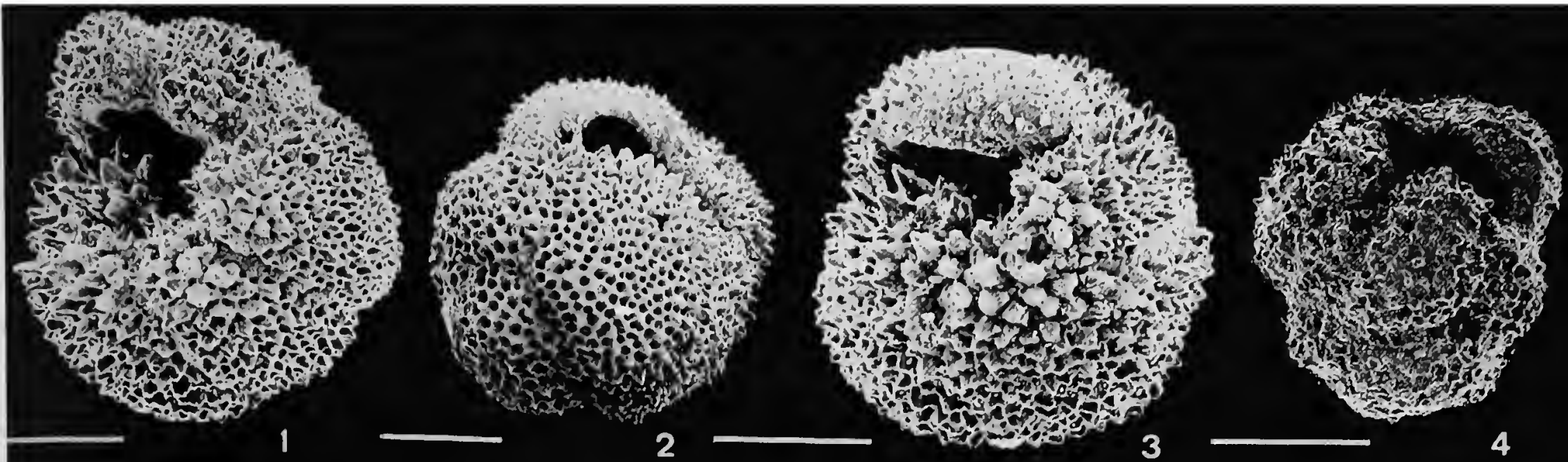

2

3

4
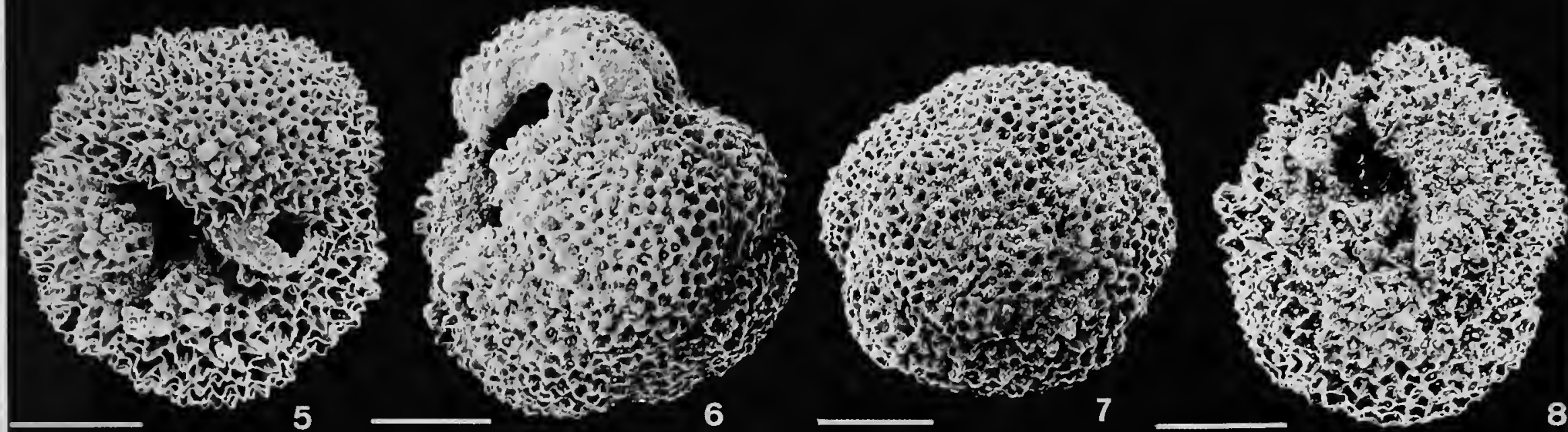

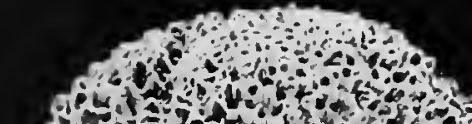

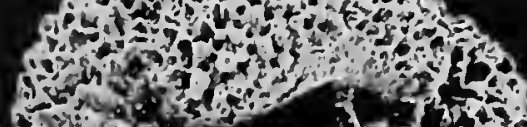
3.

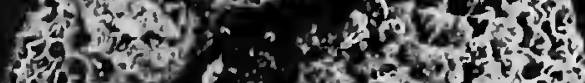

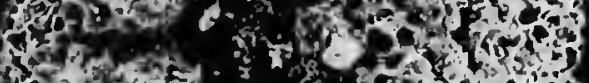

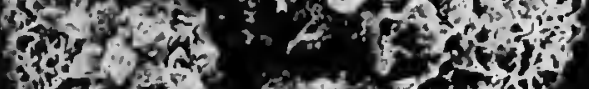

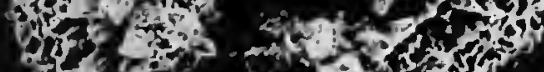
ofto nos.

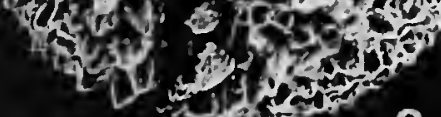
9

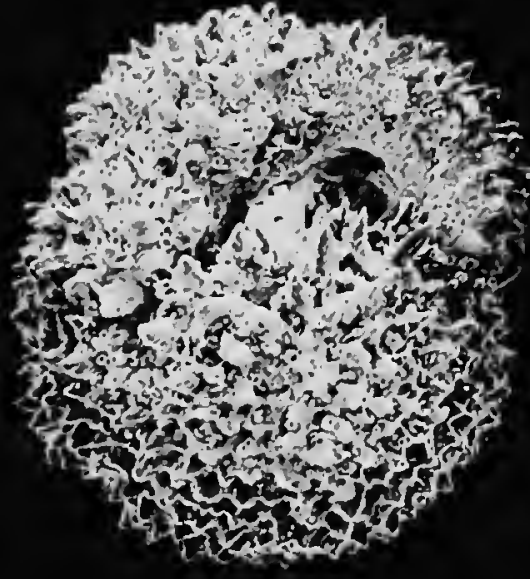

10
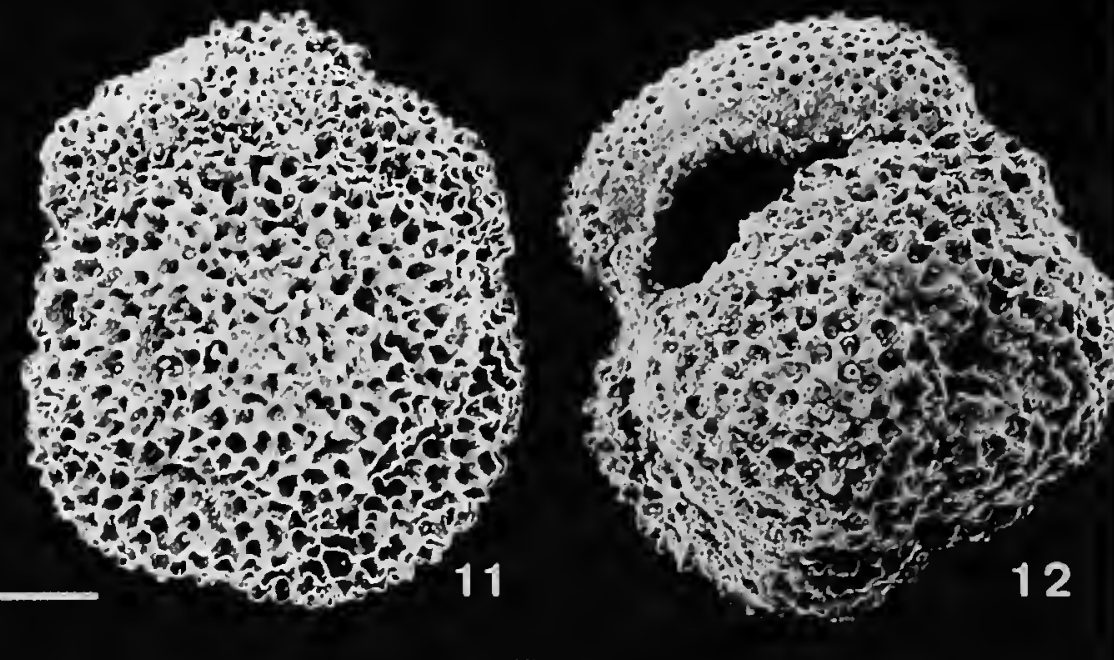

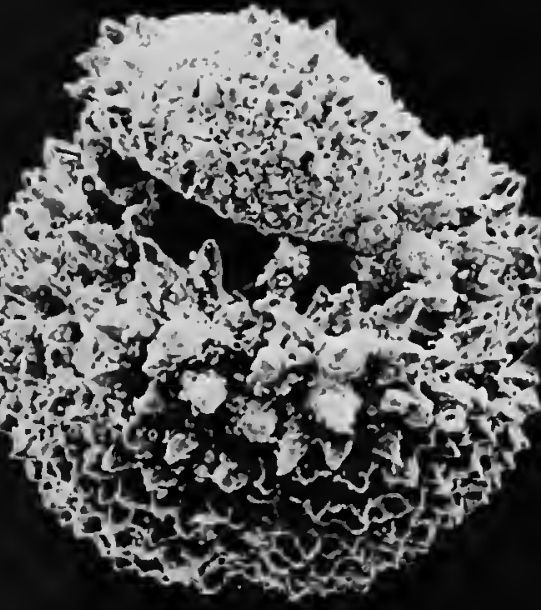

13

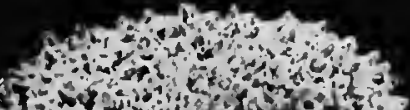

4)

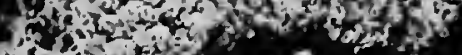

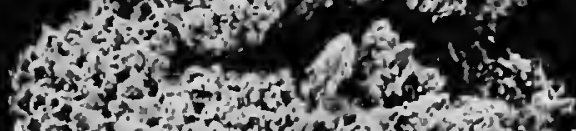

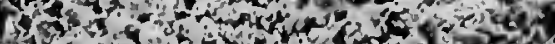

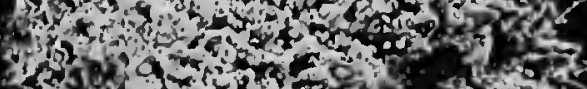

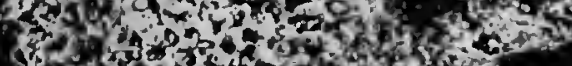

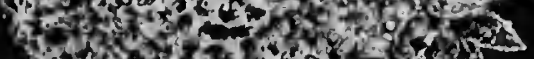

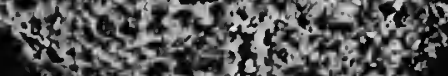

M.

14
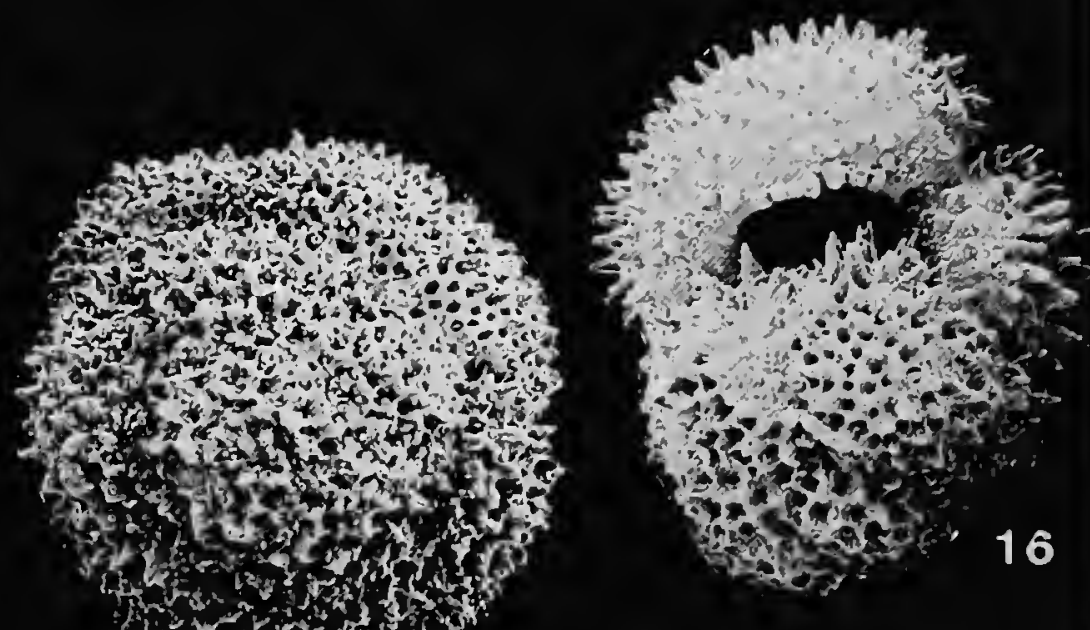


\section{PLATE 45}

Morozovella acuta (Toulmin, 1941)

$$
\text { (bars }=100 \mu \mathrm{m})
$$

FIGURES 1, 3, 5, 6, 9-11.-Zone P4, Velasco Fm., Tamaulipas, Mexico.

FIGURES 2, 12-14.-Zone P3, DSDP Site 465/5/4: 63-64 cm; Hess Rise, central North Pacific Ocean.

Figures 4, 7, 8. Zone P4, Vincentown Fm., Glendola Well, New Jersey, sample 230-232 feet. 

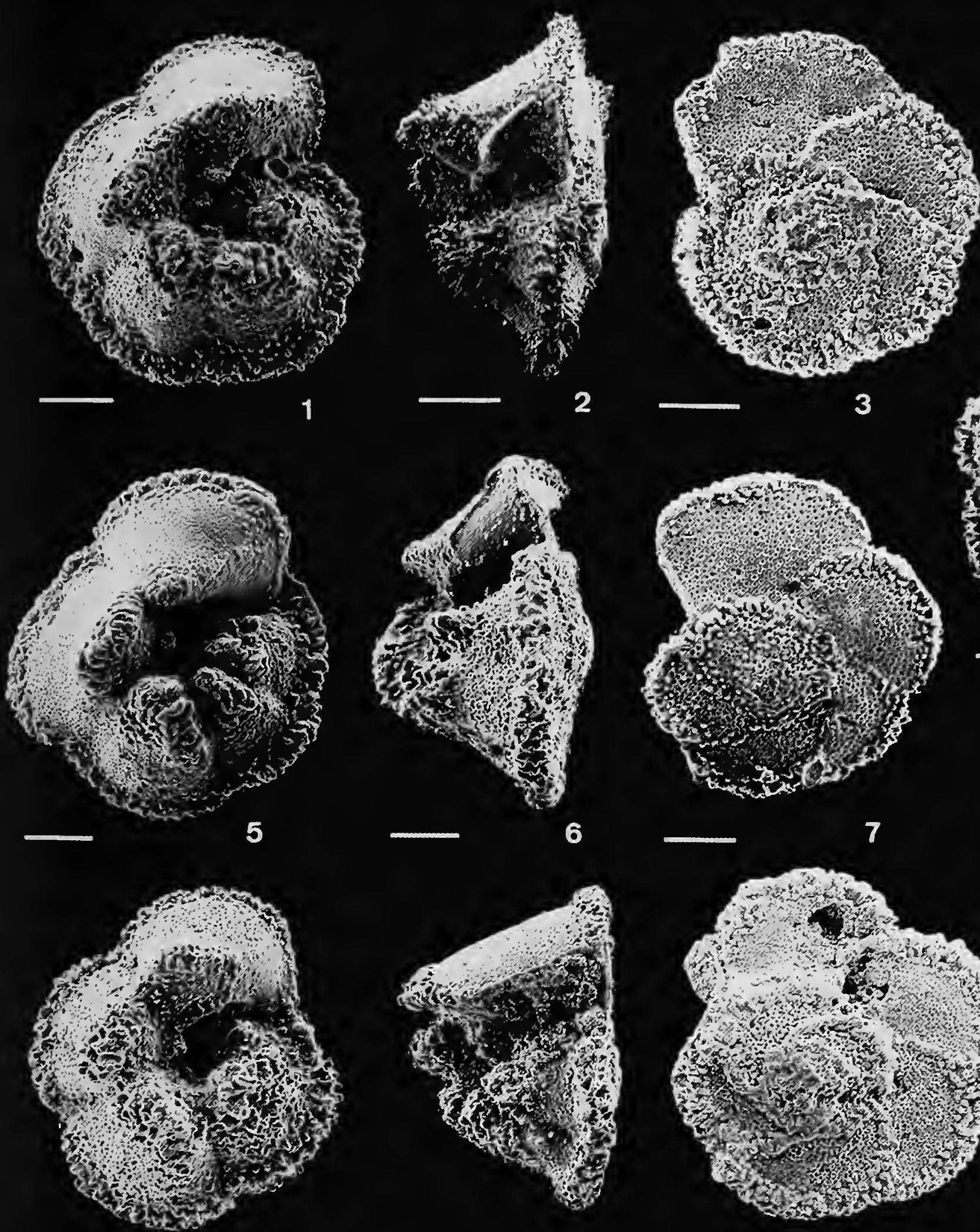

9

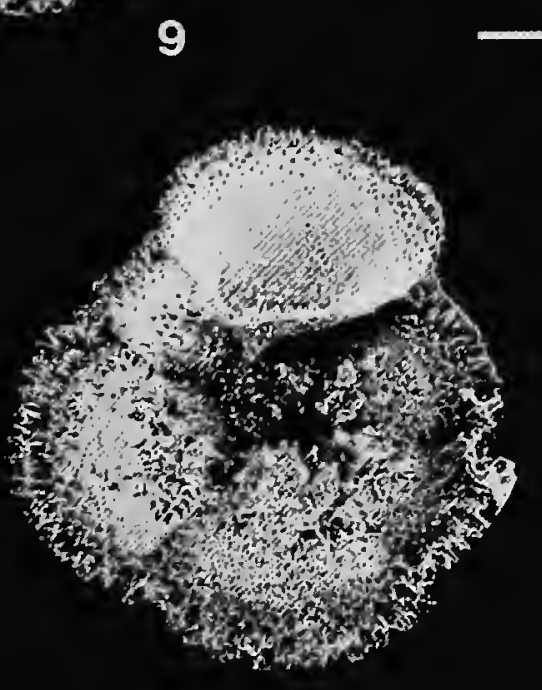

12
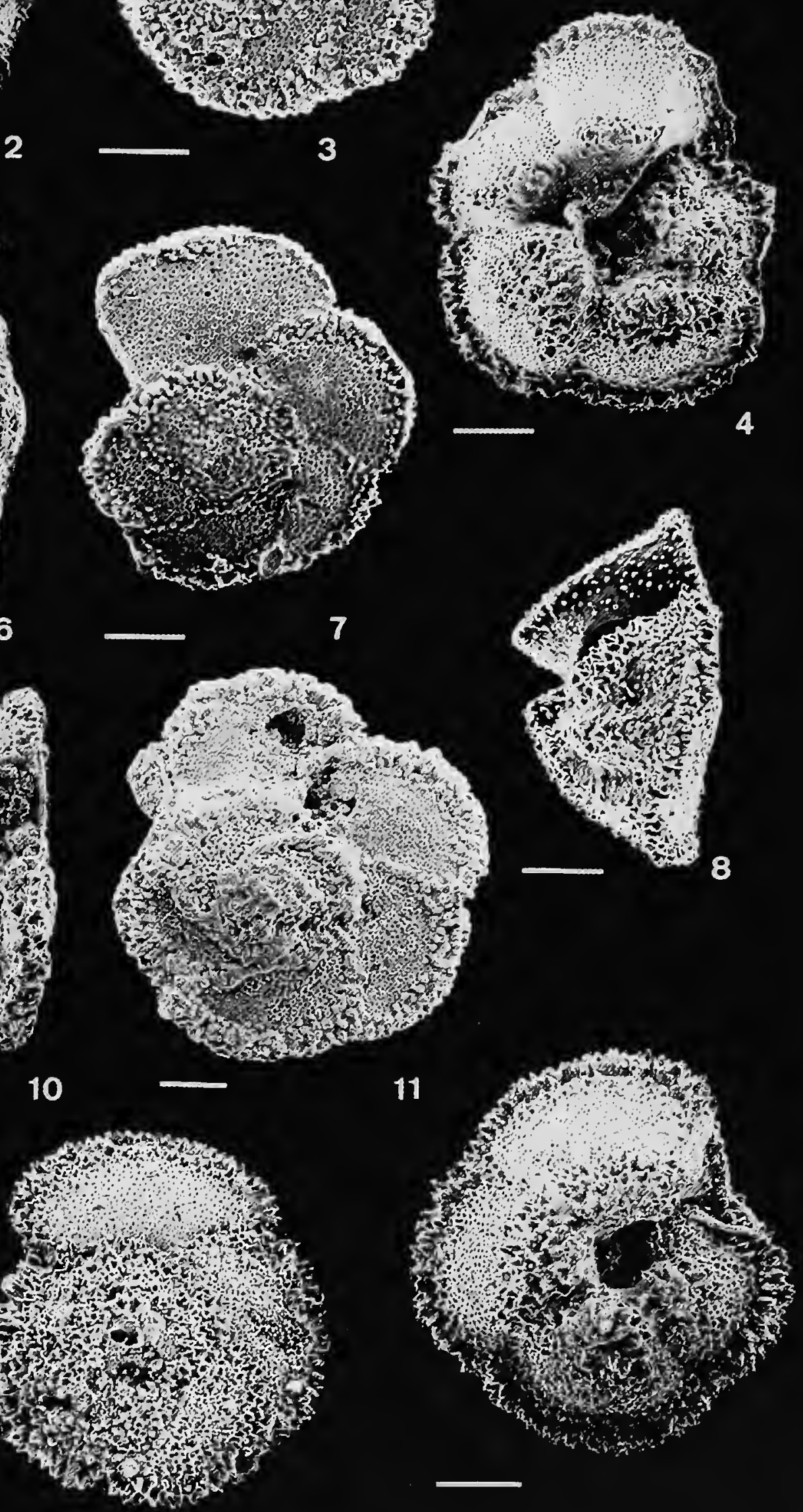

13 


\section{PLATE 46}

\section{Morozovella acutispira (Bolli and Cita, 1960)}

$$
\text { (bars }=100 \mu \mathrm{m})
$$

FIGURES 1-6.-Zone P3b, DSDP Site 527/28/6: 30-32 cm; Walvis Ridge, South Atlantic Ocean.

FIGURES 7, 12.-Zone P4, Vincentown Fm., Whitesville Well, New Jersey, sample 212-220 feet.

Figures 8, 9.-Zone P4?, ODP Hole 864C/13/2: 73-75 cm; East Pacific Rise, eastern central Pacific Ocean.

FIGURES 10, 11.-Zone P4, DSDP Site 465/3/4: 62-64 cm; Hess Rise, central North Pacific Ocean.

FIGURES 13-15.-Topotypes, Zone P4, Paderno d'Adda, northern Italy. 


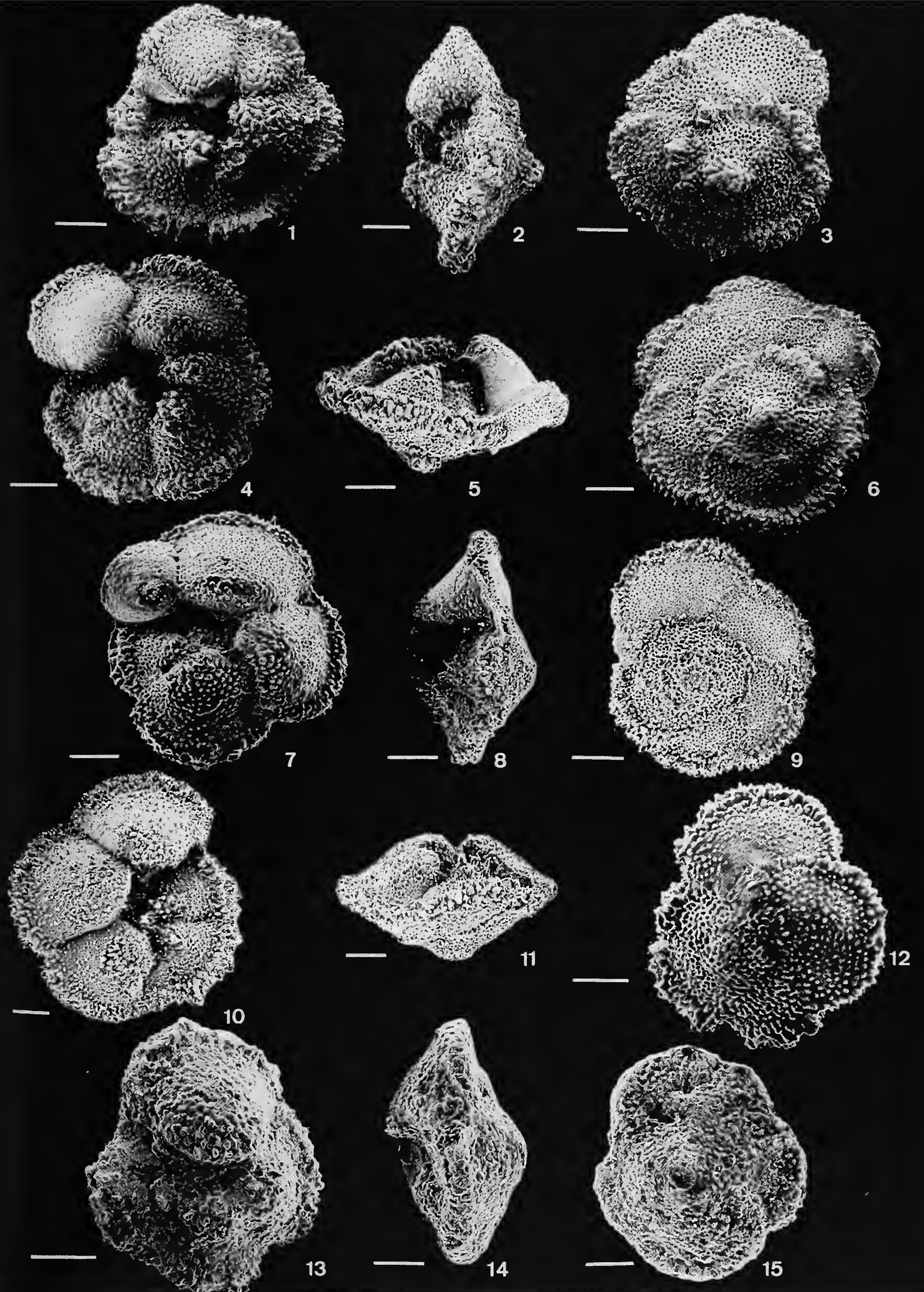




\section{PLATE 47}

Morozovella aequa (Cushman and Renz, 1942)

(Figures 1-3,7-10, 13-16: bars $=100 \mu \mathrm{m}$; Figures 4-6, 11, 12: bars $=200 \mu \mathrm{m}$ )

FIGURES 1-3.-Zone P5, ODP Hole 758A/28/5: 50-52 cm.

FIGURES 4, 6, 7.-Zone P5, ODP Hole 758A/28/1: 50-52 cm, Ninetyeast Ridge, Indian Ocean.

FIGURES 5, 11, 12.-Zone P5, DSDP Site 465/3/1: 59-61 cm.

FIGURES 8-10.-Zone P4, DSDP Site 465/3/3: 98-100 cm; Hess Rise, central North Pacific Ocean.

Figures 13, 14, 16.-Zone P4, Vincentown Fm., Glendola Well, New Jersey, sample 230-232 feet.

FIGURE 15.-Zone P4, Velasco Fm., Tamaulipas, Mexico. 

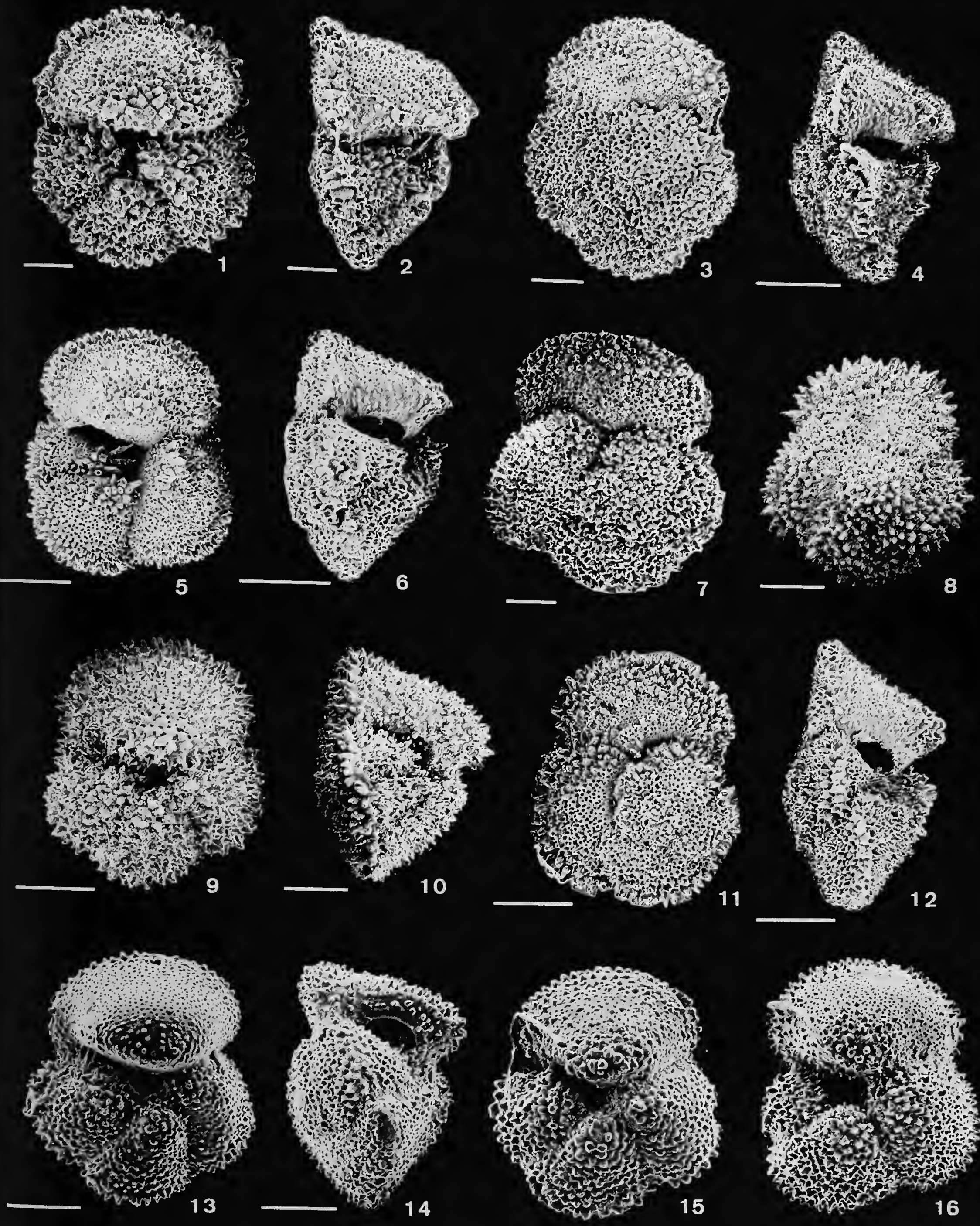


\section{PLATE 48}

\section{Morozovella angulata (White, 1928)}

(bars $=100 \mu \mathrm{m})$

FIgures 1-3, 11.-Zone P3, DSDP Site 356/21/4: 110-112 cm; São Paulo Plateau, South Atlantic Ocean; Figures 1-3, $M$. aff. $M$. angulata.

FIGURES 4, 5, 7.-Zone P3, DSDP Site 4.65/6/5: 66-68 cm; Hess Rise, central North Pacific Ocean.

FIGURE 6.-Zone P2, DSDP Site 384/11/1: $86-88 \mathrm{~cm}$.

FIGURES 8-10.-Zone P2, DSDP Site 527/30/1: 50-52 cm; Walvis Ridge, South Atlantic Ocean.

FIGURE 12.-Zone P2, DSDP Site 384/1 1/3: 30-32 cm.

FIGURES 13-16.-Zone P2, DSDP Site 384/10/CC; southeast Newfoundland Ridge, North Atlantic Ocean. 







\section{PLATE 49}

Morozovella apanthesma (Loeblich and Tappan, 1957)

$$
\text { (bars }=100 \mu \mathrm{m})
$$

FIGURES 1-6.-Zone P4, DSDP Site 465/4/1: 62-64 cm.

FIGURES 7-9.-Zone P3, DSDP Site 465/6/5: 66-68 cm.

FIGURES 10, 11.-Zone P3, DSDP Site 384/10/5: 24-26 cm; southeast Newfoundland Ridge, North Atlantic Ocean.

FIGURES 12-15.-Zone P3a, DSDP Site 465/7/CC; Hess Rise, central North Pacific Ocean. 

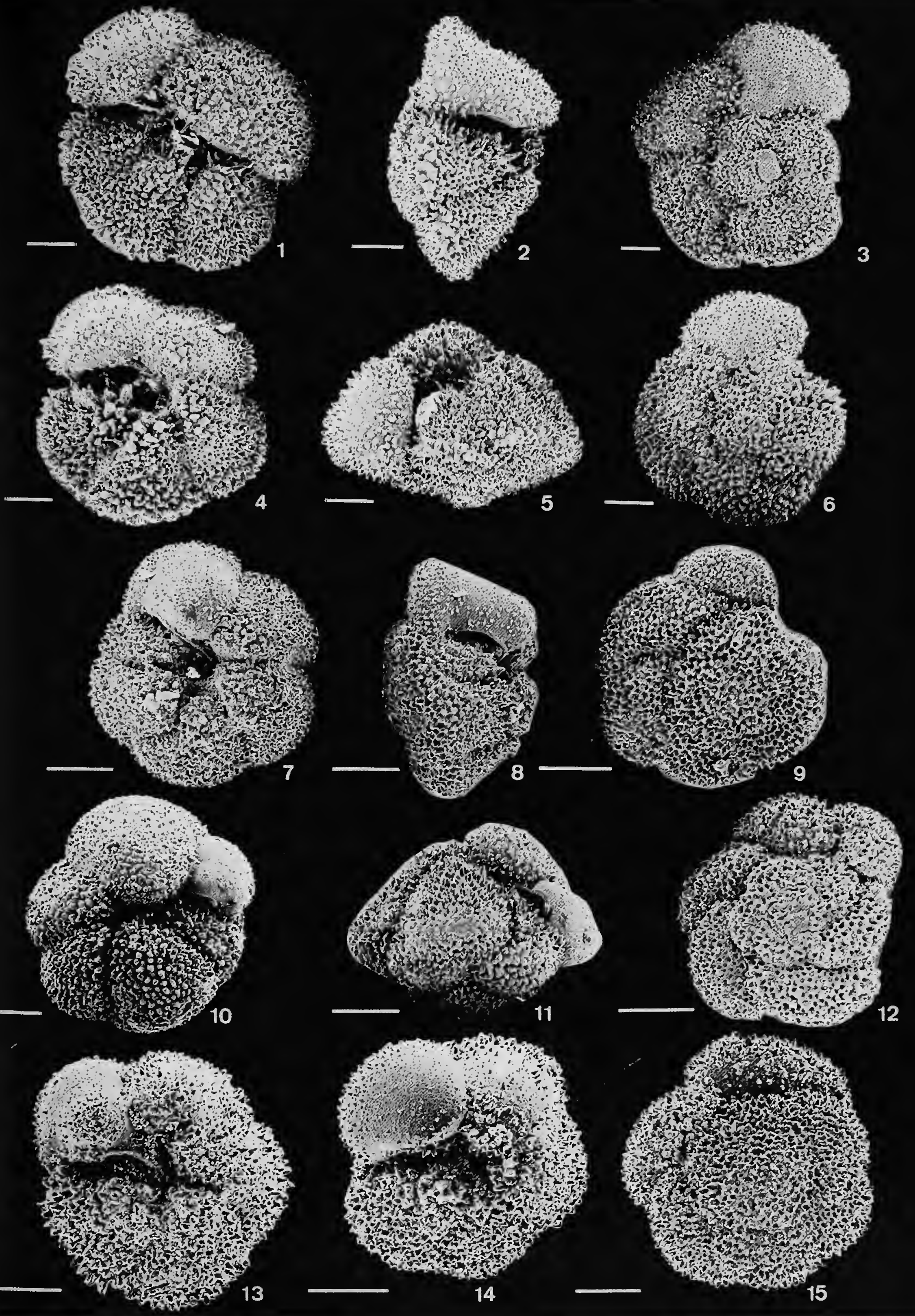

$$
14
$$




\section{PLATE 50}

\section{Morozovella conicotruncata (Subbotina, 1947)}

(Figures 1, 5, 9-15: bars $=100 \mu \mathrm{m}$; Figures 2-4, 6-8: bars $=200 \mu \mathrm{m}$ )

FIGURES 1-3.-Zone P3, DSDP Site 384/10/2: $136-138 \mathrm{~cm}$.

FIGURES 4-6,-Zone P3, DSDP Site 465/6/5: 66-68 cm.

FIGURES 7-9.--Zone P3b, ODP Hole 758A/31/1: 50-52 cm; Ninetyeast Ridge, Indian Ocean.

Figures 10-12.-Zone P3, DSDP Site 465/6/3: 61-63 cm; Hess Rise, central North Pacific Ocean.

FIGURES 13-15.--Zone P3, DSDP Site 384/10/3: 10-12 cm; southeast Newfoundland Ridge, North Atlantic Ocean. 

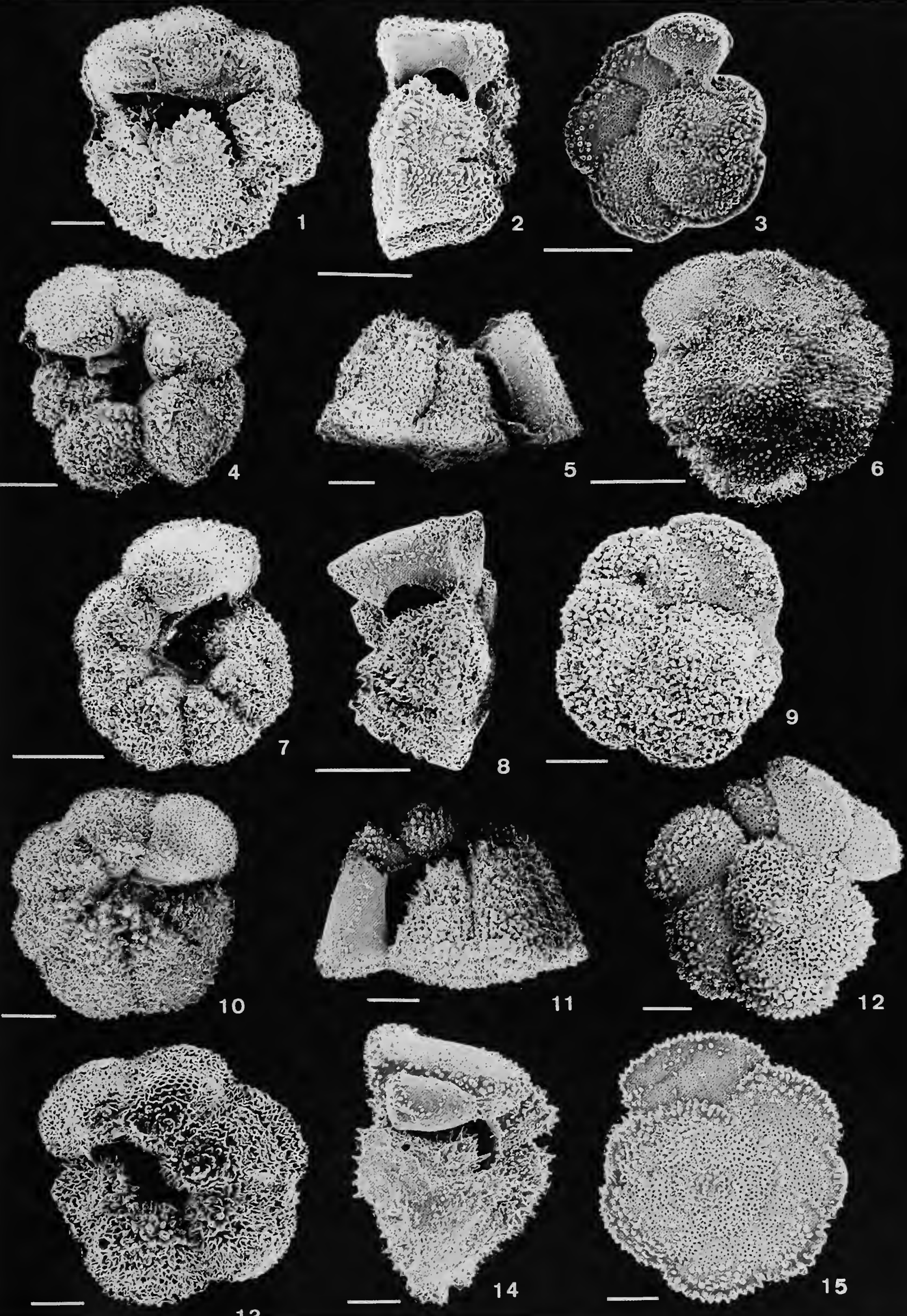


\section{PLATE 51}

Morozovella occlusa (Loeblich and Tappan, 1957)

$$
\text { (bars }=100 \mu \mathrm{m} \text { ) }
$$

FIGURES 1-3.-Zone P4, DSDP Site 465/4/1: 62-64 cm.

Figures 4, 8, 9.-Zone P4, Velasco Fm., Tamaulipas, Mexico.

FIgURES 5, 6.-Zone P4, DSDP Site 384/6/CC; southeast Newfoundland Ridge, North Atlantic Ocean.

FIGURE 7.-Zone P4, ODP Hole 758A/29/4: 50-52 cm; Ninetyeast Ridge, Indian Ocean.

FIGURES 10, 11.-Zone P4, DSDP Site 465/4/4: 62-64 cm.

Figures 12, 15.-Zone P4?, ODP Hole 864C/13/2: 73-75 cm; East Pacific Rise, eastern central Pacific Ocean.

FIGURES 13, 14.-Zone P4, DSDP Site 465/3/3: 98-100 cm; Hess Rise, central North Pacific Ocean. 

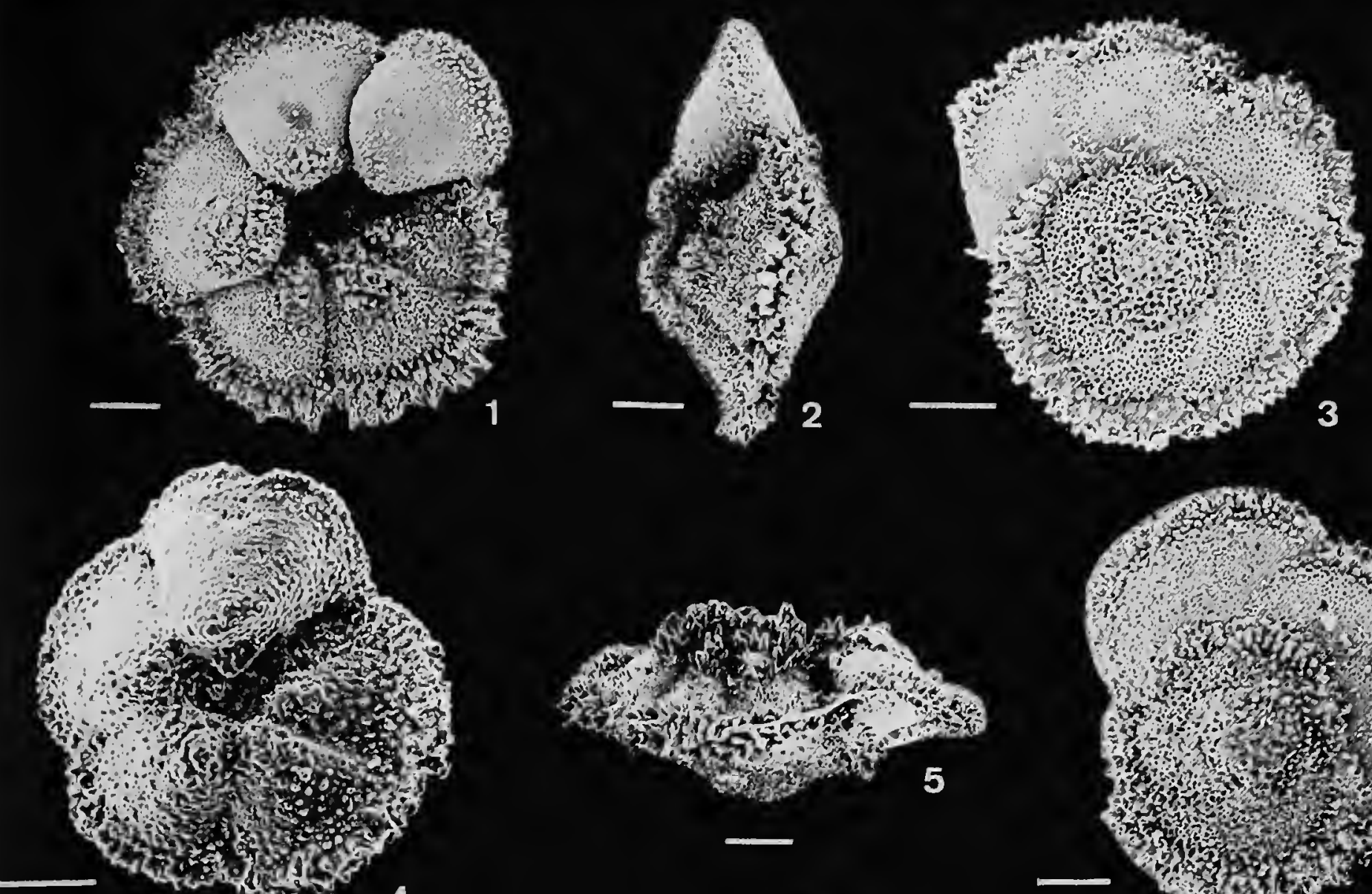

4
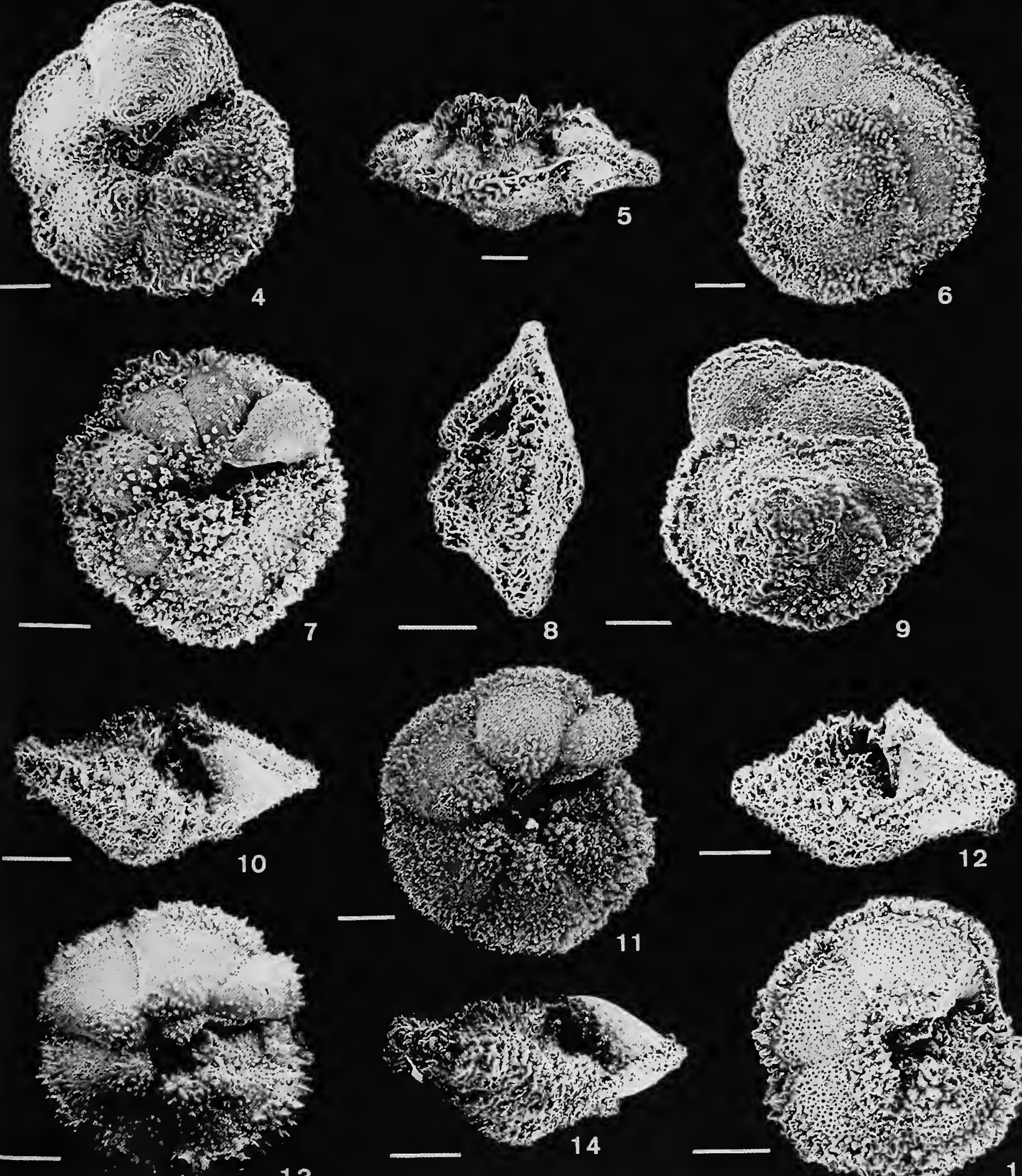

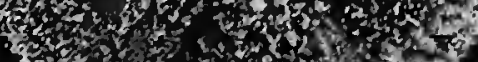
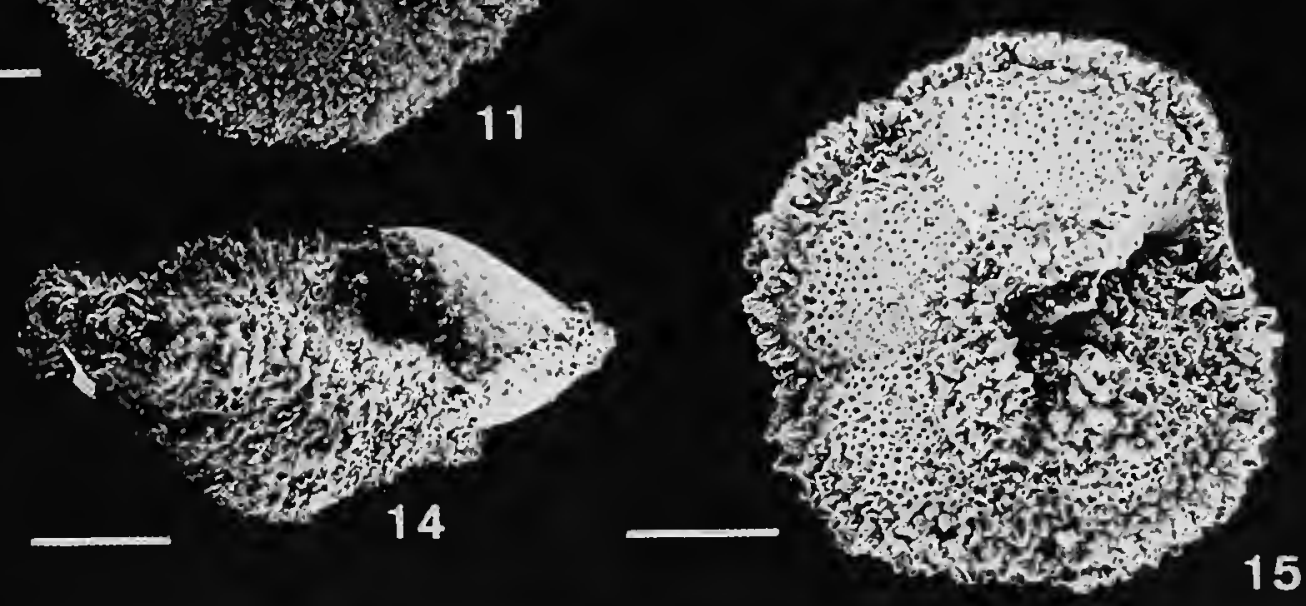


\section{PLATE 52}

\section{Morozovella pasionensis (Bermúdez, 1961)}

(Figures 4, 5, 7, 8, 12, 14: bars $=100 \mu \mathrm{m}$; Figures 1-3, 6, 9-11, 13, 15: bars $=200 \mu \mathrm{m}$ )

FIGURES 1-3, 10, 14.-Zone P3, DSDP Site 465/5/2: 62-64 cm.

FIGURES 4, 7, 13.-Zone P4, DSDP Site 465/3/3: 98-100 cm; Hess Rise, central North Pacific Ocean.

FIGURES 5, 8, 12.-Zone P4, ODP Site 865B/14/3: 138-140 cm; Allison Guyot, central equatorial Pacific Ocean.

FIGURE 6.-Zone P4, DSDP Site 384/7/1: $90-92 \mathrm{~cm}$.

FIGURE 9.-Zone P4, DSDP Site 384/6/CC.

FIGURE 11.-Zone P4, DSDP Site 384/7/2: $106-108 \mathrm{~cm}$.

FIGURE 15.-Zone P4, DSDP Site 384/6/3: 30-34 cm; southeast Newfoundland Ridge, North Atlantic Ocean. 

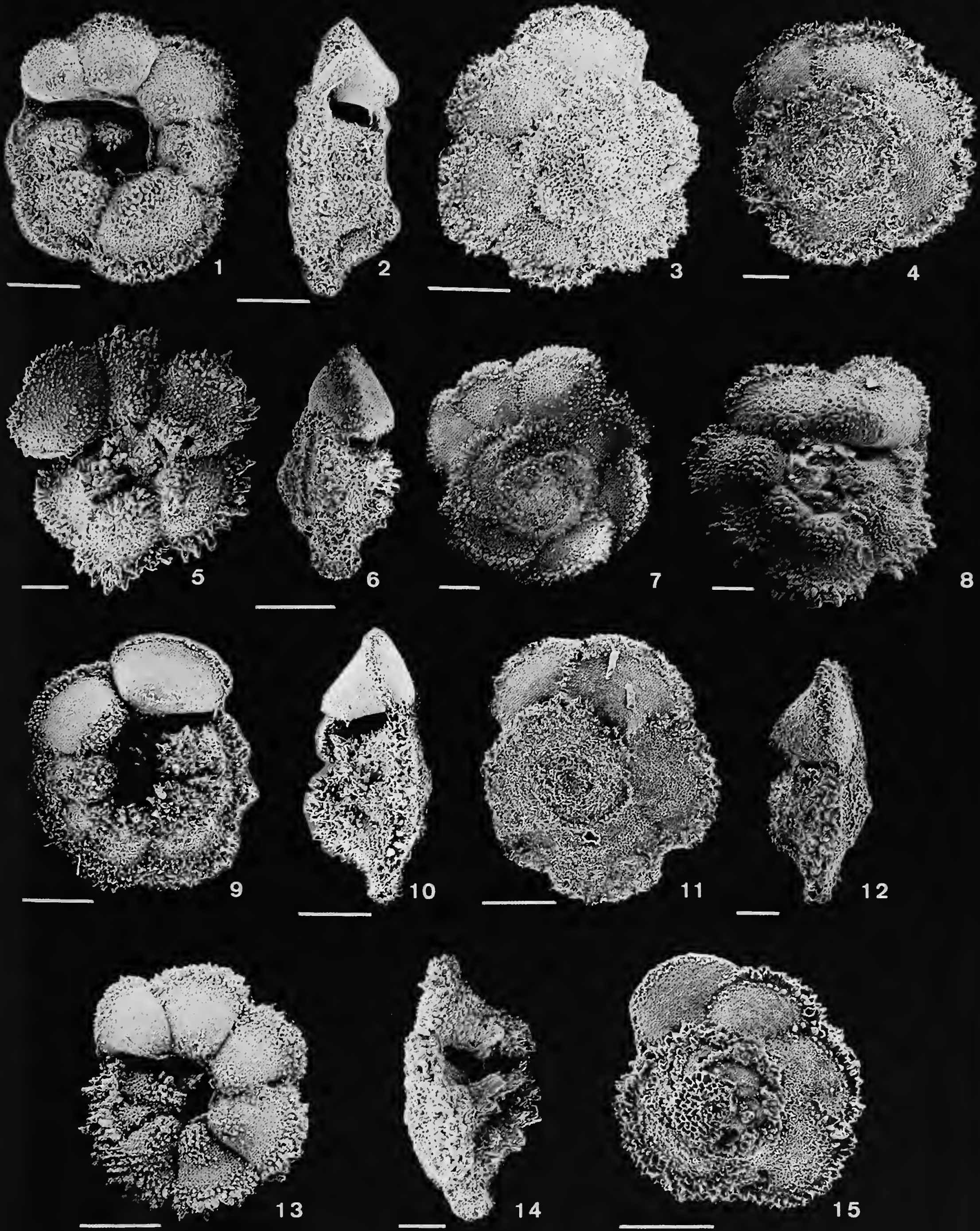


\section{PLATE 53}

\section{Morozovella praeangulata (Blow, 1979)}

$$
\text { (bars }=100 \mu \mathrm{m})
$$

Figures 1-3, 11-13.-Zone P3b, DSDP Site 356/24/2: 92-94 cm; São Paulo Plateau, South Atlantic Ocean.

FIGURES 4-6.-Zone P3, DSDP Site 384/10/5: 24-26 cm.

FIGURE 7.-Zone P3b, DSDP Site 465A/1/1: 52-54 cm; Hess Rise, central North Pacific Ocean.

FIGURE 8.-Zone P3, DSDP Site 384/10/CC.

Figures 9, 10.-Zone P2, DSDP Site 384/11/1: 86-90 cm; southeast Newfoundland Ridge, North Atlantic Ocean. 


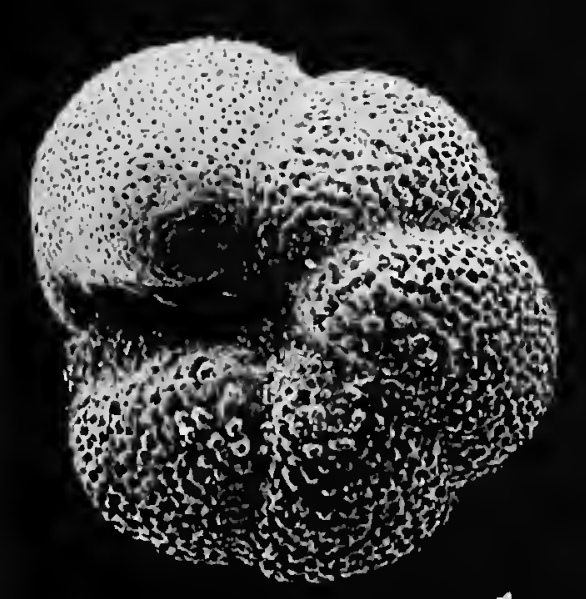

1

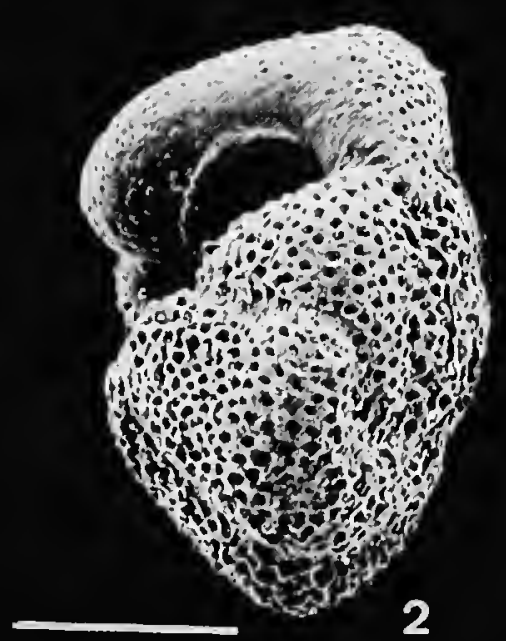

2
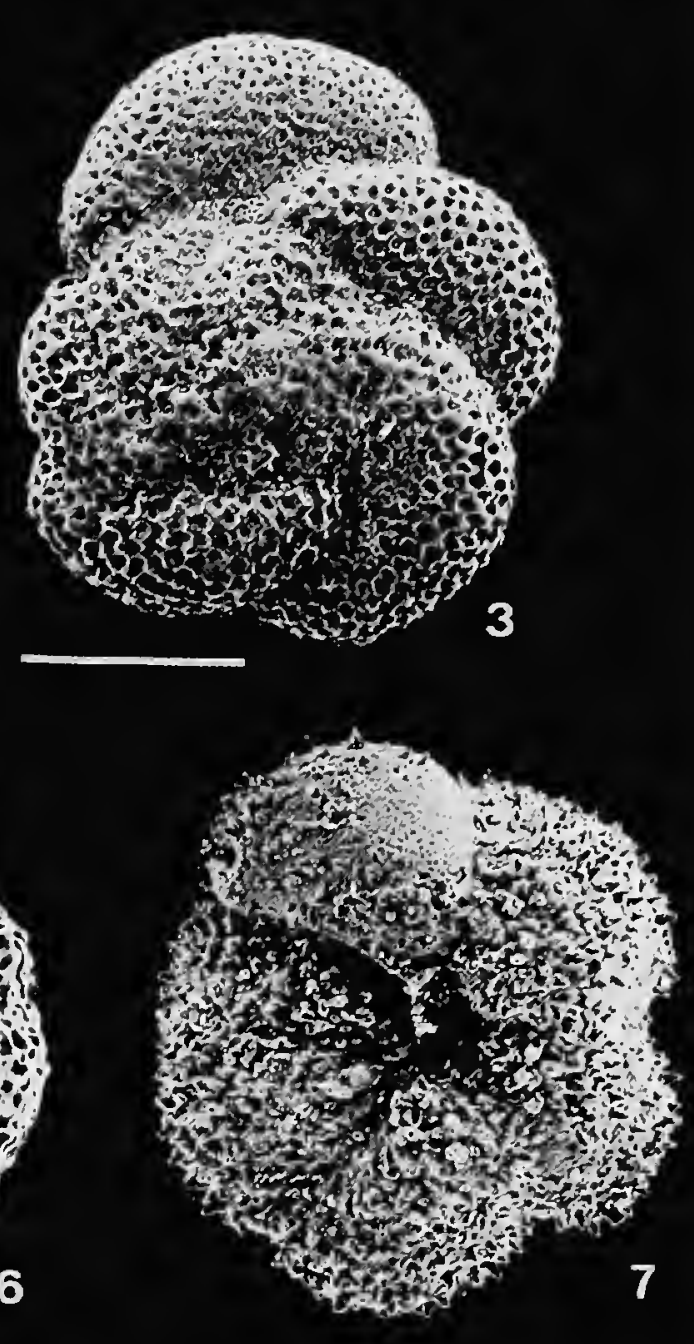
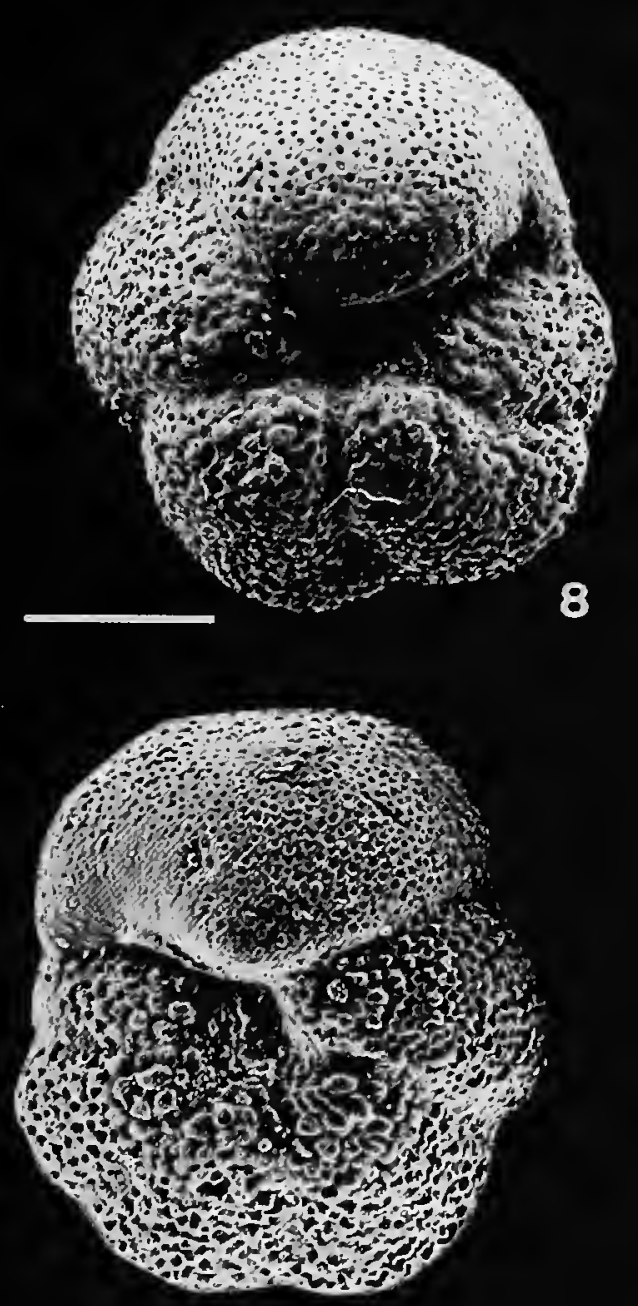

11

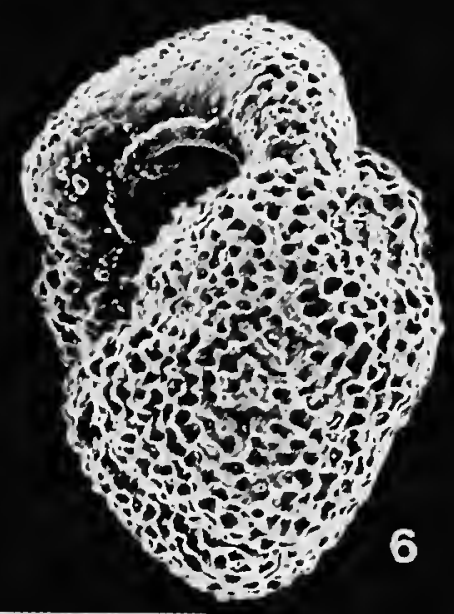

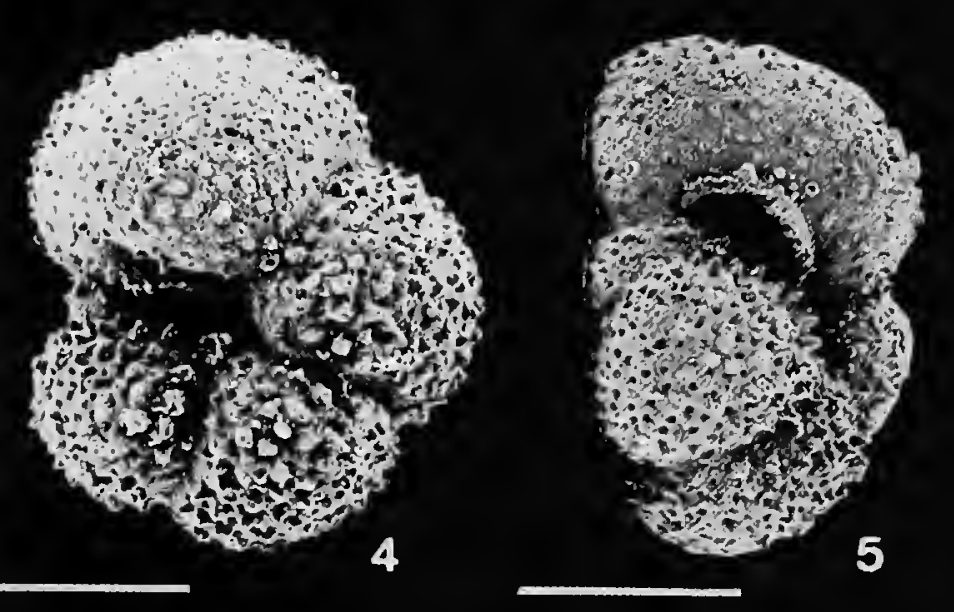


12 


\section{PLATE 54}

\section{Morozovella subbotinae (Morozova, 1939)}

(Figures 1-3: bars $=50 \mu \mathrm{m}$; Figures $4-12$ : bars $=100 \mu \mathrm{m}$ )

FIGURES 1-3.-Zone A P6a, ODP Hole 738C/10R: 277.78 mbsf; southern Kerguelen Plateau, southern Indian Ocean.

Figures 4, 5.-Zone P5, ODP Hole 758A/28/1: 50-52 cm; Ninetyeast Ridge, Indian Ocean.

FIGURES 6-9.-Zone P4-P5, DSDP Site 465/3/1: 59-61 cm; Hess Rise, central North Pacific Ocean.

FIGURES 10-12.-Zone P5, DSDP Site 213/16/1: 104-106 cm; eastern Indian Ocean.

Morozovella gracilis (Bolli, 1957)

(bars $=100 \mu \mathrm{m})$

FIGURES 13-15.-Zone P5, DSDP Site 213/16/1: 104-106 cm; eastern Indian Ocean. 


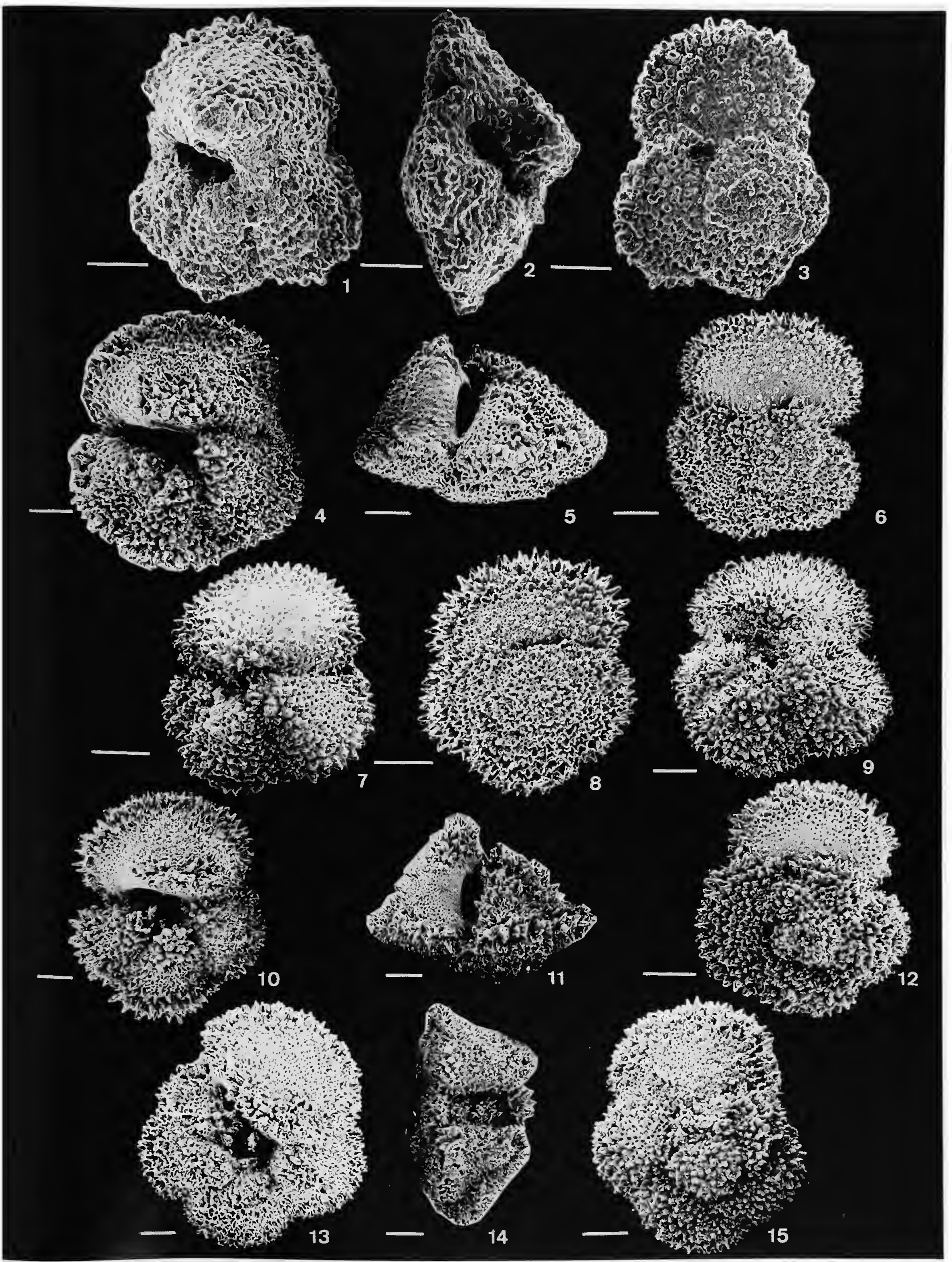




\section{PLATE 55}

Morozovella velascoensis (Cushman, 1925)

(Figures 2, 3, 7, 12: bars $=100 \mu \mathrm{m}$; Figures $1,4-6,8-11,13-15$ : bars $=200 \mu \mathrm{m}$ )

FIGURES 1-3.-Zone P5, DSDP Site 213/16/1: 104-106 cm; eastern Indian Ocean.

FIGURES 4-6.-Zone P4, DSDP Site 465/3/1: 59-61 cm.

FIGURES 7-9.-Zone P4, ODP Hole 758A/28/1: 50-52 cm.

Figures 10, 12.-Zone P4, DSDP Site 465/3/4: 62-64 cm; Hess Rise, central Pacific Ocean.

FIGURE 11.-Zone P5, ODP Hole 758A/28/1: 50-52 cm; Ninetyeast Ridge, Indian Ocean.

FIGURES 13-15.-Zone P4, DSDP Site 384/9/CC; southeast Newfoundland Ridge, North Atlantic Ocean. 

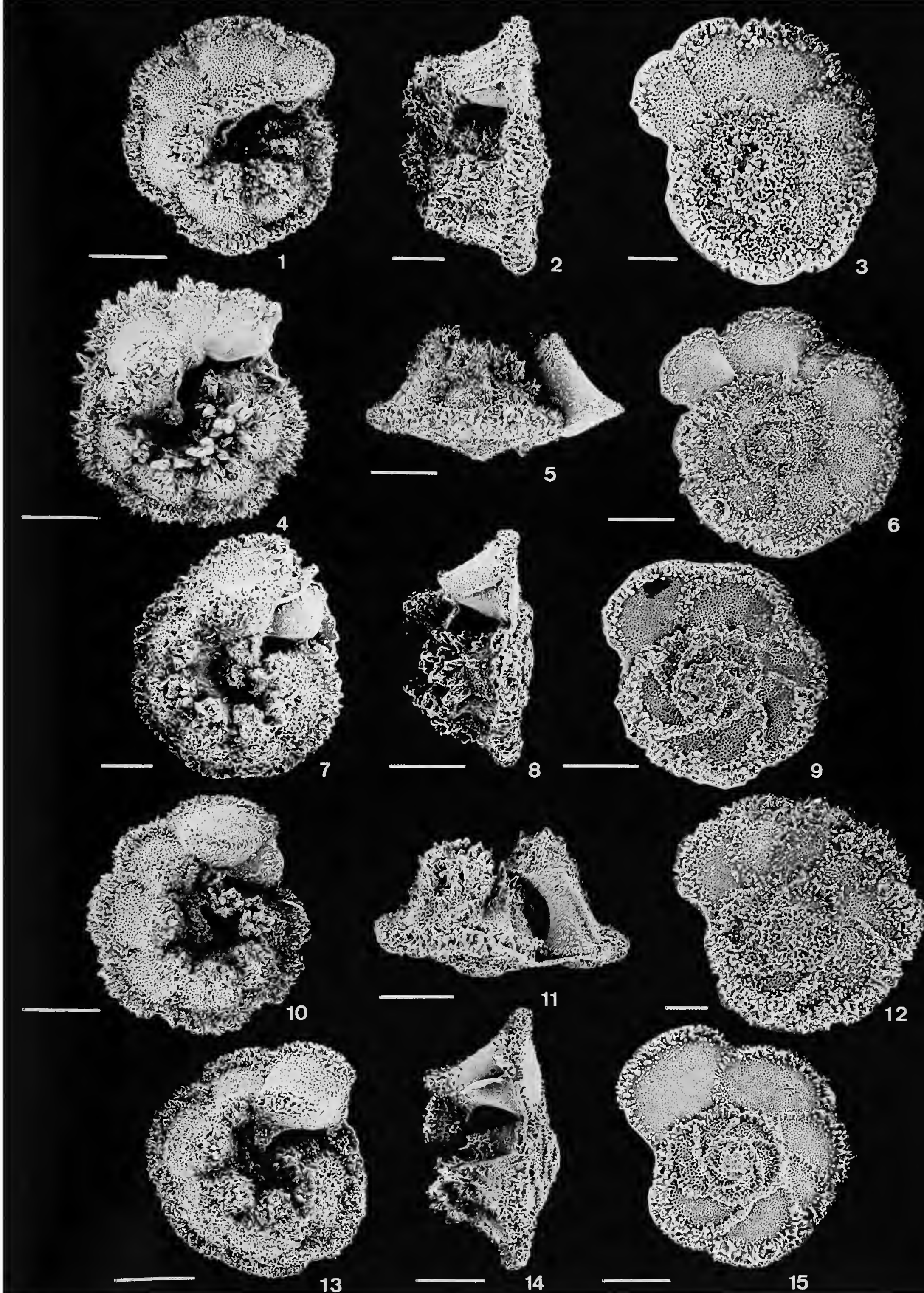


\section{PLATE 56}

\section{Igorina albeari (Cushman and Bermúdez, 1949)}

(Figures 1-12, 16: bars $=100 \mu \mathrm{m}$; Figures 13, 15: bars $=40 \mu \mathrm{m}$; Figure 14: bar $=10 \mu \mathrm{m}$ )

FIGURES 1-3, 9.-Zone P4, DSDP Site 465/3/3: 98-100 cm; Hess Rise, central North Pacific Ocean.

Figures 4, 8, 12.-Zone P4, DSDP Site 384/8/1: 126-128 cm; southeast Newfoundland Ridge, North Atlantic Ocean.

Figures 5-7, 10, 11.-Zone P4, ODP Hole 758A/29/4: 50-52 cm; Ninetyeast Ridge, Indian Ocean.

FIGURES 13, 16.-Zone P4, DSDP Site 356/24/2: 92-94 cm.

Figures 14, 15.-Zone P4, DSDP Site 356/24/1: 110-112 cm; São Paulo Plateau, South Atlantic Ocean. 




\section{PLATE 57}

\section{Igorina pusilla (Bolli, 1957)}

(Figures 1, 2, 5, 9-11, 13-16: bars $=100 \mu \mathrm{m}$; Figures 3, 4, 6-8, 12: bars $=40 \mu \mathrm{m}$ )

FigurEs 1, 2.--Zone P4, DSDP Site 384/7/3: 130-132 cm; southeast Newfoundland Ridge, North Atlantic Ocean.

FIGURES 3, 4.-Zone P3b, DSDP Site 3/21/CC; Gulf of Mexico.

FIGURE 5.-Zone P3, ODP Hole 761B/18X/2: $52-54 \mathrm{~cm}$.

Figures 6-8, 12.-Zone P4, Vincentown Fm., Glendola Well, New Jersey, sample 286 feet.

FigurEs 9, 10.-Zone P3, DSDP Site 465/6/5: 66-68 cm.

FIGURE 11.-Zone P3, DSDP Site 465/5/4: 63-64 cm; Hess Rise, central Pacific Ocean.

Figures 13-16.-Zone P4, ODP Hole 761B/18X/1: 52-54 cm; Wombat Plateau, Indian Ocean. 


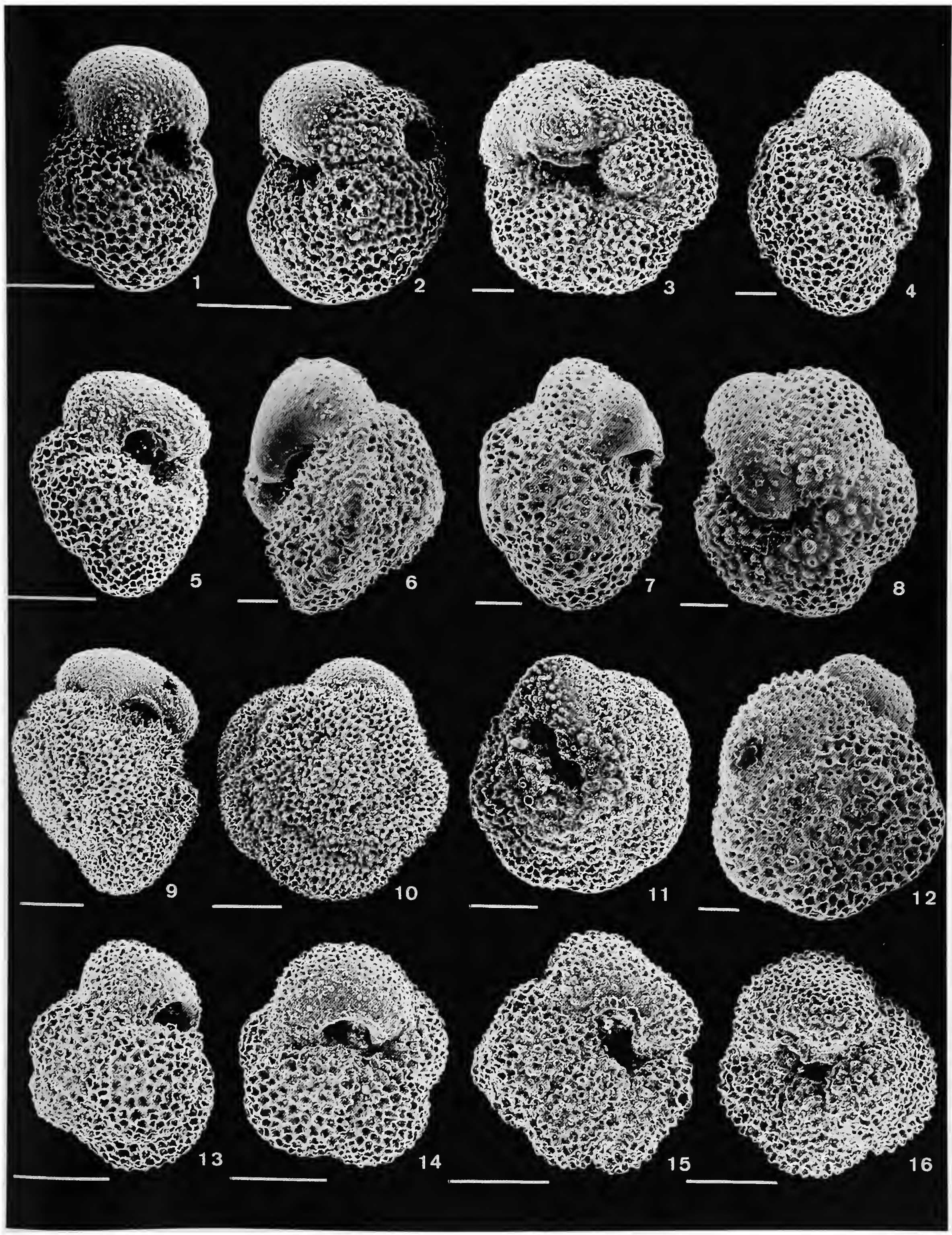




\section{PLATE 58}

\section{Igorina tadjikistanensis (Bykova, 1953)}

(Figure 1: bar $=40 \mu \mathrm{m}$; Figures 2-12: bars $=100 \mu \mathrm{m}$ )

Figures 1, 2, 4, 6, 8, 10, 12.-Zone P4, Velasco Fm., Tamaulipas, Mexico.

Figures 3, 5, 7, 9, 11.-Zone P4, Vincentown Fm., Glendola Well, New Jersey, sample 230-232 feet. 

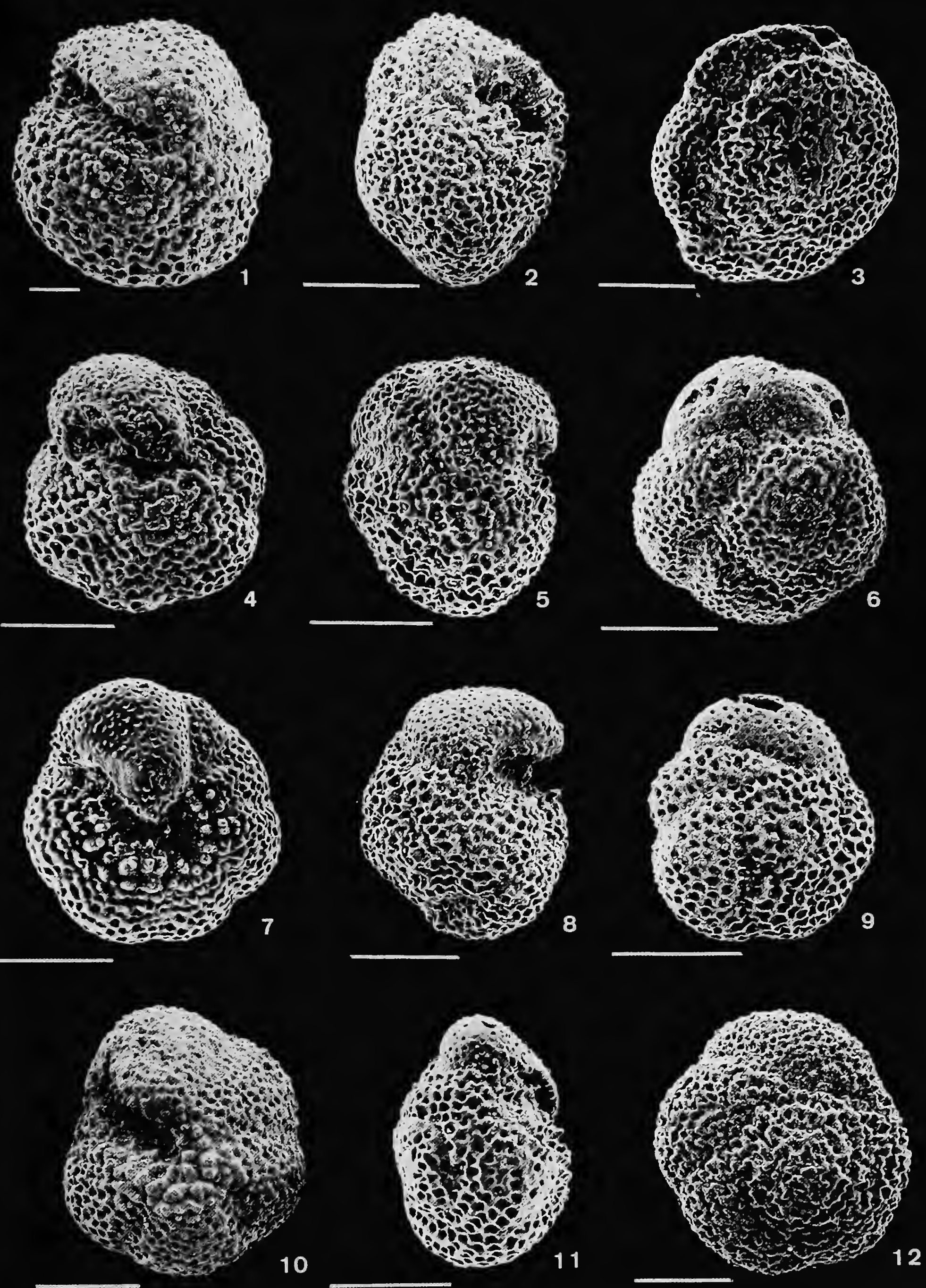


\section{PLATE 59}

Praemurica inconstans (Subbotina, 1953)

$$
(\text { bars }=100 \mu \mathrm{m})
$$

FIgures 1-3, 13, 15. - Zone P3, DSDP Site 465/7/CC; Hess Rise, central Pacific Ocean.

FIgURES 4-7, 12, 16.-Zone P1c, DSDP Site 356/26/4: 117-118 cm; São Paulo Plateau, South Atlantic Ocean. FiguRES 8-11.-Zone P1c, DSDP Site 527/30/4: 30-32 cm; Walvis Ridge, South Atlantic Ocean.

FIGURE 14.-Zone P2, DSDP Site 384/1 1/3: 30-32 cm; southeast Newfoundland Ridge, North Atlantic Ocean. 

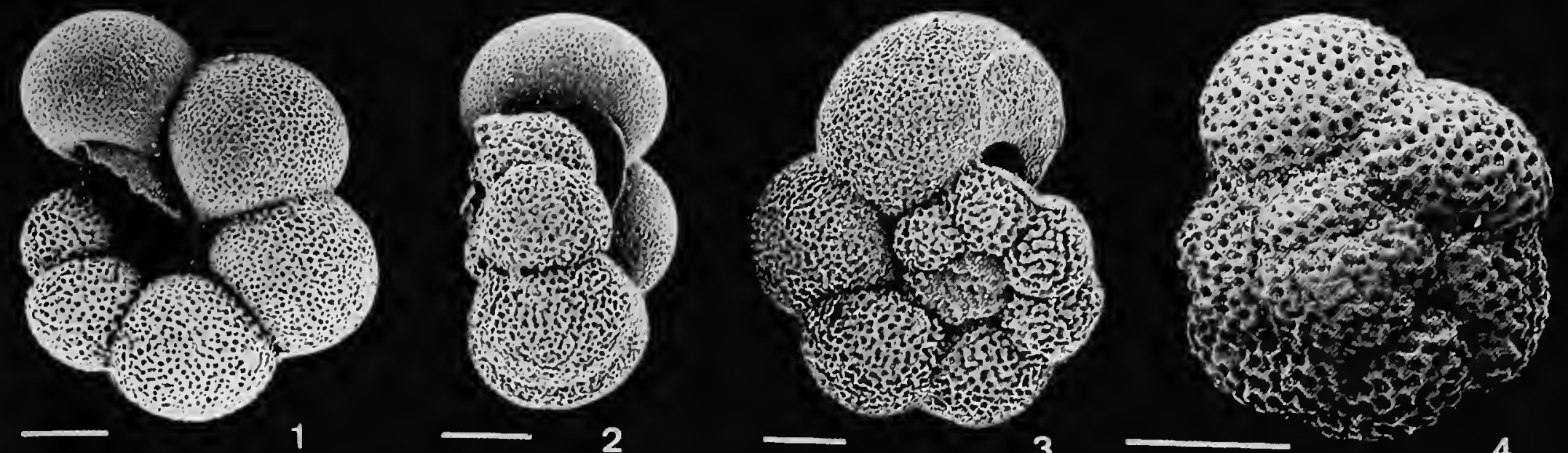

3

4
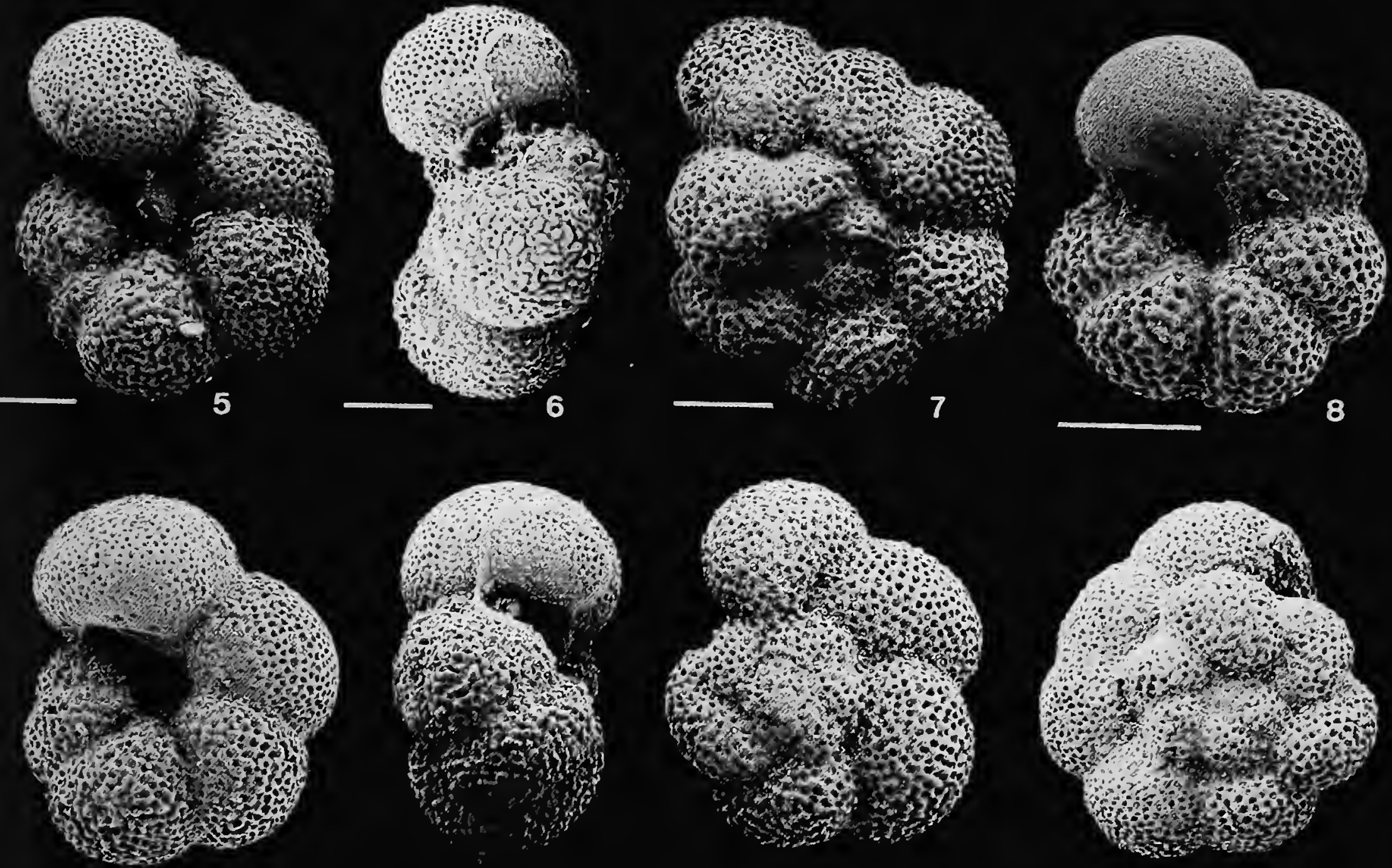

10

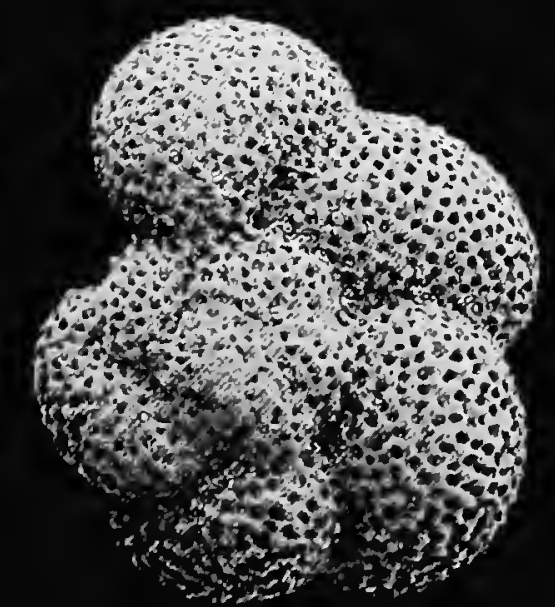

11

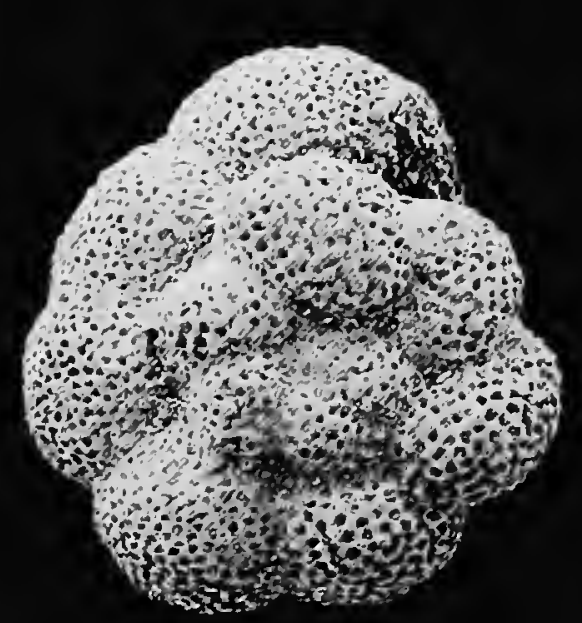

12

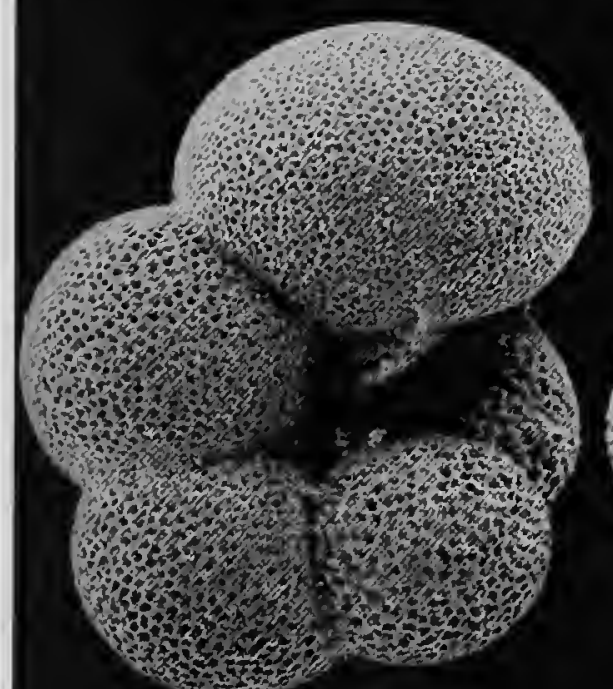

13

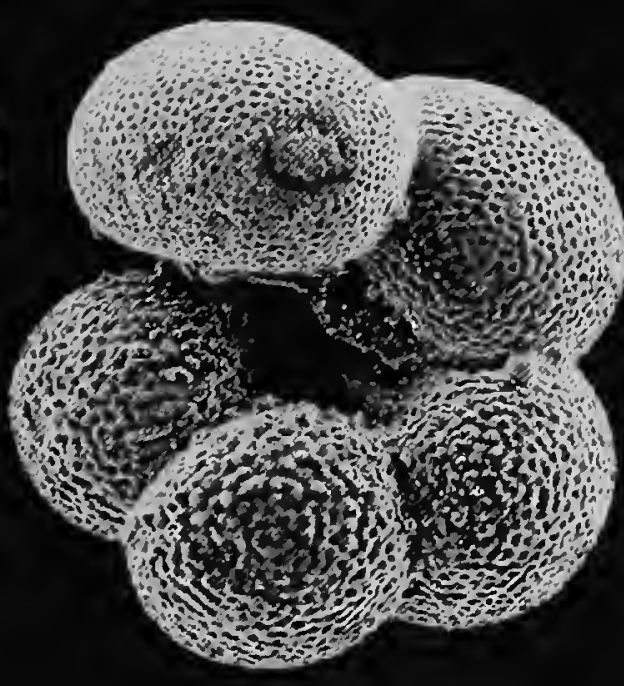

14
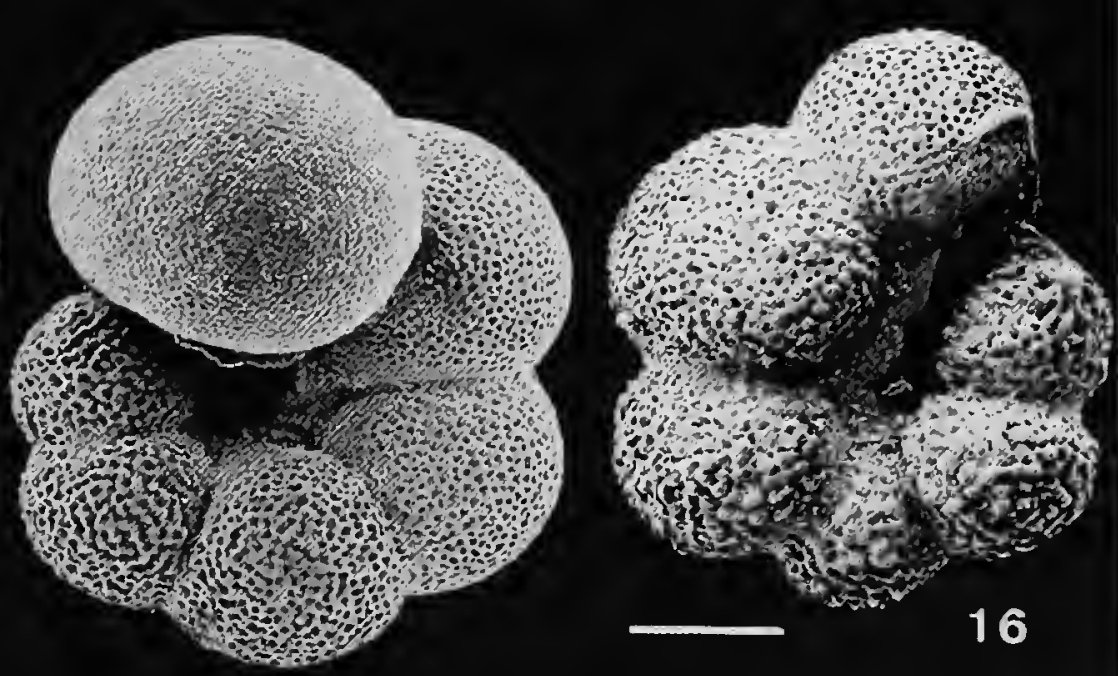

16 


\section{PLATE 60}

\section{Praemurica pseudoinconstans (Blow, 1979)}

(Figures 1-11: bars $=50 \mu \mathrm{m}$; Figures 12, 13: bars $=10 \mu \mathrm{m}$ )

Figures 1, 3, 6.-Zone P $\alpha$, Millers Ferry, Alabama, core 226, sample 85.

Figures 2, 10-13.-Zone Pla, Millers Ferry, Alabama, core 225, sample 194; Figure 12 (view of 2nd chamber of Figure 11) and Figure 13 (view of 4th chamber of Figure 10) showing cancellate nonspinose wall texture.

FIGURE 4.-Zone Pla, DSDP Site 384/13/2: 140-142 cm; southeast Newfoundland Ridge, North Atlantic Ocean.

Figure 5.-Zone P2, DSDP Site 356/25/5: 148-150 cm; São Paulo Plateau, South Atlantic Ocean.

FIGURES 7, 9.-Zone P la, Millers Ferry, Alabama, core 225, sample 216.

FIGURE 8.-Zone Pla, DSDP Hole 465A/3/3: 120-122 cm; Hess Rise, central Pacific Ocean. 


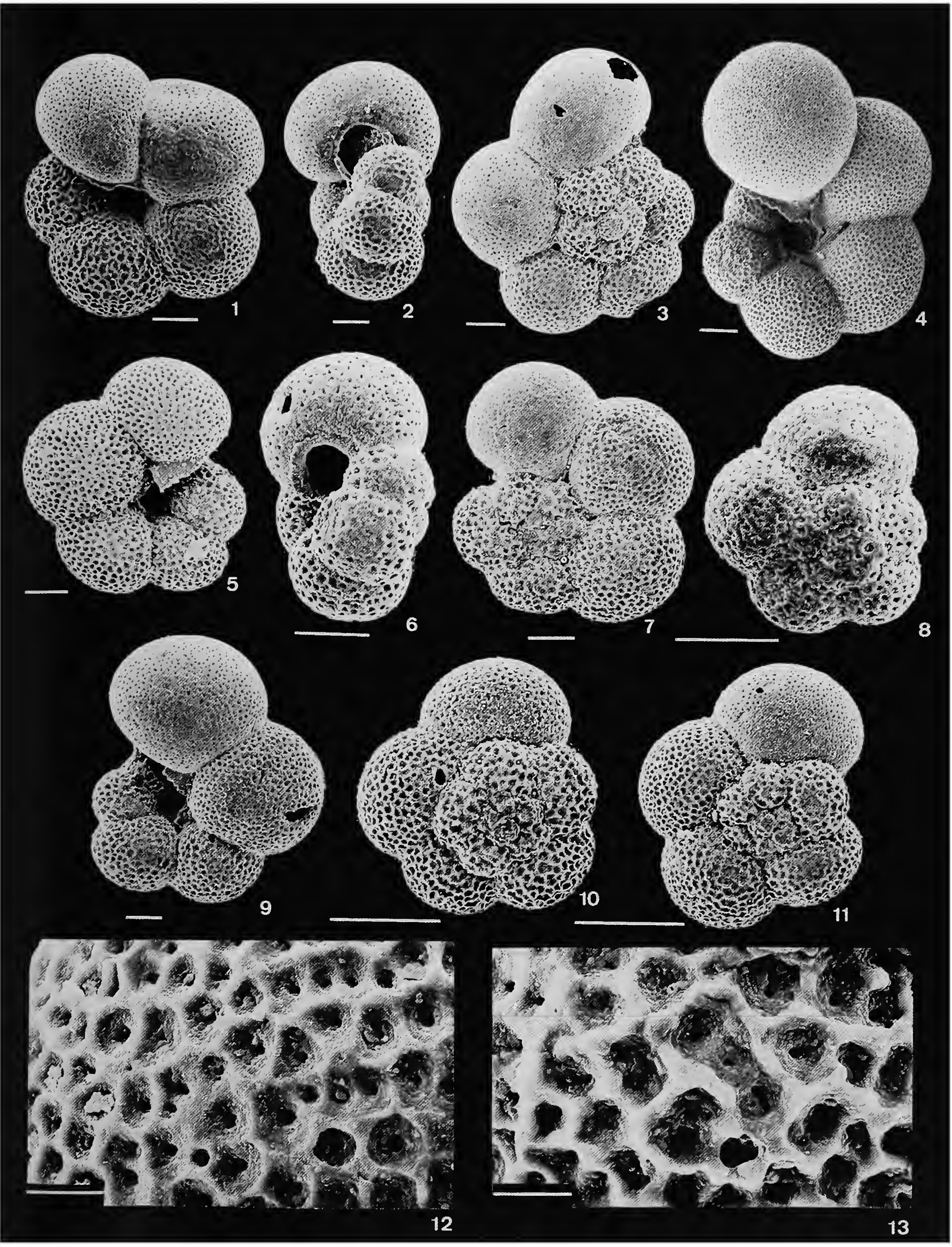




\section{PLATE 61}

\section{Praemurica taurica (Morozova, 1961)}

(Figures 2, 4, 7, 9, 11, 12: bars $=100 \mu \mathrm{m}$; Figures 1, 3, 5, 6, 8, 10, 15: bars $=40 \mu \mathrm{m}$; Figures 13, 14: bars $=10 \mu \mathrm{m}$ )

FIGURES 1, 3.-Zone P1a, Millers Ferry, Alabama, core 225, sample 216.

FIGURES 2, 4.-Zone Pla, Millers Ferry, Alabama, core 225, sample 194.

FIGURE 5.-Zone P $\alpha$, Millers Ferry, Alabama, core 226, sample 5.

FIGURE 6.-Zone Pla, ODP Hole 750A/15/2: 8-12 cm; southern Kerguelen Plateau, southern Indian Ocean.

FIgUREs 7, 9, 13, 14.-Zone P1a, Millers Ferry, Alabama, sample 30 feet above Prairie Bluff; Figures 13, 14, views of wall of Figure 9 showing cancellate nonspinose wall texture.

FIGURE 8.-Zone P $\alpha$, Millers Ferry, Alabama, core 225, sample 334.

FIGURE 10.-Zone P $\alpha$, Millers Ferry, Alabama, core 226, sample 15.

FIgURES 11, 12, 15.-Zone P1c, DSDP Site 356/26/CC; São Paulo Plateau, South Atlantic Ocean. 

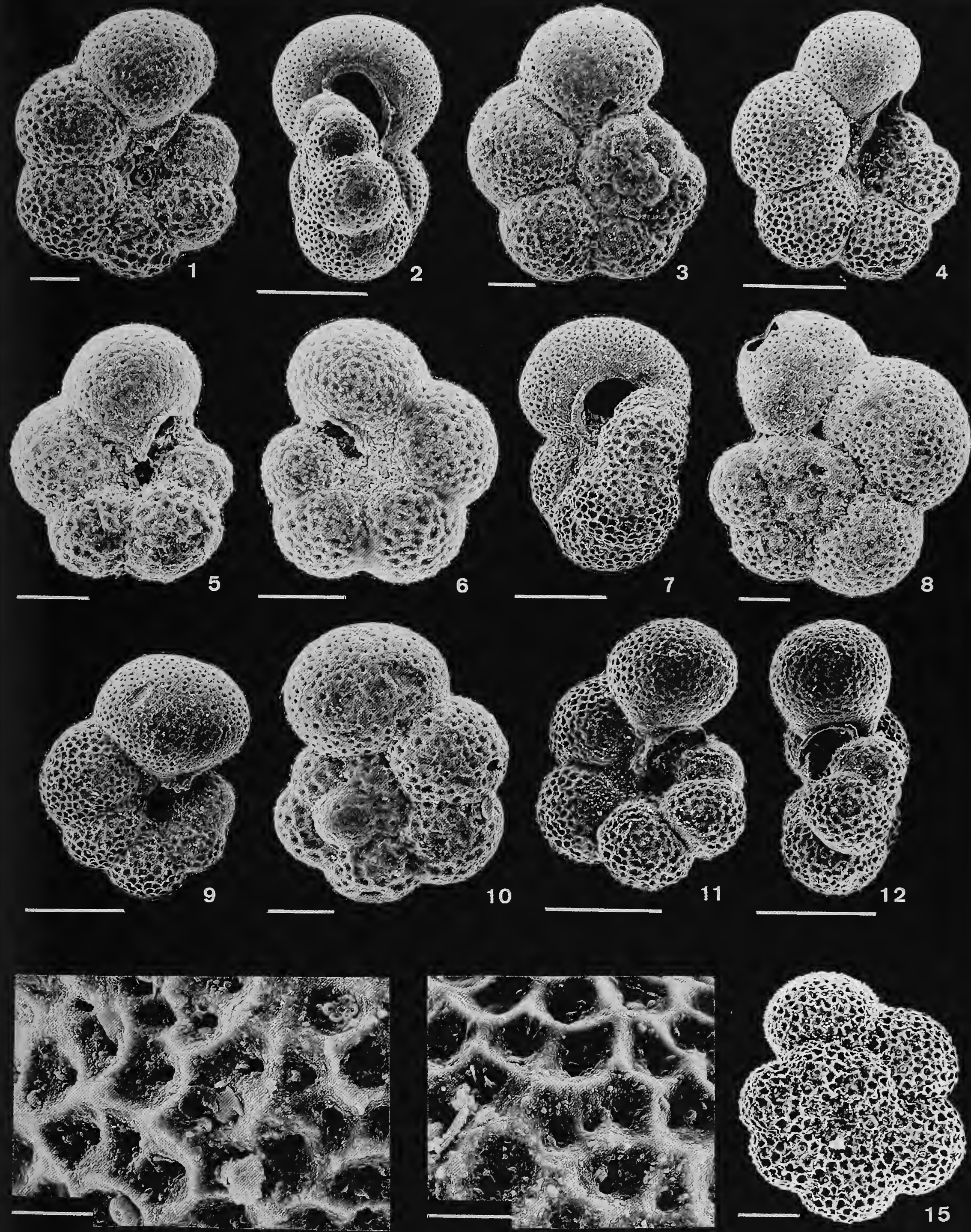


\section{PLATE 62}

\section{Praemurica uncinata (Bolli, 1957)}

(bars $=100 \mu \mathrm{m})$

Figures 1-3, 5-7, 16.-Zone P3, DSDP Site 465/7/CC; Hess Rise, central Pacific Ocean.

FIgURES 4, 8, 9, 12-15.-Zone P2, DSDP Site 384/11/3: 30-32 cm.

FIGURES 10, 11.-Zone P2, DSDP Site 384/11/3: 136-138 cm; southeast Newfoundland Ridge, North Atlantic Ocean. 

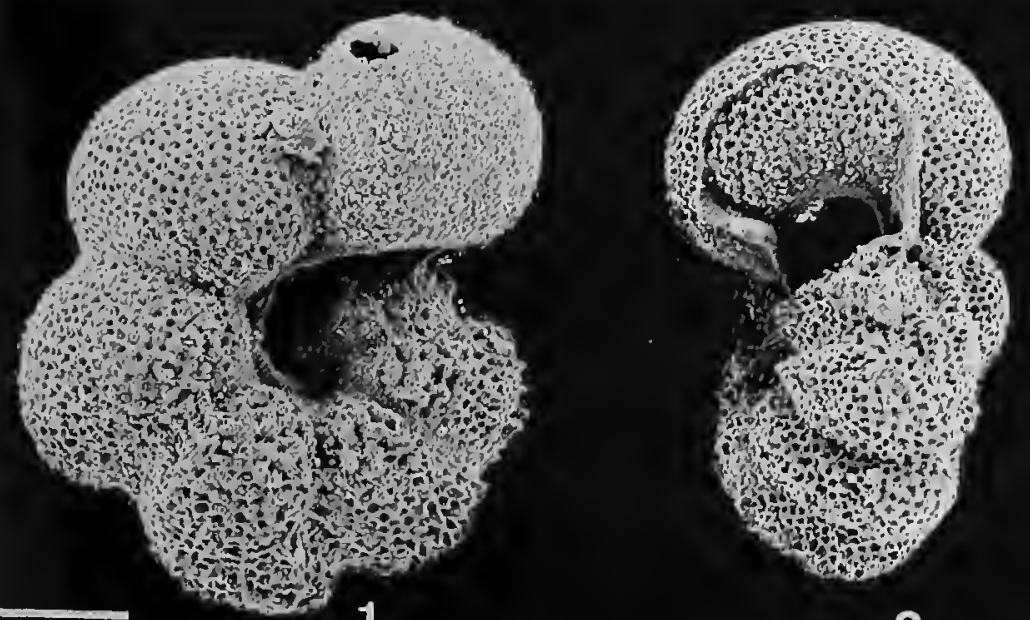

2
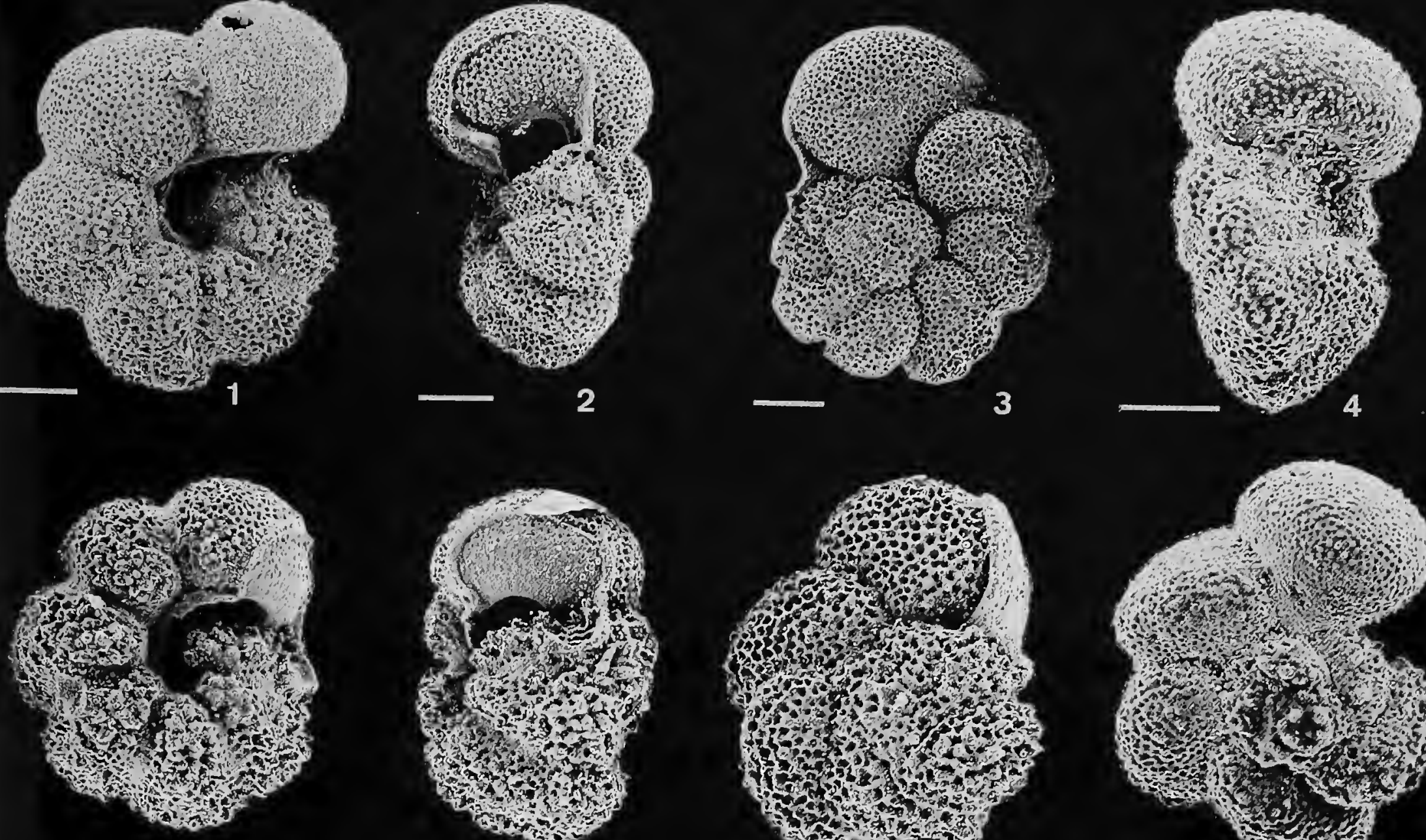

5
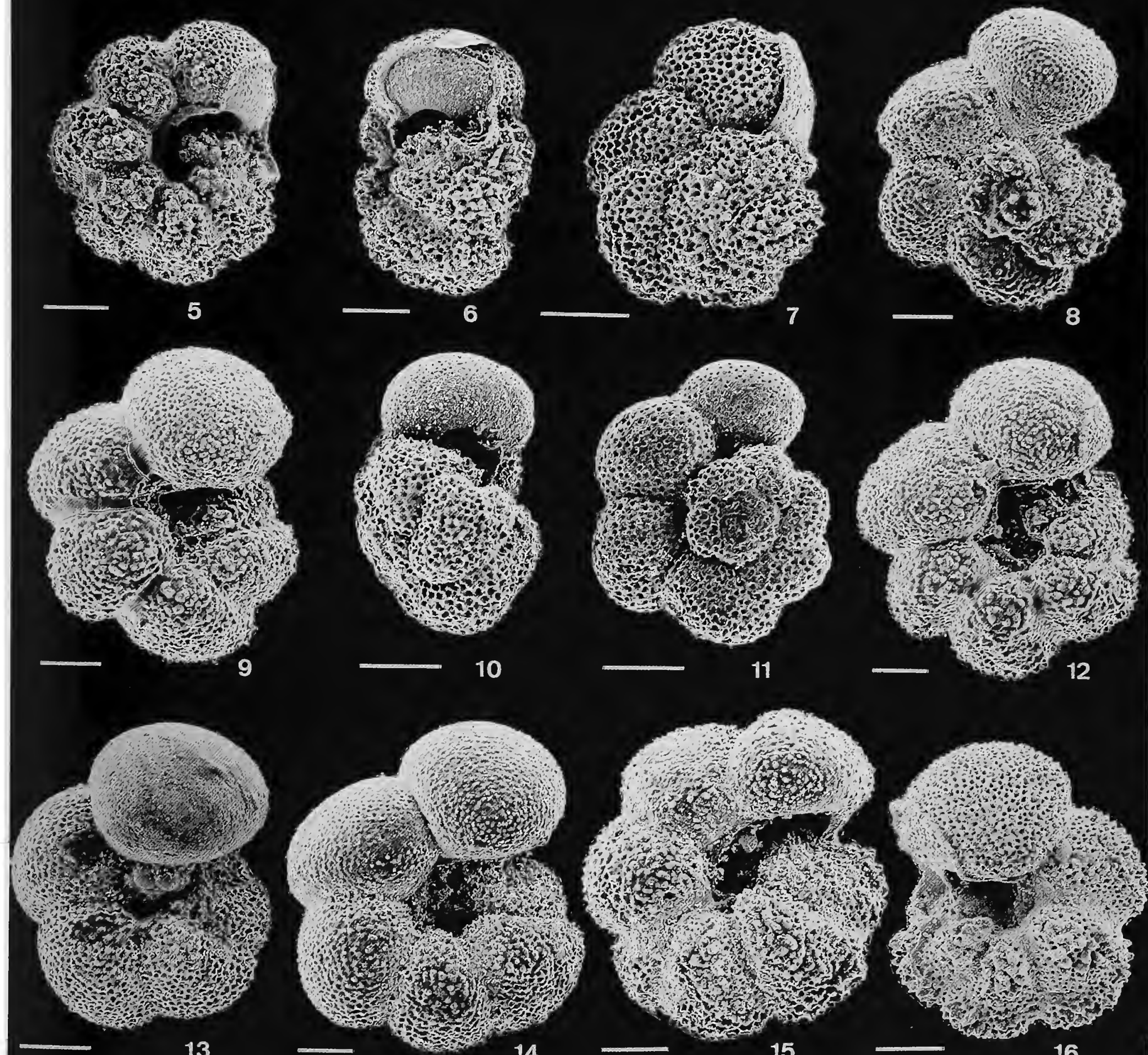

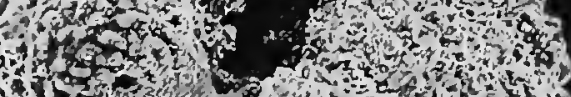
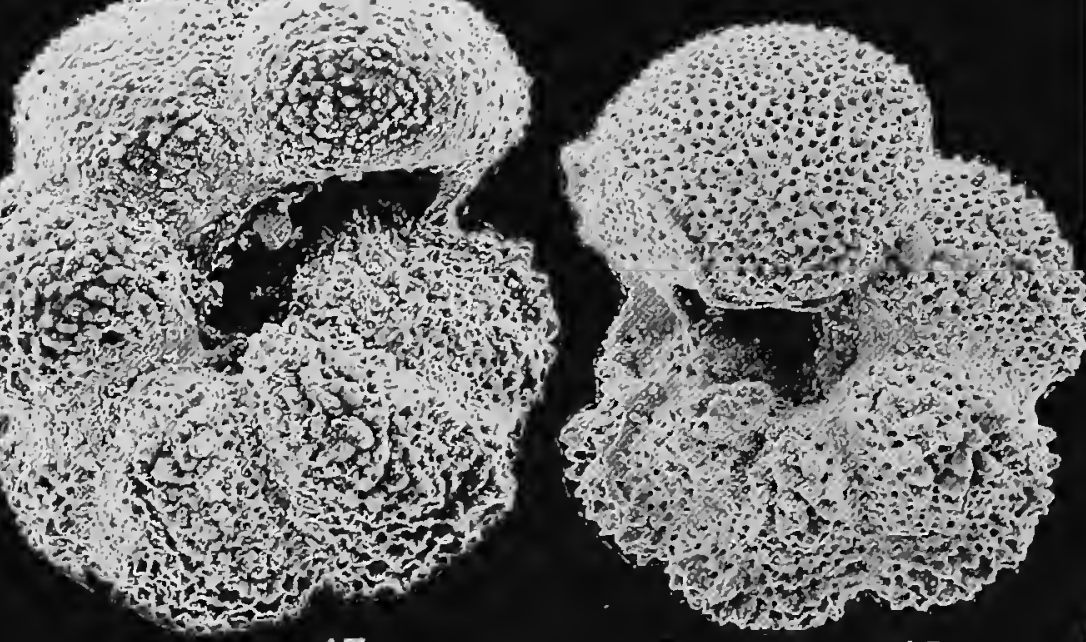


\section{PLATE 63}

\section{Guembelitria cretacea Cushman, 1933}

(Figures 1-5, 7-12: bars $=50 \mu \mathrm{m} ;$ Figure 6: bar $=10 \mu \mathrm{m}$ )

FIGURES 1-4.-Upper Maastrichtian, Redbank Fm., New Jersey.

FIGURES 5, 6, 10-12.-Zone P $\alpha$, Millers Ferry, Alabama, core 226, sample 18; Figure 6, view of wall of Figure 5 showing typical pore mounds of this species; Figure 12, specimen showing transitional morphology to Woodringina.

FIGURE 7.-Zone P $\alpha$, DSDP Hole 390A/1 1/5: 135-136 cm; Blake-Bahama Basin, North Atlantic Ocean.

FIGURES 8, 9.-Zone P $\alpha$, DSDP Site 577/12/5: 115-117 cm; Shatsky Rise, northwestern Pacific Ocean. 

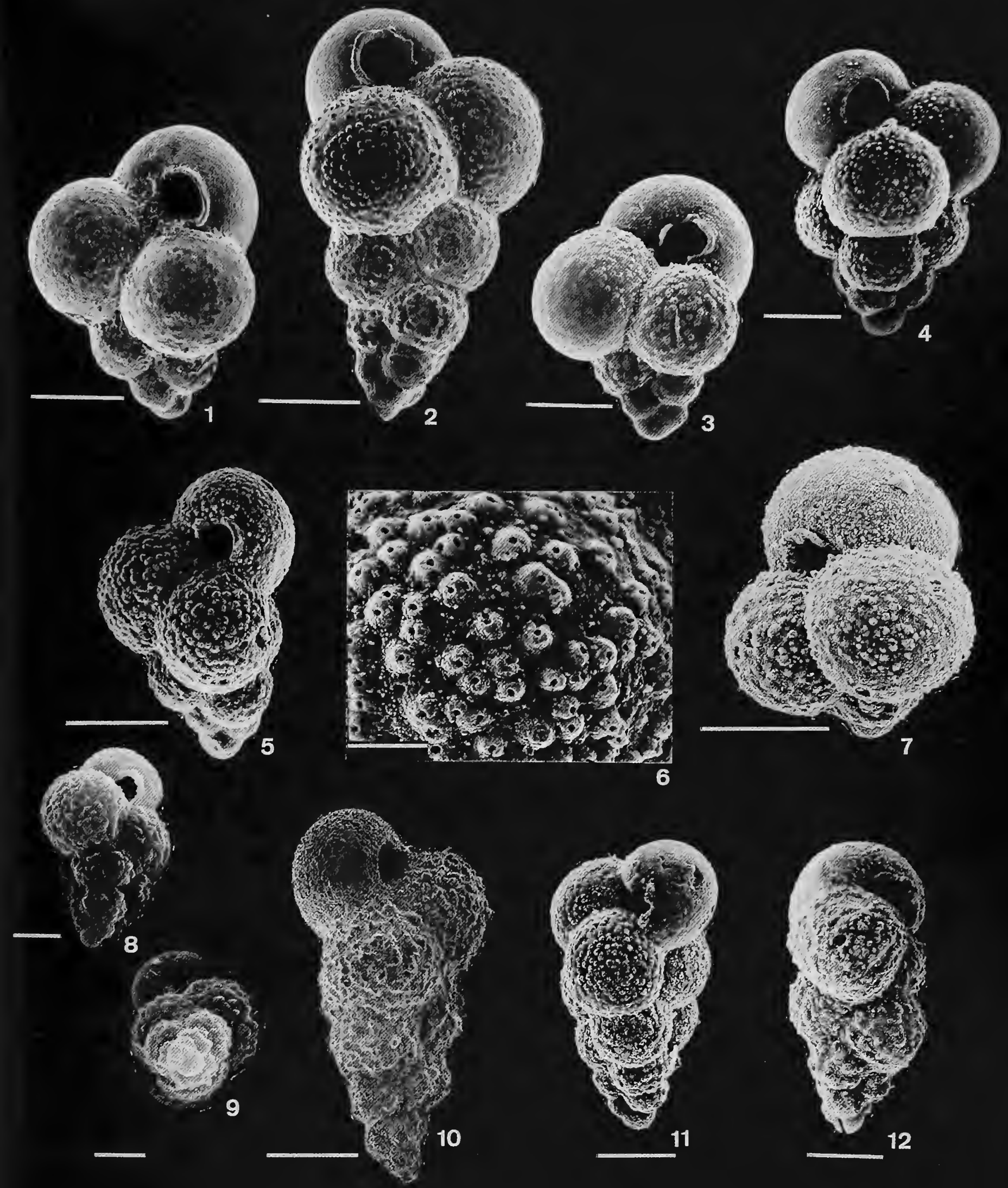


\section{PLATE 64}

\section{Globoconusa daubjergensis (Brönnimann, 1953)}

(Figures 1-7, 10-12: bars $=50 \mu \mathrm{m}$; Figures 8, 9: bars $=10 \mu \mathrm{m}$ )

Figures 1-3, 5, 6, 8, 9.-Zone P1c, Brightseat Fm., Maryland; Figure 8 (view of ultimate chamber of Figure 6) and Figure 9 (view of ultimate chamber of Figure 5) showing microperforate wall texture and poreless sharp pustules.

FIGURE 4.-Zone P0, Brazos River, Texas.

Figure 7.-Zone P $\alpha$, Millers Ferry, Alabama, core 225, sample 256.

Figures 10-12.-Zone P1c, Midway Fm., Texas, Plummer station 14. 

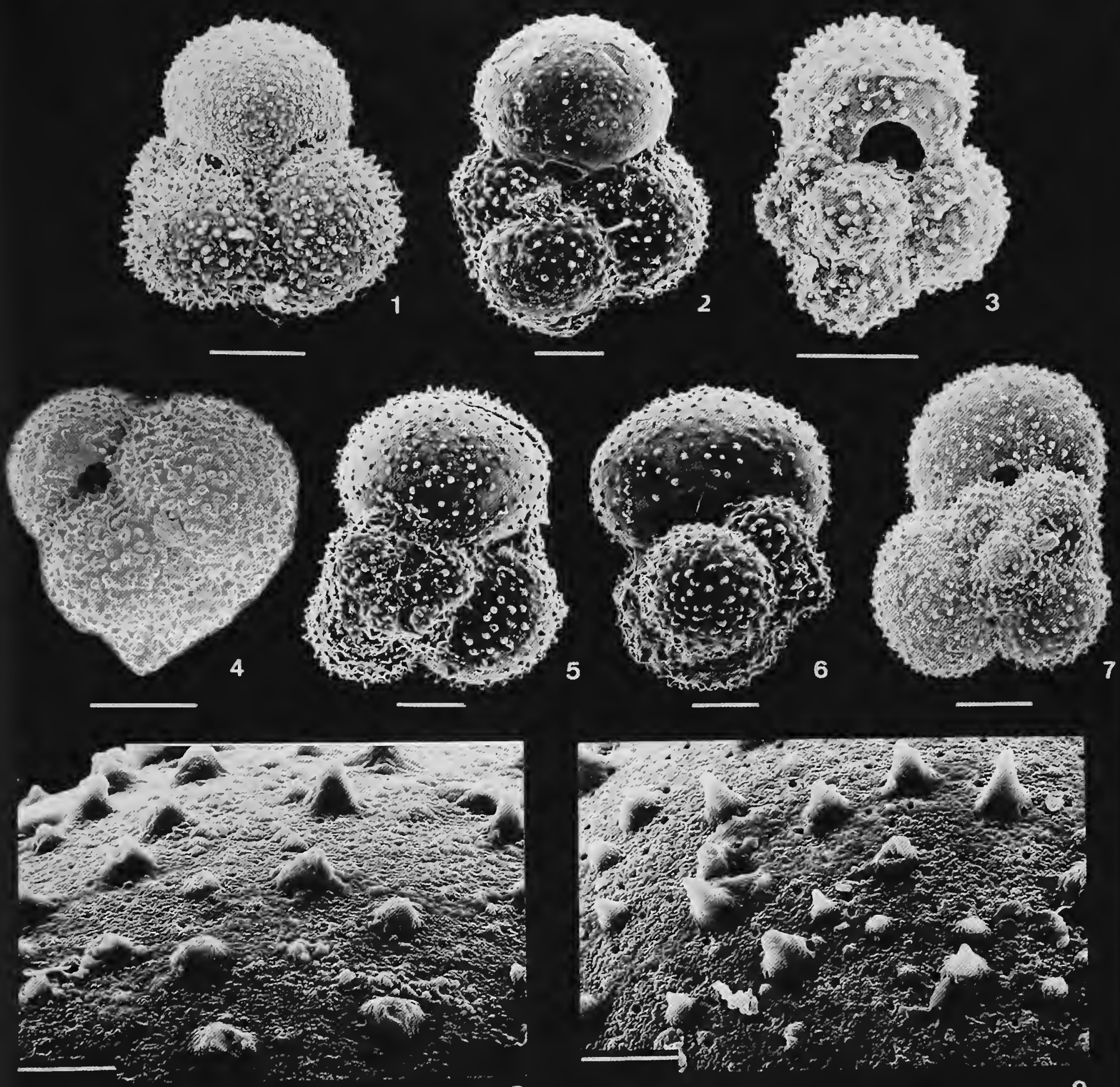

8
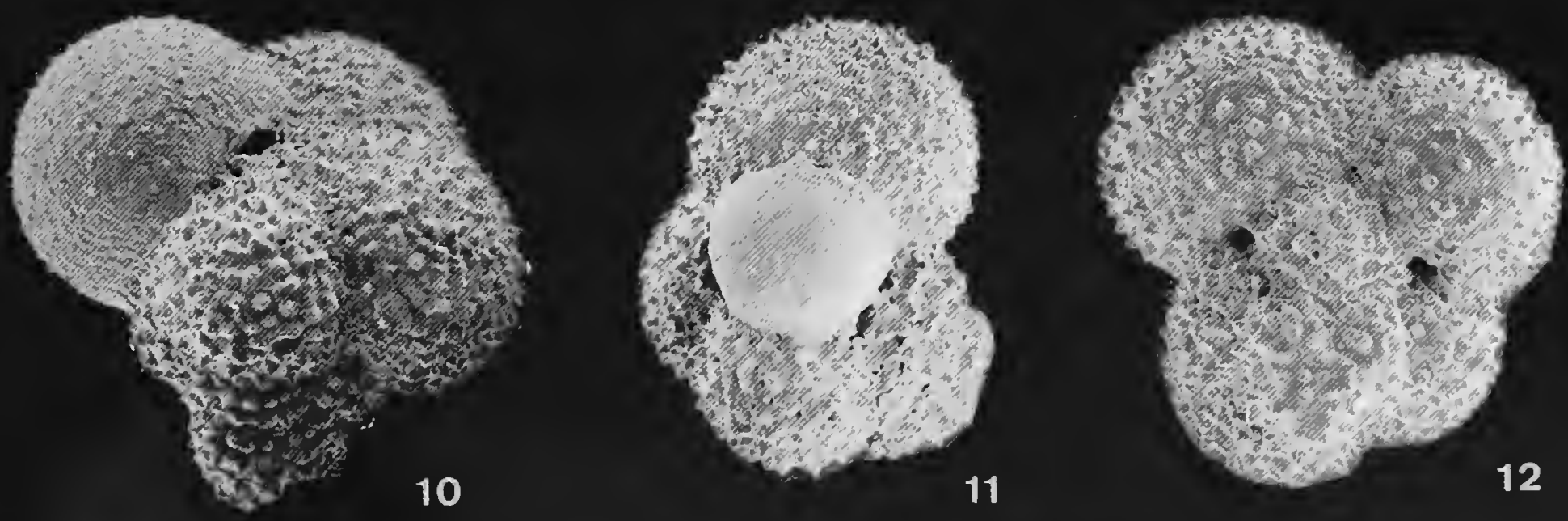


\section{PLATE 65}

\section{Parvularugoglobigerina alabamensis (Liu and Olsson, 1992)}

(Figures 1-5: bars $=50 \mu \mathrm{m}$; Figure 6: bar $=10 \mu \mathrm{m}$ )

FIGURE 1.-Zone P1a, Millers Ferry, Alabama, core 225, sample 265.

FIGURES 2, 3.-Zone Pla, Millers Ferry, Alabama, core 225, sample 266.

FIguRE 4.-Zone Pla, Millers Ferry, Alabama, core 226, sample 20.

Figures 5, 6.-Zone Pla, Millers Ferry, Alabama; Figure 5, holotype, sample 40 feet above Prairie Bluff Chalk;

Figure 6, view of wall of 3rd chamber of holotype showing microperforate pore mound texture.

\section{Parvularugoglobigerina extensa (Blow, 1979)}

$$
\text { (bars }=50 \mu \mathrm{m})
$$

FIGURES 7, 9-12.-Zone P $\alpha$, DSDP Site 577/12/5: 94-96 cm; Shatsky Rise, northwestern Pacific Ocean.

Figure 8.-Zone P $\alpha$, El Kef, Tunisia.

FIGURE 13.-Zone P $\alpha$, type level of $P$. eugubina, Gubbio section, central Appennines, Italy. 

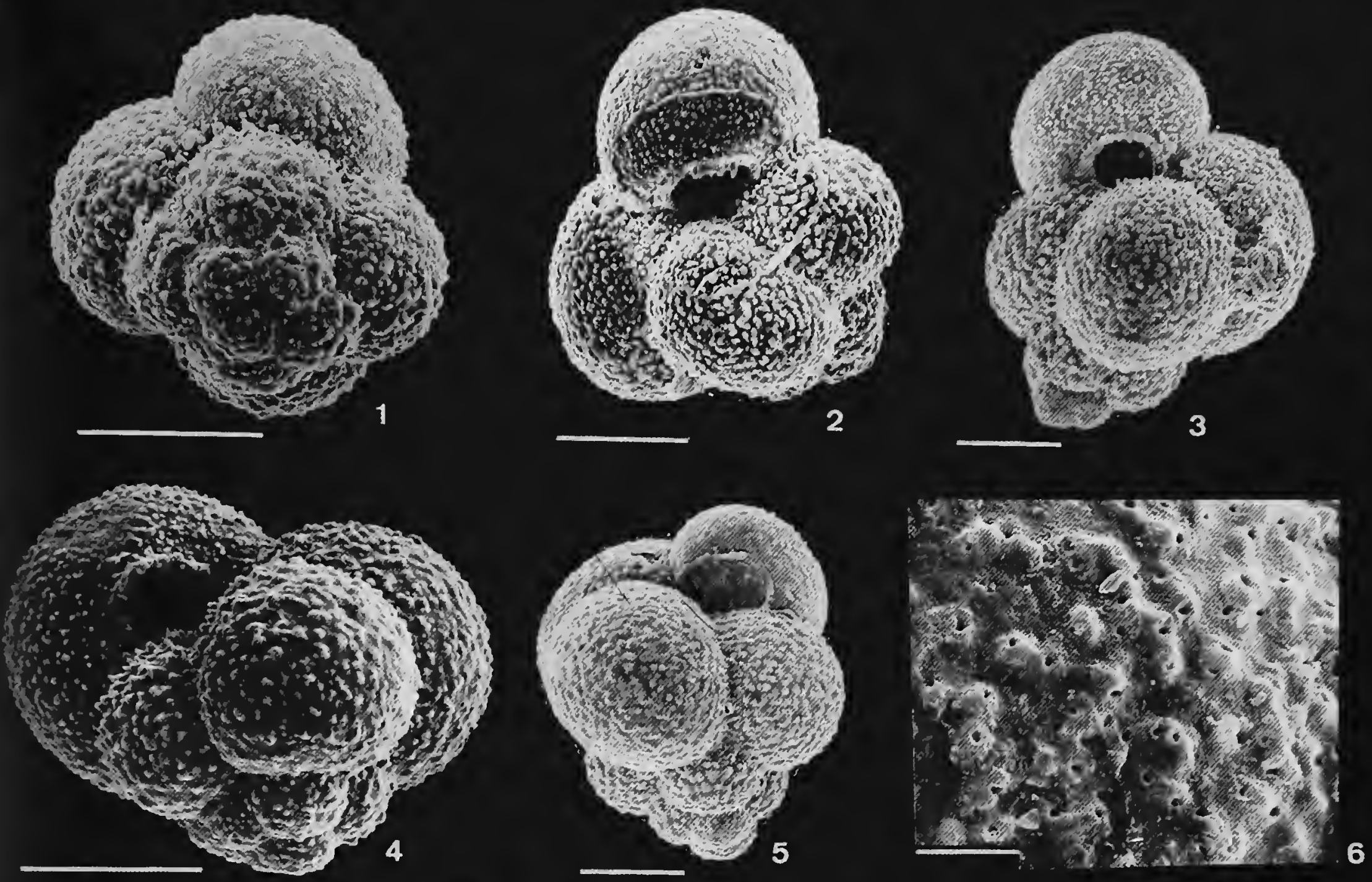

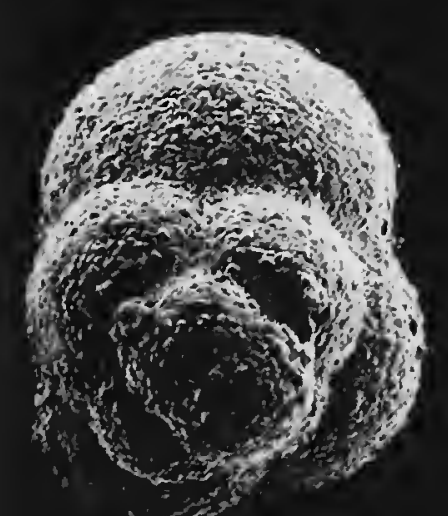

7
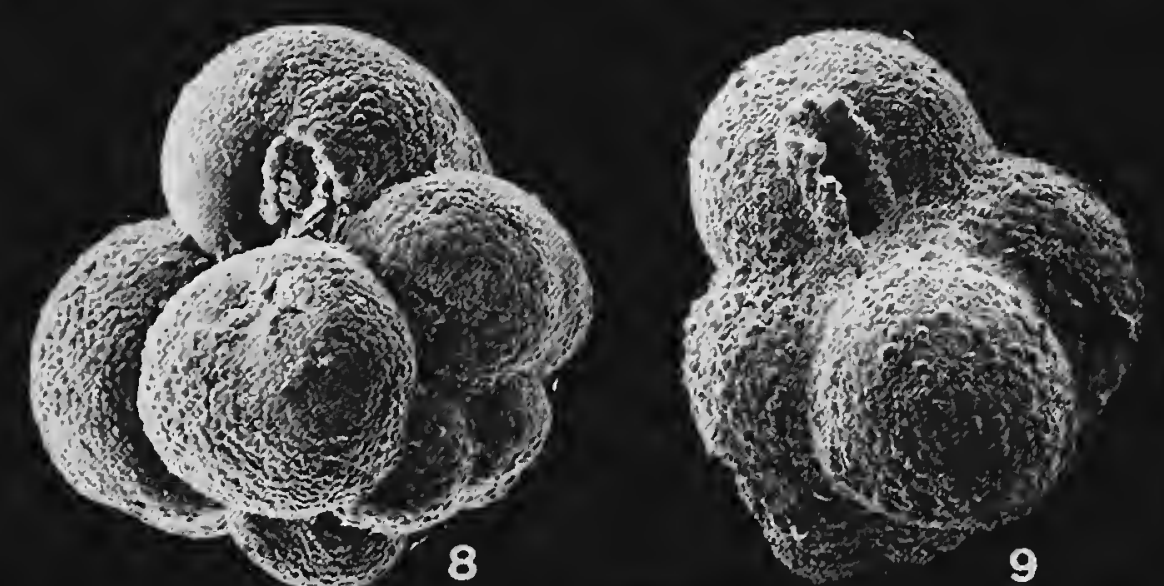

9
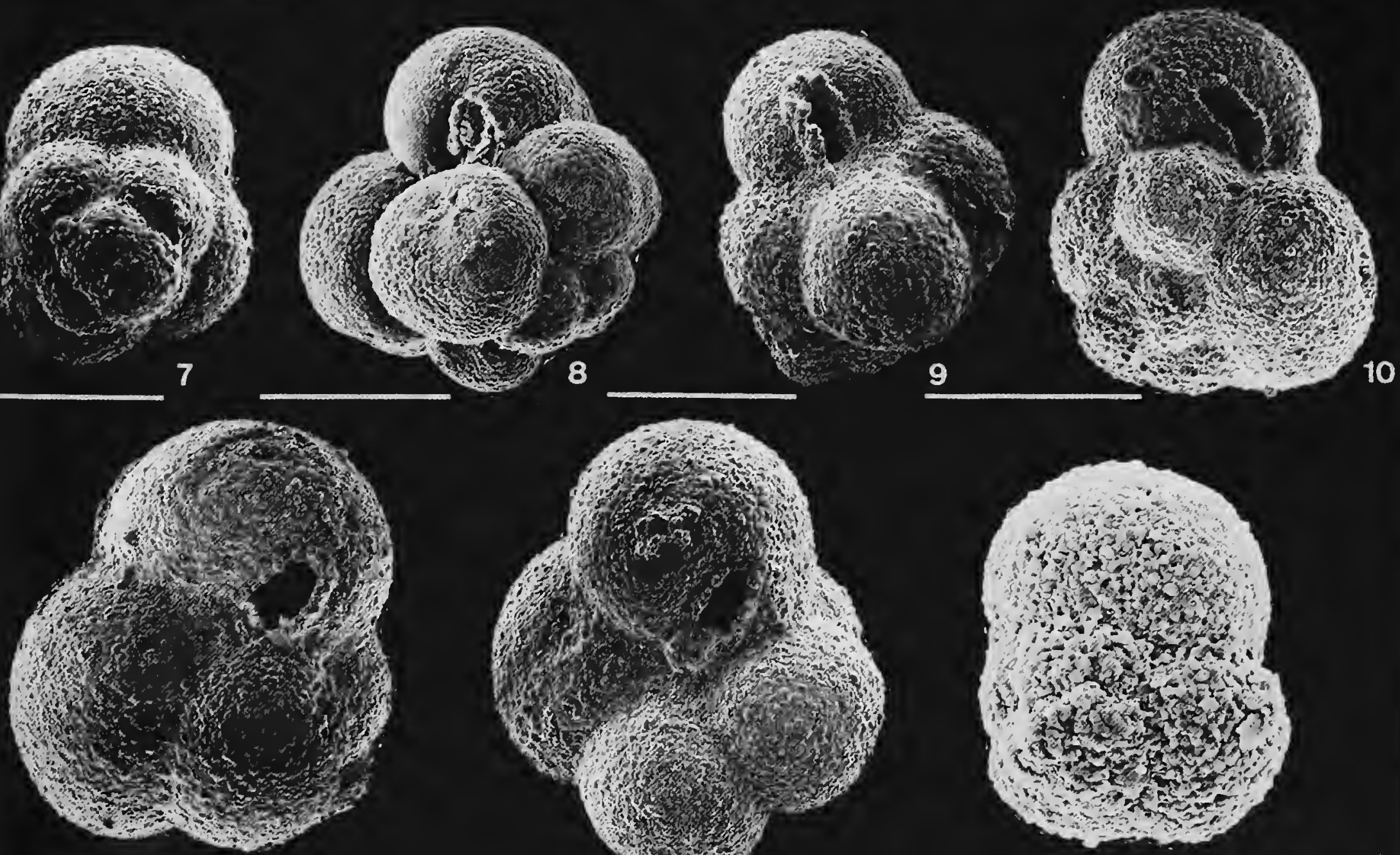

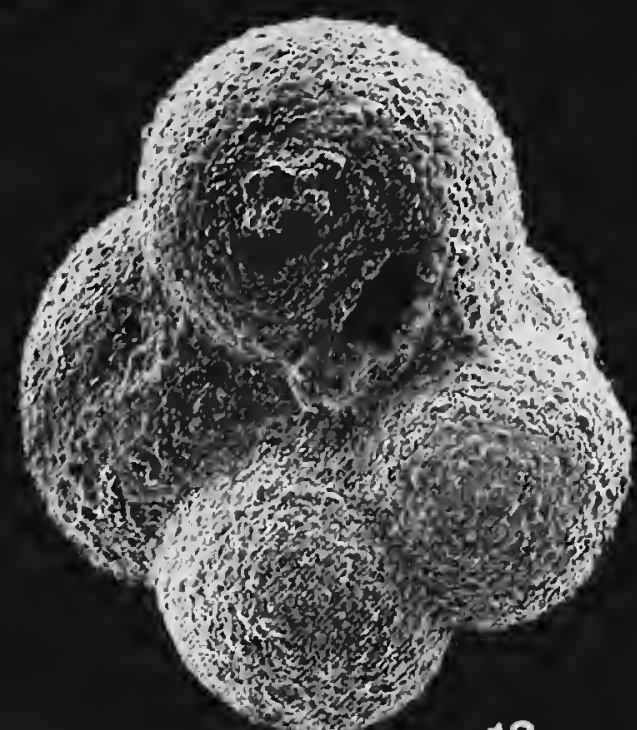

12

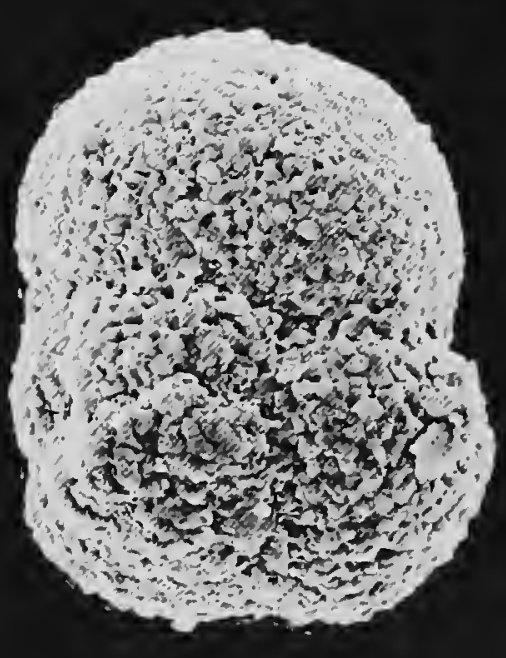

13 


\section{PLATE 66}

Parvularugoglobigerina eugubina (Luterbacher and Premoli Silva, 1964)

(Figures $1-4,6-12:$ bars $=50 \mu \mathrm{m}$; Figure 5: bar $=10 \mu \mathrm{m}$ )

FIGURES 1-5.-Zone P $\alpha$, Millers Ferry, Alabama, core 225, sample 328; Figure 5, view of wall of 2nd chamber of Figure 2 showing microperforate wall texture with a few incipient pore mounds.

FIGURES 6, 8, 9, 12.-Zone Pa, DSDP Site 577/12/5: 115-117 cm.

Figures 7, 10.-Zone Pa, El Kef, Tunisia.

FIGURE 11.-Zone P $\alpha$, DSDP Site 577/12/5: 134-136 cm; Shatsky Rise, northwestern Pacific Ocean. 

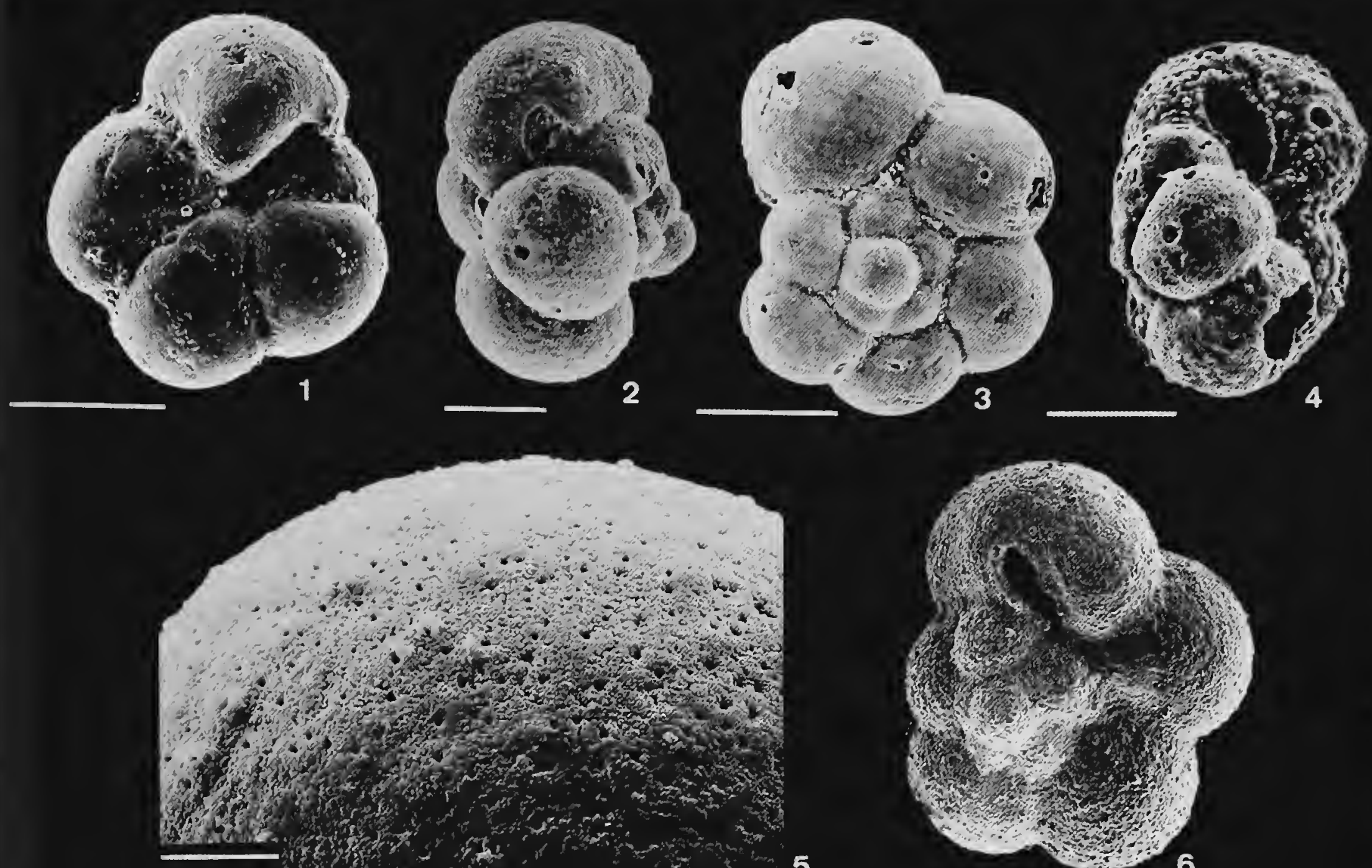

5
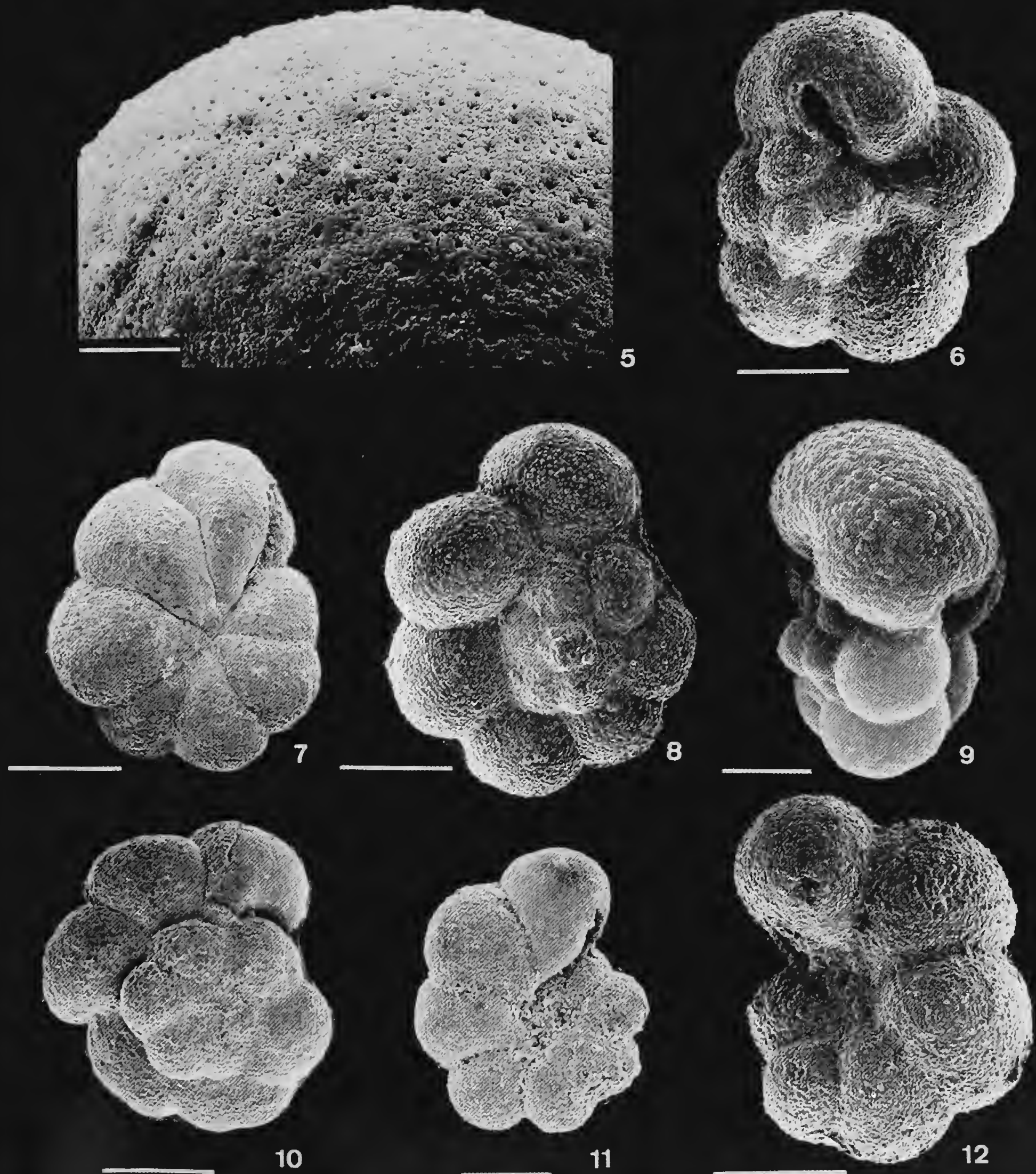


\section{PLATE 67}

\section{Parvularugoglobigerina eugubina (Luterbacher and Premoli Silva, 1964)}

(Figures 1-10, 12, 13: bars $=50 \mu \mathrm{m} ;$ Figures 11, 14: bars $=10 \mu \mathrm{m}$ )

FIGURES 1-9.-Zone P $\alpha$, type level of $P$. eugubina, Gubbio section, central Appennines, Italy.

FIGURES 10-12.-Zone P $\alpha$, DSDP Site 577/12/5: 125-126 cm; Shatsky Rise, northwestern Pacific Ocean; Figure 11, view of Figure 10 showing recrystallized wall that obscures microperforate wall texture.

FIGURES 13, 14.-Zone Pa, Millers Ferry, Alabama, core 226, sample 20; Figure 14, view of wall of 4th chamber of Figure 13 showing microperforate wall texture and scattered pore mounds. 

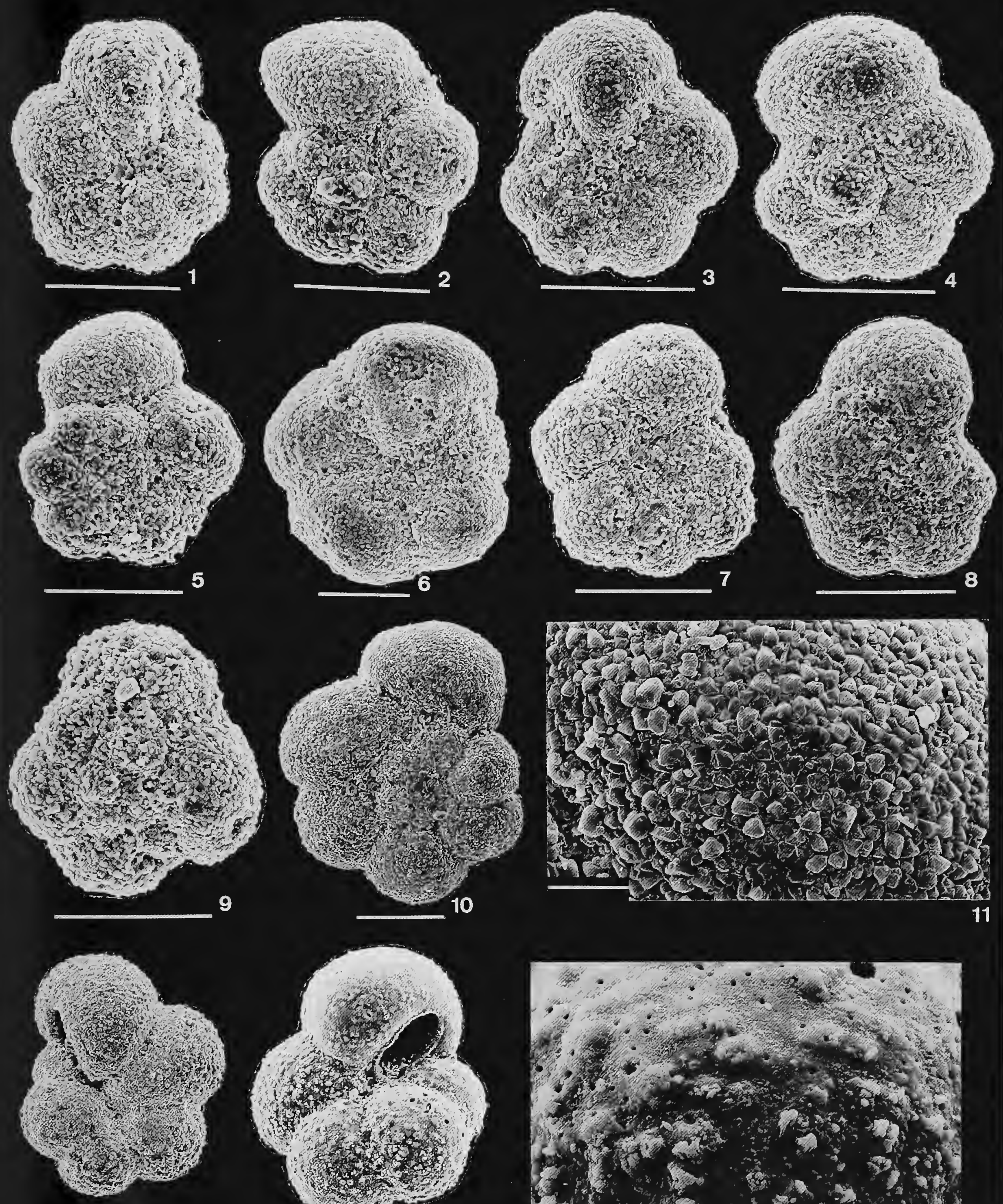

12
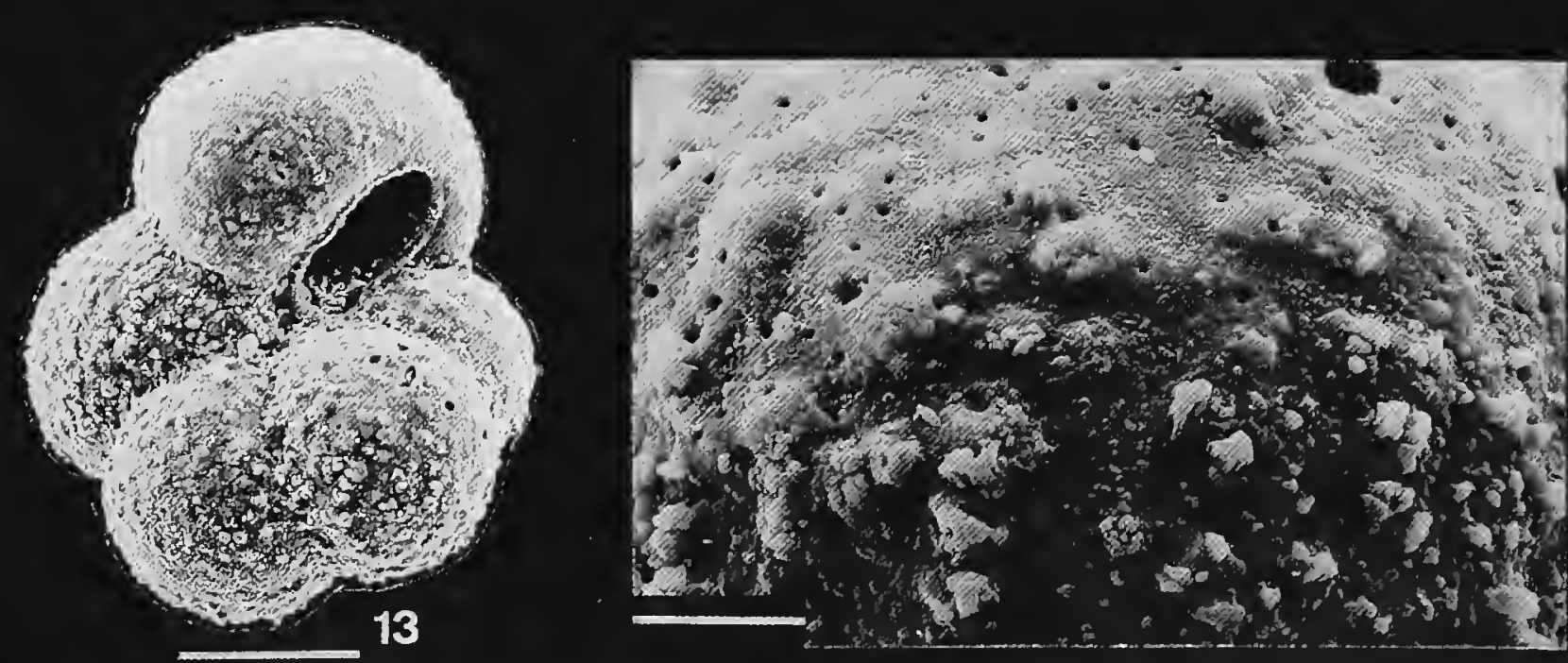


\title{
PLATE 68
}

\author{
Woodringina claytonensis Loeblich and Tappan, 1957
}

(Figures 1-5: bars $=50 \mu \mathrm{m} ;$ Figure 6: bar $=10 \mu \mathrm{m}$ )

FIGURE 1.-Zone P0, Brazos River, Texas.

FIGURES 2, 6.-Zone Pla, DSDP Hole 390A/11/5: 135-136 cm; Blake-Bahama Basin, North Atlantic Ocean; Figure 6, view of 2nd chamber of Figure 2 showing microperforate wall texture and blunt pustules.

FIGURE 3.-Zone P $\alpha$, Millers Ferry, Alabama, core 226, sample 18.

FIGURE 4.-Zone Pla, Midway Group, Texas, Plummer station 4.

FIGURE 5.-Zone P $\alpha$, DSDP Site 577/12/5: 115-117 cm; Shatsky Rise, northwestern Pacific Ocean, specimen showing intermediate morphology with Guembelitria cretacea.

\section{Woodringina hornerstownensis Olsson, 1960}

$$
\text { (bars }=50 \mu \mathrm{m})
$$

FIGURES 7, 8.-Topotypes, Zone P3, Hornerstown Fm., New Jersey.

FIGURES 9, 10, 13, 14.-Zone P $\alpha$, DSDP Site 577/12/5: 113-114 cm; Shatsky Rise, northwestern Pacific Ocean.

Figures 11, 12.-Zone P1c, Midway Fm., Texas, Plummer station 14. 

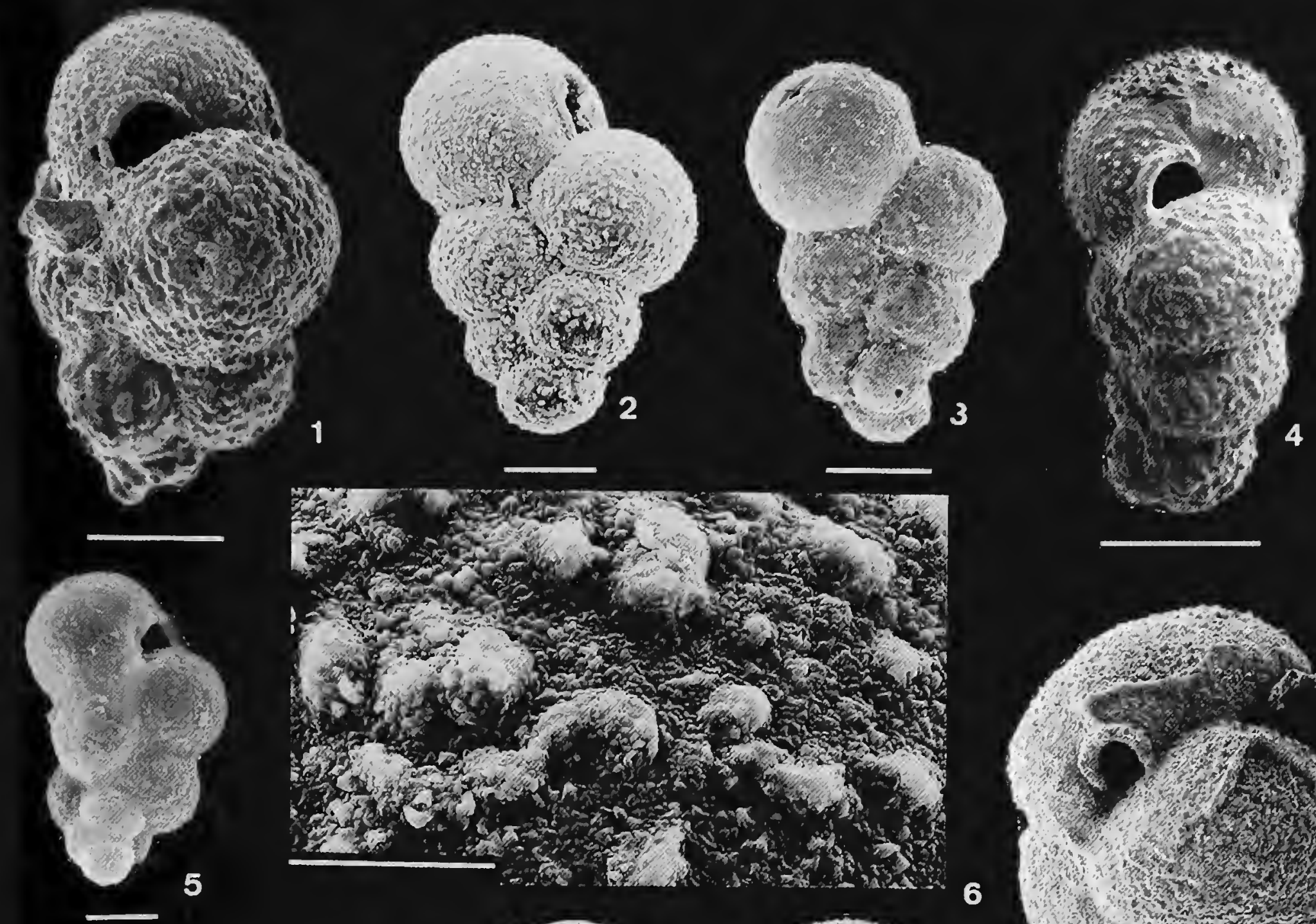

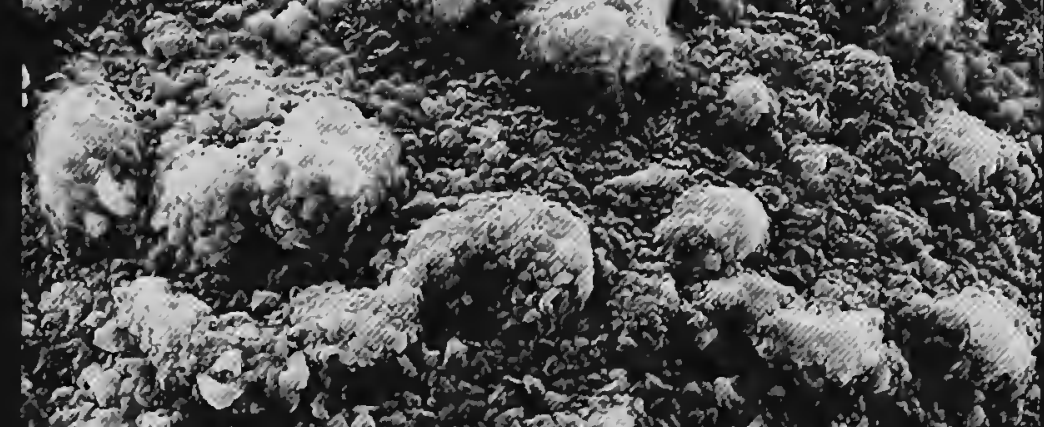

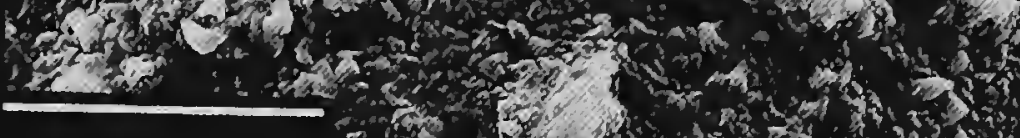

5

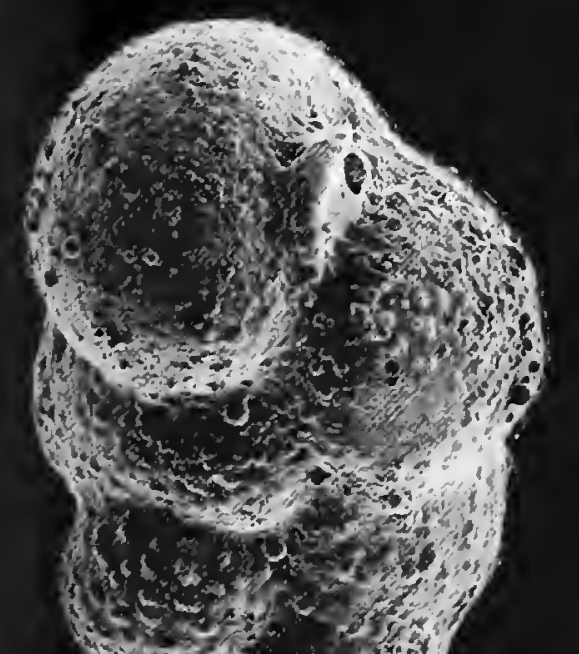
(1) $x, y$

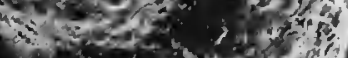

$\left(x^{\infty}+3\right)$

- 350 ?

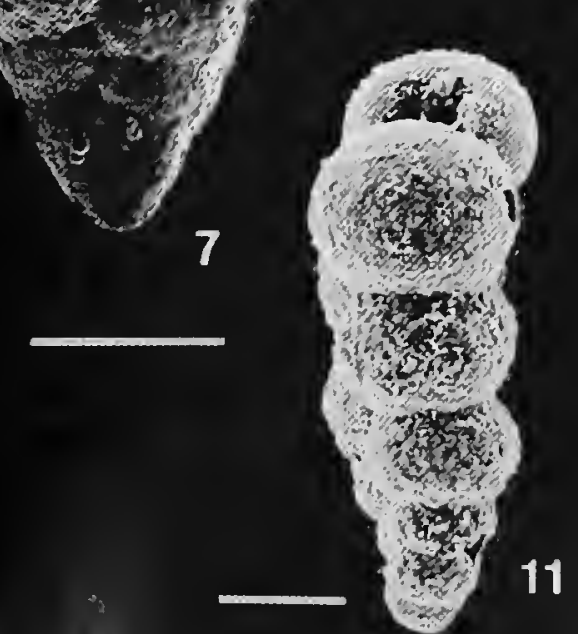

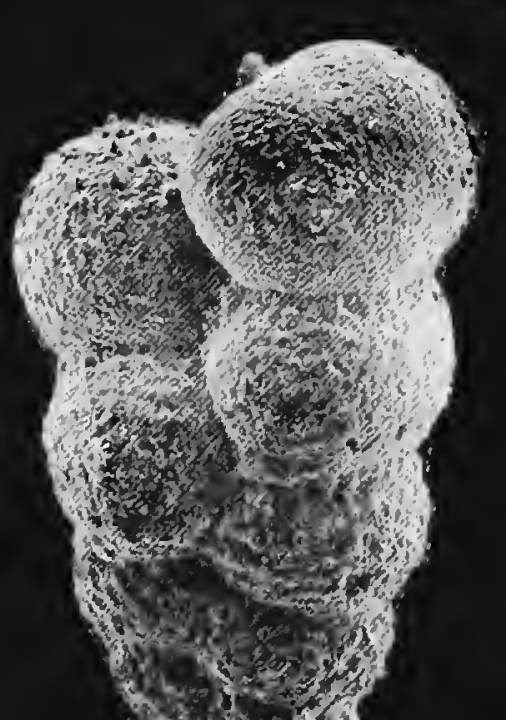

Not $x$
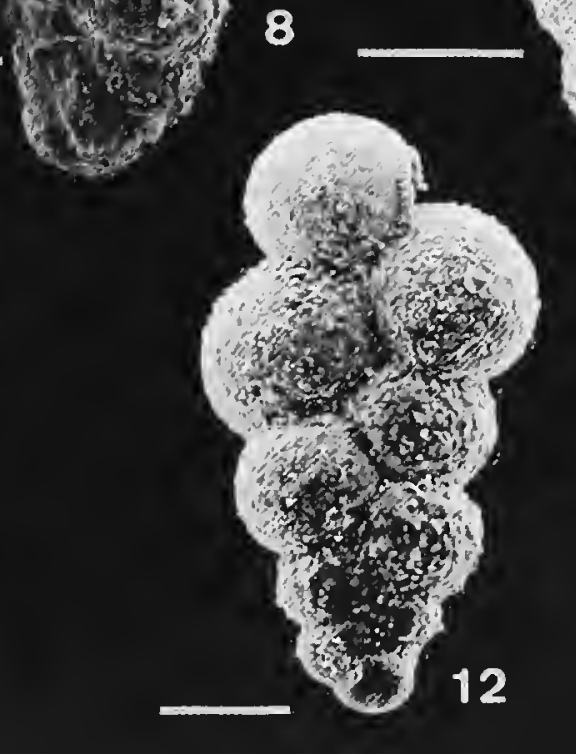

6

6

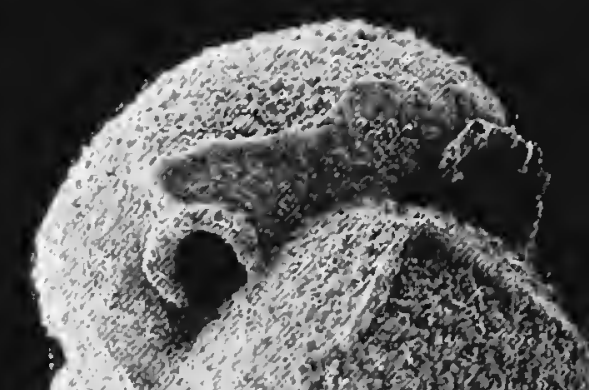

W. H

$2 x^{2}+2$

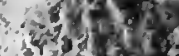

(3)

a on

7

$4 t^{2}-2$

1) 10

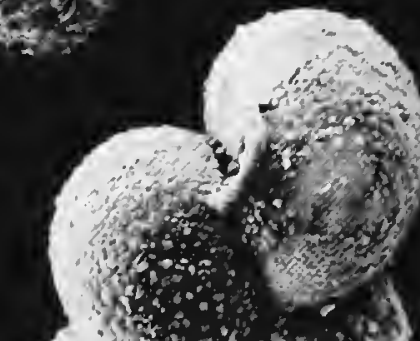

9
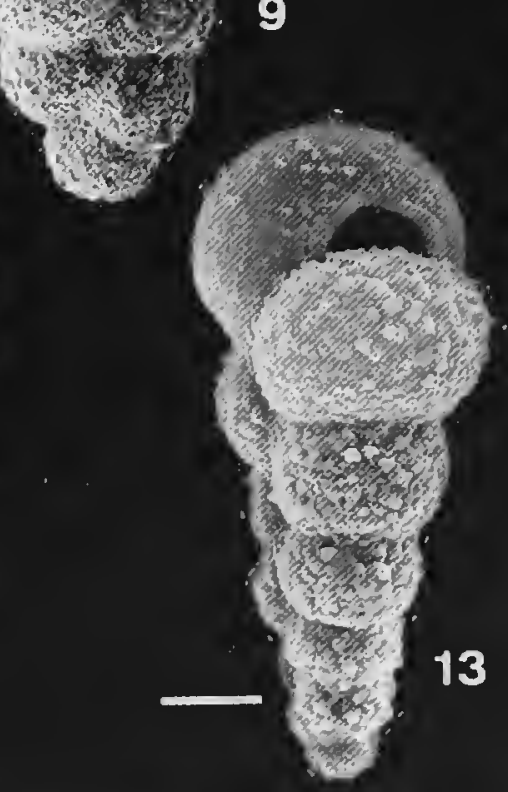

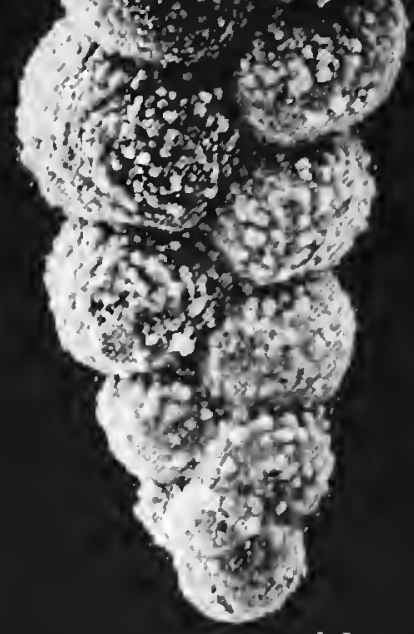

14 


\section{PLATE 69}

\section{Chiloguembelina crinita (Glaessner, 1937)}

(Figures 1-7: bars $=50 \mu \mathrm{m}$; Figure 8: bar $=10 \mu \mathrm{m}$ )

FIGURES 1-8.-Zone P4, Glendola Well, New Jersey, sample 230-232 feet; Figure 8, view of 2nd chamber of Figure 3 showing pustulose wall texture.

\section{Chiloguembelina morsei (Kline, 1943)}

(Figures 9-14: bars $=50 \mu \mathrm{m}$; Figure 15: bar $=10 \mu \mathrm{m}$ )

FIGURES 9, 10.-Danian, ODP Hole 690C/14R/1: 76-80 cm; Maud Rise, Southern Ocean.

FIGURES 11-15.-Zone P2, DSDP Site 356/25/5: 148-150 cm; São Paulo Plateau, South Atlantic Ocean; Figure 15 , view of 3rd chamber of specimen showing pustulose wall texture.

Chiloguembelina midwayensis (Cushman, 1940)

(Figures 16, 18-22: bars $=50 \mu \mathrm{m}$; Figure 17: bar $=10 \mu \mathrm{m}$ )

FIGURES 16-22.-Zone P2, DSDP Site 356/25/5: 148-150 cm; São Paulo Plateau, South Atlantic Ocean; Figure 17 , view of 3 rd chamber of Figure 18 showing pustulose wall texture. 


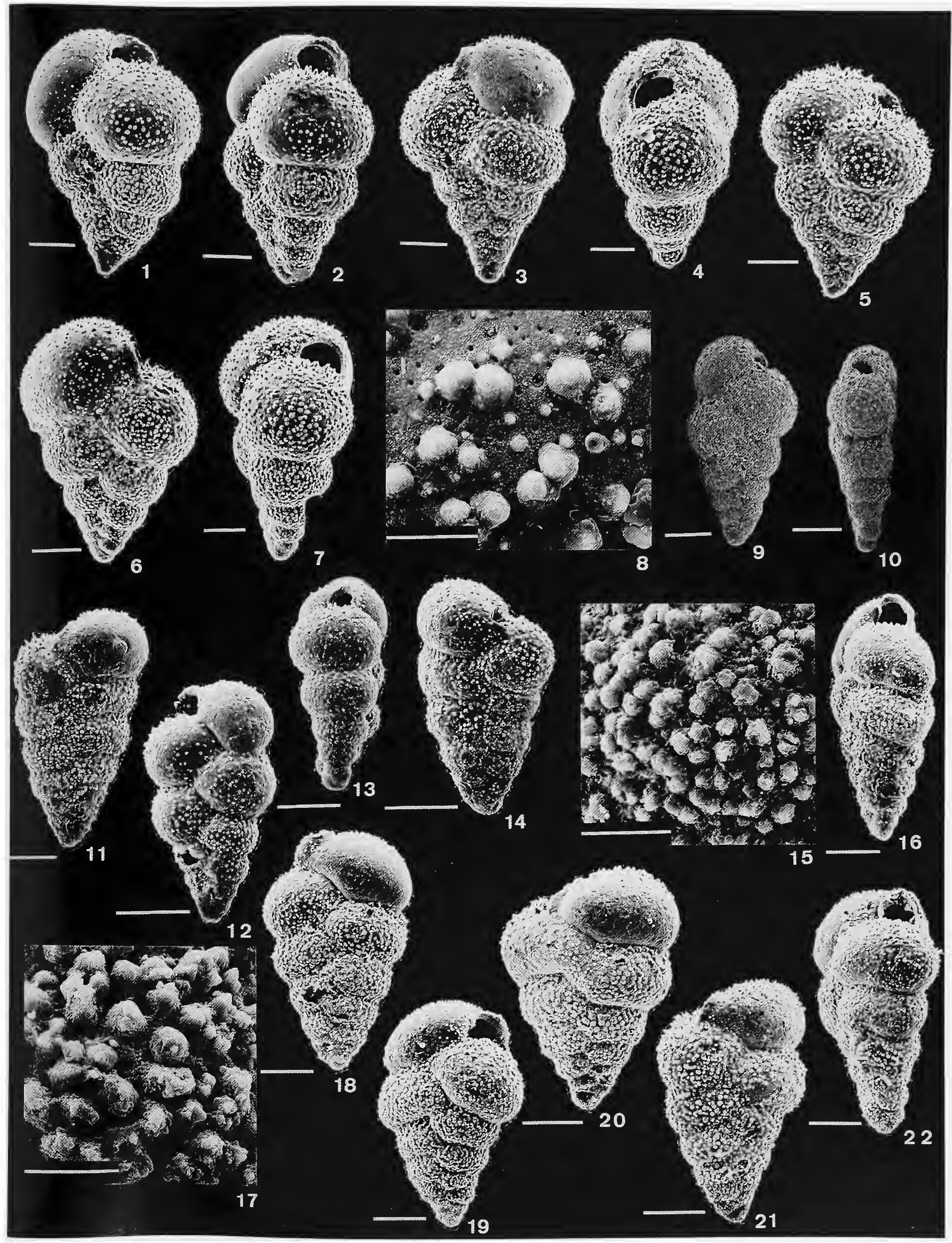




\section{PLATE 70}

Chiloguembelina subtriangularis Beckmann, 1957

(Figures 1-3, 5-7: bars $=50 \mu \mathrm{m} ;$ Figure 4: bar $=10 \mu \mathrm{m}$ )

Figures 1-7.-Zone P2, DSDP Site 356/25/5: $148-150 \mathrm{~cm}$; São Paulo Plateau, South Atlantic Ocean; Figure 4 , view of 2 nd chamber of Figure 7 showing pustulose wall texture.

Chiloguembelina trinitatensis (Cushman and Renz, 1942)

(Figures 8-10: bars $=5 \mu \mathrm{m}$; Figure 14: bar $=20 \mu \mathrm{m}$ )

FIGURES 8, 9.-Zone P5, DSDP Site 152/4/3: 20-24 cm.

FIGURES 10, 14.-Zone P5, DSDP Site 152/4/2: 16-18 cm; Caribbean Sea; Figure 14, view of 3rd chamber of Figure 10 showing pustulose wall texture.

Chiloguembelina wilcoxensis (Cushman and Ponton, 1932)

(Figures 11-13, 15-17: bars $=50 \mu \mathrm{m}$; Figure 18: bar $=20 \mu \mathrm{m}$ )

FIGURES 11-13, 16-18.-Upper Paleocene, ODP Hole 690B/16X/5: 76-80 cm; Maud Rise, Southern Ocean; Figure 12, dissection of Figure 11 showing the asymmetrical position of apertures in earlier formed chambers; Figure 18, view of 2 nd chamber of Figure 17 showing pustulose wall texture.

FIGURE 15.-Hypotype, specimen illustrated in Beckmann, 1957, pl. 21: fig. 13; lower Eocene, type Globorotalia rex Zone, Lizard Springs Fm., Trinidad. 

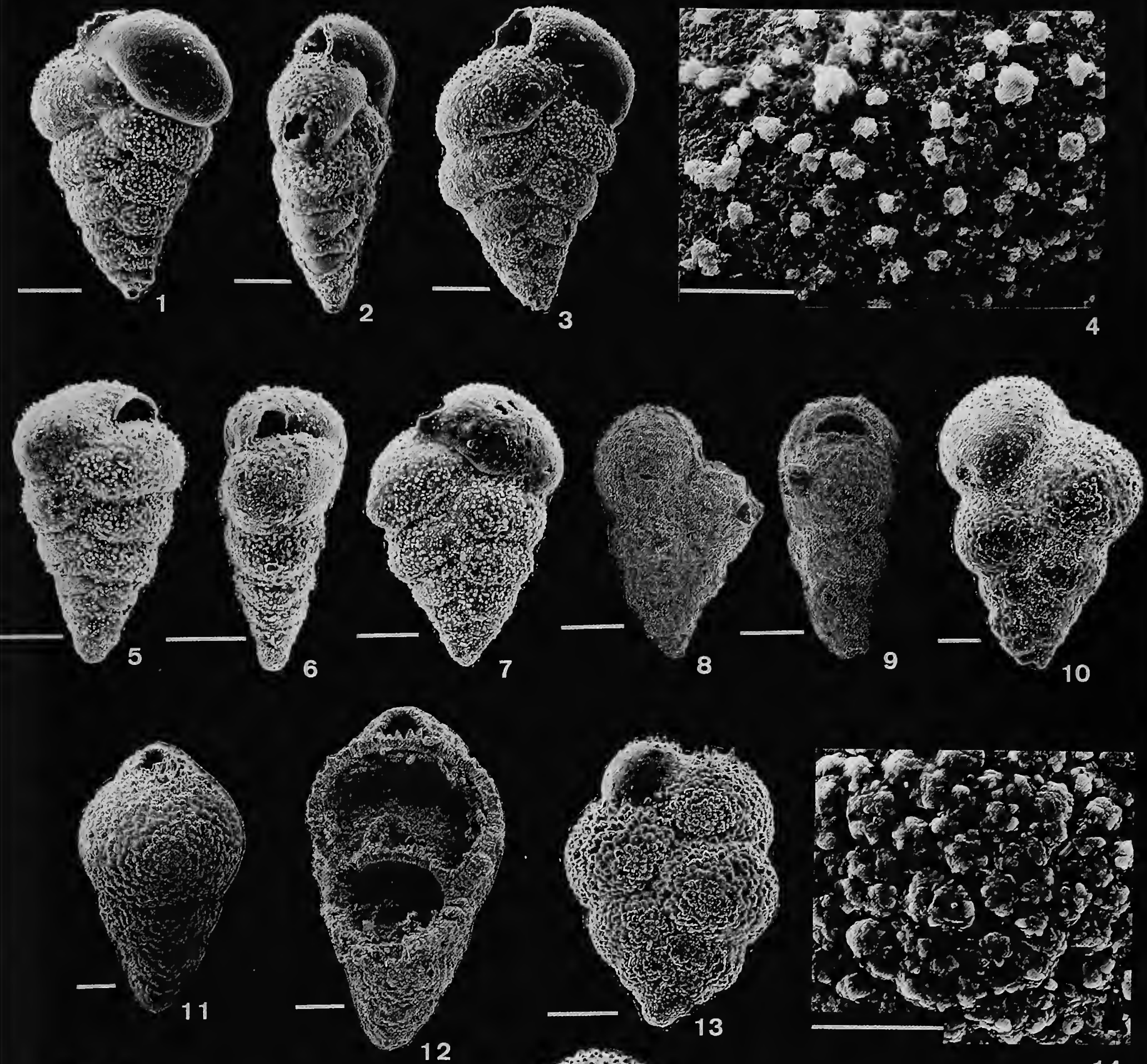

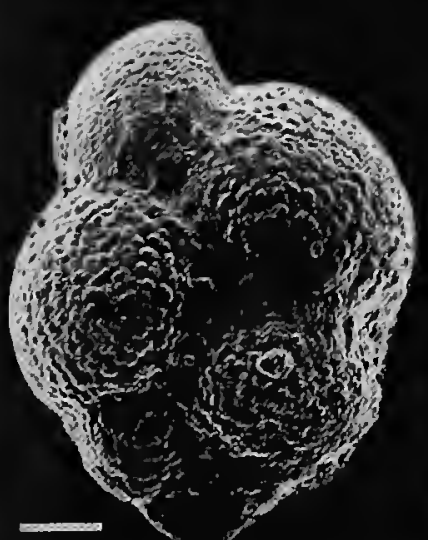

15

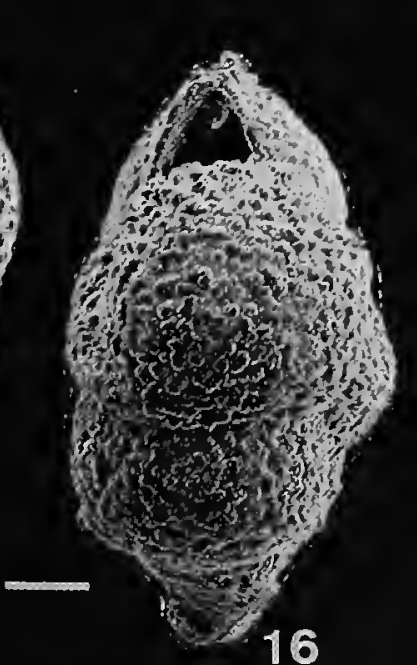

12

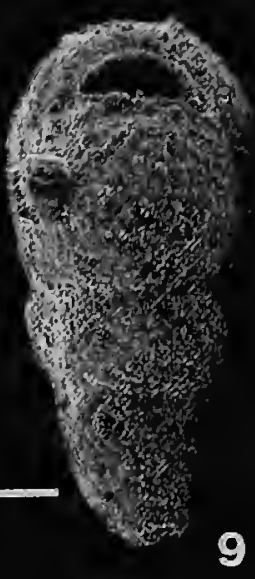

$9+10$ 


\section{PLATE 71}

Zeauvigerina waiparaensis (Jenkins, 1965)

(Figures 1-4, 6-15, 17, 18: bars $=50 \mu \mathrm{m}$; Figures $5,16:$ bars $=10 \mu \mathrm{m}$ )

FIGURES 1-5.-Z. waiparaensis sensu stricto: Maastrichtian, ODP Hole 750A/46R/1: 130-131 cm; Figure 5, apertural view of Figure 4 showing equidimensional lip partially surrounding aperture.

FIGURE 11.-Z. waiparaensis sensu stricto: Maastrichtian, ODP Hole 750A/18X/CC.

FIGURE 12.-Z. waiparaensis sensu stricto: Maastrichtian, ODP Hole 750A/18R/CC.

FIGURES 6-8.-Z. waiparaensis forma prolata: Maastrichtian, ODP Hole 750A/17R/1: 52-54 cm.

FIGURES 9, 10.Z. waiparaensis forma palmula: Late Paleocene, ODP Hole 738C/13R/CC.

FIGURES 13-16.-Z. waiparaenis forma improcera: Maastrichtian, ODP Hole 750A/16R/1: 130-131 cm; Kerguelen Plateau, southem Indian Ocean; Figure 16, apertural view of Figure 15 showing equidimensional lip partially surrounding aperture.

FIGURES 17, 18.-Z. waiparaensis forma velata: Maastrichtian, ODP Hole 738C/21R/CC; Kerguelen Plateau, southern Indian Ocean.

Zeauvigerina aegyptiaca Said and Kenawy, 1956

$$
\text { (bars }=50 \mu \mathrm{m} \text { ) }
$$

FIGURES 19, 20.-Upper Paleocene, DSDP Site 98/12/1: 119-120 cm; Bahama Platform, western Atlantic Ocean.

$$
\text { "Zeauvigerina" virgata (Khalilov, 1967) }
$$

(Figures 21, 22: bars $=50 \mu \mathrm{m}$; Figure 23: bar $=20 \mu \mathrm{m}$ )

FIGURES 21-23.-Upper Paleocene, ODP Hole 750A/1 1R/2: 40-41; Kerguelen Plateau, southern Indian Ocean; Figure 23, apertural view of Figure 22.

Rectoguembelina cretacea Cushman, 1932

$$
\text { (bars }=50 \mu \mathrm{m} \text { ) }
$$

FIGURES 24-26.--Upper Paleocene, DSDP Site 357/30/CC; Rio Grande Rise, South Atlantic Ocean. 


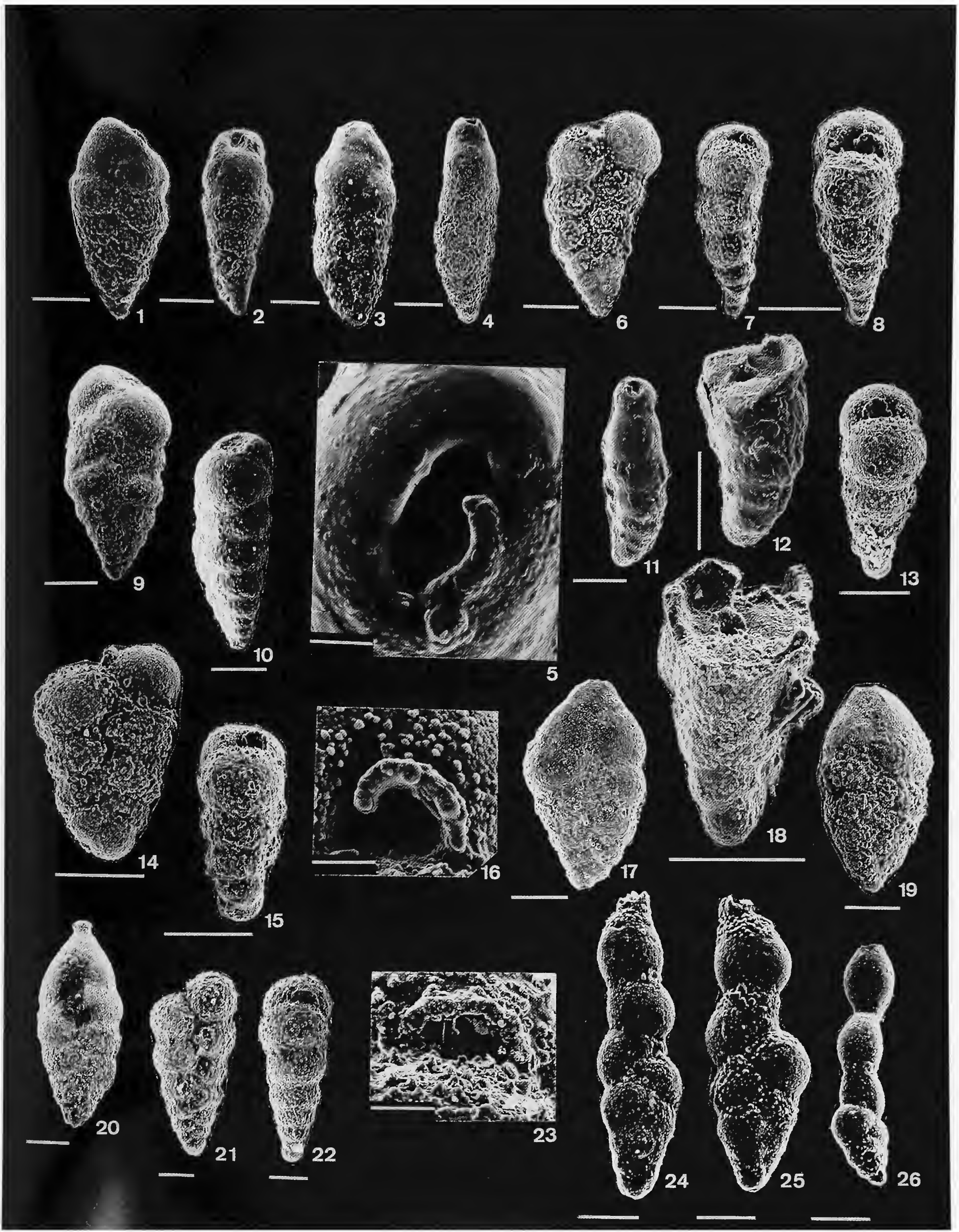




\section{Index}

(Page number of principal account is in italics.) abundocamerata, Globorotalia angulata, 60 acarinata, Acarinina, 46, 48 acarinata, Globorotalia (Acarinina) acarinata, 48 Acarinina, 1, 12, 46

acuta, Globorotalia, 55 acuta, Globorotalia (Morozovella), 55 acuta, Globorotalia velascoensis, 55 acuta, Morozovella, 55; 196 acuta (var.), Globorotalia wilcoxensis, 55 acutispira, Globorotalia, 56 acutispira, Globorotalia (Morozovella) occlusa, 56 acutispira, Morozovella, 3, 19, 56; 198 acutispira (aff.), Globorotalia sp., 56 aegyptiaca, Zeauvigerina, 95; 248 aequa, Acarinina, 57 aequa, Globorotalia, 57 aequa, Globorotalia (Morozovella) aequa, 57 aequa, Globorotalia (Truncorotalia) aequa, 57 aequa, Morozovella, 12, 19, 57; 200 aequa (var.), Globorotalia crassata, 57 aequa (var.), Globorotalia (Truncorotalia) crassata, 57

aequus, Truncorotaloides (Morozovella), 57 alabamensis, Guembelitria?, 83

alabamensis, Parvularugoglobigerina, 83; 236 albeari, Globorotalia, 69 albeari, Globorotalia (Globorotalia), 69 albeari, Igorina, 17, 69; 218 anconitana, Globigerina, 83 angulata, Globigerina, 58 angulata, Globorotalia, 58 angulata, Globorotalia (Truncorotalia), 58, 60 angulata, Globorotalia (Morozovella), 58 angulata, Morozovella, 19, 58; 202 angulatus, Truncorotaloides (Morozovella), 58 apanthesma, Acarinina, 59 apanthesma, Globorotalia, 59 apanthesma, Globorotalia (Morozovella), 59 apanthesma, ? Globorotalia (Morozovella), 59 apanthesma, Morozovella, 19, 59; 204 arabica, Globigerina, 73 archeocompressa, Globanomalina, 2, 11, 17, 37; 170

archeocompressa, Globorotalia (Turborotalia), 37 aspera, Eouvigerina, 95 australiformis, Globanomalina, 3, 18, 38; 172 australiformis, Globorotalia, 38 australiformis, Globorotalia (Planorotalites), 38 australiformis, Planorotalites, 38

azzouzi, Guembelitria, 79

besbesi, Guembelitria, 79

bohemica, Pseudotextularia, 94

bollii, Globorotalia, 65

bullata, Globorotalia (Morozovella) aequa, 57 californica, Globorotalia, 56 cancellata, Subbotina, 2, 17, 29; 154, 156 cancellata, Subbotina triangularis, 29 cancellata (aff.), Subbotina, 17 cancellate spinose, 13 cancellate nonspinose, 17 Cassigerinella, 78 caucasica, Globorotalia velascoensis, 63 chapmani, Globanomalina, 18, 39; 174 chapmani, Globorotalia, 39 chapmani, Planorotalites, 40 chascanona, Acarinina, 53 chascanona, Globigerina, 53 chascanona, Muricoglobigerina, 53 Chiloguembelina, 2, 89

Chiloguembelinidae, 88

Chiloguembelitria, 79

claytonensis, Woodringina, 86; 242

coalingensis, Acarinina, 18, 47; 184

coalingensis, Globigerina, 47

compressa, Globanomalina, 17, 40;170, 176

compressa, Globorotalia, 40, 44

compressa, Globorotalia (Globorotalia), 40

compressa, Globorotalia (Turborotalia) compressa, 40

compressa, Globigerina, 40

compressa (var.), Globigerina compressa, 40 compressus, Planorotalites, 40

conicotruncata, Acarinina, 60

conicotruncata, Globorotalia, 60

conicotruncata, Globorotalia (Morozovella) angulata, 60

conicotruncana, Morozovella, 19, 60; 206

conusa, Globoconusa, 80, 81, 85

convexa, Globorotalia, 71

convexa, Globorotalia (Acarinina), 72

convexa, Morozovella, 72

convexus, Truncorotaloides (Morozovella), 71

convexa (cf.), Globorotalia (Acarinina) convexa, 72

Corrosina, 78

crassaformis, Acarinina, 46

crassaformis, Globorotalia, 64

crassata, Globorotalia, 66

cretacea, Guembelitria, 2, 10, 79; 232

cretacea, Rectoguembelina, 94; 248

crinita, Chiloguembelina, 90; 244

crinita, Gümbelina, 90

crosswickensis, Globorotalia, 62

crosswickensis, Globorotalia (Morozovella) occlusa, 62

dammula, Guembelitria, 79

danica, Chiloguembelitria, 79

daubjergensis, Globastica, 81

daubjergensis, Globigerina, 80, 81

daubjergensis, Globigerinoides, 81

daubjergenisis, Globoconusa, 81; 234 edita, Eoglobigerina, 13, 19, 20; 142

edita, Eoglobigerina edita, 20

edita, Globigerina, 19

edita, Globorotalia (Globorotalia), 20

edita, Parvularugoglobigerina, 30

edita (cf.), Globigerina, 84

ehrenbergi, Globanomalina, 17, 42; 176

ehrenbergi, Globorotalia, 40

ehrenbergi, Globorotalia (Globorotalia), 40

elongata, Globorotalia, 40

eobulloides, Eoglobigerina, 1, 11, 13, 20, 21; 144

eobulloides, Eoglobigerina eobulloides, 21

eobulloides, Globigerina (Eoglobigerina), 20

Eoglobigerina, 12, 13, 19

Eouvigerina, 95

eugubina, Parvularugoglobigerina, 3, 83; 238, 240

eugubina (aff.), Parvularugoglobigerina, 85

eugubina (cf.), Parvularugoglobigerina, 84

eugubina, Globigerina, 82, 83

extensa, Eoglobigerina?, 85

extensa, Parvularugoglobigerina, 85; 236

falsospiralis, Acarinina, 53

fodina, Eoglobigerina?, 85

fringa, Eoglobigerina, 21

fringa, Globigerina, 2, 21, 29

fringa, Parnularugoglobigerina, 30

gerpegensis, Globigerina, 30

gigantea, Globoconusa daubjergensis, 81

glabrans, Heterohelix, 97

Globanomalina, 2, 11, 17, 18, 37

Globastica, 80

Globigerinidae, 19

Globoconusa, 2, 80

gracilis, Eouvigerina, 95

gracilis, Globorotalia formosa, 61

gracilis, Globorotalia (Morozovella), 61

gracilis, Globorotalia (Morozovella) subbotinae, 61

gracilis, Morozovella, 19, 61; 214

gracilis, Morozovella formosa, 62

gradata, Heterohelix, 88

Guembelitria, 2, 79

Guembelitriella, 77

Guembelitriidae, 77

hariana, Postrugoglobigerina, 84

haunsbergensis, Globorotalia, 42

haunsbergensis, Globorotalia (Turborotalia), 42

Hedbergella, 2, 34

Hedbergellidae, 34

hemisphaerica, Globigerina (Eoglobigerina), 20, 84

hemisphaerica (cf.), Globorotalia (Turborotalia), 83

Heterohelicidae, 93

holmdelensis, Hedbergella, 3, 11, 35; 166 
hornerstownensis, Woodringina, 3, 87, 88; 242 hornerstownensis group, Woodringina, 85 Igorina, 12, 17, 68

imitata, Globanomalina, 18, 42; 178

imitata, Globorotalia, 42

improcera (forma), Zeauvigerina waiparaensis, 97 inaequispira, Globigerina, 30, 47

inconstans, Acarinina inconstans, 73

inconstans, Globigerina, 73

inconstans, Globorotalia, 73

inconstans, Globorotalia (Acarinina), 73

inconstans, Globorotalia (Globorotalia), 73

inconstans, Globorotalia (Turborotalia), 73

inconstans, Morozovella, 73

inconstans, "Morozovella," 74

inconstans, Praemurica, 17, 73; 224

inconstans, Subbotina, 73

indolensis, Acarinina, 76

intermedia, Acarinina, 49

irregularis, Guembelitria, 79

kelleri, Woodringina, 87

kelleri (cf.), Woodringina, 87

kolchidica, Globorotalia, 56

kolchidica (aff.), Globorotalia sp., 56

kozlowskii, Globigerina, 81

kubanensis, Globorotalia, 60

kubanensis (var.), Globorotalia angulata, 60

lacerti, Globorotalia, 57

lacerti, Globorotalia (Morozovella) aequa, 57

laevigata, Globorotalia pusilla, 69

laevigata, Tubitextularia, 94

Laeviheterohelix, 94, 95

lakiensis (var.), Globanomalina ovalis, 40

loeblichi, Globorotalia, 57

longiapertura, Globorotalia (Turborotalia), 83

longiapertura, Parvularugoglobigerina, 84

luxorensis, Anomalina, 40

marginodentata, Morozovella, 56

mckannai, Acarinina, 18, 48; 186

mckannai, Globigerina, 48

mckannai, Globorotalia, 48

mckannai, Globorotalia (Acarinina), 48

mckannai, Muricoglobigerina, 48

membranacea, Globorotalia, 40, 42, 45

microcellulosa, Globigerina (Globigerina), 31

microperforate, 10

microsphaerica, Acarinina, 53

midwayensis, Chiloguembelina, 90, 91; 244

midwayensis, Chiloguembelina midwayensis, 90

midwayensis, Gümbelina, 90

minutula, Globigerina, 85

monmouthensis, Globorotalia, 35

monmouthensis, Hedbergella, 3, 12, 17, 35; 168

Morozovella, 12, 18, 54

morsei, Chiloguembelina, 91; 244

morsei, Gümbelina, 91

muricate, 12,18

muricate keel, 12

nana, Globigerina triloculinoides, 33

nana, Subbotina triloculinoides, 31

nartanensis, Globorotalia, 65

nitida, Acarinina, 18, 48; 188

nitida, Globigerina, 48

normalis, Heterohelix gradata, 88

occlusa, Globorotalia, 62 occlusa, Globorotalia (Morozovella), 62

occlusa, Globorotalia (Truncorotalia) velascoensis, 62

occlusa, Morozovella, 19, 62; 208

occlusa (cf.), Globorotalia (Morozovella) occlusa, 62

oculis, Heterohelix, 99

ovalis, Globanomalina, 18, 43; 180

palmula (forma), Zeauvigerina waiparaensis, 97

parallelus, Heterohelix, 99

Parasubbotina, 12, 17, 24

parva, Globorotalia (Morozovella) velascoensis, 55

parva, Globorotalia velascoensis, 55

parva (var.), Globorotalia velascoensis, 55

Parvularugoglobigerina, 2, 82

Parvularugoglobigerina morphotype 1, 85

Parvularugoglobigerina morphotype 2, 85

Parvularugoglobigerina morphotype 3, 84

pasionensis, Globorotalia, 63

pasionensis, Morozovella, 19, 63; 210

pasionensis, Pseudogloborotalia, 63

patagonica/triangularis group, Subbotina, 30

pentacamerata, Acarinina, 65

pentagona, Globigerina (Eoglobigerina), 20

pentagona (cf.), Globorotalia (Turborotalia)?, 83

planocompressa, Globanomalina, 18, 44; 178

planocompressa, Globorotalia planocompressa, 44

planocompressa, Globorotalia (Turborotalia) compressa, 44

planoconica, Globanomalina, 18, 44; 174

planoconica, Globorotalia, 44

polycamera, Eoglobigerina edita, 20

polycamera, Globigerina edita var., 20

Postrugoglobigerina, 82

praeangulata, Acarinina, 51

praeangulata, Globorotalia (Acarinina), 64

praeangulata, Morozovella, 18, 19, 64; 212

praecursoria, Acarinina, 48, 73

praecursoria, Globorotalia (Acarinina) praecursoria, 76

praedaubjergensis, Postrugoglobigerina, 81

praeedita, Eoglobigerina, 20

Praemurica, 12, 72

Praemuricate, 12

praenartanensis, Globorotalia, 57

praepentacamerata, Acarinina, 51

praepentacamerata, Globorotalia, 51

praepentacamerata (var.), Globorotalia angulata. 50

primitiva, Acarinina, 47

primitiva, Globigerina, 47

primitiva, Globoguadrina, 47

primitiva, Globorotalia (Acarinina), 47

primitiva, Pseudogloboguadrina, 47

prolata (forma), Zeauvigerina waiparaensis, 97

protocarina, Morozovella, 58

pseudobulloides, Globigerina, 25

pseudobulloides, Globorotalia, 25, 74

pseudobulloides, Globorotalia (Globorotalia), 25

pseudobulloides, Globorotalia (Turborotalia), 25

pseudobulloides, Parasubbotina, 2, 17, 24; 148

pseudobulloides, Subbotina, 25

pseudobulloides (transitional), Globorotalia, 73 pseudobulloides (aff.), Parasubbotina, 17, 25; 150 pseudo-bulloides, Globigerina, 24

Pseudohastigerina, 11

pseudoinconstans, Globorotalia (Turborotalia), 74

pseudoinconstans, Praemurica, 17, 74; 226

pseudoiota, Globigerina, 43

pseudomenardii, Globanomalina, 17, 45; 182

pseudomenardii, Globorotalia, 45

pseudomenardii, Globorotalia (Globorotalia), 45

pseudomenardii, Planorotalites, 45

pseudoscitula, Globorotalia, 69

pseudotriloba, Globigerina, 30, 31

pusilla, Globorotalia, 70

pusilla, Globorotalia pusilla, 70

pusilla, Globorotalia (Globorotalia?) pusilla, 70

pusilla, Igorina, 17, 70; 220

pusilla, Morozovella pusilla, 70

pusilla, Planorotalites pusilla, 70

quadratoseptata, ? Acarinina, 64

quadrilocula, Globorotalia (Turborotalia), 26

quadripartitiformis, Globoconusa, 53

quadritriloculinoides, Globigerina, 33

Rectoguembelina, 93

rex, Globorotalia, 65

rex, Globorotalia (Morozovella) aequa, 65

sabina, Globigerina, 83

scabrosa, Globorotalia, 73

saxipara, Dimorphina, 94

schachdagica, Globigerina, 73

scobinata, Globigerina, 73

simplex, Globanomalina, 43

simplicissima, Eoglobigerina eobulloides, 22

simulatilis, ? Discorbina, 62

simulatilis, Globorotalia (Truncorotalia) aequa,

65

simulatilis, Morozovella, 62

Smooth-walled, 17

soldadoensis, Acarinina, 2, 18, 50; 190

soldadoensis, Globigerina, 50

soldadoensis, Globorotalia (Acarinina), 50

soldadoensis, Muricoglobigerina soldadoensis, 50

soldadoensis (cf.), Globigerina, 48

spinulosa, Morozovella, 66

spiralis, Eoglobigerina, 13, 22; 146

spiralis, Globigerina, 22, 53

spiralis, Igorina, 22

stainforthi, Globigerina, 31

stainforthi, Subbotina triloculinoides, 31

stonei, Globigerina, 48

strabocella, Acarinina, 12, 18, 50; 192

strabocella, Globorotalia, 51

strabocella, Globorotalia (Acarinina), 51

Streptochilus, 88

strombiformis, Chiloguembelina midwayensis, 90

Subbotina, 13, 17, 28

subbotinae, Globorotalia, 65

subbotinae, Globorotalia (Morozovella) subboti-

nae, 65

subbotinae, Morozovella, 19, 65; 214

subsphaerica, Acarinina, 2, 18, 52; 194

subsphaerica, Globigerina, 52

subsphaerica, Globorotalia (Acarinina), 53

subtriangularis, Chiloguembelina, 92; 246

tadjikistanensis, Globorotalia, 71 
tadjikistanensis, Globorotalia (Morozovella), 72 tadjikistanensis, Igorina, 17, 68, 71; 222

taurica, Chiloguembelina, 88

taurica, Chiloguembelitria, 87

taurica, Globigerina (Eoglobigerina), 75, 84

taurica, Morozovella, 75

taurica, Praemurica, 2, 12, 17, 75; 228

tauricus, Planorotalites, 70

tetragona, Globigerina (Eoglobigerina), 20

tetragona (cf), Globorotalia (Turborotalia), 83

teuria, Zeauvigerina, 96

texana, Rectoguembelina, 94

theodosica, Globigerina (Eoglobigerina), 20

tholiformis, Globorotalia (Morozovella) aequa, 57

triangularis, Globigerina, 30

triangularis, Subbotina, 17, 30; 158

triangularis triangularis, Subbotina, 30

trifolia, Globigerina (Eoglobigerina), 81

trifolia, Guembelitria, 79

trifolia, Guembelitria (?), 79

triloculinoides, Globigerina, 30, 31

triloculinoides, Subbotina, 13, 17, 31; 160

triloculinoides, Subbotina triloculinoides, 31

trinidadensis, Globorotalia, 73

trinitatensis, Chiloguembelina, 92; 246

trinitatensis, Guembelina, 92

trinitatensis, Rectoguembelina, 94 tripartita, Globoconusa, 81

triplex, Acarinina, 47

triplex, Globorotalia (Acarinina), 47

trivialis, Eoglobigerina, 32

trivialis, Globigerina, 32

trivialis, Subbotina, 17,32; 162

trivialis (aff.), Eoglobigerina, 32

trivialis (cf.), Eoglobigerina, 32

trochoidea (var.), Anomalina lorneiana, 34

troelseni, Globorotalia, 40

Truncorotaloididae, 45

Tubitextularia, 94

umbrica, Globigerina, 83

uncinata, Acarinina inconstans, 76

uncinata, Globorotalia, 76

uncinata, Globorotalia uncinata, 76

uncinata, Morozovella, 77

uncinata, Praemurica, 17, 18, 76; 230

uncinata (transitional form), Globorotalia, 64, 73

uruchaensis, Globigerina, 30

varianta, Globigerina, 26

varianta, Globorotalia (Globorotalia), 26

varianta, Parasubbotina, 17, 26; 150

varianta, Subbotina, 26

variospira, Globorotalia (Turborotalia), 28

variospira, Morozovella, 28

variospira, Parasubbotina, 17, 28; 152 velascoensis, Globigerina, 33

velascoensis, Globigerina var. compressa, 33

velascoensis, Globorotalia, 66

velascoensis, Globorotalia (Morozovella) velascoensis, 67

velascoensis, Globorotalia (Truncorotalia) velascoensis, 67

velascoensis, Morozovella, 12, 19, 66; 216

velascoensis, Pseudogloborotalia, 67

velascoensis, Pulvinulina, 66

velascoensis, Subbotina, 17, 33; 164

velascoensis, Truncorotaloides (Morozovella), 66

velata (forma), Zeauvigerina waiparaensis, 97

virgata, "Zeauvigerina," 98; 248

virgata, Heterohelix, 98

waiparaensis, Chiloguembelina, 2, 97

waiparaensis, Zeauvigerina, 97; 248

waiparaensis s.s., Zeauvigerina, 97

whitei, Globorotalia, 48

wilcoxensis, Acarinina, 50

wilcoxensis, Chiloguembelina, 92; 246

wilcoxensis, Gümbelina, 92

wilcoxensis, Pseudohastigerina, 43

Woodringina, 2, 86

Woodringina spp., 77

Zeauvigerina, 2, 94

zelandica, Zeauvigerina, 94 




\section{REQUIREMENTS FOR SMITHSONIAN SERIES PUBLICATION}

Manuscripts intended for series publication receive substantive review (conducted by their originating Smithsonian museums or offices) and are submitted to the Smithsonian Institution Press with Form SI-36, which must show the approval of the appropriate authority designated by the sponsoring organizational unit. Requests for special treatment-use of color, foldouts, case-bound covers, etc.-require, on the same form, the added approval of the sponsoring authority.

Review of manuscripts and art by the Press for requirements of series format and style, completeness and clarity of copy, and arrangement of all material, as outlined below, will govern, within the judgment of the Press, acceptance or rejection of manuscripts and art.

Copy must be prepared on typewriter or word processor, double-spaced, on one side of standard white bond paper (not erasable), with 11/4" margins, submitted as ribbon copy (not carbon or Xerox), in loose sheets (not stapled or bound), and accompanied by original art. Minimum acceptable length is 30 pages.

Front matter (preceding the text) should include: title page with only title and author and no other information; abstract page with author, title, series, etc., following the established format; table of contents with indents reflecting the hierarchy of heads in the paper; also, foreword and/or preface, if appropriate.

First page of text should carry the title and author at the top of the page; second page should have only the author's name and professional mailing address, to be used as an unnumbered footnote on the first page of printed text.

Center heads of whatever level should be typed with initial caps of major words, with extra space above and below the head, but no other preparation (such as all caps or underline, except for the underline necessary for generic and specific epithets). Run-in paragraph heads should use period/dashes or colons as necessary.

Tabulations within text (lists of data, often in parallel columns) can be typed on the text page where they occur, but they should not contain rules or numbered table captions.

Formal tables (numbered, with captions, boxheads, stubs, rules) should be submitted as carefully typed, double-spaced copy separate from the text; they will be typeset unless otherwise requested. If camera-copy use is anticipated, do not draw rules on manuscript copy.

Taxonomic keys in natural history papers should use the aligned-couplet form for zoology and may use the multi-level indent form for botany. If cross referencing is required between key and text, do not include page references within the key, but number the keyed-out taxa, using the same numbers with their corresponding heads in the text.

Synonymy in zoology must use the short form (taxon, author, year:page), with full reference at the end of the paper under "Literature Cited." For botany, the long form (taxon, author, abbreviated journal or book title, volume, page, year, with no reference in "Literature Cited") is optional.

Text-reference system (author, year:page used within the text, with full citation in "Literature Cited" at the end of the text) must be used in place of bibliographic footnotes in all Contributions Series and is strongly recommended in the Studies Series: "(Jones, 1910:122)" or "...Jones (1910:122)." If bibliographic footnotes are required, use the short form (author, brief title, page) with the full citation in the bibliography.

Footnotes, when few in number, whether annotative or bibliographic, should be typed on separate sheets and inserted immediately after the text pages on which the references occur. Extensive notes must be gathered together and placed at the end of the text in a notes section.

Bibliography, depending upon use, is termed "Literature Cited," "References," or "Bibliography." Spell out titles of books, articles, journals, and monographic series. For book and article titles use sentence-style capitalization according to the rules of the language employed (exception: capitalize all major words in English). For journal and series titles, capitalize the initial word and all subsequent words except articles, conjunctions, and prepositions. Transliterate languages that use a non-Roman alphabet according to the Library of Congress system. Underline (for italics) titles of journals and series and titles of books that are not part of a series. Use the parentheses/colon system for volume (number):pagination: "10(2):5-9." For alignment and arrangement of elements, follow the format of recent publications in the series for which the manuscript is intended. Guidelines for preparing bibliography may be secured from Series Section, SI Press.

Legends for illustrations must be submitted at the end of the manuscript, with as many legends typed, double-spaced, to a page as convenient.

Illustrations must be submitted as original art (not copies) accompanying, but separate from, the manuscript. Guidelines for preparing art may be secured from the Series Section, SI Press. All types of illustrations (photographs, line drawings, maps, etc.) may be intermixed throughout the printed text. They should be termed Figures and should be numbered consecutively as they will appear in the monograph. If several illustrations are treated as components of a single composite figure, they should be designated by lowercase italic letters on the illustration; also, in the legend and in text references the italic letters (underlined in copy) should be used: "Figure 9b." Illustrations that are intended to follow the printed text may be termed Plates, and any components should be similarly lettered and referenced: "Plate $9 \underline{b}$." Keys to any symbols within an illustation should appear on the art rather than in the legend.

Some points of style: Do not use periods after such abbreviations as "mm, $f t$. USNM, NNE." Spell out numbers "one" through "nine" in expository text, but use digits in all other cases if possible. Use of the metric system of measurement is preferable; where use of the English system is unavoidable, supply metric equivalents in parentheses. Use the decimal system for precise measurements and relationships, common fractions for approximations. Use day/month/ year sequence for dates: "9 April 1976." For months in tabular listings or data sections, use three-letter abbreviations with no periods: "Jan, Mar, Jun," etc. Omit space between initials of a personal name: "J.B. Jones."

Arrange and paginate sequentially every sheet of manuscript in the following order: (1) title page, (2) abstract, (3) contents, (4) foreword and/or preface, (5) text, (6) appendices, (7) notes section, (8) glossary, (9) bibliography, (10) legends, (11) tables. Index copy may be submitted at page proof stage, but plans for an index should be indicated when the manuscript is submitted. 


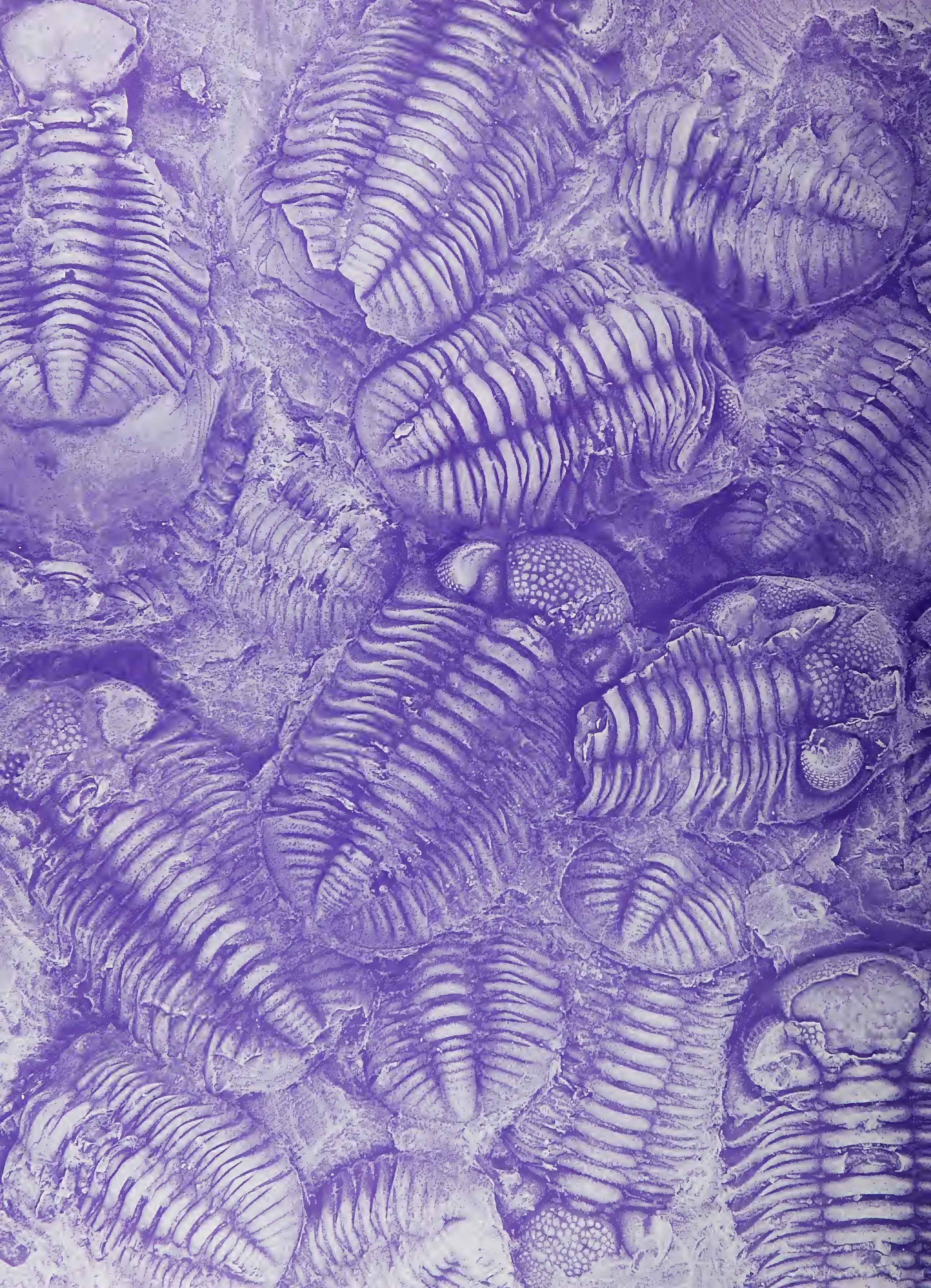

